\title{
HLA \& transplantatie : de ontwikkeling van een matchingspraktijk
}

\author{
Citation for published version (APA):
}

van Dorp, M. H. (2001). HLA \& transplantatie : de ontwikkeling van een matchingspraktijk. [Doctoral Thesis, Maastricht University]. Thela Thesis. https://doi.org/10.26481/dis.20011116md

Document status and date:

Published: 01/01/2001

DOI:

10.26481/dis.20011116md

Document Version:

Publisher's PDF, also known as Version of record

\section{Please check the document version of this publication:}

- A submitted manuscript is the version of the article upon submission and before peer-review. There can be important differences between the submitted version and the official published version of record. People interested in the research are advised to contact the author for the final version of the publication, or visit the DOI to the publisher's website.

- The final author version and the galley proof are versions of the publication after peer review.

- The final published version features the final layout of the paper including the volume, issue and page numbers.

Link to publication

\footnotetext{
General rights rights.

- You may freely distribute the URL identifying the publication in the public portal. please follow below link for the End User Agreement:

www.umlib.nl/taverne-license

Take down policy

If you believe that this document breaches copyright please contact us at:

repository@maastrichtuniversity.nl

providing details and we will investigate your claim.
}

Copyright and moral rights for the publications made accessible in the public portal are retained by the authors and/or other copyright owners and it is a condition of accessing publications that users recognise and abide by the legal requirements associated with these

- Users may download and print one copy of any publication from the public portal for the purpose of private study or research.

- You may not further distribute the material or use it for any profit-making activity or commercial gain

If the publication is distributed under the terms of Article $25 \mathrm{fa}$ of the Dutch Copyright Act, indicated by the "Taverne" license above, 
HLA \& Transplantatie 



\section{HLA \& TRANSPLANTATIE \\ De Ontwikkeling van een Matchingspraktijk}

\section{PROEFSCHRIFT}

ter verkrijging van de graad van doctor aan

de Universiteit Maastricht, op gezag van de Rector Magnificus, Prof. dr. A.C. Nieuwenhuijzen Kruseman volgens het besluit van het College van Decanen, in het openbaar te verdedigen op vrijdag 16 november 2001 om 16.00 uur

door

Michiel Herman van Dorp

geboren op 2 augustus 1962

te Groningen 


\section{Promotor:}

Prof. dr. L. Boon

Co-promotor:

dr. H. Smit

Beoordelingscommissie:

Prof. dr. R. Vos (voorzitter)

Prof. dr. ir. W.E. Bijker

Prof. dr. N. Oudshoorn (Universiteit Twente)

Prof. dr. H. Philipsen

Prof, dr. J.J. van Rood (Universiteit Leiden)

Deze uitgave is mede mogelijk gemaakt dankzij financiele bijdragen van:

Faculteit der Gezondheidswetenschappen,

Faculteit Psychologie,

Capaciteitsgroep Zorgwetenschappen (Sectie

Gezondheidsethiek en Wijsbegeerte) van de Universiteit Maastricht,

Onderzoeksschool Wetenschap. Technologie en Moderne Cultuur.

1.E. Jurriaanse Stichting (Rotterdam).

Wellcome Foundation (Londen).

\section{Bijdragen in natura van:}

de Stichting Eurotransplant en

de Vakgroep Immunohaematologie en Bloedbank van het LUMC. 


\section{INHOUD}

\section{Voorwoord 9}

1 De Ontwikkeling van Eurotransplant 11

I.I Geluk door een Ongeluk II

1.3 Legitimiteit van de Eurotransplantpraktijk 17

I.4 Opbouw van dit boek 20

2 Een klinische observatie 27

2.I Inleiding 27

2.2 De Bloedbank 27

2.3 Mevrouw H. 3I

2.4 'LEUCOCYTE GROUPING' 36

3 Standaardisatie via 'Workshops' 45

3.I Inleiding 45

3.2 Histocompatibility Testing Conference and Workshop ${ }_{4} 6$

3.3 De Tweede Workshop 48

3.4 Het Vervolg - De Derde Workshop 65

3.5 Keerzijde van Succes 70

3.6 Gestandaardiseerde Praktijk? 74

4 De Vorming van een Typeringspraktijk 81

4.I Inleiding $8 \mathrm{r}$

4.2 Werken aan Schaarste 82

4.3 Andere Partijen 89

4.4 Een Spanningsveld 97

5 De 'Leidse' Context 101

5.I Inleiding roI

5.2 Transplantatie-Antigenen 102

5.3 Het Isolatiepaviljoen IRS 108

5.4 Beenmergtransplantaties 112

5.5 Modellen voor Stralingsslachtoffers 115

5.6 'Rolls Royce is tot Volkswagen gemaakt' $n 8$

5.7 De Eerste Niertransplantatie in Leiden 120 
5.8 'Leukocyte group compatibility testing deserves a place in clinical organ transplantation' 126

6 Het Matchingseffect 129

6.I Inleiding 129

6.2 Huidtransplantatie-matchingsexperimenten I3I

6.3 Klinisch Typeren 134

6.4 Retrospectief Klinisch Onderzoek 136

6.5 Prospectief Klinisch Onderzoek ${ }_{14} 6$

6.6 Prospectief Klinisch Onderzoek met Kadaverdonoren ${ }_{14} 8$

6.7 Heeft Matchen Effect? I50

6.8 De Controverse Duurt Voort ${ }_{15} 8$

7 Beschikbaarheid Creëren 161

7.I Inleiding 161

7.2. 'Aanwezigheid' van Donornieren ${ }^{2} 6_{2}$

7.3 Verspreiding van 'Geschiktheid' 166

7.4 Wachten in plaats van Zoeken 178

7.5 Regionalisering 189

7.6 Betrouwbaarheid door Uniformiteit I9I

7.7 Europa Verdeeld I94

7.8 Aanwezig, Geschikt èn Georganiseerd is Beschikbaar 202

8 De Wording van een Matchingspraktijk 205

8.I Inleiding 205

8.2 Een Organisatie in Ontwikkeling 206

8.3 Grenzenloze Geneeskunde ${ }_{23} 6$

8.4 De Matchingspraktijk Eurotransplant 258

9 Epiloog 263

9.1 Inleiding $26_{3}$

9.2 Bouw van een Fundament 264

9.3 Fusie van Praktijken 269

9.5 Slotbeschouwing 273

Bijlagen 277

Summary 297

Bronnen 299

Literatuur 299

Primaire bronnen 30I

Gesprekken en interviews 317

Curriculum vitae 318 
Lijst van Figuren

figuur 2.I: $4 \mathrm{a}, 4 \mathrm{a} 4 \mathrm{~b}, 4 \mathrm{~b} \quad 43$

figuur 3.r: Invoerverklaring 56

figuur 3.2: Invoerlijst 57

figuur 3.3: "The enclosed form" 62

figuur 3.4: Het verdelen van de eer 79

Lijst van Bijlagen

Bijlage I: Het Eurotransplant-voorstel 277

Bijlage 2: Antigenen in 1967279

Bijlage 3: Voorbeeldpagina van het 'ET-telefoonboek' 280

Bijlage 4: De brief aan Thiel 28I

Bijlage 5: Manual for Cadaver-Kidney-Transplantation 283

Bijlage 6: Wat te doen bij een mogelijke orgaandonor 289

Bijlage 7: Instructies voor bloed-en serumtransport per trein 291

Bijlage 8: Correcties op drukproeven van artikel in 'Het Parool' 292

Bijlage 8: 'Match' van de eerste harttransplantaties in Kaapstad 296 



\section{VOORWOORD}

Driemaal is scheepsrecht. Eén AIO-periode levert drie geboorten op. Onze dochters Saskia en Marjoleine en nu dan eindelijk dit proefschrift. Karin heeft in alle drie de geboorten een zeer groot aandeel gehad en heeft zich vele opofferingen getroost.

Met kinderen weet je op voorhand niet wat je te wachten staat. Slechts terugziend op de tijd heb ik de woorden verworven om over de geboorte van de kinderen en hun eerste levensjaren te denken en te spreken. Met het schrijven van een proefschrift is dit eender. Bij aanvang is de toekomst onbekend, het onderwerp slechts vaag omlijnd en het uiteindelijke boek een abstract doel waarnaar wordt gestreefd. In de loop der jaren wordt duidelijk welke woorden kunnen worden gebruikt om het verhaal te vertellen. De vraag en de boodschap van het boek worden voor mij steeds duidelijker, maar deze ideeën op papier tot uitdrukking te laten komen, zodanig dat ook anderen de waarde ervan zien, vraagt meer tijd.

Met Harry Smit, mijn directe begeleider, heb ik vele uitdagende en inspirerende gesprekken gehad, over onderwerpen die ons direct of indirect interesseerden. Met een open geest dacht hij met mij mee, maar soms zo ver dat ik hem niet meer kon volgen. Deze gesprekken scherpten mijn gedachten en waren belangrijk voor mijn ontwikkeling. Zo leerde ik schrijven. Proberend, associërend en met vage ideeën in mijn achterhoofd, leek ik een boek te zullen gaan schrijven bestaande uit meerdere delen en een kleine rooo pagina's. Louis Boon, mijn promotor, was de sturende supervisor op de achtergrond. Met overzicht bezag hij wat mij en Harry bewoog, waar dit toe zou kunnen leiden en plaatste daar zijn kanttekeningen bij, zonder mij mijn vrijheid te ontnemen. Zo kon ik mijn eigen positie bepalen, zijn opmerkingen internaliseren en de omvang beperken.

Opa en tante Vreni ben ik dankbaar. Dankbaar voor de anderhalf jaar dat ik bij hen mocht logeren om bij Eurotransplant archiefonderzoek te doen en dankbaar voor hun rol in mijn leven.

Naast deze mensen zijn er nog vele anderen die grotere of kleinere bijdragen hebben geleverd aan dit onderzoek. Met achtereenvolgens Rob de Vries, Antoinette de Bont en Loes Kater heb ik binnenskamers heel wat gepraat, gelachen en gediscussieerd. De omgeving waarin dit gebeurde was de Vakgroep Gezondheidsethiek en Wijsbegeerte van de Universiteit Maastricht. Hier heb ik me op verschillende terreinen verder kunnen ontplooien. Naast de verschillende discussiegroepen zoals: ZTC, BOTS en de workshops van NGSSTS/WTMC, verdient de AIO-soep een bijzondere vermelding. Eens in de zes weken bij elkaar komen en na de soep een stuk van een van ons wel zeer kritisch bespreken, is een extreme vorm van lotgenoten- 
contact. Allemaal in hetzelfde schuitje, maar in verschillende stadia van ontwikkeling. Menig maal leidde dit tot Babylonische spraakverwarringen, maar wanneer de indiener wat aan alle kritiek zei te hebben gehad, gingen we toch naar huis met het idee dat het uiteindelijk wel goed zou komen.

Bijzondere dank ben ik verschuldigd aan professor Van Rood en mevrouw Van Leeuwen. De gesprekken met hen en de zoektochten door archieven en kasten op verborgen plaatsen, brachten de geschiedenis voor mij tot leven. Hun inspanningen hebben er in hoge mate toe bijgedragen dat ik het archief van Eurotransplant heb kunnen onderzoeken en dit proefschrift zo'n empirisch rijk verhaal heeft kunnen worden. In dit verband wil ik Vakgroep Immunohaematologie en Bloedbank AZL en in het bijzonder Janny van Nieuwkoop en Miep van Leeuwen van het Bloedbank laboratorium, danken voor hun inspanningen rond het uit de opslag van de Fa. Roc$\mathrm{kal}$ in Sassenheim krijgen van de dozen archiefmateriaal. Het personeel van het Weefseltyperingslaboratorium van het LUMC gunde mij een kijkje in de hedendaagse typeringspraktijk.

De interviews met Dr. Bruning, en met Prof. Starzl en Sir Roy Calne na afloop van een Witness seminar van the Wellcome Foundation, zijn ieder van belang geweest voor mijn gedachtenontwikkeling.

Familie en vrienden dank ik voor hun directe of indirecte hulp en steun aan mij en mijn gezin.

Saskia van der Lyke en Ingrid Lathouwer dank ik voor hun formidabele inspanning om het gehele manuscript voor een laatste maal door te nemen en van commentaar te voorzien.

En last but not least wil ik de Stichting Eurotransplant in Leiden, onder leiding van Guido Persijn en Bernard Cohen, en alle medewerkers van Eurotransplant danken voor hun hulp, collegialiteit en vertrouwen, om mij, in mijn woorden, hun geschiedenis te laten schrijven.

Michiel van Dorp

Maastricht, augustus 2001 


\section{DE ONTWIKKELING VAN EUROTRANSPLANT}

\subsection{Geluk door een Ongeluk}

Het is rond negenen 's avonds, wanneer Wim de parkeerplaats afdraait. Het is een prachtige zomerdag geweest, maar Wim moest werken. Als goedmakertje wil hij even lekker rijden in z'n nieuwe cabrio. Niet over de snelweg, maar binnendoor, langs de Vecht. Het gaat lekker, auto goed, dak naar beneden, bulderende wind, muziek wat harder, even zoeken ... Wanneer Wim van zijn nieuwe autoradio opkijkt wordt hij verrast door de zon. Even is hij verblind, het laatste dat hij ziet is de schaduw van de boom in de flauwe bocht ...

Een ambulance is snel ter plaatse. Wim zit niet bekneld en hij kan direct uit het wrak worden gehaald. Hij is bewusteloos en heeft een grote wond aan de linker voorkant van zijn. hoofd. Haast is geboden. Twintig minuten na de klap is Wim op weg naar het AZU. Onderweg wordt hij zo goed mogelijk gestabiliseerd en gecontroleerd. Een kwartier later wordt een jonge man van 28 jaar, in zorgwekkende toestand opgenomen op de Eerste Hulp. De traumatoloog die Wim bekijkt, vraagt direct een $O K$ aan omdat het ambulancepersoneel vertelt dat de patiênt bij hun aankomst al bewusteloos was en tijdens de rit pupilvenvijding optrad aan het linkeroog. Grote spoed! De druk in Wims hoofd is zo hoog, dat direct actie moet worden ondernomen om verdere hersenbeschadiging te voorkomen. Helaas, de spoedoperatie mag niet baten. Het hersenletsel is al te ernstig. Wim is na de operatie, met een gelicht schedeldak, overgebracht naar de Intensive Care. Hier wordt hij beademd en krijgt hij alle zorg die mogelijk is, maar een aantal uren later wordt Wim hersendood verklaard.

Els, Wims vrouw, kan het nog niet begrijpen. Net thuisgekomen, staat de politie voor haar deur met het bericht dat Wim een auto-ongeval heeft gehad en met ernstig letsel in het $A Z U$ is opgenomen. Nu zit ze hier naast hem, op de Intensive Care... Buiten het verband over zijn hoofd en alle slangetjes en draadjes die aan hem zitten vastgeplakt, ziet hij er ongeschonden uit. Maar de arts die naast haar staat, zegt dat de prognose zeer slecht is. Gedurende de uren die volgen wordt een aantal onderzoeken gedaan om de toestand van Wims hersenen te bepalen. Op een gegeven moment komt de arts naar Els toe, gaat bij haar zitten en vertelt dat Wim is opgegeven, hij is hersendood. ... Het kan niet, het mag niet, ze zijn pas getrouwd en willen samen kinderen. Na enige tijd vraagt de intensivist of $z e$ bereid zou zijn om een aantal organen van Wim beschikbaar te stellen voor transplantatie. Waarop ze direct antwoordt dat ze altijd al een codicil hadden en zonder het volledig tot zich door te laten dringen, stemt ze toe ...

Met de verkregen toestemming voor donatie ${ }^{1}$, wordt een protocol in werking gesteld 
dat niet meer is gericht op het herstel van de patiënt. Nu wordt bloed afgenomen voor verschillende onderzoeken die gericht zijn op de transplantatie van de organen. Met datzelfde oogmerk wordt het lichaam van de 'patiënt' in leven gehouden tot de gewenste organen uitgenomen worden. De patiënt wordt beademd en verschillende vitale functies worden actief gecontroleerd. Van de toekomstige donor worden de verschillende bloedgroepen bepaald ${ }^{2}$ en er wordt een weefseltypering uitgevoerd: een HLA-typering ${ }^{3}$. De typeringsgegevens worden vervolgens doorgegeven aan Eurotransplant in Leiden. Daar wordt aan de hand van het HLA-type en de bloedgroep bepaald welke patiënten op de wachtlijst - waarvan de HLA-typering en bloedgroepen eerder zijn bepaald en in de database bij Eurotransplant zijn opgeslagen het meest geschikt zijn om de organen van deze donor te ontvangen. Vervolgens wordt contact opgenomen met de behandelende ziekenhuizen, om na te gaan of de patiënten daadwerkelijk voor transplantatie beschikbaar zijn en of het ziekenhuis in staat is om de transplantatie uit te voeren. Is dit het geval en accepteert het ziekenhuis het aangeboden orgaan, dan wordt het transport van het uitnemende, naar het transplanterende ziekenhuis door Eurotransplant geregeld. Het transplanterende ziekenhuis neemt contact op met diegene die het transplantaat zal ontvangen.

Het is rond negenen 's avonds. De kinderen zijn naar bed en de koffie loopt door. Marjan denkt erover om zo ook maar naar bed te gaan, morgen weer een zware dag: dialyse. Zo langzamerhand krijgt ze daar schoon genoeg van. Steeds weer naar dat ziekenhuis, nooit eens lekker spontaan, zomaar een paar dagen weg, naar zee of zo. Nee, altijd maar weer die dialyse. Natuurlijk, het is nodig, maar ze zou zo graag weer eens vrij zijn en niet zo moe. Na de dialyse ben je helemaal kapot. En wanneer je daarvan dan weer bijgekomen bent, heb je een dag dat je je redelijk voelt, maar dan begint het weer opnieuw. En het wachten. Iedere keer dat de telefoon gaat hopen dat ie er is, dat je aan de beurt bent. Dat je alles mag laten vallen en direct naar het ziekenhuis moet. Wachten op die nieuwe nier, die je weer onafhankelijk maakt. Voor de twee meiden en Karel allemaal ook geen pretje, zij delen mee in de ziekte van moeder.

$\mathrm{Na}$ de koffie gaat ze naar bed en slaapt vrijwel meteen.... Dan gaat de telefoon, het ziekenhuis, het is even over drieën en ze hebben een nier. Meteen is het huis in rep en roer. Ze kleden zich aan en, met de al ingepakte koffer, stappen ze in de auto. Vijf minuten na het telefoontje zijn ze onderweg naar het ziekenhuis. Marjan weet precies wat er gaat gebeuren en wat er vooraf gedaan moet worden. Na aankomst gaat het snel. Ze wordt meegenomen naar de OK-afdeling en voorbereid op de operatie. Kort nadat de nier op de OK is gearriveerd, wordt ze onder narcose gebracht ... Wanneer ze langzaam begint te ontwaken, ligt ze op de PACU ${ }^{4}$ en heeft ze een nieuwe nier.

In bovenstaande verhalen is er sprake van een transplantatie: een orgaan wordt verplaatst van een donor naar een ontvanger. Dat is in dit geval een nier, die na toe-

donorregistratiesysteem, dat bij wet geregeld is. ledere Nederlander van 18 jaar of ouder, is of wordt in de gelegenheid gesteld om haar of zijn keuze, voor wel of niet doneren te laten registreren. Wanneer men geen keuze laat registreren, wordt het al dan niet doneren overgelaten aan de nabestaanden.

2 De boedgroep van het ABO-systeem en het Rhesus-systeem.

3 HLA staat voor: Humaan Leukocyten Antigeen. Het HLA-systeem is een extreem polymorf systeem van antigenen dat een belangrijke rol speelt in het immuunsysteem, bij de afweer tegen pathogenen. Bij een transplantatie resulteert dezelfde afweerreactie voor de afstoting van een transplantaat.

4 Post Anesthetical Care Unit (Recovery) 
stemming van een familielid van de donor, wordt getransplanteerd naar een patiènt die op een wachtlijst stond. De verhalen maken duidelijk dat een transplantatie een complex gebeuren is. Bij een transplantatie zijn talrijke actoren betrokken. Naast dat sprake is van een donor en een ontvanger, zijn chirurgen, anesthesisten, andere medici en paramedici bij de transplantatie aanwezig. Verder is het complex omdat er speciale plaatsen zijn waar verschillende mensen hun werk verrichten: de transplantatie zelf wordt verricht in een OK, Wim wordt verzorgd op de IC en Marjan komt bij op de PACU. Daar komt bij dat er verschillende, typische biomedische han delingen worden verricht: het bepalen van bloedgroepen, het doen van HLA-typeringen, et cetera. De complexiteit van de transplantatiepraktijk is zelfs nog groter aangezien vóórdat een transplantatie kan worden verricht, allerlei voorwaarden moeten zijn vervuld. De donor moet een codicil dragen, de familie moet toestemming geven en de organen van de donor moeten in een goede conditie zijn. Verder moet er een stelsel van adequate transportsystemen zijn waardoor een orgaan op tijd bij de ontvanger arriveert. Wanneer een orgaan ergens arriveert, dan is dat bij een ontvanger die verzekerd is (anders komt hij of zij niet in aanmerking voor een transplantatie), die voor wat betreft de bloedgroepen en het HLA-systeem is getypeerd, die als potentiële ontvanger op een wachtlijst is geplaatst, die vervolgens daadwerkelijk wacht, voortdurend paraat is en de koffer klaar heeft staan ...

Hoe is deze complexe transplantatiepraktijk ontstaan? Welke (wetenschappelijke) ontwikkelingen liggen eraan ten grondslag? Dit boek beschrijft de ontstaansgeschiedenis van een organisatie die centraal staat in deze praktijk: Eurotransplant.

Anno $200 \mathrm{I}$ is Eurotransplant een samenwerkingsverband van ziekenhuizen uit zes landen: België, Nederland, Luxemburg, Oostenrijk, Duitsland en Slovenië. Het is een non-profit organisatie, die gefinancierd wordt door, bij inschrijving op de wachtlijst, een vast bedrag per patiënt te rekenen. De hoogte van dit bedrag wordt bepaald door de begrote kosten te delen door het totaal aantal verwachte nieuwe inschrijvingen op de wachtlijst.

Eurotransplant coördineert de uitwisseling van donororganen voor transplantaties binnen deze zes landen. Deze organen zijn afkomstig van mensen die hebben aangegeven, dat zij na hun overlijden willen dienen als orgaandonor ${ }^{5}$. Wanneer het overlijden op een "voor transplantatie geschikte manier" plaatsvindt en de bereidheid tot doneren rond het overlijden van zo'n persoon bekend is - dan wel toestemming wordt verkregen van de nabestaanden - wordt de donor aangemeld bij Eurotransplant. Dan worden de relevante medische gegevens bepaald en zo nodig wordt, ten bate van de nog uit te nemen organen, getracht om het lichaam van de overledene in een goede conditie te houden 6 .

Voor een beschikbaar gesteld orgaan selecteert Eurotransplant de meest geschikte ontvanger ${ }^{7}$. Die ontvanger wordt gekozen uit een wachtlijst waarop patiënten staan

5 Voor sommige organen en weefsels moet de donor overleden zijn (hart, longen, bot, hoornvlies, etc.), voor andere (bijvoorbeeld: bloed, nier, of een stuk van de lever) kan het een levende donor zijn.

6 Xenotransplantaties zouden in theorie aan de 'noodzaak' van menselijke donoren een einde kunnen maken. (Bij xenotransplantaties worden organen en weefsels getransplanteerd die niet afkomstig zijn van dezelfde soort.) Daarnaast wordt recentelijk ook gesproken over het kweken van bepaalde organen uit embryonale stamcellen. Van klinische toepassing daarvan is de eerst komende jaren echter nog geen sprake.

7 Aanvankelijk werd dit selecteren alleen gedaan voor nieren, maar na de introductie van cyclosporine (begin jaren tachtig) - waarmee afstoting beter te voorkomen dan wel te beheersen werd - werd deze 'matchingservice' geleidelijk uitgebreid naar andere organen en weefsels. 
die voor transplantatie in aanmerking willen komen. Deze patiënten zijn daartoe door hun behandelend arts, met medeweten van de patiënt zelf, aangemeld bij Eurotransplant. Van de aangemelde patiënten worden allerlei gegevens verzameld en opgeslagen in de database van Eurotransplant. Naast de gebruikelijke personalia, de inschrijvingsdatum, het behandelend transplantatiecentrum en de verzekeringsgegevens, worden ook allerlei relevante medische gegevens bepaald, zoals bloedgroepen en de HLA-typering. Dan begint voor de patiënt het - soms lange - wachten, tot een donororgaan beschikbaar komt en er een transplantatie kan plaatsvinden.

Als een donororgaan beschikbaar is gesteld en Eurotransplant van de wachtlijst een patiënt heeft geselecteerd, onderzoekt Eurotransplant of de transplantatie ook daadwerkelijk kan worden uitgevoerd. Vervolgens worden uitname en transport geregeld. De ontvanger gaat naar het ziekenhuis en wordt voorbereid, terwijl het betreffende orgaan wordt uitgenomen en naar dit ziekenhuis wordt vervoerd, waar als alles goed gaat - de transplantatie dan plaatsvindt.

Uit het voorafgaande blijkt dat selectie op basis HLA-typeringen een centrale rol speelt in de procedure van Eurotransplant. Deze selectieprocedure hangt samen met het doel dat Eurotransplant nastreeft: het succes van transplantaties verhogen door de kans op afstoting te verkleinen. Dit wordt gedaan, door die ontvanger te selecteren waarvan het HLA-type zoveel mogelijk overeenkomt met de weefselkenmerken van de donor. Dit heet 'matchen'. De match is een van de belangrijkste (medische) criteria op basis waarvan de toewijzing (allocatie) plaatsvindt ${ }^{8}$. Maar hoe heeft zich een praktijk ontwikkeld waarin het 'juiste' orgaan bij de 'juiste' ontvanger terechtkomt? Dit boek beschrijft de ontstaansgeschiedenis van deze matchingspraktijk. Hieruit zal blijken dat dit tevens de ontstaansgeschiedenis van Eurotransplant zelf is. Eurotransplant belichaamt de matchingspraktijk.

\subsection{Een Bijzondere Praktijk}

De ontstaansgeschiedenis van deze complexe praktijk zal vanuit een specifieke invalshoek worden geschreven. De nadruk zal (in eerste instantie) liggen op een bijzonder aspect van de transplantatiegeneeskunde, namelijk het feit dat Eurotransplant is gebaseerd op een speciaal natuurgegeven: het HLA-systeem. Dit systeem is betrokken bij het onderscheiden van eigen en niet-eigen en speelt een rol bij onze verdediging tegen pathogenen. In de transplantatiegeneeskunde wordt kennis over dit systeem gebruikt om de kans te minimaliseren dat een orgaan wordt afgestoten. In de praktijk betekent dit dat de gegevens over het HLA-systeem van de donor en de ontvanger worden vergeleken. Daarom werd in de beschreven casuistiek een HLAtypering gemaakt. De gedachte hierbij is dat, hoe meer het HLA-systeem van de ontvanger lijkt op dat van de donor, des te kleiner de kans op afstoting is. De toepassing van deze gedachte op het gebied van transplantaties heeft er mede toe bijgedragen dat transplantatiegeneeskunde een bijzondere vorm van geneeskunde is geworden. Maar waarin schuilt precies het bijzondere karakter van deze praktijk?

8 De doelstellingen van Eurotransplant, zoals deze vermeld staan op hun internetsite.

1. Optimal use of available donor organs.

2. A transparent and objective allocation system, based upon medical criteria.

3. Support of donor organ procurement to increase the supply of donor organs and tissue.

4. Improvement of transplantation results through scientific research.

5. Promotion, support and co-ordination of organ transplantation in the broadest sense.

(Eurotransplant, 1999) 
De transplantatiegeneeskunde is niet bijzonder omdat gebruik wordt gemaakt van een natuurgegeven. Dat gebeurt ook in andere takken van de geneeskunde. In de vaccinatie-geneeskunde bijvoorbeeld, maakt men gebruik van het feit dat de immuunrespons bij een tweede contact met hetzelfde antigeen heftiger is dan bij de eerste respons; bij het bestrijden van infectieziekten met penicilline maakt men gebruik van het natuurgegeven dat schimmels concurreren met bacteriën. Het bijzondere van de transplantatiegeneeskunde, zo zal in dit boek worden betoogd, schuilt in de manier waarop een natuurgegeven in en naar een praktijk wordt vertaald. Een korte schets van de ontwikkeling van de transplantatiepraktijk kan duidelijk maken wat hiermee wordt bedoeld.

Toen in de jaren veertig en vijftig van de vorige eeuw werd ontdekt dat het im. muunsysteem een belangrijke rol speelt bij het afstoten/tolereren van transplantaten, werd duidelijk dat het falen van transplantaties niet voortkwam uit gebrekkig medisch handelen. Als een transplantatie faalde, dan kwam dat niet door een foutieve chirurgische ingreep, maar door iets dat 'achter de rug van de chirurg om gebeurde', namelijk door een respons van het immuunsysteem. De identificatie van de antilichamen en antigenen, betrokken bij deze respons, opende een nieuwe weg naar succesvolle transplantaties. Het was namelijk al bekend dat succesvolle transplantaties mogelijk zijn in geval van identieke tweelingen. Toen duidelijk werd dat het immuunsysteem betrokken is bij afstoting van getransplanteerde organen, kon daar aan worden toegevoegd dat identieke tweelingen elkaars organen accepteren, omdat het immuunsysteem van de ene, weefsel afkomstig van de ander, als eigen herkent en er dus geen afweerreactie optreedt. Dit inzicht leidde tot de gedachte, dat meer kennis over dat immuunsysteem ertoe zou kunnen leiden dat ook in andere gevallen, dan die van een identieke tweeling, de kans op afstoting kon worden verkleind. Daarvoor zou het HLA-type van de ontvanger met dat van de donor moeten worden vergeleken. De vraag rees echter of kennis over het HLA-systeem ook praktisch bruikbaar kon worden gemaakt. Zou onderzoek naar het HLA-systeem de belofte van transplanteren zonder risico op afstoting waarmaken? In de tijd dat deze vragen nog grotendeels onbeantwoord zijn - in de tweede helft van de jaren zestig - wordt Eurotransplant opgericht. Hoe ging dat in zijn werk? Hoe hangt het zoeken naar antwoorden op deze fundamentele vragen samen met de oprichting van een uitvoeringsorganisatie? Deze vragen zullen in dit boek nader worden onderzocht.

In dit onderzoek zal onder andere ingegaan worden op de relatie tussen kennis over het immuunsysteem en de chirurgische transplantatiegeneeskunde. Twee zaken zijn hierbij belangrijk. In de eerste plaats valt op dat de kennisontwikkeling rond het HLA-systeem geen directe invloed heeft gehad op het niveau van de medische handelingen. De handelingen van chirurgen, anesthesisten, et cetera, zijn misschien in de loop van de tijd wel veranderd, maar niet als gevolg van kennis over het HLA-systeem. Als gevolg van de kennisontwikkeling rond het HLA-systeem zijn slechts de voorwaarden voor medische handelingen veranderd: of een orgaan van donor A bij patiënt B wel of niet wordt getransplanteerd, wordt afhankelijk gemaakt van het al dan niet overeenkomen van de HLA-typering van A en B. Maar hoe dat orgaan uit het lichaam van A wordt gehaald en vervolgens in B's lichaam wordt geplaatst, daarover zegt die kennis weinig. Kennis over het HLA-systeem staat in deze zin dus los van de medische handelingspraktijk. Maar dit is slechts de helft van het verhaal. In de tweede plaats valt op, dat door de introductie van het HLA-systeem in de medische praktijk, er een nieuw biomedisch criterium wordt geỉntroduceerd. Na- 
melijk een criterium dat bepaalt bij wie een bepaalde donornier zal worden getransplanteerd. Een criterium, gebaseerd op het idee dat het maximaal haalbare resultaat kan worden bereikt, wanneer het HLA-systeem van de donor en de ontvanger zoveel mogelijk op elkaar lijken. Dan zal de afstotingsreactie minimaal en de overlevingsduur van de getransplanteerde nier maximaal zijn. Toepassing van dit criterium, zo is de gedachte in de transplantatiegeneeskunde, zou ten goede komen aan het leven en welzijn van de ontvangende patiënt. Gegeven het (hierboven besproken) gebruik van onvolledige kennis van het HLA-systeem steekt hier een probleem de kop op. Is het vertrouwen dat in het medisch criterium wordt gesteld wel terecht, als de kennis over het HLA-systeem onvolledig is? Om deze vraag te analyseren, zal ik in detail het ontwikkelingsproces van de kennis over het HLA-systeem in samenhang met de transplantatiepraktiik onderzoeken.

Het antwoord op deze legitimiteitsvraag heeft een cognitieve en een sociale kant. Het (aan het HLA-systeem ontleende) cognitieve medische criterium bepaalt wie in aanmerking komt voor een transplantatie. Dat is een keuze die op basis van een vergelijking van gegevens wordt gemaakt. Maar er zit ook een sociaal/ethische dimensie aan het medische criterium en die dimensie verandert gedurende de ontwikkeling van de transplantatiepraktijk. Er moet namelijk een keuze worden gemakkt uit een bestaande pool van mensen die wachten op een orgaan. De ontwikkeling van het keuze-criterium heeft met andere woorden geleid tot het ontstaan van een wachtlijst. Marjan moest in de casus wachten op een geschikte nier. Is het gerechtvaardigd om patiënten te laten wachten? In de transplantatiegeneeskunde leeft de utilistische gedachte dat het voordeel van het gebruik van het HLAcriterium opweegt tegen het nadeel dat mensen moeten wachten op een donornier. Het idee is dat een patiëntenpopulatie als geheel meer profijt heeft als iedere individuele patiënt een tijd wacht, omdat transplantatie van een geschikt orgaan een grotere kans op een succesvol resultaat heeft. Men vindt dat de winst van het zo effectief mogelijk gebruiken van (schaarse) donornieren, door patiënten te laten wachten op een goed gematchte nier, opweegt tegen de risico's van het langer moeten dialyseren en zelfs tegen het eventueel overlijden van patiënten terwijl deze op de wachtlijst staan.

Dit boek is enerzijds een historisch onderzoek naar het ontstaan van Eurotransplant, als onderdeel van de transplantatiepraktijk. Ik zal beschrijven hoe vanaf het midden van de vorige eeuw de transplantatiegeneeskunde in het algemeen, en Eurotransplant in het bijzonder, tot ontwikkeling kwamen. Anderzijds is het een boek, waarin een theoretisch probleem wordt onderzocht. In de transplantatiepraktijk komt een (bio)medisch criterium tot ontwikkeling, aan de hand waarvan besluiten worden genomen over de vraag wie in aanmerking komt voor een transplantatie. De totstandkoming en legitimiteit van dit medische criterium in de transplantatiepraktijk vormen daarom, naast het historisch overzicht, onderwerp van onderzoek.

Omdat dit boek het resultaat is van historisch bronnenonderzoek, en bovendien de pretentie heeft een onderzoek te zijn naar de legitimiteit van een medisch criterium, rijst de vraag hoe het onderzoek is verricht. Welk kader is gehanteerd bij het onderzoek? Welk materiaal is bestudeerd om antwoorden te krijgen op de gestelde vragen?

In dit het onderzoek is als kader de zogeheten actornetwerktheorie van Latour gehanteerd 9 . Aan deze theorie zijn twee algemene richtlijnen ontleend die zijn ge- 
bruikt bij het empirisch-historisch onderzoek naar de ontwikkeling van Eurotransplant.

In de eerste plaats is aan de theorie de richtlijn ontleend, dat de ontwikkeling van praktijken niet volgens een standaardrecept verloopt. De gedachte, dat er eerst ontdekkingen worden gedaan, die daarna praktisch toepasbaar worden gemaakt en dan pas als uitgekristalliseerde producten op de markt worden gezet, schetst volgens de actornetwerktheorie een zeer simplistisch (en historisch gezien onjuist) beeld. Dit zogeheten standaardbeeld van wetenschap is geen adequaat beeld van hoe praktijken zich ontwikkelen. Het is volgens de theorie beter om tijdens het onderzoek naar praktijken niet uit te gaan van gangbare onderscheidingen, zoals die tussen de ontdekking van kennis en de toepassing van kennis. Die onderscheidingen zijn tijdens het (historisch) onderzoek voor een historicus eerder misleidend dan verhelderend. Deze richtlijn heb ik in mijn onderzoek serieus genomen: in deze studie ga ik niet uit van de gedachte, dat door wetenschappers eerst het HLA-systeem is ontdekt en dat deze kennis over het HLA-systeem pas is toegepast in de chirurgische transplantatiepraktijk toen bleek dat deze kennis bruikbaar was. Aan de actornetwerktheorie ontleen ik de (agnostische) gedachte dat daarover op voorhand geen algemene uitspraak te doen is. Met andere woorden: of, en zo ja hoe, in de ontwikkeling van de transplantatiepraktijk kennis steeds het voortouw heeft gehad bij ontwikkelingen en het sturend element was bij de organisatie van de klinische praktijk, moet blijken uit nader onderzoek. De inzet van mijn studie is om een beter en interessanter beeld te schetsen van de ontwikkeling van de transplantatiepraktijk, dan het beeld dat door naieve concepties van wetenschap wordt opgeroepen.

In de tweede plaats heb ik aan de actornetwerktheorie de richtlijn ontleend, dat de ontwikkeling van praktijken plaatsvindt binnen heterogene netwerken. In de ontwikkeling van praktijken zijn cognitieve elementen slechts één van de elementen die een praktijk vorm geven. Naast cognitieve zijn er ook andere elementen (zoals financiën, technieken, moraal, et cetera) die een praktijk constitueren. Dit boek is om deze reden dan ook geen ideeëngeschiedenis. Naast een beschrijving van de ontwikkeling van kennis, zal in deze studie ook aandacht worden geschonken aan de meer materiële en sociale elementen die bij de ontwikkeling van de transplantatiepraktijk een rol hebben gespeeld. De ontwikkeling van de transplantatiepraktijk zal in deze studie worden gezien als een co-evolutionair proces: aan de ontwikkelingen dragen verschillende elementen hun steentje bij en die elementen evolueren niet los van elkaar, maar juist tezamen. Uit de interacties tussen deze verscheidene elementen ontstaat de transplantatiepraktijk in het algemeen, en Eurotransplant in het bijzonder.

\subsection{LEGITIMITEIT VAN DE EUROTRANSPLANTPRAKTIJK}

Naast wetenschapstheoretische overwegingen, is er een meer medisch-inhoudelijke overweging aan te geven waarom de actornetwerktheorie is gekozen als kader voor mijn onderzoek. Zoals in paragraaf 1.2 al is uitgelegd is de transplantatiepraktijk om verschillende redenen een bijzondere medische praktijk. Eurotransplant komt enerzijds voort uit een medische praktijk, maar is om te kunnen functioneren afhankelijk van patiënten, donoren, financiering, et cetera. Juist omdat Eurotransplant func-

9 Een uitzetting van de ActorNetwerkTheorie geeft Latour in Science in Action (Latour, 1987). 
tioneert in het grensgebied tussen wetenschap en maatschappij, is ervoor gekozen om bij het onderzoek naar dat functioneren niet uit te gaan van een bepaalde opvatting over de verhouding tussen wetenschap en maatschappij: namelijk van de opvatting dat Eurotransplant een organisatie is die kennis over het HLA-systeem heeft gebruikt voor een reorganisatie van de klinische transplantatiepraktijk. Ook hier geldt dat een preconceptie is ingeruild voor een onderzoeksvraag. Hoe heeft Eurotransplant een plaats 'verworven' in het grensgebied tussen wetenschap en maatschappij? De vraag is uiteraard nauw verweven met de vraag hoe het medisch criterium een centrale positie heeft gekregen in die praktijk. Om deze vraag nog wat meer uit te werken, zal ik nogmaals kort ingaan op de huidige functie van Eurotransplant in de transplantatiepraktijk.

Hoewel de aan Eurotransplant verbonden artsen geen patiënten opereren en geen medicijnen voorschrijven, heeft de organisatie een grote invloed op het leven en welzijn van de bij haar ingeschreven, wachtende patiënten. Waaruit bestaat die invloed? Eurotransplant is voor de patiënt belangrijk, omdat hij of zij via deze organisatie hoopt te worden getransplanteerd. De directe invloed van Eurotransplant op het leven en welzijn van de patiënt is dat de organisatie hen laat wachten, wachten op een voor hem of haar geschikte donornier. Eurotransplant is immers opgericht in de veronderstelling dat de transplantatieresultaten met sprongen vooruit zullen gaan, wanneer de getransplanteerde nieren, door te matchen, geschikter zijn voor de betreffende ontvangers dan zonder matchen mogelijk zou zijn. De vraag rijst of dit veronderstelde positieve effect op transplantaties, ook nu nog de legitimatie van de Eurotransplantpraktijk vormt. Is het zo dat deze veronderstelling de door Eurotransplant gehanteerde selectieprocedure en daarmee Eurotransplant zelf rechtvaardigt?

Voor mijn onderzoek naar het ontstaan van Eurotransplant heb ik gebruik gemaakt van het archief van Eurotransplant en de Bloedbank van het Academisch Ziekenhuis Leiden $(A Z L)^{10}$. De voor dit onderzoek bestudeerde periode eindigt rond I970, aangezien rond die tijd Eurotransplant als institutie gaat functioneren. De belangrijkste vraag die ik aan het archief stelde was: hoe ontstaat Eurotransplant? Hierbij heb ik mijn aandacht vooral gericht op het werk achter de schermen; alles wat niet in artikelen wordt weergegeven. Aanwijzingen voor de praktijk van alledag, waar ik een beeld van wilde krijgen door het bestuderen van correspondentie, notities, notulen en wat ik verder in het archief zou aantreffen. Door analyse van dit materiaal wilde ik een beeld krijgen van de ideeën, overwegingen en problemen van verschillende aard die op een zeker moment leidden tot bepaalde keuzen. Keuzen die later mogelijk weer - bij het maken van de keuze niet te voorziene - consequenties hebben ${ }^{11}$.

1o Tegenwoordig Leids Universitair Medisch Centrum (LUMC)

II De keuze voor, en de rijkdom van dit archief, hebben ook consequenties voor dit boek. Dat het archief van Eurotransplant als belangrijkste bron is gebruikt, heeft erin geresulteerd dat in dit boek een Leids perspectief dominant is, Dit is niet verwonderlijk, aangezien het van meet af aan de bedoeling was dat het onderzoek over het ontstaan van Eurotransplant zou gaan. Het gebruik van andere bronnen zou ongetwijfeld tot een ander boek hebben geleid.

Een ander gevolg van het gebruik van het archief is de onzichtbaarheid van de talloze medewerkers - in Leiden en elders - die bijdragen hebben geleverd aan de ontwikkelingen. In het archiefmateriaal dat ik voor deze studie heb gebruikt, worden deze medewerkers slechts zelden bij naam en toenaam genoemd. Voor Leiden heb ik dit enigszins gecorrigeerd door te spreken over 'de Leidse groep', waarmee ik meer mensen aanduidt dan alleen zij die met name worden genoemd. 
De speurtocht door dit archief heeft mij (terug)gevoerd tot 23 september r946, met de mededeling dat de Bloedbank van start gaat. Door het verhaal van Eurotransplant ook grotendeels aan de hand van het archiefmateriaal te vertellen, in plaats van aan de hand van de gepubliceerde artikelen, maak ik dingen zichtbaar die anders buiten beeld zouden zijn gebleven, zoals opportunisme als handelingscriterium. Zo verhalend laat ik verschillende thema's de revue passeren. Startend met de ontwikkeling van het biomedisch fundament van Eurotransplant, komt vervolgens de vervlechting van verschillende medische deelgebieden aan de orde, tot in Hoofdstuk 7 de verschillende thema's bij elkaar komen in het Eurotransplant-voorstel. In hoofdstuk 8 laat ik zien hoe dit voorstel wordt vertaald in een functionerende organisatie.

De ontwikkeling van een gestroomlijnde organisatie, zal verre van eenvoudig blijken. Door het ontstaan van Eurotransplant te beschrijven laat ik zien hoe contingent wetenschapsontwikkeling is. Men moet bij het lezen van dit boek het idee loslaten dat de orgaanuitwisselingsorganisatie Eurotransplant van aanvang aan het doel was waar naar gestreefd werd. Men zal dan zien dat vele - en niet allemaal succesvolle - ontwikkelingen aan de oprichting van Eurotransplant vooraf zijn gegaan. Wanneer in $195^{8}$, in Leiden, een klinische observatie wordt gedaan die niet in overeenstemming is te brengen met de standaardverklaringen, bevroedt niemand dat tien jaar later - mede door die klinische observatie - een orgaanuitwisselingsorganisatie gestart wordt, die bovendien nog op meerdere plaatsen in de wereld navolging krijgt ook.

In de beschrijving van het ontstaan van Eurotransplant, ligt de nadruk op niertransplantaties. Dit heeft twee redenen. Ten eerste is de transplantatie van nieren historisch gezien de ingreep waar de Eurotransplantpraktijk zich rond ontwikkelde; ten tweede omdat, ook tegenwoordig nog, bij niertransplantatie veel belang wordt gehecht aan de uitslag van weefseltypering voor de allocatie van een donornier ${ }^{12}$. Eurotransplant wordt primair verbonden met het, op basis van weefseltyperingen, bepalen wie een donororgaan zal krijgen. In zekere zin is dit uitgangspunt ook het vertrekpunt van dit boek: het lijkt volkomen logisch dat aan de hand van een medisch en daarmee waardevrij criterium wordt bepaald bij wie een bepaalde donornier zal worden getransplanteerd. Dit (medische) criterium zorgt er immers voor dat het best haalbare resultaat wordt bereikt: door minimalisering van de afstotingsreacties, een maximale overlevingsduur van de getransplanteerde nier verkrijgen. Matchen zorgt dus voor een maximalisering van leven en welzijn van de ontvangende patiënt. De vermeende winst van het gebruik van dit medisch criterium rechtvaardigt ook de praktijk dat mensen op een nier moeten wachten.

Geheel onproblematisch is deze wijze van legitimeren niet. Dat blijkt uit het gegeven dat Eurotransplant, in 1996 , een nieuw allocatieprotocol in werking stelt, het Eurotransplant Kidney Allocation System protocol (ETKAS). In dit allocatieprotocol speelt de kwaliteit van de match weliswaar nog een belangrijke rol, maar zijn de medische criteria niet meer de enige op basis waarvan wordt bepaald wie een bepaalde nier krijgt aangeboden. Dit lijkt vreemd. Een medische praktijk die niet meer op uitsluitend medische gronden (verdelings) besluiten neemt. Het lijkt op een breuk met het verleden en een bron van morele problemen. Waarom zouden de bij Euro-

12 Naast nieren is Eurotransplant in de loop van de tijd ook andere organen en weefsels gaan bemiddelen. 
transplant aangesloten transplantatiecentra die veilige, neutrale medische criteria, als unieke allocatiecriteria verlaten en rekening gaan houden met zaken als wachttijd van de patiēnt, afstand van de ontvanger tot de donor en bestaande samenwerkingsverbanden? Het in medische zin best haalbare resultaat lijkt daarmee niet meer het exclusieve doel van het allocatieprotocol te zijn. Eurotransplant lijkt haar doelstelling te verleggen. Er wordt een puntensysteem in gebruik genomen om te bepalen wie voor een bepaald donororgaan in aanmerking komt. Een puntensysteem waarin iemand weliswaar een bepaald aantal punten krijgt voor de kwaliteit van de match, maar ook voor andere variabelen. Met ETKAS wordt geprobeerd om de gemiddelde wachttijd te verkorten, correcties voor zeldzame HLA-typen en homozygositeit toe te passen, een redelijk evenwicht in de uitwisseling van donornieren tussen landen te bereiken en een optimale HLA-match-verdeling en algemene transplantatie-uitkomst te garanderen. Enerzijds lijkt de individuele patiënt aan terrein te winnen kortere wachttijd - ten opzichte van het meest effectieve gebruik van donornieren, maar anderzijds kan dit voor dezelfde patiënt betekenen dat hij of zij een - in immunologische zin - minder geschikte nier krijgt.

Om een afweging te kunnen maken tussen het gebruik van uitsluitend medische criteria en het nieuwe ETKAS-protocol, wordt eerst de ontstaansgeschiedenis beschreven van het medisch criterium en de oorsprong van het vertrouwen dat in matchen gesteld wordt. Verbazing over het afzwakken van het medisch criterium zou plaats kunnen maken voor verbazing over het feit dat dit niet veel eerder is gebeurd. Met het afnemen van de bewondering voor de macht van het HLA, zou een zekere waardering kunnen ontstaan voor de creatie en instandhouding van het bijzonder heterogene netwerk dat Eurotransplant is. In dit boek zal blijken dat de transplantatiepraktijk ook geheel anders had kunnen zijn, waar Eurotransplant niet noodzakelijk deel van uit had hoeven maken. Rond het ontstaan van Eurotransplant is namelijk een grote tegenstrijdigheid te zien. Dat Eurotransplant bestaansrecht kreeg, is voor een groot deel te danken aan het uitblijven van een biomedisch/technische oplossing van het afstotingsprobleem. Dankzij immunosuppressie heeft zich een transplantatiepraktijk kunnen ontwikkelen. Maar immunosuppressie blijkt het afstotingsprobleem niet volledig op te kunnen lossen. Daardoor blijft er ruimte om aanvullende benaderingen te onderzoeken. Benaderingen die het afstotingsprobleem zouden kunnen verkleinen, of zelfs oplossen. De ruimte die de immunosuppressiva open laat, biedt matchen de gelegenheid zich een plaats te verwerven in de transplantatiepraktijk. De tegenstrijdigheid gaat echter nog verder, want het is niet ondanks, maar dankzij het al aanwezige gebruik van immunosuppressiva, dat het matchingscriterium die gelegenheid krijgt. Maar ook matchen blijkt niet de heilige graal voor de transplantatiegeneeskunde te zijn. Zowel het gebruik van immunosuppressiva, als het matchen, verminderen de ernst van een aantal medische problemen rond transplantatie, maar noch ieder apart, noch in combinatie, kunnen ze alle problemen oplossen. Voor een aantal oude en nieuwe (medische) problemen biedt de oprichting van Eurotransplant sociaal/organisatorische oplossingen. In dit boek wordt beschreven hoe een matchingspraktijk ontstaat binnen de transplantatiepraktijk en hoe verschillende problemen leiden tot Eurotransplant.

\subsection{OpBouW VAN DIT BOEK}

De centrale vraag van dit boek, hoe ontstaat Eurotransplant en waardoor wordt haar bestaan gelegitimeerd, wordt uitgewerkt door enerzijds de ontwikkeling van we- 
tenschappelijke kennis en anderzijds de ontwikkeling van praktijken te bestuderen.

In Hoofdstuk 2 wordt een ontwikkeling beschreven die gaat van het in staat zijn een klinische observatie tot een bijzondere en produktieve waarneming te maken, naar de aanzet voor de ontwikkeling van een dialleel ${ }^{13}$ systeem van leukocytenantigenen. Een antigeensysteem dat verder kan worden onderzocht, met een methode - waar een computer deel van uitmaakt - die overal kan worden toegepast. Het overal toepasbaar zijn van de methode, kan echter niet bewerkstelligen dat de verschillende lokale producten ook onderling vergelijkbaar zijn.

In Hoofdstuk 3 laat ik zien hoe de verschillende parallelle ontwikkelingen in het leukocytenonderzoek in de wereld gesynchroniseerd worden. Dit wordt gedaan door een van de vele variabelen te standaardiseren. Onderzoekers komen samen en analyseren ieder op eigen wijze, met eigen antisera dezelfde antigenen. Zo kunnen de uitkomsten van de tests vergeleken worden en zijn dus ook de verschillende lokale antisera onderling te vergelijken.

In Hoofdstuk 4 laat ik zien hoe wordt geprobeerd de in de Leidse Workshop gecreëerde vergelijkbaarheid over de wereld te verspreiden, ofwel terug te vertalen naar lokale praktijken. Hierbij kunnen twee verschillende, maar van elkaar afhankelijke groepen worden onderscheiden. Ik laat zien hoe enerzijds de onderzoeksgroepen de antigeenvariabele proberen te standaardiseren en hoe anderzijds grote organisaties proberen de antisera te standaardiseren. De verschillende doelstellingen van deze groepen staan op gespannen voet met elkaar, waardoor ook de samenwerking niet altijd soepel verloopt.

In Hoofdstuk 5 laat ik zien wat de lokale, Leidse achtergronden zijn van een groot deel van de vragen waar in de hoofdstukken $2 \mathrm{t} / \mathrm{m} 4$ aan gewerkt werd. Hoe de kennisontwikkeling wordt ingepast in en verweven raakt met andere lokale klinische praktijken, waaruit de met typering verbonden niertransplantatiepraktijk in Leiden voortvloeit.

Hoofdstuk 6 gaat vervolgens over het ontwikkelen en op verschillende manieren hard maken van de claim dat matchen een positieve invloed heeft op het uiteindelijke transplantatieresultaat; de aanwezigheid van het matchingseffect. De basis voor het opzetten van Eurotransplant.

In Hoofdstuk 7 beschrijf ik hoe, ondanks de afwezigheid van vaststaande kennis, een voorstel wordt gedaan om onzekere kennis te institutionaliseren. Om te laten zien wat de rationale achter dit voorstel is, splits ik de term 'beschikbaarheid' van donornieren uit naar 'aanwezigheid' en 'geschiktheid' van donornieren, om te concluderen dat pas over 'beschikbaarheid' gesproken kan worden wanneer het allemaal ook 'georganiseerd' is.

Hoofdstuk 8 bouwt voort op de conclusie van Hoofdstuk 7 en laat zien hoe de interne organisatie binnen Eurotransplant wordt vormgegeven en hoe deze organisatie zich gedurende het voorafgaande decennium heeft kunnen ontwikkelen, als co-evolutie van medisch-technische wetenschap en maatschappij, tot de transplantatiepraktijk Eurotransplant.

Zoals aangekondigd zal ik in het negende en afsluitende hoofdstuk terug komen op de inzet van dit boek en een beschouwing geven over de verschillende lessen, die

I3 Systeem dat door twee allelen, de afzonderlijke genen op de twee chromosomen van een chromosomenpaar, wordt gecodeerd. 
door wetenschappers, beleidsmakers en publiek uit dit onderzoek kunnen worden geleerd.

Ook al is het een historisch werk, dit boek volgt niet een strakke chronologie. De hoofdstukken zijn thematisch geordend, maar hebben onderling en intern wel een overwegend chronologische tendens. Het is echter niet zo dat ieder hoofdstuk een eigen, afzonderlijke periode behandelt. Voor wat betreft de periode waarop zij betrekking hebben, vertonen de verschillende hoofdstukken een grote mate van overlap. De in de verschillende hoofdstukken beschreven ontwikkelingen, vinden dus deels gelijktijdig plaats. Op deze manier kan ik zowel het verloop van verschillende ontwikkelingen schetsen, als inzicht geven in de complexiteit ervan. In de hoofdstukken zal ik de expliciete wetenschapstheoretische beschouwing op de daar beschreven ontwikkelingen achterwege laten, hetgeen echter niet betekent dat er geen wetenschapstheoretisch perspectief aan ten grondslag ligt en ook in te herkennen zal zijn.

Tot slot een opmerking over het gebruik van citaten en referenties. In dit boek staan veel citaten. Veel van deze citaten zijn ruimer dan alleen de kern. Hiervoor is gekozen, om naast de inhoud, ook iets mee te geven van de sfeer. Uiteraard zijn de citaten letterlijk overgenomen. Daar waar bewust iets in een citaat veranderd is, wordt dat expliciet aangegeven.

Uit de vorm van de referenties kan het type bron worden afgeleid. Referenties van de vorm: (van Rood, 1962), hebben betrekking op een artikel of een boektitel, terwijl het bij referenties met datum (van Rood, 2 augustus, 1962) een archiefbron betreft. Wanneer een citaat of referentie cursief is weergegeven, is deze informatie afkomstig uit een interview met de betrokkene. 

Tabel met parallelle ontwikkelingen in verschillende lijnen naast elkaar.

\begin{tabular}{|c|c|c|c|c|}
\hline & Hoofdstuk 2 & Hoofdstuk $_{3}$ & Hoofdstuk 4 & Hoofdstuks \\
\hline 1946 & $\begin{array}{l}\text { Oprichting van Bloedbank } \\
\text { Leiden en omstreken }\end{array}$ & & & \\
\hline $\begin{array}{l}1947 \\
1951\end{array}$ & $\begin{array}{l}\text { ontwikkeling van bloedbank- } \\
\text { praktijk naar economisch } \\
\text { model }\end{array}$ & 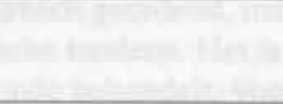 & 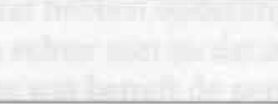 & \\
\hline 1952 & $\begin{array}{l}\text { Van Rood wordt hoofd Bloed- } \\
\text { bank }\end{array}$ & & & \\
\hline $\begin{array}{l}1953 \\
1957\end{array}$ & $\begin{array}{l}\text { Professionalisering van de } \\
\text { bloedbank onder toenemend } \\
\text { ruimtegebrek. } \\
1955 \text { start systematisch op } \\
\text { antilichamen testen van sera } \\
\text { van mensen met koorts na } \\
\text { bloedtransfusie }\end{array}$ & & $\begin{array}{l}1954 \text { Beschrijving agglu- } \\
\text { tinatietechniek door Dausset }\end{array}$ & 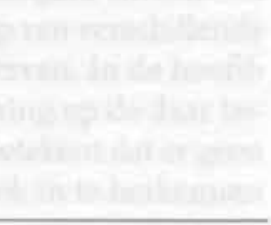 \\
\hline 1958 & $\begin{array}{l}\text { Onverklaarbare transfusie- } \\
\text { reactie van Mevr. } \mathrm{H} \text {. }\end{array}$ & & & $\begin{array}{l}\text { oprichting Instituut voor Ra- } \\
\text { diopathologie en Stralings- } \\
\text { bescherming }\end{array}$ \\
\hline 1959 & 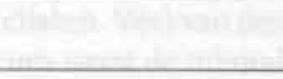 & 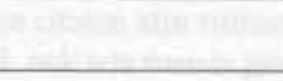 & & $\begin{array}{l}\text { vorming werkgroep been- } \\
\text { mergtransplantatie }\end{array}$ \\
\hline 1960 & $\begin{array}{l}\text { Start van structureel formeren } \\
\text { Leids donorpanel met } \\
\text { seminaristen uit Warmond }\end{array}$ & & & $\begin{array}{l}\text { eerste beenmergtransplanta: } \\
\text { tie in Leiden }\end{array}$ \\
\hline \multicolumn{5}{|l|}{1961} \\
\hline 1962 & Proefschrift Van Rood & & & \\
\hline 1963 & & $\begin{array}{l}\text { Wereldwijde gebruik van com- } \\
\text { puters ter 'herkenning' van } \\
\text { leukocytenantigenen }\end{array}$ & $\begin{array}{l}\text { Via Amos, eerste contacten } \\
\text { met NIH }\end{array}$ & $\begin{array}{l}\text { Sabatical Year in VS Van Rood } \\
\text { en bericht dat Starzl van Rolis } \\
\text { Royce een Volkswagen heeft } \\
\text { gemaakt }\end{array}$ \\
\hline 1964 & 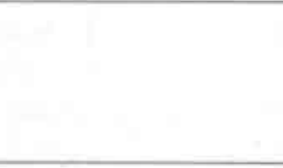 & $\begin{array}{l}\text { Eerste Histocompatibility } \\
\text { Conference and Workshop in } \\
\text { Durham, ter demonstratie en } \\
\text { vergelijking van veelheid aan } \\
\text { technieken }\end{array}$ & $\begin{array}{l}\text { Introductie microcytotoxici- } \\
\text { teitstest door Terasaki }\end{array}$ & $\begin{array}{l}\text { selectie eerste patiënten voor } \\
\text { niertransplantatie en start } \\
\text { bouw Isolatiepaviljoen }\end{array}$ \\
\hline 1965 & & $\begin{array}{l}\text { Tweede Histocompatibility } \\
\text { Conference and Workshop in } \\
\text { Leiden, ter vergelijking van de } \\
\text { verschillende antisera en 'her- } \\
\text { kende antigenen' } \\
\text { Leids Laboratorium wordt } \\
\text { 'WHO Reference Laboratory }\end{array}$ & $\begin{array}{l}\text { instelling van Serumbank } \\
\text { door NIH en ingaan contract } \\
\text { tussen Leiden en NIH }\end{array}$ & $\begin{array}{l}\text { Ingebruikneming Isolatie- } \\
\text { paviljoen }\end{array}$ \\
\hline 1966 & & $\begin{array}{l}\text { Groeiende concurrentie bin- } \\
\text { nen de Tissue Typing Club, } \\
\text { zich o.a. uitend in discussies } \\
\text { over nomenclatuur }\end{array}$ & $\begin{array}{l}\text { introductie microcytotoxicity- } \\
\text { tray (Terasaki-bakjes) }\end{array}$ & $\begin{array}{l}\text { Eerste niertransplantatie in } \\
\text { Leiden }\end{array}$ \\
\hline 1967 & - & $\begin{array}{l}\text { Derde Histocompatibility } \\
\text { Conference and Workshop in } \\
\text { Turijn, waar Eurotransplant } \\
\text { voorstel wordt gedaan. }\end{array}$ & $\begin{array}{l}\text { Invriezen leukocyten voor ge- } \\
\text { bruik in cytotoxiciteitstest } \\
\text { wordt mogelijk } \\
\text { Agglutinatietechniek verliest } \\
\text { (ook in Leiden) terrein }\end{array}$ & \\
\hline 1968 & z & $\begin{array}{l}\text { Leukocytenantigeen bena- } \\
\text { ming wordt vastgesteld op } \\
\text { 'HL-A' }\end{array}$ & & \\
\hline
\end{tabular}




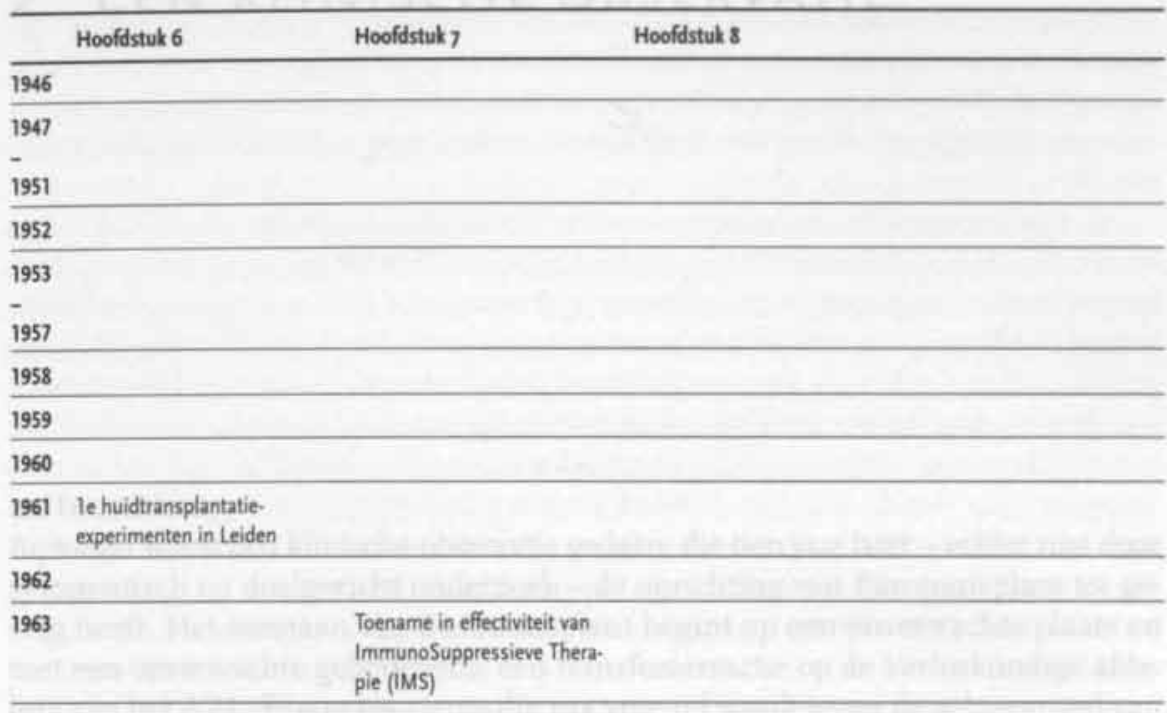

1964

1965 Tegenstrijdige berichten over resultaten huidtransplantatieexperimenten in Turijn en Durham

Start prospectief typeren Verwante donoren

1966 Verzoek om hulp bil prospectief typeren kadaverdonoren uit Minneapolis. Retrospectief onderzoek naar Matchingseffect en start Prospectief onderzoek naar Matchingseffect

1967 Start Prospectief typeren van kadaverdonoren

Start controverse over optreden Matchingseffect.
Onderzoek door TNO naar

gebruik kadavernieren

Opkomst perifere laboratoria

VS. Reis combinatie met standaardisering perifere laboratoria

Eurotransplant wordt opgestart

Leidse Typeringscursus (augustus) Start van verdeling Europa in regio's
Vanuit verschillende richtingen komt steun voor Eurotrans. plant initiatief

Naast ET worden ook andere gelijksoortige organisaties opgezet in Europa

Stabilisering en institutionali. sering Eurotransplant 



\section{EEN KLINISCHE OBSERVATIE}

\subsection{INLEIDING}

Bij toeval wordt een klinische observatie gedaan, die tien jaar later - echter niet door systematisch en doelgericht onderzoek - de oprichting van Eurotransplant tot gevolg heeft. Het ontstaan van Eurotransplant begint op een onverwachte plaats en met een onverwachte gebeurtenis: een transfusiereactie op de Verloskundige afdeling van het AZL. Een gebeurtenis die pas vreemd wordt tegen de achtergrond van de dan heersende opvattingen over bloedtransfusies.

In tegenstelling tot wat misschien verwacht zou worden, start dit boek over de ontwikkeling van transplantatiepraktijken niet met de transplantatie van organen ${ }^{1}$. Dit boek begint met een andere vorm van transplantatie, namelijk transplantatie van bloed, ofwel bloedtransfusie. De reden hiervoor is dat door problemen die bij bloedtransfusies optreden, een link wordt gelegd met de aanwezigheid van leukocyten in het bloed, waarmee een deel van de problemen verklaard en voorkomen kunnen worden. De link die wordt gelegd tussen leukocyten en die problemen nodigt uit tot nader onderzoek. Het optreden van de problemen kan immers verschillende oorzaken hebben. Een van de oorzaken van de problemen - zwangerschap als inductor van antilichaamproductie - blijkt antilichaam bevattende sera op te leveren waarmee verder onderzoek kan worden gedaan. Het verdere onderzoek in Leiden bestaat onder andere uit het bezien of er een systeem zit in de verschillende antigenen die op leukocyten worden aangetroffen. Dit wordt gedaan door, met behulp van een panel van leukocytendonoren en een computer, de vergelijkbaarheid van antisera te bepalen. In een later stadium wordt het panel gebruikt om de specificiteit van antisera en daarmee indirect van antigenen te identificeren. Het panel blijft hierbij essentieel voor de indirecte classificatie van een bepaald antigeen ${ }^{2}$. Hier start ik met het ontstaan van de bloedbank in Leiden en hoe daar een klinische observatie kon worden verricht, die als aanzet voor het opzetten van Eurotransplant kan worden beschouwd.

\subsection{De Bloedbank}

Met het 'in werking treden' van de bloedbank 'voor Leiden en omstreken', op 23 september 1946, wordt - zeer kort door de bocht gesteld - 'de eerste steen gelegd

I Later in dit boek zal beschreven worden hoe het verband met therapeutische transplantatie van organen wordt gelegd.

2 Op het belang van het panel en het indirecte karakter van het classificatiesysteem kom ik in het hier op volgende hoofdstuk uitgebreid terug. 
voor de bouw' van de internationale orgaanuitwisselingsorganisatie Eurotransplant. Deze bloedbank vormt de achtergrond van 'de observatie' in 1958 . Maar waaruit bestaat deze achtergrond, wat is de bloedbank die de grondlegger zal zijn voor Eurotransplant, wat wordt er gedaan en wat is haar geschiedenis? Kortom, waaruit bestaat de achtergrond die ervoor zorgt dat de observatie een 'bijzondere observatie' wordt?

In 1946 neemt de bloedbank de voorziening (productie en distributie) van verschillende hoeveelheden bloed, plasma, glucose en zoutoplossing ter hand. Niet langer hoeven de 'gebruikers' zelf zorg te dragen voor de aanwezigheid van deze zaken, daarvoor is nu een centrale instantie ingesteld. Bij deze instantie, de bij de polikliniek geneeskunde gevestigde bloedbank, kunnen nu kant en klare flessen worden afgehaald door iemand met een volledig ingevuld aanvraagformulier. De handleiding voor het geven van een transfusie, wordt gevoegd bij de brief die het van start gaan van de bloedbank meedeelt. Voordien waren bloedtransfusies blijkbaar een zeldzaamheid, aangezien de procedure blijkbaar moet worden uitgelegd. $\mathrm{Na}$ de transfusie moet het glaswerk naar de bloedbank worden teruggezonden, "voorzien van een volledig ingevuld transfusieverslag." (Anonymus, 23 september, 1946) ${ }^{3}$.

De bijgevoegde handleiding geeft weer hoe er over het functioneren van de bloedbank wordt gedacht. De bloedbank is in deze begintijd een bank naar economisch model, waar bloed het ruilmiddel is.

Met de meeste aandrang verzoek ik $U$ de dag, volgende op de dag der transfusie (uitgezonderd Zon- en feestdagen) om to uur minstens evenveel donores

(familieleden, kennissen) naar de bloedbank te sturen als door U fleschen bloed gebruikt zijn. (voor plasmafleschen minstens $2 x$ zooveel donores). (Anonymus,

23 september, 1946)

Doordat de bewaarduur van bloed nog erg kort is, kan de 'oppotfunctie' van de bank nog niet zo groot zijn. Met de bloedgroepen hoeft door de donorleveranciers geen rekening te worden gehouden. Daar zijn ze ook nauwelijks toe in staat. Over de rhesusfactor wordt nog niet gerept ${ }^{4}$. Dat er een economisch model van de bank wordt gehanteerd, blijkt uit de gehanteerde terminologie, zoals bijvoorbeeld in de zin: "Bij operatiepatiënten doet U goed reeds van te voren een saldo bij de bank te vormen." (Bloedbank/AZL, r949)(sic). Tot in de jaren '5o wordt geprobeerd de beschikbaarheid van bloed te realiseren, door het gebruik van bloed van de bloedbank in economische termen te gieten. Met voorgedrukte briefjes worden de gebruikers van bloed gewaarschuwd en gemaand hun saldo aan te vullen. Hun conto wordt zelfs geblokkeerd wanneer het debet langere tijd aanhoudt. De noodzaak van aanvullen van

3 Deze transfusieverslagen spelen een belangrijke rol in de aanloop naar Eurotransplant (Dit wordt in $\int 2.3$ besproken). Naast ruimte voor algemene medische gegevens over de toestand van de patiënt voor en na de transfusie, zijn op de transfusieverslagen ook een aantal symptomen voorgedrukt, die na een transfusie mogelijk kunnen optreden. Hierbij wordt tevens verzocht aan te geven hoeveel minuten na het begin van de transfusie de symptomen optreden. Waarschijnlijk komen deze problemen dus vaak voor. Op de eerste plaats staat 'Koude rilling', gevolgd door 'Temperatuursverhoging', twee kenmerkende symptomen van transfusiereacties. Deze verschijnselen treden op na een bloedtransfusie waarbij in het bloed van de ontvanger al antistoffen aanwezig zijn tegen witte bloedcellen van de donor. Bij het afbreken van die cellen in het zojuist getransfundeerde donorbloed komen koortsverwekkende stoffen vrij die de symptomen veroorzaken.

4 De rhesusfactor wordt ook niet gevraagd op de Transfusieverslag-kaart uit t949 (Bloedbank/AZL, 1949), al is deze factor reeds in 1940 ontdekt. 
het saldo staat ook op de aanvraagkaart voor bloed vermeld: "Uw debet bij de Bank moet aangezuiverd zijn vóór U opnieuw bloed kunt aanvragen." (Bloedbank/AZL, $1952)^{5}$.

Het aantal donoren dat bloed geeft is aanvankelijk bescheiden. Na een rustig begin in 1946 met ongeveer 500 donoren en 1216 donoren in 1947, neemt het aan. tal toe tot 4237 donoren in 1952. De twee daarop volgende jaren neemt dit aantal iets af tot iets minder dan 3900 donoren, maar vervolgens neemt het weer fors toe tot 6327 donoren in 1959 (Bloedbank anonymus, 1959). Maar niet alleen het aantal donoren is bescheiden, dit geldt ook voor de huisvesting, bezetting en middelen. De gehele bloedbank is gevestigd in één kamer van de interne kliniek, genaamd 'Kamer 7'. Daar wordt het bloed afgenomen, bewerkt en bewaard en vindt de administratie plaats. Het is niet ruim bemeten - de laboratoriumtafels en de twee afnamebedden nemen veel plaats in - maar het voldoet en de meeste apparatuur wordt geleend van andere afdelingen (van Rood, 1954).

Bloed wordt gebruikt als een therapeutisch hulpmiddel en de bloedbank is, aangezien zij het bloed uitgeven, naast verantwoordelijk voor het verzamelen van bloed, ook verantwoordelijk voor het probleemloos laten verlopen van bloedtransfusies. Vandaar dat om de bloedvoorziening en -toediening zo optimaal en effectief mogelijk te laten zijn, veel onderzoek wordt gedaan. Zo onderzoekt men in de loop van de tijd onder andere hoe bloed het best kan worden bewaard, zodat de beschikbaarheid wordt vergroot en doet men onderzoek naar de overlevingsduur van verschillende bloedbestanddelen in de ontvanger na transfusie, teneinde de meest efficiënte toedieningsschema's te kunnen bepalen van onder andere bloedplaatjes (trombocyten) en erythrocyten (van Rood, et al., 1957; Eernisse, et al., 1958). Daarnaast wordt onderzoek gedaan naar de overdracht van ziekten als hepatitis B. Een screeningsmethode die geïnfecteerd bloed opspoort, zou voorkomen dat patiënten via bloedtransfusies met deze ziekte worden besmet. Veiligheid is belangrijk voor de acceptatie en het aanzien van een techniek. Een bloedtransfusie die de toestand van een patiënt in eerste instantie verbetert, maar vervolgens weer ziek maakt op een ander gebied, zal niet geaccepteerd raken, vandaar dat ook in deze richting onderzoek wordt verricht 6 .

Begin jaren vijftig is de bloedbank nog een zeer kleinschalige onderneming. Maar met de groei van de vraag naar bloed groeit ook de behoefte aan ruimte voor afname en onderzoek. In de ruimte waar aanvankelijk drie mensen werken, kunnen zeven mensen hun werk niet meer naar tevredenheid uitvoeren. Het is te vol. Na het koloniseren van de gang bij Kamer 7, de wachtkamers en de Wc's, waar de centrifuges worden geplaatst, wordt voor de bloedbank eindelijk een nieuw gebouw gerealiseerd. Bloedafnemen op de gang werd toch niet meer aanvaardbaar gevonden. Aan de verhuizing zijn jaren van 'op elkaar zitten' voorafgegaan. De capaciteit van de bloed-

5 Aan deze werkwijze komt een eind, wanneer de taak van het verzamelen van bloed na verloop van tijd geleidelijk wordt overgenomen door de Bloedtransfusiedienst van het Rode Kruis. Deze dienst, die nauw samenwerkt met de bloedbank, neemt de donorwerving ter hand en houdt een register bij van alle donoren die regelmatig kunnen worden opgeroepen om bloed te geven.

6 Een deel van het vanuit de bloedbank verrichtte onderzoek betreft bet zoeken naar de mechanismen die het onderscheid tussen 'zelf' en 'niet-zelf maken, om de risico's te beperken en liefst problemen te voorkomen. Hiermee wordt de immunologie ook vanuit de bloedbanken mede vorm gegeven. Door inzicht te verwerven in de immunologische mechanismen, ontstaan mogelijkheden om met die mechanismen orm te gaan en te gebruiken. 
bank heeft geen gelijke tred gehouden met de vraag en de toename van het aantal toepassingen van bloedtransfusies.

Tot 1953 is het gebruik dat de dagelijkse leiding wordt toevertrouwd aan de jongste assistent van de afdeling Interne Geneeskunde. Met iedere nieuwe jongste assistent' wisselt dus de 'leiding', met als gevolg dat de bloedbank feitelijk wordt geleid door de laboranten. Een van deze jongst assistenten is Jon van Rood. Kort nadat hij in 1952 de bloedbank betreedt, neemt door het starten van thorax-chirugie de behoefte aan bloed sterk toe. Dit brengt verwerkings- en beschikbaarheidsproblemen met zich mee. Mede als gevolg hiervan, vinden de faculteitsbestuurders dat een reorganisatie noodzakelijk is en dat er in de leiding van de bloedbank meer continuiteit moet komen. Van Rood is op dat moment, als jongste assistent, de meest aangewezen persoon om voor die continuïteit te zorgen en wordt naar het Centraal Laboratorium van de Bloedtransfusiedienst (CLB) in Amsterdam gestuurd om zich verder op het bloedbankvak te oriënteren. Bloedbankarts is dan geen positie die algemeen geambieerd wordt. In het jaarverslag van i96 i schrijft Van Rood over de ontwikkeling van de bloedbank:

De commissie heeft zich steeds gerealiseerd, dat de taak van een bloedbankarts een bijzonder onaantrekkelijke is.

Het is niet zonder reden dat deze functie in minder officiële gesprekken als 'flessen-boer' wordt aangeduid. De problemen zijn voornamelijk

organisatorisch, de mogelijkheden in het zuivere bloedbankwerk zijn zeer

beperkt. (van Rood, 11 december, $196 \mathrm{r}$ )

Toch heeft hij het dan al negen jaar uitgehouden in dit 'bijzonder onaantrekkelijke' werk. Dit doet vermoeden dat er ook andere problemen dan alleen organisatorische opgelost dienden te worden en dat de mogelijkheden in het 'zuivere bloedbankwerk' minder beperkt waren dan hij in bovenstaand citaat schrijft. Dit negatieve beeld komt ook niet overeen met de ideeën van de Faculteitscommissie Bloedbank over het profiel van een bloedbankarts:

Verder was de commissie van mening, dat het uitgesloten was, een goed functionerende bloedbank te verkrijgen zonder dat de bloedbankarts competent was

A) wat betreft de organisatie van de bloedbank maar ook zonder dat hij op de hoogte was van en werkzaam in

B) bepaalde problemen van de immunologie

C) bepaalde problemen van het anaemie onderzoek (b.v. cytokinetica). (van

Rood, in december, 1961)

De commissie ziet dus wel wetenschappelijke taken in het 'zuivere bloedbankwerk'. De bedoeling van 'competentie in bepaalde problemen van de immunologie' is er op gericht die problemen het hoofd te bieden. En zo wordt deze taak ook opgevat, hetgeen blijkt uit de onderzoekingen die in die eerste jaren van Van Roods aanstelling zijn gedaan. Naast de gebruikelijke bloedgroepbepalingen en kruisproeven, wordt de bewerking van bloed ter hand genomen, wordt een begin gemaakt met onderzoek naar de leukocytenantilichamen, tracht men een oplossing te vinden voor het risico van hepatitisoverdracht via bloedtransfusies, enzovoort. Naast het reguliere bloedbankwerk, de verzorgende functie, wordt er dus wel degelijk gewerkt aan ontwikkeling. Er wordt onderzoek gedaan om de toepassing van bloedtransfusies betrouwbaarder, veiliger en efficiënter te maken. Het meer weten over de mechanismen die bij bloed(transfusies) aan het werk zijn, vergroot de mogelijkheid om 
problemen voor te zijn. Dit heeft tevens tot gevolg dat, door het beter kunnen anticiperen op problemen, het toepassingsgebied vergroot wordt. Hoe meer bestanddelen van bloed bekend en eventueel te scheiden zijn, des te meer aandoeningen kunnen worden behandeld. Zo ontwikkelt men - voortbouwend op eerdere observaties en onderzoek - behandelingen voor voordien onbehandelbare ziekten.

\subsection{Mevrouw $\mathrm{H}$.}

De betrekkelijk nieuwe techniek van het transfunderen van bloed, creëert een hoop vragen en problemen. Afgezien van alle logistieke problemen als bloedverzameling, opslag, distributie, toediening, etc., treden er ook medische problemen op. Een taak van de bloedbank is dan ook om de medische problemen te onderzoeken en te trachten er een verklaring voor te geven, zodat die problemen in de toekomst kunnen worden voorkomen. De transfusieverslagen zijn daarbij van groot belang, omdat zo feedback verkregen kan worden over het resultaat van de gegeven transfusies. Voor de bloedbank is het in handen krijgen van die verslagen daarbij een probleem. Voor de directe patiëntenzorg zijn die verslagen namelijk niet van belang, hetgeen de geneigdheid van de behandelend artsen om ze ingevuld en wel te retourneren, niet vergroot. En in tegenstelling tot de verplichting om voor vervangende donoren te zorgen, staat op het niet-retourneren van transfusieverslagen geen sanctie. Het wetenschappelijke belang en daarmee het indirecte belang voor de klinische patiëntenzorg, ligt veel verder verwijderd van de mensen die 'op zaal werken. Toch zijn deze gegevens voor de bloedbank van groot belang om een compleet beeld te krijgen van de resultaten van de transfusies. De bloedbankarts wordt weliswaar bij de meest ernstige problemen geroepen, maar de minder ernstige gevallen blijven vaak verborgen voor het bloedbankpersoneel en daarmee blijft een belangrijke bron van informatie voor een groot deel ontoegankelijk, wat de kwaliteit van de dienstverlening niet ten goede komt.

Transfusiereacties zijn in die tijd een veel voorkomende complicatie bij transfusies. Inmiddels is duidelijk dat dit verschijnsel optreedt nadat een patiënt meerdere bloedtransfusies heeft gehad (Dausset, 1954). Antistoffen tegen witte bloedcellen, de leukocyten, zijn verantwoordelijk voor de complicatie. Patiënten die deze reacties vertonen zijn door eerdere transfusies geïmmuniseerd tegen de leukocyten van de donoren (van Loghem, et al., 1956). De herhaaldelijke blootstelling aan lichaamsvreemd bloed, in het bijzonder aan de leukocyten, heeft hun lichaam aangezet om zich daar de volgende keer sterk tegen te verweren. Het gevolg is, dat een goed bedoelde bloedtransfusie snel teniet wordt gedaan door het immuunsysteem. Niet alleen voelt de patiënt zich heel beroerd, de behandeling als zodanig heeft ook een zeer beperkt effect.

Omdat de antistoffen specifiek gericht zijn tegen de leukocyten zou het verwijderen van de leukocyten uit het donorbloed een voor de hand liggende oplossing zijn (van Loghem, et al., I956). Dit is echter makkelijker gezegd dan gedaan. Om dit te doen zijn de kennis, noch de middelen aanwezig. Het bewerken van bloed, anders dan het scheiden van plasma en vaste bestanddelen, wordt nog niet gedaan. Nadat echter leukocyten als het problematische bestanddeel in het donorbloed zijn geïdentificeerd, is duidelijk dat bloed een samengestelde vloeistof is, waarin verschillende, van elkaar te scheiden, bloedcellen zitten. De volgende casus laat zien tot welke klinische handelingen deze ideeën leiden.

Eens per maand komt Meneer R. naar de bloedbank. Deze man lijdt aan een 
aplastische anaemie en aanvulling van zijn rode bloedcellen is iedere maand noodzakelijk. Het feit dat hij iedere maand een bloedtransfusie krijgt, is op zich niet spectaculair, wel de transfusiereacties die hij als gevolg van die transfusies keer op keer vertoont. Het vooruitzicht om iemand iedere maand weer hondsberoerd en rillend van de koorts in een schuddend bed te zien liggen, motiveert tot het zoeken van een oplossing. Door het CLB wordt bevestigd dat in het bloed van meneer $\mathrm{R}$. antistoffen zitten die reageren met de leukocyten van een groot aantal gezonde donoren. Het enige dat de bloedbank dan te doen staat is het verwijderen van de leukocyten uit het te transfunderen bloed. Voor de eerste poging om leukocytenarm bloed te maken wordt het benodigde materiaal bij elkaar gezocht. Tijdens de overdracht van nacht- naar ochtenddienst, 'leent' Van Rood leverbiopsienaalden van de interne afdeling (van Rood, 1993). Dan gaat hij naar het laboratorium voor de stofwisselingsziekten waar een geschikte centrifuge staat, centrifugeert het donorbloed en zuigt vervolgens de leukocyten af, die als een wittig laagje op de rode bloedcellen 'drijven'. Wanneer blijkt dat meneer R. geen transfusiereactie meer krijgt wanneer hij dit leukocytenarme bloed krijgt, is dit een bevestiging van de ideeën van Van Loghem, zoals Van Rood later zegt (van Rood, 21 december, 1993) 7 . Het verwijderen van de leukocyten uit het donorbloed voorkomt dus het optreden van een transfusiereactie.

Niet iedereen heeft hier echter direct baat bij. Het verwijderen van de 'buffycoat's is nog geen routineprocedure. Leukocytenarm bloed maken is tijdrovend en de noodzakelijke apparatuur is niet direct beschikbaar. $\mathrm{Zo}$ is in het laboratorium van de bloedbank geen centrifuge voor flessen aanwezig. Centrifugeren is echter niet de enige methode om de witte bloedcellen te scheiden van de rest. Het 'volle' bloed kan ook worden vermengd met 'Dextran'. Een stof die maakte dat de rode bloedcellen, de erythrocyten, in een cylindervorm - als munten - aan elkaar vast gaan zitten. Dit noemt men het 'geldroleffect'. Het zich verenigen tot 'geldrol' verhoogt de daalsnelheid in het plasma ten aanzien van de niet geklonterde leukocyten. Na verloop van tijd zijn dan de rode bloedcellen uitgezakt en kan er een plasmalaag met daarin vooral leukocyten worden verwijderd. Op deze manier witte bloedcellen verwijderen is echter zeer tijdrovend. Eenmaal begonnen kan de procedure niet meer worden onderbroken omdat de leukocyten op een gegeven moment weer zover zakken, dat ze opnieuw mengen met de erythrocyten. Het verwijderen moet dus gedaan worden na een bepaald aantal minuten. Deze manier van bloedbewerking houdt het laboratoriumpersoneel af van andere (tijdrovende) taken. Leukocytenarm bloed wordt dus alleen gemaakt voor diegenen die anders zeker een transfusiereactie zullen krijgen, ieder ander die dat behoeft krijgt 'vol bloed' van een geschikte bloedgroep toegediend.

In 1958 krijgen de meeste patiënten dus bloed waar de leukocyten niet uit zijn verwijderd. Vaak gaat dit goed, maar toch treden regelmatig transfusiereacties op. Meestal is de oorzaak van de transfusiereactie eenvoudig te herleiden, maar bij een vrouw op de verloskundige afdeling blijkt dit niet mogelijk en wordt een andere verklaring gezocht voor het ontstaan van de leukocytenantilichamen.

7 In zijn eigen woorden:

... dan ging ik met bloed wat we afgenomen hadden naar het laboratorium en draaiden dat af en zogen dan de buffycoat af, de witte cellen er af en gaven dat aan die meneer $R$. en toen was de reactie weg. Dus dit is een van de cerste bevestigingen van het werk van Van Loghem geweest. (van Rood, 21 december, 1993)

Overigens claimen Payne en Dausset dat zij de relatie tussen transfusiereacties en leukocyten eerder hebben gezien dan Van Loghem (van Rood, 11 augustus, 2000).

Zo wordt het na centrifuge verschenen wittige laagje leukocyten genoemd. 
On April 14, 1958, Mrs H., a mother of four children, was delivered of twins.

Soon afterward she had postpartum bleeding that led to pre-shock and she was transfused. Her blood pressure rose again, but a few hours later the patient had shaking chills, felt nauseated, and collapsed. Thanks to Van Loghem's findings we realized that the patient probably had suffered from a nonhemolytic transfusion reaction caused by leukoagglutinins. Strong leukoagglutinins were indeed found, but that in itself confronted us with a question: Where and when the patient had received the blood transfusions? Blood transfusions were thought at that time to be the only inducers of leukocyte antibody formation. A report had even been published that no antibodies had been found in 100 women with previous pregnancies. Leiden is a small town with only one Blood Bank, and the patient was born in Leiden and lived there, but George Eernisse could find in the Blood Bank no record of previous transfusions. When we went back to the patient to ask where she had received blood transfusions she looked at us in horror and said: This was the first blood transfusion I have ever received, and as far as I am concerned, it will be the last. (van Rood, r993) De ideeën over de oorsprong van de transfusiereactie worden weliswaar bevestigd, want er worden leukocytenantilichamen gevonden, maar hoe zijn die ontstaan? Voor zover bekend zijn meerdere bloedtransfusies de enige veroorzakers van leukoagglutininen vorming. Men weet van geen andere aanleiding voor het immuunsysteem om leukocytenantilichamen te gaan vormen. De laboratoriumgegevens van Mevrouw H. kloppen weliswaar met het klinische beeld, maar waar de antistoffen in haar bloed vandaan komen is een raadsel. De behandelend artsen kunnen in het bloedbankarchief geen eerdere transfusies vinden, terwijl de vrouw haar hele leven al in de regio woont en de bloedbank een uitgebreid archief heeft van transfusieverslagen. In dit archief wordt informatie verzameld over alle ontvangers, donoren en de resultaten van de gegeven bloedtransfusies. Er is echter geen spoor te vinden van aan mevrouw. $H$. gegeven transfusies. Was dit wel het geval geweest, dan zou er aan dit specifieke geval verder geen bijzondere aandacht meer hoeven te worden besteed. Maar omdat de bloedbankartsen die 'zekerheid' niet krijgen, vragen ze aan mevrouw zelf waar zij de veronderstelde transfusies heeft gekregen. Mevrouw H. zegt echter nooit eerder een transfusie te hebben gehad.

De ontkenning van Mevrouw $\mathrm{H}$. werpt een geheel nieuw licht op het ontstaan van de leuko-agglutininen. Hoe kan het dat iemand die nooit een transfusie heeft gehad toch leuko-agglutininen produceert? Wat kan in dit geval het vormen van antilichamen veroorzaken? Andere inductiewijzen zijn niet bekend. Van Loghem, hoofd van het CLB, heeft zwangerschapsimmunisatie al eens 'antilichaam inductie' genoemd, maar daarmee bedoelde hij niet de immunisatie tegen leukocyten. Het fenomeen rhesusantagonisme is bekend en ook het feit dat antistoffen gevormd kunnen worden tegen bijzondere bloedgroepen. Daarom houden Van Loghem c.s. in een artikel een pleidooi voor het altijd op de juiste wijze doen van een kruisproef bij patiënten die transfusies hebben gehad of door zwangerschapsimmunisatie (incomplete) antilichamen hebben gevormd (van Loghem, et al., 1956). Het is dit artikel van Van Loghem dat de ruimte voor een mogelijke verklaring voor de transfusiereactie van mevrouw $H$. creëert ${ }^{9}$. Mevrouw $H$. was al moeder van vier kinderen

In weerwil van een eerder gepubliceerd artikel van Dausset, waarin zwangerschap als mogelijke oorzaak 
en is nu bevallen van een tweeling, heeft wel leuko-agglutininen in haar bloed, maar heeft noch volgens haar zelf, noch volgens de beschikbare gegevens, ooit een bloedtransfusie gehad. Bovendien blijken deze antistoffen gericht tegen de leukocyten van de vader van haar kinderen. Daarmee lijkt zwangerschap dus ook de vorming van tegen leukocyten gerichte antilichamen te kunnen veroorzaken.

Om het idee van zwangerschap als antilichaaminductor verder te onderzoeken gaat Van Rood (c.s.) weer naar Van Loghems Centraal Laboratorium van de Bloed Transfusie Dienst in Amsterdam. Het CLB ontvangt namelijk bloedmonsters vanuit het gehele land. Die bloedmonsters worden onderzocht om verschillende redenen en de gevonden resultaten (en mogelijk ook delen van de bloedmonsters zelf) worden bewaard. In de archieven van het CLB vinden ze een vergelijkbaar geval als mevrouw H.: een vrouw die nog nooit een bloedtransfusie heeft gehad, maar wel antilichamen tegen leukocyten in haar serum heeft. Dit geval is onopgemerkt gebleven. Van Loghem en zijn medewerkers zijn meer georiënteerd op trombocyten ('bloedplaatjes'), dan op leukocyten. Het vinden van een vergelijkbaar geval is voor het CLB geen reden zich te storten op de leukocytenserologie. Zo althans komen ze dat overeen met de Leidse onderzoekers. Het CLB zegt toe vast te zullen houden aan trombocytenserologie, omdat zij het geval onopgemerkt hebben laten passeren ${ }^{10}$.

In Leiden zelf wordt ook verder gezocht naar versterkingen voor het idee van zwangerschap als antilichaaminductor. Sinds januari 1955 zijn de sera van mensen die koorts hadden gekregen na een bloedtransfusie systematisch op de aanwezigheid van leukocytenantilichamen getest. Het bloed van mevrouw $\mathrm{H}$. op leukocytenantilichamen onderzoeken is dan ook een routinehandeling (van Rood, et al., 1959; van Rood, et al., 1959). Ook in deze gegevens van de afdeling verloskunde wordt gezocht naar een eerder geval dat dit idee zou kunnen bevestigen. En ook hier worden vrouwen gevonden met antilichamen, zonder dat zij ooit eerder een transfusie hebben gehad. Van de verloskundige afdeling zijn, naast deze gegevens - ook in de diepvries - van 40 vrouwen sera bewaard, met daarin anti-A, anti-B en/of anti-D antilichamen. Deze sera worden nu ook getest op aanwezigheid van leukocytenantilichamen. Gekeken wordt of deze sera een of meer van twaalf leukocytensuspensies agglutineren: de cellen doet samenklonteren. Het samenklonteren van leukocyten wordt namelijk veroorzaakt doordat de antilichamen uit het serum aan antigenen op de cellen binden. Uit deze diepvries komen zo nog vier gevallen die allen in meerdere of mindere mate met de leukocyten van het donorpanel - een aantal mensen die steeds als 'leukocyten-leveranciers' dienen -, reageren. Deze zes vrouwen hebben gemiddeld zeven zwangerschappen doorgemaakt, tegen de vrouwen zonder antilichamen gemiddeld drie. Dat brengt hen tot de volgende, voorzichtige conclusie:

Thus we believe that leucocyte antibodies can occur in the sera of pregnant women who have never received a blood transfusion. It is possible that these

van antilichaam productie tegen leukocyten juist wordt uitgesloten. Zoals Dausset schrijf:

We have not had the opportunity of observing the relation between pregnancy and the appearance of leukoagglutinins. (Dausset, et al., 1954)

10 Dr. Aad van Leeuwen, sinds 1951 verbonden aan de bloedbank als (hoofd)analiste, zegt in 1994 hierover: Ze wisten niet wat ze weggaven, HLA is nu verschrikkelijk groot geworden. (van Leeuwen, 17 oktober, 1994) 
antibodies are the result of immunization from previous pregnancies, and it cannot be excluded that these antibodies may be specific to certain blood groups.

(van Rood, et al., 1958)

De wereld draait echter niet om Leiden. Geheel onverwacht, ongeveer op hetzelfde moment, trekken anderen dezelfde conclusie op basis van geheel ander onderzoek. Rose Payne en Mary Rolfs, verbonden aan de Standford University School of Medicine, San Francisco, California, verrichten al enige tijd systematisch onderzoek naar vrouwen die meerdere zwangerschappen hebben gehad. Hun onderzoek laat eveneens zien, dat zwangerschap tot productie van antilichamen kan aanzetten ${ }^{11}$. In hun artikel schrijven ze niet alleen dat leukocytenantilichamen ook door zwangerschap kunnen worden geïnduceerd, maar tevens dat de zo ontstane antilichamen de leukocyten van de pasgeborene en diens (genetische) vader agglutineren (Payne, et al., I958). In Leiden is de klinische indicatie - het optreden van een transfusiereactie de indicatie voor de aanwezigheid van leuko-agglutininen. Payne en Rolfs verzamelen hun sera door verloskundepatiënten te selecteren op het criterium dat zij vier of meer zwangerschappen hebben gehad ${ }^{12}$.

Het directe belang van deze bevindingen en een gebruiksmogelijkheid van de aldus gevonden sera, beschrijven Payne en Rolfs ook:

A most interesting possibility arises from the finding of leukoagglutinins in nontransfused women. This particular kind of antileukocyte serum may provide the tool necessary for the separation to the different human leukocyte antigens.

The sera for distinct and separate leukocyte types has been attempted with limited success. The lack of clear-cut results in the past may have been due to the fact that sera from persons with multiple transfusions were employed. The use of leukoagglutinins from maternal sera should provide better results, for the antibodies will have been derived from a more limited antigenic stimulus, i.e., the husband's leukocyte factors as they are inherited by the children. (Payne, et al., 1958 )

Mogelijk dat antisera die zijn ontstaan door zwangerschap het noodzakelijk instrument vormen om meer over de leukocytenantigenen te weten te komen. Payne en Rolfs denken dat naar mate er meer bekend is over de bij bloedtransfusies complicatie veroorzakende mechanismen, de mogelijkheden om die complicaties te voorkomen, ook zullen toenemen. Zij zien dit op de volgende manier voor zich:

If the leukocytes could be typed, then febrile transfusion reactions might be prevented by proper matching of leukocytes rather than by removal of the leukocytes from the donor blood. This latter method is more wasteful of time, equipment and blood than a typing procedure would be. (Payne, et al., I958) Om 'proper matching' als mogelijke oplossing voor transfusiereacties te kunnen bedenken, moeten zij een systeem van leukocytenantigenen voor ogen hebben, dat

11 Overigens had in een eerder onderzoek van Payne al een aanwijzing voor de mogelijkheid van foetale stimulatie gevonden kunnen worden. Een patiënte met 'refractory anemia in pregnancy' had leukoagglutininen zonder eerdere bloedtransfusies. Het bestaan van die antilichamen werd echter niet toegeschreven aan de zwangerschap maar aan de haematologische afwijking, waar in dat onderzoek naar gezocht werd. Hierbij moet ook opgemerkt worden dat de leukoagghtininen post partum verdwenen (Payne, 1957).

12 Van de 144 op deze manier gevonden vrouwen, blijken er 25 leukocytenantilichamen in hun bloed te hebben. Van deze 25 hebben 7 vrouwen ooit bloedtransfusies gehad. Zo blijven er nog I 8 vrouwen over waarbij de enige verklaring voor de aanwezigheid van leukoagglutininen de zwangerschap kan zijn. 
lijkt op het ABO-systeem ${ }^{13}$. Een eenvoudig systeem, met slechts enkele antigenen, zou perspectief bieden op het gebied van matching, zoals dat bij het $\mathrm{ABO}$-systeem al praktijk is.

Zo blijkt dat verschillende groepen, op verschillende plaatsen in de wereld en op verschillende manieren, tot dezelfde conclusie over het ontstaan van leukocytenantigenen komen. Klinische vragen zijn hiermee in het laboratorium opgelost: het optreden van de transfusiereactie bij mevrouw $\mathrm{H}$. is verklaard. En Payne en Rolfs schetsen daarbij mogelijke toepassingen van deze kennis, terwijl in Leiden de daarvoor benodigde en geschikte antisera al gevonden zijn. Klinische toepassingen lijken niet lang op zich te hoeven laten wachten.

\section{4 'LEUCOCYTE GROUPING"4}

Voor de mogelijke oplossingen zoals Payne en Rolfs die zien, zoals het matchen van bloedtransfusies, is nog veel werk nodig. Vele vragen over de leukocytenantigenen zijn nog niet of slechts gedeeltelijk beantwoord. Eén van de eerste vraagstukken die om beantwoording vragen, is of de antistoffen die onder invloed van zwangerschap worden gemaakt en dezelfde verschijnselen oproepen als de antistoffen gemaakt na meerdere bloedtransfusies, ook werkelijk van dezelfde aard zijn. Van Rood wil hierover meer zekerheid, alvorens de antistoffen 'iso-antilichamen' te noemen ${ }^{15}$. Daarnaast bestaat er onduidelijkheid over het aantal verschillende antistoffen in antisera en moet de reproduceerbaarheid van de gebruikte laboratoriumtechnieken verhoogd worden. Al dit werk neemt in 1958 een aanvang, als gevolg van de observatie bij mevrouw $\mathrm{H}$.

Agglutinatic en absorptic zijn de belangrijkste technieken die gebruikt worden om op bovenstaande vragen een antwoord te krijgen. Deze technieken kunnen complementair genoemd worden. Bij agglutinatie wordt gekeken naar het reageren van antilichamen met (antigenen op) leukocyten, bij absorptie wordt gebruik gemaakt van de mogelijkheid van leukocytenantigenen om aan antilichamen te binden en ze vervolgens uit het serum te verwijderen. Het serum wordt daartoe vermengd met leukocyten waarna het een bepaalde 'inwerkperiode' of 'incubatieperiode' krijgt. Vervolgens wordt de suspensie gecentrifugeerd en worden de leukocyten, met de eventueel daaraan gebonden antilichamen, uit het serum verwijderd. Of deze behandeling daadwerkelijk de antilichamen uit het serum heeft gehaald, kan vervolgens getest worden door te kijken of het 'gezuiverde' serum de leukocyten nog agglutineert. Er zou geen agglutinatie meer plaats mogen vinden. Met deze methoden laat men zien dat de antilichamen, ofwel de leuko-agglutininen, specifiek zijn voor bepaalde leukocyten.

The following observations are in favour of the concept that these

13 Systeem van erythrocytenantigenen dat Karl Landsteiner begin zoe eeuw heeft beschreven. De antigenen A en B kunnen aan- dan wel afwezig zijn. Mogelijke bloedgroepen zijn dan: A; B; AB en O. Bloedgroep $O$ heeft niet de antigenen, maar wel de antilichamen die met A en B reageren. het gevolg is dat iedereen bloed van dezelfde bloedgroep kan krijgen, maar daarnaast iemand met bloedgroep $O$ als universele donor kan optreden, terwijl lemand met bloedgroep AB bloed van iedere donor kan ontvangen (vooropgesteld dat de Rhesusfactor overeenkomt). (De toevoeging positief of negatief slaat op de aan- of afwezigheid van het Rhesus-antigeen)

14 (van Rood, 1962)

15 Iso-antilichamen zijn antilichamen gericht tegen de leukocytenantigenen van een ander individu van dezelfde soort en niet gericht tegen de leukocyten van de persoon zelf of een exogeen antigeen. 
leucocyteagglutinins are true antibodies against leucocytes.

I. The agglutinins can be absorbed specifically, i.e. they can only be absorbed with leucocytes which give a positive agglutination test.

2. The absorption is quantitative, i.e. the amount of leucocytes needed for the absorption correlates with the titre ${ }^{16}$ of the agglutinin and the amount of serum. ... (van Rood, et al., 1958)

De leukocyten van de 'zwangere' vrouwen reageren in geen van de gevallen met hun eigen serum, maar wel met de leukocyten uit het bloed van hun echtgenoot. Het eenduidig bewijs is volgens de onderzoekers, hiermee geleverd.

From these observations it is concluded that pregnancy in itself can stimulate the formation of antibodies directed against antigens present in the leucocytes of the husband, and are therefore to be considered as iso-immune antibodies.

(van Rood, et al., I958)

In Leiden gaat men dan verder met het onderzoeken van het antigeensysteem van de leukocyten. Daarvoor worden de in de diepvries 'gevonden' antisera getest tegen honderd verschillende mensen, afkomstig 'van het terrein' van het $A Z L^{17}$ Hierbij wordt eerst van ieder serum bekeken of het leukocyten agglutineert, om vervolgens met de positief reagerende sera verder te werken. Deze sera worden nu niet alleen geabsorbeerd om te laten zien dat ze specifiek met bepaalde leukocyten reageren, maar ook om te kijken of ze reageren met leukocyten van verschillende personen. De sera blijken allemaal in verschillende mate te reageren met de leukocyten van het donorpanel.

Payne en Rolfs schrijven het gebrek aan succes bij het leukocytenonderzoek in het verleden toe aan het gebruik van antisera afkomstig van 'multitransfusees' 18 . Wanneer in ieder serum altijd een groot aantal verschillende antistoffen zitten, blijft het erg moeilijk om leukocytenantigenen te identificeren. Dausset had getracht met door bloedtransfusie (van één donor) geinduceerde antilichamen leukocytenantigenen te herkennen, maar verder dan één antigeen ("MAC"19) was hij niet gekomen (Dausset, r958). Ook in Leiden komen ze tot de conclusie dat de antisera die door zwangerschap geïnduceerd worden, door het beperkte aantal antigenen waartegen antistoffen worden gemaakt, wel eens betere antisera zouden kunnen zijn dan waar tot dan toe mee gewerkt werd om het antigeensysteem mee te doorgronden.

Absorption experiments showed that two of the sera contained at least two antibodies or perhaps more, while one serum might contain only one antibody. The antigen recognized with this antibody had a frequency of about $\mathrm{n} \%$. We had

16 De 'titer' is een maat voor concentratie van antistoffen in het serum. Deze maat is, in dit geval, gebaseerd op het vermogen van een serum om na verdunning nog te reageren met de leukocyten waar het voor verdunning ook mee reageerde.

17 Mevrouw van Leeuwen vertelt hierbij waar de bewaarde monsters van afkomstig waren.

Toen zijn we begonnen. We hadden het geluk dat we met dat rhesusantagonisme bezig waren geweest, begin vijfiger jaren. We hadden een diepvries vol met sera van zwangere vrouwen, .... Toen zeiden we: Als we nou met die sera cens beginnen, we hebben ze gewoon in de diepvries, die gaan we eens testen tegen honderd verschillende mensen, hier van het terrein. (van Leeuwen, 6 september, 1994)

18 Ter herinnering:

The lack of clear-cut results in the past may have been due to the fact that sera from persons with multiple transfusions were employed. (Payne, et al., r958)

19 De leukocyten van drie donoren uit de groep die hij gebruikte, agglutineerden niet met zijn antiserum. Daaruit concludeerde Dausset dat deze drie donoren dit antigeen niet bezaten. Als naam voor het zo gevonden antigeen gebruikt hij de eerste letters van de namen van die drie niet-reagerende donoren. (Brent, 1997) 
several sera, which gave positive results in about $60 \%$. It is possible that one of them identified the first leucocyte antigen described, the antigen Mac of

Dausset. To minimise the chance of confusion with the erythrocyte antigens, we propose to call our antigen big II and its allele small 2. (van Rood, et al., 1958) De mogelijkheid dat er toch meerdere antistoffen in het veronderstelde monospecifieke serum zitten, wordt door Van Rood nog niet uitgesloten, want het kan zijn dat er een antistof in zit dat gericht is tegen een antigeen dat bij maar zeer weinig mensen voorkomt en in ieder geval niet bij de mensen in het panel. Dit doet echter niet af aan het idee dat de agglutinerende sera die door zwangerschap zijn veroorzaakt, in ieder geval beter bruikbaar lijken te zijn voor vervolgonderzoek dan de positieve sera die na meerdere bloedtransfusies zijn gevormd. Die sera zullen namelijk verschillende antistoffen bevatten die door de leukocyten van verschillende donoren zijn geïnduceerd. De antistoffen in het bloed van de 'zwangere vrouwen' zijn de reactie op de aan het kind doorgegeven leukocytenantigenen van één vader. Daarmee is de antigene bron veel beperkter dan bij antistoffen door herhaalde bloedtransfusies en zullen er veel minder verschillende antilichamen in die sera aanwezig zijn.

Nevertheless, cross-absorption tests suggest that the sera from pregnant women in general contain a considerably smaller number of different leucocyte antibodies than the sera from patients with repeated transfusions. (van Rood, et al., 1959)

Deze bevindingen voeden het idee dat er sera zouden kunnen zijn die maar enkele of zelfs maar één antistof tegen leukocyten bevatten. Ook wordt er enige gelijkenis gezien met andere antigeensystemen, hetgeen de plausibiliteit van een Teukocytenantigeensysteem' vergroot.

Toch mogen wij vaststellen, dat er leukocyten-bloedgroepen bestaan en dat een enkele ervan herkenbaar is door middel van het serum van zwangere vrouwen.

De situatie lijkt meer of minder analoog aan de situatie met de rhesus:

antistoffen, met dit grote verschil, dat er bij de leukocyten geen antigeen schijnt

te bestaan dat in vergelijking met de andere antigenen zo duidelijk sterker

antigeen is, zoals dit het geval is met het D-antigeen in het rhesus-systeem. (van Rood, et al., 1959)

Aan dit 'leukocyten-bloedgroepen'-onderzoek wordt in Leiden een vervolg gegeven door verdere samenwerking te zoeken met de verloskundige afdelingen van het AZL en het Elisabeth Ziekenhuis (Eernisse, et al., 28 april, 1958). Dit zijn de aangewezen plaatsen om meer vrouwen te vinden met zwangerschapsgeinduceerde leukoagglutininen in hun bloed. De nauwe banden tussen - het laboratorium van - de bloedbank en de klinieken in Leiden zijn opnieuw op een bijzondere manier gunstig. De klinieken hebben een lokale verzorgingsfunctie en dus zullen de te onderzoeken vrouwen ook in de directe omgeving wonen. Een voordeel dat in de CLBonderzoeks-situatie ontbreekt. Voor hen is het niet zo eenvoudig om 'grote' hoeveelheden bloed van een specifiek persoon te verkrijgen om verder laboratorium onderzoek mee te kunnen doen. Een andere, maar ook bijzonder gunstige bevinding is, dat blijkt dat zelfs na vele jaren er nog steeds antilichamen in het bloed van vrouwen aanwezig zijn, terwijl bij getransfundeerde patiënten de hoeveelheid leukoagglutininen na verloop van tijd afneemt. Door dit fenomeen kunnen vrouwen die al jaren geleden hun laatste zwangerschap hebben doorgemaakt, nog steeds in aanmerking komen als potentiële serumdonor. Dit betekent ook dat, wanneer een vrouw 
bereid blijft om bloed te geven, zij een stabiele bron van een bepaald antiserum is.

De verschillende initiatieven om vrouwen te screenen op leukocytenantilichamen leveren meerdere positief reagerende monsters op. Ook aan de 'nieuw gevonden vrouwen' wordt - naast aan de reeds gevonden patiënten - gevraagd om bloed te geven, waarmee het onderzoek kan worden uitgebreid. Het aantal positief reagerende, geschikte sera groeit. De bijzondere manier waarop de antistoffen zijn opgewekt, blijkt inderdaad nieuwe mogelijkheden voor onderzoek te bieden.

The leucocyte antibodies stimulated by pregnancy have the evident advantage for the investigation of leucocyte groups of having been formed in response to a known and constant source of antigen, whereas the specificity of leucocyte antibodies stimulated by frequent blood transfusions appears to be much more complex. (van Rood, et al, 1959)

De verwachting is dat met behulp van deze sera individuele antigenen op leukocyten gemakkelijker te identificeren zullen zijn. Naast 'MAC' zullen dan andere leukocytenantigenen komen te staan. Al snel denkt men echter aan een ingewikkelder systeem dan de tot dan toe bekende bloedgroep-systemen. Met de gebruikte technieken en het beperkte aantal verschillende leukocytensuspensies dat wordt gebruikt, wordt zichtbaar dat het een ingewikkeld systeem moet zijn.

From the above, it will be clear that it is not as yet possible to present a definite system of leucocyte groups. It can only be said that this system must be extremely complex. Of the sera discussed here, there were only 2 that were probably identical. [van de II verschillende sera, MD] (van Rood, et al., 1959) Bij 'uiterst complex' moet echter niet gedacht worden aan honderden verschillende antigenen. Dat het aantal van twee 'mogelijk identieke sera', op een totaal aantal van elf, weinig wordt gevonden, duidt erop dat het gerelateerd wordt aan 'eenvoudige systemen', als het ABO- of het Rhesus-systeem. Tegen die achtergrond is twee (mogelijk) identieke sera weinig, maar wanneer er al identieke sera zijn bij een totaal van elf, kan het systeem toch ook weer niet zo complex zijn, dat het niet te doorgronden is.

De verwachte, maar beperkte complexiteit van het leukocytenantigeensysteem, inspireert tot verder onderzoek. Hoe meer bekend wordt over de specifieke antigenen die dit systeem vormen, des te groter wordt de kans dat deze kennis omgezet kan worden in praktische toepassingen, zowel binnen, als buiten de kliniek.

Although there is still much that is obscure about the leucocyte groups, they

may eventually be of some use in forensic medicine and in bone marrow

transplantation. (van Rood, et al., 1959)

Het idee van beenmergtransplantatie wordt mede ingegeven door lokale ontwikkelingen. In anticipatie op de mogelijkheid van een nucleair ongeval wordt het Instituut voor Radiopathologie en Stralingsbescherming (IRS) opgericht ${ }^{20}$. Vanwege dit instituut wordt onderzoek verricht naar de behandeling van stralingsslachtoffers en worden de voorzieningen getroffen om deze patiënten zo nodig te kunnen behandelen aan de gevolgen van blootstelling aan radioactiviteit. Zo komt het dat vanuit dit instituut bij de bloedbank in Leiden - en later bij de dan opgerichte vakgroep Immunohaematologie - onder andere onderzoek naar beenmergtransplantatie wordt gedaan. 
The use and abuse of ionizing radiation have stressed the need for research and development of bone-marrow and platelet transfusion. After total body irradiation bleeding is an important cause of death. The haemorrhages are due to a thrombocytopenia which can be corrected by transfusion of viable platelets. (Bosch, et al., I96I)

Het leukocytenantigeenonderzoek wordt zo verbonden met het onderzoek ten bate van stralingsslachtoffers. Een verbinding die - zoals later zal blijken - van groot belang is voor het opzetten van Eurotransplant.

Intussen gaat in Leiden het zoeken naar bruikbare antisera door. Er worden zeer vele agglutinatie-experimenten gedaan om te kijken of er een agglutinatiereactie plaats vindt. De agglutinerende sera worden geselecteerd uit een totaal van meer dan 2000 sera. Daarnaast worden nog eens meer dan Iooo sera, afkomstig van patiënten van de cardiologische afdeling en van donoren van de bloedbank, bekeken op de mogelijke aanwezigheid van antilichamen. Leukocyten van donoren van de bloedbank worden gebruikt om deze aanwezigheid vast te stellen (van Rood, 1962; van Rood, 1962 ). In totaal worden 67 antisera gevonden, bruikbaar voor verder onderzoek naar de leukocytenantigenen.

De 67 op deze manier gevonden agglutinerende sera van 'zwangere vrouwen', worden successievelijk 'ingezet' met de leukocyten van roo donoren met bloedgroep O. Deze lijst van donoren - het donor panel - bestaat uit de onderzoekers zelf en ander personeel van het ziekenhuis (van Rood, I962). Door te proberen de sera te laten reageren met de leukocyten van steeds dezelfde donoren, wordt de leukocytenantigeen-variabele in ieder geval constant gehouden. De sera kunnen hierdoor met elkaar worden vergeleken. Vanwege de niet optimale reproduceerbaarheid van de tests, doet men voor iedere leukocyten-serumcombinatie meerdere bepalingen. Pas daarna wordt besloten of er al dan niet een agglutinatiereactie heeft plaatsgevonden (van Rood, et al., 196r).

Het werk wordt nog verder uitgebreid, aangezien er onzekerheid bestaat over de betrouwbaarheid van verschillende technieken. De agglutinatietests worden daarom niet alleen herhaald, maar ook dubbel uitgevoerd, met leukocyten verkregen met verschillende scheidingstechnieken. Dit heeft tot doel om, naast de sera onderling, ook de gebruikte technieken te vergelijken. Over welke techniek het best gebruikt kan worden voor het bereiden van leukocytensuspensies voor agglutinatietests, bestaat nog geen overeenstemming. Ten eerste wordt gebruik gemaakt van de techniek van Dausset, waarin leukocyten uit gedefibrineerd bloed worden gebruikt. Hierbij wordt bloed onstolbaar gemaakt door in het bloed glaskralen te laten bewegen, die de bij de stolling betrokken factoren laten reageren zonder dat zich een feitelijk stolsel kan vormen. Vervolgens laat men met Dextran de erythrocyten uitzakken, waarna in het resterende plasma de leukocyten achter blijven. De andere techniek is die, die Van Loghem hanteert, waarbij gewerkt wordt met uit sequestrinebloed gewonnen leukocyten. In deze techniek wordt sequestrine (EDTA ${ }^{21}$ ) gebruikt om het bloed onstolbaar te maken en dan eveneens Dextran om de erythrocyten van de leu. kocyten te scheiden. In de leukocytensuspensies zijn bij de eerste techniek $4000 \pm$ rooo leukocyten per $\mathrm{mm}^{3}$ plasma aanwezig en bij de tweede techniek $6000 \pm 1500$ (van Rood, 1962). Omwille van deze techniekevaluatie wordt dus de hoeveelheid 
werk minstens verdubbeld. Het normale werk bestaat uit het verzamelen van bloed, het bereiden van de sera en de leukocytensuspensies, het opslaan van de sera en het uitvoeren van de agglutinatietests. Dit moet nu voor een groot deel dubbel en op verschillende wijzen worden gedaan. Uiteindelijk leidt deze vergelijking tot de conclusie, dat de technieken weliswaar tot vergelijkbare resultaten komen, maar mogelijk een verschillend toepassingsgebied hebben.

De uitslagen die niet met de verwachting overeenstemden, zijn met leukocyten uit sequestrinebloed bijna uitsluitend reacties die wij gemakshalve fout-negatief zullen noemen, met leukocyten uit gedefibrineerd bloed daarentegen eigenlijk alleen fout-positief.

De conclusie die wij voor de praktijk hieruit moeten trekken is, dat het dus niet zo maar te zeggen is, welke van beide technieken de beste is. Men zal namelijk moeten weten: a. met welk serum, en b. voor welk doel men de bepaling doet.

Indien het erom gaat, uit te maken of er al dan niet leukocyten-antistoffen aanwezig zijn, is de techniek van Dausset met leukocyten uit gedefibrineerd bloed de beste; men moet hierbij echter steeds rekening houden met het gevaar van 'fout-positieve' reacties. Wil men daarentegen leukocytengroepen bepalen, dan verdient de sequestrinetechniek de voorkeur, voornamelijk wegens

laboratorium-technische redenen. (van Rood, 1962 )

Deze evaluatie van de twee technieken kan alleen gedaan worden middels het laboratoriumwerk. Aangezien er voor de resultaten van de verschillende tests nog geen referentie is, kan men ook niet de juist- of onjuistheid van de resultaten bepalen. Maar hoe meer de resultaten van de sera in een logisch verband met elkaar kunnen worden geplaatst, des te beter kunnen de uitkomsten voorspeld worden op basis waarvan men uiteindelijk tot bovenstaande conclusie komt.

Het vele laboratoriumwerk genereert een grote stroom testresultaten. Door de manier waarop de uitkomst van iedere afzonderlijke test wordt opgeschreven, krijgen die testresultaten de naam 'breiwerken': grote lijsten met afleesbeoordelingen, waar iedere dag weer een stukje aangebreid wordt, resultaten van nieuwe sera die ingezet worden met de leukocyten van het donorpanel. Op de lijsten worden dan de donornummers van het donorpanel afgezet tegen de serumnummers met alle respectievelijke afleesresultaten. Op deze 'breiwerken' is dan ook direct te zien dat niet alle sera op dezelfde manier met alle leukocytenmonsters reageren. Dat er ook sera zijn die wel op vergelijkbare wijze met het donorpanel reageren, is veel moeilijker te zien. Het dubbele laboratoriumwerk genereert bovendien een dubbele hoeveelheid resultaten. Dat betekent dan ook, dat er, in plaats van $6_{700}$ uitkomsten $\left(\sigma_{7}\right.$ sera ingezet met leukocyten van roo donoren), twee maal die hoeveelheid moet worden verwerkt (van Rood, et al., 196r).

Het is duidelijk dat voor de interpretatie van deze $2 \times 6700$ uitkomsten enig systeem onontbeerlijk is. Wij hebben daarom de positieve en negatieve uitkomsten van elk serum met de positieve en negatieve uitkomsten van elk ander serum vergeleken. (van Rood, 1962 )

Dat betekent dat er bij iedere serumcombinatie vier getallen komen te staan die de overeenkomsten en verschillen tussen de sera laten zien. Twee getallen geven aan wanneer de beide sera met bepaalde leukocyten overeenkomstig reageren, in positieve, dan wel in negatieve zin; de andere twee getallen geven aan dat en hoe de twee sera verschillend reageren met bepaalde leukocytenmonsters. Deze twee getallen laten dus zien hoeveel leukocytenmonsters het ene serum wel en het andere niet agglutineert en omgekeerd. 
Met behulp van de toets van Fisher is vervolgens nagegaan, in hoeverre de verdeling van deze getallen toevallig zou kunnen zijn. De aldus verkregen $\chi$-kwadraten werden in de laatste kolom genoteerd. Er wordt een hoge $\chi^{2}$ gevonden, indien twee sera de leukocyten van een groot aantal van dezelfde donors wèl, resp. niet agglutineren. Hier is er dus sprake van een identiteit van beide sera. (van Rood, 1962$)^{22}$

Nadat de zwak agglutinerende en slecht reproduceerbare sera uit de gegevens zijn verwijderd, blijven er 45 sera over waarvan de onderlinge $\chi^{2}$-en worden vergeleken. Op basis van deze getallen wordt vervolgens bepaald welke sera identiek of bijna identiek zijn. Alleen echt identieke sera zouden met precies dezelfde leukocytenmonsters reageren. Vele sera reageren voor een deel met dezelfde leukocytenmonsters, maar reageren verschillend met enkele anderen. Het statistische idee daarbij is, dat wanneer er enig verband zit in het reactiepatroon van de beide sera met het leukocytenpanel, er ook in de sera iets aanwezig moet zijn dat correspondeert met dat verband. Dat zouden dan wel eens de antilichamen kunnen zijn. Een hoge $\chi^{2}$ zou hier dus op duiden.

Het met de hand uitrekenen van al die $\chi^{2}$-en, ook al betreft het 'slechts' 45 sera, is een monnikenwerk. Voor het verwerken van deze laboratoriumuitslagen wil Van Rood echter een nieuwe benadering hanteren. De - tegenwoordig eenvoudige oplossing voor het analyseren van grote hoeveelheden data, het inschakelen van een computer, is begin Goer jaren echter niet eenvoudig te realiseren. Ten eerste worden computers sowieso nog nauwelijks gebruikt en als er al een is, is het de vraag of deze geschikt is voor hetgeen gevraagd wordt, zoals Van Rood in een interview zegt:

In die tijd was het in de medische faculteit compleet ongebruikelijk lom een computer te gebruiken], Er was in Leiden een computer, dat was de computer bij Astronomie en die was bedoeld voor grote ingewikkelde berekeningen, die eigenlijk van algebraisch karakter waren, voor een belangrijk gedeelte ook meetkundig. Onze problematiek was echter statistisch... (van Rood, 21 december, 1993)

De op de Leidse Universiteit aanwezige computer wordt dus niet geschikt geacht voor het doen van de vele statistische berekeningen die voor de serumvergelijking noodzakelijk zijn. Toevallig hoort men van een firma in Utrecht die over een 'Hollerith sorteersysteem' beschikt.

They had in a big attic an enormous cuckoo-clock, a mechanical Hollerith sorting system, all wooden hammers and wheels. (van Rood, 1993)

Met behulp van deze machine zou er misschien enige lijn in de vele gegevens te krijgen zijn. Ook begrijpen die mensen wat de bedoeling is. Ze doen echter iets teveel:

The only thing wrong was that they had compared not every serum with every serum, but every cell with every cell! Quite a number of very interesting patterns came out, but it was too early for us to interpret them. After that they went bankrupt. ... (van Rood, 1993)

Door het wegvallen van de Utrechtse firma moet er opnieuw gezocht worden naar een computer die de $\chi^{2}$-en van de verschillende sera kan berekenen. De Rijkscentrale voor Mechanische Administratie biedt uitkomst. Hun computer ${ }^{23}$ berekent de salarissen van alle ambtenaren in Nederland en is ook in staat deze statistische be-

$22 \chi^{2}$ (spreek uit: ghi-kwadraat) is een statistische maat voor homogeniteit.

23 Een IBM 604 


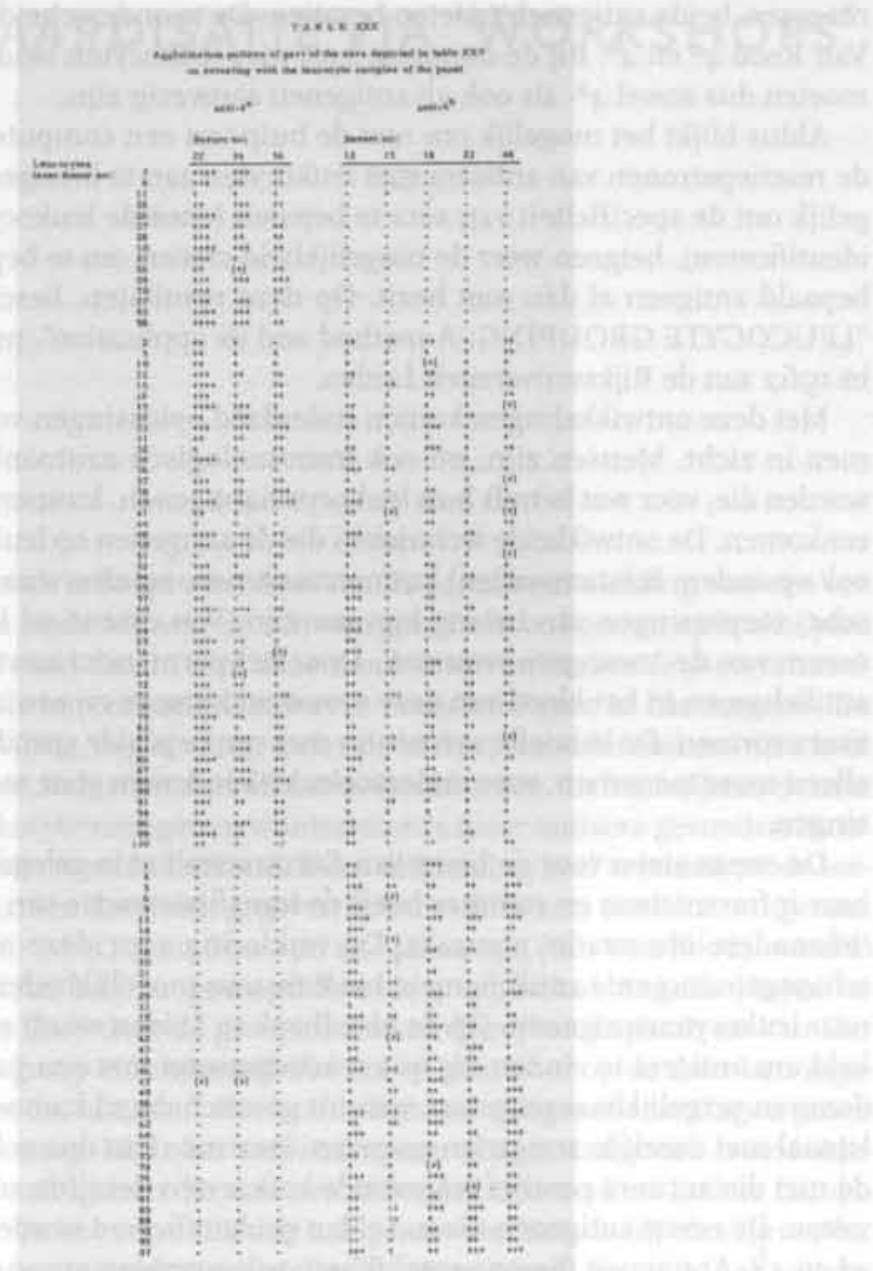

figuur 2.1: $4 a, 4 a 4 b, 4 b$

(van Rood, 1962)

rekeningen te verrichtten. De statistische analyse van de gegevens laat zien dat er twee groepen te maken zijn. In figuur 2.I staat links een cluster van drie sera en rechts een cluster van vijf. Binnen deze twee clusters reageren de sera onderling grotendeels overeenkomstig met de leukocyten van de paneldonoren, maar deels verschillend vergeleken met de sera van het andere cluster. Tussen de clusters is echter ook overlap, hetgeen betekent dat de sera in beide clusters met de leukocyten reageren. De interpretatie hiervan is dat de beide clusters ieder een ander antigeen ${ }^{24}$ herkennen en dat de leukocyten die met zowel het ene, als het andere cluster

24 De contemporaine benaming voor leukocytenantigenen is leukocytengroepen. Getuige ook de titel van Van Roods proefschrift: "Leucocyte Grouping". 
reageren, beide antigenen moeten bevatten. De te onderscheiden antigenen noemt Van Rood $4^{a}$ en $4^{b}$. Bij de donoren, met wier leukocyten beide clusters reageren, moeten dus zowel $4^{\mathrm{a}}$-als ook $4^{\mathrm{b}}$-antigenen aanwezig zijn.

Aldus blijkt het mogelijk om met de hulp van een computer enige ordening in de reactiepatronen van antisera met leukocyten aan te brengen. Zo is het dus mogelijk om de specificiteit van sera te bepalen (door de leukocytenantilichamen te identificeren), hetgeen weer de mogelijkheid creëert om te bepalen of iemand een bepaald antigeen al dan niet bezit. Op deze resultaten, beschreven in het boek: "LEUCOCYTE GROUPING: A method and its application", promoveert Van Rood in 1962 aan de Rijksuniversiteit Leiden.

Met deze ontwikkelingen komen inderdaad oplossingen voor klinische problemen in zicht. Mensen zijn, nu ook immunologisch aantoonbaar, individuen geworden die, voor wat betreft hun leukocytenantigenen, kunnen verschillen en overeenkomen. De ontwikkelde technieken die de antigenen op leukocyten (en mogelijk ook op andere lichaamscellen) kunnen aantonen, zouden voor verschillende (klinische) toepassingen van belang kunnen zijn. Van essentieel belang daarbij is het serum van de 'zwangere vrouwen'. Door het permanent aanwezig blijven van de antilichamen in het bloed van deze vrouwen, kunnen zij een stabiele bron van antisera vormen. De behoefte aan serum met een bepaalde specificiteit is groot en zal alleen maar toenemen, voor onderzoeksdoeleinden en voor meer klinische toepassingen.

De eerste steen voor de bouw van Eurotransplant is gelegd. De bloedbank met haar infrastructuur en routines heeft de transfusiereactie van Mevrouw $\mathrm{H}$. tot een 'bijzondere observatie' gemaakt. De verklaring voor deze observatie, zwangerschapsgeinduceerde antilichamen, biedt nieuwe mogelijkheden voor het onderzoek naar leukocytenantigenen. Op de bloedbank in Leiden wordt een methode ontwikkeld om antisera te vinden die qua reactiepatroon met een panel van leukocytendonoren vergelijkbaar reageren, waaruit geconcludeerd kan worden dat de sera allemaal met dezelfde antigenen reageren. Daarmee kan dus ook gezegd worden dat de met die antisera positief reagerende leukocyten dezelfde antigenen moeten bevatten. De eerste antigenen die in Leiden geïdentificeerd worden, krijgen de namen $4^{\mathrm{a}}$ en $4^{\mathrm{b}}$. Antigenen die op vergelijkbare wijze worden gevonden op andere plaatsen in de wereld, worden door de respectievelijke vinders van een naam voorzien. Maar komen de op verschillende plaatsen geidentificeerde antigenen met elkaar overeen, of niet? Het zou zo kunnen zijn dat - zoals Van Rood in 1958 al schrijft een van de in Leiden gevonden antisera gericht is tegen het door Dausset gevonden en door hem 'MAC' gedoopte antigeen, maar dit hoeft niet zo te zijn. Vooralsnog blijft onduidelijk hoe de in Leiden geidentificeerde antigenen zich verhouden tot bevindingen elders. In het volgende hoofdstuk zal onderzocht worden hoe men aan deze incomparabiliteit een einde probeert te maken. 


\section{StANDAARDISATIE VIA 'WORKSHOPS'}

\subsection{INLEIDING}

In het vorige hoofdstuk is besproken hoe Van Rood, naar aanleiding van een onverwachte observatie in de kliniek, de aanwezigheid van antigenen op leukocyten aantoont. Van Rood staat daarin niet alleen: ook anderen maken leukocytenantigenen zichtbaar, zoals bijvoorbeeld Dausset in Parijs en Payne in Los Angeles. De vraag die eind jaren vijftig, begin zestig onder de leukocytenonderzoekers rijst, is in hoeverre de gevonden antigenen met elkaar overeenkomen. In het onderzoek naar de verschillende leukocytenantigenen worden steeds meer antisera gevonden waarmee antigenen kunnen worden herkend. Deze uitbreiding is af te leiden uit de toename in het aantal namen dat wordt gegeven aan met deze sera ontdekte antigenen. Aan de eerste namen: 'MAC' (van Dausset) en ' $4 a$ ' en ' $4 \mathrm{~b}$ ' (van Van Rood), worden onder andere 'LAI, LA2, LA3' toegevoegd door de groep in Los Angeles (Payne en Bodmer) en ' $\mathrm{Zw}^{\mathrm{a}}$ ' en ' $\mathrm{Zw}$ ' ' door de groep in Amsterdam (Van Loghem en Van Der Weerdt) ${ }^{1}$. De Leidse groep zit onderwijl niet stil en gaat door op de door hen ingeslagen weg: ' $5 \mathrm{a}$, $5 \mathrm{~b}$ en $6 \mathrm{a}$, b, c, etc.'. Kortom de lijst van antigeenbenamingen groeit begin jaren zestig gestaag. Maar het verband tussen al deze antigenen is onduidelijk. Zijn het dezelfde antigenen die van verschillende onderzoekers andere namen hebben gekregen? Zijn het verschillende antigenen die, net als bij bloedgroepen, uiteindelijk onder te brengen zijn in een classificatiesysteem? En zo ja, hoe ziet dat systeem er dan uit? Dit soort vragen is voor de onderzoekers interessant voor nader onderzoek. Uiteindelijk komt men midden jaren zestig tot de conclusie dat de gevonden antigenen deel uitmaken van het - zoals men het in 1968 noemt - HL-A. systeem. In dit hoofdstuk zal worden beschreven hoe de antigenen 'vergelijkbaar worden gemaakt', ofwel hoe de vele lokale onderzoekspraktijken zich proberen te verenigen.

De noodzaak voor het vergelijkbaar maken van antigenen ontstaat niet slechts door de veelheid aan namen, maar ook door de variaties in gehanteerde technieken. Er worden verschillende testtechnieken gebruikt, zoals onder andere de agglutinatietechniek, de cytotoxiciteitstest en de complementfixatietest, waarbij van ieder ook nog verschillende variaties worden gebruikt. Los daarvan zijn er ook variaties in de wijze waarop het bloed wordt verzameld, de leukocytensuspensies worden bereid, de antisera worden bewerkt en variaties in hoe de technieken worden afgelezen en 
vastgelegd. Dit alles heeft tot gevolg dat er op verschillende plaatsen in de wereld zeer verschillende laboratoriumpraktijken rond de leukocytenantigenen ontstaan. De kennis die hierbinnen wordt gegenereerd is dan ook in eerste instantie lokale kennis'.

Het onderzoek van Van Rood biedt een opening om een einde te maken aan het uitsluitend lokale karakter van de kennis. In zijn proefschrift beschrijft hij een methode, waarmee, door gebruik te maken van statistiek en een computer, uit grote hoeveelheden testresultaten conclusies over de overeenkomsten en verschillen tussen antisera te trekken zijn. Door deze methode te volgen, kunnen andere onderzoekers de opbrengst van hun onderzoek vergroten.

Hoewel zijn proefschrift veel gelezen en ook nagevolgd wordt, brengt Van Rood de verschillende lokale praktijken niet daarmee op één lijn. De gebruikers van zijn analysemethode nemen zijn testmethode en procedures, die hij uiteraard ook beschrijft, niet over. Daardoor blijft uniformering van de verschillende praktijken uit. De conclusies die met behulp van Van Roods analysemethode worden getrokken, kunnen wel met elkaar in verband worden gebracht door de eenheid in methode, maar de feitelijke bepalingen in deze verschillende praktijken behouden hun lokale karakter omdat de methode op praktisch niveau geen vergelijkbaarheid tussen de verschillende praktijken creëert. Onderzoekers zijn dan wel beter in staat om clusters van antisera zichtbaar te maken en daarmee antigenen te identificeren, maar zij doen die ieder op eigen wijze, in hun eigen techniek. Dit heeft tot gevolg dat antisera tussen de verschillende praktijken niet uitwisselbaar zijn. Daardoor is ook niet na te gaan of ze met dezelfde, dan wel met verschillende antigenen reageren. De productiviteit gaat omhoog, maar om de verschillende lokale praktijken tot een onderzoekspraktijk te laten fuseren, is meer nodig.

In 1964 gaan de onderzoekers actief zoeken naar een gemeenschappelijke modo praescripto, 'voorgeschreven werkwijze', om de resultaten vergelijkbaar te maken en zo de mogelijkheid te hebben antisera uit te wisselen. In combinatie met conferenties worden workshops georganiseerd. Hier demonstreren de verschillende onderzoeksgroepen de door hen gebruikte technieken en vergelijken ze de technieken door steeds dezelfde leukocyten te gebruiken. De leukocyten zijn afkomstig van een panel van donoren. Zo wordt een van de variabelen geëlimineerd en worden de testresultaten vergelijkbaar. Nu kan gekeken worden of de verschillende antisera mogelijk dezelfde antigenen herkennen. Donorpanels spelen een belangrijke rol bij het combineren van de gegevens uit de verschillende laboratoria. Zeker wanneer een van die panels tot een 'gouden standaard' wordt verheven waaraan alle sera getoetst (moeten) worden. Met het instellen van een internationaal referentiepanel is een begin gemaakt met het verenigen van de verschillende lokale onderzoekspraktijken tot één gemeenschappelijke onderzoekspraktijk.

In dit hoofdstuk zal echter blijken dat het 'succes' van de zich ontwikkelende onderzoekspraktijk een prijs heeft. De groei van het aantal typeringslaboratoria zorgt voor schaarste aan antisera en er treden verwijderingen op tussen onderzoekers van het eerste uur. De prijs voor succes.

\subsection{Histocompatibility TESTING CONFERENCE AND WORKSHOP}

In I964 organiseert Bernard Amos (Duke University) een conferentie en een workshop over 'Histocompatibility Testing'. De onderzoekers bespreken hun ideeën tij- 
dens de Conferentie en demonstreren in de Workshop hun technieken. Een van de deelnemers geeft echter een zeer kritische bespiegeling op al die verschillende tests.

I wonder if some of the in vitro tests are not exploring one unknown with

another. 1 don't think this is at all a bad thing as long as we continue to keep in

perspective the possibility that we are just doing that. ... (Lawrence, 1964)

Dit lijkt een vraag naar meer duidelijkheid. Welke test, op basis van welke theoretische principes, is te prefereren? Deze duidelijkheid zou kunnen ontstaan door samenwerking tussen de verschillende lokale onderzoekspraktijken. Men lijkt tot één gedeelde praktijk te willen komen, want gezien deze conferentie blijkt er een gemeenschappelijk onderzoeksgebied te zijn.

Dr. Ceppellini concluded by pointing at the need for continued close cooperation. The number of investigators involved in tissue typing is still small and communication is relatively easy. Nevertheless, it is important to come to some decision over terminology and the identification of sera, and this, together with the establishment of a major international panel and collaboration in the setting up of smaller reference panels at a number of laboratories, is a matter of urgency. (Amos, 1964)

Door een standaardpanel te maken waar lokale referentiepanels van afgeleid worden, zou een voor iedereen werkbare situatie kunnen ontstaan. Wanneer dan ergens een 'nieuw' serum wordt gevonden, kan aan de hand van het lokale referentiepanel (en dus indirect het standaardpanel) gekeken worden of het nieuwe serum een antigeen herkent dat anderen ook al hebben benoemd. Hoe een eenduidige nomenclatuur van de leukocytenantigenen eruit moet zien is nog een open vraag.

Naast het instellen van een internationaal Standaardpanel, zou het volgens Amos ook zinvol zijn om meer uniformiteit te scheppen in de veelheid aan testtechnieken. Het is immers de vraag of de verschillende technieken - met bijvoorbeeld leukocyten van het standaardpanel - dezelfde testresultaten opleveren, of dat daar grote verschillen in te zien zijn. Om enige aanwijzingen in deze richting te krijgen wordt, aansluitend aan de conferentie, in een workshop een groot aantal technieken en variaties gedemonstreerd door "those most competent to perform the tests" (Amos, 1964). Per techniek vergelijkt men de verschillende variaties van die techniek. Bij uitvoering van de verschillende tests - waarvan de agglutinatietest de meest gebruikte is - worden alle sera gebruikt die door de deelnemers zijn meegebracht. De leukocyten zijn afkomstig van acht donoren. Het bloed waaruit de leukocytensuspensies worden bereid, wordt onder supervisie van de betreffende onderzoeker afgenomen, want ook hierbij hebben de verschillende onderzoeksgroepen een eigen werkwijze. Na afloop van alle tests en demonstraties volgt een afsluitende discussie, waarbij de resultaten van de verschillende variaties van de technieken worden vergeleken.

All the methods used were capable of distinguishing the negative control serum and all scored a number of positive results with each of the antisera. Some tests, especially that of Dr. Lalezari, gave extremely strong agglutination, but there were considerable differences between the incidence of positive results obtained with different methods when reactions against individual cells were compared. (Amos, 1964)

De schaarste aan antisera, gecombineerd met het gebrek aan consensus over de te prefereren methode, geeft de deelnemers aan de bijeenkomst een opdracht. Urgently required is a micro or semimicro method with both high sensitivity 
and specificity. (Amos, 1964 )

Bij de technieken die tot nu toe worden gebruikt, zijn de benodigde hoeveelheden antiserum zo groot, dat de voorraad snel uitgeput raakt. De gewenste testtechniek moet, volgens Amos, naast zuinig, ook gevoelig en precies zijn. De test moet in staat zijn om ook de zwakste antigenen te detecteren, maar mag geen 'fout positieve' resultaten geven. Bij de beschikbare testen is er geen die aan al deze eisen voldoet. Tot zo'n test beschikbaar is, of een van de huidige technieken tot standaard verheven wordt, zullen de sera (die zij van collega's krijgen) met de bij het serum 'horende' techniek moeten worden gebruikt. De resultaten zullen anders hoogstwaarschijnlijk verschillen van de resultaten die elders met dezelfde sera verkregen worden, wat het werk nutteloos maakt.

Naast het probleem van een uniforme testmethode, blijft het de vraag of nieuwe antisera geen antilichamen tegen al bekende antigenen bevatten. Dit tweede probleem kan alleen indirect worden opgelost, waarvoor Amos het vormen van een internationaal referentiepanel voorstelt. Dit referentiepanel moet bestaan uit een groep mensen die getypeerd zijn met alle bekende antisera. Wanneer een onderzoeker een (monospecifiek) serum vindt en daarmee een nieuw antigeen meent te kunnen herkennen, kan met behulp van dit referentiepanel gekeken worden of het antiserum met een nieuw, of met een al bekend antigeen reageert. Via het panel wordt zo het nieuwe serum vergeleken met de al bekende sera. Wanneer het serum niet reageert met de bekende antigenen maar wel een positieve reactie oplevert, herkent het een nieuw antigeen en is de herkende leukocytendonor een aanvulling op het panel.

De in het panel aanwezige antigenen vormen zo de standaard voor het karakteriseren van antisera. Het is Van Rood die aanbiedt om zo'n internationaal referentiepanel op te zetten, hetgeen Amos meldt in zijn samenvatting in het conferentieverslag Histocompatibility Testing (Amos, 1964).

\subsection{DE TWEEDE WORKSHOP}

Het initiatief van de Histocompatibility Testing Conference and Workshop in New York en Durham, wordt gewaardeerd en nog voor het jaar om is, wordt besloten om er een vervolg aan te geven.

... it was decided by some of the participants to band together into a loosely

affiliated "Tissue Typing Club" and to hold a similar meeting in Europe as soon as practicable. (Amos, 7 mei, 1965) ${ }^{2}$

Men besluit dat deze tweede bijeenkomst vanwege het panel, het beste in Leiden gehouden kan worden. Direct na dit besluit vraagt Van Rood aan de geneesheer-directeur van het AZL, of het mogelijk zou zijn om onderdak te verlenen aan de ze Internationale Histocompatibility Testing Workshop. Om dit verzoek kracht bij te zetten schetst hij eerst het belang van "een zekere mate van histocompatibiliteit" tussen donor en ontvanger voor het succes van niertransplantaties, hetgeen is gebleken uit de gegevens, verkregen uit de eerste " $500-1000$ niertransplantaties in de gehele wereld".

Het ligt in de bedoeling van Maandag 16 augustus tot en met Zaterdag 21 augustus 1965 een tweede workshop te organiseren, indien mogelijk in Leiden.

2 In een brief aan Van Rood geeft Amos aan hoe die 'club' ontstaan is.

An informal club has been formed from a number of the resarch workers who attended a practical workshop on leucocytes and tissue typing in Durham, N.C. in June 1964. (Amos, 18 december, 1964) 
De reden dat Leiden hiervoor uitgekozen is, ligt in het feit, dat hier de grootste panel van volledig getypeerde donors aanwezig is. Het hoeft geen verder betoog dat, indien de workshop hier gehouden kan worden, dit voor ons werk hier van het allergrootste belang zou zijn, daar de deelnemers met hun sera ons panel verder zouden typeren. Dit geeft ons de mogelijkheid bij het zoeken naar nieuwe leucocytengroepen zo efficiënt mogelijk te werk te gaan. (van Rood, 2 november, 1964)

Aldus verbindt Van Rood de vereisten voor een succesvolle transplantatiegeneeskunde aan de winst die het voor hen oplevert.

De initiatiefnemer en mede-organisator van de eerste bijeenkomst, Dr. Bernard Amos (Duke University), wordt algemeen gezien als de drijvende kracht achter de pogingen om de lokale praktijken te verenigen. Dausset en Van Rood stellen daarom voor dat Amos voorzitter wordt van het organisatiecomité dat de volgende bijeenkomst zal organiseren. Amos reageert hierop met "I gather I am to be chairman or whatever it is called, ..." (Amos, Io november, 1964) en dat Van Rood dan de hard werkende secretaris zal zijn die de bijeenkomst feitelijk organiseert. Amos zal echter wel - mede op aandringen van Van Rood - een voorlopige lijst samenstellen met onderzoekers, waarvan de deelname aan de Conferentie en de Workshop moet worden overwogen ${ }^{3}$. Amos stelt tevens een procedure voor ten aanzien van de toekomstige meetings. De secretaris van de huidige bijeenkomst wordt de voorzitter van de volgende, "thus Jon [van Rood] would do this next, while Jean [Dausset], say would be the next secretary...." (Amos, 16 november, 1964) ${ }^{4}$. Volgens hem zou het organisatiecomité - nu bestaand uit Amos, Dausset en Van Rood - kunnen worden uitgebreid tot 5 mensen. Hij zou daarvoor Walford en Ceppellini willen vragen 5 .

Daarnaast stemt Amos in met het voorstel van Van Rood om de onderzoekers bij deze tweede 'white cell meeting' ${ }^{6}$ te laten vergezellen van analisten, met de aantekening dat het aantal beperkt moet blijven, aangezien er anders ruimtegebrek ontstaat. Hij ziet grote voordelen in het meekomen van analisten, aangezien deze veel werk kunnen overnemen van de onderzoekers, die dan met collega's hun technieken kunnen bespreken, zonder de tests te verstoren. Bovendien is zijn ervaring van de eerste Workshop, dat de beste discussies of in kleine groepjes plaatsvinden, of aan de laboratoriumtafels (Amos, 13 juli, 1964) ${ }^{7}$. Daarnaast heeft het mee laten komen van analisten ook een direct praktisch voordeel: zij kunnen de tests herhalen en zo de eigen bepalingen controleren. Dat dit in Durham niet is gebeurd, ziet Amos als een tekortkoming van die Workshop: "Lack of duplication was a grave weakness of our meeting." (Amos, 16 november, 1964)

3 Van Rood vraagt dit vanwege de situatie in Europa, omdat, door de korte afstanden en de daardoor persoonlijke banden, het voor hem erg moeilijk is om sommige mensen "nee" te verkopen (van Rood, $n$ december, 1964).

4 Amos gaat er hierbij overigens vanuit dat de volgende Workshop in Parijs zal worden gehouden; echter niet Jean Dausset, maar Rugerro Ceppellini zal de volgende 'Secretary' worden, aangezien de 1967 workshop in Turijn wordt gehouden.

5 Later wordt dit comité nog verder uitgebreid met Rose Payne en Paul Terasaki. (Amos, 23 februari, 1965)

6 Er worden verschillende benamingen voor de bijeenkomst in 1965 gebruikt. Uiteindelijk wordt het geheel aangeduid met ' 1965 Workshop', het grote belang dat aan de workshop wordt gehecht reflecterend, maar met name bij de uitnodigingen wordt nog het strikte onderscheid tussen de 'Conference' en de 'Workshop' gehanteerd.

7 De 'beste' discussies gingen blijkbaar over bijwoorbeeld de 'ins en outs' van de uitvoering van bepaalde technieken, of over de eerste meer theoretische ideeën. 
Het belang voor onderzoekers van zowel de eerste, als de tweede conferentie is, bestaat in de gelegenheid elkaar te leren kennen en informatie uit te wisselen ${ }^{8}$ en aldus de samenwerkingsverbanden te versterken. De tweede Workshop heeft echter een andere doelstelling dan die in Durham. Tijdens de Workshop in Durham demonstreerde men de eigen techniek met gebruikmaking van dezelfde sera en cellen, zodat een grove vergelijking tussen de technieken gemaakt kon worden. De doelstelling van de tweede Workshop is erop gericht de Workshop zelf een vorm van samenwerking te laten zijn.

... The aims of the second Workshop are rather different. Since most of the investigators now have a number of sera which are probably monospecific under the conditions of the particular test used, it is planned to ask each investigator to test his own sera against the cells of a panel. In this way a direct comparison can be made and correspondence between different sera established. ... (van Rood, 1965)

Niet iedereen is het overigens direct met deze doelstelling van de Workshop eens. Dr. Rose Payne vindt het onbegrijpelijk.

It would be more informative for me to discuss problems in the workshop than to spend days running tests. A "proving ground" for monospecificity of a serum at the workshop seems incomprehensible to me. I think Jon van Rood and his colleagues by now have obtained reasonably good correlations with our antisera. 1 am in a quandary as to what more could be done with my sera in this area at the workshop? Confirmation of a group or of monospecificity is a long an arduous labour best done in one's own laboratory. (Payne, 24 februari, 1965) Door te verwijzen naar het klinische belang dat het werk van de leukocytenonderzoekers in de toekomst mogelijk zal krijgen, probeert Van Rood haar te overtuigen van de noodzaak om toch naar Leiden te komen en in de workshop te participeren.

I quite agree with you that leukocyte grouping is boring, tedious and repetitious.

However, I am sure you will agree with me that only by doing these tests, we will be able to solve the problem of histocompatibility in man, which is a matter of life and death for so many of our patients. (van Rood, 17 mei, 1965)

Het is echter niet zo dat iedereen die graag naar Leiden wil komen, ook wordt toegelaten. Er is sprake van ballotage. Ten eerste wordt men geïnviteerd. De leden van het 'interim comité' maken herhaaldelijk hun goed-en afkeuring kenbaar over door Amos voorgestelde mensen.

Many distinguished people have not been considered - please find enclosed a second ballot. Please mark this list in order of preference, then we can continue sending out notices to fill gaps caused by refusals. (Amos, 23 februari, 1965) Daarnaast wordt, als gevolg van de onmogelijkheid van vrije inschrijving, ook in de lokale voorbereidingsgroep gesproken over het al dan niet toelaten van gegadigden. Zo valt in notulen van die groep te lezen, dat iemand die volkomen onbekend is binnen de groep, wordt geweigerd (Workshop-groep, 25 juni, 1965). De "Tissue Ty-

8 Bij de tweede Conference is genoeg uit te wisselen:

The aims of the second Conference are similar to those of the first. In the 44 months since the first Conference, there has been a very rapid increase of information relating to different antigenic factors and systems. ... (van Rood, 1965)

9 Starzl, als geinteresseerde en betrokken buitenstaander, introduceert deze benaming. Later noemt hij het kortweg de 'typing fraternity' (Starzl, 1991) 
ping CLub" - ook wel de 'White Cell Fraternity' ${ }^{\prime 9}$ genoemd - wordt beschermd tegen 'vervuiling' ${ }^{10}$. Naast selectie vooraf, wordt ook ten aanzien van de genodigden, on. derscheid gemaakt tussen 'insiders' en 'outsiders'. Alleen de 'gevestigde onderzoekers' - zij die in staat zijn 'monospecifieke' sera te vinden en/of aanwezig waren bij de vorige workshop ${ }^{11}$ - kunnen maximaal bijdragen aan de doelstelling van de bijeenkomst en kunnen worden toegelaten tot de kring van 'insiders'. De anderen zijn welkom op de Conferentie, maar worden van de Workshop geweerd.

If he [Amos] invited you for the Conference on August 16 and 17 , this means, I am sorry to say, that it was not possible to have you attend to the Workshop also. I am terribly sorry if this might upset you, but you will realise that the Workshop will be most effective if the number of people is strictly limited. In principle, only those people who have monospecific sera recognising leucocyte antigens are invited to this Workshop. (van Rood, 2 juni, 1965)

Er zijn verschillende redenen voor het selectieve toelatingsbeleid. Zo is de ruimte beperkt, evenals de beschikbare hoeveelheid bloed en willen de organisatoren een maximale effectiviteit van de workshop realiseren. De Workshop is bedoeld als onderzoeksbijeenkomst, niet als opleidingscursus. Daarom vertrouwt men alleen de resultaten van de gevestigde onderzoekers. Wanneer veel nieuwe mensen mee zouden doen, zou dat de resultaten van de workshop als geheel 'minder hard maken'. Binnen de gemeenschap wil men wat terugkrijgen voor de investeringen die men doet $^{12}$. Er is als het ware sprake van coöptatie. De groep is klein en de samenwerking gebeurt op basis van vertrouwen en wederkerigheid ${ }^{13}$. Nieuwe deelnemers zijn met zorgvuldigheid gekozen en beoordeeld op hun 'serumwaardigheid'. In een interview, terugkijkend op die tijd zegt mevrouw Van Leeuwen - de langst aanwezige medewerkster van Van Rood en een van de lokale organisatoren van de workshopdat het vooral een kwestie van vertrouwen was.

Je wist dat iemand goed was en dan dacht je: "Nou daar durf ik mijn sera wel aan te

geven en als die het dan kan bevestigen dan helpt dat weer." Want zo ging het

natuurlijk wel. (van Leeuwen, 6 september, 1994)

'Beginners' hebben dan ook meer moeite met het verkrijgen van goede sera, aangezien niet duidelijk is hoe zij de 'gevers' van dienst kunnen zijn. De groep onderzoekers beschouwt zichzelf als een soort 'familie', waardoor het mogelijk is om ge-

10 Hieraan wordt overigens een kleine concessie gedaan omwille van het gebruik van faciliteiten en mogelijk ook financiering.

If you really think 80 or 100 people should be asked to come, I think it would perhaps be not too bad an idea to advertise the meeting and have something like 15 places available for applicants. If we do this, 1 can have the meeting in the framework of the Boerhaave-courses, which would enable us to use all kinds of facilities in Leiden and probably squeeze a good deal of money out of the committee, (van Rood, $\mathrm{z}$ december, 1964)

11 Als soortement verantwoording geeft Amos de toelatingscriteria voor de Workshop:

These latter [Workshop participants] will be largely drawn from those who participated at the previous session and will be confined to investigators engaged in practical tissue and white cell typing. (Amos, 7 mei, 1965)

12 Is daar grote kans op, dan kan het zijn dat men wordt toegelaten tot het selecte gezelschap dat aan de Workshop mag meedoen, zoals uit een brief aan Henry Wilson blijkt.

Originally you had been scheduled only for the Conference, but we understand that you would very much like to attend both the Conference and the Workshop. This is possible, and you have already send in the sera. You will have to send to Dr. Bruning a list of the equipment needed, ... (Amos, et al., 12 juli, 1965)

13 Vaak is die wederkerigheid in zeer directe zin:

Could you also let us have a little antiserum sometime in the next month or so to see if we have the same antibodies in our panel? If so, 1'll reciprocate and send you our sera to check out. (Amos, 25 februari, 1965) 
zamenlijk aan een en hetzelfde project te werken en een en dezelfde praktijk te vormen $^{14}$. De namen waarmee deze groep onderzoekers door henzelf -Tissue Typing Club - of door anderen - White Cell Fraternity - wordt aangeduid, klinken in dit licht niet meer zo vreemd. De zelforganisatie waardoor deze praktijk zich vormt, blijkt meer voort te komen uit een wederzijds vertrouwen, dan uit de aanwezigheid van een gemeenschappelijke methode.

Via samenwerking komen de leukocytenonderzoekers tot gemeenschappelijke afspraken, die vervolgens door anderen worden overgenomen. Dit is een vorm van standaardisatie die in de eerste Histocompatibility Testing Conference and Workshop in 1964 , begint. Tijdens de voorbereiding van de tweede Histocompatibility Testing Conference and Workshop in 1965 - waar een groot deel van de deelnemers aan de eerste workshop ook weer aanwezig zal zijn - plannen de organisatoren een bijeenkomst met het doel de vorm van zelforganisatie te bespreken. Ook vindt Amos het tijd om een overzicht te geven van de behaalde resultaten.

Finally, at some time during the meeting we must have at least one organizational type of session in which the existing group can get together and decide what kind of organization we are and whether we wish to continue as a club or whether we should affiliate with one of the existing societies, perhaps as a separate sub-group. We should also conclude our meeting by issuing a summary of all the known leucocyte groups and of the reagents available with an account of the criteria by which they are accepted and the frequency with which they have been detected in different laboratories. (Amos, 20 april, 1965) Door deze onderwerpen op de agenda voor de volgende Conference en Workshop te zetten, geeft Amos aan, dat er volgens hem al een gemeenschappelijke praktijk is. Juist het gevoel van gemeenschappelijkheid, dat in deze zich ontwikkelende praktijk heerst, resulteert erin dat ze voor de tweede maal bijeenkomen.

\subsubsection{De Keus voor Leiden}

Waarom wordt deze tweede Histocompatibility Testing Conference and Workshop in Leiden gehouden? Van Rood schrijft aan de geneesheer directeur, dat de keus op Leiden is gevallen, omdat "hier de grootste panel van volledig getypeerde donors aanwezig is" (van Rood, 2 november, 1964), om te vervolgen met dat het voor de Leidse onderzoekers gunstig is dat de deelnemers met hun eigen sera het Leidse panel verder typeren. Maar welke voordelen halen andere deelnemers met het naar Leiden komen? In een verzoek om financiële ondersteuning bij Euratom ${ }^{15}$, legt Van Rood een verband tussen Leiden - met zijn 'volledig' getypeerde panel - als de aangewezen plaats om de workshop te houden en het doel van de Workshop: "The com. parison of monospecific sera recognizing leukocyte antigens as they are determined by the different workers in this field." (van Rood, 14 april, 1965). Dat in Leiden al een (getypeerd) donorpanel aanwezig is waarmee deze doelstelling kan worden gerealiseerd, voert Van Rood aan als argument om voor Leiden te kiezen en de workshop financieel te ondersteunen. Kort na de eerste Conference en Workshop, spreekt men over een geschikte locatie voor een vervolg. Turijn, Leiden en Parijs worden als mogelijke locaties genoemd, maar mede vanwege het panel valt de keus op Leiden

14 Overigens moet hierbii gezegd worden dat naast de samenwerking die er ontegenzeggelijk is, er wel degelijk sprake is van een zekere wedijver (van Rood, 11 augustus, 2000).

15 Het samenwerkingsverband van de Europese Gemeenschap op het gebied van Atoomenergie (kernenergie). 
als plaats voor de volgende 'tissue histocompatibility meeting'. Bij de besluitvorming lijken strategische en inhoudelijke argumenten te worden ingezet tegen politieke. Zo heeft Amos zijn bedenkingen tegen Parijs.

Personally I would prefer either to Paris, which is too distracting for a thoughtful conference. Neither Turin nor Leiden is famous for its night life. I don't know how many of your participants would manage to get to morning sessions in Paris however! (Amos, 21 augustus, 1964)

Van Rood schrijft aan Amos dat hij vanwege dit argument akkoord gaat met de suggestie van Dausset om de workshop in Leiden te houden.

I agree with you that Torino with Ruggero's new institute would have been extremely nice. The main reason that we went along with Dausset's suggestion for Leiden is that I personally think that it is unlikely that Ruggero [Ceppellini] will be able to have available a panel, comparable to ours. Dausset thought this of importance, because he feels that it would be nice to make a comparison of monospecific antisera, one of the main themes of the next meeting. (van Rood, 22 september, 1964)

In deze lijn wordt de argumentatie voor Leiden dan ook verder opgebouwd. Het vergelijken van de, van verschillende onderzoekers afkomstige, sera is van groot belang, omdat dit de uitwisseling van informatie in 'de Club' zou betekenen. Tijdens de vorige conferentie en workshop kwam men niet tot een standaardmethode, waardoor het praktisch geen zin heeft om sera uit te wisselen, aangezien de in de verschillende laboratoria met die sera verkregen resultaten niet te vergelijken zijn.

There are no two centers which use exactly the same technique to detect the antigens. Exchange of sera for that reason suffers from the difficulty that the person who received the serum will probably not be quite familiar with the technique used by the original investigator. This has already led to misunderstandings and difficulties in reproducing the results from an other center. If the various investigators have the possibility to test their own sera against one panel, as completely typed as possible, those difficulties will be overcome. (van Rood, 14 april, 1965)

Om uiteenlopende redenen wordt Leiden dus als de meest geschikte plaats gezien voor de workshop, maar vooral omdat daar een met het grootste aantal monospecifieke sera getypeerd panel van leukocytendonoren beschikbaar is (van Rood, 24 maart, 1965 ). Dit panel is getypeerd voor de verschillende (Leidse ${ }^{16}$ ) antigenen. Het panel - de honderd leukocytendonoren dankzij wie Van Rood zijn proefschrift kon schrijven - is gedurende de voorgaande jaren aangevuld en uitgebreid. De nieuwe paneldonoren zijn niet primair geselecteerd op hun bereidheid bloed af te staan, maar op de zeldzaamheid van hun antigenen. Het zijn donoren waarvan de leukocyten met weinig antisera reageren.

The panel members are selected in the following way. We looked for and found people with certain sometimes rare leukocyte phenotypes. We did so to enable more rapid determination of the specificity of the serum. (van Rood, 17 mei, 1965)

Voor het samenstellen van het donorpanel is de typering van de donor van belang,

16. Dit zijn de antigenen die met de in Leiden gevonden antisera bepaald zijn en dus de Leidse benaming hebben: $4 a, 4 b$, etc. 
maar daarnaast blijft de bereidheid om voor experimentele doeleinden regelmatig bloed af te staan een vereiste. Om met name in die bereidheid toch enige stabiliteit te verkrijgen, zijn de mogelijke leukocytendonoren onder andere gezocht bij theologische opleidingsinstituten. De studenten verblijven daar gedurende meerdere jaren en zouden door hun geloofsovertuiging mogelijk snellen bereid zijn om bloed te geven voor 'de goede zaak'. Mede door deze aanpak is in Leiden een relatief groot donorpanel tot stand gekomen. Dit panel zal nu worden gebruikt voor de Workshop.

In Leiden, we have a panel of about 200 people, which we typed for the leukocyte group Four (J. of Clin. Invest. $1_{9} 6_{3}$ ), group Five (Vox Sang. Sept. 1964), group Six (Conference on Histocomp.Testing, Nat. Ac. Sci., 1964), Group Seven, Eight, Nine and Ten (unpublished data). The participants are invited to take as many monospecific sera along as they think they can test in a three days working period against at least fifty different cells. (van Rood, 14 april, 1965) De leukocyten van de Leidse paneldonoren kunnen door de verschillende deelnemers aan de workshop met hun eigen sera worden onderzocht. Met dit geselecteerde panel kan voorkomen worden dat er sprake is van dubbel werk - de zorg die Bernard Amos in zijn 'Summary' in 'Histocompatibility Testing' uitsprak (Amos, 1964).

De Workshop in Leiden te laten plaatsvinden, geeft Van Rood tegelijkertijd invulling aan zijn aanbod om een 'central refence panel' op te zetten. En creëert met dit 'central refence panel' een centrale plaats voor de Leidse onderzoeksgroep binnen de zich ontwikkelende mondiale praktijk. Ook dit gebruikt Van Rood als argument richting Euratom om een subsidie voor de Workshop te krijgen. Hij stelt dat een centraal referentiepanel het karakteriseren van monospecifieke antisera zal versnellen, waarmee 'dubbel werk' kan worden voorkomen, door nieuwe sera aan het referentie panel te toetsen (van Rood, 14 april, 1965$)^{17}$. Hij onderstreept daarbij het belang van de komende workshop voor Leiden door erop te wijzen hoe door deze workshop het belang van het in Leiden aanwezige donorpanel voor de leukocytenonderzoekspraktijk zal veranderen. Doordat het door alle onderzoekers met hun eigen technieken zal worden getypeerd, wordt het een door iedereen erkende referentie. Dit vertaalt hij vervolgens in een strategisch argument richting Euratom.

The possibility could even be considered to use for the August meeting in Leiden, instead of the neutral designation "workshop", something like:

"the initiation of the reference panel for histocompatibility testing" (van Rood,

14 april, 1965)

Schijnbaar brengt hij dit in, met het idee dat Euratom eerder geneigd is om een bijdrage te leveren aan het opzetten van hèt referentiepanel, dan aan een van de vele workshops. In het schema zoals dat gedurende de eerste conferentie is bedacht, is immers sprake van één centraal en van meerdere, kleinere, lokale referentiepanels. Aan dit centrale panel wordt door de gemeenschap veel waarde gehecht ${ }^{18}$. Al met

17 In Van Rood's eigen woorden:

The description of leukocyte groups is an extremely time-consuming procedure. It is therefore at the moment very important to avoid unnecessary duplication. The first step to the description of a leukocyte group is the selection of monospecific sera. If the different investigators can compare their monospecific sera against the same panel, again with their own techniques, then the possibility of such duplication will be drastically diminished. (van Rood, 14 april, 1965)

18 Zonder internationaal referentiepanel lijkt men bang voor een zekere stuurloosheid:

... I think that the International Panel will be the only possibility of getting good reference points for the following year. (Dausset, 15 december, 1964) 
al heeft de argumentatie succes: Euratom draagt in aanzienlijke mate bij aan de financiering van de Workshop, die dan ook in Leiden plaats kan vinden.

\subsubsection{Voorbereiding van de Workshop}

In vergelijking met de eerste bijeenkomst over Histocompatibility Testing, wordt aan de Workshop in Leiden door de meeste onderzoekers meer waarde gehecht ${ }^{19}$. Tijdens de tweede workshop ligt de nadruk niet op de onderlinge vergelijking van de methoden, maar op de resultaten die door de verschillende onderzoekers worden geproduceerd. ledere groep onderzoekers neemt zijn eigen laboratoriummateriaal en eigen antisera mee. Het is de bedoeling dat iedereen probeert zo zijn eigen laboratorium te 'herscheppen', met als doel de eigen methode zo normaal mogelijk uit te voeren. Men moet dus de specifieke, essentiële delen van het eigen laboratorium naar Leiden verplaatsen ${ }^{20}$. Al tijdens de vorige workshop, waar het accent lag op het demonstreren van de eigen techniek, bleek het glaswerk een groot probleem te vormen. Juist om de omstandigheden in het eigen laboratorium zo goed mogelijk te benaderen en de eigen techniek zo normaal mogelijk uit te kunnen voeren, adviseerde Amos Van Rood toen ook al om eigen glaswerk te gebruiken.

I think it would be worth your while to make up a box of the things you most specifically need and send it on very shortly. (Amos, 23 maart, 1964)

Van Rood krijgt rond de voorbereiding van de 1965 Workshop over dit aspect advies van Chester Zmijewski. Samen met Bernard Amos heeft Zmijewski de Workshop in Durham georganiseerd en daarbij, met name wat betreft het glaswerk, enkele problemen gehad.

As you well know, we leukocyte groupers are a bunch of "prima donnas". Everyone wanted different sized tubes washed in different ways, with different solutions, etc. I would suggest that everyone ship their own glassware and request only heavy equipment to be supplied by you.... Sera I think should be hand carried and not shipped frozen as they thaw out and go to pot. (Zmijewski, 4 januari, 1965)

De Workshop-groep, het lokale organisatiecomité, zorgt ervoor dat de meeste deelnemers niet hun eigen microscoop mee hoeven te nemen. Voor centrifuges wordt ook gezorgd, al zullen die wel gedeeld moeten worden met anderen (Workshop-groep, I2 juli, 1965). Voor de rest worden de deelnemers geacht hun eigen laboratoriummaterialen mee te nemen. Dit vergt ruim van tevoren enige inspanningen, zoals blijkt uit correspondentie afkomstig van het ministerie van Landbouw en Visserij (figuur 3.1) en de daarmee vergezeld gaande lijst (figuur 3.2), waarop de door Chalmers benodigde materialen vermeld staan.

19 Geheel in tegenstelling tot Rose Payne, dringt Dausset aan op meer nadruk op de Workshop.

Personally I feel that it would be better to devote all our activity to actual practical laboratory work, and 1 would prefer in the place of real communications that one hour was allowed to each team to present their results and answer any question raised by the audience. (Dausset, 3 maart, 1965)

Overigens is het grote belang van de Workshop in het conferentieverslag. 'Histocompatibility Testing 1965 (Balner, et al., 1965) niet te zien. In verhouding worden erg weinig pagina's besteed aan de Workshop. Uit hetgeen op die pagina's geschreven staat, blijkt het belang echter wel.

20 Voor het "juist' uitvoeren van de technieken wordt dit al meer gedaan. Zo zegt Van Rood, voor een onderzoeksreis naar Nigeria, ook dat hij zijn eigen glaswerk en reagentia mee zal nemen. (van Rood, 26 januari, 1965) 


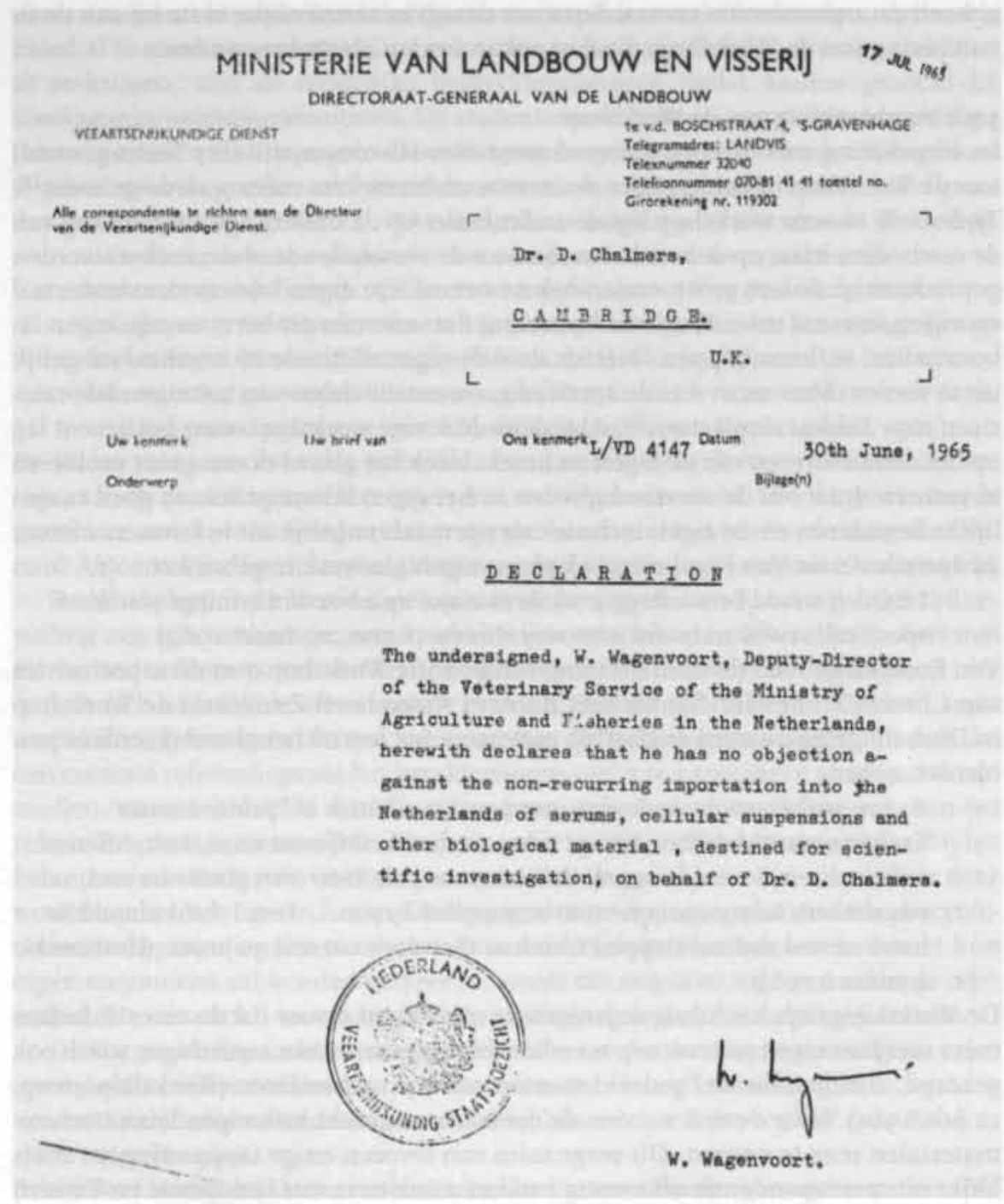

\section{figuur 3.1: Invoerverklaring}

(Ministerie van Landbouw en Visserij, et al., 30 juni, 1965)

De Workshop-groep besluit dat de spoelfaciliteiten voor gebruikt laboratoriumglaswerk zullen worden geleverd. Maar, zo schrijven zij, "speciale bewerkingen vallen onder de verantwoordelijkheid van de werkers zelf." (Workshop-groep, 2I juni, $1965)^{21}$

Iedere onderzoeker doet vergelijkbare inspanningen om de eigen specifieke tech-

21 Sommigen voeren speciale behandelingen van het glaswerk uit, bijvoorbeeld om minder leukocyten aan het glas te laten kleven. (siliconeren) 


\section{IN V O I C B}

To:

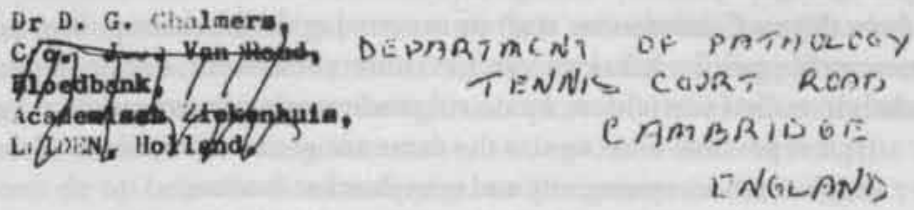

Contents:

6 dozen glass bottles (treated \& sterilized)

3 dozen glass tubes (troated \& sterillzed)

2 dozen pipettes (various sizes)

1 bottle Muenatu: -teal stain

3 hottles containing biological fixative solution

1 bottle cell culture mediwa

: bottie thytoharasgglutin

2 jeitz filters.

The material is the property of the Univeraity of Cambridge, and is for the use of D. D. G. Chalaera at a Meeting in Leiden from 14th - 22nd Auguat, 1965. See attached pervit froe the Ministry of Agriculture and Fishories in the Notherlands. The aterial w11 be returned to the U.K. after use.

figuur 3.2: Invoerlijst

(Ministerie van Landbouw en Visserij, et al., 30 juni, 1965)

nieken zo goed mogelijk te kunnen uitvoeren, al leidt dat niet in alle gevallen tot het gewenste resultaat. Sommigen hebben achteraf bedenkingen over de betrouwbaarheid van hun gegevens, daar het toch altijd anders is dan 'thuis'. Het 'herscheppen' van het eigen laboratorium lukt minder goed dan gehoopt. Twijfel over de betrouwbaarheid van de bepalingen roept dan ook reserves op bij enkele deelnemers over de verslaglegging van de workshop.

In principle, I favour publication. The primary objection is that I for one have some misgivings about the validity and/or reproducibility of my own results, particularly those of the first day, during which time I was having light source trouble. I expect others are also uncertain about their results under other than their own "home conditions", magnificent though your laboratory arrangements were. (Wilson, 22 november, 1965$)^{22}$

22 Overigens is het deze Henry Wilson, die pas na zijn aandringen tot de Workshop werd toegelaten. Het kan zijn dat onervarenheid toch een rol speelt bij zijn uitvoering en zijn twijfels. 
De reserves die men maakt zijn echter minimaal en over het geheel genomen wordt de opzet en organisatie van de workshop als succesvol beschouwd.

\subsubsection{De Workshop}

Na twee dagen Conferentie, start op woensdag de Workshop. Met de hoop dat het gemeenschappelijke karakter van het onderzoekswerk, dat de deelnemers aan de Workshop zullen verrichten, op de volgende vragen antwoorden zal geven.

(I) is it possible to recognize the same antigens with different techniques (agglutination, cytotoxicity and complement fixation);

(2) to which extent are the antigens described by the various workers identical;

(3) what is the total number of antigens which can be recognized at the

moment? (Bruning, et al., 1965)

$\mathrm{Na}$ de eerste verkenning van de variaties in technieken die in Durham plaatsvond, zal nu een inhoudelijke vergelijking worden gemaakt, door de resultaten van de verschillende laboratoria in de wereld, op een lijn te brengen.

Twenty-eight workers tested a total of 118 sera against the leukocytes of 45 (or

less) members of the "Leiden panel". (Bruning, et al., 1965)

Een aantal donoren van het Leidse Donorpanel levert het te testen materiaal, de geselecteerde (c.q. getypeerde ${ }^{23}$ ) leukocyten, waar het in deze Workshop allemaal om draait. Op de workshopdagen start men om 9.00 uur met het 'bloeden' van de paneldonoren.

Per donor wordt $150 \mathrm{cc}$. bloed benodigd.

Panel: 3 groepen van 15 + kleine reserve. In de eerste groep zit een mengsel, ze

en ze groep bevatten de belangrijkste. (Workshop-groep, 12 juli, 1965)

Per workshopdag krijgt iedereen hetzelfde bloed van dezelfde vijftien donoren, verzameld op de door hen gevraagde wijze. De procedure wordt aan de deelnemers medegedeeld in 'notes to the participants:'

The course of things will be that after the bleeding of the donors, which will be done only by our assistants, you will receive the blood samples in your own or in our tubes, labelled with the number of the leucocyte sample and your name. The test results, filled in by you on a uniform sheet in duplicate, will be collected on a large wall-board. To obtain optimal results from the computer analysis of the test data, you must indicate on the form which of your sera are monospecific and reliable. The data obtained with the 45 leucocyte samples will be computed immediately after completion of the experiments. (Workshop-groep, 1965) ledere onderzoeker wordt geacht zelf een onderscheid te maken tussen zeer goede sera enerzijds en sera die minder betrouwbare resultaten kunnen opleveren anderzijds. De eerste dag beschouwen de organisatoren overigens als minder belangrijk, aangezien ook zij enige startproblemen verwachten door de toch vreemde laboratoriumomstandigheden. Daarom bevatten de ze en ze groep de belangrijkste donoren.

De resultaten van al deze verschillende tests zijn vergelijkbaar, doordat de geteste leukocyten afkomstig zijn van dezelfde donoren. Zo wordt bekeken of de reactie-

23 In Histocompatibility Testing 1965 , geeft Brunning een opsomming van de Leidse antigenen waarop de donoren dus al getest zijn.

These leukocytes had been typed for the antigen described by the Leiden group: i. e. $4 a, 4 b, 5 a, 5 b, 6 a, 6 b$, $7 \mathrm{a}, 7 \mathrm{~b}, 7 \mathrm{c}, 7 \mathrm{~d}, 8 \mathrm{a}$ and $9 \mathrm{a}$ (21). (Bruning, et al., r965) 
patronen van de verschillende - en deels ook van verschillende laboratoria afkomstige - sera met dezelfde bloedmonsters overeenkomsten vertonen ${ }^{24}$.

De resultaten van de tests schrijven de onderzoekers, in duplo, op voorgedrukte formulieren - "met nummers van de donors op volgorde" (Workshop-groep, 12 juli, 1965). Deze formulieren neemt één persoon op het 'scorebord' over (Workshopgroep, 12 juli, 1965). De deelnemers moeten op de formulieren niet alleen aangeven of er al dan niet een reactie plaatsvindt, maar ook wat de sterkte van de reactie is, door gebruik te maken van een '-, dan wel,,++++++ , of ++++ '. Vervolgens vertaalt één persoon de op het scorebord samengebrachte gegevens, in 'o-en en r-en', waar de computer mee kan worden gevoed. De overeenkomsten en verschillen tussen alle nullen en enen van al de verschillende reactiepatronen vertaalt de computer in correlaties $\left(\chi^{2}\right)$. Een aantal verschillende antisera vertonen een gezamenlijke correlatie van Io of hoger. Daaruit blijkt dat zij op min of meer overeenkomstige wijze reageren met de verschillende leukocytenmonsters, waaruit men de conclusie trekt dat deze antisera dus antistoffen tegen dezelfde antigenen bevatten.

Naast hulp bij de analyse, speelt de computer nog een andere rol in het verhaal. Afgezien van de strategische argumenten om mensen al dan niet toe te laten tot de Workshop, is niet alleen de beschikbare laboratoriumruimte een beperkende factor voor het aantal mensen. Het maximale aantal sera dat de computer kan verwerken, stelt ook een limiet aan het aantal deelnemers. De computer bepaalt dus ook de maximale omvang van de Workshop.

Because the program for the computer limited the number of sera which could be analyzed in one run to 77 , the sera were divided into (a) group I for the best sera and (b) group II for the "second choice" sera. The "Leiden sera" were placed in both groups and the results of every serum in each group was compared with the results of every other single serum in that group. (Bruning, et al., 1965) Het al dan niet tot "second choice" serum gerekend worden, is dus afhankelijk van de beoordeling van het serum door de onderzoeker zelf. De Leidse sera worden in de analyse echter met alle sera vergeleken en niet alleen met de 'eerste' c.q. 'tweede' keus sera. De Leidse sera ${ }^{25}$ vormen zo de meetlat waarlangs men de andere sera meet.

In 'Histocompatibility Testing 1965 ', het uit de Conference en Workshop resulterende boek, houden de schrijvers ${ }^{26}$ bij de bespreking van de meest opvallende correlaties in 'Leukocyte Antigens' - het workshopverslag - de struktuur van de Leidse antigenen aan (Bruning, et al., 1965 ). Uitgaande van de Leidse benaming, dus in de volgorde $4 \mathrm{a}, 4 \mathrm{~b}, 5 \mathrm{a}$, etc., worden alleen die sera besproken, die een hoge correlatie met de Leidse sera vertonen.

$\mathrm{Na}$ analyse van de resultaten concludeert men, dat een aantal verschillende antisera significant met elkaar correleert.

It turned out that the greater part of the sera which showed a significant

24 In de vorige paragraaf bleek echter dat dat 'herscheppen van het eigen laboratorium' niet altijd even goed gelukt is.

25 Mogelijk is het vertrouwen van de Leidse onderzoekers in de reproduceerbaarheid van hun eigen typeringen nog niet zodanig, dat het ook zelf opnieuw typeren als overbodig kan worden beschouwd.

Hertyperen zou immers niet nodig zijn, daar het panel al getypeerd was met de Leidse antisera. Maar ook andere argumenten kunnen hierbij van belang zijn, bijvoorbeeld het vertrouwen van andere deelnemers en het tonen en bediscussiëren van de gehanteerde techniekien).

26 Bruning. Van Leeuwen en Van Rood. 
correlation with one or more of the other sera - independently of the technique used - recognized one of the twelve antigens for which the Leiden panel was

typed. (van Rood, 21 oktober, 1965)

Naast deze vaststelling concludeert Van Rood dat "Io of the 12 leukocyte antigens recognized by the Leiden group can probably also be recognized by sera used by other investigators" (van Rood, 23 december, 1965). Daar voegt hij aan toe dat "many of the antigens which can be recognized by agglutinins can also be recognized by cytotoxic antibodies" (van Rood, 23 december, 1965). Zo worden de vragen of met verschillende technieken dezelfde antigenen herkend kunnen worden en of de door verschillende onderzoekers beschreven antigenen identiek zijn, positief beantwoord.

Hoe vervolgens over al de verschillende antigenen moet worden gesproken, zal een speciaal ingestelde commissie gaan bekijken.

The question of nomenclature of the leukocyte antigens has been raised during

the Workshop. An advice on this matter will be formulated by a committee on

nomenclature, which has been formed during the Workshop. (The members are

R. Ceppellini (chairman), J. Dausset, W. Bodmer, F. Milgrom, F.H. Allen, Jr. -

J.J. van Rood (bureau)) (Bruning, et al., 1965)

Deze commissie komt echter tot de vaststelling dat het te vroeg is om een besluit over nomenclatuur te nemen. Over de relatie tussen de verschillende antigenen, waartussen tijdens de workshop een correlatie werd aangetoond, is nog te weinig bekend.

Ondanks alle tekortkomingen en de daaruit voortvloeiende onzekerheden, beschouwt het merendeel van de deelnemers de Workshop als een groot succes.

\subsubsection{Directe Gevolgen}

Als gevolg van de Workshop gaat Leiden een centrale plaats in de leukocytenpraktijk innemen. Het 'Leiden Donor Panel' belichaamt de referentie voor al hetgeen er in de leukocytenpraktijk gebeurt 27 . In Leiden is dan al een "WHO influenza reference laboratory" gevestigd en naar dit model wil Van Rood ook met het donorpanel een WHO leukocytenantigeen-referentielaboratorium opzetten, onder meer als tegenprestatie voor de financiering van de 'Conference and Workshop'. Van Rood een briefwisseling met Dr. Howard Goodman van de WHO in Genève, om accreditering door de WHO te verkrijgen. (van Rood, 22 december, 1965). Op vragen of hij sera wil typeren, reageert Van Rood dan ook positief en verzoekt daarbij om de sera te adresseren aan het 'WHO Reference Laboratory', gevestigd bij de vakgroep Immunohaematologie van het AZL (van Rood, 26 november, 1965; van Rood, ro november, I965). Ook maakt hij de resultaten van de specificatie met deze accreditatie kenbaar.

Met de formele aanwijzing van Leiden als het WHO Reference Laboratory, lijkt de positie van Leiden gevestigd. Nadat de 'leden' van de Tissue Typing Club Leiden als inhoudelijk centrum van het typeringsonderzoek hebben aangemerkt, gebeurt dit nu ook door maatschappelijke instituties, hetgeen het aanzien bij anderen weer vergroot $^{28}$. In de kleine kring van de leukocytenonderzoekers was het uitwisselen

27 Juist op dit punt blijkt dat niet alles koek en ei is in de Tissue Typing Club. Van Rood vertelt, dat aan het einde van de Workshop Walford naar hem toe kwam en zei: "Jij hebt nu een goed panel, maar wat hebben wij?" (van Rood, nt augustus, 2000). Leiden heeft niet alleen de mogelijkheid om een centrale positie in te nemen, maar ook de verantwoordelijkheid jegens de Workshopdeelnemers om dit te doen. 
van antisera al op kleine schaal gestart. Ook vóór de Workshop werden al pogingen gedaan om elkaars resultaten te reproduceren en zo antisera te vergelijken. Het idee was ook toen al dat andere leden van 'de club' over de uitkomsten van deze vergelijkingen vervolgens geinformeerd zouden kunnen worden.

Dear Jean,

Thank you for your letter of December 15th, and the anti-Yc. As you can see from the included results, anti-Yc and $6 c$ are identical. I think it might be useful to send a circular as I did for the serum of Lalezari. The enclosed form could be used as such if you agree. I will be interested to know if our $6 \mathrm{~b}$ and $6 \mathrm{c}$ sera also fitted your group Y. (van Rood, 19 januari, 1965)

De uitwisseling tussen onderzoekers lijkt op zich probleemloos, maar in de correspondentie tussen Van Rood en Dausset over het vergelijken van elkaars antisera, is toch wedijver te bespeuren. In een ogenschijnlijk neutraal gestelde concept-brief aan de leden van de Tissue Typing Club (figuur 3.3), is de centrale positie die Van Rood voor Leiden ziet, te herkennen.

De eigen benaming van de antigenen stelt Van Rood centraal; hij laat Dausset de vraag stellen of het serum 'een anti- $6 c$ ' is. In zijn antwoord op Van Rood, plaatst Dausset zijn serum naast het serum van Van Rood.

Dear John,

Thank you very much for your letter of January igth.

I have heard with pleasure that you have found my anti-Yc to be identical with your anti- $\sigma^{c}$ as we expected. In our hand and with your sera both systems have also appeared to be identical. Of course you can send your letter to all the members of the Club. (Dausset, 3 februari, 1965)

Deze, nauwelijks te onderscheiden rimpelingen in het contact, zullen het topje van de ijsberg blijken te zijn. Voor wat betreft het (dwingend) gebruik van de Leidse naamgeving, heeft Van Rood na de Workshop meer recht van spreken. Wanneer na de Workshop een collega, zoals Dausset in bovenstaand geval, een serum ter typering naar het 'WHO Reference Laboratory' stuurt en dat serum blijkt inderdaad tegen een bepaald antigeen gericht, dan wordt de deelnemers aan de leukocytenonderzoekspraktijk gemeld dat die en die persoon, dat en dat serum heeft, met die bepaalde (Leidse) specificiteit. Het Leidse WHO Reference Laboratory stuurt dan een circulaire rond waarop deze gegevens aan iedereen kenbaar worden gemaakt.

Enclosed please find a draft of the kind of circular we usually send to all people working in the field of leucocyte grouping, when the specificity of a serum has

been determined. (van Rood, 17 december, 1965 )

Sommige onderzoekers zijn zich er echter niet van bewust dat zij deel uitmaken van de 'Tissue Typing Club', waar Van Rood dan over zegt

The co-operative group for studying these antigens exists indeed. The Workshop is one of its activities, the circular letters I sent you several times belong to its activities too. (van Rood, 18 maart, 1965)

Na de Workshop in Leiden krijgt het WHO Reference Laboratory een toenemend aantal verzoeken om sera te typeren. Daaronder zijn ook verzoeken van buiten 'de Club'. Het leukocytenwerk trekt de aandacht, mede doordat het beloftevol is voor de 


\title{
January 1965.
}

\section{Dear...}

A serum was reoelved from Profesaor Dr. Jean Dauseet

Institut ce Recherohes de la Faoutte de kedeoine, Paris, with

the queetion whether thio wae a sanple of un snt1-60. The serum

was teoted against 23 leukooyte samples, of which 9 wore

60-positivo. (2 of these gamples gavo w1th Bome Boru AKapreactione (agglutination-negative-sborption-poeitivo).

14 were 6o-negutive.

The resu-ts vere as follows:

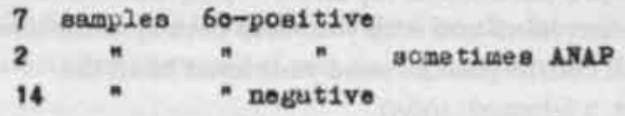

The titer of the serum is $1 / 16$.

Cgnolueion: Yo 18 a beautiful example co an ant1-60 serua.

\section{sinoerely yours,}

\author{
Jon J. van Rood, X.D. \\ Departwent of Imeunohematology
}

figuur 3.3: "The enclosed form"

(van Rood, 19 januari, 1965)

transplantatiegeneeskunde 29 . Op verschillende plaatsen wordt gestart met het opzetten van typeringslaboratoria, inclusief eigen donorpanels en screening op antisera. Naast verzoeken om sera te specificeren, wordt ook veel om hulp gevraagd bij het opzetten van eigen panels.

29 Vanuit Leiden wordt dit uiteraard niet bestreden:

As already mentioned in the introduction, strong evidence is available that some of the leukocyte antigens 
Your advice may well assist us in setting up a suitable panel of known leukocyte antigen donors. (Buchanan, 7 december, 1965 )

Doordat nu enigszins bekend is hoe de lokaal herkende antigenen van de collega's vertaald moeten worden in de antigenen van het International Reference Panel, kunnen deze collega's gaan fungeren als 'vooruitgeschoven posten'. Zo nemen zij een deel van het werk van de Leidse groep over, maar 'verkondigen' daarmee tevens de 'Leidse boodschap'. Van Rood delegeert dan ook een deel van de aanvragen om hulp naar collega's, die, in zijn ogen, nu geaccrediteerd zijn vanwege het feit dat zij hebben deelgenomen aan de Workshop en met hun eigen sera het Leidse panel hebben getypeerd. De antisera van de deelnemers aan de Workshop zijn nu geherdefinieerd naar de Leidse antigenen. Met die antisera kunnen elders in de wereld 'Leidse antigenen' herkend worden, die nu tevens de antigenen van het WHO Reference Panel zijn.

Voor de antiserumvoorziening is dit ook gunstig. De behoefte aan antisera neemt namelijk aanzienlijk toe, doordat ook verschillende aanvragen om antisera voor het lokaal typeren worden gedaan. De collega's kunnen hun eigen panel uitbreiden en daarmee ook op de Leidse antigenen screenen, waardoor van verschillende kanten antisera geleverd kunnen worden. Hiermee zou in de toekomst aan de toegenomen vraag tegemoet gekomen kunnen worden.

It is impossible for any one group of investigators to provide sera for the typing of all future kidney homografts. For this reason, it is extremely gratifying that as a result of the Workshop the number of centers which can recognize these antigens has been greatly increased. (Bruning, et al., $\mathrm{rg}_{95}$ )

Dat de resultaten van de Workshop zo snel te gebruiken zijn, kan gezegd worden doordat de deelnemers aan de Workshop in de meeste gevallen al over een getypeerd panel beschikten. De onderzoekers hoeven alleen maar de vertaalsleutel van de Workshop toe te passen op de aanwezige typeringen, waarna er een zekere vergelijkbaarheid tussen het WHO Reference Panel en het lokale panel is. In ieder geval is dan bekend welke antigenen (min of meer) overeenkomen. In tijden van schaarste kan Van Rood mensen dan ook niet alleen voor hulp, maar ook voor antisera naar collega's verwijzen, zoals bijvoorbeeld naar Kissmeyer-Nielsen (van Rood, Io november, 1965). Nieuwkomers kunnen in de leukocytenpraktijk worden opgenomen als zij zelf een donorpanel opzetten. Met deze panels kunnen zij op een gestructureerde manier antisera zoeken en de technieken leren. De meest voor de hand liggende manier daarbij is om donoren te zoeken en van hen de typering vast te stellen met behulp van bekende antisera. Voor dit doel vraagt men antisera aan bij het WHO Reference Laboratory, zodat de resulterende typeringen overeenkomen met het Central Reference Panel. Na de Workshop, en ook al ervoor, onderneemt de Leidse groep 'expedities' naar de laboratoria van collega's. Deze collega's hebben zelf voor de leukocytendonoren gezorgd en de panels worden door Van Rood en zijn medewerkers, met hun 'Leidse sera' getypeerd. Zo worden lokale 'kopieën' van het latere 'referentiepanel' opgezet. Voor de uniformiteit is dit een groot voordeel. De sera die vervolgens met behulp van deze lokale panels gevonden worden, zijn vergelijk-

are transplantation antigens $(8,21)$. This implies, that future kidney donors and recipients should, if possible, be typed for these antigens, especially in the light of Terasaki's findings that long-term kidney homograft survivors are more compatible as far as leukocyte groups are concerned than a random control group (24). (Bruning, et al., 1965) 
baar met de 'Leidse sera'. De vergelijkbaarheid in de leukocytenpraktijk vaart hier dus wel bij ${ }^{30}$.

Gesteund door de zich ontwikkelende leukocytenonderzoekspraktijk ontstaat voor de onderzoekers in Leiden de volgende situatie. Eerst is een eigen panel gecreëerd, vervolgens wordt dit verheven tot referentiepanel, waarna veel werk wordt verzet om elders met de Leidse sera panels te typeren. Vanuit een klein lokaal gebied wordt zo de vertaling gemaakt naar andere gebieden, die daarmee niet alleen een getypeerd panel krijgen, maar ook een sterke aanwijzing om bepaalde technieken te gebruiken. Hierdoor hanteren steeds meer mensen het Leidse classificatiesysteem. Zo lijkt Leiden een situatie te creëren waarmee zij ervoor zorgen dat anderen 'hun taal' gaan spreken, 'hun' antigenen herkennen en daarmee bewerkstelligen dat 'hun' norm de algemene wordt. De pogingen om elders identieke panels op te zetten, is een bijzondere vorm van standaardisatie; het is standaardisatie via een materiële route. Door met Leidse antisera lokale paneldonoren te typeren, vertellen deze donoren hoe het in Leiden is. Zo wil Van Rood zelfs de panels van andere, gevestigde onderzoekers graag 'zelf' typeren, als vorm van 'informatie-uitwisseling' (van Rood, I8 maart, 1966$)^{31}$.

De op basis van (vroege) 'Leidse sera' gemaakte panels, moeten echter opnieuw worden getypeerd, dan wel aangevuld om weer een echt internationaal panel te zijn. In de loop van de tijd slinken de panels namelijk, terwijl het aantal herkenbare antigenen groeit met het toenemende aantal verschillende antisera, die ook het International Reference Panel veranderen.

I personally hope that you will come and type a small panel for me. Most of the people you did three years ago have passed to the four winds. Furthermore, when you were here you only had $4^{\mathrm{a}}$ and $4^{\mathrm{b}}$ so please, please plan to come.

(Zmijewski, 30 september, 1966)

In dezelfde brief waarschuwt $\mathrm{Zmijewski} \mathrm{echter} \mathrm{voor} \mathrm{een} \mathrm{al} \mathrm{te} \mathrm{grote} \mathrm{bereidwilligheid}$ om elders panels te typeren. Er vindt door de toenemende belangstelling verdunning plaats in de 'Tissue Typing Club'. De omvang van 'de Club' groeit, maar niet iedereen is bereid zijn steentje bij te dragen. Dit wekt onder andere bij Zmijewski irritatie op. Hij waarschuwt Van Rood voor het nutteloos typeren van panels bij "dead heads", die alleen maar profiteren en niets presteren. Zo geeft hij als voorbeeld Henry Winn, die sera heeft gekregen om te gaan typeren, maar na een paar maanden vraagt naar de specificiteiten en daarbij vertelt zelf niet te gaan screenen

30 Meer gericht op de toekomst vormt deze uniformiteit echter ook een nadeel. Door het gebruik van de gestandaardiseerde antisera kan niet gesproken worden van representativiteit van het lokale panel voor de lokale populatie. Het hoeft namelijk niet zo te zijn dat het voorkomen van de antigenen in Leiden op dezelfde wijze verdeeld is, als op de betreffende plaats, of zelfs maar dat er dezelfde antigenen voorkomen. Dat betekent dat 'nieuwe', 'lokale' antigenen, in eerste instantie, mogelijk gemist worden. Voor klinische, typeringsdoeleinden heeft iedere populatie zijn eigen, specifieke antisera nodig, antisera die 'alle' aanwezige antigenen in die populatie kunnen herkennen. Dit zal in de toekomst nog problemen opleveren en bijdragen aan de ongelijke kansen op beschikbaarheid van een donororgaan voor mensen van verschillende rassen.

31 Later herhaalt hij dit voorstel en benadrukt het belang.

... I would like her to type your panel and those of Roy Walford and Rose Payne with our sera. This will be a lot of work and will cost us a lot of serum. however. I still think that this will be the most rapid way to exchange the information on the leucocyte groups. As it will limit our capacity for leucocytegrouping for other projects I would not like to do this unless you, Roy and Rose endorse this fully. (van Rood, 30 juni, 1966) 
"because it was too much trouble" (Zmijewski, 30 september, 1966). En dit terwijl hijzelf zoveel tijd besteedt aan het verkrijgen van antisera en typeren, dat er nauwelijks tijd over is voor onderzoek. Zijn tirade gaat verder met een tweede voorbeeld. Een andere onderzoeker, Iwasaki, beweert een test te hebben ontwikkeld om transplantatie-antilichamen te detecteren. Zmijewski doet een 'placebo' experiment met hem, door voor de test normaal AB serum in een "pre-graft" en een "post-graft" monster te verdelen. En zie, hij vindt antilichamen in het post-, maar niet in het pre-monster. Zijn test is zo, dat alleen hij hem kan lezen. "Bah! Humbug! Do you detect a trace of bitterness in all of this? Well you're right!" (Zmijewski, 30 september, 1966)

Er lijkt een binnen- en een buitencirkel van leukocytenonderzoekers te ontstaan. Het is echter niet zo dat de onderzoekers van het eerste uur allemaal dezelfde doelstelling hebben. Van Rood stelt de waarschuwingen van Zmijewski dan ook wel op prijs en herkent zijn gevoelens, maar wil toch doorgaan ${ }^{32}$. Hij deelt de zorg van Zmijewski over Iwasaki en Winn en hij belooft de laatste, wanneer hij hem tegen het lijf loopt, ook eens flink de waarheid te zeggen (van Rood, 27 juni, 1966).

$\mathrm{Al}$ met al wordt het steeds moeilijker om in te schatten of investeringen in deze groeiende 'leukocytenpraktijk', de moeite waard zijn voor deze praktijk. Ten aanzien van onderzoekers van het eerste uur heerst deze twijfel nier ${ }^{33}$. Maar diegenen die, aangetrokken door de successen van het leukocytenonderzoek, leukocytenantigeentypering willen gaan toepassen in de transplantatiepraktijk, zijn niet gericht op verdere ontwikkeling van het onderzoek naar leukocytenantigenen. De belofte van klinische toepasbaarheid van leukocytenantigeentypering, wekt de belangstelling van andere disciplines.

\subsection{Het Vervolg - De Derde Workshop}

$\mathrm{Na}$ het alom geprezen succes van de tweede Workshop, ligt het in de lijn der verwachting dat er een derde aflevering zal volgen. Niet Dausset, maar Ceppellini krijgt de 'eer' om de Organizing Secretary van de op 'Leiden' volgende meeting te zijn. In 1967 mag hij in zijn nieuwe instituut in Turijn, de deelnemers aan de derde Histocompatibility Testing Conference and Workshop ontvangen.

Sinds de tweede Workshop is in Turijn - onder andere met hulp van Van Rood ${ }^{34}$ - een leukocytendonorpanel opgezet. Het aantal daar beschikbare donoren overtreft nu zelfs vele malen het aantal donoren van het bij de vorige Workshop aanwezige donorpanel. Een klein deel van hen wordt geselecteerd om bloed te geven voor daad-

32 Van Rood's bedoelingen gaan verder dan uitsluitend het typeren van panels.

We are going down to Denver because I am really interested in the data Starzl, Terasaki and Porter put together and I think it is a good approach and worth some good typing. (van Rood, 27 juni, I966)

Evenals in Denver (naar aanleiding van een artikel van Starzl, Terasaki en Porter e.a. over afstoting, gerelateerd aan de kwaliteit van de match (Starzl, et al., 1965)) wil Van Rood in Boston ook niertransplantatiepatiënten en ontvangers gaan typeren en zo mogelijk ook huidtransplantaties, waarmee interessante informatie te halen kan zijn. Zie voor een uitgebreide beschijving van de V.S.-reis Hoofdstuk 6.

33 Hier zijn het vooral financięle problemen en tijdgebrek, die de samenwerking midden jaren '60 belemmeren.

34 Van Rood heeft met medeneming van apparatuur, sera en personeel in Turijn getypeerd en in Leiden geanalyseerd.

1 just got the bill for the computer analysis. The grand total for the work in Torino was $f 1599,34$ which is equivalent to $\$ 430,-$ It is about the double from wat I expected it to be. (van Rood, 22 maart, 1966) 
werkelijk gebruik in de workshop. Op basis van voorbereidende typeringen worden de meest informatieve families geselecteerd.

There were also the 400 families of Torino who agreed to collaborate with the Workshop. Eleven of the most informative were selected, and these families came at dawn each morning to be bled at the Centro Ortopedico e Traumatologico INAIL, where the magnificent new laboratories had been put to our disposal. (van Rood, 1967 )

De goede voorzieningen en het grote aanbod aan bereidwillige donoren zijn goede redenen om de Workshop in 'Torino' te houden. Ten aanzien van het gebruik van proefpersonen blijken interessante verschillen tussen landen te bestaan ${ }^{35}$.

Aan de vaststelling van het thema van deze Workshop gaat heel wat overleg vooraf. Ceppellini ziet aanvankelijk twee mogelijke onderwerpen. A. Genetica, maar daarbij tekent hij aan dat de antisera nog niet goed genoeg zijn om 'linkage studies' te kunnen doen. En B. een correlatiestudie tussen de leukocytenantigenen en roo huidtransplantaties tussen 'siblings' "(that should settle the question whether the known antigens are relevant for transplantation)" (Ceppellini, 2 augustus, 1966). Welk onderwerp ook gekozen zal worden, Van Rood vindt dat ook gezocht moet wor-

35 In Italiê (b)lijkt het makkelijker dan in Nederland om leukocytendonoren te werven en ook zijn meer belastende onderzoeken in Italië wel mogelijk, terwijl deze in Nederland om verschillende redenen op problemen stuiten. Zo worden bijvoorbeeld in Nederland apen gebruikt voor immunisatie onderzoek, terwijl dezelfde soort onderzoekingen in Italiê met mensen worden verricht, al lijkt de wijze van onderzoek hierbij wel minder belastend voor de onderzoekssubjecten te zijn.

Balner immunized Rhesus monkeys very much the same way as you have immunized your people from the mental hospital. Only, Balner used also skin grafts and intradermal injections. (van Rood, 3 januari, 1966)

Ook eerder wordt al gebruik gemaakt van de andere ideeën ten aanzien van het gebruik van mensen voor het doen van experimenten. Na de Workshop in Leiden kreeg de samenwerking tussen de Leidse groep en de groep van Ceppellini in Turijn, vorm in een voorstel voor een gemeenschappelijk project, waarbij uit opportunistische motieven voor Turijn wordt gekozen. Het plan was om in Turijn 'zwangere' vrouwen te screenen op antilichamen, van de positieve sera de specificiteit te bepalen door ze te testen tegen het Leidse panel en de vrouwen waar deze sera van afkomstig waren vervolgens te hyperimmuniseren met dezelfde specificiteit waar ze toch al antilichamen tegen hadden gevormd. Na die hyperimmunisatie zou de concentratie van dat bepaalde antilichaam in hun serum heel hoog zijn. Door die sera vervolgens te winnen door middel van plasmaforese - een methode waarbij alleen het serum uit het bloed wordt gehaald zouden goede antisera verkregen kunnen worden.

If you could screen sera from pregnant women in Torino, and select these sera which seem to have reasonable good antibodies ... If these women would be willing to be hyperimmunized, we could then, by using selected donors, with known genotypes, really get screaming high titters. These women could then be plasmaphoresed, etc.

The reason I would like to do this with you is twofold. In the first place immunizing women, even after the childbearing age here, would probably be impossible. Also plasmaphoresing would give tremendous difficulties. This is mainly due to the fact that I am not allowed to pay women for this kind of project. I think your position in this aspect is different, and that you can pay them, and then this might be easier to do. The second reason I would like to do this in collaboration with you is that this part of the project (immunizing volunteers) is really your idea. How do you feel about it?

The problem, of course, will be to find women willing to be immunized, and to be plasmaphoresed. Concerning the medical ethical aspect of it, I don't think we can do them much harm. They have leucocyte agglutinins to start with, so that does not make any difference, and as far as the serum hepatitis goes, if we use donors of the Blood transfusion service, this should not be a tremendous problem. (van Rood, 25 januari, 1965)

Technisch gesproken is er geen reden om hetzelfde onderzoek niet in Nederland uit te voeren. Praktisch gesproken lijkt het echter onmogelijk. De ruimere mogelijkheden die in Italië aanwezig zijn voor de werving van proefpersonen maakten het interessant om het onderzoek als gezamenlijk project voor te stellen. Het gegeven dat er in Italiě andere regels gelden ten aanzien van het gebruik van menselijke proefpersonen dan in Nederland, biedt perspectief. Later blijkt hoe onmogelijk het in Nederland is, wanneer na plasmaforese de donoren weg blijven. 
den naar echt identiek reagerende sera, waarbij hij opmerkt dat dit eenvoudig met de genetische studie kan worden gecombineerd (van Rood, 22 april, 1966; van Rood, $\mathrm{II}$ augustus, $\left.{ }_{1966}\right)^{36}$. Na consultatie van de andere deelnemers aan de vorige Workshop en enkele "authorities in the field, i.e. Medawar, Starzl, Race", schrijft Ceppellini aan Van Rood, dat het onderwerp de Genetica van de Leukocytenantigenen wordt ${ }^{37}$.

Naast alle correspondentie over het onderwerp van de Workshop, wordt ook weer nagedacht over de vraag wie aan de Workshop mag deelnemen. Evenals bij de vorige Workshop, wordt een lijst met namen samengesteld met de voor de Workshop geschikt geachte onderzoekers. Een van de belangrijkste besluiten ten aanzien van de Workshop is dat het aantal deelnemende groepen beperkt wordt. Waren er in 'Leiden' nog 26 teams aanwezig, in 'Torino' wil men het beperkt houden tot 10 à 12 teams $\mathrm{s}^{38}$. Over de centrale onderzoekers is men het snel eens, waarbij het onderwerp en doel van de Workshop een belangrijk selectiecriterium vormt. Amos en Zmijewski doen een voorstel, waar Ceppellini in grote lijnen mee instemt ${ }^{39}$. Aan deze lijst worden nog enkele namen van onderzoekers toegevoegd die ze onmogelijk kunnen passeren, mede met het oog op de toekomst.

I see you left out the Scandinavian people. I haven't very strong feelings about

this. I think it would be wise to check sometime at the end of the year what kind of work they are involved in. Both, Kissmeyer and Jensen are good immuno-

haematologists; and this is a rare bird. For that reason if they continue to work

in this direction I think it would be wiser to ask them. (van Rood, 22 april, 1966) Meer correspondentie is nodig om te bepalen van welke 'nieuwkomers' het zinvol is om hen te laten deelnemen aan de Conference. Het is duidelijk dat iedere nieuwkomer veel zou kunnen leren gedurende de workshop ${ }^{40}$, maar de leukocytenpraktijk is inmiddels zo gevestigd, dat ze zich kunnen veroorloven om alleen die teams uit te nodigen die ook iets voor de Workshop kunnen betekenen. Om vergelijkbare

We lost three of our best leucocyte-donors by plasmaphoresing them. By losing I dorit mean that they died,

but they just simply and absolutely refused to give blood again. (van Rood, 27 juni, 1966)

36 Hoofdstuk 4 gaat dieper op dit punt in.

37 Huidtransplantatic als onderwerp voor de Workschop, trekt Ceppellini in.

Owing to the opinion of the majority, I have withdrawn my proposal of doing skin-grafting for the workshop. But I am well determined to go on. (Ceppellini, 8 augustus, 1966)

In Hoofdstuk 6 zal verder worden ingegaan op de samenwerking tussen Ceppellini en Van Rood ten aanzien van de huidtransplantatie-experimenten in Turijn.

38 Ceppellini doet dit voorstel, daarbij aantekenend dat zijzelf en Leiden waarschijnlijk niet meer hoeven te typeren vanwege het voorbereidende werk.

In general I suggest that no more than to bench-working teams should be invited. Each team should be composed by one investigator and possibly one technician. The Torino group and possibly the Leiden group, maybe do not need to work on the bench during the workshop because they should have already typed the subjects. My technicians however will be very busy for the general logistics. (Ceppellini, 8 augustus, 1966)

Uiteindelijk zijn er in Turijn toch 16 deelnemende groepen anwezig.

39 Ceppellini laat dit hen en Van Rood weten.

Participants: your list is o.k. for me. For J V R information: they have suggested Terasaki, Zmijewski, Amos, Van Rood, Van Loghem, JVR, Walford, Lawler, Batchelor, Dausset, Payne, RC [Ceppellini] and as biometricians Bodmer, CAB Smith, and Woodbury.

I would only add Ivany from Prague. ... (Ceppellini, 8 augustus, 1966)

40 Dit wordt door Ceppellini dan ook wel overwogen, als speciaal onderdeel voor de nieuwkomers:

We can also give demonstrations of standard typing techniques to the outsiders [only invited for the Conference). After it we can begin the family typing ( 4 days) - then the weekend with excursion - then 4 more days of work - then one day for preliminary analysis of the results. (Ceppellini, 8 augustus, 1966) 
reden willen sommigen ook de Conference beperken tot diegenen die in Leiden aanwezig waren ${ }^{41}$. Bij Amos stuit het categorisch uitsluiten van 'beginners' op verzet. Hij argumenteert dat niet alle 'starters' gelijk zijn. Mensen die eerst in een ander laboratorium hebben gewerkt en vervolgens een eigen onafhankelijk programma starten, zijn niet te vergelijken met mensen die echt vanaf nul beginnen. En hij plaatst Anja Tiilikainen in de eerste groep.

... a previously experienced scientist who had been working in a leucocyte typing laboratory, who had now set up and independent program, and who could both contribute to and learn much from the conference. (Amos, 13 maart, 1967)

Als verdere nuancering stelt Amos dat de groep niet te gesloten mag zijn en dat goede nieuwe mensen een kans moeten krijgen.

We obviously cannot keep a tightly closed group. Anybody in the group must compete for his own place by contributing ideas and data, but new people of competence who are really interested must also be brought in. (Amos, 13 maart, I967)

Amos vindt dat de meeste druk komt van mensen die alleen leren en niet bijdragen en zegt dat deze mensen beter naar Parijs kunnen gaan, naar het congres van de Transplantation Society, waar ze ook erg veel kunnen leren.

Een beperkt aantal geīnteresseerde personen krijgt in tweede instantie toch een uitnodiging voor de conferentie, maar de deelname aan de Workshop blijft beperkt. Dit onderscheid maakt Van Rood ook naar Anja Tiilikainen wanneer hij haar uitnodigt.

Mainly because of limited blood supply of the donors to be tested it is

impossible to invite you also for the workshop. (van Rood, 12 april, 1967)

Het is echter de vraag of de "limited blood supply" de ware reden voor de inperking is. De doelstelling van de Workshop is vooral inhoudelijk geworden en gericht op de resultaten die met de bestaande (vernieuwde) technieken bereikt kunnen worden. Ze zijn niet bereid om concessies te doen aan het resultaat van de Workshop. Minder ervaren, of minder betrouwbare onderzoekers worden niet toegelaten.

Vanwege de oriëntatie op resultaat, wordt veel werk gemaakt van het selecteren van het panel dat in de Workshop gebruikt zal worden. In Leiden was er simpelweg een getypeerd panel, waarvan een aantal geschikte en beschikbare mensen bereid waren gevonden om bloed te geven voor de tests. In Turijn zijn inmiddels veel meer mensen getypeerd, waarvan een groot deel, door het genetische onderzoek dat normaal door Ceppellini gedaan wordt, een gewone of bijzondere ${ }^{42}$ familierelatie met één of meer donoren heeft. Dit grote aanbod aan potentiële donoren moet ook met de Leidse sera en technieken worden getypeerd, waarna die families en donorcombinaties geselecteerd kunnen worden, die de meeste informatie voor de doelstelling van de workshop zullen opleveren. Ceppellini dringt er dan ook bij Amos op aan om de komst van een 'Leids team' te bepleiten bij het $\mathrm{NIH}^{43}$ om alle potentiële dono-

41 Dit probeert Van Rood aan Anja Tilikainen uit te leggen.

On the suggestion of Sir Peter Medawar who is the President of the Transplantation Society, it was decided as it was impossible to open the workshop for all people who started working in the

histocompatibilitytesting field, to keep this meeting closed and restricted to those who had attended the Leiden meeting. I know it is a decision which will be unjust to a number of people and you seem to be one of them. (van Rood, 3 februari, 1967 )

42 Tweelingen

43 Amos heeft zitting in de commissie van het NIH die gaat over het samenwerkingsprogramma, waar een groot deel van de leukocyten-onderzoekers aan deelneemt. 
ren te typeren.

But please understand the importance for the good success of the Workshop that Van Rood comes down to type the families to be selected with his sera. We have developed great distrust in our ability of using agglutinating sera obtained from other investigators. On the contrary we do not have any difficulty in using cytotoxic sera (the new fluorescence technique is a beauty). Therefore, D B A, do defend this item of the Budget at NIH. (Ceppellini, 8 augustus, 1966)

Naar Van Rood gebruikt Ceppellini het argument dat ze met het vooraf typeren 'voorinformatie' krijgen en kunnen sturen, hetgeen opweegt tegen de belasting die het extra werk vormt.

It is certainly a burden for us, but besides the necessity of such work for the good success of the workshop, we shall be in the privileged situation of sorting out the families who are most interesting for our sera and of knowing already the main results before the Workshop. (Ceppellini, 8 augustus, 1966) Er zijn echter ontwikkelingen die interfereren met de voorbereidingen van de Workshop in Turijn. Zo heeft Van Rood niet meer zo'n grote voorraad van zijn goede sera. Het NIH is met een aantal onderzoekers, waar Van Rood er een van is, een contract aangegaan. Door het aangaan van dit contract heeft hij de beschikking gekregen over een groot budget voor onderzoek, maar als tegenprestatie is overeengekomen dat goed getypeerde antisera in de serumbank van het NIH worden gedeponeerd. De gevoelens over die serumbank zijn echter zeer dubbel. Enerzijds is het heerlijk om grote sommen geld ter beschikking te krijgen, maar anderzijds verliezen de onderzoekers door het contract de controle over wat er met 'hun' sera gebeurt, wie ze krijgt en wat die personen er mee (kunnen) doen 44 . Van Rood grijpt het typeren van de donoren voor de Workshop dan ook aan, om een gedeelte van 'zijn' antisera terug te krijgen.

P.S. I forgot to ask you if you would please ask from the Serum Bank $15 \mathrm{ml}$ quantities of the sera I put in the Bank to be used for typing of the families in Torino for the Workshop. In this way I get some of my sera back again and we get credit for doing work for NIH. (van Rood, 5 september/oktober, 1966)

De sera worden niet alleen teruggevraagd vanwege het feitelijk terugkrijgen van het materiaal, maar ook omdat op deze manier zichtbaar wordt gemaakt dat er daadwerkelijk activiteiten verricht worden ten gunste van de verschillende $\mathrm{NIH}$-contracten. Deze sera ondersteunen verscheidene projecten, waarvan de Workshop op dit moment de belangrijkste is.

$\mathrm{Na}$ alle voorbereidingen gaat op I4 juni i 967 de ' 3 e Histocompatibility Testing Conference and Workshop' van start. De Workshop begint in Turijn en de bijeenkomst eindigt op 24 juni na de conferentie in Saint-Vincent, een plaatsje in de bergen ten noorden van Turijn.

Van de in totaal 400 families zijn er in uitgekozen om het onderzoeksmateriaal voor de Workshop te leveren (totaal 77 personen). Daarnaast zijn nog 21 niet-verwante donoren geselecteerd voor correlatiestudies. Dit levert een totaal op van $9^{8}$ personen. De voor die dag benodigde families worden - voor een goed verloop van het verkrijgen van het materiaal - iedere morgen persoonlijk gewekt en in alle vroegte komen deze 12 tot 14 personen dan naar het instituut om bloed te geven.

44 In hoofdstuk 4 zal uitgebreid op de dilemma's rond de serumbank van het NIH worden ingegaan. 
Het bloed wordt verzameld in de verschillende, van de gewenste antistollingsmiddelen voorziene, opvangmaterialen. Dit bloed wordt verder verdeeld en gecodeerd, zodat het 'blind' kan worden uitgegeven aan de verschillende onderzoeksgroepen. Zo kennen de onderzoekers, tijdens het doen van de bepalingen, de genetische verwantschap van de verschillende monsters niet. De resultaten van de bepalingen leveren ze in, waarna deze vermenigvuldigd worden. De volgende dag maakt men de familierelaties bekend en kijken de verschillende onderzoekers welke antigenen aan de verschillende donoren kunnen worden toegekend. Deze gegevens worden op ponskaarten gezet die men vervolgens naar Leiden stuurt, waar de computer ze verwerkt. De uitkomsten komen vrijdag uit Leiden terug en Van Rood presenteert de resultaten op zaterdag, de laatste dag van de conferentie.

Naast de genetische conclusies over onderlinge afstanden van de verschillende (sub)loci op de chromosomen, concludeert men uit de resultaten van de workshop, dat er - verspreid over de wereld - meerdere sera zijn die onderling een grote mate van overeenstemming vertonen in hun reactiepatroon met een leukocytenpanel. Hieraan verbindt men de conclusie dat het zinvol is om op meerdere plaatsen in de wereld gelegenheid tot gestandaardiseerde vergelijking te creëren. Dat kan door lokale panels nogmaals, maar nu met 'internationale sera', te typeren, waarmee ze vergelijkbaar worden gemaakt met het 'International Reference Panel' in Leiden. Het toenemen van de vergelijkbaarheid bestaat uit twee onderdelen. Ten eerste worden de lokaal gedefinieerde antigenen geverifieerd, en ten tweede worden de in Leiden gehanteerde benamingen van de antigenen aan de lokale panels toegevoegd. Deze 'internationale panels' kunnen vervolgens een rol gaan spelen in de specificering van antisera ${ }^{45}$. Deze lokale referentiepanels kunnen de eerste schifting van nieuwe sera doen, waarna voor definitieve vaststelling van de specificiteit van een serum het WHO Reference Laboratory in Leiden kan worden ingeschakeld. ${ }^{46}$

De Workshop in Turijn levert dus enerzijds meer kennis op over het genetische systeem van de leukocytenantigenen en anderzijds is het vinden van verschillende, identiek reagerende antisera aanleiding om meerdere referentiepanels op te zetten waarmee het zoeken naar identiek reagerende en nieuwe antisera kan worden geïntensiveerd. Zo krijgt het leukocytenonderzoek zowel in de zin van kennis, als in de zin van de omvang van de praktijk, een bredere basis. Echter, niet alle consequenties van deze groei zijn positief.

\subsection{Keerzijde van Succes}

De leukocytenpraktijk breidt zich op verschillende manieren uit en het belang van de leukocytenantigenen wordt duidelijker voor zowel de onderzoekers zelf, als voor andere geneeskundige disciplines. Een aantal leukocytenantigenen zijn geïdentificeerd, zijn herkenbaar met behulp van serologische technieken en blijken een rol te spelen bij de afstoting van transplantaten. Wanneer het leukocytenantigeenon-

45 Hoe men de rol van die internationale pancls ziet blijkt onder andere uit een brief van Ceppellini aan van Rood over het Workshopverslag.

The list of laboratories which have an "international panel". i.e. a panel typed with the sera of at least one other center and therefore can act as reference center, should be given on a different Table. (Ceppellini, $\mathrm{u}$ juli, 1966)

46 Overigens is het tijdens de conferentie in St. Vincent dat Van Rood het voorstel doet om de orgaanuitwisselingsorganisatie Eurotransplant op te zetten. Zie hiervoor verder Hoofdstuk 7 en Bijlage $\mathrm{r}$ : Het Eurotransplant-voorstel. 
derzoek inderdaad een medische doorbraak blijkt te zijn, is er ook perspectief op te verdelen 'prijzen'. ledereen wil daarom graag erkenning krijgen voor zijn of haar bijdrage aan de totstandkoming van deze praktijk. Er ontstaat echter onenigheid over de vraag wie wat als eerste heeft beschreven en over de relatieve waarde van verschillende bijdragen, waardoor de atmosfeer binnen de Tissue Typing Club verslechtert. Deze verslechtering lijkt zelfs nog voor de Workshop in Leiden al te zijn begonnen, want Van Rood spreekt in januari 1965 zijn bezorgdheid al uit naar Bernard Amos.

As I discussed with Overman, I think one of the most important things on the moment is to keep a good mentality in the group and an atmosphere of cooperativeness. I hope I am mistaken (but I doubt very much so) when I have the impression that in the last half year or so frictions are starting to grow. (van Rood, 22 januari, 1965$)^{47}$

In 1967 blijkt die verslechtering echter door te zijn gegaan, wat sommigen een zorgelijke situatie vinden, waar ze graag verbetering in zouden willen zien.

From the personal standpoint, I particularly admired your gracious speech at the dinner in Saint-Vincent. I think that you have made a major step forward towards insuring the survival of close and, hopefully even closer ties between the "leucocyters". (Rapaport, 14 augustus, 1967)

Aan deze speech heeft Van Rood dan zelf al een vervolg gegeven, want hij is een correspondentie met Dausset gestart over de wederzijdse erkenning van hun werk. Ook anderen zien dit als een mogelijkheid om een einde te maken aan de situatie van 'achterdocht en wantrouwen' (Rubinstein, 12 september, 1967 ) ${ }^{48}$ Tijdens het kort na de Workshop en Conference gehouden Congres van de Transplantation Society in Parijs, komen de strubbelingen aan de oppervlakte en direct daarna start Van Rood zijn correspondentie met Dausset.

I have been sorry that much of the pleasure of seeing the congress to be such a success, must have been spoiled for you because of the misunderstandings and the frictions which occurred. This may have the advantage, however, that now everybody has had a chance to say his word, the air is cleared and we can enter a period of really fruitful co-operation, I sincerely hope so.

I feel that if we want our co-operation to be successful we will have to speak up if there is something we are unhappy about. I think you agree. I realize that it is difficult to put such things in a letter, misunderstandings occur so easily.

However it is the only way I can contact you now: I hope you will understand me without taking offence. The only thing I am trying to do is to create an atmosphere of true co-operation.

When I entered the field, about io years ago, I was still young. I remember me calling you, jokingly, "mon pere intellectuel": a nomination you accepted by calling me "mon fils". Apart from jokes you were in many other ways an

47 Deze frictie is in ieder geval tussen Van Rood en Dausset ontstaan, over de presentatie van Dausset in Stokholm en het daarin afwezig zijn van enige referentie naar de in Leiden behaalde resultaten; en hoe Dausset - via tussenkomst van Rapaport - aan de Leidse sera is gekomen.

Zo schrijft Rubinstein althans over de onstane atmosfeer.

... I feel now sure that you have done the right thing in starting the whole exchange: now there is at least a chance for your differences to get straightened up and a new episode of fruitful co-operation to replace suspicions and mistrust. (After all that is what your good friend Rapaport was after, wasn't it?). (Rubinstein. 12 september, 1967) 
example for me: for instance in the very generous way you gave reference to other people's work. I have tried since then very conscientiously to live up to your example. (van Rood, r juli, 1967)

$\mathrm{Na}$ deze inleiding, waarin Van Rood zijn best doet om een voorkomende en enigszins nederige positie in te nemen, legt hij uit waarom hij teleurgesteld is over de introductie van de 'St. Vincent paper' van Dausset.

... I really think it is unfair to our contributions in this field. Enclosed you will

find a copy of the introduction of our own paper. I am sure the difference will be self-evident. Actually you are quoting our Munksgaard paper but not the data on linkage which were presented in that paper. I know that the linkage data can be criticized but so can your association data. I do not think that this detracts in any way the intrinsic value of your or our observation. ... (van Rood, I juli, 1967)

Verder vindt hij dat Dausset een verkeerde weergave geeft van hun opvattingen over het afhankelijk dan wel onafhankelijk zijn van de verschillende antigenen van groep 'Four' en 'Six'. Toch blijft de toon van deze brief nog zeer verzoenend en voorkomend.

... I hope you can accept this letter for what it is: a sincere attempt to create a basis on which further fruitful co-operation will be possible. If you are willing to change the introduction of your paper, fine, but if you think it is unnecessary, don't do it.

Hope to hear from you. (van Rood, 1 juli, 1967 )

De reactie van Dausset volgt zeer spoedig en hij begint ook met te zeggen dat hij verheugd is over Van Roods initiatief en dat hij de brief met veel welwillendheid gelezen heeft. Hij neemt deze gelegenheid te baat om te zeggen hoezeer hij de wijze waarop de competitie tussen hen zich gedurende een aantal jaren heeft gemanifesteerd, op prijs stelt en spreekt zijn waardering uit voor het werk en de wetenschappelijkheid van Van Rood.

Je saisis cette occasion pour vous dire combien j’ai apprécié la correction et lhonnêteté de notre compétition depuis quelques années. Je profite également de cette occasion pour rendre hommage à votre travail et à votre esprit scientifique. (Dausset, 24 juli, 1967 )

Tevens geeft hij aan hoe hij de introductie van het betreffende stuk zal wijzigen en spreekt daarbij de verwachting uit dat dit geheel naar Van Roods tevredenheid zal zijn. Dan echter, gaat hij verder met op zijn beurt bezwaren te uiten tegen het SaintVincent artikel van Van Rood. Dit punt gaat over wederzijdse erkenning voor behaalde resultaten en over de vraag wie het eerst het systeem van de leukocyten. groepen' doorgrond had. Dausset vindt - en meent dat Van Rood dat mondeling ook erkend heeft - dat de Parijse groep in $1_{9} 65$, ten tijde van de Workshop in Leiden, verder was met het begrip van de relaties tussen de verschillende leukocytengroepen. Dausset zou dit dus graag gewijzigd zien, want in dat stuk wordt volgens hem ten onrechte de suggestie gewekt dat Leiden en Parijs, via verschillende wegen, op dat moment hetzelfde bereikt hadden. Hij nodigt Van Rood uit om hem weer te schrijven, mocht hij het met zijn bezwaren niet eens zijn. Want, zo schrijft hij:

C'est par la discussion amicale et sincère que la vérité se fera un jour. (Dausset, 24 juli, 1967$)^{49}$ 
Dausset spreekt zelfs de wens uit dat zij tot algehele overeenstemming komen over de respectievelijke verdiensten op het gebied van de ontdekking van de weefselgroepen, vooral wanneer mocht blijken dat deze groepen werkelijk belangrijk zijn voor transplantatie (Dausset, 24 juli, 1967).

Na deze brief van Dausset volgt, precies een maand later, een zeer uitgebreid antwoord van Van Rood. Deze zegt blij te zijn met de openheid die Dausset aan de dag legt door deze punten te bespreken. Dan echter, blijkt de broosheid van dit contact.

As to your following point it is only with great reluctance that I follow up your

invitation to speak up and answer. I am so happy that the air has cleared

between us and I am most anxious not to spoil this atmosphere of mutual

appreciation. (van Rood, 24 augustus, 1967)

Ondanks zijn huiver gaat Van Rood toch uitgebreid in op de kwestie van het in $1_{9} 6_{5}$ op hetzelfde punt aanbeland zijn van beide onderzoeksgroepen.

The essential point for me is that we both came to more or less the same conclusion (the existence of an analogue of $\mathrm{H}-2^{50}$ in man) although using different approaches. (van Rood, 24 augustus, 1967)

Waar Dausset echter als belangrijkste verdienste van de Leidse groep, het laten zien van het allelisch karakter van 4 a en 4 b schetst, ziet Van Rood andere zaken als minstens even belangrijk.

As for our contributions I think even more fundamental than the allelic nature of $4 \mathrm{a}$ and $4 \mathrm{~b}$ is the method to recognize these antigens: screening of a large number of sera, selection of the best ones, the use of a large panel and 'Fisher four squares' test to study their similarity and antithetical nature. This, together with the concept of the pre-immunized recipient to show that an antigen is a transplantation antigen, are, I think, our major contributions. (van Rood, 24 augustus, 1967 )

Hij verdedigt zijn belangen in niet mis te verstane bewoordingen, gedetailleerd en diep op de materie ingaand. Teneinde de ontstane dialoog niet te verstoren, ondanks het uitspreken van grote verschillen van mening, schrijft hij - ondanks veel denken (her)schrijfwerk - nog steeds niet tevreden te zijn over deze brief. Ook vraagt hij Dausset, om in gedachten te houden dat hij blij is met hun nieuwe wederzijdse begrip; dat hij Dausset ziet als de pionier in het veld en dat hij daar in verschillende artikelen ook blijk van heeft gegeven. En als relativerende opmerking over de hele 'Who Saw What First' discussie:

Basically the thing which gives me most satisfaction is the understanding of these biological and genetical mechanisms. In a roo years (perhaps in ro or 20) nobody will care who exactly said what or when. The whole group of us will be known (or forgotten) as the ones who provided the basis for the recognition and the evaluation of the tissue antigens. (van Rood, 24 augustus, 1967 )

Beiden herhalen steeds dat de geest van deze schriftelijke discussie wordt gewaardeerd, maar de details van Van Rood worden door Dausset met details bestreden. Ook Dausset gaat diep in op de materie en erkent de belangrijke bijdragen van de Leidse groep, maar ziet zijn eigen bijdragen als verdergaand en belangrijker dan 'pionier'. Hij stelt dat hun bijdrage in ${ }_{19} 65$ fundamenteel was voor het begrip van de meest ingewikkelde genetische situatie bekend bij de mens.

so $\mathrm{H}-2$ is de naam van het leukocytenantigeensysteem bij muizen. 
Je ne pense donc pas que Pon doive limiter mon rôle à celui, quoique très honorable, de pionnier et j'estime que notre contribution de 1965 a été fondamentale pour la comprehension d'une des situations génétiques les plus complexes encore connues chez lhomme. ... (Dausset, I9 september, 1967) Dausset sluit de brief af met de verwachting dat Van Rood deze opmerkingen neemt in de geest waarin ze zijn gedaan, namelijk in alle openhartigheid en met de wens zo veel mogelijk tot de bodem te gaan (met alle noodzakelijke details) teneinde de moeilijke en vaak emotionele toestand op te helderen.

J'espère que vous prendres ces remarques come je les ai faites c'est-à-dire dans un esprit de franchise totale avec le désir d'aller, le plus possible, au fond des choses (avec tous les détails nécessaires) afin d'éclairer une situation difficile et souvent émotionelles.

Je suis très heureux de vous retrouver dans quelques jours.

Très amicalement.

Prof. Ag. J. DAUSSET.

(Dausset, r9 september, 1967)

Per brief krijgt de discussie geen vervolg. 51

\subsection{Gestandaardiseerde Praktijk?}

In de loop van de jaren is het pad van de leukocytenantigenen vruchtbaar gebleken. Verspreid over de wereld zijn velen, aanvankelijk ieder op eigen wijze, bezig geweest met het zichtbaar maken van leukocytenantigenen door middel van serologische reacties. Na verloop van tijd ontstaat de behoefte om tot meer uitwisseling van kennis' te komen. Deze kennis zit vooral in materialen en antisera, niet alleen in ideeën. De eerste Conference en Workshop is echter vooral gericht op het uitwisselen van ideeën en het demonstreren van de verschillende gebruikte technieken. Dit levert wel inzicht op in elkaars methoden, maar combineerbaarheid van de 'kennis' wordt er niet mee bereikt. Tijdens de tweede workshop wordt een andere strategie van kennisoverdracht gevolgd. Door de verschillende onderzoekers via hun eigen methoden en met hun eigen antisera, hun eigen specificiteit te laten bepalen van dezelfde, Leidse bloedmonsters, wordt een gemeenschappelijke basis gecreëerd voor verder gesprek. Bij deze gelegenheid blijkt dat verschillende onderzoeksgroepen met hun respectievelijke sera, dezelfde antigenen kunnen herkennen. Toch blijven er ook na deze tweede Workshop vele vragen over. Zo zijn de reactiepatronen van verschillende, met hetzelfde antigeen reagerende antisera niet volledig identiek. Hierbij wordt de vraag gesteld of dit komt doordat meerdere varianten van het antigeen herkend worden, of dat technische problemen verantwoordelijk zijn voor deze verschillen.

As far as I am concerned, I think on the moment the main problem is to make a choice between the possibility that two sera recognise two variants of an antigen, or whether these two sera recognize the same antigen, but that differences are

51 Een saillant detail hierbij is, dat in 1980 Dausset, samen met Snell en Benacerraf, de Nobelprijs voor Fysiologie en Geneeskunde krijgt. Leslie Brent doet in 1997 hierover ten aanzien van Van Rood een opmerkelijke uitspraak:

It is unfortunate that the Nobel Committee did not see fit to include him among the recipients of the 1980 Prize in Physiology and Medicine, for not only was he a co-discoverer of HLA but he has continued to the present day to make many significant contributions to the HLA story. (Brent, 1997) 
found due to technical difficulties. (van Rood, 28 januari, 1966)

De leukocytenonderzoekspraktijk is op de goede weg, maar er moet nog erg veel worden opgehelderd. Er zijn sterke aanwijzingen voor het bestaan van 12 tot 15 an. tigenen, waartussen in verschillende mate verband bestaat. En men heeft het vertrouwen dat dit verband in de komende tijd verder verhelderd zal worden. Toch zijn er nog teveel onzekerheden om te komen tot een welomschreven nomenclatuur. Van Rood doet een voorstel voor de wijze waarop het kiezen en gebruik van bena. mingen voor 'nieuwe' antigenen voorlopig plaats zou moeten vinden, teneinde verdere verwarring te voorkomen.

To minimise further confusion of those working in the field and those watching it, it is strongly advised that before "new" antigens are claimed, the investigator should check his sera against panels typed for the antigens already described.

Such panels are present in a number of places in the world. (van Rood, 28 januari, 1966)

Bij deze referentiepanels kan vervolgens gekeken worden of het reactiepatroon van het serum volledig overeenkomt met dat van een van de al bekende antigenen, of dat het in beperkte mate overeenkomt, hetgeen zou kunnen duiden op een variant van een al bekend antigeen. In het tweede geval zou men middels een indexletter aan kunnen geven dat het een variatie op een bekend antigeen is. De derde mogelijkheid is, dat het reactiepatroon met geen enkel antigeen overeen komt, wat betekent dat het serum een nieuw antigeen herkent. In dit geval is de onderzoeker vrij om een naam te kiezen (van Rood, 28 januari, 1966). Later kan dan een nieuwe, definitieve nomenclatuur worden vastgesteld.

When the question has been settled whether we are dealing with endless variations of similar antigens, or with a few main antigens with some variants and the relations of linkage of the different antigens has been elucidated, a nomenclature can be set up which will be most logical and correct. The idea to give a locus a letter and his alleles numbers, seems in this respect a good one. (van Rood, 28 januari, 1966)

Het tijdens de Workshop in Leiden ingestelde Nomenclatuur-comité neemt de conclusie over, dat het nog te vroeg is om een definitieve nomenclatuur vast te stellen, zolang nog onbekend is of er meerdere sera zijn die dezelfde antigenen herkennen, zoals Van Rood dat aan Ceppellini schrijft.

As long as this has not been settled I don't think it is wise to start changing names. I do think, however, that in the literature the first name should be used, with an indication whether the serum which is recognizing that antigen, is giving identical or similar reactions. In other words I do agree with the way Rose Payne went about it and I think that Jean Dausset was absolutely wrong on this point in renaming antigens of which sera had been sent to him. On this score I do then agree with you (for instance the Buffo affair) and Shulman. ... (van Rood, 28 december, 1966 )

Voorlopig moeten de onderzoekers dus onderling uitmaken wat de officiële benaming van een bepaald antigeen wordt.

The difficulty is of course with $\mathrm{Mac}, \mathrm{Br}, \mathrm{La}$ which one will it be? Personally I don't care a damn and think that Dausset, Payne and Shulman should decide this among themselves. If they cannot reach an agreement we could call it $8 \mathrm{a}$. The advantage will be that all three will be against this decision! (van Rood, 28 december, 1966) 
De nomenclatuur blijft een heet hangijzer. Niet alleen bestaat nog geen consensus over de samenhang tussen de verschillende antigenen, maar tevens wordt een deel van de strijd om erkenning uitgevochten via de nomenclatuur. Hierboven verwijst Van Rood al naar een twistpunt, maar ook bij het vaststellen van het definitieve nomenclatuur-systeem wordt deze strijd gevoerd. Gedurende de voorbereiding van de conferentie in St. Vincent bespreken de organisatoren het houden van een korte sessie over nomenclatuur, aangezien de 'bloedgroepers' bezwaar maken tegen ' $\mathrm{Hu}$ ' als benaming van leukocytenantigenen.

I have received the answer of the Blood Group people: the majority is rather strongly against Hu because of Hunter. Shall we discuss nomenclature? may be 15' (referee: Fred Allen) during the last session, recommending that for the moment no new terminology as Hu-r should be proposed, until more is known. (Ceppellini, 3 juni, 1967)

Tijdens de Workshop wordt voorgesteld een WHO commissie in te stellen, die moet trachten een goed benamingssysteem te ontwikkelen. Met berichtgevingen over mogelijke benamingen en de vaststelling van een bepaalde nomenclatuur wordt echter ook een beeld geschetst van de belangrijke mensen in het veld. De geschiedenis is gemaakt, nu moet hij 'eerliik' verdeeld worden. Wie vond wat het eerst? Wie krijgt waarvoor erkenning? Welke nomenclatuur wordt vastgesteld voor gebruik? Momenten waarop een overzicht van de geschiedenis wordt gegeven, bestemd voor een breder publiek, zijn de momenten waarop de belangen van de afzonderlijke onderzoekers zo goed mogelijk verdedigd moeten worden. Een brief aan Science, waarin Bernard Amos de geschiedenis en stand van zaken beschrijft en melding maakt van de voorlopig te hanteren nomenclatuur, vormt dan ook een twistpunt voor wat betreft de verdeling van de eer.

$\mathrm{Na}$ de Torino Workshop wordt een commissie ingesteld onder voorzitterschap van Trnka van de WHO. Deze commissie zal zich buigen over de te gebruiken nomenclatuur voor de leukocytenantigenen (Curtoni, et al., I967). Nog voordat die commissie is geïnstalleerd, spreken in Williamsburg (Virginia) verschillende onderzoekers, die ook in Turijn aanwezig waren, over de nomenclatuur van leukocytenantigenen. Vervolgens schrijft Amos hierover een brief die in Science zou moeten worden gepubliceerd.

Several of the investigators who took part in the Torino workshop met recently for a preliminary discussion of the analysis of the data. The problem of deciding upon a name for the major locus was discussed and, after consideration of a number of alternatives, the name HL-A was agreed upon as being most acceptable. The letters have no fixed significance; thus, $\mathrm{H}$ can be interpreted as being "Human," "Histocompatibility," "Hominid," etc., L as "Leucocyte," "Lymphocyte," "Locus," etc. A was preferred over $\mathrm{I}$ as a designation for the major locus since it is thought likely that numbers will be used to designate individual specificities controlled by this unit of genetic information. (Amos, 5 oktober, 1967$)$

Naar aanleiding van dit concept belt Van Rood naar Amos en Zmijewski. Zijn kritiek geldt niet zozeer de naam HL-A, als wel het - in zijn ogen - gebrek aan aandacht voor de bijdragen uit Leiden. Op dit telefoongesprek reageren Amos en Zmijewski tamelijk fel.

We have discussed the telephone conversation of this morning and fail to see why you are making such strenuous objections.... We do not believe that you 
have any strong grounds for disputing the joint letter and believe that you are in as grave a danger of isolating yourself from the field as you were on a previous occasion when Bernard had cause to write to you in this way....

Assuring you of our continued regard for you, we suggest you reconsider your recent impulsive behaviour. (Amos, et al., 5 oktober, 1967)

In reactie op deze brief krijgt Ceppellini van Van Rood het dringende verzoek, om de brief aan Science toch vooral niet op te nemen in Histocompatibility Testing 1967 (van Rood, 13 oktober, 1967). De inhoud van de brief aan Science stuit bij Van Rood op grote bezwaren. Hij wil een aantal wijzigingen en zegt dat, wanneer die niet geaccepteerd worden, hij de hele brief niet zal tekenen, al stelt hij dat ook afhankelijk van de mening van Ceppellini en anderen.

The general objection, we discussed already, is that the letter (in my opinion) over-emphasises the contribution of Dausset, and under-emphasises the contributions of all other people. The letter as it is now suggests more or less that without the introduction of the computer approach these antigens would also have been worked out. I think this is unlikely. As far a I can see at the moment, the computer approach has been essential in the recognition of the antigens and this is something which is not emphasised. But still, I will not on this point alone refuse to sign. The fact that Dausset and our group arrived at the same time at the concept of HL-A is for me on the other hand an essential one. (van Rood, 13 oktober, 1967 )

$\mathrm{Na}$ uitgebreid overleg met Ceppellini en mede uit zijn naam, legt Van Rood per brief zijn bezwaren voor aan Van Loghem. Van Rood ageert tegen de vooraanstaande positie die Dausset krijgt en doet een aantal wijzigingsvoorstellen om dit te corrigeren $^{52}$. Hij lijkt, door lobbyen, te proberen, de bijdragen van anderen minder aan die personen gekoppeld te laten zijn en hun eigen bijdragen juist meer naar de voorgrond te halen. Deze meer 'formele' weg lijkt Van Rood in te slaan na zijn 'impulsieve' eerste reactie naar Amos. Binnen een maand stuurt hij Amos en Zmijewski een uitgebreide brief waarin hij heel precies beschrijft waar hij bezwaar tegen maakt, op welke gronden en hoe hij dat graag gewijzigd zou zien. Hij is wel bereid mede te ondertekenen, mits enkele van zijn punten worden overgenomen. Het voorstel van Ceppellini, dat Amos de brief alleen tekent, steunt hij echter ook.

Terwijl zijn telefonische poging juist zo'n tumult veroorzaakte, schrijft Van Rood

52 Mede uit naam van Ceppellini geeft Van Rood een opsomming van zaken die zij naar aanleiding van Amos brief ter discussie menen te moeten brengen.

Wat mij ergert is dat de hele brief zo breed Dausset's bijdragen uitmeet en zo weinig aandacht schenkt aan het werk van anderen. ...

Naar ons beider gevoel zou de brief beter zijn indien de volgende punten worden gecorrigeerd:

1. Mac in de eerste alinea identificeert een auteur (...). Het lijkt beter deze alinea b.v, als volgt te veranderen: Ten years have passed since definite proof has been given that human leukocyte isoantigens exist and can be recognized with in vitro techniques. The significance of these findings was not fully appreciated until several years later and only recently it has been proven that most of these isoantigens are components of a very complex system.

2. The next impetus followed the introduction of computer techniques. Vind ik nogal slapjes. Hadden wij zo snel al deze antigenen herkend zonder deze methoden?

\#. Five wordt HL-B. Ik vind het best, maar het werd niet besproken, het heeft geen haast zoals HL-A en dit lijkt mij de taak van de WHO commissie. N-A vind ik beter dan HL.C. Laten wij HL houden voor weefselantigenen. ...

Dit is alles. Ben zeer benieuwd naar je mening. (van Rood, 18 oktober, 1967 ) 
nu aan Amos en Zmijewski dat hij zijn bezwaren op dit gebied eigenlijk liever niet per brief kenbaar wil maken.

As far as the emotional part is concerned this is so complex and difficult that 1

think it is better not to discuss this by letter. Misunderstandings arise so easily.

(van Rood, 24 oktober, 1967)

In zeer voorzichtige bewoordingen laat hij echter wel weten op een aantal punten gegriefd te zijn. Over wat er tijdens het telefoongesprek gebeurde, heeft hij blijkbaar een geheel ander beeld dan Amos en Zmijewski. In de afsluiting van zijn brief refereert hij aan de manier waarop zij tegen het telefoongesprek met hem aankeken.

Let me finish by assuring you of my continued regard for both of you. I promise never to be impulsive again (anyhow not in your presence, well.... anyhow I will try!). (van Rood, 24 oktober, 1967 )

Rond het tot stand komen van de Science-brief wordt duidelijk dat de Tissue Typing Club op zijn eind loopt. Inhoudelijke en persoonlijke zaken worden gescheiden. De leukocytenonderzoekspraktijk is zover ontwikkeld, dat er ruzie kan worden gemaakt over de toekenning van de verdiensten. Het idee bestaat blijkbaar dat persoonlijke emoties het 'ware', inhoudelijke van de kennis kan vertroebelen. Zo althans legt Ceppellini zijn visie op de brief uit aan Van Rood.

I have written to Amos telling him that the 'letter' for me is only a way for removing, once for ever, personal emotions from the future discussions on terminology, which will be very difficult. Therefore, because I think that you were the one who received less in Williamsburg, I completely back your suggestions and do not propose any change of my own. (Ceppellini, 25 november, 1967)

In totaal reageren acht mensen met wijzigingen, op het rondzenden van het concept. De meesten daarvan zijn stilistisch, enkele inhoudelijk. Met name vanuit Europa komen de meer inhoudelijke commentaren. Van Loghem, Van Rood en Ceppellini reageren in dezelfde trant, zoals Amos aan Van Rood laat weten. Daarnaast zegt hij hoe hij de brief aanpast en waarom een aantal wensen van Van Rood niet worden gehonoreerd. 'Toen hij ' $4 a$ ' en ' $4 \mathrm{~b}$ ' opnam, moest hij ook vele andere verschillende antigenen noemen en vond zichzelf "back at the edge of the emotional morass" (Amos, 22 december, 1967$)^{53}$. Uiteindelijk krijgt de brief een plek bij de Workshop verslagen in Science en is Amos de enige ondertekenaar (zie figuur 3.4).

53 In zijn eigen woorden:

The most significant change that affects you relates to the recognition of one complex locus. Instead of saying "confirmatory evidence was soon available," it now reads "Similar conclusions were drawn from linkage studies," Secondly the use of the computer has been much more strongly emphasized. Thirdly, HL$B$ and $\mathrm{HL}$. C have been withdrawn because there was less unanimity about them and three people all proposed different changes that were impossible to reconcile. Fourthly I started to work in $4 \mathrm{a}$ and $4 \mathrm{~b}$ in the beginning, but then had to mention LA-2, Br, etc. and found myself back at the edge of the emotional morass, so I read back over the letter and found that on page two Group 4 is very clearly mentioned as being the first group to be described, and to put down the same thing twice would be just repetitious and would seem rather odd in a brief statement.

The letter as now amended lists the signatories only as agreeing to the designation HL.A. (Of all the people contacted, only one objected.) It has gone to Science and to Trynka to insert in the WHO bulletin. (Amos, az december, 1967$)$ 


\section{Human Histocompatibility}

\section{Locus HL-A}

Ten years bave passed since the first human leukocyte isoantigen was recog. nized by in vitro techniques. The significance of that discovery was not fully appreciated until several years later, and only recently has it been proved that the first antigenic specificity, Mac, was one of many components of one very complex system.

Inereasing numbers of investigators have become attracted to the study of leukocyte antigens because these antigens are also present on a wide variety of tissue cells. On the tissues, a number of these factors serve as, or are closely associated with, transplantation or histocompatibility antigens and are implicated in graft rejection. The investigations have been greatly accelerated by the discovery that the isoantibodies to leukocytes were present in serums from multiparous womes. The introduction of simple computer programs made possible the comparison of large numbers of serums, revealing systematic differences and similarities.

Many leukocyte isoantigens have now been detected. From a consideration of the intricate relations among ten dis- crete antigens in a random population, the concept was derived that these factors were components of a single complex system. Similar conclusions were drawn from linkage studies. In certain families, including those recently studied at the Torino workshop (Torino, Italy, June 1967), the patterns of the isoantigens in the children's leukocytes can be explained on the basis of the inheritance of an "allelic" unit of inheritance from each parent. Purther confirmation has come from a comparison of serologic findings with survival of experimental skin grafts exchanged between siblings and from culture reactions. Other isoantigenic systems independent of the main locus have been described. In some of these, the antigens are widely distributed on the tissues; in others, the antigens appear to be restricted to a single cell lineage.

Several names have been proposed for the major locus: Group IV, after the first leukocyte "group" to be detected: Hu-1, for the association shown among ten antigens; Du- 1 , from the relationship of three complex subgroups; LA, because of the intricate relationship among the four antigens of the LA system; TO, for the antigens detected in Torino; and LC, emphasizing the expression of these antigens on the lymphocyte. Some investigators have used simple numbers. Yet another nomenelature was devised in which each antigen was identified by its cellular or tissue distribution, for example, on platelets or granulocytes, and so forth.

A World Health Organization (WHO) committee is being formed to discuss and formulate terminology. As an interim measure, the investigators listed below, who agreed as a result of discussions held at a meeting at Williamsburg. Virginia, in November 1967, suggest that the major locus be designated HL-A. We hope that this designation will be generally accepted.

Investigators accepting the proposed terminology HL-A for the major locus were: P. H. Allen, D. B. Amos, H. Balner, J. R. Batchelor, W. Bodmer, R. Ceppellini, J. Dausset, V. Eijsvoogel, C. P. Engelfriet, P. Ivanyi, F. Kissmeyer-Neilson, P. Lalazari, S. Lawler, J. J. van Loghem, R. S. Metzgar, V. Miggiano, R. D. Owen, R. Payne, N. Rogentine, J. J. van Rood, P. Terasaki, R. Walford. Ch. M. van der Weerdt, and C. M. Zmijewski.

D. B. Amos

Department of Microbiology and Immunology, Duke Universiry Medical Center, Durham, North Carolina 
Amos' brief in Science markeert het einde van de Tissue Typing Club. De workshops hebben in grote mate bijgedragen aan het standaardiseren van de praktijk en daarmee de schaalvergroting mogelijk gemaakt. Maar het succes van de groep bijt hen in de staart: het uitzicht op succesvolle praktische toepassingen verstoort de kameraadschappelijkheid binnen de leukocytenonderzoekspraktijk. Het twistpunt is: het verdelen van de eer.

De verschillende lokale onderzoekspraktijken hebben zich verenigd tot één leukocytenonderzoekspraktijk, een praktijk gericht op het verwerven van kennis over de leukocytenantigenen, op begrip van de biologische en genetische mechanismen, zoals Van Rood het aan Dausset schreef. Maar naast deze onderzoekspraktijk, ontstaat een andere praktijk. Een praktijk die gebruik maakt van de ontwikkelde kennis, methoden en materialen, maar die gericht is op het klinische toepassen van die verworvenheden, de Typeringspraktiijk. Het volgende hoofdstuk beschrijft hoe deze typeringspraktijk zich vanuit en naast de onderzoekspraktijk ontwikkeld. 


\section{DE VORMING VAN EEN
TYPERINGSPRAKTIJK}

\subsection{INLEIDING}

In het vorige hoofdstuk werd duidelijk hoe uit heterogene lokale praktijken door samenwerking van leukocytenonderzoekers, een onderzoekspraktijk wordt gecreëerd rondom leukocytenantigenen. In deze 'leukocytenonderzoekspraktijk' vindt uitwisseling van antisera en technieken plaats.

Dit hoofdstuk is gericht op de vraag: hoe leidt de, rond de leukocytenantigenen ontstane, onderzoekspraktijk tot de ontwikkeling van een klinische typeringspraktijk, een praktijk waar met het oog op transplantaties wordt getypeerd. In tegenstelling tot de onderzoekspraktijk - waar het combineren van testresultaten uiteindelijk leidt tot een classificatiesysteem - worden de bepalingen in de typeringspraktijk niet gedaan om de kennis over de antigenen te vergroten, maar om te bepalen welke antigenen bij een individu aanwezig zijn. Zo kan onderzocht worden of individuen een of meerdere antigenen eender hebben. Dit zou onder andere van belang kunnen zijn bij transplantaties. Als er tussen de ontvanger en de gever (van bijvoorbeeld een donornier) zo min mogelijk verschillen voor wat betreft de leukocytenantigenen bestaan, dan zou dit de kans op afstoting van een getransplanteerd orgaan verkleinen. In het ideale geval (als alle antigenen hetzelfde zijn) zou de situatie van een identieke tweelingtransplantatie worden geïmiteerd en zal er zelfs geen afstoting optreden ${ }^{1}$. Door deze 'belofte' groeit de vraag naar klinische typeringen.

De typeringspraktijk ontwikkelt zich uit de onderzoekspraktijk die rondom de leukocytenantigenen is ontstaan. Hierbij blijft het basisschema van het leukocytenonderzoek ongewijzigd. Ook in de typeringspraktijk laat men antisera, met behulp van verschillende technieken, met leukocyten reageren. Men gebruikt voor typeringen dezelfde technieken en materialen. Het verschil met de onderzoekspraktijk bestaat in de oriëntatie op reproduceerbaarheid van de resultaten. Alleen met reproduceerbare typeringsresultaten kan, ook wanneer die typeringsresultaten van verschillende laboratoria komen, worden gekeken naar overeenkomsten en verschillen tussen individuen. De onderzoekspraktijk levert echter geen gestandaardiseerde, reproduceerbare resultaten garanderende techniek.

Met het ontstaan van een andere oriëntatie, verschijnen andere 'spelers' ten

I Overigens moet de verwachting omtrent het bereiken van dit ideaal niet te hoog worden gesteld. Het bestaan van een Minor systeem ( $\mathrm{H}-\mathrm{r})$ bij de muis, naast het Major systeem $(\mathrm{H}-2)$ is al lang bekend (van Rood, 11 augustus, 2000). Mogelijk speelt deze wetenschap een rol bij de inschatting van het belang van leukocytenantigenen bij transplantaties bij de mens. 
tonele. $\mathrm{Zij}$ nemen het oorspronkelijke initiatief van de leukocytenonderzoekers over en bouwen de typeringspraktijk verder uit. Voor een belangrijk deel zijn deze spelers (inter)nationale organisaties, zoals het in het vorige hoofdstuk genoemde $\mathrm{NIH}$, die hun stempel op het ontstaan van de typeringspraktijk drukken. Zij werken hierin echter wel nauw samen met (mensen uit) de onderzoekspraktijk. In ruil voor het financieren van onderzoek, zouden de organisaties graag gebruik willen maken van 'uitgekristalliseerde' versies van technieken en antisera. Daarvan zouden zij de 'beste' versies tot standaard willen verheffen.

Hoe kijken de leden van de onderzoekspraktijk tegen deze 'ruil' aan? Ambivalent. Hierdoor ontstaat er tussen de onderzoekspraktijk en de organisaties een spanningsveld. De vrijheid van de onderzoekers wordt namelijk ingeperkt als gevolg van de praktische criteria die de (inter)nationale organisaties ${ }^{2}$. De organisaties trachten de handelingsvrijheid te beperken, door iedereen precies hetzelfde te laten doen, teneinde een uniforme typeringspraktijk te bewerkstelligen. De onderzoekspraktijk wil echter door middel van standaardisatie de handelingsvrijheid juist vergroten, om zo wetenschappelijke kennis te ontwikkelen.

Door middel van afspraken over nomenclatuur, de uitwisseling van antisera en technieken en de vorming van een internationaal referentiepanel, vergroten onderzoekers in deze periode de mogelijkheid om informatie en materialen uit te wisselen en over onderzoek te praten. Tegelijkertijd is de onderzoekspraktijk ook direct betrokken bij het ontwikkelen van de typeringspraktijk. Veelvuldig wordt hulp gevraagd voor het aanleren van de vaardigheden, nodig voor het goed uitvoeren van de technieken en de behandeling van antisera. De (inter)nationale organisaties kunnen dit niet direct overnemen. Het spanningsveld bestaat mede omdat de onderzoekers ook deel uitmaken van de typeringspraktijk-in-wording. Veel onderzoekers hebben ook klinische rollen en doen klinische typeringen. Eenheid van methode is zowel in de onderzoekspraktijk, als in de klinische typeringspraktijk van belang, maar wat men respectievelijk met de typeringen wil bereiken, verschilt.

Wat uit de interactie tussen de organisaties en de onderzoekspraktijk voortkomt, zal in dit hoofdstuk worden beschreven. Startend met een schets van de inspanningen van de leukocytenonderzoekspraktijk, om problemen rond de typeringstechnieken en de schaarste aan antisera te verminderen, zal een beschrijving worden gegeven van de pogingen om tot een mondiaal gestandaardiseerde typeringspraktijk te komen.

\subsection{WERKEn AAN SCHAARSte}

Met het groeien van het klinische belang van antigeentypering, groeit de vraag naar antisera. Wat wordt vanuit de onderzoekspraktijk gedaan om de schaarste aan antisera geen onoverkomelijk probleem te laten worden?

Zoals in de voorgaande hoofdstukken al duidelijk is geworden, zijn voor het leukocytenonderzoek donoren onontbeerlijk. Als bron van leukocyten, maar vooral ook voor de antiserumvoorziening. Aanvankelijk is men voor het verkrijgen van antisera zelfs volledig afhankelijk van (I) de screening op antilichamen van 'zwangere' vrouwen $^{3}$ en (2) de donatiebereidheid van de positief reagerende vrouwen. De

2 Het National Institute of Health (NIH) is hiervan de belangrijkste, de WHO speelt meer een rol op de achtergrond van de onderzoekspraktijk.

3 Door zwangerschap geimmuniseerde vrouwen. (zie hoofdstuk 2) 
donoren leveren namelijk hun bloed op vrijwillige basis. Dit vrijwillige karakter van de donaties maakt deze 'materiaalvoorziening' tot een onstabiele factor ${ }^{4}$. Donoren kunnen verhuizen, overlijden, of simpelweg hun medewerking opzeggen ${ }^{5}$. Met name bij antisera waarbij men voor die bepaalde specificiteit afhankelijk is van éen enkele donor, kunnen deze problemen funest zijn voor de serumvoorziening (van Rood, 27 juni, 1966). Mede door de afhankelijkheid van deze onbetrouwbare biologische leveranciers zijn goede antisera zeer schaars. Daarom moet aan de ene kant zo zuinig mogelijk met antisera worden omgesprongen en verspilling worden voorkomen $^{6}$, terwijl men aan de andere kant op verschillende manieren probeert om de beschikbaarheid van bruikbare antisera te verhogen. Zo probeert men bijvoorbeeld om vrouwen die toch al circulerende antilichamen hebben, nog extra te immuniseren (hyperimmunisatie) om hen zo geschikt te maken als serumdonor; en wordt geprobeerd niet eerder gesensibiliseerde personen te immuniseren middels intradermale injecties met leukocyten ${ }^{7}$, waarna ook zij middels 'bloeden', of (liever) plasmaforese, antiserum kunnen leveren.

In samenwerking met de Leidse onderzoeksgroep, onderzoekt het Radiobiologisch Instituut TNO te Rijswijk, een andere benadering. Het idee is dat ook apen als serumleveranciers kunnen dienen om de schaarste aan antisera te verminderen, mits die apen antisera tegen menselijke antigenen maken. Sommige, van mensen afkomstige, antisera blijken namelijk te reageren met leukocyten van chimpansees en omgekeerd, waarmee de aanwezigheid van 'menselijke' leukocytenantigenen op de cellen van chimpansees is aangetoond (Balner, et al., 1967). Aangezien chimpansees en mensen antigenen gemeenschappelijk hebben, zouden de apen door immunisatie met apenleukocyten van een bepaalde specificiteit, aangezet kunnen worden tot de productie van antilichamen tegen de menselijke antigenen met die specificiteit (Balner, et al., 1967 ). Het is echter de vraag of verwacht mag worden dat de serumschaarste hierdoor zal worden opgelost, want ook de van chimpansees verkregen antisera blijken niet onproblematisch:

... However, Cross-absorption experiments with chimpanzee and human leukocytes revealed that some sera contained extra antibodies and that the human antigens identified on chimpanzee cells with human iso-antisera and those demonstrable on human cells with the same sera may be variants of the same antigen. (Balner, et al., I967)

Zowel wat de kwaliteit als wat de kwantiteit betreft, blijft de antiserumvoorziening problematisch.

Naast de vele inspanningen die verricht worden om het aanbod aan antisera te vergroten, wordt er ook gewerkt aan een efficiēnter gebruik van de beschikbare hoeveelheden. Daarvoor ontwikkelt men microtechnieken. De ontwikkeling van

4 Zie ook, Hoofdstuk 3, het verzoek van Zmijewski aan Van Rood om opnieuw een klein panel te typeren.

5 Denk aan het voorbeeld in Hoofdstuk 3, een donor die verdere medewerking weigert na plasmaforese.

6 Dit stelt bijvoorbeeld beperkingen aan het aantal tests dat per dag kan worden gedaan, zoals Van Rood aan Starzl schrijft. (zie voor de VS-reis verder hoofdstuk 6)

This is not an unwillingness of us to do more work, but is inherent in the test. The incubation time is extremely critical and you need both time to set the test up and time to read it. If we get more samples we. just will have to throw them away, which I think would be a bloody shame. (van Rood, yt oktober, 1966)

7 Bijvoorbeeld het immuniseren van psychiatrische patiënten (van Rood, 3 januari, 1966) en hyperimmuniseren van vrouwen (van Rood, 25 januari, 1965). 
microtechnieken heeft echter ook tot gevolg dat er een concurrentieslag tussen tech. nieken ontstaat.

Zijn de eerste stappen in de leukocyten serologie gezet met de agglutinatietechniek (Dausset, 1954), later komen daar andere technieken bij, zoals onder andere de cytotoxiciteitstest en de complementfixatietest ${ }^{8}$. Van deze twee wordt vooral de cytotoxiciteitstechniek een concurrent van de agglutinatietechniek. Aanvankelijk kan de agglutinatietest de 'aanvallen' gemakkelijk weerstaan. De cytotoxiciteitstest is in ontwikkeling en levert nog geen betrouwbare resultaten. Daar komt nog bij dat de cytotoxinen ${ }^{9}$ even ingewikkeld zijn als de agglutininen. Eenvoud versus complexiteit kan de strijd dus niet beslissen. Het gebrek aan correlatie tussen de resultaten van de cytotoxiciteitstest en de agglutinatietest, spreekt in het begin van de strijd in het voordeel van de laatste (Amos, I8 december, 1964). Wanneer Terasaki in samenwerking met agglutineerders van het eerste uur, laat zien dat die correlatie wel te maken is, verdwijnt dit voordeel (Terasaki, 9 februari, 1965 ).

In geen van beide technieken kunnen de antisera van de andere techniek zonder meer worden gebruikt. Agglutinerende antisera zijn vaak niet in de cytotoxiciteitstest te gebruiken en cytotoxische antisera niet in de agglutinatietest ${ }^{10}$. Een gevolg daarvan is dat de twee technieken ook niet dezelfde antigenen herkennen. In die zin zijn de technieken dus complementair. Dit maakt kiezen tussen een van beide moeilijk.

In een onderzoekspraktijk waar de agglutinatie- en cytotoxiciteitstechniek naast elkaar bestaan, proberen verschillende onderzoekers voor beide technieken microvariaties te ontwikkelen. Het minimaliseren van de per bepaling benodigde hoeveelheid antiserum is nastrevenswaardig. Zo wordt getracht om tests te ontwikkelen die microliters serum gebruiken in plaats van milliliters. De cytotoxiciteitstest is de eerste techniek die op microschaal uitgevoerd kan worden ${ }^{11}$. Voor Van Rood heeft het ontwikkelen van een microvariatie van de agglutinatietechniek niet de hoogste

8 De complementfixatietest wordt, door de bewerkelijkheid van de techniek en het beperkte aantal daarvoor aanwezige antisera, aanvankelijk weinig gebruikt. Vanaf begin jaren ' 70 komt hier verandering in. Er is dan een microvariatie ontwikkeld, komen er meer en meer sera en wordt een computer gebruikt om de tests af te lezen. De microscoop densitometer (D'Amaro, et al., 1971).

9 Zo worden de antilichamen dan genoemd die met behulp van de cytotoxiciteitstechniek gedetecteerd zijn. zoals voor de agglutinatietechniek deze antilichamen 'agglutininer' worden genoemd.

10 Daarnaast blijft het probleem van de diversiteit van de antisera. Dit geldt voor zowel de agglutinerende, als voor de cytotoxische antisera. Er zijn slechts enkele antisera gevonden die, gebruikt in dezelfde techniek. een exact overeenkomstig reactiepatroon laten zien, wat lijkt te impliceren, dat daar exact dezelfde soort antilichamen in zouden zitten. Dit is de reden dat Van Rood wil dat er in de Workshop in Turijn ook naar 'identiek reagerende sera' wordt gezocht. Op het eerste gezicht lijkt het duidelijk wat daarmee bedoeld wordt, maar uit de reactie van Amos blijkt, dat zelfs daar nog verschil van mening over kan bestaan. I do not quite understand your comment about sera with identical results. Do you mean in the same test or. as 1 think you mean, with different tests - i.e., a cytotoxic 8 a and an agglutinating 8 a. This would be extremely useful to know. (Amos, 4 mei, 1966)

Amos vindt het zeer belangwekkend om sera te vinden die in verschillende soorten tests een identiek reactiepatroon hebben. Echter. Van Rood bedoelt het eerste. In zekere zin is zijn bedoeling daarmee minder ambitieus. Hij wil sera vinden, afkomstig van verschillende donoren, die een echt overeenkomstig reactiepatroon hebben wanneer ze in dezelfde techniek gebruikt worden.

With identical sera 1 mean identical sera in the same test. Only the complement fixation anti $\mathrm{Br}$ (and anti Cr) show identical results. In agglutination tests we have now a number of sera which show identical results with anti $5 b$, anti $4 \mathrm{~b}$, while anti $7 \mathrm{c}$ looked very promising also in the cytotoxicity test. Still this kind of sera is rare and $I$ think we should know why. Comparing sera in different techniques complicates the matter further and $t$ think is only the next step. (van Rood, 16 mei, 1966)

11 Aan de micro-cytotoxiciteitstest wordt Terasaki's naam verbonden. 
prioriteit. Hij vindt informatie-uitwisseling ${ }^{12}$, onder andere door het voor anderen typeren van een panel, even belangrijk, zo niet belangrijker. Voor wat de microtechnieken betreft, wil hij graag meerijden op de kar die anderen trekken ${ }^{13}$. Anderen geven er een hogere prioriteit aan en voor verschillende technieken komen er microvariaties.

Een deel van de ontwikkeling van de microcytotoxiciteitstest bestaat voor Terasaki uit het ontwikkelen van de specifieke laboratoriumbenodigdheden voor het uitvoeren van de test: de 'disposable oil-chamber' ${ }^{14}$. Op verzoek van Terasaki schrijft Van Rood een brief ter ondersteuning voor het op de markt brengen van een "disposable oil-chamber for microcytotoxicity and agglutination tests" (van Rood, 5 april, I966). In deze brief uit 1966 spreekt Van Rood echter de verwachting uit dat de agglutinatietechniek op zijn retour is.

We are presently only involved in leukocyte agglutination work, but I understand that this tray can be used for this also.

Anyhow, I think that the leukocyte agglutination test, though it has been extremely useful in the past, will be less and less used in the future. One of the main reasons for this is, that the antigen cannot be stored, as it can for

cytotoxicity work. (van Rood, 5 april, 1966)

De onmogelijkheid antigenen op te slaan, draagt volgens Van Rood bij aan het in onbruik raken van de agglutinatietest. Daarnaast geeft het feit dat de microcytotoxiciteitstest wordt gekoppeld aan speciaal voorgevormd laboratoriummateriaal, de cytotoxiciteitstest een voorsprong op de agglutinatietest. Het gebruik van de microcytotoxiciteitstechniek van Terasaki wordt versterkt door de beschikbaarheid van de 'test plates' (de 'disposable oil-chamber'). Later stuurt de exporteur van Falcon Plastics, op instigatie van Terasaki, monsters van deze testplaatjes voor evaluatie en tests naar Van Rood. Bij de mogelijkheden voor gebruik vermeldt de fabrikant, dat de microcytotoxiciteitstest de eerste toepassing was.

12 Het typeren van een groep donoren met verschillende technieken en sera (zoals in de tweede Workshop). levert onder andere informatie over de onderlinge relatie tussen de verschillende antisera.

Wij hebben reeds geruime tijd een goede samenwerking met Prof, Dr. R. Ceppellini in Turijn. ... De Italiaanse werkers gebruiken een techniek om de leucocytengroepen te herkennen, die in vele opzichten overeenkomt met de onze, maar op enige punten daarmee wezenlijk verschilt. Het is nog steeds niet bekend welke methode eigenlijk de beste is en in hoeverre de beide methoden elkaar aanvullen. ... het is nu duidelijk dat beide methoden elkaar aanvullen. Het is belangrijk dit nu verder te preciseren. Dit kan het beste geschieden via familiestudies. Prof. Ceppellini heeft in het afgelopen half jaar 200 families verzameld die bereid zijn enige maanden wat bloed af te staan voor een dergelijk onderzoek.

$\mathrm{Hij}$ is bereid ons in de gelegenheid te stellen met onze techniek deze families ook te onderzoeken. ... Het is nu de bedoeling dat Mevr. Castelli deze Italiaanse families met onze technieken en onze sera op Prof. Ceppellini's laboratoria zou onderzoeken.

Dit zou de enige manier zijn waarop dit materiaal voor ons ter beschikking zou kunnen blijven. Het is onmogelijk om het met de post te versturen en het is ook uitgesloten om deze families tijdens enige werkbezoeken te bestuderen. (van Rood, 7 augustus, 1967)

Het vergelijken van technieken vormt zo een 'eenvoudig' maar sterk argument om vanuit Leiden, iemand aangesteld te krijgen in Turijn, als vooruitgeschoven post. Mevr. Castelli is een oud-medewerkster van het Leidse laboratorium, getrouwd met een Italiaan en vervolgens naar Turijn verhuisd. Deze vrouw, die de in Leiden gebruikte technieken kan toepassen en weet heeft van de 'ins en outs' van de Leidse sera, is daarom bijzonder geschikt voor dit project.

13 Al wordt er in Leiden wel aandacht aan besteed, want hij schrijtt Ceppellini: ... we are working on some new technique variations, which would save material and time and give more information ... (van Rood, 28 december, 1966)

14 Een plastic bakje met daarin cupjes, waarin het serum en de cellen samengebracht kunnen worden, zodat zij met elkaar kunnen reageren en verdamping wordt voorkomen door een laag olie. 
... designed for the testing of micro quantities of reagents and tissue cells.... The optically clear, flat bottom permits direct microscopic evaluation of wells with an inverted phase contrast microscope, employing a $25 \mathrm{X}$ objective, with the cover in place. Observations with $16 \mathrm{X}$ and $10 \mathrm{X}$ objectives from above with a conventional microscope are also possible. The first application for which it was used was the micro droplet cytotoxicity test. This test is for determining compatibility by typing human lymphocytes, in matching potential organ donors to recipients. (Mayer, II december, 1967)

Naast de micro-eigenschappen hebben de 'Terasaki-bakjes' nog een voordeel. De bakjes kunnen worden ingevroren met van antisera voorziene cupjes en zo, gebruiksklaar, worden verstuurd. Niet alleen heeft de verzender op deze manier controle over de antisera die gebruikt worden, maar oefent hij ook invloed uit op de techniek in het ontvangende laboratorium te gebruiken techniek. In het ontvangende laboratorium hoeven alleen nog de te testen cellen aan de - ontdooide - cupjes te worden toegevoegd en de tests te worden afgelezen na de benodigde incubatietijd. De bakjes elimineren een aantal variabelen, waardoor de resultaten betrouwbaarder worden. Door de verbinding te maken tussen de antisera in gebruiksklaar laboratoriummateriaal en een enkele techniek gaat, zo is de verwachting, de betrouwbaarheid omhoog. Het ontvangende laboratorium heeft aan het kennen van die ene techniek voldoende om met de sera te kunnen werken. Het is overigens de vraag of deze verwachting terecht is.

De cytotoxiciteitstechniek heeft - aanvankelijk vooral voor de onderzoekspraktijk - nog een voordeel. Met deze techniek is het uitwisselen van informatie ook op een andere manier te realiseren. In plaats van de antisera, kunnen de antigenen (op de cellen) worden verstuurd. De cytotoxiciteitstechniek kan (in tegenstelling tot de agglutinatietechniek) met niet verse, dat wil zeggen niet ter plaatse verkregen, leukocyten werken. Omdat de cellen zo te stabiliseren zijn dat ze verstuurd kunnen worden en hun reactiviteit in de cytotoxiciteitstechniek behouden, biedt dat de mogelijkheid om een op locatie A verzameld monster te typeren in laboratorium B. Het alternatief is dat de betreffende donor naar het typerende laboratorium reist en daar, ter plaatse bloed geeft ${ }^{15}$. Naast het verfijnen van de technieken wordt ook gewerkt aan het stabiliseren van leukocyten. Het idee hierbij is dat wanneer leukocyten ingevroren kunnen worden en na ontdooien nog even goed te gebruiken zijn als 'verse' leukocyten, biedt dat de mogelijkheid om de typeringen onafhankelijk van de afnameplaats uit te voeren. Een voorwaarde is wel dat ze tijdens transport in bevroren toestand blijven. 16

15 Voor deze ontwikkelingen (en het decentraal typeren in perifere laboratoria) worden bijvoorbeeld inderdaad donoren en ontvangers vanuit Belgiè naar Leiden gestuurd om zich te laten typeren.

16 Het is vooral de onderzoekspraktijk die direct voordeel heeft van het invriezen van leukocyten. Naast antilichamen kunnen nu ook antigenen worden opgeslagen in een diepvries en als materiaal dienen in toekomstig onderzoek. Het is van belang dat de leukocyten na ontdooiing op dezelfde wijze en in dezelfde mate blijven reageren met de antilichamen in de sera.

In the meanwhile, we are freezing by the controlled rate method, in liquid nitrogen, with DMSO

[dimethylsulfoxide], lymphocytes for future lymphocytotoxicity testing. So far our experience indicates that thawed lymphocytes are fully as good as fresh lymphocytes for this purpose and this would allow us to do a retrospective study some time in the future when enough serums become available, or for someone else to do tests at any time. (Allen, 1o maart, 1967)

Ook in Leiden wil men de in New York ontwikkelde invriestechniek gaan gebruiken voor het verzamelen en opslaan van leukocytenmonsters. Enerzijds voor toekomstig gebruik, anderzijds kunnen hier monsters, die 
Zo wordt niet alleen gewerkt aan het invriezen van antisera; men gaat ook werken aan het ontwikkelen van technieken om leukocyten in te vriezen. Ingevroren en weer ontdooide cellen zijn volgens Fred Allen - in de cytotoxiciteitstest - even goed als verse, hetgeen nieuwe mogelijkheden voor onderzoek biedt (Allen, ro maart, 1967). Anderen komen tot dezelfde conclusies en verbinden daar ook nieuwe mogelijkheden aan, zoals bijvoorbeeld het uitgeven van ingevroren standaardcellen (Sanderson, 4 januari, 1967).

Dat de cytotoxiciteitstechniek met ingevroren cellen kan werken, maakt deze techniek sterker ten opzichte van de agglutinatietechniek. Ofschoon agglutinatietests gemakkelijker uit te voeren en af te lezen zijn, vindt een aantal laboratoria het raadzaam om over te gaan op de cytotoxiciteitstechniek.

In recent months, the leukocyte agglutination technique has fallen into

disrepute in many histocompatibility testing laboratories. The poor

reproducibility experienced by a variety of workers has been claimed as one of the chief reasons for the decline of such a relatively simple serologic method in favour of cytotoxicity. From the technical point of view a cytotoxic test is much more complicated. It is more difficult to read, since it must be quantitated, and introduces yet another variable, namely the complement employed. (Zmijewski, et al., 1967 )

Agglutinatie verliest terrein ${ }^{17}$. Zelfs in het agglutinatiebolwerk Leiden denkt men aan het overstappen op de cytotoxiciteitstechniek. Hiervoor wordt Kissmeyer-Nielsen gevraagd of de meest ervaren analiste in Leiden de techniek bij hem mag komen leren. Hiermee kiest Leiden voor Kissmeyers variatie van de cytotoxiciteitstechniek.

Om de 'nieuwe' techniek van Kissmeyer-Nielsen in het eigen lab te kunnen gebruiken, moeten ofwel de benodigde laboratoriummaterialen worden aangeschaft,

elders zijn verzameld, in worden bewaard en geleidelijk gebruikt.

Naar aanleiding van het overleg met de hoogleraren Vink, de Graeff en van Bekkum, zou ik u willen vragen, toestemming te verlenen van het, door TNO aan de transplantatiewerkgroep ter beschikking gestelde

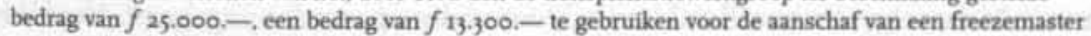
type $\mathrm{r}$ biologische invriesautomaat, compleet met invrieskamer en regeleenheid. ... Dit apparaat zal ons in staat stellen om lymphocyten ook in kleine hoeveelheden in te vriezen. Hiermede is het mogelijk deze lymphocyten, die noodzakelijk zijn voor het histocompatibiliteitswerk, zowel bij mensen als bij primaten en honden, lange tijd te bewaren. Onder andere is het op deze wijze mogelijk over de gehele wereld lymphocyten van primatenfamilies te verzamelen. Dit materiaal is essentieel voor de selectie van adequate sera en het controleren van de techniek. (van Rood, 13 oktober, 1967 )

17 In deze moeilijke tijden probeert de agglutinatietechniek het hoofd boven water te houden, door nieuwe voordelen ten opzichte van cytotoxiciteit te creëren. Een mogelijkheid hiertoe is het claimen van een specifiek werkgebied, waar agglutinatie bij uitstek geschikt voor is, terwijl alternatieve technieken daar juist minder geschikt voor zijn.

Zur Differenzieriung mehrerer Leukocytenantigene unterschiedlicher Stărke ist es notwendig, mehrere Tests einzusetzen. Mit der Komplementsfixationstechnik allein würden zu viele Seren entweder negativ sein oder als monospezifisch erscheinen. Andererseits erfordert der Cytotoxizitătstest meist eine Absorption der Antiseren. Van Rood bevorzugt deshalb zur Testung von Seren zunăchst die Agglutination. Die einerseits genügend empfindlich und einfach zu handhaben, andererseits ausreichend unempfindlich ist. Allerdings werden schwache Antikörper damit nicht erkannt, so daß manche Seren allein in diesem Test noch als monospezifisch erscheinen. ...

Gegenüber dem Cytotoxizitätstest beansprucht die Agglutinationsreaktion wesentlich weniger Zeitaufwand, deshalb ist sie für Suchtests besser geeignet. (Gabl, et al., 1967)

In Leiden probeert men een niche te creëren voor de agglutinatietechniek.

In the meantime we continue work with the EDTA agglutination technique. At the moment we are reorganizing our screening procedures and techniques to define specificity and usefulness in immunogenetic work. (van Rood, 30 oktober, 1967) 
of worden gemaakt ${ }^{18}$. Een techniek bestaat daar immers voor een deel uit. Met de in Leiden gebruikte materialen voor de Kissmeyer-Nielsen variatie, die door een fabrikant worden geleverd, treden echter nogal wat problemen op. Een groot aantal glasplaatjes breekt in de vriezer bij $-70^{\circ} \mathrm{C}$ en de plastic rand die op de glasplaatjes gelijmd is om de gebruikte 'afdekolie' binnen te houden, laat nogal eens los, waardoor de olie wegloopt. Het directe gevolg van zo'n lekkage is een smeerboel, terwijl het toch al moeilijk is om netjes te werken met de techniek. Een voordeel van deze techniek ten opzichte van die van Terasaki is echter, dat de tests met gewone, aanwezige microscopen kunnen worden afgelezen. Ondanks de tegenslagen krijgt de Kissmeyer-Nielsen variatie voet aan de grond in Leiden. De voorsprong van Leiden komt in gevaar, want men dreigt geïsoleerd te raken wanneer men blijft volharden in het uitsluitend werken met de agglutinatietechniek. Om de centrale positie te behouden, moet in Leiden naast andere technieken ook de cytotoxiciteitstechniek kunnen worden gebruikt. Marginalisering kan alleen voorkomen worden door alle aanwezige antisera en leukocytendonoren te hertyperen met een cytotoxiciteitstest.

We are in the process of switching over to cytotoxicity, especially the microtechnique. This of course will put us back for a year or something in that order

but I think we had to do this. (van Rood, 30 oktober, 1967)

Buiten de directe kring wordt deze switch met verbazing ontvangen. Zelfs uit Australië komen vragen of het echt waar is dat in Leiden cytotoxiciteit agglutinatie verdringt.

I have heard rumours that your are switching to cytotoxicity Jon, could this be

so? This will rock the whole tissue typing world to its very foundations!!!

(Morris, 21 juni, 1968)

Van Rood moet hierop bevestigend antwoorden, maar het gaat niet van harte (van Rood, 28 juni, 1968$)^{19}$.

Deze schermutselingen rond sera en technieken vinden plaats tegen de achtergrond van een, ten bate van een toenemend aantal niertransplantaties, groeiende typeringspraktijk. Door velen wordt het op geleide van een weefseltypering koppelen van een donor(orgaan) aan een ontvanger als positief voor de transplantatie-uitkomst gezien. In de volgende hoofdstukken zal hier nader op worden ingegaan. Hier is het van belang, dat door het algemener worden van de mogelijkheid om nieren te transplanteren, ook de vraag naar klinische typeringen groeit, waardoor de behoefte aan typeringslaboratoria groter wordt ${ }^{20}$. Velen komen (uiteindelijk) in Leiden terecht,

18 Dit kan op zich al een heel werk zijn.

In this new method the micro test is performed on ordinary microscope slides which have been partially siliconed, leaving a number of spots unsiliconed. These non-siliconed spots are the regions on which the micro test is performed and the whole test is carried out under mineral oil (BDH Heavy grade SG $0.865-$ $0.89)$ to prevent evaporation. ... The spotted slides are made by putting drops of nail varnish on a slide, (Cutex colourless) using a glass syringe and an all metal hypodermic needle with the bevel removed. (Plastic components may dissolve in the nail varnish solvent). The optimal spot size is $2-3 \mathrm{~mm}$. diameter when using $1 \mu$ litre volumes of reagents. After drying, the slide is siliconed (Hopkins and Williams Repelcote), the nail varnish removed by acetone and the slides are thoroughly rinsed in running tap water and distilled water. (Joysey, ND)

19 De 'voorsprong' op de rest gaat hiermee verloren. Een voorsprong die volgens Van Rood was ontstaan doordat zij in de periode ' $58 . ' 65$ in plaats van te werken met slechte sera in 'goede' technieken, zochten naar goede sera die ze gebruikten in een ietwat moeilijkere techniek. (van Rood, n augustus, 2000)

20 Wanneer interesse ontstaat om typeringslaboratoria op te zetten, wordt daarbij aangetekend dat die labs geleid moeten gaan worden door ervaren immunologen en tevens wordt voor die nieuwe laboratoria uitgezien naar een vereenvoudiging van de technieken. Klinisch werk moet eenvoudig en betrouwbaar zijn, 
met vragen over het opzetten van een typeringslaboratorium, welke techniek men moet gebruiken, of vragen om antisera. Vanuit Leiden wordt geprobeerd het ontstaan en de kwaliteit van typeringslaboratoria zoveel mogelijk onder controle te houden. Zo wordt aan startende laboratoria gevraagd om een screeningsprogramma op te zetten. Hiermee kan, of in de eigen behoefte aan sera worden voorzien, of men levert in ieder geval een bijdrage aan de groeiende behoefte aan antisera. Leiden mag dan de agglutinatietechniek 'verliezen'; de centrale positie in de onderzoekspraktijk blijft behouden. Bij het ontwikkelen van een klinische typeringspraktijk zijn ze echter niet de enige sturende partij.

\subsection{Andere Partijen}

Het toenemende aantal laboratoria dat typeringen wil gaan uitvoeren zorgt voor een grote vraag naar (getypeerde) antisera. In de onderzoekspraktijk regelden de onderzoekers de verwerving en distributie van antisera altijd onderling. Het National Institute of Health (het NIH) - met daarbij een grote inbreng van Amos - neemt dit midden jaren 60 voor een groot deel van hen over. Deze organisatie sluit contracten af met een groot aantal onderzoekers, fourneert hen zeer veel geld, maar vraagt daar onder andere grote hoeveelheden goed getypeerd serum voor terug. Die sera worden (naar idee van Amos (van Rood, 11 augustus, 2000)) geplaatst in een serumbank. Alle geinteresseerden, ervaren of startend, kunnen aanvragen doen bij het NIH om in het bezit te komen van sera. Het kan gaan om de voortzetting van bestaand onderzoek, of om het starten met klinische typeringen. Starters krijgen van het NIH een "Starter Package" (Berah, 31 juli, I967). Zo'n set bestaat uit kwalitatief minder goede sera, waarmee het moeilijk is om betrouwbare resultaten te krijgen, maar waarmee - volgens het NIH - de techniek van het typeren geleerd kan worden. Dit voorkomt dat goede sera verspild worden ${ }^{21}$. Verder bevat dit pakket een instructie met een beschrijving van één techniek, namelijk de cytotoxiciteitstechniek. Het NIH krijgt hierdoor een sterke stem in de ontwikkeling van de typeringspraktijk. De relatie tussen de lokale onderzoeksgroepen en het NIH is echter ambivalent. Aan de ene kant geeft het NIH een groot aantal onderzoeksgroepen financiële ruimte, maar tegelijkertijd perken ze de academische vrijheid in. Dit doen ze bijvoorbeeld door de typeringssera naar zich toe te trekken. Hiermee krijgt het NIH ook zeggenschap over deze sera en kunnen zij bepalen wie welke sera waarvoor krijgt. Zo kan ook de richting van onderzoek gestuurd worden. De individuele onderzoeksgroepen zijn hier niet altijd even gelukkig mee.

De contacten tussen het NIH en de leukocytenonderzoekers ontstaan in de periode rond de eerste twee Workshop. Aanvankelijk heeft het NIH weinig belangstelling en schrijft Bernard Amos aan Van Rood dat op korte termijn niet veel van het $\mathrm{NIH}$ te verwachten is. Hij suggereert Van Rood om zelf een grant request te

ook de behandelingsdoelstelling stelt eisen aan de praktijk.

During my last visit in Amsterdam you told me that the methods were going to be simplified, has this been realized yet? (Kolff, 16 maart, 1967 )

21 Dit beleid staat lijnrecht tegenover de ideeën hierover in Leiden. Zoals ze daar zelf gewerkt hebben, vinden ze ook dat starters het vak moeten kunnen leren. Goede sera zorgen ervoor dat de starter zich over de sera geen zorgen hoeft te maken, maar zich daar ook niet achter kan verschuilen wanneer de resultaten slecht zijn. Resultaten met een lage reproduceerbaarheid, zijn dan te wijten aan de uitvoering van de techniek. Zo leert men kritisch te zijn naar het eigen werk. Volgens het NIH echter, zal herhaling uiteindelijk een goede uitvoering van de techniek opleveren. 
schrijven en in te dienen.

It would have to stress the uniqueness of Leiden as a center since only things that cannot be done in the States will get paid regardless of merit. (Amos, 23 maart, 1964)

Amos heeft directe contacten met het NIH. Hij is de voorzitter van de Ad Hoc Committer on Transplantation and Immunity en vanuit die functie heeft hij regelmatig contact met John Overman, de Associate Director for Collaborative Research van het National Institute of Allergy and Infectious Diseases (NIAID), een afdeling van het NIH. Hij zit dus dicht bij het vuur en heeft zowel de mogelijkheid enigszins richting te geven aan het beleid van het $\mathrm{NIH}$, als de mogelijkheid anderen gericht te coachen in hun pogingen projecten door het NIH gefinancierd te krijgen.

John Overman will be over in early January. He is very enthusiastic and I believe is in a position to help. We have had one meeting and set up a couple of sub committees to consider standards for reagents and standards for methods. We will meet again late this month to discuss their reports, probably to discuss antigen preps and perhaps storage, and then finally late in January to discuss contracts. (Amos, ro november, 1964)

Amos schrijft Van Rood dat het waarschijnlijk mogelijk is om op kosten van het $\mathrm{NIH}$ ruimte te huren, zelfs om te verbouwen, maar verwacht niet dat het mogelijk zal zijn om laboratoriumruimte te kopen. Toch zal een onderzoekscontract met het NIH de mogelijkheden aanmerkelijk doen toenemen.

Mbg yoondat de contractern miel het 1 whs getekend zijn, is 'net ürzacht op een overeenkomst een stimulans om in de richting van het $\mathrm{NIH}$ alvast energiek aan de slag te gaan. Van Rood stelt Ceppellini voor om een gemeenschappelijk project te starten, dat goede agglutinerende antisera zou kunnen 'produceren'. Hiermee zouden ze een wezenlijke bijdrage kunnen leveren aan het vullen van de serumbank, aangezien "one of the main objects of you and in general the programme of N.I.H. is to obtain strong monospecific leukocyte agglutinins." (van Rood, 25 januari, 1965). Wanneer Ceppellini zou kunnen screenen, kunnen ze proberen de specificiteit van de positieve sera te bepalen aan de hand van het dan al aanwezige panel in Leiden.

If these women would be willing to be hyperimmunized, we could then, by

using selected donors, with known genotypes, really get screaming high titters.

These women could then be plasmaphoresed, etc.(van Rood, 25 januari, 1965)

Op deze manier krijgt Van Rood de beschikking over nieuw onderzoeksmateriaal en worden tegelijkertijd nieuwe antisera gevonden en gemaakt tegen de Leidse antigenen. De doelstellingen van het NIH zouden zo worden verbonden met Leidse belangen. De regelgeving in Italië is namelijk dusdanig, dat een dergelijk project daar een grotere kans van slagen heeft dan in Nederland. Hij denkt daarbij wel aan risico's die de proefpersonen in dit soort experimenten lopen, maar blijkens een opmerking in de trant van het zal hen niet meer schade berokkenen dan ze toch al hebben en nieuwe risico's zijn te beperken', vindt Van Rood dat daar bij deze opzet geen sprake van is 22 . Het enige probleem dat Van Rood ziet is het vinden van vrouwen.

22 Het principe van nict schaden lijkt het medisch ethische aspect te zijn waar Van Rood bij dit onderzoek aan denkt. Maar de medisch ethische principes lijken niet van groot belang te worden geacht.

Concerning the medical ethical aspect of it, I don't think we can do them much harm. They have leukocyte agglutinins to start with, so that does not make any difference, and as far as the serum hepatitis goes, if we use donors of the Bloodtransfusionservice, this should not be a tremendous problem.(van Rood, 25 januari, ז965)

Tegenwoordig zijn dit de principes van Niet Schaden, Weldoen, Rechtvaardigheid en Autonomie. 
The problem, of course, will be to find women willing to be immunized, and to

be plasmaphoresed. (van Rood, 25 januari, 1965)

Van Rood zegt het niet alleen te willen doen om Ceppellini de erkenning te laten krijgen die hem toekomt, aangezien het idee om vrijwilligers te immuniseren van hem afkomstig is, maar hij wil dit project ook praktisch inzetten op het punt van het 'geven en krijgen van erkenning'. Erkenning is namelijk nu niet meer alleen in morele zin van belang. In het licht van het NIH-contract wordt die ook geld waard. Daarom wil Van Rood dat de verbinding wordt gelegd tussen in het verleden verricht 'voorbereidend werk' en het onder het NIH-contract vallende huidige werk. Hij vraagt erkenning voor het werk dat de Workshop mogelijk maakte en probeert dat tevens als legitimatie te gebruiken voor het leveren van slechts kleine hoeveelheden antisera aan de Serumbank. (van Rood, 2 december, 1965$)^{23}$ Het NIH is echter niet direct bereid om deze redeneertrant te volgen, wat zijn weerslag heeft op de contacten tussen het NIH en Leiden. Dat problemen rond de serumvoorziening zouden kunnen ontstaan, voorzag Van Rood overigens al kort na het $\mathrm{NIH}$-aanbod en de eerste gesprekken met Amos, wanneer hij zijn bedenkingen uit tegen het idee "een sera leverancier voor anderen te zijn" (van Rood, 23 september, 1963) ${ }^{24}$. Zijn vrees lijkt bewaarheid te worden.

Het NIH tracht de verdere ontwikkelingen te bestieren en de voordien zelfstandig en onafhankelijk werkende onderzoekers ervaren het contract meermaals als knellend en ondoorgrondelijk. Zowel Ceppellini als Van Rood hebben kort na de start van het project, problemen met het NIH. Afwijkende visies op een aantal zaken spelen hierbij een grote rol. Het $\mathrm{NIH}$, in de persoon van Overman, wil de kennis over de leukocytenantigenen verspreiden door via de serumbank de antisera aan 'iedereen' beschikbaar te stellen, terwijl Van Rood vindt dat het elders typeren van panels ook een vorm van kennisverspreiding is. Dit wordt door Overman echter niet direct als zodanig $(\mathrm{h})$ erkend noch gewaardeerd. Door Van Roods lobbyen om dit alsnog te bewerkstelligen, ontstaat bij verschillende mensen het idee dat hij tegen het verspreiden van kennis is. Hij haast zich te schrijven dat dit niet het geval is.

... the idea of both the contract in general and the dissemination of knowledge of

the leucocyte groups especially, are excellent ones. (van Rood, 2 maart, 1966)

Er bestaat volgens Van Rood alleen verschil van mening over de manier van verspreiden. Naar zijn mening is de kwaliteit van de meeste sera nog niet hoog genoeg om die naar willekeurig wie te versturen. Betrouwbaar gebruik van die sera is alleen

23 Of zoals Van Rood het schrijf:

I would like to point out that we spent about an equal amount of serum [rooo ml. MD] in building up and rechecking the panel used for the Workshop. As a direct result of this, in a three days' period it was possible to supply all those who participated in the Workshop with the information necessary to recognise their own sera, which were monospecific. These 3 days saved many of them one, two or more years of work. As it was our serum that made this possible, I think we should also be credited for this. (van Rood, 2 december. 1965)

24 Zo schrijft Van Rood hierover aan Wil Heymans, zijn 'zaakwaarnemer' rond het NIH-contract gedurende

Van Roods Sabbatical, en anderen:

Een ander principieel punt is dat ik van plan geweest was aan Amos te schrijven dat ik natuuriljk zeer vereerd was maar dat een contract dat me allen maar in staat stelde om een sera leverancier voor anderen te zijn, inclusief het eventuele typeren, nauwelijks iets was waar ik me erg over kon opwinden. Dit natuurlijk met mijn bekende tact en beleefdheid gebracht. Deze adder zit namelijk wel degelijk onder het gras; wanneer ze ons aan dat contract vast hebben, tenzij dat contract zo is opgesteld dat deze mogelijkheid met name wordt uitgesloten, kunnen ze ons op zodanige wijze met "orders" overstelpen dat we met al de hulp van de wereld niet meer aan ons eigenlijke werk meer toe kunnen komen. Dus contract of geen contract mijn vrijheid om tegen een vent verrek jij maar te kunnen zeggen is me meer waard dan alle dollars van de wereld, nou ja in ieder geval dat bedrag waar zij mee komen aandragen. Maar ik neem aan dat dit wel ter sprake zal zijn gekomen met Amos. ... (van Rood, 23 september, 1963) 
mogelijk wanneer al veel kennis en vaardigheden aanwezig zijn bij de gebruiker 25 . Als alternatief voor het via de serumbank verspreiden van kennis, biedt hij aan alle panels van deelnemers aan het samenwerkingsprogramma te typeren (van Rood, 2 maart, 1966) ${ }^{26}$. Overman vindt dit op zich een aardig idee, maar de verplichting om sera in de serumbank te deponeren blijft staan. Hierop zegt Van Rood toe om dan toch de sera naar de Serumbank te sturen. In Leiden is dan de indruk ontstaan, dat ze bij het NIH het gevoel hebben dat de Leidse groep niet aan zijn verplichtingen voldoet. Van Rood betreurt dat.

... As you will understand from the above, we feel rather frustrated an unhappy about the whole thing. I am sure that this was neither your nor the Committee's intention. In all probability inadequate communication is one of the causes of this. I hope this letter will clear some points. ... (van Rood, 18 april, 1966)

De erkenning, die Van Rood graag wil hebben voor het gedane werk en de geleverde antisera, lijkt uit te blijven, laat staan dat hij een financiële compensatie krijgt. Hij klaagt zijn nood bij Ceppellini.

We are also having difficulties with the NIH contract. It appears we loose part of our money. Because we didn't give enough serum to the bank? I do not know.

(van Rood, 22 april, 1966)

Zeer kort daarna ontvangt Van Rood een brief van Overman. Hij snapt de zorg van Van Rood, maar wijt de problemen die zijn ontstaan, voor een groot deel, aan het optreden van hem zelf: "There is no denying the fact that your not sending sera to the bank influenced the Committee's discussions." (Overman, 28 april, 1966). Van Roods gevoel, dat de problemen met het NIH-contract voortkomen uit het (te) spaarzaam doneren van serum aan de serumbank, klopt dus. Voor het NIH is dit immers het hoofddoel van het contract.

As you know, the contracts to the various laboratories had, as a major goal, the production of antileucocyte sera and the deposit of these sera into one of two banks. On this basis, I am pleased that you are depositing the sera you listed. I can assure you that I will protect these sera and make certain that they are used only for top priority purposes. Moreover, you can file requests for portions of this sera to be redistributed to your laboratory if required. (Overman, 28 april, 1966)

Volgens Overman is vooral het idee dat Van Rood het concept van de Serumbank niet zou ondersteunen debet aan de verlaging van de subsidie 27 . Toch treedt ook bij het NIH een menigsverandering op, want Overman is het op een aantal punten met Van Rood eens, maar zegt ook aan handen en voeten gebonden te zijn.

25 De kennis is nog niet in de sera geincorporeerd. Sommige sera die negatieve resultaten geven moeten gecontroleerd worden door ze te absorberen aan bepaalde donoren, waarna een preciezere typering kan worden vastgesteld. (Zie later in deze paragraaf hoe het controleren van 'lokale sera' in zijn werk gaat.)

26 Intussen schrijft Amos aan Van Rood, dat 'ze' er nog niet uit zijn of de panelbenadering een vruchtbare is. The committee meeting is tomorrow and we will discuss the whole philosophy of banks versus panels, relative costs, practicability etc. and then the questions of standardization of results. A lot will obviously depend upon the results that Chester obtains. If he gets good agreement between results obtained with the two typed panels, then the panel method is applicable and more should be set up. If he does not, we shall have to see how to better standardize the environment etc. to make it work. (Amos, 31 maart, 1966)

$27 \mathrm{Hij}$ schrijft:

However, more significant were the conversations you had with various contractors on the program. 1 believe that several of these persons mistakenly believed that you did not support the concept of the serum bank. (Overman, 28 april, 1966) 
I am well aware that many of the points you have made in the past are correct. For example, I agree that sera produced and used by the producer for further characterization and panel typing should be counted in overall production. Likewise, better criteria must be set up for the sera accepted by the banks. Despite all this, Jon, you must realize that we have a very special problem. We sold this program on the basis of antiserum reagents available to all contractors. We are, therefore, at the point where we must show results or stop the program. Many people look over my shoulder.

I still believe that in the long run you will come out ahead on this program and, in a year or so, you will find that many of our present problems have disappeared (only to be replaced by a new set of problems). (Overman, 28 april, 1966)

Zo lijkt voor Van Rood de kou weer even uit de lucht te zijn, voor anderen echter nog allerminst. Zmijewski wil graag officieel deelnemen aan het project, om daarmee ook enigszins zijn kosten te dekken, maar hij krijgt nul op het rekest, ofschoon hij vindt dat hij wel degelijk iets te bieden heeft.

I wanted to apply for a contract myself to help cover the expenses incurred in obtaining large quantities of sera from these multiparous females who we have to pay. Bernard [Amos] was not very hot on that idea at all. Since I've returned, he told me that I should send litre quantities of my sera to the bank for free just to get "the ball rolling and set a good example". However, since I have no money I have refused. Anyway, I resubmitted a renewal and made it quite strong, emphasizing the fact that because of the recent trip to your lab and Ruggerro's I now have a very valuable collection of sera. I also told them that I was personally encouraged by you and Ruggero to continue this work. Therefore if someone from the National Heart Institute, (the agency that I am negotiating with) should happen to write to you and ask you about my work, I would appreciate a good recommendation. (Zmijewski, 28 april, 1966)

De samenwerking met het $\mathrm{NIH}$ verloopt dus zeker niet naar ieders tevredenheid. Het NIH-contract wordt ervaren als een keurslijf, zoals Van Rood in antwoord op Zmijewski schrijft.

We are very distressed of hearing about your grant difficulties. The last months have convinced me that living with these yearly renewals is certainly no sinecure. (van Rood, 24 mei, 1966)

Ook wordt de opstelling van het NIH veelal te rigide gevonden. Het primaire doel van het NIH lijkt gericht te zijn op het voor zo veel mogelijk groepen beschikbaar maken van kennis en materialen ten bate van klinisch typeren, hetgeen niet het primaire doel is van (sommige) contractonderzoekers. $\mathrm{Zij}$ willen de vrijheid houden om zoveel mogelijk verschillende lijnen te exploreren. Maar fundamenteel onderzoek wordt door het NIH minder gewaardeerd, dan de productie van antisera en toegepast onderzoek. Daarmee lijkt de prijs voor de ruime financiële ondersteuning, voor sommigen onverteerbaar te worden.

I am planning this experiment and I ask if you want to join us. If you agree I shall ask permission to $\mathrm{NIH}$ : if they do not agree on the grounds that it is "research" and not "bank feeding", I shall withdraw from the collaborative study. (Ceppellini, $\mathrm{s}$ april, 1966)

Men vindt het NIH ook te 'inhalig', wat de antisera zelf betreft. De contractuele verplichting om alle geproduceerde sera naar de serumbank te sturen wordt dan ook 
nogal eens omzeild. Enkele zeer vertrouwde collega's (Ceppellini in dit geval) krijgen wel eens sera toegestuurd, waarbij men zich bewust is te handelen in strijd met het contract.

Due to the circumstances, I am asking you to consider the sending of these sera

as a confidential matter between us. Thank you. (van Leeuwen, 9 maart, 1966)

Of deze overtredingen door het NIH worden opgemerkt, is niet zo van belang, want de veranderende houding ten aanzien van Leiden lijkt door te zetten. Ook bij het NIH krijgt men het idee, dat het alleen maar voor de bank produceren van antisera misschien niet voor iedereen de beste werkwijze is, zoals Zmijewski aan Van Rood schrijft.

Serum Bank - Bernard [Amos] will take up this problem with Kayhoe ${ }^{28}$. The point is that they don't want to hamper you in your own work. In other words, and this is strictly off the record, they are beginning to feel that it would be better for you to provide typed panels rather than antisera. As the old saying goes, "Too soon old, too late smart!" (Zmijewski, 30 september, 1966)

Er ontstaat een haat/liefde verhouding tussen de lokale onderzoeksgroepen en de Serumbank. Enerzijds neemt de bank veel werk uit handen. Aanvragen van 'nieuwelingen' bijvoorbeeld, kunnen nu worden doorverwezen naar de Serumbank. Anderzijds lijkt het NIH meer gericht op het toepassen van de leukocytenantigeentypering en minder op fundamenteel onderzoek, wat als gevolg zou kunnen hebben dat er minder antisera tegen nieuwe antigenen gevonden worden.

Nog voordat er over een NIH-Serumbank gesproken wordt, spreekt men al over het uitbesteden van de serumscreening aan commerciële laboratoria. Dit zou de werklast van de onderzoekslaboratoria verlichten, zodat die zich meer op het onderzoek kunnen richten.

I think your idea to have the service screening of sera done by a commercial lab is excellent.... Then we would sort the interesting sera out. There is one snag here, however. I am getting more and more convinced that with the more difficult systems it is essential to have information concerning the genotype of the women who made the serum. For that reason, I think that the organization should always be so, that it remains possible to go back to the women who produced the antibody. (van Rood, in december, 1964)

In samenwerking met commerciële laboratoria zou het zo mogelijk zijn om grotere hoeveelheden sera op de aanwezigheid van antilichamen te onderzoeken. Een goed registratiesysteem van donoren is daarbij noodzakelijk, zodat de interessante serum leverende donoren makkelijk te traceren zijn. Met die screening kunnen dan zowel sera van een bekende specificiteit, als nieuwe antigeenherkennende antisera gevonden worden. Uit de resultaten zouden ervaren onderzoekers vervolgens de veelbelovende sera kunnen selecteren. Deze opzet zou nu ook vruchtbaar kunnen zijn voor de serumbank en snijdt het mes aan twee kanten. Op deze manier worden en vele nieuwe serumdonoren gevonden - waarvan mogelijk een aantal nog onbekende antigeenherkennende antilichamen produceert - , en wordt de serumbank van het $\mathrm{NIH}$ gevuld.

Een ander probleem voor en van het NIH en de Serumbank is, dat er voor het

28 Dr. Donald E. Kayhoe, Chief, Transplantation Immunology Branch, NIAID, NIH. Naast Overman de andere directe gesprekspartner bij het $\mathrm{NIH}$. 
typeren van leukocytenantigenen geen uitgekristalliseerde test is, zodat de reproduceerbaarheid te wensen overlaat. Het is geen simpelweg te leren techniek die eenvoudig kan worden toegepast. "A second difficulty is that typing still is not a "science" but an "art", with all the disadvantages stemming from that."(van Rood, II december, 1964) De met een test behaalde resultaten vereisen interpretatie om tot een definitief oordeel te komen. Zeker kort na de start van de Serumbank zijn de daar aanwezige sera nog niet 'gemakkelijk': ze bevatten niet (allemaal) slechts één soort antilichaam. Maar zelfs wanneer antisera wel monospecifiek genoemd worden, wil dat nog niet zeggen dat ze 'eenvoudig' zijn. Aanvankelijk noemt men de leukocytenantigenen ook 'leukocytengroepen', omdat men niet precies weet waar men mee van doen heeft. Een antigeen zou wel een samenstelsel van verschillende onderdelen kunnen zijn, wat de problemen bij het vinden van 'identieke sera' zou kunnen verklaren. (van Rood, II december, 1964$)^{29} \mathrm{Bij}$ al deze problemen moet niet vergeten worden dat de monospecifieke status van een serum gekoppeld is aan een bepaalde techniek (van Rood, 1966). Andere technieken kunnen immers andere, ook in het serum aanwezige, antilichamen activeren; antilichamen die met de oorspronkelijke techniek niet detecteerbaar zijn. Het in de serumbank 'storten' van een serum bestaat dus niet slechts uit het opsturen van het serum, maar moet vergezeld gaan van een handleiding hoe men het serum moet gebruiken en hoe men de resultaten moet interpreteren.

Het lokale karakter van de sera blijkt in extreme mate bij sera die niet via de serumbank verstuurd worden. De handleiding bij die sera wordt soms zelfs toegesneden op de lokaal aanwezige leukocytendonoren. Negatieve resultaten moeten zelfs door de gebruiker gecheckt worden op echte afwezigheid van het antigeen. Het is namelijk mogelijk dat de antilichamen wel door de betreffende cellen geabsorbeerd worden, maar er niet in slagen de cellen te doen klonteren ${ }^{30}$.

I) If serum $5 \mathrm{I}$ is negative or weak then you have to absorb this serum and you can test it with the leukocytes of Marco Pugnani, Enrico Pugnani, Gagliardi Maride, Tognolo Maria Louisa or Rosina Clementio.

2) If serum 26 is negative or doubtful then you have to absorb this serum and you can test it with the leukocytes of Luino Pierguido $(\mathrm{A}+)$ or Scagloiotti Cesare $(\mathrm{A}+)$. Blood group serum 26 is $\mathrm{O}$, therefore be careful with the A Donors!!

If 105r is weak or doubtful then you can titrate this serum in saline. Is the titer higher than $\mathrm{I} / 4$, the leukocytes are $7 \mathrm{~b}$ positive. (van Leeuwen, 9 maart, 1966 ) Meest ideaal voor het gebruik van sera in den vreemde is dat iemand die de sera kent (en dus weet hoe ze te behandelen) met de sera meereist en ter plaatse de typeringen uitvoert. Daarom is dit ook de opzet die Van Rood aan Terasaki voorstelt voor het typeren van een panel in Los Angeles. De analiste uit Leiden ${ }^{31}$ is in staat om de laboratoriumomstandigheden uit Leiden te kopiëren en kent de specifieke moeilijkheden van de verschillende sera. De betrouwbaarheid van de door haar verkregen

29 Hierover schrijft Van Rood aan Amos:

For instance, 1 am especially unhappy with group Four, in which we found now in a larger series of random people, a surplus of $434 \mathrm{~b}$ 's. ... I don't know as yet how to explain these findings, but $I$ am certain that the

last word has not been said about group Four ... (van Rood, 11 december, 1964)

30 Agglutination Negative, Absorption Positive fenomeen (ANAP)

31 Mejuffrouw Schippers.

For the typing of the panels and of the recipients and donors, we will procure our sera, which Miss Schippers knows to handle. (van Rood, 18 maart, 1966) 
typeringsresultaten zou hoger zijn dan wanneer Terasaki zelf met de 'vreemde sera' de typeringen zou uitvoeren (van Rood, 18 maart, 1966).

Bij het NIH heerst onbegrip over dit soort problemen met sera. Met name het lokale karakter van de agglutinerende sera is voor hen erg lastig te begrijpen. $\mathrm{Bij}$ gebruik van de cytotoxiciteitstechniek schijnt minder sprake te zijn van een lokaal karakter van de sera. Het is voor de serumbank dan ook veel gemakkelijker om sera voor die techniek uit te geven, dan voor de agglutinatietechniek. Weliswaar is de cytotoxiciteitstest moeilijker te leren, maar de techniek ondervangt een groot deel van de variaties die in de agglutinatietechniek mogelijk zijn.

Rond de antisera speelt nog een aantal andere problemen. Zo worden antisera wel als 'veelbelovend' geselecteerd met behulp van een computer, maar moet vervolgens nog veel werk worden verzet om de (mono)specificiteit vast te stellen. De computer biedt dus geen oplossing voor het probleem van de 'lokale' sera. Na het selecteren van een mogelijk bruikbaar serum, moeten er nog veel tests worden gedaan om te bepalen of het ook daadwerkelijk een voor typeringsdoeleinden bruikbaar serum is.

... it should be pointed out that the computer is used only to indicate which sera might be useful to recognize an antigen, but that a serum is never used for grouping on the basis of the computer data alone. Before a serum is used for antigen detection it has been thoroughly absorbed and tested against leukocyte samples obtained from random donors and family members to investigate whether it is monospecific and reliable for antigen recognition. I am stressing this point because I recently realized that there is rather wide-spread misunderstanding on this matter. (van Rood, 1966)

De winst van het gebruik van een computer moet volgens Van Rood niet overschat worden. Afgezien van het vele werk dat verricht moet worden om de testresultaten in de computer in te voeren, vragen ook de computerresultaten nog veel interpretatie en levert het zeker geen garantie voor een eenduidig overzicht.

I should also like to point out that with the exception of the data shown here, and those of group Five, the computer data for the sera recognizing the other groups were not equally simple and convincing. (van Rood, 1966)

Een probleem van geheel andere orde is, dat na verloop van tijd blijkt dat de frequenties waarin antigenen in verschillende populaties voorkomen, verschillen. Dit heeft onder andere tot gevolg dat ook de antiserum specificiteiten niet in gelijke mate voorkomen.

It certainly is funny that none of my sera are anti-sb but that's what I've been saying all along. We are using your anti-5b serum and screening our leukocyte donors. It works beautifully and so far we've found two 5 b negatives. Maybe now we can start a mass screening of sera. I think I will also start screening Negroes to try to get an idea of the incidence of the antigen. It's quite possible that the vast majority of them are $5 \mathrm{~b}$ positive and that's why we don't find the antibody. (Zmijewski, 20 juni, 1966) $)^{32}$

32 Inter-etnische verschillen zullen een grote rol gaan spelen, met name in de beschikbaarheid van organen voor verschillende bevolkingsgroepen. Overigens blijken de $5 \mathrm{a}$ en $5 \mathrm{~b}$ antigenen volgens Van Rood Minor Histocompatibility Antigens te zijn, maar worden daar officieel niet toe gerekend omdat ze niet met cytotoxische T-lymphocyten zijn te herkennen, maar met antilichamen, hetgeen in strijd is met de definitie van de Minor Antigens (van Rood, 1 augustus, 2000). (Het ga antigeen maakt geen deel uit van het HLA. systeem, omdat het specifiek voorkomt op de granulocyten.) 
Het niet homogeen voorkomen van antigenen in verschillende populaties, heeft gevolgen voor het vullen van de serumbank. Sommige antisera zijn in bepaalde populaties schaars. Het heeft ook gevolgen voor de klinische typeringspraktijk ${ }^{33}$.

Door antisera bij de serumbank in bewaring te geven en van daaruit over de wereld te verspreiden, wordt getracht ze voor iedereen beschikbaar te maken. Maar ondanks de pogingen vanuit het $\mathrm{NIH}$ om de controle over het verspreiden van sera over de wereld in handen te krijgen, blijven startende onderzoekers aan Van Rood vragen om hen medewerking te verlenen en antisera te leveren voor klinische typeringsdoeleinden, omdat ze toch met de agglutinatietechniek verder willen gaan.

I hope we will be able to maintain a close co-operation because we are desirous

of continuing to base our work on your classification and your techniques. Any

further help or typing sera which you may be able to give our team would

indeed, be very deeply appreciated. ... (Morris, 4 september, 1967)

Het uniform maken van de typeringspraktijk blijkt meer te zijn dan slechts het versturen van antisera naar allerlei laboratoria, verspreid over de wereld. Het scheppen van de voorwaarden om de praktijk te kunnen standaardiseren, stuit op verschillende problemen. Naast problemen met onderzoekers die de NIH-Serumbank moeten vullen, blijkt de tijd nog niet rijp om een gestandaardiseerde typeringspraktijk te vormen. Monospecifieke antisera zijn nog niet in voldoende mate aanwezig, noch is er een gestandaardiseerde en eenvoudig te leren techniek voorhanden, die de garantie van betrouwbare resultaten biedt. Met het oplossen van deze problemen is de onderzoekspraktijk nog volop bezig. Het even opzetten van een mondiaal uniforme typeringspraktijk is voor het NIH te hoog gegrepen, maar de intrede van het NIH in de leukocytenonderzoekspraktijk gaat niet onopgemerkt voorbij.

\subsection{Een Span ningsveld}

Rondom de leukocytenantigenen ontstaan spanningen tussen de onderzoekers 'verenigd' in de onderzoekspraktijk enerzijds en de (inter)nationale organisaties (het NIH en de WHO) anderzijds.

Tijdens de Workshop van 1965 in Leiden is het daar aanwezige panel getypeerd door onderzoekers uit de hele wereld en vervolgens verheven tot WHO Reference Panel. Dit panel vormt de vertaalsleutel voor alle, dan aanwezige, verschillende antisera en hun benamingen in de wereld 34 . De inspanningen vanuit Leiden, om op basis van het WHO Reference Panel ook elders panels te typeren, kan beschouwd worden als poging om de onderzoekspraktijk uit te breiden. Vanuit een klein lokaal

33 Het gevolg is namelijk dat met een standaardset, sommige antisera nooit positief zullen reageren. simpelweg omdat het antigeen niet in de betreffende populatie aanwezig is. Dit is op zich niet zo erg. anders dan dat het als verspilling van de betreffende antisera kan worden beschouwd. Een consequentie van een standaardset is echter ook, dat voor de betreffende populatie specifieke antigenen niet gedetecteerd worden, door afwezigheid van een antiserum daartegen. Bij een, op basis van zơn typering, verrichtte transplantatie, kan dat negatieve gevolgen hebben. Om dit te voorkomen zijn er twee mogelijkheden. Of de standaardset wordt zo omvangrijk gemaakt, dat werkelijk ieder te detecteren antigeen ter wereld er mee kan worden herkend, maar dit is zowel praktisch, als theoretisch onhaalbaar. Of men accepteert dat een serumset niet 'globaal' is en werkt met een 'lokale' basisset. Zo nodig, bi 'lege plaatser' in de typering ('blanks'), zoekt men gericht, uitgaande van etnische gegevens, verder met een specifieke set.

34 Een indicatie voor hoeveel verschillende benamingen voor dezelfde antigenen in de loop van de tijd worden gebruik, is het overzicht dat Van Rood geeft in zijn bijdrage aan het handboek: Organ Transplantation, van Felix Largiadèr, dat in r970 verschijnt. Zie hiervoor bijlage 2: Antigenen in 1967. 
gebied worden vertalingen gemaakt naar andere gebieden - zowel bij nieuwe, als bij gevestigde onderzoekers ${ }^{35}$. Het lijkt erop dat Van Rood er op deze manier voor wil zorgen, dat anderen 'zijn taal gaan spreken', zijn antigenen herkennen en dat zo zijn norm de algemene norm wordt. Het WHO Reference Panel is hierbij voor Leiden de troef die zij in handen hebben. Door de Workshop in Leiden was het Leidse panel al de belichaming geworden van de aanwezige kennis in de onderzoekspraktijk. Het elders typeren aan de hand van Leidse sera maakt die positie alleen maar sterker.

De (inter)nationale organisaties (NIH en WHO) maken gebruik van de onderzoekspraktijk, doch zijn er niet op uit deze uit te breiden. Door standaardsera uit te geven en methodieken voor te schrijven, proberen zij de onderzoekspraktijk zo te standaardiseren, dat op dit fundament een klinische typeringspraktijk kan worden gebouwd. Daar hoort een bepaalde strategie bij. Voor het NIH en de WHO zijn de vele mensen die een typeringslaboratorium willen starten degenen die de klinische typeringspraktijk gaan vormen. De sera die deze mensen van de serumbanken krijgen, gaan vanzelfsprekend vergezeld van een gebruiksaanwijzing. In deze gebruiksaanwijzing ligt de nadruk echter niet op het gebruik van de respectievelijke sera - zoals bij uitwisseling van sera in de onderzoekspraktijk - maar op de techniek. Omdat cytotoxiciteit beter te standaardiseren is, propageert het NIH de cytotoxiciteitstechniek. Want ofschoon moeilijker te leren, levert de cytotoxiciteitstest uiteindelijk beter reproduceerbare en controleerbare resultaten. Door 'beginners' een 'Starter Package' te geven, kunnen zij de techniek leren, waardoor de kans groeit dat later de betere, kostbare sera goed gebruikt zullen worden. Voor deze beginnende typeurs is het opzetten van een klinisch typeringslaboratorium in eerste instantie het doel, waarbij het goed toepassen van de (gestandaardiseerde) techniek een vereiste is om deel te kunnen nemen aan het NIH-programma. De onderzoekers die zichzelf rekenen tot de onderzoekspraktijk willen natuurlijk ook betrouwbare resultaten krijgen, maar willen die resultaten vooral vergelijken zodat zij meer kennis krijgen over de antigenen, de genetica van die antigenen etc. Welke techniek daarbij gebruikt wordt, is voor hen minder van belang. Het zijn voor een deel echter wel deze onderzoekers, die de commissies van het NIH en de WHO bevolken en daar bezig zijn met het opstellen van de regels en richtlijnen.

Van achter de laboratoriumtafels klinkt de roep om standaardisatie en de (inter)nationale organisaties lijken die standaardisatie te bewerkstelligen. Echter, de commissies die de standaardiseringsvoorstellen doen, bestaan uit mensen die zelf voor de ontstane pluriformiteit hebben gezorgd: de 'onderzoekers van het eerste uur' in de leukocytenonderzoekspraktijk. Standaardisatie vindt dus noch uitsluitend van bovenaf (NIH), noch uitsluitend van onderaf (onderzoekspraktijk) plaats. Aanvankelijk is tussen standaardisering van boven- en onderaf nauwelijks een onderscheid te maken. Er is immers een verwevenheid van typeringspraktijk en onderzoekspraktijk, waarin soms klinische typeringen en soms typeringen uitsluitend ten bate van onderzoek worden gedaan. Pas later zal ook een infrastructurele scheiding ontstaan, tussen laboratoria die voornamelijk bezig zijn met het uitvoeren van klinische typeringen en laboratoria die aan andere doelstellingen werken.

35 Dit ziet Van Rood immers als een vorm van informatic uitwisscling (van Rood, 18 maart, 1966; van Rood, 30 juni, 1966). 
Voorafgaand aan de vraag: hoe leidt de, rond de leukocytenantigenen ontstane, onderzoekspraktijk tot de ontwikkeling van een klinische typeringspraktijk, blijkt nog een vraag gesteld te moeten worden: Ontstaat er een klinische typeringspraktijk? Op basis van hetgeen in dit hoofdstuk beschreven is, moet deze vraag ontkennend worden beantwoord. Het NIH slaagt er niet in om een mondiaal uniforme typeringspraktijk naar haar model te laten ontstaan, terwijl de verschillende lokale onderzoekspraktijken er niet in slagen hun lokale praktijken aaneen te smeden. De organisaties en de onderzoeksgroepen blijken van elkaar afhankelijk, maar ieder met verschillende doelstellingen. Uit dit spanningsveld ontstaan, los van elkaar, regionaal gestandaardiseerde, klinische typeringspraktijken, en een van deze typeringspraktijken is onderdeel van Eurotransplant ${ }^{36}$.

Het nu volgende hoofdstuk beschrijft de Leidse situatie: de inbedding van het Leidse onderzoek naar leukocytenantigenen en hoe dat leidt tot de oprichting van Eurotransplant.

36 Zie de hoofdstukken $7 \& 8$ voor het ontstaan van deze regionaal gestandaardiseerde, klinische typeringspraktijken en van Eurotransplant. 



\section{De 'LeIDSE' CONTEXT}

\subsection{INLEIDING}

In de vorige hoofdstukken heb ik beschreven hoe een onderzoekspraktijk ontstaat, waarin de antigenen op leukocyten onderzocht kunnen worden. Ten eerste werd duidelijk dat op leukocyten aanwezige antigenen de oorzaak van transfusiereacties zijn. Ten tweede is beschreven hoe een groeiend aantal onderzoekers sinds eind jaren vijftig aan het werk is met de interactie tussen leukocytenantigenen en antilichamen. Zij zoeken de 'best mogelijke' opstellingen om de antigenen met de antilichamen te laten reageren, of proberen de manier van bereiding van een leukocy. tensuspensie te verfijnen, etc. Met deze inspanningen proberen onderzoekers de relatie tussen verschillende antisera en verschillende leukocyten te analyseren. Hoe reageren de antisera met leukocyten? Hoeveel antigenen zitten er op een leukocyt? Wat is genetisch gezien het verband tussen verschillende antigenen? Ten derde is besproken hoe vanuit ontwikkelingen in en rond de onderzoekspraktijk geprobeerd wordt een typeringspraktijk tot ontwikkeling te brengen.

Het onderzoek naar de leukocytenantigenen staat niet op zichzelf, maar heeft een inbedding. In dit hoofdstuk zal blijken dat er in Leiden al lang voordat sprake is van klinische toepassing van leukocytenantigeentyperingen, contacten tussen de bloedbank en andere disciplines, waaronder (transplantatie) chirurgen, ontstaan. Het is daarom interessant om te onderzoeken hoe in Leiden een transplantatiepraktijk wordt gecreëerd. Welke disciplines en organisaties vinden elkaar en wie zijn daar verder bij betrokken. Naast het in de vorige hoofdstukken beschreven onderzoekswerk in het kader van de bloedvoorziening, worden door het Leidse bloedbank-laboratorium namelijk ook werkzaamheden verricht ten bate van andere afdelingen in het ziekenhuis. Het gaat daarbij niet alleen om klinische bepalingen in het kader van diagnosen, maar ook om onderzoek naar mogelijke behandelingen voor ziektebeelden. De doelstellingen van de bloedbank en de aanvragende afdelingen liggen daarbij soms zo in elkaars verlengde, dat het contact uitgroeit tot samenwerking op onderzoeksgebied.

Onderzoek naar de rol van antigenen bij de afstoting van getransplanteerde organen en weefsels, is voor verschillende groepen interessant. Een van de eerste organisaties die belangstelling heeft, is het Instituut voor Radiopathologie en Stralingsbescherming (IRS). Al sinds de oprichting (I958) heeft dit instituut nauwe banden met de Bloedbank (Steenbergen, 9 december, 1965). De contacten tussen het IRS en de Bloedbank worden structureel in het zogenoemde Beenmergtransplantatieproject. Een beenmergtransplantatie wordt gezien als een mogelijke behan- 
deling voor een patiënt bij wie, door straling - of anderszins - de functies van het beenmerg verloren zijn gegaan. Deze patiënten zijn zowel hun rode-, als wittebloedcellen-vormende-stamcellen kwijt en dus ook hun immuunsysteem. Daarmee zijn deze stamcel-loze patiënten zeer gevoelig geworden voor infecties. Dit kan alleen hersteld worden door middel van een beenmergtransplantatie. Omdat onderzoek naar de leukocytenantigenen de toepassing van beenmergtransplantatie als klinische behandelingswijze dichter bij zou kunnen brengen, draagt het IRS ook financieel bij aan het leukocytenonderzoek van de Bloedbank.

Maar de contacten betreffen niet alleen het onderzoek naar leukocytenantigenen. Het IRS wil zich namelijk voorbereiden op een mogelijk stralingsongeval. Om de patiënten na zo'n ongeval te kunnen verplegen, wil het IRS een verpleegafdeling bouwen. Als voorbereiding op de bouw van deze verpleegafdeling, wordt vanuit het IRS de werkgroep 'Isolatie-Paviljoen' opgericht. Hierin wordt ook een bijdrage van andere disciplines gevraagd, waar onder de Immunohaematologie (de groep van Van Rood). Uiteindelijk mondt deze samenwerking uit in de bouw en ingebruikname van het Isolatiepaviljoen. Een stralingsongeval waarvoor patiënten in het Isolatiepaviljoen moeten worden opgenomen, vindt echter niet plaats. Hierdoor is onderzoek bij deze patiënten niet mogelijk. Dit probleem wordt opgelost door te zoeken naar modellen voor stralingsslachtoffers. Daarvoor worden onder meer patiënten gekozen, waarbij het immuunsysteem niet functioneert. Hiertoe behoren patiënten die worden behandeld met immunosuppressiva.

Binnen dit samenwerkingsverband - samenwerking tussen het IRS, de immunohaematologen en anderen - worden voorbereidingen getroffen voor de eerste niertransplantatie in Leiden. Voordat men tot transplantatie bij mensen overgaat, wordt eerst nog geoefend op diermodellen. Zowel bij mensen, als bij dieren, wordt de belofte die 'matchen' op leukocytenantigenen inhoudt - namelijk dat daarmee de situatie van een identieke tweeling zou kunnen worden geimiteerd - onderzocht. Dierexperimentele bevindingen blijken echter niet altijd eenvoudig naar patiënten te vertalen te zijn. Maar uiteindelijk concludeert Van Rood, mede op basis van de resultaten die bij de eerste transplantaties worden behaald, dat het typeren van leukocytenantigenen een plaats verdient in de klinische orgaantransplantatiepraktijk.

\subsection{TRANSPLANTATIE-ANTIGENEN}

$\mathrm{Na}$ de gebeurtenissen in Leiden rond mevrouw H., in 1958 , worden verschillende vragen opnieuw actueel. Dat leukocyten een overeenkomstig immuniserend effect hebben als een huidtransplantaat, liet Medawar ruim een decennium eerder zien, door konijnen eerst te immuniseren tegen een bepaalde donor en vervolgens de overlevingsduur van huidtransplantaten, afkomstig van die donor en van willekeurige donoren, te bepalen (Medawar, 1944; Medawar, 1945). De vraag, of het immuniserende effect veroorzaakt wordt door de in (huid)weefsel aanwezige leukocyten, of dat de op leukocyten aangetoonde antigenen ook op de cellen van andere weefsels aanwezig zijn, werd door dit experiment echter niet beantwoord.

$\mathrm{Na} 195^{8}$ wordt in Leiden op verschillende manieren geprobeerd deze vraag te beantwoorden. Ook andere lichaamscellen worden met de in de sera aanwezige antilichamen in contact gebracht, om te onderzoeken of die soms ook met de antilichamen reageren. Dit met elkaar in contact brengen is echter niet zonder meer mogelijk, daar de meeste lichaamscellen niet - zoals leukocyten - vrij beschikbaar zijn en er geen methoden bestaan om de reactie van antilichamen met eventueel 
aanwezige antigenen zichtbaar te maken. Door echter de antisera te vermengen met een suspensie van cellen van andere organen, zouden eventuele antigenen op de cellen kunnen reageren met de antilichamen in het serum. Na verwijdering van de betreffende lichaamscellen uit het serum, zouden dan ook de gebonden antilichamen moeten zijn verdwenen. Dit heeft tot gevolg dat het 'geabsorbeerde' serum niet meer reageert met een leukocytensuspensie, waarmee het vóór de behandeling wel reageerde.

Door middel van absorptieproeven konden wij aantonen, dat de erythrocyten niet in staat zijn, de leukocyten-antistoffen te absorberen. Trombocyten deden dit echter wel, kwantitatief zelfs sterker dan de leukocyten, en even specifiek. ...

Uit verdere proeven bleek bovendien, dat gehomogeniseerd, meermalen gewassen placentaweefsel in staat was leukocyten-antistoffen specifiek te absorberen. ... Het is op het ogenblik nog niet uit te maken, welk weefsel (placenta, leukocyten, trombocyten) het ontstaan van de leukocyten-antistoffen stimuleert. Misschien werken ze alle drie tezamen. (van Rood, et al., 1959) ${ }^{1}$ De bevinding dat de antigenen op trombocyten zitten en in placentaweefsel aanwezig zijn, opent de mogelijkheid dat deze antigenen ook op cellen van andere oorsprong zitten. Daar richt het vervolgonderzoek zich dan ook op 2 .

Leucocytegroups in general enjoy at the moment a certain popularity, due to their possible identity with the transplantation antigens. In a number of experiments

we attempted to prove or disprove this identity. (van Rood, et al, 196r)

De experimenten laten zien dat de 'leucocytengroep-substantie' zeer verspreid voorkomt (van Rood, II juli, I96I). En omdat het aantonen op huidcellen met absorptieexperimenten niet lukt, proberen Van Rood en zijn medewerkers dat op een andere manier te doen, namelijk via overlevingsduur-experimenten van trombocyten ${ }^{3}$. Via

I Hetzelfde artikel verschijnt in het voorgaande jaar in het Engels onder de titel: Antibodies Against Leucocytes in Sera of Pregnant Wornen (van Rood, et al., 1958)

2 Ze schrijven:

Whether these antigens are also present in other tissue e.g. skin, kidney etc., is being investigated at present. (van Rood, et al., 1959)

3 De overlevingsduur wordt getest door trombocyten te labelen met een radioactieve stof en die vervolgens in te brengen bij de patiënt. Zo kan gekeken worden of de overlevingstijd verkort is voor die bepaalde trombocyten, wat zou kunnen duiden op de aanwezigheid van antistoffen.

Aangezien trombocyten leukocytenagglutininen absorberen, kan daaruit geconcludeerd worden dat er in ieder geval overeenkomstige antigenen op deze cellen aanwezig zijn.

The observations of Dausset and collaborators (13) and van Rood and collaborators (4) indicate the presence of at least some of the leucocyte antigens on platelets. Moreover Dausset reported on the very good correlation ( $98 \%$ ) of the leucocyte agglutination- with the thrombocyte agglutination test. We were therefore not surprised to find a shortened survival in 4 patients who had leucocyte agglutinins in their serum. ... These results sustain the reports that at least some of the leucocyte antigens are present on platelets. ...(Bosch, et al., 196r)

Maar ook zonder aantoonbare leukoagglutininen kan de overlevingstijd van trombocyten verkort zijn, hetgeen kan betekenen dat er ook trombocytenantigenen zijn.

We could demonstrate this in a series of split skin transplantations which was carried out in our laboratory to investigate the identity of leucocyte- and transplantation antigens. In one case a thrombocyte survival measured at the same time as the grafting of the skin was found to be normal. After rejection of the graft the survival of the thrombocytes of the skin donor was always $(7$ cases) shortened... After platelet survival tests, antibodies against leucocytes were found in all cases. ... The presence of leucocytes and/or thrombocytes in the transplanted graft might still be responsible for the immunizing effect. This possibility seems improbable because a split skin contains virtually no blood. Our findings therefore suggest that blood platelets and skin cells have antigens in common. (Bosch, et al., 1961)

Hiermee blijtt de mogelijkheid bestaan dat de antigenen die de trombocyten en huidcellen gemeenschappelijk hebben, toch dezelfde zijn als de antigenen op de leukocyten, aangezien er na afstoting van het huidtransplantaat altijd leukocytenantilichamen worden gevonden en de hoge correlatie tussen de leukocyten- en trombocytenagglutinatietest. 
deze tomweg' zijn voor de aanwezigheid van de antigenen op huidcellen aanwijzingen te vinden. Uit de bevinding dat vele andersoortige lichaamscellen in staat blijken om in sera aanwezige leukocytenantilichamen te binden, concluderen de onderzoekers niet meteen dat deze antigenen ook verantwoordelijk zijn voor afstotingsreacties. Daarvoor moet eerst worden aangetoond dat de leukocytenantigenen dezelfde zijn als de transplantatie-antigenen. Pas nadat dit is gebeurd, kan de relatie tussen leukocytenantigenen en afstoting van een transplantaat met meer zekerheid worden gesteld (Werkgroep Beenmergtransplantatie, 14 maart, 196r). Een aanwijzing in die richting is, dat niet alleen na transfusies, maar ook na de afstoting van een transplantaat, soms leukocytenantistoffen in het serum van de getransplanteerde kunnen worden aangetoond. Het lijkt er dus op dat ook de antigenen op die cellen, evenals de antigenen op leukocyten, een immuniserend effect hebben. Men blijft echter voorzichtig en vindt dat daarmee nog niet is aangetoond dat de leukocytenantigenen identiek zijn aan de transplantatie-antigenen ${ }^{4}$. "Experimenteel onderzoek van de aard en de werking van weefselantigenen" blijft dan ook op de agenda staan.

1. De beste benadering van dit onderzoek lijkt de bestudering van

leucocytenantigenen, omdat er aanwijzingen zijn dat deze een zekere identiteit vertonen met de transplantatie-antigenen. Het voordeel van de leucocyten als materiaal voor onderzoek is tweeërlei: ten eerste is er een zekere systematische indeling van leucocytenantigenen in groepen bekend en ten tweede zijn leucocyten van een groot aantal personen makkelijk te verkrijgen. (Steenbergen, 20 december, 1963 )

Een van de manieren waarop men probeert te beoordelen of het deze antigenen zijn die een rol spelen bij het afstoten, is door te onderzoeken of het mogelijk is om de tijd die het duurt tot een transplantaat wordt afgestoten te verlengen. Dit wordt gedaan door middel van kleine huidtransplantaties. Leukocytengroepen ${ }^{5}$ worden bepaald en er wordt geprobeerd bij elkaar passende leukocytenmonsters te vinden, waarna men van de compatibele donoren stukjes huid uitwisselt. Vervolgens wordt bekeken of die transplantaten langer blijven zitten dan wanneer een willekeurige combinatie wordt gemaakt. Een transplantaatoverlevingsduur, langer dan de overlevingsduur bij een willekeurige combinatie, zou een gevolg moeten zijn van de compatibiliteit van de leukocytenantigenen, c.q. transplantatie-antigenen. Een duidelijke verlenging van de overlevingstijd van de getransplanteerde huid wordt in dit onderzoek echter niet gevonden (van Rood, et al., 1961).

Op de Bloedbank wordt overigens al geruime tijd onderzoek verricht naar antilichamen. Zo is men bijvoorbeeld in de tweede helft van de jaren vijftig - nog ruim voordat Mevr. H. de 'onverklaarbare' transfusiereactie had - al bezig met onderzoek naar de relatie tussen circulerende antilichamen, trombocyten en erythrocyten (van Rood, et al., 1957; Eernisse, et al., 1958; van Rood, et al., 1959; van Rood, et al., 1959). Bij een tekort aan trombocyten (trombocytopenie), kan een trombocytentransfusie worden gegeven, waarmee het stollend vermogen van het bloed hersteld wordt. Het

4 Analoog aan de benaming 'Leukocytenantigenen' wordt voor de antigenen op andere cellen in plaats van 'Transplantatie-Antigeneri, ook de benaming 'Weefselantigenen' gebruikt, wasrmee weer een algemene benaming voor de locatie wordt gegeven, in plaats van een benaming, gerelateerd aan een activiteit.

5 Men spreekt in deze tijd - begin jaren '60 - nog niet van leukocytenantigenen, maar van leukocytengroepen, naar analogie van de 'bloedgroepen' (Bruning, 17 april, 1968). Zie ook Hoofdstuk 2. 
gewenste effect is echter meestal van korte duur, door de effecten van in het bloed circulerende en tegen trombocyten gerichte antilichamen, zodat frequente herhaling van de behandeling noodzakelijk is. Om het meest efficiënte moment voor een nieuwe behandeling te bepalen, onderzoekt men de overlevingsduur van trombocyten. In dit verband worden ook de labelingstechnieken met radioactieve stoffen ontwikkeld. Men bepaalt namelijk de overlevingsduur door trombocyten te labelen met een radioactieve stof. Zo kan gekeken worden of de overlevingstijd verkort is voor die bepaalde trombocyten, hetgeen zou kunnen duiden op de aanwezigheid van antistoffen. Mede via dit onderzoek legt men contact met het Instituut voor Radiopathologie en Stralingsbescherming (IRS), dat voor dit soort onderzoeken vanaf de oprichting van het IRS in I958 - personeel bij de bloedbank detacheert (Steenbergen, 9 december, 1965). Naast extra personeel, probeert men ook apparatuur ten bate van onderzoek te krijgen van het IRS en andere afdelingen van het ziekenhuis, die mogelijk profijt zouden kunnen hebben bij een doorbraak op het onderzochte gebied. Het IRS is een van die instanties, aangezien zij 'de verpleging en behandeling van patiënten na stralingsongevallen' als doelstelling hebben (Steenbergen, 1964$)^{6}$. Met dit idee doet Van Rood in I960 een aanvraag bij het IRS, waarin hij beargumenteert waarom de aanschaf van bepaalde apparatuur noodzakelijk is.

Verzoek tot aanschaf van een automatische meetapparatuur voor gammastralen.

Een belangrijk aspect van de beenmerg-aplasie is de daarbij optredende

thrombopenie, welke een haemorrhagische diathese tengevolge heeft. De enige mogelijkheid om deze thrombopenie te bestrijden bestaat uit het toedienen van thrombocytentransfusies.

Over de optimale condities, waaronder dit geschieden moet, onder andere de bereidingswijze van deze thrombocyten-suspensies, is nog weinig bekend. (van Rood, 15 juni, 1960)

Onderzoek naar de meest optimale condities waaronder trombocytentransfusies gegeven moeten worden, neemt het IRS dan ook op in het programma van de werk. groep Beenmergtransplantatie en gedelegeerd aan de bloedbank ${ }^{7}$.

In het kader van het onderzoek naar de meest optimale condities, worden

6 Of zoals dhr. Steenbergen van het IRS dit eind 1963 in de ontwerp-begroting van het IRS voor 1965 schrijft in het kader van de "Grote Projecten". Project "Behandeling van stralingsongevallen". Werkplan van het "Isolatie-Paviljoen" en het "beenmergtransplantatie project" van het Instituut voor Radiopathologie en Stralenbescherming voor het jaar 1965 .

Doelstelling.

Het behandelen van patiënten welke bloot hebben gestaan aan ioniserende straling met

beenmergtransplantatie of de transplantatie van fracties van het beenmerg. (Steenbergen, 20 december, 1963)

7 Het IRS is opgericht in anticipatie op een mogelijk nucleair ongeval bij een van de nucleaireonderzoekscentra in Nederland (Het Reactor Centrum Nederland, in Petten en een in Rotterdam). Van de, uit zo'n ongeval voortkomende, patiênten kan verwacht worden dat zij beenmergschade hebben opgelopen. Daarmee zullen zij (onder andere) beroofd zijn van hun trombocyten vormende stamcellen. Vandaar dat onderzoek naar de overlevingsduur van trombocyten, ingezet ter behandeling van trombopenieên van andere oorsprong dan straling, ook voor het IRS binnen de doelstelling valt, en als zinvol onderzoek voor het behandelen van stralingsslachtoffers wordt beschouwd.

De stoornissen in de haemostase worden veroorzaakt door een tekort aan trombocyten. De behandeling hiervan is het toedienen van geconcentreerde thrombocytensuspensies. De technieken van de thrombocytentransfusies en het langdurig bewaren van thrombocyten bij zeer lage temperaturen, welke reeds worden toegepast, dienen verder te worden onderzocht en mogelijk verbeterd. (Steenbergen, 20 december, 1963) 
verschillende variabelen getest, waarbij de overlevingsduur van getransfundeerde trombocyten als effectmaat wordt gehanteerd. Met behulp van radioactief Chroom wordt de overlevingsduur in gezonde proefpersonen bepaald. Teneinde de proefpersonen zo min mogelijk te belasten, wil men de doses radioactiviteit zo laag mogelijk houden. Met een apparaat dat automatisch, herhaaldelijk de gammastraling meet, zouden de technische en organisatorische problemen die de lage dosis radioactiviteit met zich meebrengt, zijn opgelost ${ }^{8}$. Evenzo probeert Van Rood een apparaat gefinancierd te krijgen dat het aantal cellen in een suspensie telt. Dit apparaat is primair bedoeld voor het doen van de absorptie-experimenten, maar kan ook gebruikt worden voor het toepassen van trombocytentransfusies. De aanschaf van zo'n apparaat past bij de doelstellingen van het IRS (van Rood, I5 november, 196r). Het onderzoek van het IRS is echter niet alleen gericht op het tijdelijk herstellen van de haemostase. Weliswaar is dat van groot belang, maar het therapeutisch effect van een trombocytentransfusie is van beperkte duur 9 . Wel geeft het een patiënt overlevingskansen en de behandelaars tijd voor het voorbereiden en instellen van meer structurele behandelingen, zoals een beenmergtransplantatie. Een deel van de onderzoeken die vanuit de gelijknamige werkgroep worden ondernomen, zijn dan ook relevant voor zowel korte- als langetermijnoplossingen. Het leukocytenonderzoek heeft zowel betrekking op overlevingsduur-verlenging van trombocyten, als op de voorwaarden waaronder een beenmergtransplantatie kan slagen.

Onderzoek naar transplantatie-compatibiliteit.

Het is de bedoeling een proefopstelling te maken waarbij de transplantatiecompatibiliteit onderzocht kan worden in vitro door middel van transformatie van lymfocyten. (Hirshorn, 1963); en in vivo door middel van huidreacties (Medawar, 1963). (Steenbergen, 20 december, 1963)

Voor de eerste serie (in vitro) experimenten, kan volstaan worden met het verza. melen van de leukocyten van een aantal getypeerde donoren. Voor de tweede serie (in vivo) experimenten zullen mensen een klein stukje huid van een donor getransplanteerd krijgen ${ }^{10}$. Dit vormt een veel grotere belasting voor die proefpersonen en brengt ook meer risico's met zich mee, dan het afstaan van wat bloed. De redenen om over te gaan tot zo'n experimentele opzet, zijn volgens het IRS dan ook zwaarwegend. De leukocytengroepen zouden immers transplantatie-antigenen kunnen zijn.

8 Van Rood beargumenteert zijn aanvraag bij het Directorium van het IRS als volgt.

Samenvattend worden de moeilijkheden veroorzaakt door:

1) lage dosis radioactiviteit

2) kleine bloedmonsters

3) hoog nuleffect van de scintilatietellers

4) Vrijwel volledige bezetting van de huidige apparatuur met ander werk.

Eerste drie factoren maken langere teltijd noodzakelijk, terwijl daarbij nog enige onnauwkeurigheid veroorzaakt wordt door de variatie van het nuleffect in de loop van de dag. Deze onnauwkeurigheid kan voorkomen worden door herhaalde afwisselende metingen van monsters, standaard en nuleffect hetgeen zeer tijdrovend is en bovendien het continu toezicht van een werkkracht verreist. Dit kan voorkomen worden door de aanschaf van een apparatuur welke in staat is automatisch een tevoren bepaald programma van tellingen zonder verdere bediening af te werken. (van Rood, 15 juni, 1960)

9 Ingeval van een patiènt met circulerende antilichamen, voorkomt een gematchte trombocytentransfusie de versnelde afbraak van de vreemde trombocyten.

10 Over de haalbaarheid van het uitvoeren van het onderzoek naar de relatie tussen huidtransplantatie en leukocytengroepen is men niet zeker. Het zou prettig zijn wanneer dit onderzoek in Leiden gedaan zou kunnen worden, maar er wordt rekening mee gehouden dat de 'ethische zijde van dit vraagstuk in Nederland een beperkende factor zou kunnen zijn.' (Werkgroep Niertransplantatie, 3 februari, I964) 
Indien dit zo mocht zijn, zijn zij van doorslaggevende betekenis bij eventuele beenmergtransplantaties.

Leukocytenantigenen zitten ook op thrombocyten en zijn dus ook van belang voor thrombocytentransfusie. (Steenbergen, 1964)

De belofte van de leukocytenantigenen is groot geworden. Daarom wordt het juist gevonden om proefpersonen te vragen zich te onderwerpen aan een belastend experiment. Het vooruitzicht dat beenmergtransplantatie, naast andere transplantaties, tot de reële behandelingsmogelijkheden zou gaan behoren, rechtvaardigt individuele offers.

Eerdere pogingen om met huidtransplantaties te laten zien dat leukocytenantigenen ook transplantatie-antigenen zijn, waren niet succesvol. In een nieuwe onderzoeksopzet wordt nagegaan in hoeverre de leukocytenantigenen van invloed zijn op de overlevingsduur van huidtransplantaten.

In de afgelopen jaren is het mogelijk gebleken 12 leucocytenantigenen te herkennen. ... Het feit, dat antigenen op de leucocyt herkend kunnen worden, wil natuurlijk nog niet zeggen dat zij dan ook zonder meer als transplantatieantigenen kunnen worden aangemerkt. Besproken zullen worden de methoden, waarmee selectief kan worden nagegaan welke van de antigenen transplantatieantigenen zijn. (van Rood, 25 november, 1965)

In plaats van het bij elkaar zoeken van een compatibele donor/ontvanger-combinatie, wordt gezocht naar een specifieke incompatibiliteit. Hiermee proberen de Leidse onderzoekers aan te tonen dat een bepaald antigeen verantwoordelijk is voor een effect op de overlevingsduur van een transplantaat. In ongeimmuniseerde ontvangers is het zeer moeilijk gebleken een dergelijk verband aan te tonen (van Rood, et al., 1964), vandaar dat wordt gezocht naar een methode waarmee het mogelijk zou zijn voor elk antigeen afzonderlijk na te gaan of het de overlevingsduur van een huidtransplantaat kan beinvloeden. De Leidse groep doet dit met antigeen ' $7 c$ '. Mogelijk is middels deze opzet wel een verband aan te tonen tussen leukocyten. antigenen en verkorting van de overlevingsduur van een transplantaat, zoals in het

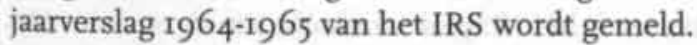

In de uiteindelijk gebruikte methode wordt een ontvanger (die het te onderzoeken antigeen niet op zijn leucocyt draagt) geïmmuniseerd met leucocyten, die identiek zijn met die van de ontvanger op het te onderzoeken antigeen na. Dit laatste ontbreekt dus bij de ontvanger en is aanwezig bij de donor. Op deze wijze hoopt men te bevorderen dat de ontvanger antistoffen zal vormen tegen het te onderzoeken antigeen. Gebruikelijk is dat dit gebeurt twee weken na een intradermale injectie van de leucocyten. Op dat moment krijgt de ontvanger huidtransplantaten van twee verschillende donors: de ene donor draagt het betreffende antigeen op zijn leucocyt niet, de andere wel. ...

(Steenbergen, 1966)

De resultaten van deze experimenten met leukocytenantigeen $7 c$ laten zien dat er statistisch significante verschillen in overlevingsduur zijn tussen huidtransplantaten met, en huidtransplantaten zonder het antigeen waartegen geïmmuniseerd was (van Rood, et al., 1966). Hieraan verbindt het IRS de conclusie: "dit maakt het uitermate waarschijnlijk, zo niet zeker, dat het $7 c$ leucocytenantigeen een transplantatieantigeen is." (Steenbergen, 1966). Dausset onderzoekt met dezelfde methode de antigenen $4 \mathrm{a}, 4 \mathrm{~b}$ en $8 \mathrm{a}$ (MAC) en komt tot eenzelfde significante overlevingsduurverkorting. 
Hiermee is het zeer waarschijnlijk gevonden dat van de dertien nu te herkennen leucocyten-antigenen er tenminste vier transplantatie-antigenen zijn.

(Steenbergen, 1966)

Via deze studie is dan eindelijk de 'moeilijke vertaling' van leukocytenantigenen naar transplantatie-antigenen tot stand gekomen, waardoor het legitiem is geworden om in het kader van orgaantransplantatie verder te werken aan onderzoek naar leukocytenantigenen. Het onderzoek naar de transplantatie-antigenen heeft hierdoor aantoonbare relevantie gekregen voor mogelijke behandelingen van slachtoffers van stralingsongevallen.

\subsection{Het IsOlatiepaVILJOEN IRS}

De contacten tussen de Bloedbank en het IRS houden meer in dan alleen het onderzoek naar leukocyten- c.q. transplantatie-antigenen. Na de oprichting van het IRS in 1958 wordt gestart met voorbereidingen om eventuele stralingsslachtoffers op te vangen en te behandelen. Daartoe wordt door het IRS enerzijds een aantal werkgroepen opgericht, die bijvoorbeeld gericht onderzoek gaan doen naar wat er precies met het lichaam gebeurt bij een stralingsongeval en werkgroepen die te trachten tot behandelingen te komen. Anderzijds wordt ook de werkgroep Isolatie-Paviljoen ingesteld, die zal werken aan het opzetten van een speciale verpleegeenheid waar deze patiënten, de specifiek door hen benodigde, verpleging en verzorging kunnen krijgen. Ondanks de onduidelijkheid over de precieze effecten van ioniserende straling op het menselijk organisme, is wel duidelijk dat stralingsslachtoffers schade aan hun beenmerg zullen oplopen, waardoor ze zeer waarschijnlijk een anaemie, leukopenie en andere bloedproblemen zullen ontwikkelen. Om te voorkomen dat deze patiënten, kort na een besmetting, overlijden aan een anders onschuldige infectie, maakt het IRS de plannen om een (nagenoeg) pathogeen vrije afdeling op te zetten, het Isolatiepaviljoen. De patiënten worden in het Isolatiepaviljoen beschermd tegen pathogenen uit de omgeving.

Omdat het gehele immuunsysteem van stralingsslachtoffers door de inwerking van de straling wordt aangetast, besteedt het IRS ook aandacht aan deze vorm van verpleging en aan de te nemen profylactische maatregelen ${ }^{11}$. Vroeg in de jaren ' 60 start het overleg voor de bouw van het Isolatiepaviljoen (Steenbergen, 5 augustus, I96o). Tijdens deze vergadering in het kader van het beenmergproject, vraagt Dr. Jongsma (Directeur-Geneesheer van het AZL) waarom het Isolatiepaviljoen niet bij TNO in Rijswijk kan worden gebouwd, aangezien op het terrein van het AZL weinig ruimte is en er toch al samenwerking bestaat tussen TNO en het IRS. De voorzitter, Prof. Querido, antwoordt dat het Medisch Biologisch Laboratorium van TNO uitsluitend voor laboratoriumdoeleinden wordt gebruikt. Daarnaast zijn er in Leiden aanvullende faciliteiten, zoals "het Laboratorium voor Stollingsfysiologie, medische specialisten en verplegend personeel” (Steenbergen, 5 augustus, 1960). Het IRS kan profiteren van de faciliteiten die bij het AZL aanwezig zijn, terwijl het AZL daarmee

II Deze patiënten vormen een nieuwe categorie, waarvoor ook een nieuwe verplegingsvorm geintroduceerd wordt.

... het beschermen van de patiènt tegen de omgeving. In de moderne geneeskunde bestaat een steeds groeiende behoefte aan een dergelijke verpleging waaraan uiteraard geheel andere eisen worden gesteld. Het betreft de behandeling van de patiënt die om een of andere reden een onvoldoende weerstand, d.w.z. cen defect afweermechanisme heeft tegen bacteriële infectie. (Werkgroep Beenmergtransplantatie, ND) 
een gespecialiseerde afdeling krijgt. Geruime tijd later wordt 'de bouw van de barak' door de directie van het IRS goedgekeurd en kan begonnen worden met de bouw (Werkgroep Beenmergtransplantatie, 6 april, 1961). Tot de nieuwbouw klaar is, kan voor de behandeling van 'modellen van stralingsslachtoffers' 12 een ander paviljoen op het terrein van het AZL worden gebruikt ${ }^{13}$.

Niertransplantatiepatiënten zouden een van de modellen kunnen zijn, maar wanneer men begin 1964 spreekt over de praktische voorzieningen voor transplantaties in Leiden, is het Isolatiepaviljoen nog niet gereed. De oplevering wordt echter wel op korte termijn verwacht, zodat structurele noodoplossingen niet nodig zijn (Werkgroep Niertransplantatie, 3 februari, 1964$)^{14}$. Enige tijd later besluit de werkgroep Beenmergtransplantatie, vanwege de verwachting dat het Isolatiepaviljoen halverwege 1964 klaar zal zijn, te beginnen met de werving van verpleegkundigen en verdere voorbereidende maatregelen te nemen ${ }^{15}$. Er wordt een bestuur ingesteld, "waarin diegenen zitting hebben die zowel bij de administratieve als de werkelijke gang van zaken betrokken zijn" (Querido, 4 juni, 1964). Kort daarop worden de verantwoordelijkheden verdeeld.

Cleton zal belast worden met de verantwoordelijkheid voor de algemene gang van zaken in het paviljoen, waaronder toezicht op het personeel en handhaven van een zekere discipline in de verpleging vooral met oog op de steriliteit.

(Werkgroep Beenmergtransplantatie, 25 juni, 1964)

Het Isolatiepaviljoen wordt medio 1964 echter niet opgeleverd. Toch komt de oplevering nog onverwacht. Na herhaaldelijk uitstel (Bestuur Isolatiepaviljoen, I3 oktober, 1964; Bestuur Isolatiepaviljoen, 3 december, 1964) en met de voorbereidingen nog in volle gang, aangezien ook de werving van verplegend personeel en een bacterioloog niet vlot verloopt, schrijft men eind maart 1965:

Het paviljoen is eerder in gebruik genomen dan was voorzien, door een

aanvraag tot opname van een patiënt uit de kinderkliniek van het AZL. Op 16 maart werd een 6 maanden oud jongetje, lijdende aan agamma globulinaemie opgenomen. (Bestuur Isolatiepaviljoen, 23 maart, 1965)

Dit, terwijl een maand eerder nog het 'Concept-plan voor het bacteriologisch onder-

I2 Patiënten die qua 'ziektebeeld' gelijken op stralingsslachtoffers. Zie hiervoor de paragraaf 'Modellen voor Stralingsslachtoffers', later in dit hoofdstuk.

13 De zogenaamde Balansbarak.

14 Eventueel kan naar de Balansbarak worden uitgeweken.

Indien dit voor het klaarkomen van de transplantatiebarak nodig mocht zijn, kunnen eventuele candidaten voor een transplantatie toch in de balansbarak worden verpleegd, daar deze voorlopig zeker minder geinfecteerd zal zijn dan andere afdelingen van het A.Z.L. (Werkgroep Niertransplantatie, 3 februari, 1964) De werkgroep denkt primair aan de benodigdheden voor het uitvoeren van niertransplantaties - ook blijkens de gebruikte naam: transplantatiebarak - wat goed te verenigen is met de behoefte van het IRS aan modellen, zodat de niertransplantatie patiënten in het Isolatiepaviljoen kunnen worden verpleegd.

15 In de werkgroep Beenmergtransplantatie wordt al zeer vroeg aandacht besteed aan de personele invulling van het Isolatiepaviljoen, aangezien de leden dan al verwachten dat dit problemen op zal leveren. Ook dan is er namelijk al een tekort aan verpleegkundigen. En men vindt dat, als structurele maatregel, het salaris van Academisch Ziekenhuis verpleegkundigen hoger zou moeten zijn, dan dat van verpleegkundigen in perifere ziekenhuizen. Dat zou het werken in academische ziekenhuizen aantrekkelijker maken. Ook vindt men dat het ministerie ten aanzien van de financiering en werving van verpleegkundigen, in dit geval, een grotere rol zou moeten spelen, mede omdat Nederland, international gezien, niet veel geld voor grote, met atoomenergie verband houdende projecten krijgt en dit project daar direct verband mee houdt.

Prof. Querido is voorts van mening, dat de noodzaak van het beschikbaar zijn van verpleegsters aan de ministeriele instanties scherp moet worden gesteld, aangezien het voor Nederland blamerend zou zijn, als de ontwikkeling van het beenmergproject op gebrek aan verplegend personeel zou moeten stranden.

(Steenbergen, 5 augustus, 1960 ) 
zoek in het "Isolatie-Paviljoen", IRS' gepresenteerd werd, waarin 'de meest belangrijke richtlijnen voor het routine bacteriologisch onderzoek van patiënten, staf en paviljoen gegeven' werden (Cleton, ir Februari, 1965) ${ }^{16}$.

Er lijkt dus sprake te zijn van een plotselinge, en enigszins overhaaste ingebruikneming van het paviljoen. Het bacteriologisch onderzoek is nog niet volledig georganiseerd, noch is de personeelsvoorziening compleet, wanneer de eerste patiënt verpleegd wordt.

Door het gebrek aan huishoudelijk personeel zijn de eerste weken de artsen en

analisten ingeschakeld bij het schoonhouden van een gedeelte van het paviljoen

en de sterilisatie. (Bestuur Isolatiepaviljoen, 23 maart, 1965)

Naast deze organisatorische onvolkomenheden, wordt gedurende deze eerste opname duidelijk dat deze verpleegvorm niet alleen een zeer specifieke doelgroep kent, maar ook arbeidsintensiever is dan de verpleging op een normale ziekenhuisafdeling. De specifieke eisen die aan het personeel worden gesteld, maken dat de omvang van het personeelsbestand opnieuw wordt bekeken.

De eerste ervaring heeft geleerd dat de verpleging in omgekeerde isolatie meer arbeidsintensief is dan was verwacht. Het grootste probleem vormt het aantal verpleegsters dat noodzakelijk is. Dit bedraagt ten minste zes. Bij ziekte of besmetting met staphylococcen van een der verpleegsters is het niet mogelijk normale werktijden te handhaven. (Bestuur Isolatiepaviljoen, 23 maart, 1965) Het personeelstekort blijkt niet direct op te lossen, simpelweg omdat er geen extra verpleegkundigen solliciteren. Hierdoor moet het 'hoofd' alle diensten meedraaien 17 en moeten ook andere personeelsonvriendelijke maatregelen worden genomen ${ }^{18}$ (Bestuur Isolatiepaviljoen, 27 oktober, 1965).

Naast de personele, zijn er verschillende andere problemen. Zo wordt van een 'monster' afkomstig uit het paviljoen, een 'banale schimmel' gekweekt, waaruit geconcludeerd wordt dat 'de ventilatie met steriele lucht niet voldoende was'19; kan, om verschillende redenen, aan de grote behoefte aan voedingsbodems voor bacte-

16 In dit plan wordt geschetst hoe men een bacteriologische besmetting vroegtijdig wil trachten te herkennen en te voorkomen. De volgende punten worden in dit plan besproken:

I bacteriën waarnaar gericht gezocht zal worden

II objecten die in aanmerking komen voor bacteriologisch onderzoek.

a. patiënten

b. staf inclusief de artsen consulenten.

c. de omgeving en de objecten die behoren tot de inrichting. alsmede verplegingsartikelen

III Diversen. voorzieningen in verband met de sterilisatie

IV Bacteriologisch Laboratorium. (Cleton, II Februari, 1965)

Een bacteriologisch lab was niet gepland, men had gedacht dat al dit onderzoek op de afdeling

infectieziekten zou plaats vinden. Nu moet er een ruimte worden ingericht als lab en daar mensen en materialen voor beschikbaar worden gemaakt.

17 Dit zal uiteindelijk leiden tot een ontslagaanvrage van de hoofdverpleegkundige (Bestuur Isolatiepaviljoen, 20 juni, 1965), waardoor het personeelsprobleem nog nijpender wordt.

18 Wanneer het Paviljoen een week zonder patiënten is, vanwege het verhelpen van technische problemen. worden de verpleegkundigen verplicht vrije dagen op te nemen, zodat hun beschikbaarheid, wanneer het Paviljoen wel open is, vergroot wordt.

Het paviljoen is een week zonder patiënten geweest, omdat er nog enkele reparaties noodzakelijk waren. Tegelijkertijd is ervoor gezorgd dat de verpleegsters opgespaarde vijie dagen hebben opgenomen. (Bestuur Isolatiepaviljoen, 28 april, 1965)

19 Niet zozeer de doorstroming, maar de 'steriele lucht' zelf vormt het probleem.

Inderdaad bleek bij een meer uitgebreid onderzoek dat de bacteriefilters door onbevoegden waren verwijderd. Met behulp van de technische dienst van het A.Z.L. werd dit verholpen. (Bestuur Isolatiepaviljoen, 28 april, 1965) 
riologisch onderzoek niet worden voldaan 20 ; moeten er klimatologische verbeteringen worden aangebracht in het Isolatiepaviljoen ${ }^{21}$; en tot slot, moet de voedselvoorziening voor patiënten gewijzigd worden om hen pathogeenvrij voedsel te kunnen geven 22 (Bestuur Isolatiepaviljoen, 28 april, 1965). Deze problemen laten zien dat nog geen garantie kan worden gegeven dat het Paviljoen pathogeenvrij is. De te nemen maatregelen zijn vooral gericht op verbetering van de verpleging in het Isolatiepaviljoen zelf.

Naast problemen in het Isolatiepaviljoen, lopen patiënten ook grote risico's op besmetting, wanneer zij voor behandelingen naar een andere lokatie moeten. Dr. van Bekkun, van TNO, signaleert dit probleem en suggereert een oplossing.

Uit het verslag blijkt dat patiënten regelmatig uit de isolatie moeten gaan voor

bestraling, operatie etc. Zou het niet beter zijn deze patiënten in plastic

isolatoren te vervoeren? (Bestuur Isolatiepaviljoen, 27 oktober, 1965)

Dit transportprobleem is slechts een voorbeeld van zich steeds opnieuw aandienende problemen, waarop moet worden gereageerd.

Het aanbod aan patiënten blijkt groter dan wat de capaciteit, en het verplegendpersoneel, van het Isolatiepaviljoen, aan kan. Daarom wordt "in overleg met de afdelingen Interne Geneeskunde, Kinderkliniek en Heelkunde (tumoren)' een 'wachtlijst' ingesteld" (Bestuur Isolatiepaviljoen, 28 april, 1965) De eerste acht maanden waarin het Isolatiepaviljoen geopend is, worden een elftal patiënten, afkomstig van andere afdelingen, verpleegd ${ }^{23}$. Gedurende deze periode wordt ervaring opgedaan en verricht men aanpassingen aan het Isolatiepaviljoen. Aanpassingen blijven echter noodzakelijk en het Isolatiepaviljoen wordt zelfs de hele maand januari van ${ }_{9} 66$ gesloten, vanwege wisseling van het verpleegkundig-team (Bestuur Isolatiepaviljoen, 30 maart, I966). Plannen voor een grootscheepse verbouwing zijn dan overigens al in de maak ${ }^{24}$.

20 Maar ook voor dit probleem vindt men een oplossing

Het maken van de voedingsbodems vormde een probleem omdat hiervoor in het eigen laboratorium niet voldoende faciliteiten waren. Uitbesteding van dit werk leek op het terrein van het AZL niet mogelijk, deels door personeelsgebrek, deels door de hoge kosten die hieraan verbonden waren. (Begroot op ongeveer $f_{30.000}$ per jaar) Hiervoor is tijdelijk een oplossing gevonden, door het genereuse aanbod van Dr. Wolf van het instituut voor tropische geneeskunde, deze voedingsbodems zonder kostenvergoeding op zijn afdeling te laten maken. (Bestuur Isolatiepaviljoen, 28 april, 1965)

2r De meeste problemen in het Isolatiepaviljoen hebben betrekking op de specifieke functie van dit paviljoen, maar zijn soms van onverwachte oorsprong.

... het onderzoek van de ventilatie van de ziekenkamer. De zonnewarmte doet de temperatuur in de bezoekersgang aanzienlijk stijgen, waardoor luchtstromingen vanuit deze gang naar de kamers ontstaat. De beste oplossing hiervoor lijkt het aanbrengen van markiezen. (Bestuur Isolatiepaviljoen, 28 april, 1965)

22 Ook het voedsel dat de patiënten geserveerd krijgen moet pathogeenvrij zijn. Verschillende mogelijkheden worden geopperd: oppervlakkige sterilisatie met UV-licht, doorstraling met cobalt bron, steriel koken door middel van 'pressurecookers' (Bestuur Isolatiepaviljoen, 20 juni, 1965). Het blijkt geen overbodige luxe hier aandacht aan te besteden. Veel voedsel, vooral vers bereid, blijkt vaak pathogenen te bevatten.

Voedselvoorziening van ziekenhuis vaak besmet met pathogenen, de diepvries maaltijden (Iglo) zijn bacteriologisch bijzonder schoon en voldoen aan de gestelde eisen. (Bestuur Isolatiepaviljoen, 27 oktober. 1965)

23 De elf patiënten die worden opgenomen in het Isolatiepavilioen hebben, of een primair probleem in de haemostase, of een secundair probleem in de haemostase tengevolge van de behandeling van een vorm van kanker (Bestuur Isolatiepaviljoen, 27 oktober, 1965).

24 De verbouwing is gewenst vanwege praktische 'problemen'.

De reden voor deze verbouwing is gelegen in de practische moeilijkheden die zich in het eerste jaar na het in gebruik nemen van het Paviljoen hebben voorgedaan. Alle materiaal dat afkomstig is van de patiënten moet steeds buitenom naar de spoelruimte en de laboratoria worden gebracht, hetgeen vooral in de winter en bij slecht weer onaangenaam is voor het personeel. (Bestuur Isolatiepaviljoen, 6 mei, 1966). 
Begin 1966 start met de praktische voorbereiding van de eigenlijke doelstelling van het Isolatiepaviljoen: de verpleging en behandeling van slachtoffers van een stralingsongeval25. Wanneer het concept-plan voor de behandeling van stralingsongevallen er ligt, bestaat nog onzekerheid over de stralingsdosis waarbij directe opname in het Isolatiepaviljoen aangewezen is. Maar ongeacht deze definitieproblemen wordt in dit concept-plan gesteld dat alles in het Isolatiepaviljoen in gereedheid is en wordt gehouden middels andere patiënten - om stralingsslachtoffers te ontvangen. Hiermee voldoet het IRS aan haar doelstelling.

De bedden in het Isolatie Paviljoen worden gebruikt voor patiënten van het Academisch Ziekenhuis, zodat de installatie ten alle tijde functioneert. Een eerste maatregel die na het bericht van een stralingsongeval moet worden genomen is het evacueren van deze patiënten naar andere afdelingen van het ziekenhuis. Hiertoe is sinds geruime tijd een afspraak gemaakt met de leiding van de afdelingen voor interne geneeskunde. (Bestuur Isolatiepavilioen, 1966) Het IRS kan stralingsslachtoffers verplegen, en tot zich een stralingsongeval voordoet, kunnen andere afdelingen van het AZL gebruik maken van de door het IRS gecreëerde faciliteiten. Zowel voor verpleging van immunodeficiënte patiënten, als voor het doen van verschillende onderzoeken bij die patiënten, waarmee weer wordt beantwoord aan de doelstelling van het IRS.

\subsection{BeEn MERGTRANSPLANTATIES}

Begin jaren " 60 valt, naast de werkgroep "Isolatie-Paviljoen", ook de werkgroep "Beenmergtransplantatie" onder het project "Behandeling van stralingsongevallen". Het IRS stelt deze werkgroep in, voor verder onderzoek naar de immunologische gevolgen van een stralingsbesmetting 26 . In de praktijk wordt de verzamelnaam echter snel de "werkgroep Beenmergtransplantatie", waar de werkgroep IsolatiePaviljoen dan onder gaat vallen ${ }^{27}$. De Bloedbank, c.q. de afdeling Haematologie van het AZL, verricht een aanzienlijk deel van het onderzoekswerk voor de werkgroep van het IRS 28 . Het IRS brengt vooral groepen bij elkaar. Naast verscheidene klinische groepen van het AZL en het Radiobiologisch Instituut van TNO, is ook het CLB in het IRS-project vertegenwoordigd.

Het vanuit het IRS verrichtte werk beperkt zich niet tot zuiver wetenschappelijk onderzoek, maar omvat ook toegepast klinisch onderzoek. Hieronder valt ook het in bedrijf nemen van het Isolatiepaviljoen, "voor behandeling van patiënten die een verminderde weerstand tegen infectie hebben, zoals bijvoorbeeld patiënten met

25 Onverwacht laat, onderneemt men de voorbereidende stappen.

Er wordt gewerkt aan een 'Plan stralingsongevallen'. Hiervoor is het nodig dat die plaatsen waar stralingsongevallen kunnen voorkomen, geinventariseerd worden. (Bestuur Isolatiepaviljoen, 30 maart. r966).

26 Het IRS heeft naast dit project ook de projecten "Invloed van straling op het genetisch materiaal van microorganismer" en "Onderzoek naar de mutatie-inductie door straling en naar het gedeeltelijk herstel van de primaire stralenbeschadiging" opgezet.

27 Dit blijkt onder andere uit de verslaglegging van de werkgroep Beenmergtransplantatie, want Van Rood meldt als eerste punt in zijn verslag van de voor de werkgroep Beenmergtransplantatie verrichtte werkzaamheden, dat "de bouwtekening van 'de verpleegeenheid' (het Isolatie-Paviljoen) door de Haematologische werkgroep uitvoerig werd bestudeerd" (van Rood, 1960)..

28 De titel van het verslag: "Verslag van de werkzaamheden voor het beenmergtransplantatieproject voor Radiopathologie en Stralenbescherming verricht in 1960 op de afdeling Haematologie van de afdeling Interne Geneeskunde Academisch ziekenhuis te Leiden" (van Rood, 1960) 
aplastische anaemie of patiënten met grote brandwonden" (Steenbergen, 20 december, 1963). Dit past binnen de doelstelling van het instituut, omdat stralingsslachtoffers een subcategorie van de patiënten met aplastische anaemie vormen en ook zij een verminderde weerstand tegen infecties zullen hebben. In het Isolatiepaviljoen zullen alleen de ernstig bestraalde patiënten geobserveerd, verpleegd en behandeld kunnen worden. Sterk bestraalde patiënten moeten direct naar Leiden worden vervoerd, omdat de kans op besmetting in het Isolatiepaviljoen kleiner is, dan mogelijk in een gewoon ziekenhuis. Alleen in het Isolatiepaviljoen kan de speciale medische hulp geboden worden onder omgekeerde isolatie omstandigheden. Wanneer een patiënt eerst in een ander ziekenhuis is geweest, zal het weinig zin meer hebben om nog naar Leiden te komen.

Kort verblijf in een ander ziekenhuis zal veelal reeds een zodanige besmetting van neus en keel met resistente bacteriën veroorzaken, dat de gehele opzet van de

profylaxe zinloos wordt. (Werkgroep Beenmergtransplantatie, december 8,1960 ) Een tweede argument voor het direct naar Leiden overbrengen van stralingsslachtoffers, is dat patiënten, als meer structurele behandeling van de opgelopen beenmergschade, bij het IRS ook in aanmerking kunnen komen voor beenmergtransplantatie. Wanneer patiënten direct naar Leiden zijn vervoerd, kan zo kort mogelijk na de bestraling bloed worden afgenomen voor typering en kruisproeven - tests die een eventuele beenmergtransplantatie mogelijk moeten maken. Snelheid is daarbij geboden, aangezien al enige uren na een hoge stralingsdosis het aantal leukocyten in het bloed af begint te nemen.

Het is daarom van het grootste belang dat reeds vanaf het begin alle

behandelingen en observaties gedaan kunnen worden door een team dat de mogelijke consequenties van het ongeval zo goed mogelijk kan overzien.

(Werkgroep Beenmergtransplantatie, december 8, 1960)

Het speciale type patiënten, de mogelijke behandeling, de beschikbare faciliteiten en de aanwezige kennis, maken dat het IRS de plaats bij uitstek moet worden voor de opvang van deze patiënten.

Het aanbieden van een beenmergtransplantatie aan stralingsslachtoffers, is echter een voorschot nemen op de toekomst. De ervaring met beenmergtransplantatie is namelijk zo minimaal, dat het niet als therapeutische behandeling kan worden aangeboden, maar slechts als experimentele en eigenlijk zelfs nog slechts als theoretische mogelijkheid. Verslagen van elders verrichtte beenmergtransplantaties zijn in dit verband weinig bemoedigend. Zo bespreekt de Werkgroep Beenmergtransplantatie een onderzoek bij vier patiëntjes die door Mathé, in Parijs, zijn behandeld met beenmergtransfusie. Bij twee van hen is het beenmerg weliswaar aangeslagen, maar zijn veel secundaire klachten ontstaan en zijn ook zij overleden. De doodsoorzaak van die patiënten is nog niet bekend (Werkgroep Beenmergtransplantatie, 16 juni, 1960). In Leiden is men daarom terughoudend.

Van Putten wijst er in dit verband nog eens op dat de beenmergtransfusie in

Leiden voorlopig dan ook alleen in incidentele gevallen (ongelukken, overdose-

ring) zal worden toegepast. (Werkgroep Beenmergtransplantatie, 16 juni, 1960) De behandeling is nog zo prematuur, dat ze niet als reguliere behandeling kan worden aangeboden en alleen in uiterste nood naar dit middel gegrepen zal worden.

Een van de voorbereidende activiteiten die in het kader van het beenmergtransplantatieproject plaatsvinden, is het werven van beenmergdonoren. Hiervoor wordt een specifieke, besloten groep benaderd. Bij de keuze van deze groep worden speci- 
fieke eisen gesteld, zodat er "enigermate op discretie kon worden gerekend" (van Rood, 1960). Deze groep wordt uiteindelijk gevonden in het Seminarie te Warmond ${ }^{29}$. Na een (noodzakelijk) persoonlijk gesprek, melden ruim 60 'Seminarister' zich aan als adspirant beenmergdonores (van Rood, 1960$)^{30}$. Enkele van hen zullen ook worden gebruikt als donor voor huidtransplantatie-experimenten ${ }^{31}$.

Naast het werven van donoren wordt in het kader van het IRS-onderzoek ook gewerkt aan de technieken om het beenmerg af te nemen. Ook daarover is weinig bekend, noch is er geschikt instrumentarium. Verschillende typen spuiten en naalden worden onderzocht en getest op hun bruikbaarheid, waarna wordt besloten om voor dit doel voorlopig het "zogenaamde lymphklierspuit type" te gebruiken, ofschoon ook deze spuit nog voor verbetering vatbaar is.

Verschillende modellen werden bestudeerd en ook in de praktijk beproefd.

Inmiddels zijn er dertig spuiten besteld van het zogenaamde lymphklierspuit

type. Aan deze spuiten kleeft nog steeds het euvel dat luchtlekken met daardoor

optredende schuimvorming van het opgezogen beenmerg niet geheel te

vermijden zijn. (van Rood, 1960)

Zo treft de werkgroep op verschillende gebieden voorbereidingen, zodat het IRS bij een eventueel nucleair ongeval zo goed mogelijk hulp kan bieden.

Binnen een half jaar na Van Puttens voorzichtige woorden op 16 juni, wordt in Leiden (en in Nederland) de eerste beenmergtransfusie verricht. Het betreft inderdaad een incidenteel geval: een vrouw met 'beenmerg aplasie na goudmedicatie'. Voor deze patiënte mag de behandeling niet baten, hetgeen op voorhand ook niet verwacht kon worden (Werkgroep Beenmergtransplantatie, 6 april, 1961). Als experimentele klinische toepassing levert het echter wel veel gegevens op.

Het lijkt gerechtvaardigd om in dit verband de spreken van een 'desperate remedy'32, aangezien de verwachtingen over de uitkomst van de behandeling weliswaar mogelijk hoopvol, maar toch niet hoog zijn. Zonder verdere behandeling zal de patiënte zeker sterven, met behandeling heeft ze een kans. De behandeling van deze patiënte biedt echter wel de mogelijkheid om met de toepassing van beenmergtransplantatie te experimenteren. Vandaar dat er 'autopsie en post mortem bloed- en pericardkweken' worden verricht. Hier wordt aan toegevoegd dat de doodsoorzaak niet duidelijk is wanneer de kweken negatief blijken te zijn (Werkgroep Beenmergtransplantatie, Io januari, 1961), hetgeen zou betekenen dat er iets over het hoofd wordt gezien. Deze beenmergtransplantatie maakt duidelijk dat aan het toepassen van deze behandelingswijze nog erg veel te verbeteren valt. De slechte afloop stimuleert tot verder onderzoek. Later wordt bij deze eerste beenmergtransplantatie - tot opluchting van de Leidse artsen - een 'doodsoorzaak' gevonden.

Obductiegegevens van de met beenmerg behandelde patiënt zijn thans volledig.

Uit het pericardvocht is E.coli gekweekt. (Werkgroep Beenmergtransplantatie, 14 maart, 196r)

Met deze doodsoorzaak hoeft het overlijden van de patiënt niet aan de behandeling

29 Een dorpje op slechts enkele kilometers van Leiden en het AZL

30 Er moeten ook vrouwelijke donoren komen. Querido stelt de Marva voor als instituut waar mogelijk een stabiele populatie is te verwerven. (Werkgroep Beenmergtransplantatie, 16 juni, 1960)

31 Januari 1966 (Immunohaematologie \& Bloedbank. 17 januari \& 21 januari, 1966)

32 Desperate remedies phenomenon: "...There must be some likelihood of success before the desperate remedy becomes more than a desperate search for an opportunity to try a new procedure awaiting trial..."(Moore, 1989, p.r.484. geciteerd in (Fox, et al., r992), p.r8) 
zelf te worden toegeschreven, dus kan deze lijn van onderzoek verder gaan. ... programma toekomstig onderzoekingen ... Het doel van dit onderzoek is inlichtingen te verkrijgen over twee punten die voor de behandeling van stralingsongevallen van belang zijn.

a. De mogelijkheid effectieve thrombocytentransfusies toe te passen (en de compatibiliteit van deze transfusies te voren te kunnen voorspellen).

b. Gegevens te verkrijgen over transplantatie-antigenen bij de mens en over de herkenning van deze antigenen zonder een sensibiliserende transplantatie toe te passen.

(Werkgroep Beenmergtransplantatie, 14 maart, 196r)

Het mag dan zo zijn dat de eerste beenmergtransplantatie voor de betreffende patiënt geen gunstig resultaat heeft gehad, voor het IRS is het een eerste stap richting 'effectieve' klinische behandeling van stralingsslachtoffers.

\subsection{Modellen voor Stralingsslachtoffers}

Stralingsongevallen blijven uit. Er zijn dus geen stralingsslachtoffers die verpleegd moeten worden. Maar er zijn dus ook geen stralingsslachtoffers waarbij onderzoek kan worden gedaan. Er zijn echter wel patiënten die voor verpleging in het Isolatiepaviljoen in aanmerking komen, namelijk patiënten met een ernstig verminderde weerstand. Voor het IRS is het aanbieden van hun faciliteiten een mogelijkheid om bepaalde categorieën patiënten, die model kunnen staan voor stralingsslachtoffers, aan zich te binden en te gebruiken. De patiënten hebben profijt van de voorzieningen en het IRS krijgt de gelegenheid hen een rol te laten spelen in hun onderzoek. Hierbij gaat het vooral om 'patiënten met een onvoldoende werking van het beenmerg ${ }^{33}$. De oorzaak van de onvoldoende werking van het beenmerg doet daarbij niet ter zake, aangezien - zoals ook bij stralingsslachtoffers het geval zou zijn - alleen aan de gevolgen iets gedaan wordt. De behandeling van leukaemie bijvoorbeeld zorgt voor een toestand van verminderde weerstand. Daardoor is de kans op opportunistische infecties groot. De door bestraling, kunstmatig opgewekte beenmergonderdrukking, die een beenmergtransplantatie mogelijk moet maken, is in grote mate te vergelijken met de te verwachten toestand van een stralingsongevalpatiënt.

33 In de jaarverslagen en begrotingen van het IRS, wordt steeds opnieuw de uitbreiding van de indicatiestelling voor gebruik van de IRS-faciliteiten verantwoord.

Het ligt in de verwachting dat de frekwentie van stralingsongevallen gering zal zijn. Ten einde voldoende ervaring in de behandeling te verkriigen zal de doelstelling verruimd worden tot de behandeling van patiènten met ziekten welke soortgeliike afwijkingen tonen als gezien worden na stralingsongevallen. Het betreft hier patiënten met een onvoldoende werking van het beenmerg veroorzaakt door beenmergziekten (aplastische anaemie) of geinduceerd door therapeutische handelingen zoals rôntgenbestraling of toedienen van celdeling-remmende geneesmiddelen. Deze twee laatste vormen van therapie worden in de latste jaren steeds meer toegepast, zowel voor de behandeling van maligne tumoren als voor het onderdrukken van het immunologische afweermechanisme bij de orgaantransplantatie. (Steenbergen, r964)

In de begroting voor 1965 worden de parallellen tussen stralingsslachtoffers en orgaantransplantatie expliciet behandeld.

De problemen welke zich voordoen bij de behandeling van stralingsongevallen en bij de behandeling van patiënten na orgaantransplantatie vertonen op vele punten een analogie. Bij transplantatie wordt tolerantie voor homoloog weefsel geinduceerd door middel van het onderdrukken van de immunologische afweerreacties van het lichaam met behulp van bestraling of het toedienen van cytostatische stoffen. Beide vormen van therapie geven complicaties als vergrote kans op infectie en stoornissen in de haemostase.

(Steenbergen, 20 december, 1963) 
Omdat patiënten uit de primaire doelgroep van het IRS uitblijven, breidt het IRS de doelstelling uit, met onderzoek naar transplantatie-immunologie en in het bijzonder de orgaantransplantatie.

... Als eerste toepassing van orgaantransplantatie wordt gedacht aan

niertransplantatie, aangezien hiermede elders reeds gunstige ervaring is

verkregen. (Steenbergen, 20 december, 1963)

Zo wordt aan de categorieën patiënten die in aanmerking komen om als model te dienen, een nieuwe categorie toegevoegd: patiënten die in verband met een orgaantransplantatie een verminderde weerstand hebben. Enige tijd daarvoor onderzoeken de professoren Vink en Zwaveling vanuit de afdeling Chirurgie, de mogelijkheden om te komen tot een "werkgroep Orgaantransplantaties".

In eerste instantie gingen onze gedachten uit naar een onderzoek betreffende de mogelijkheden van niertransplantaties in het dierexperiment.

Gezien de talloze problemen - bekend en onbekend - die hiermede samen hangen, moge ik $U$ uitnodigen tot een oriënterende bespreking over deze kwestie op woensdag 6 december a.s. te 77.00 uur op mijn kamer in de heelkundige kliniek. (Vink, 23 november, 196r)

Dit initiatief, onderzoek naar niertransplantatie, komt van de grond en wordt geincorporeerd in de doelstelling van het IRS. De tweedeling tussen primair: behandeling van stralingsslachtoffers en secundair: onderzoek en behandeling van op stralingsslachtoffers gelijkende patiënten, blijkt voor de continuiteit van het IRS een goede formule. De functie van deze 'model-patiënten' geldt zowel het dienen als onderzoekssubject, als het handhaven van de paraatheid van het Isolatiepaviljoen ${ }^{34}$.

Voor het onderzoek naar de gevolgen en behandeling van slachtoffers van een stralingsongeval vormen mensen met schade aan hun beenmerg het meest geschikte model. Maar het gebruik van mensen als modellen van stralingsslachtoffers heeft ook nadelen. De onderzoeker is afhankelijk van welke patiënten zich aandienen en welke behandeling voor hun aandoening het meest geindiceerd is. Dit beperkt het soort onderzoekingen en experimenten dat gedaan kan worden. Ook al is er sprake van 'desperate remedy', er moet voor de patiënt wel enig perspectief op 'verbetering' zijn, om het experiment uit te mogen voeren.

Naast onderzoek met patiënten wordt ook onderzoek met dieren uitgevoerd. Aanvankelijk worden vooral apen gebruikt voor onderzoek naar de immunologie

34 Veel later (1977), in een nota over de organisatiestructuur van het Isolatiepaviljoen I.R.S., blijkt de behandeling van op stralingsslachtoffers gelijkende patienten, geheel ten dienste van het opvangen en behandelen van echte stralingsslachtoffers is komen te staan. In een nota, bestemd voor het Bestuur I.R.S., afkomstig van de Commissie van Advies I.R.S. wordt het als volgt omschreven.

I. Het Interuniversitair Instituut L.R.S. heeft ... tot taak wetenschappelijk en experimenteel onderzoek m.b.t. de behandeling van stralingsongevallen en de instandhouding van een Isolatiepaviljoen voot de behandeling van stralingsongevallen in samenwerking met het Academisch Ziekenhuis Leiden. 2. Het Isolatiepaviljoen dient in staat te zijn om op elk ogenblik waarop het noodzakelijk is slachtoffers van stralingsongevallen op te nemen en te behandelen. De technische uitrusting en de personele voorzieningen moeten daarop zijn afgestemd. Onder voorwarde dat aan deze voortdurende beschikbaarheid geen afbreuk wordt gedaan, staan de voorzieningen van het I.P. ter beschikking voor experimenteel en klinisch onderzoek m.b.t. de behandeling van stralingsongevallen. Met het oog hierop komen voor opname in het I.P. in aanmerking patiënten wier ziektebeeld belangrijke aspecten gemeen heeft met die welke na stralingsongevallen kumen optreden.

De behandeling van zulke patiênten stelt de medische staf in staat kennis en ervaring op te doen en aldus de paraatheid van het I.P. in geval van calamiteiten die stralingsongevallen veroorzaken te waarborgen.

(Commissie van Advies IRS, 9 angustus, 1977) 
van transplantatie. Onder andere omdat de leukocytenantigenen van chimpansees een grote mate van overeenstemming blijken te vertonen met de leukocytenantigenen van mensen. Van Bekkum schrijft Van Rood dat de apen in Rijswijk bij het Radiobiologisch instituut GO-TNO ${ }^{35}$ kunnen worden gehuisvest, waar de apen ook zullen worden getraind om ermee te kunnen werken ${ }^{36}$, $\mathrm{Na}$ ontvangst van deze uitnodiging doet Van Rood een verzoek aan het IRS.

Naar aanleiding van ons gesprek d.d. 1o december 1964 , verzoek ik U langs deze weg te willen nagaan in hoeverre het mogelijk is voor het beenmergproject van het 1.R.S. een bedrag van $f 58.000$ uit het budget van I $_{9} 64$ vrij te maken ten behoeve van de aankoop en huisvesting van tien chimpansees. Deze chimpansees zijn essentieel voor het transplantatieantigenenonderzoek van het beenmergproject... (van Rood, 14 december, 1964)

Hier voegt Van Rood aan toe dat het helaas niet mogelijk is de chimpansees in Leiden te huisvesten, maar dat collega van Bekkum bereid is gevonden, de voor het IRS-Project noodzakelijke chimpansees onderdak te verlenen (van Rood, I4 december, 1964). Enkele dagen later kan Van Rood al aan Van Bekkum schrijven:

Zojuist ontving ik bericht van Prof. Sobels dat onze aanvraag voor aanschaf van Io chimpansees door het I.R.S. geaccepteerd is en gefinancierd kan worden.

Prof. Sobels verbond hieraan echter de uitdrukkelijke voorwaarde dat de chimpansees niet bestraald zouden worden. Mocht dit uiteindelijk toch noodzakelijk zijn, dan wenst hij hier tijdig van op de hoogte gebracht te worden en behoudt zich het recht voor van eventueel verbod. (van Rood, I7 december, I964)

Het IRS voelt er dus niet voor om $f 58.000$, - te besteden aan 'verbruiksartikelen'. De chimpansees moeten voor langere tijd beschikbaar blijven. Experimenten met een - op voorhand duidelijke - dodelijke afloop worden dan ook niet toegestaan.

De aanschaf van chimpansees blijkt meer voeten in aarde te hebben dan verwacht en in plaats van 1o, koopt men in eerste instantie 5 apen. In afwachting van de resterende vijf, verzoekt Van Rood om verdere uitbreiding van de chimpanseekolonie, "gezien de ervaringen met andere soorten apen, tot ten minste $20-25$ " (van Rood, 27 oktober, 1965). Voor de financiering hiervan oppert hij dat dit mogelijk uit de post 'verpleegkosten' van het budget voor het Isolatiepaviljoen I9 $_{95}$ kan komen. Hij meent dat de bestedingen uit dat budget waarschijnlijk lager zijn uitgevallen doordat het Isolatiepaviljoen pas in maart in gebruik is genomen, waar hij aan toevoegt dat het belang van chimpansees als proefdier erg groot blijkt te zijn (van Rood, 27 oktober, 1965). Met een uitgebreide kolonie zullen opnieuw immunisatie- en trans-

35 Gezondheidsorganisatie TNO; Organisatie voor Toegepast Natuurwetenschappelijk Onderzoek ten behoeve van de Volksgezondheid.

36 De experimenten met gebruik van chimpansees kunnen voor meerdere projecten gebruikt worden, maar het vergt veel (voorbereidend) werk.

Het lijkt mij wel mogelijk om op korte termijn een tiental chimps aan te schaffen en te huisvesten ten behoeve van het onderzoek betreffende transplantatie-antigenen en leucocytengroepen. ... Ik neem aan dat je er mee accoord gaat, dat de resultaten indien mogelijk eveneens ten behoeve van ons onderzoek over beenmergtransplantatie kunnen worden toegepast.

Als een en ander doorgaat wil dat niet zeggen, dat direct na aankomst met de proeven kan worden begonnen. Hoewel we tot dusverre met de eerste groep chimps geen moeilijkheden ondervonden is onze ervaring nog niet groot. Wel weten we dat de dieren enige maanden nodig hebben om te wennen en om voldoende getraind te worden. Zonder deze training is het heel moeilijk er mee te werken. (van Bekkum, ro december, 1964) 
plantatieprogramma's gestart kunnen worden. Ook hierbij wordt weer gewezen op het verwachte nut voor potentiële stralingsslachtoffers en met hen voor alle patiënten met immunologische problemen van welke aard of oorsprong dan ook (van Rood, 27 oktober, 1965).

Patiënten met andere ziektebeelden staan model voor stralingsslachtoffers en apen staan model voor alle patiënten met immunologische problemen. Vooralsnog worden de chimpansees echter te duur gevonden om hen tot echte stralingsslachtoffers te maken en bestraalde patiënten blijven uit. Maar met deze categorieën modellen, kan aan de (verruimde) doelstelling van het IRS worden voldaan. De samenwerking tussen het IRS en de vakgroep Immunohaematologie en Bloedbank (IHB) kan dan ook worden voortgezet en uitgebouwd. Hierbij maken verschillende klinische groepen dankbaar gebruik van de faciliteiten die door het IRS zijn gecreëerd en de financiering die van het Instituut wordt verkregen.

\section{6 'Rolls Royce is tot VolKSWAGen GemaAkT'}

Een succesvolle transplantatie (zonder gebruik te maken van enige beperking van de immunologische activiteit) is mogelijk in het geval van identieke tweelingen, zoals Murray en medewerkers dat in I954 - twee dagen voor Kerstmis - laten zien. In de jaren die volgen blijkt dat in alle andere gevallen gebruik moet worden gemaakt van immunosuppressie (onderdrukking van het immuunsysteem). Uitgaande van het inzicht - sinds Medawar - dat afstoting een immunologisch fenomeen is, wordt in deze jaren op verschillende manieren geprobeerd om het immuunsysteem zo te bewerken dat een transplantaat kan functioneren en (enige tijd) kan blijven zitten in de ontvanger. De gunstige effecten van corticosteroïden op afstoting zijn al langer bekend. Andere methoden en middelen om het immuunsysteem te verzwakken volgen: 'total body irradiation' en ' 6 Mercapto Purine (6MP)'. Daarnaast worden pogingen ondernomen om het immuunsysteem zelf te veranderen en tolerantie te creëren door toepassing van beenmergtransplantaties ${ }^{37}$. Maar dit blijkt onmogelijk door het onveranderlijk optreden van de zogenoemde 'Graft Versus Host Disease'38.

Mede door het ontbreken van een methode om specifieke tolerantie op te wekken, blijven transplantatiechirurgen verschillende manieren van immunosuppressie beproeven. Nieuwe immunosuppressiva worden ook gevonden ${ }^{39}$, waaronder

37 Men probeert donorspecifieke tolerantie te induceren.

The objective of producing specific and stable allogeneic (often called Medawarian) non responsiveness became the holy grail of transplantation when in 1955, Main and Prehn simulated in adult mice an environment that they likened to that in perinatal Billingham-Brent-Medawar animals. The three steps were first, to cripple the immune system with supralethal total body irradiation, next to rescue it with allogeneic bone marrow (creating a chimera), and finally to engraft skin from the bone marrow donor. Their efforts were successful. ... the prototype strategy for induction of tolerance in large animals and in humans seemed at first to be obvious. (Starzl, 1993)

38 Het verschijnsel dat de Immunologisch actieve cellen in het getransplanteerde beenmerg een immuunreactie ontketenen op de (leukocyten)antigenen van de ontvanger. De 'eigen' cellen van de ontvanger worden door zijn 'niet eigen' immuunsysteern als vreemd gezien en dus aangevallen. Bad news was close behind. Within a few months, it became clear that GVHD similar to that in the perinatal mouse model could be expected almost invariably after all bone marrow engraftments that "took" following irradiation, except those from perfectly histocompatible donors. (Starzl, 1993)

Al kan dit laatste toentertijid niet gezegd zijn.

39 De eerste immunosuppressiva zijn onmisbaar voor het overwinnen van het afstotingsprobleem bij transplantaties, anders dan bij eeneiige tweelingen, maar leveren ook veel problemen op. 
azathioprine (Imuran). Ook worden verschillende methoden en middelen in combinatie geprobeerd ${ }^{40}$. Aan bestraling als methode van immunosuppressie blijken echter meer na-, dan voordelen te zitten en niertransplantaties zonder 'gehelelichaams-bestraling' blijken ook succesvol te kunnen zijn ${ }^{41}$.

Rond deze tijd gaat Van Rood met Sabbatical (van Rood, 1993). Een deel van de tijd brengt hij door in Boston bij Murray en Merrill, en in Denver bij Starzl. Tussen deze twee plaatsen bestaat een grote tegenstelling. Waar in Boston zeer veel transplantatiepatiënten overlijden, overleven de meeste patiënten in Denver, mede door het gebruik van meerdere immunosuppressieve middelen tegelijkertijd. De andere aanpak van Starzl, blijkt succesvol en het transplanteren van nieren lijkt in een nieuwe fase te zijn aanbeland.

... toen ik daar was geweest heb ik een telegram gestuurd naar Mulder. Mulder zei altijd: "Als je iets belangrijks hebt moet je een telegram sturen, want brieven lees ik niet." dat was niet helemaal waar, maar wel gedeeltelijk. Dus toen heb ik een telegram gestuurd, dat naar mijn gevoel Starzl van een Rolls Royce-achtige procedure inderdaad een Volkswagen had gemaakt in de transplantatiegeneeskunde, door veranderingen in de immunosuppressie en klinische zorg, en dat ik vond dat we daar ook in Leiden mee aan de gang moesten gaan. (van Rood, 21 december, 1993) ${ }^{42}$

Het feit dat men met het toedienen van het 6-M.P. een staat van 'immuuntolerantie' kon bewerken bij een volwassen proefdier, is van fundamenteel belang geweest voor de verdere ontwikkeling van het transplanteren van organen.

Gezien het aantal ongewenste bijwerkingen van 6-M.P. zoals emstige remmingen van de beenmergfunctie is men naar andere pharmaca gaan zoeken, die minder toxisch zijn. (De Planque, et al., 1970)

40. Zo beschrijtt Starzl hoe hij in voorbereiding op zijn - en de cerste levertransplantatie - cen niertransplantatie uitvoert met gebruikmaking van drie verschillende immunosuppressieve behandelingswijzen tegelijkertijd: bestraling. Imuran en corticosteroiden.

The transplantation with a kidney from his mother went forward on November 24,1962 , with combination treatment by irradiation, Imuran, and prednisone, (Starzl, 1991)

41 Starzl dertig jaar nadien:

Three more kidney transplantations were performed but omitting total body irradiation. Two of these patients who were treated with Imuran and prednisone also are alive, both with their original grafts from a

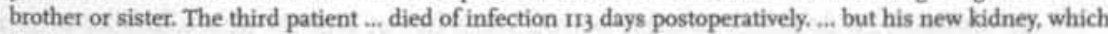
had been donated by his wife, functioned well until the end. It seemed to us that the immune barrier now had been surmounted repeatedly. (Starzl, 1991)

42 Dit door Van Rood genoemde telegram heb ik overigens niet gevonden. Wel het antwoord van Van Rood op de vraag van Nauta of ze moeten starten met het voorbereiden van transplantaties, want dat is "sinds tientallen jaren de droom van elke chirurg" (Nauta, 6 september, 1963). Van Rood antwoordt:

1) ja, ik geloof dat het nu het moment is om ons in te werken in transplantaties.... de rede waarom ik geloof dat we in Leiden actief moeten worden zijn de volgende.:

a) sinds Nov 1962 zijn in het Veteran's hospital te Denver 27 patienten van een nier voorzien, die van een vriend, kennis of bloedverwant, maar niet van een identieke tweeling afkomstig was en 25 van deze patienten hebben de "critieke" eerste drie maanden overieefd, de langste dus nu ro maanden. Clinisch schijnen deze patienten uitstekend te zijn. Het is hun dit gelukt door met antimitotica en prednison het RES ze een oplazer te geven dat geen of niet voldoende antilichamen worden gevormd om het transplantaat af te stoten. Niemand weet hoe deze patienten over twee of tien jaar zullen zijn, maar de gegevens van dierexperimenten rechtvaardigen een grote mate van optimisme.

b) ik ben zelf actief geweest een twee andere approaches die hoewel misschien theoretisch aantrekkelijker nog in het experimentele vlak zitten. Een ervan zijn de jouw wel bekende leucocytengroepen; sommige mensen menen dat ze bewezen hebben dat deze groepen met het wel of niet afstoten van het en nieren. Ik weet dat nog niet zo zeker, maar wel weet ik dat ons inzicht in deze groepen midden volgend jaar zo volledig zal zijn dat een daadwerkelijk onderzoek naar hun eventuele samenhang met de transplantatie antigenen inderdaad zinvol zal zijn. Daarvoor is de actieve samen werking van chirurgen voor nodig. Met de ander mogelijkheid heb ik me dit laatste jaar bezig gehouden; antilichaam vorming in vitro. Wanneer we een beter inzicht hebben in het mechanisme van de antilichaam vorming zal het ook eerder 


\subsection{De Eerste Niertransplantatie in Leiden}

Het bericht uit Denver krijgt gevolgen. Het (dan nog te bouwen) Isolatiepaviljoen kan ook voor nierpatiënten van nut zijn. Mocht het zo zijn dat men in Leiden ook niertransplantaties gaat doen, dan kunnen deze patiënten ook in de pathogeenarme-omgeving van het Isolatiepaviljoen worden verpleegd. De immunosuppressieve behandeling maakt dit noodzakelijk.

Voordat de eerste niertransplantatie daadwerkelijk plaatsvindt, wordt vanuit de verschillende IRS-werkgroepen veel onderzoek geëntameerd, opdat een eerste transplantatie maar zo probleemloos mogelijk zal verlopen. Begin 1964 maakt men in de Werkgroep Niertransplantatie de afweging tussen ofwel snel klinisch toepassen bij mensen, ofwel meer experimenteel onderzoek (bij honden) en de behandeling daarmee eerst technisch (en immunologisch) perfectioneren ${ }^{43}$. In een aantal centra verspreid over de wereld - waaronder Londen en Edinburgh - worden deze operaties al op mensen verricht. De resultaten daarbij zijn echter over het algemeen niet erg hoopgevend, wat de Werkgroep Niertransplantatie doet besluiten "om nog niet binnen afzienbare tijd tot transplantaties bij mensen over te gaan", maar de nadruk te leggen op het experimentele gedeelte (Werkgroep Niertransplantatie, 20 januari, 1964).

Naast het leukocytengroepenonderzoek, wordt ook chirurgisch-technisch onderzoek verricht. Ook voor deze kant van een niertransplantatie wordt naar een 'model' gezocht. Daarvoor worden honden gebruikt en gaat een dierenarts deel uitmaken van de werkgroep. Net als voor de apen, wordt ook voor de honden gebruik gemaakt van de faciliteiten van TNO in Rijswijk. Het oefenen van niertransplantaties op honden wordt voortvarend ter hand genomen. In korte tijd worden drie honden getransplanteerd. Nieren en milt van de ontvanger worden verwijderd en vervolgens wordt de nier van een andere hond getransplanteerd. Het is daarbij de bedoeling dat de ontvangende hond overleeft.

Op het tijdstip van de bespreking was er bij drie honden een transplantatie van een nier na splenectomie en nephrectomie verricht. De eerste twee overleden binnen enkele dagen aan een lekkende ureternaad, resp. een wondinfectie. De derde hond is één week na de transplantatie goed. Voorzover het de immuran, de cortison en de actinomycine betrof, werd het in Denver gebruikelijke schema toegepast.

Dit project zal met een frequentie van één hond per 2 weken worden voortgezet. Ureter-blaas en Ureter-Ureter anastomosen zullen beiden worden beproefd. (Werkgroep Niertransplantatie, 3 februari, 1964)

mogelijk zijn het op een iets subtielere manier in toom te houden dan door het mechanisme zo hard op het hoofd te slaan met antimitotica etc. (zie boven) dat het niets meer doet. Dit lijkt me voorlopig nog zuiver experimenteel.

a) Ik geloof dat je dus naar Denver moet, eventueel na Boston Merrill naar de verhalen te oordelen voornamelijk om te zien hoe je het niet moet doen. Denver lijkt me belangrijk w.b. de zorg prophylaxe voorbereiding etc. van patient; chirurgisch technisch kan ik niet beoordelen. ... (van Rood, I9 september, 1963) (sic)

43 Uit de toekomstbespiegelingen van de Werkgroep:

Uitvoerig wordt de vraag besproken in hoeverre in de naaste toekomst gestreefd moet worden naar een zo spoedig mogelijke toepasbaarheid bij patiënten of dat het accent in deze eerste periode moet liggen op een vervolmaking van de technische en immunologische mogelijkheden. Vanzelfsprekend zal onafhankelijk van de beslissing het ene nooit zonder het andere kunnen. (Werkgroep Niertransplantatie, 20 januari, 1964). 
Dat jaar, 1964 , worden nog tien honden voor allotransplantatie- en twaalf voor autotransplantatie-experimenten op de operatietafel gelegd. Daarbij wordt niet alleen de chirurgische techniek geoefend, maar worden tevens de effecten van immunosuppressieve middelen op gezonde modellen bekeken. De honden overlijden echter snel. Soms zijn chirurgische complicaties daarvan de oorzaak, soms de bijwerkingen van de immunosuppressiva ${ }^{44}$. Na de eerste twee honden wordt de operatietechniek gewijzigd.

De derde hond (Tinus) heeft na de transplantatie 33 dagen geleefd. ... De

Imuran-therapie leidde tot complicaties (leverparenchiembeschadiging en totale beenmergremming).... De anastomosen waren goed. Bij deze hond was de ureter in de blaas gehecht. (Werkgroep Niertransplantatie, II maart, 1964) Door de ervaringen die zo worden opgedaan, verbeteren de chirurgische technieken. Naar de complicaties tengevolge van de immunosuppressiva wordt ook gericht onderzoek verricht. Zo wordt bijvoorbeeld Imuran aan gezonde honden gegeven ter controle van leverbeschadiging, beenmergremming en maagdarmstoornissen (Werkgroep Niertransplantatie, II maart, 1964). Op deze manier wordt een indruk verkregen van de minimale therapeutische dosering, van de bijwerkingen en van de meest succesvolle combinatie van middelen. Wanneer het een autotransplantatie 45 betreft, is er geen sprake van afstoting en is het dus niet nodig om immunosup. pressiva te gebruiken.

Meer dan de helft van de getransplanteerde honden overlijdt binnen twee weken aan verschillende complicaties. Van de allotransplantaties zijn er drie die respectievelijk $14,{ }_{5}$ en 32 dagen overleven. Ondanks de zeer lage overlevingscijfers, blijft men honden gebruiken voor verschillende experimenten, zoals voor het testen van nieuwe vormen van beinvloeding van het immuunsysteem ${ }^{46}$; voorbereidend onderzoek voor levertransplantaties (Werkgroep Orgaantransplantatie TNO, 19 december, I966) en voor huidtransplantatie-experimenten ${ }^{47}$ (Werkgroep Orgaantransplantatie TNO, 8 maart, 1968). Omdat het verbruik van honden groot is, gaat een verzoek uit naar TNO of zij voor nieuwe 'aanvoer' kunnen zorgen. TNO antwoordt dat men gaarne bereid is honden te fokken, mits ze de eerste honden ${ }^{48}$ aangeleverd krijgen.

44 Het verslag:

De eerste 2 honden leefden respectievelijk 5 en 8 dagen en zijn overleden aan chirurgische complicaties.

Hond $\mathrm{r}$ aan een lekkage van urine in de buik door het barsten van de ureter-ureter anastomose. Hond 2 is afgemaakt; er was een groot abces in de rechter nierloge en een wondinfectie. Het microscopisch onderzoek van de nier van de eerste hond gaf een "toxische" beschadiging van de tubuluscellen te zien (Imuran?),... (Werkgroep Niertransplantatie, $n$ maart, 1964)

45 Algemeen: transplantatie van weefsel dat van de ontvanger zelf afkomstig is (bijvoorbeeld huidtransplantatie bij brandwonden). Hier: het uitnemen van een orgaan en het vervolgens weer terugplaatsen ter oefening van de techniek.

46 Anti Lymphocyten Serum (ALS) en extracorporale bestraling (ECR) (Werkgroep Orgaantransplantatie TNO. 19 december, 1966)

47 Niet alleen de honden bij TNO worden gebruikt, ook wordt onderzocht of elders geschikte honden te vinden zijn.

5 closed colony beagles van Organon:

Cleton deelt mede dan hij een onderzoek heeft ingesteld naar de leukocytengroepen van de honden in de fokkolonie van Organon. Daarbij zijn zeer interessante resultaten verkregen. Hij zal trachten om bepaalde compatibele combinaties voor onderzoek van Organon los te krijgen; zonodig zullen huidtransplantaties te Oss kunnen worden verricht ... (Werkgroep Orgaantransplantatie TNO, 8 maart, 1968)

48 Aan deze honden worden bijzondere eisen gesteld. Onder andere om de variabiliteit in het aantal verschillende leukocytenantigenen te beperken moet gewerkt worden met ingeteelde honden. Het verkrijgen van zo'n kolonie is een langdurige en dus kostbare zaak, of om zo aan te schaffen, of om. gedeeltelijk ingeteelde honden zelf verder in te telen. 
Daarnaast mogen de aanwezige kolonies niet in gevaar worden gebracht (Centraal proefdieren bedrijf TNO afd. Vermeerdering, 24 mei, I968) 49 .

Toch blijft de chimpansee de uitgelezen diersoort om proeven mee te doen, omdat zowel de effectiviteit van de immunosuppressieve techniek bestudeerd kan worden, als de waarde van het bij elkaar zoeken van leukocytenantigenen kan worden onderzocht.

Twee redenen om niertransplantatie bij de aap onder ALS "demping" en met op leukocytengroep compatibiliteit geselecteerde donors te gaan doen:

a) aap staat dichtst bij de mens, informatie over ALS effecten bij de aap daarom belangrijk

b) leukocytentypering bij de aap zover gevorderd dat invloed van

"compatibiliteit" op nierhomograft overleving onder ALS getest kan worden.

(Werkgroep Orgaantransplantatie TNO, 19 december, 1966)

De eerste initiatieven in Leiden voor niertransplantaties bij mensen dateren uit het begin van de jaren 60 (Vink, 23 november, 1961). De vroege start van de Werkgroep Orgaantransplantatie krijgt een impuls door de ontwikkelingen elders - onder andere de successen van Starzl - en niertransplantatie wordt als reële behandelingsoptie gezien. Ook in de doelstellingen van het IRS, zoals die in het 'Werkplan voor 1965' worden gegeven, wordt niertransplantatie geïncorporeerd. Voor het immunologisch onderzoek ziet men op twee manieren een rol weggelegd om de resultaten van niertransplantaties gunstig te beïnvloeden.

I. Bij de keuze van de minst met de recipiënt incompatibele donor

II. Bij de beïnvloeding van de afstotingsreactie

a) door het afweermechanisme van de ontvanger te drukken

b) door de hoeveelheid van het antigene materiaal in het transplantaat te verminderen.

(van Rood, et al, 12 januari, 1964)

Enerzijds wordt er dus aan gedacht om de kans op afstoting zo klein mogelijk te maken door het selecteren van de 'best passende donor', uitgaande van een ongewijzigd immuunsysteem van de ontvanger. Anderzijds wordt eraan gedacht om actief in de immuunreactie in te grijpen. Hiervoor zijn verschillende mogelijkheden. (IIa) "De mogelijkheden om het immunologisch apparaat lam te leggen (Imuran) of te blokkeren (Prednison, Actinomycine) zijn voldoende bekend. Dit kan ook worden bereikt door een 'immunparalyse' op te wekken met een grote hoeveelheid bij voorkeur gezuiverde transplantatie antigenen." (van Rood, et al., 12 januari, 1964)

49 Naast honden worden voor het transplantatieonderzoek ook ratten en muizen gebruikt (Werkgroep Orgaantransplantatie TNO, 23 maart, 1967). Voor chirurgische experimenten zijn deze dieren weliswaar klein, maar om verschillende redenen toch goed bruikbaar.

Als doel van het onderzoek kan worden gezien de ontwikkeling van een zo eenvoudig en snel mogelijke procedure van transplantatie van de rattenier, om verschillende methoden van immunosuppressie bij homologe transplantatie te kunnen screenen.

De resultaten zullen zo mogelijk worden vergeleken met en eventueel als leidraad worden gebruikt bij de behandeling van niertransplantaties bij de hond en de mens. (Tinbergen, november, 1966)

Het lijkt hierbij wel zo dat deze dieren meer als verbruiksartikel worden gezien, dan grotere proefdieren zoals bijvoorbeeld honden en apen.

De voordelen van de rat als proefdier bij het onderzoek zijn duidelijk: de rat is goedkoop, verreist weinig nazorg, de operatie behoeft niet onder strikt steriele omstandigheden te geschieden en wat het aantrekkelijkste is: in een ingeteelde stam is een isologe transplantatie mogelijk, terwijl homologe transplantaties van de ene ingeteelde stam naar de andere zeer goed vergelijkbaar zijn. (Tinbergen. november, 1966 ) 
Een andere mogelijkheid wordt gezien in (IIb) het verminderen van de antigeniciteit van een orgaan. Daarvoor wil men verschillende mogelijkheden uitproberen.

Het is praktisch zeker dat de thrombocyt de transplantatie-antigenen bevat. Het is zeer waarschijnlijk dat de thrombocyt aan het endotheel wordt geadsorbeerd en hier (soms?) als het ware in oplost. Doorspoelingsmethoden die het endotheel zoveel mogelijk van dergelijk geadsorbeerd materiaal bevrijden zouden de antigeniciteit van een getransplanteerd orgaan drastisch en misschien zelfs critisch kunnen verlagen. (van Rood, et al., 12 januari, 1964$)^{50}$ Een groot deel van de experimenten wordt echter niet bij mensen, maar op diermodellen uitgevoerd. Dit levert, afgezien van dier-specifieke moeilijkheden, problemen op ten aanzien van de 'geschiktheid' van de modellen. In hoeverre zijn de resultaten die in het dier verkregen worden, representatief voor wat in de mens zou gebeuren? Een extra probleem daarbij is, dat veel van wat al bij de mens bekend is over de leukocytenantigenen eerst vertaald moet worden naar de betreffende diersoort.

Chimpansees vormen hierop dus een gunstige uitzondering. Van mensen afkomstige antisera kunnen immers ook chimpansee-antigenen herkennen. Bij muizen ligt dat veel moeilijker. De leukocytenantigenen van een muis, zijn niet direct met menselijke antisera te herkennen. Het leukocytenantigeen systeem bij muizen $-\mathrm{H}_{2}$ genaamd - kan daarom wel als denkmodel voor het systeem bij mensen fungeren, maar is de bij muizen verkregen immunologische kennis niet direct vertaalbaar naar de mens. Ook de in proefdieren onderzochte immunosuppressiva blijken niet eenvoudigweg te vertalen naar mensen. Een van de problemen blijft de vertaling van doseringen van rat naar mens.

Men hoopte dat dergelijke gegevens d.m.v. extrapolatie voor de behandeling van patiënten van nut zouden kunnen zijn. De moeilijkheid is echter dat niet duidelijk is hoe men de doses Imuran en ALS van rat naar mens moet omrekenen b.v. per kg. lichaamsgewicht of per oppervlakte. (Werkgroep

Orgaantransplantatie TNO, 24 maart, 1969)

Dit soort problemen vormen de achtergrond waartegen de eerste niertransplantatie in Leiden plaatsvindt. Op verschillende gebieden heerst nog onzekerheid en is men volop in beweging. Dit weerhoudt de Leidse Werkgroep Niertransplantatie er echter niet van om een niertransplantatie voor te bereiden.

Na vele voorbereidingen, wordt het Isolatiepaviljoen half maart 1965 in gebruik genomen. Kort daarvoor besluit de Werkgroep Niertransplantatie dat een patiënt voor niertransplantatie in aanmerking komt.

A. Alle aanwezigen gaan ermede accoord, dat een niertransplantatie bij patiënt

$\mathrm{V}$. is aangewezen indien chronische dialyse niet mogelijk blijkt te zijn. De moeder, ..., is in alle opzichten als donor acceptabel. ...

50 Zo wordt al onderzocht of getransplanteerde organen antigenen 'loslaten' en of het 'doorspoelen' van een nier effecten heeft.

Nathan bestudeerde in hoeverre een getransplanteerde nier weefseltransplantatieantigenen loslaat. Het bleek, dat na de sensibilisatietijd, die varieerde van twee tot tien uur, inderdaad deze antigenen vrijkwamen en de gastheer sensibiliseerden voor een volgend transplantaat. Hij onderzocht ook in hoeverre het vooraf doorspoelen (op verschillende manieren) van de nier invloed hierop had. Hoewel zijn experimenten zeker niet volledig zijn, is er geen verschil gevonden tussen gewoon en zeer grondig doorspoelen van de getransplanteerde nier. Dit is echter een belangrijk punt, dat zeker een verder onderzoek wettigt.

(Werkgroep Niertransplantatie, 1964) 
B. Aangezien de mogelijkheid, dat chronische dialyse wegens gebrek aan coöperatie van de patiënt niet te verwezenlijken is, lang niet denkbeeldig is, zal er toch naar worden gestreefd om eind Maart a.s. alle voorbereidingen voor een transplantatie gereed te hebben. (Werkgroep Niertransplantatie, 3 maart, 1965) Het vooruitzicht dat er eind maart mogelijk een niertransplantatie zal plaats vinden, wordt besproken door het Bestuur van het Isolatiepaviljoen. Men houdt er rekening mee, maar de transplantatie blijft vooralsnog uit. Eind april spreekt men weer over een mogelijke opname, nu ter voorbereiding van een niertransplantatie half mei (Bestuur Isolatiepaviljoen, 28 april, 1965). In tegenstelling tot wat gezegd werd, blijkt de patiënt wel 'coöperatief', want pas op 6 oktober spreekt men opnieuw over deze patiënt in een vergadering van de Niertransplantatie-werkgroep.

Op 3 maart j.l. werd door de werkgroep in principe besloten tot transplantatie van een nier bij patiënt $\mathrm{V}$., indien chronische dialyse onbevredigend zou blijken. ... Inmiddels is sedert bovengenoemde datum een half jaar verstreken, waarin twee maal per week haemodialyse via een Scribner-shunt werd toegepast. $\mathrm{Na}$ enige technische moeilijkheden in het begin verliepen deze dialyses vlot. ... Ofschoon de klinische toestand van patiënt V. redelijk mag worden genoemd, en de bloedchemie aardig op peil kan worden gehouden, kunnen toch de volgende argumenten vóór een niertransplantatie worden aangevoerd:

a. De klinische toestand is zeker niet optimaal. Een objectieve beoordeling wordt bemoeilijkt, doordat patiënt uiterst kleinzerig is en klagerig, en in hoge mate infantiel mag worden genoemd....

b. De coöperatie van patiënt is veel beter dan aanvankelijk werd verwacht. Psychisch lijkt hij echter de terugkerende dialyses steeds slechter te verdragen.

c. De werkgroep kan een niertransplantatie nu aan; de chirurgische techniek is in deze periode sterk verbeterd; Dr. Lameijer heeft practische ervaring opgedaan met de postoperatieve controle van dit soort patiënten ${ }^{51}$; het isolatiepaviljoen is in gebruik genomen.

d. Het chronische dialyseprogramma dient, waar mogelijk, te worden ontlast, zodat voor andere patiënten therapeutische mogelijkheden vrijkomen.

(de Graeff, 6 oktober, 1965)

Deze argumenten blijken overtuigend genoeg om te besluiten tot transplantatie over te gaan.

De niertransplantatie bij patiënt V. zal op I november 1965 gebeuren. Patiënt zal 9 dagen voor de operatie ( 23 October) in het Isolatie paviljoen worden opgenomen, teneinde de verpleegsters aldaar de kans te geven hem te leren kennen. Patiënt stemt met de ingreep in. (Werkgroep Niertransplantatie, 13 oktober, 1965)

Vele voorbereidingen hebben dan plaatsgevonden. De transplantatie zelf is geoefend op dieren en in combinatie daarmee is geëxperimenteerd met immunosuppressieve behandelingen. Er zijn vele contacten gelegd met en reizen gemaakt naar trans-

SI Zij heeft een maand doorgebracht bij Peart en Mowbray in Londen, waar tot dan toe - sinds eind I963- ig cadaver transplantaties zijn gedaan, waarvan er nog 8 in leven zijn, Gedurende haar verblijf daar woont ze enkele operaties bij, doet ze de nazorg van enkele getransplanteerden en verricht enig aanvullend onderzoek. (Lameijer, 13 juli, 1965: Lameijex, 5 augustus, 1965; Lameijer, 6 augustus, 1965) 
plantatiecentra, waar men zich liet informeren over de daar bereikte resultaten en gevolgde procedures. Ook wordt rondvraag gedaan naar de betrouwbaarheid van de N.L.T.-test ${ }^{52}$ in het voorspellen van een gunstige uitkomst van een niertransplantatie, waarop van verschillende kanten antwoorden komen (Russell, 23 februari, 1965). Amos antwoordt op deze vraag, dat het immuniseren van de donor-hetgeen gebeurt als test voor de mate van compatibiliteit - een negatief effect heeft op de overleving van de getransplanteerde donornier en dat dit dus voorkomen moet worden. In plaats daarvan geeft hij een ander advies:

Since you do not have any choice of donor and the only question is whether the donation is likely to be worth while, why not make your evaluation on the basis of serological tests? The correlation so far between Terasaki's typing and Starzl's transplantations results seems to be good. (Amos, 23 februari, I965)

Bij de voorbereidende onderzoeken wordt wel gebruik gemaakt van de N.L.T-test, maar niet op de voorziene donor en de patiënt zelf 53 . Bij de patiënt en diens moeder worden uiteraard wel de leukocytengroepen bepaald en laat men verschillende andere bloedonderzoeken door het CLB uitvoeren (van der Weerdt, 27 juli, 1965; Eijsvoogel, 9 november, 1965$)^{54}$. De laatste brief is gedateerd op 9 november, dus later dan de geplande datum voor de niertransplantatie. De transplantatie laat weer op zich wachten. Op 2 maart 1966 vindt de niertransplantatie van patiënt V. uiteindelijk plaats (Bestuur Isolatiepaviljoen, 8 mei, 1967 ). In de eerste drie maanden na transplantatie treedt er een vroege afstoting op, die behandeld wordt waardoor de nier behouden blijft (Bestuur Isolatiepaviljoen, 8 mei, I967). Anderhalf jaar later wordt de toestand van de patiënt zelfs "goed" genoemd (Bestuur Isolatiepaviljoen, oktober, 1967$)^{55}$. Intussen wordt door de IRS-werkgroepen ook gewerkt aan transplantatie van andere organen. In verband met de noodzakelijke immunosuppressie wordt ook voor deze experimentele transplantaties ${ }^{56}$, evenals voor volgende niertransplantaties gebruik gemaakt van de bijzondere kwaliteiten van het Isolatiepaviljoen.

52 Normal Lymphocyte Transfer test.

Lymphocyten van de toekomstige ontvanger worden intradermaal ingespoten bij de toekomstige donor. Deze lymphocyten zullen, wanneer zij een sterke weefsel-incompatibiliteit vinden, reageren tegen de donor-antigenen en plaatselijk roodheid veroorzaken. (Werkgroep Niertransplantatie, 1964)

53 Voor de proefpersonen wordt in verband met het risico op serumhepatitis een verzekering afgesloten (van Rood, 17 juni. 1965).

54 Voor wat betreft de dan te testen leukocytenantigenen is er tussen de ontvanger en de donor op drie plaatsen verschil. Er wordt getest op: $4 \mathrm{a}, 4 \mathrm{~b}, 6 \mathrm{a}, 6 \mathrm{~b}, 7 \mathrm{a}, 7 \mathrm{a}, 7 \mathrm{~b}, 7 \mathrm{c}, 7 \mathrm{~d}$, en $8 \mathrm{a}$. De patiënt heeft $4 \mathrm{~b}$ en $8 \mathrm{a}$, terwijl deze bij zijn moeder ontbreken en reageert negatief op $7 \mathrm{a}^{\prime}$, terwijl die bij zijn moeder wel aanwezig is. Voor het overige zijn ze op dat moment hetzelfde (van Hooff, I4 december. 1981 ). Vanwege het negatief zijn voor het antigeen $7 \mathrm{a}^{\prime}$, en het daarvoor positief zijn van de donor zou deze combinatie als incompatibel moeten worden beschouwd.

55 Hoe goed blijkt ruim dertig jaar later, wanneer deze patiènt in een televisie-uitzending zelf kan vertellen hoe hij de transplantatie beleefd heeft.

56 Bijvoorbeeld een levertransplantatie:

Het betreft een vraag van de Kinderkliniek of in het Paviljoen een kind kan worden behandeld na levertransplantatie. Gezien de slechte prognose na een dergelijke operatie heeft men zich de vraag gesteld in hoeverre de artsen in het Paviljoen verantwoordelijk zijn voor deze behandeling. Prof. Querido meent dat er geen sprake is van verantwoordelijkheid voor het Paviljoen en dat er gewoon gastvrijheid wordt verleend voor de nabehandeling van een dergelijke patiënt. Dr. van Rood vindt dat het transplantatiebeleid als geheel toch wel een zaak is die velen op het AZL aangaat. Prof. Querido stelt voor een brief te schrijven aan de afdelingen Kindergeneeskunde en Heelkunde waarbij gevraagd wordt deze opname schriftelijk bij het bestuur van het Paviljoen aan te vragen. (Bestuur Isolatiepavilioen, 6 mei. 1966) 


\section{8 'LEUKOCYTE GROUP COMPATIBILITY TESTING DESERVES A PLACE IN CLINICAL ORGAN TRANSPLANTATION'57}

Het samengaan van immunohaematologen en chirurgen (en anderen), vindt in Leiden plaats in het Isolatiepaviljoen van het Instituut voor Radiopathologie en Stralingsbescherming. Hier wordt onderzoek gedaan naar het systeem dat verantwoordelijk is voor afstoting, waardoor een behandeling van beenmergschade in zicht komt en de kansen op acceptatie van een getransplanteerd orgaan worden vergroot. Het IRS levert de faciliteiten en een deel van de financiën, waardoor de immunologen en chirurgen in staat worden gesteld hun specifieke onderzoek uit te voeren. Dit gebeurt allemaal in het kader van de behandeling van stralingsslachtoffers. De (nier)transplantaties die chirurgen uitvoeren, staan model voor de behandeling van stralingsslachtoffers. Omdat de immunohaematologen de gelegenheid krijgen om donoren op basis van typering te selecteren, zou een effectievere behandeling van stralingsongevalslachtoffers ontwikkeld kunnen worden.

Het Isolatiepaviljoen vormt het ontmoetingspunt van verschillende doelstellingen, die daar met elkaar verweven raken en versmelten. In de multidiciplinaire werkgroepen verdwijnt het disciplinaire onderscheid door de gemeenschappelijke doelstellingen. Wanneer de eerste resultaten van deze samenwerking ten aanzien van niertransplantatie zichtbaar worden, schetst Van Rood hoe de ontwikkeling van de immunologie van belang is geworden voor de klinische praktijk:

Medawar's demonstration in 1946 that leukocytes are capable of inducing

homograft sensitivity implies that at least some of the antigens of the leukocytes must be transplantation antigens. The serological recognition of these antigens had a slow start. When it was realized, however, that antibodies against leukocytes are quite often formed as a consequence of pregnancy and a better insight into the limitations of the test procedures had been obtained, it became possible to devise methods to recognize some of the antigens of the leukocytes. ...It could be demonstrated that at least 5 of the 15 antigens mentioned above were transplantation antigens. (van Rood, 1966)

De samenwerking in het Isolatiepaviljoen, tussen chirurgen en immunohaematologen, creëert in Leiden een (nier)transplantatiepraktijk. In deze praktijk wordt gebruik gemaakt van de voordelen die een verwante, levende donor biedt. Enerzijds benadert een venwante donor meer de ideale situatie van een identieke tweeling, dan een onverwante donor. Anderzijds biedt het gegeven dat de potentiële donoren in leven zijn, de gelegenheid om de immunologisch minst van de patiënt afwijkende donor, zonder hoge tijdsdruk te selecteren. Het selecteren van de best 'passende' donor voor een gegeven patiënt kan beschouwd worden als het proberen de ideale situatie van een identieke tweeling te imiteren. In levende verwante donoren worden deze voordelen gecombineerd. Daarvan profiteert de patiënt en kan tegelijk de zin van het bepalen van leukocytengroepen worden geillustreerd. De bepaling van transplantatie-antigenen begint zich een plaats te verwerven in de transplantatiepraktijk ${ }^{58}$.

57 Citaat uit (van Rood, 1966; van Rood, et al., 1967)

58 Binnen de transplantatiepraktijk krijgt beenmergtransplantatie - ofschoon het uitgangspunt van het transplantatieonderzoek in Leiden - een bijzondere plaats toebedeeld. Er wordt een onderscheid gemaakt tussen orgaantransplantatie aan de ene kant en beenmergtransplantatie aan de andere kant. Blijkbaar wordt onderscheid gemaakt tussen getransplanteerde organen die door het immuunsysteem kunnen worden afgestoten en een niet solid orgaan dat zelf deel van het immuunsysteem is. De consequenties van dit 
On the moment, only a few centers are actively engaged in this kind of work, but the number of transplanting teams are sprouting up all over the United States and Europe, and it appears now extremely likely that leukocyte grouping is a conditio sine qua non for this kind of work. (van Rood, 5 april, 1966) Doordat transplantatie-antigenen niet orgaanspecificiek, maar op vele typen cellen aantoonbaar zijn, kunnen de in het leukocytenantigeenonderzoek ontwikkelde serologische methoden ook gebruikt worden voor de selectie van passende donorontvanger-paren (Bruning, 17 april, 1968). Naast het op deze wijze benaderen van de immunologische afweerreacties, blijft ook de immunosuppressieve benaderingswijze van het afstotingsprobleem onderwerp van nader onderzoek. Want ook de immunohaematologen erkennen, dat door het onderdrukken van immunologische afweerreacties met immunosuppressiva, het uiteindelijke resultaat van een transplantatie verbetert (Bruning, 17 april, 1968). Daarnaast vinden zij het van groot belang om te zoeken naar een goede compatibiliteit van de leukocytenantigenen, om niertransplantaten langer te laten overleven.

... on this basis ${ }^{59}$ and on the basis of groupings performed on recipients and donors of kidney grafts it appears extremely likely that the leukocyte groups are of prime importance for the survival of kidney transplants. For this reason

leukocyte group compatibility testing deserves a place in clinical organ transplantation. (van Rood, I966)

Het volgende hoofdstuk beschrijft de pogingen om histocompatibiliteitsbepaling tot een vast onderdeel van de klinische orgaantransplantatiepraktijk te maken, door het effect van matching op de overlevingsduur van een transplantaat aan te tonen.

onderscheid worden echter niet door iedereen onderschreven.

With regard to your remarks about the idea of having a symposium on bone marrow transplantation as well as a symposium on organ transplantation in September 1968 , I feel a bit disappointed that it is not yet generally accepted that we should not separate these subjects from the General theme of the Transplantation Conferences. (van Bekkum, 21 september, 1967 )

Beenmergtransplantatie blijft weliswaar binnen de transplantatiepraktijk, maar wordt tevens beschouwd als een vreemde eend in de bijt. Waar 'Host versus Graft' het afstotingsprobleem is waar bij de meeste orgaantransplantaties rekening mee moet worden gehouden, is de afstoting bij een beenmergtransplantatie vooral omgekeerd: 'Graft versus Host'. De immunologisch competente cellen van het getransplanteerde beenmerg, herkennen de normale lichaamscellen van de ontvanger niet als 'eigen' en zullen dus trachten die af te stoten, te vernietigen. Anders dan bij andere orgaantransplantaties, kunnen er geen immunosuppressieve maatregelen genomen worden, aangezien de bedoeling van de transplantatie juist het herstellen van de immunologische competentie is. Het enige wat dan over blijft is een dusdanige donorselectie, dat de donorleukocyten de weefselantigenen van de ontvanger niet als lichaamsvreemd beschouwen. De leukocytenantigenen van donor en ontvanger moeten daarvoor identiek zijn.

59 Het aantonen van identiciteit van leukocytenantigenen en transplantatie-antigenen middels verschillende huidtransplantatie-experimenten (gepreimmuniseerde en niet-gepreimmuniseerde ontvangers) 



\section{Het Matchingseffect}

\subsection{INLEIDING}

Weefseltypering zou voor donorselectie gebruikt kunnen worden, indien matchen de kans op afstoting van een niertransplantaat verkleint. Is dit het geval? Heeft het selecteren van een donor bij een ontvanger op basis van hun leukocytenantigenen effect op de overlevingsduur van een niertransplantaat? Alleen wanneer deze vraag positief te beantwoorden is, heeft het zin een allocatiepraktijk rond het matchen te bouwen. Vandaar dat de (Leidse) onderzoekers op deze vraag een antwoord proberen te geven.

Leukocytenantigenen kunnen midden jaren '6o worden herkend. Ze spelen een rol bij het optreden van transfusiereacties en bij het afstoten van een transplantaat. Als het immuunsysteem 'niet-eigen' leukocytenantigenen ( $=$ transplantatie-antigenen) herkent, neemt de kans op afstoten van het getransplanteerde orgaan toe. Als het immuunsysteem geen vreemde transplantatie-antigenen opmerkt, zou afstoting achterwege blijven. Dit is bij een identieke tweeling het geval, omdat zij dezelfde leukocytenantigenen hebben. De kans dat een willekeurige donor dezelfde leukocytenantigenen heeft, is echter bijzonder klein. Vanwege genetische verwantschap is de kans op overeenkomstige antigenen bij familieleden een stuk groter. Het vergelijken van de transplantatie-antigenen van donor en ontvanger wordt matchen genoemd. Door te matchen zou de overlevingsduur van het transplantaat kunnen toenemen. Dat matchen effect heeft zal echter moeten worden aangetoond. In dit hoofdstuk wordt beschreven, hoe met verschillende onderzoeken geprobeerd wordt dit matchingseffect aan te tonen.

Omdat er meerdere onderzoeksbenaderingen zịn waarmee verschillende onderzoekers het matchingseffect proberen aan te tonen, is dit complexe materie. Om helderheid te scheppen, geef ik eerst schematisch weer welke typen donoren er zijn, wat de methoden zijn om het matchingseffect aan te tonen, en wat in de verschillende paragrafen wordt besproken.

Voor de transplantatie van nieren kan gebruik worden gemaakt van verschillende typen donoren. De donornier kan afkomstig zijn van een levende donor, of van een overledene. Bij de levende donoren kan onderscheid gemaakt worden in de verwantschapsrelatie van de donor en de ontvanger. Zo kan er sprake zijn van donatie bij een identieke tweeling (zoals bij de eerste niertransplantatie van Murray); van een ouder-kind-donatie (parental; zoals in geval van de eerste twee niertransplantaties in Leiden); van een donatie van kinderen onderling (sib-sib, sibling); of van donatie door een genetisch niet-verwant persoon ${ }^{1}$. Een overleden donor (kadaverdonor, post- 
mortaledonor) is altijd genetisch niet-verwant. Door het identificeren van de leukocytenantigenen als belangrijke factor bij afstoting, wordt het ook mogelijk te proberen voor een ontvanger een, voor wat diens antigenen betreft, identieke donor te zoeken. Bij beschikbaarheid van potentiële verwante donoren is dit makkelijker dan bij niet-verwante donoren. Gezien de genetische verwantschap bij ouder-kind en sib-sib combinaties, is er immers een grotere kans op het identiek zijn voor de leukocytenantigenen. De overeenkomst kan toenemen, wanneer de ouders onderling ook overeenkomst(en) vertonen. Bij sib-sib combinaties kan het zijn dat beide kinderen dezelfde set antigenen van iedere ouder krijgt waardoor ze identiek zijn, maar de mogelijkheid bestaat ook dat ze verschillende sets krijgen, zodat ze maar voor de helft, of zelfs helemaal niet met elkaar overeenkomen. Bij willekeurige, nietgenetisch-verwante individuen is de kans klein dat zij identiek zijn. Dit wil echter niet zeggen dat er geen identieke, niet-verwante individuen zouden zijn; het is alleen veel moeilijker om voor een gegeven persoon een identieke donor te vinden.

Paragraaf 6.2 behandelt een experimentele, niet-klinische benadering om het matchingseffect aan te tonen. Hier laat ik zien hoe de Leidse onderzoekers proberen een verband te leggen tussen de overlevingstijd van huidtransplantaten en het aantal verschillende leukocytenantigenen. Daartoe worden bij een aantal families eerst kleine huidtransplantaten uitgewisseld. Hiervan wordt eerst bijgehouden hoe het beloop is en hoe lang het duurt voor het huidtransplantaat wordt afgestoten. en later de leukocytenantigenen van de donoren en ontvangers bepaald. De gegevens van de huidtransplantaten en de leukocyten worden vervolgens met elkaar gecorreleerd. Dit experimentele onderzoek is retrospectief, want de typering is niet van invloed op de keuze van een combinatie van donor en ontvanger.

In paragraaf 6.3 zal ik, als kort intermezzo, een eerste indruk geven van de manier waarop leukocytenantigeentypering zijn intrede doet in de klinische transplantatiepraktijk.

Paragraaf 6.4 is gewijd aan klinisch retrospectief onderzoek. Evenals bij de huidtransplantatie-experimenten voeren de onderzoekers eerst niertransplantaties uit en wordt later gekeken in hoeverre de 'bij toeval' ontstane donor/ontvanger-combinaties voor wat betreft hun typering overeenkomen.

$\mathrm{Bij}$ donor/ontvanger-combinaties met een levende donor, kan dit retrospectieve typeren worden gedaan door de leukocyten op de gebruikelijke wijze te typeren ( (56.4.I). Bij donor/ontvanger-combinaties waarbij gebruik is gemaakt van een kadaverdonor, is het retrospectief typeren minder makkelijk (\$6.4.2). Om de overleden donor veel later nog te kunnen typeren, neemt de chirurg, tezamen met de nieren, ook de milt uit. Deze wordt ingevroren en aan de hand van de op het miltweefsel aanwezige antigenen, typeert men later de donor. Soms neemt men ook van de ontvanger de milt uit en bewaart die op dezelfde wijze om hen achteraf te kunnen typeren, maar waar mogelijk gebruikt men daarvoor de leukocyten van de patiënt. De met elkaar vergeleken typeringsresultaten worden vervolgens gerelateerd aan de klinische gegevens van de getransplanteerde patiënten. Hierbij kijkt men naar het functioneren van de nier, naar het al dan niet optreden van afstoting (zowel klinisch als histologisch door middel van een biopsie), naar het functioneren van de patiënt

I Tegenwoordig worden bijvoorbeeld transplantaties uitgevoerd, waarbij de donornier afkomstig is van de partner. 
en naar de benodigde hoeveelheid immunosuppressiva.

In paragraaf 6.5, wordt beschreven hoe naast retrospectief onderzoek, ook prospectief onderzoek met transplantatiepatiënten zijn intrede doet. Door zowel de ontvanger als de levende, potentiële donoren vooraf te typeren, kan de meest geschikte donor worden geselecteerd.

Rondom kadaverdonoren (\$6.6) ontstaan twee verschillende manieren van prospectief typeren. In de eerste plaats probeert een aantal chirurgen een situatie te creëren - analoog aan de situatie bij levende donoren - waarbij voor een bepaalde patiënt een keuze kan worden gemaakt uit een aantal potentiële donoren. Deze donoren zoekt men veelal op neurologische afdelingen bij patiënten met een slechte prognose, die echter nog niet zijn overleden. Dit biedt de mogelijkheid hun leukocyten te typeren en te vergelijken met de typering van de ontvanger. Wanneer men zo meerdere donoren beschikbaar heeft, kan de meest geschikte donor na overlijden worden gebruikt voor transplantatie.

Het kiezen van één donor uit een aanbod van meerdere potentiële kadaverdo. noren voor één bepaalde patiënt kan ook worden omgedraaid: dan zoekt men naar ontvangers die kunnen passen bij één kadaverdonor. Ook dit tweede idee wordt uitgewerkt. Door alle, voor transplantatie in aanmerking komende, nierpatiënten te typeren en deze typeringsgegevens (centraal) te bewaren, kunnen deze gegevens worden vergeleken met de typeringsgegevens van een kadaverdonor. De meest geschikte ontvanger kan dan worden geselecteerd en (zo mogelijk) getransplanteerd. Het postoperatieve beloop van alle prospectief getypeerde patiënten wordt nauwlettend in de gaten gehouden, zodat later uitspraken kunnen worden gedaan over het matchingseffect. In paragraaf $6.7 \mathrm{zal}$ dit nader worden onderzocht. Tevens zal daar worden besproken hoe andere factoren (waarvan immunosuppressiva er één is) een vertroebelende rol spelen bij het onderzoek naar het matchingseffect.

In de afsluitende paragraaf 6.8 beschrijf ik hoe enkele betrokkenen op deze periode terugkijken. Daarin zal blijken dat sommigen hun aanvankelijke 'geloof' in het belang van het selecteren van donor/ontvanger-combinaties op basis van typeringen verliezen, terwijl anderen dit behouden.

Wanneer matchen een positief effect heeft op de overlevingsduur van niertransplantaten, heeft Eurotransplant zin. In dit hoofdstuk wordt daarom beschreven hoe verschillende onderzoekers proberen om het matchingseffect aan te tonen, maar ook hoe over dat matchingseffect een controverse ontstaat. Met deze controverse is de legitimiteit van het medisch-criterium, en dus van Eurotransplant in het geding.

\subsection{HUIDTRANSPLANTATIE-MATCHINGSEXPERIMENTEN}

De relevantie van leukocytenonderzoek voor de typeringspraktijk is midden jaren 60 onduidelijk. Dat blijkt ondermeer uit Ceppellini's onzekerheid over het antwoord dat hij gegeven heeft in verband met de in Italië aan te nemen transplantatiewet. De Italiaanse regering reageert op de maatschappelijk zichtbaar wordende transplantatiepraktijk, waarop Ceppellini de zich ontwikkelende typeringspraktijk in deze discussie inbrengt.

For political reasons it may be useful that we publish quickly the results which came out from our private workshop (Torino and Leiden). ... The Italian Parliament is passing in these days a law for allowing kidney homograft from a single donor. The Secretary for Public Health is, quite rightly, not very happy and has asked my opinion. I have convinced him that permission should be 
given only when "current" compatibility tests have been done with "satisfactory" results.

But what does it mean in actual facts, my suggestion? I do not know.

(Ceppellini, 1 april, 1966)

De aanhalingstekens die hij plaatst om current en satisfactory laten zijn onzekerheid zien. Mede vanuit deze onzekerheid stelt hij Van Rood voor, te participeren in een experiment, dat inzicht zou moeten geven in het belang van weefseltypering voor de transplantatiepraktijk.

Dit experiment sluit aan bij Leidse huidtransplantatie-experimenten uit het begin van de jaren ' 60 , die waren gericht op verlenging van de overlevingsduur van het transplantaat. De groep van Ceppellini heeft voor dit nieuwe experiment huidtransplantaties uitgevoerd tussen verwanten en niet-verwanten (Ceppellini, et al., 1965). Ceppellini vraagt nu aan Van Rood om deze mensen - achteraf - te typeren, zodat kan worden gekeken of de overlevingsduur van de transplantaten wellicht een relatie vertoont met een mogelijke (in)compatibiliteit, dan wel het identiek zijn van de leukocytenantigenen. In een brief aan Bernard Amos spreekt Van Rood de hoop uit dat er een relatie waar te nemen is.

In some days I will go to Torino to type Rugerro's [Ceppellini] skin graft donors and recipients, I will be extremely thrilled to see what comes out of it. My hope is that the compatible group will have less incompatibilities than the incompatible group, and that the long survivors will not be completely compatible. (van Rood, 17 november, 1965 )

Ceppellini en Van Rood vinden een correlatie tussen het aantal niet overeenkomstige leukocytengroepen en de overlevingsduur van huidtransplantaten. Tevens blijken enkele leukocytenmonsters, die in de agglutinatietechniek identiek zijn, in de cytotoxiciteitstechniek met (ongeclassificeerde) cytotoxische antisera niet identiek, en de overlevingsduur van de bijbehorende huidtransplantaten blijkt korter dan de overlevingsduur van de huidtransplantaten die in beide technieken identiek zijn. Uit deze bevindingen concluderen ze dat meer leukocytengroepen een rol spelen dan die door de agglutinatietechniek worden herkend (van Rood, 1966). De hoop met minder dan identiek toe te kunnen, lijkt de bodem ingeslagen.

Indien de leukocytenantigenen overeenkomen, dan is de overlevingsduur van een huidtransplantaat, afkomstig van een broer of zuster, significant langer dan wanneer er verschillen zijn. Bij niet-verwante donor/ontvanger-combinaties is een toenemend aantal niet-overeenkomende antigenen gecorreleerd met een afname in de overlevingsduur, maar die correlaties zijn niet significant (van Rood, et al., I966). Een logisch vervolgonderzoek zou zijn om via prospectief typeren een verlenging van de overlevingsduur van getransplanteerde huid te bewerkstelligen. Ceppellini wil voor zo'n experiment permissie aan het $\mathrm{NIH}_{\text {vragen }}^{2}$. Daarbij houdt hij rekening met een afwijzing door het $\mathrm{NIH}$, maar toch stelt hij Van Rood dit gezamenlijke experiment voor, om te bepalen of weefseltypering van waarde kan zijn voor transplantatie. Daarmee reduceert hij dan tevens zijn onzekerheid over zijn advies aan de Italiaanse regering.

Therefore I want to know if a priori leukocyte typing has any real value.

2 Bij de bespreking van de ontwikkelingen rond de NIH-contracten in Hoofdstuk 4 , is dit verzoek al even ter sprake gekomen. 
The experiment is based on the fact that test skin graft and kidney homografts follow the same trend of evolution if "equivalent" time scales are taken into account ${ }^{3}$....

We can do that in six months and the result will settle for ever the question whether leukocyte typing has any value in selecting a good donor...

Relying on your O.K. (Ceppellini, 1 april, 1966)

Kort daarvoor bereiken Van Rood, uit Durham, minder gunstige berichten over de resultaten van huidtransplantatie-experimenten. Amos schrijft dat zijn onderzoeksgroep bij niet-verwanten nog maar weinig kan voorspellen aan de hand van serologische tests. Mogelijk is dat toe te schrijven aan onvoldoende beschikbaarheid van uiteenlopende antisera, waardoor nog niet genoeg antigenen herkend kunnen worden. Daarom suggereert Amos, dat misschien een andere benadering voor het bepalen van de kans op afstoting moet worden gezocht (Amos, 16 maart, 1966) 4 . Tussen verwanten kan de uitkomst van een huidtransplantatie met serologische tests wel goed worden voorspeld, zoals zij in de Lancet meedelen (Amos, et al., r966), maar voor de keuze tussen 'niet-identieke donoren' blijven andere tests noodzakelijk (Amos, et al., I968).

Mede gezien deze onzekerheid, heeft Van Rood wel belangstelling voor een experiment waarmee in één keer duidelijkheid te verkrijgen is over de mogelijkheden van gebruik van serologische tests en tegelijkertijd het belang van weefseltypering voor transplantaties kan worden vastgesteld. Van Rood presenteert ontwikkelingen uit Leiden meteen in het licht van dit experiment ${ }^{5}$, maar ondanks zijn interesse komt het niet tot een gezamenlijk project. De aandacht lijkt halverwege de jaren 60 te verschuiven naar meer klinisch onderzoek. In het Jaarverslag van het IRS over de jaren $1_{9} 64$ en 1965 wordt namelijk gevraagd om het leukocytenonderzoek te relateren aan klinisch onderzoek.

Voordat het leucocytengroep-compatibiliteitsonderzoek aanspraak kan maken op een plaats in de klinische toepassing van de orgaantransplantaties, zal nog aan twee voorwaarden voldaan moeten worden.

In de eerste plaats zal aangetoond moeten worden dat de overlevingsduur van

3 Het is zo dat huidtransplantaten vele malen sneller worden afgestoten dan getransplanteerde nieren, maar dat daar wel een lineair verband tussen bestaat. Dit verband wil Ceppellini onderzoeken door ontvangers en donoren van huidtransplantaten op basis van hun leukocytenantigeentypering aan elkaar te koppelen.

Thus we plan to type with our sera and with your sera (at least with the most important ones) 200 blood donors who have already agreed to undergo skin grafting.

The computer analysis will sort out from the 39800 ( $\mathrm{n} \times \mathrm{n}-1$ ) donor-recipient combinations the 100 pairs who are most compatible according to leukocyte typing (i.e. about $2.5 \%$ of the total combinations). On the same 100 recipients, aside with the 1) most compatible donor, we shall also graft 2) the most incompatible donor according to the computer (or incompatible for given leukocyte antigens) and 3 ) a third donor chosen at random.. (Ceppellini, $\mathrm{r}$ april, 1966)

4 Tests die in vitro de immuunreactie simuleren, of in vivo de mate van reactiviteit op een bepaalde donor laten zien.

We're in the middle of another skin grafting experiment. We certainly cannot predict well among nonrelateds and the MLC or NLT could perhaps be better at this stage. 1 am sure we have not yet got half the sera we need for matching and it will be interesting to see what we can produce from these boys. (Amos, 16 maart, 1966)

5 Althans, hun eigen werk kan ook zeer goed voor het experiment gebruikt worden.

This concerns the matter of the people who wanted to be skin grafted. We are most interested to continue our collaboration with you and have in fact worked quite hard to be able to do so really well. We have been setting up a program on the computer by which people who are equal can be selected and also people who are equal but for one antigen, but for two etc. (van Rood, 5 september/oktober, 1966) 
ern huidtransplanbart osk in niet-geimmuniserrde ostvangers correleert met de asm- of afserigieid was de leucocytengroepen-compatiblititeit van donst en statranget:

In de fweede plate zal wit linisch material, b.x. niertransplantaties, ock een dergelifle sorrelatie af te leiden miseten zija. (Steenbergen, Ig66)

Aan de eergte woorwarde is middels het bovenbeschreven retrospectiene engeriment voldaan. De vrag om ook voor niettransplantaties een dergelijke correlatie aan te tonen, geft de uitkometen van het retrospectieve experiment cen geheel nieuwe dimensie. Naast een voornamelik theoretisch belang - leukocytenantigenen spelen een rol bij de afstoting van een huidtransplantaat - wordt via een correlatie tussen de overlevingsduur van huidtransplantaten en niertransplantaten, ook het klinisch belang van leukocytengroepenbepaling vergroot. De afstoting van een getransplanteerde nier gaat veel minder snel dan de afstoting van huid van dezelfde donor. Dit zou betekenen dat de resultaten van de huidtransplantatie-experimenten geëxtrapoleerd kunnen worden naar de overlevingsduur van getransplanteerde nieren. In cen (gemeenschappelijk) artikel van de Leidse en Italiaanse onderzoeksgroepen, schrift Van Rood hierover:

If it is permitted to compare the survival time of skin grafts in days with that of

kidney homografts expressed in months, this would imply that it is indeed

possible to predict, in the group of donor recipient pairs in which sibs

participate (on the basis of serological tests), which are the best combinations.

(van Rood, et al., 1966)

Het mogen extrapoleren naar een andere tijdschaal zou betekenen, dat de uit het retrospectieve huidtransplantatieonderzoek getrokken conclusies, ook voor niertransplantaties gelden, met dien verstande dat nieren aanmerkelijk minder snel worden afgestoten dan huid. Graag zouden Ceppellini en Van Rood meer zekerheid willen hebben deze conclusies met over willen nemen voor niertransplantaties. Met de pogingen om dezelfde effecten ook bij niertransplantaties aan te tonen, wordt zowel geprobeerd om het eventuele belang van matchen voor niertransplantatie te laten zien, als de toepassing van deze technieken bekend te maken bij de transplantatiepraktijk.

\subsection{KLINISCH TYPEREN}

Hoe de 'weefseltypeerders' In Leiden betrokken raken bij de zich ontwikkelende (chirurgische) transplantatiepraktijk, is in het vorige hoofdstuk beschreven. Naar aanleiding van de goede resultaten die Starzl in de Verenigde Staten met immunosuppressiva bereikt bij niertransplantaties, neemt in Leiden de interesse voor het doen van niertransplantaties toe en uiteindelijk vindt de eerste niertransplantatie in Leiden plaats op 2 maart 1966. De Werkgroep Niertransplantatie bereidt deze niertransplantatie voor. Binnen deze werkgroep is het vanzelfsprekend dat de immunohaematologie een rol speelt bij de selectie van de meest geschikte donor voor de patiënt. De betrokkenheid van de immunohaematologen is in Leiden vanzelfsprekend, door de langdurige relatie die al met het IRS bestaat en de verwachte relevantie van de leukocytenantigenen voor het uiteindelijke transplantatiesucces.

Bij de start van de Werkgroep Niertransplantatie, in 1964 , zijn de resultaten van de matchingsexperimenten op zich niet veel belovend. Niettemin wordt matchen gepropageerd, niet alleen door immunohaematologen, maar ook door transplanta- 
tiechirurgen. Zo is ook Starzl ${ }^{6}$ pleitbezorger van de "typing business".

Dr. Thom Starzl has been with our renal team in Johannesburg for the past 2 weeks and has performed our first 2 kidney transplants. He feels that it is essential that we set up a laboratory here where some matching techniques may be utilised to match donor and recipient. Furthermore he feels that it is paramount that I should see how these techniques are done in your laboratories. Hence I would once again like to ask you if I could visit you for about 2 weeks in November. (Abrahms, 6 september, 1966)

Omdat in die tijd duidelijk is dat het 'uit een boekje leren' van een typeringstechniek niet werkt, geeft Starzl de medici in Johannesburg het advies om in Leiden te gaan kijken en de daar gebruikte technieken te leren.

Starzl staat hierin niet alleen. Ook andere chirurgen die willen beginnen met transplanteren, trekken aan de weefseltypeerders om te gaan typeren. Blijkbaar zijn ook zij geneigd om matchen als noodzakelijk te zien (Rubinstein, 12 oktober, 1967). In Canada wordt zelfs het gebruik van weefseltypering als zodanig bepleit door overkoepelende medische organisaties, zoals blijkt uit een brief van Potworowski ${ }^{7}$. Die schrijft dat hij de matchingtest aan de hartchirurgen heeft aangeboden, maar dat deze ongeduldig zijn en willen beginnen, "whether we are ready or not" (Potworowski, 22 mei, r968).

Bij verschillende transplantatieprogramma's beginnen typeringen een vast onderdeel van de voorbereidende onderzoeken bij niertransplantaties te worden. Sommigen zien het klinisch belang van typeren in het voorkomen van 'een zekere' afstoting (Woodruff, 6 juli, I966), anderen kennen een breder belang toe aan typeren: door te matchen zou de kans op afstoting, ook bij gebruikmaking van een niet-verwante donor, zo klein mogelijk gemaakt kunnen worden.

Kort na de eerste niertransplantatie in Leiden, ontvangt Van Rood een verzoek om hulp bij het opzetten van een typeringslaboratorium van (chirurg) William D. Kelly uit Minneapolis ${ }^{8}$. Dit verzoek verandert het denken over prospectief typeren van donoren. Kelly vraagt om samenwerking op het gebied van leukocytentypering in het kader van hun niertransplantatieprogramma met kadavernieren. De ervaringen in Minneapolis, voor wat betreft de overlevingsduur van kadavernieren, maken matchen in zijn ogen noodzakelijk en daarom wendt hij zich tot Van Rood voor hulp.

... we have been well satisfied with the early functional status of the kidney but, as is to be expected with randomly selected unrelated individuals, the late results are discouraging in terms of the frequency of recurrent rejection episodes and ultimate loss of kidneys in contrast to our experience with kidney transplants from living blood-related donors. This, of course, is the general experience.

(Kelly, 31 maart, 1966)

Kelly wil komen tot een situatie, waarin geen ongematchte kadavernieren aan ontvangers worden geven. Om dit mogelijk te maken, wil hij een wachtlijst creëren, bestaande uit getypeerde patiënten. Wanneer zich dan een potentiële donor aandient, kan uit deze lijst de patiënt met de beste match geselecteerd worden.

Recently we had eight patients accepted for transplantation awaiting the

6 In het vervolg van dit hoofdstuk zal uitgebreid op het werk van Thomas Starzl en zijn positie ten aanzien van het typeren van leukocytenantigenen worden ingegaan.

7 Werkzaam bij het Institut de Microbiologie et d'Hygiène de FUniversité de Montréal

8 Department of Surgery, Medical School University of Minnesota, Minneapolis 
availability of a suitable cadaver kidney. If patients such as this could be typed by leukocyte agglutinin tests and if the cadaver donor would be typed at the time that difficulty with the case is identified (which would generally provide a period of $1-2$ hours for typing) then the best match could be chosen from among the prospective recipients. (Kelly, 31 maart, 1966$)^{9}$

Door de manier waarop Kelly de combinatie van donor en ontvanger tot stand wil laten komen, kiest hij een ander uitgangspunt dan tot dan toe gebruikelijk is. Waar de meesten een geschikte - levende, dan wel overleden - donor zoeken voor een bepaalde patiënt, wil Kelly zoeken naar een geschikte ontvanger voor een gegeven donor. In het idee zoals hij het schetst, is niet meer de patiënt met zijn specifieke leukocytenantigenen het vertrekpunt, maar vormen de leukocytenantigenen van de donor de referentie. Zijn idee kan worden uitgevoerd als er een wachtlijst met getypeerde ontvangers is. Het karakter van deze wachtlijst is niet kwantitatief - naar het principe: die het eerst komt, het eerst maalt, ofwel: wie bovenaan de lijst staat krijgt de eerstvolgende beschikbaar komende nier - maar kwalitatief, in de zin dat degene wiens weefseltype het beste past bij de typering van de donor wordt getransplanteerd (Kelly, 5 juli, 1966). Deze opzet van een klinische matchingspraktijk heeft alleen kans van slagen, indien een transplantaat een langere overlevingsduur krijgt door selectie van de 'best passende', niet-verwante ontvanger. Kortom, ook bij niet-verwanten moet er een 'matchingseffect' zijn.

\subsection{Retrospectief KLinisch Onderzoek}

Experimenteel onderzoek heeft nog niet voldoende aan kunnen tonen dat matchen een positief effect heeft op het transplantatieresultaat. Desondanks vindt leukocytenantigeentypering zijn weg naar de transplantatiepraktijk. Uitgevoerde transplantaties bieden echter ook een mogelijkheid om het effect van matchen op de overleving van een transplantaat te onderzoeken. Een van de manieren is het achteraf bepalen van de leukocytengroepen van getransplanteerde patiënten en hun donoren. Door te kijken naar de relatie tussen de mate van gematcht zijn van de donor en ontvanger enerzijds, en de overleving en het klinische beloop anderzijds, kan een indruk worden verkregen van het effect van het al dan niet overeenkomen van de leukocytenantigenen. Dit onderzoek wordt zowel gedaan bij diegenen die een nier ontvangen hebben van een levende (verwante) donor, als ook bij ontvangers van een 'kadavernier'.

\subsubsection{Levende Donoren}

Aanvankelijk worden verreweg de meeste transplantaties uitgevoerd met nieren van levende donoren. De donor is daarbij meestal een verwante van de ontvanger. Dit is voor de patiënt een gunstig gegeven, in het licht van de resultaten van het hiervoor beschreven onderzoek naar het matchingseffect. Daaruit bleek immers dat tussen verwanten uitgewisselde huidtransplantaten, een langere overleving hebben, dan

9 Terloops breidt hij daarmee ook de mogelijkheden voor het vergroten van het aantal potentiêle donoren uit. Specifically I am interested in the possibility of matching cadaver donors with prospective kidney recipients under circumstances in which the donor dies during open heart surgery and circulation to the kidney can be maintained for a number of hours with preservation of the kidney in relatively good condition. In selected cases we also will place patients dying in the intensive care unit on extra corporeal circulation to similarly protect renal viability during the several hours or so that it takes to mobilize the recipient and carry the operation to the point where the kidney can be transplanted from the donor. (Kelly. 31 maart, I966) 
tussen niet-verwanten. Voor onderzoekers heeft het de prettige bijkomstigheid, dat het retrospectief onderzoek mogelijk maakt, aangezien mogelijk niet alleen de ontvangers, maar ook de donoren nog in leven en dus typeerbaar zijn.

Alvorens niertransplantatie toe te passen, informeert men vanuit Leiden bij de centra in Parijs en Leeds naar de daar behaalde resultaten. Deze resultaten worden in een Werkbespreking Niertransplantaties gerapporteerd en het blijkt in Parijs beter te gaan, dan in Leeds. De ontvangers blijven in Parijs gemiddeld langer in leven ${ }^{10}$. Een mogelijke verklaring hiervoor zou zijn, dat men in Parijs overwegend met levende donoren, meestal familieleden van de ontvangers, 'werkt'.

De strategie om getransplanteerden en hun donoren retrospectief te typeren, wordt op meerdere plaatsen gevolgd ${ }^{11}$. In Leiden wordt het retrospectief typeren van donoren en ontvangers na niertransplantaties ook als een zinvolle onderneming gezien. Evenals Terasaki en Amos, wil ook Van Rood de patiënten en donoren van Starzl typeren. Van Rood bespreekt dit idee met Starzl tijdens een transplantatieconferentie in Londen en stelt hem later voor een analiste uit Leiden - Mej. A. Schippers - de typeringen te laten uitvoeren.

It looks like it that the technician now working for me will indeed go to the

States. On her way to Los Angeles she could stop over in Denver to do those

typings. Could you let me know also if this is still alright and how long a notice you should have beforehand to collect the patients and donors? She can do about 4 people a day.

It was really nice getting to know you a little better in London, and I am looking forward to see you back in the near future. (van Rood, $x$ april, 1966 )

Het is de bedoeling dat deze analiste in Los Angeles niet alleen de panels van Terasaki, Walford en Rose Payne met de Leidse antisera gaat typeren - als vorm van informatie-uitwisseling -, maar ook de ontvangers en donoren van de daar verrichtte niertransplantaties (van Rood, 18 maart, 1966). Van Rood zelf gaat naar Edinburgh, waar hij bij Woodruff, diens patiënten en hun donoren typeert (van Rood, 3 mei, 1966). Terug in Leiden schrijft Van Rood Woodruff om hem te bedanken voor de

to De eenste inventarisatie levert alleen weinig specifieke informatie op.

werkbespreking niertransplantaties dd. 3 februari 1964

aanwezig: Dr. J.J. van Rood, Dr. L.D.F. Lameijer, Dr. F. Cleton, Prof. W.R.O. Goslings, Dr. L.M. van Putten,

Dr. H. Stol en Dr. J. de Graeff, Prof. Dr M. Vink en Dr. M.N. van der Heyde

I gegevens uit Parijs en Leeds.

a. Parijs: Hamburger: 21 transplantaties (2 cadavernieren)

9 langer dan 6 maanden in leven.

$8-12$

8

Een patiënte overleed na 22 maanden met chronische nierinsufficièntie.

P.A. lobulaire glomerulonephritis gelijkend op oorspronkelijke aandoening

b. Leeds: Parsons: 5 transplantaties (4 cadavernieren).

2 langer dan 6 maanden in leven: $r$ overleden na 7 maanden aan longen met normale nieren.

1 langer dan 12 maanden in leven: zeer slechte nierfunctie.

De berichten uit Parijs lijken dus gunstiger dan die uit Engeland. Bij gebrek aan detafls (bestraling in

Parijs?') is het onmogelijk een vergelijking te maken. Dr. van Rood zal tijdens zijn deelneming aan een immunologiecongres in New York contact opnemen met Dr. Starzl (Denver) teneinde gegevens over het verdere beloop van zijn transplantaties te krijgen. (Werkgroep Niertransplantatie, 3 februari, 1964)

II Zo typeren Terasaki en Amos beiden patiënten van Starzl.

Tom Starzl tells me that your results agree well with his clinical findings - excellent. We are starting to go through some of his patients, too, so it will be of interest to compare results. (Amos, 25 februari, 1965) Van Rood wil de patiènten van Dausset graag typeren, maar hij schrijft dat gebrek aan tijd en typeringssera een probleem vormen (van Rood, 18 november, 1965 ). 
geboden mogelijkheid, alsmede over verdere uitbreiding van het retrospectieve project met de patiënten van Alexandre ${ }^{12}$. Om de typeringsresultaten met de klinische gegevens te kunnen vergelijken, wil Van Rood de beschikking krijgen over gegevens van de getypeerde patiënten ${ }^{13}$. Het beoordelen van de waarde van de overeenkomsten en verschillen tussen de leukocytengroepen van de donoren en ontvangers, wordt gedaan aan de hand van het succes van de transplantatie. Zo wordt gekeken of het klinisch beloop van de transplantatie een relatie vertoont met de mate van leukocytenantigeenincompatibiliteit tussen de ontvanger en diens donor. Typering ruim na afloop van verrichtte transplantaties, brengt het risico mee dat patiënten reeds zijn overleden. Van Rood kan dit niet oplossen door van alle patiënten leukocyten in te vriezen, want in de agglutinatietechniek kan daarmee niet worden gewerkt. Om ook de overleden patiënten in de beoordeling te kunnen betrekken, moet Van Rood hen vóór hun overlijden getypeerd hebben ${ }^{14}$. De eerste resultaten van de correlatie van het klinisch beloop bij getransplanteerden met de respectievelijke matchgegevens, zijn bemoedigend, maar nog niet voldoende om een sterke publicatie te rechtvaardigen. Daarvoor is een groter aantal donor/ontvanger-combinaties nodig. Dan ontvangt Van Rood een brief uit Brussel, van het hoofd van de nierafdeling aldaar, Charles Toussaint.

You may remember that we met a few weeks ago, in Prof. Morelle's department, at Louvain. This note is to ask you if it could be possible for you to determine the leucocyte groups of 3 pairs of patients. In each of these 3 pairs, a kidney was transplanted from one member to the other. The 3 grafts work very well. ... These patients are willing to go to Leiden, and we shall cover their travel expenses. (Toussaint, 16 juni, 1966)

Op deze aanbieding reageert hij prompt.

We will be delighted to type your patients. I think the best would be to do this in the last week of June. Probably the best day for this would be Thursday June 30 and Friday July ist. ... If these dates are too early it will also be possible to type these patients in the first week of July. (van Rood, 21 juni, I966)

Met de komst van het eerste 'paar' op I juli en de andere twee op 8 juli, worden de

12 Hier lijken de resultaten van de bepalingen enerzijds en het klinisch beioop anderzijds, goed met elkaar overeen te komen.

Back in Holland we would like to thank you again for your hospitality and the possibility to determine the leucocyte groups of your patients. The results so far have already been copied by collaborators. As soon as we have the final results in (after the absorption's to check the dubious reactions) we will send you these. The fit of the leucocytegroupcompatibility and the clinical picture is really quite impressive. However the numbers are of course quite small.

I will go this week to Leuven to discuss with Alexandre the leucocytegroups of his patients if here the clinical picture fits as well. .. If we have all the details together we could consider if they are good enough to be published. ... (van Rood, 24 mei, 1966)

13 Van Rood vraagt Woodruff om de namen, de operatiedatum, de uitkomst (overleden, in leven, etc.) en de familierelatie tussen donor en ontvanger van de niertransplantaties met levende donoren (van Rood, 27 mei, 1966).

14 Zolang patiênten niet voorafgaand aan hun transplantatie worden getypeerd, zullen de gegevens incompleet blijven, zoals hij aan Woodruff schrijft.

... Enclosed you will find a sheet with the copy of the definitive data. ... In the meantime we have now almost finished the typings of the group in Louvain and here again we found the same interesting pattern. The data are, of course, incomplete because the controls i.e. the patients who died can not be included. However, there are quite a number of patients who have been only a short time ago operated. We can see how they fare. You might be interested to hear that one of the patients of Alexandre of Louvain was typed by us before his operation. He was incompatible for the $4 \mathrm{a}, 4 \mathrm{~b}, 8 \mathrm{a}$ and $9 \mathrm{a}$ antigen and died 2 weeks after operation of an uretero-uretero fistula.... (van Rood, 5 juni, 1966) 
patiënten van Toussaint ook in de analyse betrokken (van Rood, 30 juni, 1966). Van Rood rapporteert aan Toussaint dat geen van de paren 'compatibel'15 is, dat het effect op de transplantatie van incompatibiliteit voor $5 \mathrm{~b}$ nog onbekend is, maar dat incompatibiliteit voor $4 \mathrm{a}$ en 8a "as far as our knowledge goes on the moment" van groot belang is voor niertransplantatie (van Rood, 25 juli, 1966). Hij zegt meerdere gevallen te hebben gezien waarin bij een dergelijke combinatie de getransplanteerde nier vrij snel werd afgestoten. Om de waarde van deze typeringen voor het retrospectieve onderzoek, te laten toenemen schrijft hij:

I would be very much obliged to you if you could give me some clinical data on the patients and if you could let me know how they are doing after the

transplant. (van Rood, 25 juli, 1966)

Uit de hierop volgende correspondentie tussen Toussaint en Van Rood blijkt dat de patiënt met de 5 b incompatibiliteit het 'niet slecht doet', terwijl van de twee andere patiënten, met beiden minimaal een 4 a8a-incompatibiliteit, er één reeds overleden is en de ander achteruit gaat. (van Rood, 6 oktober, I966; Toussaint, 22 oktober, r966) Toussaint is enthousiast over de samenwerking tussen Brussel en Leiden, en zou die graag uitgebreid zien met andere transplantatiecentra in België. Daarnaast zou hij graag een uitbreiding van het onderzoek zien in een andere richting.

Your studies seem to be engaged into a very exciting phase although, we should appreciate similar studies in cadaver transplants for, so far, we have used $\mathrm{I} 8$ cadaver kidneys for 3 live donors and every one of our to future patients is presently hemodialyzed in the hope of cadaver transplant. (Toussaint, 22 oktober, 1966)

Op deze vraag om ook kadaverdonoren in het onderzoek te betrekken, gaat Van Rood nog niet in.

Ondanks uitbreiding met de data van Toussaint, blijven de aantallen te gering voor publicatie. Door ook de patiënten bij Starzl en Terasaki te typeren, kan Van Rood het aantal donor/ontvanger-paren verder vergroten. $\mathrm{Bij}$ hen wil hij de getransplanteerde patiënten en hun donoren op 'Leidse wijze' - met medeneming van de benodigde Leidse antisera - laten typeren ${ }^{16}$. Dit plan strandt echter op de financiering. Een aanvraag bij het NIH wordt niet gehonoreerd. Als alternatief stelt Van Rood aan Terasaki voor een deel van de kosten voor zijn rekening te nemen. 'Mej. Schippers' zou dan bij hem de prospectieve typeringen ter hand kunnen nemen (van Rood, 30 juni, 1966). Maar ook dit plan slaagt niet. Dan stelt hij alles in het werk om voldoende geld bij elkaar te krijgen, zodat hijzelf en enkele anderen - via de 'Contractors-Meeting' van het $\mathrm{NIH}^{17}$ - een reis door de VS kunnen maken om per-

15 Identiek: alle antigenen in de donor zijn ook aanwezig in de ontvanger en de ontbrekende antigenen in de donor, ontbreken ook in de ontvanger.

Compatibel: De donor heeft geen antigenen die de ontvanger niet ook heef.

Incompatibel: De donor heeft antigenen die de ontvanger niet heef.

16 Van Rood schrijtt aan Terasaki:

For the typing of the panels and of the recipients and donors, we will procure the sera, which Miss Schippers knows to handle.

Enclose you will find part of a copy of a letter I sent to Overman concerning Miss Schippers' stay in your laboratory. We will wait and see how he reacts. As I have in my contract the money for her salary and her fare, I am quite hopeful. (van Rood, 18 maart, 1966)

17 Het NIH zal dan de reis- en verblijfkosten in Washington voor Van Rood en Eernisse dragen. ... I have to attend a Contractors-Meeting in the middle of November. NIH will pay my fare to Washington and probably also for that of my closest collaborator George Eernisse, (van Rood, 23 augustus, 1966) 
soonlijk de ontvangers en donoren van Starzl te gaan typeren ${ }^{18}$.

I am trying now to raise money so that I can get over miss A. van Leeuwen too. If the three of us [Van Rood, Eernisse \& Van Leeuwen] could come down to Denver we would be able to do the typing of your 35 patients and their donors in a relatively short time. ... (van Rood, 23 augustus, 1966)

Het verzoek vanuit Minneapolis om hulp bij het opzetten van een typeringslaboratorium voor niertransplantaties, sluit bij dit plan aan ${ }^{19}$. Van Rood zal optreden als - zoals hij aan Paul Russell schrijft - "a kind of consultant" (van Rood, 28 september, I966). In het kader van het project in Minneapolis zullen de getransplanteerde patiënten en hun donoren met Leidse sera getypeerd worden. Zo zal, ter plekke, de vaardigheid van het typeren worden overgedragen. Van Rood krijgt hiermee interessante gegevens over de verrichtte transplantaties. Daarnaast ontstaan nieuwe financiële mogelijkheden. Hij slaagt erin, middels deze 'typeringsvraag' uit Minneapolis, de overtocht van Aad van Leeuwen betaald te krijgen ${ }^{20}$. Omdat het NIH de reiskosten naar Washington voor Van Rood en Eernisse betaalt ${ }^{21}$, kunnen ze gedrieën tegen geringe extra kosten door de VS reizen en verschillende plaatsen aandoen. Met dit schema als uitgangspunt vraagt Van Rood aan Starzl om extra financiële ondersteuning.

I had the impression from your previous letters that you were interested and I would be happy to know if this is still the case. If so, would you be able to raise some money for our trips from Washington and for hotels etc.?

I am sorry I have to ask for this but there is an economic crisis in Holland which makes it impossible to get money for this kind of a thing. If you are not able to get money but are still interested in the project, let me know. (van Rood, 23 augustus, 1966)

18 Starzl heeft in samenwerking met vele anderen, waaronder Paul Terasaki en Ken Porter, bij zijn eigen niertransplantatiepatiënten onderzoek gedaan naar het klinisch en histologisch succes van de transplantaties. Daarbii hebben zij tevens gekeken naar mogelijke effecten van verschillende behandelingsopties en naar een eventueel effect van compatibiliteit van de leukocytenantigenen (Starzl, et al., 1965; Starzl, et al., 1966: Starzl, et al., 1966).

White blood cell antigens of the 36 surviving patients and their donors were studied with a lymphocyte cytotoxicity test to determine by retrospective analysis if this method might be helpful in evaluating the results as well as in the selection of donors for future cases. The correlation of the immunologic rating with the clinical result was imperfect in individual cases; many patients with poor matches have done well and two with good matches have had late difficulty. Nevertheless, the patients with the best course tended to be those with the least degree of antigenic incompatibility with their donors. Furthermore, the extent of donorrecipient incompatibility in the entire group was less than that which would have been predicted by indiscriminate pairing. These results suggest that the antigens being measured may have some relation, if only indirect, with histocompatibility. (Starzl, et al., 1965)

19 In hoofdstuk $7 \mathrm{zal}$ uitgebreid op de totstandkoming en inhoud van de samenwerking tussen William D. Kelly van de University of Minnesota en Van Rood worden ingegaan.

$20 \mathrm{Hij}$ schetst het belang voor Kelly en biedt drie mensen voor de prijs van een.

I think that such a visit is extremely important to get your group started on the histocompatibility testing. At the same time it would be possible for me to type a reference panel in your hospital. Such a reference panel would enable you to screen for sera of known specificities. This would make you independent of other sources which in this stage of the game is an invaluable asset.

... Our proposal is now that instead of paying for my fare you pay that of Miss Aad van Leeuwen, my head technician, who has been working with me for over ten years and with whom I have done all the leucocytegroup work. With little extra cost all three of us would come down to Minneapolis and would be able in a relatively short time to type the above mentioned panel. The only thing you would have to provide apart from some travel expenses and money for hotelaccomodation etc. would be the necessary equipment. As this is not anything extraordinary 1 don't think this will give any problems. The monospecific sera we will take along. (van Rood, 22 augustus, 1966)

2t Overigens gaat uiteindelijk niet George Eernisse, maar Hans Bruning mee. 
Ofschoon Starzl zegt dat ook zij lijden onder een soberheidsoffensief, zegt hij wel toe te zoeken naar financieringsmogelijkheden (Starzl, 7 september, 1966). Zijn 'financial wizard', Ralph Huntley, slaagt daarin en regelt verder de organisatie van het bezoek.

Gezien het grote aantal patiënten dat Starzl heeft getransplanteerd, zal in Denver dus meer dan genoeg te doen zijn voor het Leidse drietal22. Het aantal te typeren mensen wordt in Denver dan ook niet beperkt door het aanbod, maar door tijd23. Het typeren van extra mensen uit de directe omgeving van Denver, die zouden kunnen dienen als panel ${ }^{24}$, is vanwege tijdgebrek bijna niet mogelijk.

As for the number of people which can be tested ... We might be able to do an occasional extra one but preferably not. This is not an unwillingness of us to do more work, but is inherent in the test. ... In this way we would be able to accomplish about 80 tests during the whole period and this is in all probability a maximum. This kind of work is extremely tiring and I don't think it will be helpful if we give bad results. (van Rood, 31 oktober, 1966)

Er is ook weinig uitloopmogelijkheid, aangezien het typeringsprogramma tijdens de VS-reis aanzienlijk wordt uitgebreid en tussendoor ook nog de Contractors Meeting bezocht moet worden. Niet alleen in Denver zal getypeerd worden, ook in Minneapolis en Boston zullen ze de leukocytengroepen van ontvangers en donoren gaan bepalen. Los Angeles echter, waar het hele Amerikaanse idee mee begon, wordt tijdens deze reis niet aangedaan. Wel wil Van Rood nog naar New York, onder andere om daar een panel te typeren (van Rood, 28 september, 1966$)^{25}$. Verder regelt Van Rood nog een bezoek aan Boston ${ }^{26}$.

22 Van verschillende plaatsen in de VS komen mensen naar Denver om zich te laten typeren: Alaska, Hawail. etc. (Starzl, 17 oktober, 1966)

We must summon people from all over the country to Denver so that they will be available for your tissue typing work. (Huntley, 12 september, 1966)

23 Zie ook hoofdstuk 5 ten aanzien van zuinig omspringen met 'kostbare' antisera.

24 Aan Huntley schrijft Van Rood over het aantal te typeren mensen per dag:

If possible we would be happy to type of the 70 donors and recipients some of the people from the neighbourhood of Denver during the first two days. Tuesday, November 8 and Wednesday, November 9. We could do 8 people the first day (November 8 ), 12 people a day on November 9, 10, 11 , and 12 , the remaining days Miss van Leeuwen could do about 8 people and some repeats if necessary. (van Rood, az september. r966)

25 Het typeren van een panel voor Allen is een klein cadeautje, want het reisschema is al overvol.

Our travel schedule is getting into shape and it looks as if we will have a terribly crowded three weeks. The schedule is on the moment as follows:

We hope to leave on Thursday. November 3 and we will go straight to Minneapolis where we will do some typing and from where we will leave for Denver on Monday, November 7. We will all stay there till November 13, when I and Bruning will go to Washington to attend the Contractors Meeting. Aad will stay in Denver and join us on Friday, November 18, in Boston. We would leave there Tuesday morning probably, November 22 and go then to New York, from where we have to leave Wednesday night. November 23. If you think this will be useful I think it will be possible to type a small panel for you in that time. I would like however to give Aad and Bruning a chance to do some sightseeing and to talk to some people. As it is now we will hardly have time to do so. ... (van Rood, 28 september, 1966)

26 In de twee (gerenommeerde) ziekenhuizen in Boston, is Van Rood tijdens zijn sabbatical ook al eens geweest: het Peter Bent Brigham Hospital waar Merrill en Murray werken, en het Massachusetts General Hospital waar Russell de chirurgische scepter zwaait. Aan de laatste schrijft hij:

I would like to know whether you are still interested in a cooperation. The reason I am writing you is that I will be visiting the United States in the middle of November to attend a Contractors Meeting of the N.I.H. This would be an ideal opportunity to visit Boston and type the people you have been skingrafting and any of the kidney recipients and donors which might give information. This would have the added advantage for you that you start out with a well typed panel too. (van Rood, 23 augustus, 1966)

Waarop Russell hem schriift dat met het typeren van de 'niertransplantaties' tevens een panel samengesteld kan worden en ook hun eigen sera met die uit Leiden kunnen worden vergeleken (Russell, 30 augustus, 1966). 
De reis gaat uiteindelijk van Minneapolis naar Denver en via de Contractors Meeting naar Boston 27. Op alle locaties zijn niertransplantatiepatiënten en hun donoren naar het laboratorium gekomen om getypeerd te worden. En nadat Van Rood in New York een panel heeft getypeerd, gaan ze naar Leiden terug met de ruwe typeringsresultaten van ongeveer 70 donor/ontvanger-combinaties. Na thuiskomst schrijft Van Rood de artsen die op de verschillende locaties de mogelijkheden voor de typeringen hebben geboden. Enerzijds om hen hiervoor te bedanken, anderzijds doet hij dit om meer gegevens over de getransplanteerden te verkrijgen. Deze gegevens betreffen zaken als relevante personalia, bloedgroep, transplantatiedatum en de klinische toestand (van Rood, 28 november, 1966; van Rood, 28 november, 1966; van Rood, 28 november, 1966).

Kort na de trip door de VS schrijft Van Rood aan Pablo Rubinstein ${ }^{28}$ dat deze reis wel eens een verrassende uitkomst zou kunnen hebben.

I found your letters of October 25 and November 24 on my return from the States where I have been travelling around with Aad van Leeuwen and Hans Bruning, typing almost 70 kidney donor and recipient pairs. The data have not been fully analysed yet but certainly look interesting and they might be quite surprising.

If my first impression is correct, leukocyte groups might be after all not that important for the survival of the kidney grafts??? (van Rood, 30 november, 1966) In een brief aan Ceppellini laat hij zich nog negatiever uit over het belang van typeren voor transplantatie. De hoop en verwachting, dat matchen op leukocytenantigenen het klinisch resultaat van (nier)transplantaties in grote mate verbetert, zou wel eens een luchtkasteel kunnen blijken te zijn.

Aad has returned now from the States, too, and we are busy writing up the data both from the States and Torino. So far things look very bad indeed. I will send you the details in a next letter when I have analysed the data of the families more fully but I don't think they will be publishable. (van Rood, 14 december, r966)

In de volgende brief aan Ceppellini relativeert hij het pessimisme voorzichtig. Mogelijk heeft het typeren en matchen van leukocytenantigenen toch een gunstig effect op de overlevingsduur van niertransplantaten.

We are finished with the analysis and things don't look so bad after all, but some essential controls are still lacking. (van Rood, 28 december, 1966)

$\mathrm{Na}$ de allereerste analyses ontstaan er onduidelijkheden over de klinische gegevens. Van Rood probeert bij de verschillende laboratoria extra data te krijgen. Aan Starzl schrijft hij:

Analysing the data I noticed that we did not determine the leukocyte groups of a number of alive recipients and their donors. ... Am I correct in assuming that these patients were alive but that we were not able to test them for technical

27 In Boston wordt zo voor het eerst in de geschiedenis een (indirecte) samenwerking tussen het Peter Bent Brigham en het Massachusetts General tot stand gebracht. Doordat in beide ziekenhuizen de respectievelijke patiënten worden getypeerd, nemen zi) beiden deel aan een en hetzelfde project en is er dus - technisch gesproken - sprake van 'samenwerking'.

28 Een Chileense arts, die Van Rood gedurende zijn sabbatical in de VS heeft leren kennen en die een periode in Leiden onder andere aan het onderzoeken en opzetten van geautomatiseerde leukocytengroepentypering heeft gewerkt (de Autoanalyser). 
reasons? This makes a big difference in our analysis. (van Rood, 23 januari,

1967)

In zijn antwoord op de brief van Van Rood zegt Starzl, dat één niet getypeerde combinatie een identieke tweeling is en dat twee patiënten geen biopsie wilden ondergaan en daardoor voor zijn onderzoek niet interessant waren om mee verder te gaan. Verder was een donor overleden, wat het typeren van de ontvanger zinloos maakte en bij de overigen bedroeg de postoperatieve periode nog niet langer dan twintig maanden, wat hij niet voldoende vond om mensen naar Denver te laten komen. Later kunnen deze patiënten wel worden getypeerd (Starzl, 3r januari, 1967).

Van Rood stuurt eind Juni 1967 aan een aantal van de bij de Leidse transplantaties betrokken personen ${ }^{29}$ een notitie met zijn conclusies over de verschillende onderzoeken, getiteld: "De bestudering van patiënten die een niertransplantaat ontvangen hadden." Enerzijds geeft hij hierin weer dat ook bij "random donoren" de match beter kan zijn dan tot dan toe werd aangenomen, door het frequenter voorkomen van bepaalde genotypencombinaties. Hier stelt hij echter de vraag tegenover wat de waarde is van de kwalificatie 'identiek', hij betwijfelt of deze combinaties ook later, na verder onderzoek, nog identiek zullen blijken te zijn. Anderzijds zijn er aanwijzingen "dat een donor-ontvangercombinatie die identiek is op één antigeen na, een even goede prognose heeft als de gevallen die voor alle antigenen identiek zijn" (van Rood, 24 april, verstuurd 27 juni, 1967$)^{30}$. De hoop op het kunnen matchen van niet verwante donor/ontvanger-combinaties neemt toe, maar tegelijkertijd groeit ook twijfel over de betrouwbaarheid van de, uit dit retrospectieve onderzoek verkregen, resultaten. De onbekendheid van onder andere de mechanismen waarlangs afstoting precies plaatsvindt, is hier mede debet aan. De hypothese die onder meer in deze notitie wordt onderzocht, is dat die patiënten, waarbij de getransplanteerde nier geen verschijnselen van afstoting vertoont ${ }^{31}$, een betere match met hun donor moeten hebben, dan verwacht kan worden bij een willekeurige donor. Een eerste conclusie is, dat het matchen op leukocytenantigenen wel degelijk invloed heeft op de prognose van het transplantaat. Een tweede en meer verrassende conclusie is, dat een 'incompatibele' nier het niet slechter hoeft te doen dan een 'identieke' nier. Dit geldt echter alleen voor die gevallen waar de incompatibiliteit zich beperkte tot een enkel antigeen en de donor en ontvanger voor de overige antigenen wel hetzelfde zijn ${ }^{32}$. Van Roods conclusie is voorzichtig positief.

Too few data are available at the moment to allow us to make a statement on the

29 De. Lameyer, Prof. Vink, Prof. de Graeff en Dr. Struyvenberg

30 Over het mechanisme van afstoting tast men echter nog in het duister, zoals blijkt uit het vervolg van deze notitie.

Indien dit het geval is zou men kunnen veronderstellen dat de allogeneic inhibition in feite belangrijker is voor de afstoting van een orgaan dan incompatibiliteit. Allogeneic inhibition betekent dus in dit geval dat de ontvanger een of meerdere antigenen meer heeft dan de donor. Tot werkelijke afstoting zou het dus kunnen komen wanneer de donor zowel antigenen heeft, als mist, die de ontvanger respectievelijk mist en heeft. De ontvanger lymphocyten zouden dan antistoffen kunnen vormen tegen het transplantaat. Deze antistoffen zouden de lymphocyten in staat stellen zich te hechten aan het transplantaat. De zo gehechte lymphocyten zouden via de allogeneic inhibition het transplantaat te gronde kunnen richten. Dit is op het ogenblik nog zuiver speculatief en de tot nu toe beschikbare statistische gegevens pleiten noch voor noch tegen deze hypothese. (van Rood, 24 april, verstuurd 27 juni, 1967)

3I. Voor deze bepaling wordt een biopsie genomen van de getransplanteerde nier, zodat een histologische beoordeling kan plaatsvinden.

32 Overigens is dit dus in tegenspraak met de typeringsgegevens van de eerste niertransplantatie in Leiden. warbij sprake was van incompatibiliteit, zonder voor het overige hetzelfde te zijn. (Zie hoofdstuk s) 
importance of leucocyte groups for kidney graft survival using random donors. However, in view of the data in the sib-sib group it is likely that leucocyte group matching will improve the prognosis for a renal graft from a random donor. (van Rood, et al., 1967$)^{33}$

Wanneer het aantal bestudeerde donor/ontvanger-combinaties verder is uitgebreid van 45 tot 65 , wordt de conclusie stelliger, namelijk dat, voor wat betreft de sib-sib transplantaties, de prognose significant beter is bij een identieke donor/ontvangercombinatie, maar dat van andere dan sib-sib combinaties nog niets kan worden gezegd (van Rood, et al., 1967).

De voorzichtigheid en beperkte geldigheid van de claims in deze artikelen verdwijnt in de contract-hernieuwingsaanvraag voor het National Institute of Health, welke Van Rood eind 1967 aan Donald Kayhoe stuurt. Hij resumeert hierin het werk van de afgelopen jaren en geeft de plannen voor de toekomst weer ${ }^{34}$.

The work has progressed satisfactorily these last years. As a result we believe to be in a much better position to formulate the optimal conditions for the survival of a tissue graft. An analysis of kidney transplant data showed that donor and recipient should be identical for the so called HL-A antigens. ... (van Rood, I2 december, 1967)

$\mathrm{Bij}$ het retrospectieve onderzoek bij levende donoren lijkt er sprake te zijn van een matchingseffect. Hierbij gaat het in veruit de meeste gevallen niet alleen om een levende donor, maar tevens om een verwante van de ontvanger. Dat wil zeggen om een ouder, of om een broer of zuster van de ontvanger.

\subsection{2 'Kadaverdonoren'}

De meeste levende donoren kunnen later, ook na langere tijd nog, getypeerd worden. $\mathrm{Zij}$ kunnen zelfs jaren later gevraagd worden om naar het ziekenhuis te komen (om daar wat bloed af te laten nemen) voor een typering.

Bij het transplanteren van nieren afkomstig van kadaverdonoren, stelt iemand organen beschikbaar na overlijden. De mogelijkheid om jaren later de betreffende donor op te roepen voor typering, ontbreekt uiteraard bij kadaverdonoren. Het typeren van leukocyten zou alleen kort nadat de donor is overleden nog kunnen. Het conserveren van te typeren materiaal zou een oplossing kunnen zijn. Zo is bijvoorbeeld het invriezen van leukocyten in ontwikkeling ${ }^{35}$, alleen biedt dit voor de ag-

33 Op basis van het aantal overlevende identieke, compatibele en incompatibele patiënten dat verwacht kon worden en aangetroffen werd, wordt geconcludeerd dat van de identieke donor/ontvanger-combinaties waarschijnlijk niemand is overleden, dat van de compatibele groep $60 \%$ en van de incompatibele groep $75 \%$ is overleden.

In our opinion these data indicate that in sib-sib combinations leucocyte group matching is of prime importance for the prognosis of the graft. (van Rood, et al., 1967)

De eindconclusie van het artikel is echter minder stellig.

34 Van Rood geeft per hoofdpunt kort aan wat er is gedaan.

As will be evident from the enclosed reprints, the work of our group has continued along the line of our first contract proposal dated March ist, 1965. These topics were the following:

1. Monospecific reagents recognizing leukocyte antigens were screened and collected and made available in bulk to the serum bank of NIH. A total of $7060 \mathrm{ml}$. of such serum has been made available.

2. The leukocyte antigens were studied together with appropriate population and family studies.

3. The relevance of these antigens for organ transplantation was studied.

4. The purification and chemical definition of these antigens was undertaken.

(van Rood, 12 december, 1967 )

(Allen, 10 maart, t967) 
glutinatietechniek geen oplossing, aangezien deze immers alleen met 'verse' leukocyten werkt.

Voor de agglutinatietechniek biedt het gebruik van de milt, mogelijk een oplossing. In verschillende transplantatiecentra is het (in 1966) gebruikelijk om bij een transplantatie de milt van de ontvanger te verwijderen. Men verwacht dat de verwijdering van dit antilichaamproducerende orgaan een gunstig effect heeft op de prognose van het transplantaat.

Toen wij van deze gewoonte hoorden, hebben wij gevraagd de milten voortaan niet weg te gooien, maar te bewaren in de diepvries. Ook hebben wij gevraagd de milt van de patiënt die de nier had afgestaan, de donor dus, in de diepvries op te slaan. (De donors waren in het algemeen patiënten die overleden waren bij auto-ongelukken en dergelijke). Deze bevroren milten werden iedere twee à drie maanden naar Leiden verzonden, waar het mogelijk was om met deze diepgevroren milten weefsel- of leucocytengroepen van de donor en de ontvanger te bepalen. (van Rood, et al., 1970)

Door het retrospectief typeren van milten kan het matchingseffect ook bij transplantaties van kadaverdonoren worden onderzocht. Leukocytenantigenen zijn ook aanwezig in miltweefsel en door middel van absorptie-experimenten kan de typering van de leukocytenantigenen worden bepaald ${ }^{36}$. Zo wordt een uitbreiding van het onderzoek naar het matchingseffect verkregen.

Since 1966 the spleens of both the donor and recipient of a kidney transplant have been removed in St. Mary's Hospital, London, (Dept. Head Dr. S Peart, Dr. J.F. Mowbray) and in the Department of Transplantation Clinique St. Pierre, Louvain (Head Dr. G.R.J. Alexandre). These spleens were stored at $\cdot 20^{\circ} \mathrm{C}$, shipped frozen to Leiden, and there freeze-dried, after which the leukocyte groups of both the donor and the recipient were determined by an agglutination inhibition test. (van Rood, et al., 1969)

Door zowel de milt van de patiënt als de overledene in te vriezen, wordt het retrospectieve onderzoek zelfs onafhankelijk van plaats en tijdstip van transplantatie ${ }^{37}$.

De onderzoekers in Leiden hebben verschillende contacten voor wat betreft dataverzameling op basis van milten. Uit Leuven (van Alexandre) en uit Londen (van Mowbray en Peart) krijgt Van Rood milten opgestuurd ${ }^{38}$. De resultaten van dit in 1966 gestarte retrospectieve typeringsonderzoek bij kadaverdonoren verschijnen in 1969 in de eerste aflevering van Transplantation Proceedings, het officiële tijdschrift

36 Leucocyte agglutination-inhibition test:

Het absorberen van leukocyten-antistoffen. Voor alle absorptieproeven werd het mengsel van leukocyten en serum gedurende ten minste 20 minuten bij $37^{*} \mathrm{C}$ (waterbad) geincubeerd. Na absorptie werd de buis to mimuten bij 4500 toeren per minuut gecentrifugeerd. Vervolgens werd het geabsorbeerde serum verwijderd en getoetst aan een nieuw monster van de leukocyten waarmee de absorptie werd uitgevoerd. (van Rood, et al., 1959)

Bii de milten wordt de ingevroren milt ontdooit, gehomogeniseerd en vervolgens gevriesdroogd. Sera worden vermengd met het miltpoeder, geincubeerd en vervolgens gecentrifugeerd. De geabsorbeerde sera worden vervolgens getest op overblijvende antilichaamactiviteit.

37 Wanneer de milt ook daadwerkelijk bij de donor wordt uitgenomen. Dit wordt echter wel eens vergeten, zoals Alexandre aan Van Rood schrijft.

I hope that in the future he will remember it, even in the hurry of the moment. (Alexandre, iz januari, 1967)

38 Daarnaast worden verschillende aanbiedingen gedaan om milten op te sturen (Abbott, 21 november, 1966; Beck, 23 juni, 1967; Stewart, 3 april, 1968), die Van Rood echter af moet slaan vanwege de arbeidsintensiviteit van de milttyperingen (van Rood, 24 mei, 1966). 
van de Transplantation Society. De conclusie luidt dat matchen niet alleen een positief effect heeft op de overleving van een niertransplantaat bij een levende, verwante donor, maar ook bij een niet-verwante kadaverdonor. Tevens wordt geconcludeerd, dat volledige identiciteit niet noodzakelijk is voor een verbetering in de prognose.

\section{Conclusions}

I. Leukocyte-group matching is able to improve the prognosis of a kidney allograft, irrespective of whether the donor is a sib, a parent, or an unrelated individual.

2. Donor-recipient pairs identical for the main HL-A antigens have the best prognosis, but, so far, a mismatch for one antigen still entails a better than average prognosis. (van Rood, et al., r969)

Het retrospectief typeren van zowel ontvangers als levende- en kadaverdonoren heeft laten zien dat een matchingseffect optreedt. Het lijkt dus de moeite waard om voor een wachtende ontvanger een identieke of bijna identieke donor te zoeken.

\subsection{Prospectief KLinisch Onderzoek}

Het onder immunosuppressieve bescherming uitvoeren van transplantaties is in de jaren 60 een wijd verbreide praktijk geworden. Op verschillende plaatsen in de wereld worden niertransplantaties uitgevoerd. Leuven is sinds I963 een van die plaatsen. Leiden volgt drie jaar later, na een lange voorbereidingsperiode. Een deel van die voorbereidingen zorgen ervoor, dat Leiden ook aan de andere centra, waaronder Leuven, iets te bieden heeft. Zoals het CLB service verleent aan andere ziekenhuizen door bijzondere bloedgroepen te bepalen, zo biedt het laboratorium in Leiden aan om leukocytengroepentyperingen te verrichten voor andere niertransplantatiecentra.

We are prepared to send you our patients with their living donors but one detail we should work over is the payment of the trip. Can you get money to pay it ...

(Alexandre, 22 maart, 1966)

In Leiden kunnen per dag 8 bepalingen gedaan worden. Patiënten en hun potentiële donoren, komen vanuit Leuven per trein naar Leiden en moeten daar om ongeveer 10.00 uur arriveren. Zou men later arriveren, dan heeft dat tot gevolg dat men tot laat in de avond op het laboratorium bezig is met het uitvoeren van de bepalingen, zo schrijft Van Rood, waar hij aan toevoegt dat de reiskosten door het Leuvense ziekenhuis moeten worden betaald (van Rood, $x$ april, I966). In de hierop volgende periode zijn er echter slechts enkele transplantaties voorzien met levende donoren. De bereidheid om prospectief te typeren is aanwezig, maar in de praktijk komt het er nauwelijks van. Het aantal servicetyperingen neemt toe, wanneer het mogelijk wordt om alleen het bloed van een persoon te sturen, mits de tijd tussen afname en aankomst in het lab niet te lang is ${ }^{39}$.

Aanvankelijk zijn er naast Leiden wereldwijd slechts enkele laboratoria waar klinische typeringen worden uitgevoerd. Toch is men in Leiden ten aanzien van uitbreiding van het aantal laboratoria - kort na de Leidse Workshop in 1965-terug-

39 Overigens faciliteerde deze mogelijkheid ook het retrospectieve onderzoek. Zo kwam bijvoorbeeld de chirurg Terpstra uit Rotterdam met bloed van de ontvanger om het te laten typeren, nadat hij de niertransplantatie had verricht. (van Leewwen, 17 oktober, 1994) 
houdend. De grote verschillen in reproduceerbaarheid van typeringen tussen de verschillende onderzoekslaboratoria, de grote verscheidenheid aan technieken en het (nog) niet voorkomen van identiek reagerende antisera zijn hiervoor een belemmering. Dat verandert als onderzoekers in de gelegenheid worden gesteld de technieken in Leiden te leren.

A program to train senior technicians and other people interested in leukocyte grouping was conceived and started in October 1966.... (van Rood, 14 juni, 1967)

Wanneer mensen een langdurige training in Leiden hebben ontvangen, zijn ze qua vaardigheden in staat om een zelfstandig laboratorium op te zetten. Via de overdracht van vaardigheden worden de faciliteiten voor leukocytentypering verspreid over de wereld (V.S., Zuid- Afrika, Engeland), zoals Van Rood aan Trnka schrijft.

We know now that this program can be extremely effective and it has the

advantage that a technician who has spent six to nine moths in our laboratory on coming home will find women who produce the antibodies of known specificity needed to do leukocyte group work. (van Rood, i4 juni, 1967 ) 40

In de loop van 1966 komen er dus vanuit verschillende laboratoria mensen naar Leiden om het vak (inclusief de fijne 'Leidse' kneepjes) te leren (van Rood, 30 maart, 1966; van Rood, 26 april, 1966; van Rood, 12 juli, I966; van Rood, 15 augustus, 1966). Sommige aanvragers worden doorverwezen naar een ander laboratorium dat het vertrouwen van Leiden geniet (van Rood, 12 september, 1966) ${ }^{41}$. De komst van veel van deze mensen naar het laboratorium in Leiden houdt verband met het toenemend aantal centra waar niertransplantaties worden gedaan en waar men interesse heeft om de donorselectie te verrichten aan de hand van typeringen.

Inmiddels wordt duidelijk dat men ook in Denver al prospectief typeert bij de selectie van een levende donor. Aangezien Van Rood er bij zijn analyses in het kader van het retrospectieve onderzoek vanuit ging dat geen van de donoren prospectief getypeerd en dus gematcht was, vindt hij dit een complicatie in het onderzoek. De donor/ontvanger-combinaties die ze daar getypeerd hebben, blijken nu geen homogene groep te vormen. De prospectieve combinaties kunnen volgens Van Rood niet zomaar in de analyse van de retrospectieve gegevens worden meegenomen. De 'Denver-groep' moet nu worden gescheiden in een groep van combinaties die random getransplanteerd zijn en een groep waarbij er vooraf enige vorm van matchen heeft plaatsgevonden ${ }^{42}$. Vandaar dat Van Rood aan Starzl vraagt vanaf wanneer Terasaki prospectieve typeringen voor hem heeft gedaan (van Rood, 23 januari, 1967). Starzl's antwoord laat hij vergezeld gaan van twee artikelen, die niet erg bemoedigend zijn voor de 'weefseltypeerders'.

Terasaki did prospective typing from case $\mathrm{LD}_{5}$ onward 43 .

$I$ am enclosing two manuscripts which we presented at a recent meeting in

40 Een jaar later is de WHO bereid om $\$ 5,000$ te fourneren voor de organisatie van een cursus weefseltyperen, welke in augustus 1968 plaats vindt. Van Rood vraagt Trnka of hij dit geld volledig en naar eigen inzicht aan die cursus mag besteden. (van Rood, 14 december, 1967)

$4 \mathrm{~T}$ Laboratoria waar met de Leidse antisera en technieken panels zijn getypeerd, waardoor - voor onderzoeksdoeleinden - de Leidse situatie zo goed mogelijk gekopieerd is en waar iemand dus in Leiden is getraind. De centrumpositie van Leiden in het typeringsveld wordt op deze manier nog eens bevestigd.

42 Deze groep vormt dus op zich een prospectieve populatie, alleen niet voor de Leidse onderzoekers. Voor Starzl wel natuurlijk, maar met hun (dat wil zeggen Terasaki's) typeringstechnieken en antisera. 
California. One of these contains a thumbnail summary of the results with prospective typing. You will note that the results were somewhat more disappointing than had been hoped for. (Starzl, 31 januari, 1967)

Ondanks dit minder positieve geluid, blijft men in Leiden prospectief typeren, zowel bij de eigen patiënten, als voor andere centra. De positieve eindconclusies die ze uit de analyse van de retrospectieve typeringsgegevens trekken, rechtvaardigen dit.

Om deze problemen te ondervangen, stelt Van Rood aan zijn (bij de Leidse niertransplantaties betrokken) collega's, ten aanzien van de donorkeuze bij toekomstige transplantaties, vragen over welke criteria gehanteerd dienen te worden. Moeten ook donoren geaccepteerd worden waarvan een minder goed resultaat verwacht kan worden? De bestaande onzekerheid over het effect van matchen, maakt dat het identiekzijn van de donor niet als hard criterium gehanteerd kan worden. Het moeilijkst is deze vraag bij sib-sib relaties, daarover is het meeste bekend. Bij parent-child combinaties lijkt een antwoord makkelijker te geven, aangezien minder bekend is over de aanwezigheid van een matchingseffect. Vandaar dat Van Rood de suggestie doet om alleen die donoren uit te sluiten die sterk incompatibel zijn. Ten aanzien van random donoren bestaat geen idee over selectiecriteria (van Rood, 24 april, verstuurd 27 juni, 1967$)^{44}$. De criteria voor de positieve, dan wel negatieve keuze voor een bepaalde donor bij een bepaalde patiënt, zijn dus nog niet duidelijk. Alleen bij een waargenomen identiciteit voor bekende leukocytenantigenen bij sibs, kan een betrouwbare voorspelling worden gedaan, maar zelfs daarvan vraagt Van Rood zich af of die bij verder onderzoek inderdaad identiek zullen zijn.

Aan het evaluatie-onderzoek lijkt voorlopig geen eind te komen. Hoe meer patiënten worden betrokken in de het evaluatie-onderzoek rond leukocytenantigenen - of, zoals ze nu worden genoemd: histocompatibiliteitsantigenen -, des te beter wordt de beoordeling van het effect van matchen op het beloop van transplantaties.

\subsection{Prospectief KLinisch Onderzoek met Kadaverdonoren}

Op 21 januari 1967 wordt de eerste Leidse kadaverdonortransplantatie uitgevoerd. In het voorgaande jaar zijn twee transplantaties verricht, waarbij de getransplanteerde nier afkomstig was van een verwante donor. Bij beiden was de gedoneerde nier afkomstig van de moeder van de patiënt. De derde transplantatie in Leiden is de eerste waarbij de getransplanteerde nier niet afkomstig is van een verwante. Ook bij de vierde transplantatie is de getransplanteerde nier afkomstig van een overle-

44 Of zoals Van Rood het zelf schrijft:

1. Wat doen wij in die gevallen, waarin slechts een niet identieke of eventueel slechts een compatibele sib als donor beschikbaar is?

2. Wat doen wij bij de parent-child combinaties. De gegevens zijn op het ogenblik nog niet significant. Ik zou willen voorstellen om vooriopig de ouders, indien zij als donor in aanmerking komen, in de eerste plaats te selecteren op die factoren die buiten het histocompatibiliteitsonderzoek liggen en slechts die ouders uit te sluiten die sterk incompatibel zijn (dat wil zeggen voor twee of meer belangrijke antigenen incompatibel).

3. Voor de random donors is de situatie op het ogenblik volkomen duister. Voor zover mij bekend zijn er ook in andere centra geen goede gegevens beschikbaat. Ik stel voor om hier weer over te gaan op het verrichten van huidtransplantaties en systematisch de verschillende mogelijkheden te onderzoeken. Als de ontvanger en eventueel donors zou ik willen voorstellen, behalve faculteitsleden, ook de familieleden van toekomstige candidaten voor niertransplantatie in te schakelen. Dit geldt dan vooral ook voor de moeders van de patiènten, welke ook "gebruikt" kunnen worden voor de antilichaamproductie. Het tekort aan antilichamen blijft op het ogenblik een van de belangrijkste bottle necks. (van Rood, 24 april. verstuurd 27 juni, 1967) 
dene, terwijl bij de vijfde de vader van de patiënt als donor fungeert. De zesde en zevende transplantatie worden op dezelfde dag verricht en het is waarschijnlijk dat de nieren hiervoor van één en dezelfde donor afkomstig zijn (Niertransplantatie-werkgroep, $I 967)$. In dit jaar volgen nog twee transplantaties met nieren van overledenen, zodat het totaal in 1967 op zes kadaverniertransplantaties en één verwante-niertransplantatie komt. In het daarop volgende jaar worden totaal zeventien transplantaties verricht, waarbij in vier gevallen de getransplanteerde nier niet van een kadaverdonor afkomstig is (Hintzen, 1971). Daarmee komt het aantal kadaverniertransplantaties op negentien gedurende de eerste twee jaar, op een totaal van zesentwintig. Ten bate van het klinisch onderzoek worden relevante gegevens van de transplantatiepatiënten geregistreerd en worden de patiënten zelf opgeleid om materiaal op een gestandaardiseerde wijze te verzamelen ${ }^{45}$. Van al deze inspanningen maakt Hintzen gebruik voor zijn proefschrift met een analyse van alle primaire transplantaties die in Leiden tot 24 maart 1969 in het Academische Ziekenhuis te Leiden zijn uitgevoerd. In zijn samenvatting en conclusies zegt hij over het belang van weefseltypering het volgende:

Bij transplantaties tussen broer en zuster is het histocompatibiliteitsonderzoek van doorslaggevende betekenis; bij transplantaties tussen ouders en kinderen is dit in mindere mate het geval; bij transplantaties met nieren van niet-verwante donoren staat de waarde van het histocompatibiliteitsonderzoek nog niet vast. (Hintzen, 197I)

Om alle transplantatieresultaten te kunnen combineren en daarmee de waarde van weefseltypering te kunnen bepalen, doet Howard Goodman van de WHO het NIH (in de persoon van Charles Huttrer ${ }^{46}$ ) het voorstel om een centraal register op te zetten van alle orgaantransplantaties.

A registry of information about heart and other organ transplantation, so that a more effective assessment can be made of the value of histocompatibility matching using leukocyte antigens for the prolongation of graft survival.

(Goodman, I augustus, 1968)

Zowel lokaal, als internationaal blijven onderzoekers, op verschillende manieren bezig met het onderzoeken van het matchingseffect en de samenhang met het gebruik van immunosuppressiva. Ook de Projectgroep Orgaantransplantatie TNO 47 probeert via een experimentele aanpak antwoorden te vinden op vragen als bijvoorbeeld: wat zal er gebeuren wanneer men na drie maanden de immunosuppressieve therapie snel vermindert en tenslotte staakt? En stellen zij de vragen: "Hoe belangrijk is de selectie van donors op basis van leukocytengroepen? Is het geplande prospectieve onderzoek bij apen-nier-transplantatie nog voldoende opportuun?" (Werkgroep Orgaantransplantatie TNO, 24 maart, 1969). Vele vragen zijn, ook enkele jaren later, nog onbeantwoord. Dat de TNO-Werkgroep vraagtekens zet bij het voorgenomen prospectief onderzoek bij apen, wijst op de mogelijkheid dat dit onderzoek misschien overbodig is. Of het is al aangetoond dat matchen effect heeft op de overlevingsduur van een transplantaat, ó de hooggespannen verwachting rond het effect van matchen slinkt. Zo is het de vraag of de overtuiging van de aanwezigheid van een matchingseffect zich bij iedereen in dezelfde richting ontwikkelt.

45 Ternperatuur, gewicht, etc.

46 Dr. Charles P. Huttrer, Special assistant to the Director, Office of program planning, NIH

47 Een samenwerkingsverband tussen Leiden en Rijiswijk, waar begin 1968 Rotterdam aan wordt toegevoegd. 


\subsection{Heeft Matchen Effect?}

De verschillende studies en experimenten die in de loop van de tijd worden verricht, voeden in toenemende mate het idee dat leukocytenantigenen een belangrijke rol spelen bij de afstoting van getransplanteerde organen en dat matchen het resultaat van transplantaties zou kunnen verbeteren. Over het belang van weefseltypering is men het echter niet eens. Bij transplantaties spelen namelijk zeer veel variabelen een rol, waardoor de resultaten van verschillende experimenten en transplantatieprogramma's niet altijd even goed met elkaar blijken te correleren. Door matchen op basis van weefseltypering te presenteren als een techniek waarmee de kans op en de mate van afstoting verkleind zou kunnen worden, wordt bevorderd dat weefseltypering een prominentere plaats inneemt in de transplantatiepraktijk. Vanaf de introductie heeft weefseltypering echter een geduchte concurrent in de vorm van immunosuppressieve therapie. Tegelijkertijd is het aan deze concurrent te danken dat weefseltypering zich in de transplantatiepraktijk een plaats kan verwerven, aangezien immunosuppressiva reeds gebruikt werden ten tijde van de opkomst van leukocytengroepbepaling.

Dankzij de onder immunosuppressieve bescherming verrichtte transplantaties, kan retrospectief getypeerd worden en kan het matchingseffect worden onderzocht. In de transplantatiepraktijk staat de noodzaak tot het gebruik van immunosuppressiva vast. Voor weefseltypering kan hoogstens op een belangrijke rol worden gehoopt, die de noodzaak van het gebruik van immunosuppressiva vermindert, dan wel weg. neemt. Het aantonen van een matchingseffect is daarvoor essentieel, maar juist het gebruik van afstotingsremmende geneesmiddelen vertroebelt het onderzoek en de onderzoeksresultaten. Ook bij prospectief getypeerde transplantaties worden immers immunosuppressiva gebruikt. De overlevingsduur van een transplantaat is dus niet alleen afhankelijk van de kwaliteit van de match, maar ook van de immunosup. pressieve behandeling. Verschil in de wijze waarop onderzoekers hun onderzoekspopulaties samenstellen, resulteert in afwijkende ideeën over het effect en het belang van matchen.

De eerste berichten over het al dan niet optreden van een effect van matchen zijn niet bemoedigend. Terasaki is van mening dat, door de snel toegenomen kennis over de leukocytenantigenen, de correlatie tussen transplantaatoverleving en 'compatibility' tussen donor en ontvanger onderzocht kan worden. Terasaki verricht dit matchingsonderzoek, eerst retrospectief en later prospectief, bij de patiënten van Starzl. Hij hanteert daarbij de volgend hypothese:

If leukocyte antigens act as histocompatibility determinants, then these antigens would be expected to be well matched in human kidney transplant patients who have survived for long periods. ... (Terasaki, et al., 1966)

Terasaki neemt dus de groep klinische successen en onderzoekt deze vervolgens op overeenkomsten in antigenen. Dit zijn de patiënten die (mede) door het gebruik van immunosuppressiva zo lang hebben overleefd. Op basis van zijn onderzoek bij deze patiënten, concludeert Terasaki dat het belang van de antigenen, en dus van matchen, niet moet worden overschat.

It will be shown here that contrary to expectations, many kidney transplant survivors were incompatible with their donors in 1 or sometimes $\mathbf{2}$ of the serologically strong leukocyte antigens. These serologically detected antigens are therefore probably not by themselves strong transplantation antigens in the sense that a mismatch would result in inevitable graft rejection in spite of 
current immunosuppressive therapy. (Terasaki, et al., 1966) ${ }^{48}$

Starzl verliest, door de teleurstellende resultaten die ze er in Denver mee boeken, in de loop van de jaren zijn hoop op en vertrouwen in de waarde van prospectieve weefseltypering ${ }^{49}$. In een brief aan Van Rood - kopieën met gepubliceerde resultaten vergezellend - klinkt dan nog zijn teleurstelling door (Starzl, 31 jamuari, 1967) ${ }^{50}$.

Rond dezelfde tijd dat Starzl zijn vertrouwen in het belang van matchen begint te verliezen (na het typeringsbezoek van Van Rood), begint Van Rood juist met het in bredere kring bekend maken van de mogelijkheid van weefseltypering ten bate van niertransplantatie. Hij probeert basaal medisch-wetenschappelijke kennis over te dragen, maar geeft ook aan welke betekenis matchen zou kunnen hebben voor de overleving van een niertransplantaat.

Gaarne zou ik in de gelegenheid worden gesteld op de 92ste Algemene

Vergadering van de Nederlandse Ziektekundige Vereniging op zaterdag 14

oktober a.s. te Utrecht een voordracht te houden, getiteld: De betekenis van

leucocyten of weefseliso-antigenen voor de prognose van een niertransplantaat'.

... (van Rood, 15 augustus, 1967 )

In lijn met de resultaten van Starzl en Terasaki (e.a.), vervolgt Van Rood dat het identiek zijn van donor en ontvanger een beter resultaat oplevert, maar hij brengt dit in tegenstelling tot Starzl - als een belofte voor de toekomst. Het positieve effect van

48 Starzl, een van de co-auteurs bij dit artikel van Terasaki, is een van de eersten die weefseltypering toepaste in combinatie met niertransplantatie. Zo'n dertig jaar later zegt hij over zijn ervaringen met weefseltypering het volgende:

Well I wasn't opposed to tissue matching then and as I said here, I was the first one to ever try to use it in a systematic way ... I set up tissue matching with a guy named Terasaki and we started in October of 1964 ... and we used tissue matching for five years. Al the while everyone was expecting that it was going to be valuable. And we could see its value, but only if there was perfect matching, anything less than that we couldn't see an effect. (Starzl, 3o September, 1994)

49 Het retrospectieve onderzoek leverde bemoedigende resultaten op, geheel in lijn met de latere resultaten van de Leidse groep. Maar de genoemde pogingen van Starzl om prospectief gematchte nieren te transplanteren zijn teleurstellend.

The retrospective study was finished by autumn and when our kidney program was reopened in October 1964 , it included the first effort ever made at prospective matching (78). At the time, kidney donation in Colorado was still being accepted from volunteer convicts at the Canon State Prison who were numerous enough in many cases to allow a choice amongst as many as 50 or 60 . In spite of the size of the unrelated donor pool, it was difficult to find a perfect or even good match whereas very complete matches were encountered frequently if there were multiple potential donors within a family.

The results when the transplantations were actually performed were disappointing. The matching in unrelated cases, although never complete, was better than that previously achieved by chance when no such efforts had been made. However, no difference could be seen in the recovery of patients who received kidneys from these relatively well-matched versus completely mismatched donors or in the histopathology of the grafts which were graded by Porter after biopsy.

The results were reported as "preliminary" in 1966 , but by 1969.1 was alarmed by the continued lack of correlation between clinical outcome and quality of matching in unrelated cases (by now largely cadaver donors) and concerned about my role in starting these epidemic efforts at matching five years previously and spurring them on subsequently. We collected clinical data on all of our patients in whom we had tissue typing information from the beginning of our Colorado program in 1962 until the present and arranged the first of several gruelling work sessions at Terasaki's laboratory. The conclusion was that typing was not a discriminating instrument of donor selection using unrelated donors, that it could be used to select ideal donors within families, and that short of perfect matches, it was only equivocally helpful even within families. (Starzl, 1991)

50 Starzl schrijft in zijn autobiografie over het verschil in waardering van het belang van weefseltypering en over de consequenties die dat volgens hem gehad heeft, dat hij wel wist dat immunosuppressie de sleutel was tot echte vooruitgang in de transplantatiegeneeskunde en dat weefseltypering slechts een marginale rol zou spelen bij transplantatie van onverwante donoren, maar dat zowel de toepassing van Prednison en Imuran, als de op matchen gevestigde hoop, de transplantatiepraktijk eerder vertraagd dan vooruitgeholpen heeft (Starzl, 1992). 
matchen op de overlevingsduur van een transplantaat kan slechts bij het identiek zijn van de antigenen worden aangetoond. In 1967 heeft men dit echter alleen laten zien bij transplantaties tussen verwanten. Door dit niet te vermelden, wordt het idee gewekt dat deze verbetering van de prognose bij alle donor/ontvanger-combinaties mogelijk is, dus ook bij niet verwanten. Het Leidse vertrouwen in het positieve effect van matchen is echter sterk, want een jaar later wordt hetzelfde met stelligheid opgenomen in de begroting van de afdeling immunohaematologie voor het dienstjaar 1970 .

In de afgelopen jaren zijn de werkzaamheden betreffende de klinische betekenis van de leukocytenantigenen c.q. transplantatie-antigenen verder voortgezet. Het is nu bewezen dat niet alleen deze leukocytenantigenen van belang zijn voor orgaantransplantaties zoals b.v, niertransplantaties wanneer de donor een broer, zuster of ouder is, maar dit is ook het geval wanneer de donor een onverwant individu is. Dit heeft de bijzonder belangrijke consequentie dat er onder onverwante individuen mensen voorkomen die wat hun weefselantigenen betreft voldoende op elkaar lijken om een niertransplantaat een significant betere prognose te geven dan wanneer een ongeselecteerde donor zou zijn gebruikt. (Roodzant, 12 november, 1968 )

Wanneer de weefseltyperingen 'voldoende op elkaar lijken' is echter nog niet met zekerheid te stellen. Wanneer iemand een 'betere prognose' heeft is nog niet goed te zeggen, maar welke combinaties van niet overeenkomstige antigenen een slechtere prognose hebben kan wel goed voorspeld worden. In een strategisch stuk als een begroting echter, schetst men liever een hoopvol beeld van wat mogelijk zou zijn, en benadrukt men het feit dat er vertrouwen bestaat in toekomstige ontwikkelingen.

Bij (deels dezelfde) patiënten verrichtte onderzoeken leiden tot verschillende conclusies over het matchingseffect. Waar Terasaki de hooggespannen verwachtingen rond het belang van matchen tempert, ziet Van Rood juist meer en meer perspectief op klinische toepassing van weefseltypering. Hoe is dit mogelijk op basis van 'dezelfde gegevens'? De aanpak van Terasaki en Van Rood verschilt voor wat betreft de populatiekeuze. Van Rood bepaalt van 'alle' getransplanteerden of de typering van de donor overeenkomt met die van de ontvanger ${ }^{51}$ en brengt dat in verband met het beloop van de transplantatie. Hij probeert hierbij alle patiënten te volgen. Terasaki bekijkt alleen de klinisch succesvolle gevallen, dat wil zeggen: alleen die gevallen waarbij de immunosuppressiva in staat waren om (volledige) afstoting van het transplantaat te voorkomen. Volgens Van Rood zit hierin dan ook een verklaring voor de 'ietwat teleurstellende resultaten' van Starzl en Terasaki, namelijk dat ze bij deze evaluatiestudies op basis van 'mean mismatch' gegevens, geen significante verschillen hebben gezien (Terasaki, et al., 1966). Van Rood wijt het ontbreken van verschillen in overlevingsduur in Terasaki's onderzoek, aan waar deze de cesuur legt. Daarom schrijft hij aan Starzl, dat over de precieze betekenis van de termen 'compatible' en 'incompatible' afspraken moeten worden gemaakt.

Another point which should be worked out between Paul [Terasaki], Bernard

[Amos] and me is the question of classifying the degree of compatibility. I personally feel that there are really two groups, one is identity or near identity

51 Of en in welke mate dit overeenkomt en hoe het eventuele verschil er precies uitziet (een genetische benadering). 
for the antigens we can recognize and the other is non-identity. So far our data indicate that it makes very little difference whether someone is incompatible or compatible. In all probability compatibility means only that people are incompatible for antigens we can not type for yet. (van Rood, 7 augustus, 1967) Van Rood beperkt de groep waarvan hij verwacht dat er een matchingseffect aanwezig is, tot die combinaties die hij als 'identiek' heeft getypeerd, terwijl Terasaki de grens tussen compatibel en incompatibel, bij een groter aantal verschillen tussen antigenen legt. Deze verschillen in interpretatie van wat identiek, compatibel en incompatibel is, zijn volgens Van Rood verantwoordelijk voor de verschillende conclusies.

De basis voor Van Roods overtuiging dat matchen op leukocytenantigenen een positief effect heeft op de overlevingsduur van een transplantaat, is echter nog niet zo stevig als hij soms pretendeert ${ }^{52}$. Zelfs identiek-zijn (voor de te herkennen antigenen) blijkt geen garantie voor het uitblijven van afstoting. $\mathrm{Bij}$ een rondetafelconferentie in Dublin over 'Immunosuppressive therapy in kidney transplantation' bespreekt Roy Calne een casus uit 'Professor Woodruff's Edinburgh series'. De patiënt was vijf jaar eerder getransplanteerd met een nier van zijn vader. Hij kreeg een zeer lage dosis Imuran en had geen afstotingsproblemen, maar de patiënt stopte met de medicatie, omdat hij wilde zien wat er gebeurde. Drie weken later volgt er een heftige afstotingsreactie.

So the balance between the organ and the recipient and the immuno-

suppressive drug is a very delicate one. The penalty of taking two pills a week

seems a very small one, and I would certainly caution anybody stopping

immuno-suppression of any of their patients. (van Rood, 31 december, 1968)

Aan deze casus voegt Van Rood toe, dat het hier om een van de patiënten gaat die door hen zijn getypeerd. De jongen en zijn vader hebben identieke leukocytengroepen, maar ondanks het feit dat vader en zoon identiek zijn, treedt er afstoting op. Van Rood concludeert dat "even in the face of identity we could not do without immuno-suppression." (van Rood, 31 december, 1968)

Enkele maanden na het schrijven van bovenstaande brief met correcties op de rondetafelconferentie, die in juni plaatsvond, verschijnt in Transplantation Proceedings een artikel van de hand van Van Rood en andere, getiteld: "Leukocyte Typing and Kidney Transplantation in Unrelated Donor-Recipient Pairs. A Study in Patients of Drs. S. Peart, J.F. Mowbray, and G.R.J. Alexandre." Daarin trekken zij de volgende conclusies:

I Leukocyte-group matching is able to improve the prognosis of a kidney allograft, irrespective of whether the donor is a sib, a parent, or an unrelated individual.

2. Donor-recipient pairs identical for the main HL-A antigens have the best prognosis, but, so far, a mismatch for one antigen still entails a better than average prognosis. (van Rood, et al., 1969)

52 Immers, de tot 1968 verrichtte klinische transplantaties zijn zonder uitzondering gedaan onder de bescherming van immunosuppressiva, in verschillende hoeveelheden en met verschillende combinaties van middelen. Dit maakt het vergelijken van de gegevens van verschillende transplantaties lastig. Te meer daar die gegevens ook nog eens afkomstig zijn uit verschillende centra. En aangezien ook de verschillende immunosuppressieve regimes een verschillend effect hebben op de overlevingsduur van een transplantaat, is het moeilijk om exact de mate te bepalen waarin matchen voor de overlevingsduurverlenging verantwoordelijk gesteld kan worden. 
In Leiden is men door de resultaten van de door hen verrichtte retrospectieve onderzoeken, overtuigd geraakt van het bestaan van een matchingseffect. Niet alleen bij transplantaties met een donornier van een verwante, maar ook met een van een niet-verwante donor afkomstige nier. Hun eigen onderzoeksresultaten doen hen de eerdere stellingname, dat alleen identieke donor/ontvanger-combinaties een betere prognose zouden geven, herzien.

Terwijl Van Rood transplantatiecentra probeert te interesseren voor het toepassen van weefseltypering, raken ook de meer pessimistische berichten van Terasaki en Starzl bekend in de transplantatiepraktijk. In het bijzonder de typeringspraktijk is niet zo blij met deze berichten.

Reports of these results at nephrology and surgery meetings created a furor in the typing fraternity. The evidence was that the antigens being matched were transplant antigens which followed classical genetic (Mendelian) laws (witness the sibling results) but that the system was so complex (more than we were measuring) that matching would not be the boon we had predicted. Terasaki suspected that there might be a "center effect" in which experience and skill with immunosuppression covered up a typing effect or that the sample size was too small to test the original hypothesis. (Starzl, I99I)

Om matchen daadwerkelijk enige rol van betekenis te laten spelen in de transplantatiepraktijk, zal dan ook op de minder hoopvolle berichten adequaat gereageerd moeten worden, want zonder tegengas kan het vertrouwen in weefseltypering snel verloren gaan. Zo schrijft Peter Knight uit Adelaide, dat het typeerwerk moeilijk is en dat hij met zijn screeningsprogramma in een jaar tijd 'slechts' 1o sera gevonden heeft, waar hij vervolgens aan toevoegt: "... and I am quite defeated as to why the progress is so slow and also somewhat discouraged by the rather depressing results being obtained by Terasaki in prospective studies." (Knight, 7 februari, 1968). Van Rood haast zich een poging te ondernemen om de schade te herstellen, door een positief beeld over de lange-termijn-mogelijkheden van weefseltypering te schetsen.

I would not be too upset about the difficulties in prospective typing of unrelated individuals.

... The difficulty is as follows: If you have to select identical sibs, things are relatively easy and if you have a number of sera even if they are rather lousy you will be able to pick up identical ones. However, if you do this between parent and child the situation is already far more difficult. Retrospectively, we are apparently able to do so rather well. We have also a number of prospective parent-child typings, which seem to be promising. For unrelated individuals the situation is even more difficult. I would not be too much upset by Terasaki's data: He did not look for identity but only for compatibility which as we pointed out in our Paris paper etc. is not enough.

... Our analysis so far suggests that the number of types is really "limited" and that you stand reasonable good chances of finding identicals or near identicals between unrelated people. (van Rood, 26 februari, 1968 )

Verontrustte reacties op berichtgevingen, als van Knight, dragen in Leiden nog eens extra bij aan het besef dat er zeer omzichtig met het publiceren van conclusies van onderzoek moet worden omgesprongen ${ }^{53}$.

53 Mede om deze reden is Van Rood dan ook niet zonder meer bereid de door Eurotransplant gegenereerde gegevens - wanneer daar door $\mathrm{D}$. Parsons uit Leeds om wordt gevraagd - uit te leveren aan de European 
Middels een artikel in The Lancet, maakt Van Rood aan een groot publiek kenbaar dat hij vindt dat er een matchingseffect is, dat relevant is voor alle vormen van transplantatie. Het artikel, getiteld: Tissue Typing and Organ Transplantation $54^{*}$ begint met een introductie waarin hij de verbinding legt tussen te transplanteren organen in het algemeen en het in praktijk brengen van de laboratoriumbevindingen.

I DISCUSS here a topic related to all transplantations - i.e., the problem of the selection of donor-recipient combinations that are optimal for the prognosis of the transplanted organs or, in other words, the problem of histocompatibility testing - with emphasis on the more recent attempts to mould the laboratory findings into a clinical reality. (van Rood, 1969)

Van Rood bouwt dit artikel op door één voor één een vijftal basale vragen te beantwoorden ${ }^{55}$. Zo geeft hij een overzicht van de kennisontwikkeling over het systeem van leukocytenantigenen ${ }^{56}$, dat dan inmiddels tot HL-A-systeem is omgedoopt. Volgens Van Rood kan orgaantransplantatie niet zonder weefseltypering. Want waarom is het transplanteren van organen zo moeilijk, afgezien van de schijnbaar overwonnen chirurgisch-technische problemen? Omdat er veel moet worden gedaan om het afstoten van een getransplanteerd orgaan te voorkomen. Daarvoor is kennis nodig over het bijzonder complexe leukocytenantigeensysteem, dat er niet is om transplantatiechirurgen te pesten 57 , maar mogelijk een rol speelt in de afweer tegen virale infecties en kankercellen. Dit doet echter niets af aan het gegeven, dat voor de transplantatiegeneeskunde het immuunsysteem een zeer lastig systeem is.

Vanuit het perspectief van de transplantatiegeneeskunde zijn er twee benaderingswijzen van het afstotingsprobleem. De eerste is: met behulp van immunosuppressiva zorgen dat het immuunsysteem niet adequaat kan reageren. Door het immuunsysteem van de ontvanger in meerdere of mindere mate te onderdrukken, wordt geprobeerd het immuunsysteem zo te bewerken dat er geen afstoting plaats kan vinden. Maar dat heeft voor de gezondheid van de patiënt een aantal negatieve consequenties $^{58}$. De tweede benaderingswijze is: proberen de immunologische re-

Dialysis and Transplantation Association (EDTA feerder het acroniem voor European Dialysis and

Transfusion Association)).

... Your idea to give an annual report I would like to discuss in more detail. Our data of course are annually reported. However, 1 think that you have in mind to come to a kind of summary concerning not only the

data of our group but also of say Kissmeyer-Nielsen. Batchelor, Dausset and Ceppellini to name only a few. (van Rood, 18 oktober, 1968)

De vrees dat de gegevens van de verschillende centra ook verschillend geinterpreteerd moeten worden en de mogelijkheid van het ontstaan van problemen wanneer deze gegevens zomaar bij elkaar worden gezet, maken dat Van Rood eerst zelf wil publiceren. Pas daarna wil hij de gegevens vrijgeven ter plaatsing in een jaarverslag van de EDTA.

54 The Medical Research Society lecture for 1968 delivered at the Royal Postgraduate Medical School on December 13, 1968

55 De vragen:

I. Why is histocompatibility almost identical with leucocyte grouping?

2. What is the present status of leucocyte grouping?

3. What proof is there that the antigens involved are relevant to organ transplantation?

4. Can histocompatibility testing improve the prognosis of a graft when the organ is procured from a postmortem donor?

5. Can better immunosuppression make histocompatibility testing unnecessary? (van Rood, 1969)

56 Voorheen ook aangeduid met: leukocytengroepen; transplantatie-antigenen; en weefselantigenen.

57 Van Rood haalt hierbij de woorden van Ceppellini aan:

As Ceppellini pointed out, it is unlikely that this is "due to an a priori hostility of Nature against transplantation surgeons". (van Rood, r969)

58 Uiteraard geheel in lijn met Van Roods hypothese, een vergrote vatbaarheid voor infecties en het vaker voorkomen van kanker. 
actie te voorkomen. Men wil het immuunsysteem van de ontvanger als het ware om de tuin leiden. Door een transplantaat te zoeken met dezelfde antigenen als de antigenen van de patiënt, zou voorkomen kunnen worden dat het getransplanteerde orgaan als lichaamsvreemd wordt herkend (als bij een identieke tweeling). Als dit zou lukken, zouden alle immunosuppressiva overbodig zijn, waardoor getransplanteerden de bijwerkingen bespaard blijven.

Zijn het echter deze antigenen die het immuunsysteem triggeren om de afweer in werking te stellen, en zo ja, heeft het, ongeacht de mate van genetische verwantschap tussen ontvanger en donor, klinisch effect om op deze antigenen te matchen? Volgens Van Rood spelen deze antigenen (mede) een rol bij de afstotingsreacties, maar kunnen nog niet alle antigenen worden herkend. Dit heeft tot gevolg dat, zelfs wanneer donor en ontvanger identiek zijn, zij dit voor onherkenbare antigenen niet behoeven te zijn ${ }^{59}$. Wel is het zo dat, wanneer er genetische verwantschap is en zij identiek zijn, dit de prognose van het niertransplantaat verbetert. Bij deze combinaties is de kans, dat ook onherkenbare antigenen overeenkomsten vertonen, groter dan bij onverwante combinaties. Om deze reden is Van Rood voorzichtiger omtrent het optreden van een matchingseffect bij kadaverdonoren, maar ook daarvoor zijn aanwijzingen.

Over de haalbaarheid van verbetering van de prognose bij onverwante donoren was men om twee redenen sceptisch. Ten eerste dacht men dat het typeren niet betrouwbaar genoeg zou zijn om een niet-verwant individu te vinden die te matchen is met de ontvanger. En ten tweede ging men ervan uit dat die combinaties zo zeldzaam zouden zijn, dat zij geen praktisch belang zouden hebben. Volgens Van Rood laat onderzoek echter zien dat deze scepsis ongegrond is, hetgeen impliceert dat in de toekomst een identieke of bijna identieke donor voor een ontvanger geselecteerd zal moeten worden. Maar hoe dit te realiseren?

In 1967 I suggested the establishment of an international organ-exchange

organisation. (van Rood, 1969)

De idee van Eurotransplant is, dat de typering van een groot aantal potentiële ontvangers wordt opgeslagen in een computer en dat, wanneer een kadaverdonor getypeerd kan worden, de computer vervolgens aangeeft waar zich de meest geschikte ontvanger bevindt ${ }^{60}$.

Het academisch onderscheid tussen de twee benaderingswijzen, wordt in de transplantatiepraktijk niet gemaakt. In de klinische praktijk wordt zowel van immunosuppressiva gebruik gemaakt, als van matchen. En Van Rood schrijft zelfs dat

59 In Van Roods woorden:

The most likely explanation for the unsatisfactory results obtained with kidneys from compatible donorrecipient pairs is given by remembering that, if donor and recipient are stated to be compatible, the words "for the antigens we are able to recognise" should immediately be added; this implies that donor and recipient will in all probability be incompatible for antigens we are as yet not able to recognise. (van Rood, 1969)

6o Van Rood zegt vervolgens dat ze het idee van Eurotransplant in praktijk hebben kunnen brengen en de organisatie sinds mei 1968 functioneert. Als resultaat en illustratie van het bestaansrecht van

Eurotransplant geeft hij de verschillen in de aantallen daadwerkelijk gevonden combinaties met $0,1,2$ of 3 mismatches en de respectievelijke aantallen mismatches die verwacht hadden mogen worden wanneer er een random donor gebruikt zou zijn.

It is especially important to note that without Eurotransplant the well-matched group would have been so much smaller and the severely mismatched groups would have been so much larger. These data show that the objective of Eurotransplant - to provide patients with kidneys that are much better matched than previously - has been realised. (van Rood, r969) 
"It should be realized that leucocyte grouping is still a time-consuming and specialised job, and it would of course be much easier if a dose of some drug could make all this superfluous" (van Rood, 1969). Dit 'wondermiddel' is er echter (nog ${ }^{61}$ ) niet. Daarmee ontstaat dus ruimte voor matchen als mogelijkheid om de noodzaak van immunosuppressiva te verkleinen. Niet alle immunosuppressieve-middelen zijn even effectief in het bestrijden van afstoting. Zo geeft Van Rood zijn visie op het gebruik van 'anti-lymfocytenglobuline' (A.L.G. ${ }^{62}$ ) door Starzl en concludeert dat A.L.G. geen beslissende invloed heeft op de overleving en het functioneren van een transplantaat.

... Starzl has shown that in a group of patients who had all received A.L.G., those with a good match for the HL-A antigens needed less prednisone and had better kidney function than those with a poor match. It is therefore evident that A.L.G. was not able to override strong histocompatibility differences. (van Rood, 1969)

De goede resultaten die zij behaalden bij 3r transplantaties zonder A.L.G., rechtvaardigen voor de Leidse groep het idee dat A.L.G. niet nodig is bij niertransplantaties. Hiermee zegt Van Rood dat, volgens hem, A.L.G. als gewoon immunosuppressivum geen waarde heeft voor de niertransplantatiepraktijk ${ }^{63}$. Naast de beperkte effectiviteit van sommige middelen, is er een belangrijk nadeel aan het gebruik van immunosuppressiva: de bijwerkingen.

A small series of recipients have developed a relatively large number of reticulosarcomas. The cause for these reticulosarcomas is still unknown but it appears at least likely that they might be related to the immunosuppression these patients received, which would seem to argue for not more but less immunosuppression for the time being. (van Rood, 1969)

Door te matchen kan de hoeveelheid benodigde immunosuppressiva omlaag (getuige het A.L.G.-onderzoek van Starzl) en dus zou daardoor het vóórkomen, dan wel de ernst van de bijwerkingen kunnen worden verminderd. Van Rood is, ten aanzien van de rol voor matchen in de transplantatiepraktijk, zeer diplomatiek door noch te zeggen dat betere immunosuppressie weefseltypering overbodig zal maken, noch te beweren dat weefseltypering immunosuppressiva overbodig zullen maken.

Zo wordt door velen rond $1968 / 69$ als vaststaand feit geaccepteerd, dat matchen op HL-A-antigenen effect heeft op de immunologische reactie van het ontvangende lichaam, in die zin, dat het transplantaat minder snel, heftig of oncontroleerbaar wordt afgestoten. Over de klinische relevantie van dit matchingseffect voor de transplantatiepraktijk is men minder eensgezind. Ten aanzien van de criteria die moeten worden aangelegd voor het antwoord op de vraag wat een goede match is, blijft het moeilijk om consensus te bereiken.

Sinds de eerste (pessimistische) publicaties van Terasaki en Starzl, zet ook Terasaki zijn onderzoek voort. Hij verzamelt data van 1200 transplantaties van ver-

6r Het is de vraag of weefseltypering dezelfde status in de transplantatiepraktijk zou hebben kunnen bereiken, wanneer Cyclosporine eind jaren " 60 al beschikbaar zou zijn geweest.

62 Hetzelfde als Anti Lymfocyten Serum (A.L.S.). Serum of de fractie daarvan met antilichamen gericht tegen lymphocyten. Deze antilichamen worden toegediend om het transplantaat tegen inwerking van lymphocyten te beschermen, door de lymphocyten zelf te elimineren.

63 Mogelijk dat A.LG. wel op een andere manier van nut blijkt te zijn.

... it may well serve to induce tolerance best if it is given not as large doses for a long period but, under the right conditions, in a small dose, in combination with matching, other immunosuppressive agents, and some antigen preparation derived perhaps from lymphocytes or even kidney tissue. (van Rood, 1969) 
schillende centra en analyseert die. Zijn bevindingen komen overeen met eerdere resultaten en hij presenteert zijn conclusies tijden het 1970 Congres van de Transplantation Society, in Den Haag ${ }^{64}$. Dat de presentatie van Terasaki geen succesverhaal van het matchen betreft moge duidelijk zijn. Het is echter niet zo dat hij al het voorgaande onderzoek naar matchen met één klap van tafel veegt. Integendeel, veel van de resultaten die anderen hebben verkregen, worden door Terasaki bevestigd. Hij stelt echter voor om, vanwege het grote aantal goed functionerende 'incompatibele' transplantaten, een ander matchingsysteem te ontwikkelen, waarbij de criteria gebaseerd zijn op empirische gegevens, in plaats van op theoretische veronderstellingen.

Overall, the data indicate that because of the larger number of patients who do well in spite of incompatibility, a more suitable means by which successful transplants can be predicted will be required. Since HL-A antigens are still the primary transplantation antigens (as shown by the successful HL-A-identical sibling transplant), empiric knowledge on the types of incompatibilities which can result in good graft survival must be developed. (Mickey, et al., 1971) 65 Klinisch georiënteerde allocatiecriteria laten echter nog op zich wachten.

\subsection{De Controverse DuURt Voort}

De problemen en meningsverschillen die over het al dan niet optreden van een matchingseffect en de klinische relevantie daarvan ontstaan, verdelen de transplantatiepraktijk. Jaren later schrijft Dausset over deze problemen:

... it was difficult to find a highly significant correlation between tissue compatibility and the survival of kidney grafts obtained from cadaver donors (that is, unrelated subjects). This produced a schism between the believers (largely immunologists) and the non-believers (largely clinical surgeons). This conflict still persists today, 30 years later. (Dausset, 1995)

Zo wordt nog steeds het 'welles-nietesspelletje' gespeeld tussen de 'believers' en de 'non-believers'. De praktijk is echter, dat in de transplantatiepraktijk gebruik gemaakt wordt van zowel immunosuppressiva als matchen. Ondanks de ontwikkeling van betere afstotingsonderdrukkende middelen, heeft weefseltypering zich een vaste plaats verworven in de transplantatiepraktijk (al hecht niet iedereen overal evenveel waarde aan matchen). Starzl wijst in dit verband, afgezien van de rem op de ontwikkelingen die door het geloof in matchen volgens hem is ontstaan ${ }^{66}$, ook op nadelen van het idee van matchen. Wat hem zorgen baart, is dat door op HLA-typering

64 Starzl schrijft over Terasaki's bevindingen en de vijandige ontvangst daarvan:

The original conclusions were validated and the new analysis was presented by Terasaki to the Transplantation Society in The Hague on September 8, 1970. Anxious and looking smaller than I remembered him. Paul walked resolutely to the podium and read his message to a huge and it seemed to me hostile audience. When he finished, there was little applause.

Within a few weeks, the federal agency funding Terasaki's UCLA laboratory paid it an emergency site visit and discontinued its support. Terasakis heretical report was not welcome, and now the messenger must be killed. ... (Starzl, r991)

65 Het 'Permissible Mismatch' systeem is hiervan een voortvloeisel. In dit systeem wordt onderscheid gemaakt tussen incompatibiliteiten van verschillende antigenen. Incompatibiliteit voor sommige antigenen blijkt namelijk geen onoverkomelijk bezwaar te zijn voor transplantatie, terwijl andere gemismatchte antigenen juist welgrote problemen opleveren.

66 Starzl maakt hierbij geen onderscheid tussen het geloof in het gebruik van (combinaties van) immunosuppressiva en matchen. Voor beiden geldt dat te groot geloof in het 'huidige', de stap naar 'het betere' in de weg staat. 
gebaseerde allocatiesystemen, in de Verenigde Staten een vorm van geinstitutionaliseerde rassendiscriminatie ontstaat.

... it's being abused and it excludes in a country like ours, which is pluralistic, racially pluralistic, minority populations from getting organs because they have different HLA profiles. And so it is the institutional organization of racial bias. (Starzl, 30

September, 1994)

Tegenover de gezondheidsproblemen als gevolg van de bijwerkingen van immunosuppressiva, plaatst Starzl dus een rechtvaardigheidsprobleem: "The waiting time for blacks for example in the US, is 3 times as long as for a Caucasian patient" (Starzl, 30 September, 1994). Het huidige, op matchen gebaseerde allocatiesysteem, is volgens hem verantwoordelijk voor een ongelijke verdeling van de aanwezige nieren. Volgens Starzl is dat discutabel, omdat hij vindt dat weefseltypering een zeer smalle basis heeft. Weefseltypering is onderwijl wel sterk ingebed in de transplantatiepraktijk, maar de oorspronkelijke pretenties zijn volgens Starzl niet waargemaakt.

The problem was that the basic premiss for Eurotransplant is typing. Well, it may be true in a small way, it is not true in the way that the people believe it is. And that's why this trouble came, lasting for nearly 30 years. (Starzl, 30 September, 1994)

... what has happened with tissue typing is that people sit around and do the serological tests, and it has created a cottage industry with thousands of employees doing these things, and fiercely defending what they do. But the situation is no different than with these drugs in the mid sixties, of which everyone said: this is it, this is universal standard. By the time the next generation had come along, nobody wanted to take the next step. So my idea is that whatever you fix as perfect what you do today, you'er gonna be wrong, because it can be improved. And tissue matching can be used, but it cant be used the way it's been used for outright. (Starl, 30 September, r994) 



\section{BeschikbaARHeid CreËren}

\subsection{INLEIDING}

In de voorgaande hoofdstukken is beschreven hoe in Leiden, eind jaren 50, vanuit de kliniek gestart wordt met het leukocytenonderzoek. Dat onderzoek raakt gaandeweg gericht op het benaderen van het klinisch ideaal van een tweelingtransplantatie. Daartoe wordt, door de immunohaematologische laboratoriumpraktijk, kennis ontwikkeld waarmee enerzijds het afstotingsprobleem kan worden verklaard en anderzijds de prognose en het rendement van klinische toepassingen kan worden verbeterd. Door te bepalen in welke mate de antigenen van een donororgaan passen bij de antigenen van een ontvanger, zou een inschatting gemaakt kunnen worden van het verloop van een eventuele (nier)transplantatie bij een bepaalde patiënt. Naast deze typeringspraktiik, waarin wordt onderzocht of donororganen geschikt zijn voor transplantatie bij een bepaalde patiënt, heeft begin jaren 60 de chirurgische transplantatiepraktijk zich verder ontwikkeld tot een praktijk waarin nieren getransplanteerd worden, mits er een donororgaan aanwezig is. Combinatie van deze praktijken geeft fundering aan de besluiten om in concrete gevallen tot transplantatie over te gaan. Hierbij is de aanwezigheid geregeld en wordt de nier geschikt geacht voor de betreffende ontvanger. Dit betekent dat er voor deze transplantatie een nier beschikbaar is (dat wil zeggen aanwezig én geschikt).

Onder invloed van verschillende factoren (verbeteringen in de immunosuppressieve behandeling, toenemend gebruik van kadaverdonoren, matchen van leukocytenantigenen, gespecialiseerde verpleegtechnieken) groeit midden jaren 60 het aanbod van, en de vraag naar niertransplantatie. Het succes van de immunosuppressive therapieën, maken dat transplantatie van nieren meer en meer als reële oplossing van chronisch nierfalen wordt gezien. De chirurgische technieken worden geperfectioneerd en verschillende andere problemen worden opgelost. Oplossingen op het ene gebied, creëren echter nieuwe problemen op een ander gebied, waarvoor weer nieuwe oplossingen moeten worden gezocht. Zo wordt bijvoorbeeld telkens gekeken naar de selectiecriteria van donoren om de aanwezigheid te vergroten. Wat als aanwezig geldt, evenals wat geschikt wordt gevonden, is voortdurend in ontwikkeling.

Tijdens de conferentie in St. Vincent, aansluitend op de Workshop in Turijn ( 1967 ), wil Van Rood een lezing geven, waarin hij voorstelt om tot internationale samenwerking op het gebied van orgaantransplantatie te komen. Deze samenwerking zou een aantal problemen oplossen, waardoor meer mensen met een geschikte nier kunnen worden getransplanteerd. De avond voorafgaand aan zijn lezing, oefent Van 
Rood zijn lezing voor een gehoor van collega's uit Leiden. Tegen het einde van zijn presentatie komt Vincent Eijsvoogel, van het Centraal Laboratorium van de Bloedtransfusiedienst (CLB), binnen en hoort Van Roods voorstel om te komen tot internationale orgaanuitwisseling. Eijsvoogel vindt dit voorstel te belangrijk om als conclusie te presenteren van een algemeen verhaal, waardoor het in het eindverslag geen bijzondere plaats zou krijgen. Direct na afloop gaat hij naar Van Rood en adviseert hem om het laatste deel van zijn voordracht als aparte publicatie op te nemen in het conferentieverslag (van Rood, 11 augustus, 2000). Van Rood neemt deze suggestie over en noemt de organisatie: Eurotransplant ${ }^{1}$. Hoe Van Rood wordt afgebracht van het oorspronkelijke idee om het voorstel op te nemen in de discussie van hun bijdrage aan de conferentie: "Immunogenetics of the group four, five and nine system" (van Rood, 1967), is typerend voor het ontstaan van Eurotransplant. Door het toevallige gegeven dat Eijsvoogel het slot van de voordracht hoort, krijgt het voorstel meer nadruk dan Van Rood oorspronkelijk voor ogen had.

Eurotransplant ontstaat zonder dat er een directe aanleiding voor is. In dit hoofdstuk zal beschreven worden dat dit ontstaan een uitbreiding van al aanwezige samenwerkingsverbanden en ideeën is, en deze praktijk grotendeels al bestaat. Er is al samenwerking met andere ziekenhuizen en er worden al prospectief getypeerde niertransplantaties verricht. Maar deze praktijk is niet formeel georganiseerd, want de samenwerking is gebaseerd op persoonlijke interessen en de overtuiging dat het zinvol is om die extra inspanningen te verrichten.

Voortkomend uit deze informele samenwerking, is het voorstel van Van Rood niet primair gericht op het opzetten van een formele organisatie. Hij probeert louter het aantal deelnemende centra te vergroten, maar voegt daar interregionale uitwisseling van donornieren aan toe. Wanneer de (internationale) samenwerking toeneemt en het aantal aangesloten centra groeit, dienen zich nieuwe problemen aan, die maken dat het Eurotransplant-idee uitgroeit tot een organisatie. Het is daarbij goed mogelijk dat het apart publiceren van het Eurotransplant-voorstel mede heeft gezorgd voor de succesvolle ontwikkeling van de Eurotransplantpraktijk.

Centraal in het Eurotransplant-voorstel staat het in praktijk brengen van matchen. Om dit te verwezenlijken zal zowel op het gebied van het aanwezig maken van donororganen, als op het gebied van het bepalen van geschiktheid veel georganiseerd moeten worden. De vraag is dan: hoe groeit in Leiden een matchingspraktijk uit de samenkomst van transplantatie- en typeringspraktijk? Ofwel, hoe krijgt de internationale orgaanuitwisselingsorganisatie Eurotransplant gestalte?

\section{2. 'AANWEZIGHEID' VAN DONORNIEREN}

Niertransplantaties bij identieke tweelingen laten zien dat transplantaties (klinisch) mogelijk zijn. Hiertoe wordt als donormateriaal een nier van een ander, identiek en gezond mens gebruikt. Dit nu gaat in tegen de hypocratische eed, die onder meer behelst: gij zult niet schaden. Gegeven de complicaties die kunnen optreden bij een transplantatie - bij zowel de ontvanger, maar vooral ook bij de donor ${ }^{2}$ - rijst de vraag

I A Proposal for International Cooperation in Organ Transplantation: Eurotransplant (van Rood, 1967) zie Bijlage s: Het Eurotransplant-voorstel.

2 Dat de risico's voor de levende donoren niet verwaarloosbaar zijn, blijkt onder andere uit een brief van Martin Botha, uit Zuid Afrika, die verbolgen schrijft dat na een transplantatie in Johannesburg "one of the two live donors is ... severely incapacitated". Starzl heeft daar transplantaties verricht "without any preliminary serological tests ${ }^{\prime}$ (Botha, 7 november, 1966). 
of hieraan wel wordt voldaan. Naast dit morele probleem is er een praktisch probleem: slechts zeer weinig patiënten hebben een identieke tweelingbroer of -zuster. De directe familieleden van een patiënt in aanmerking laten komen als (potentiële) donor op te treden, zou dit aanwezigheidsprobleem voor een aantal patiënten kunnen oplossen. Maar eind jaren 50, begin jaren 60 , zijn de resultaten van deze transplantaties niet altijd bevredigend. In de loop van de jaren 60 verbeteren de resultaten door ontwikkelingen in de toepassing van immunosuppressiva, waardoor meer mensen kunnen worden geholpen met een succesvolle transplantatie. Het toenemend succes heeft ook een keerzijde, want hierdoor groeit ook de vraag naar niertransplantaties. Ook patiënten voor wie geen potentiële donor aanwezig is, zouden voor transplantatie in aanmerking moeten kunnen komen. Steeds vaker rijst dan ook de vraag waar de te transplanteren nier vandaan moet komen. Het verzwakken van het immuunsysteem van ontvangers met immunosuppressiva, waardoor getransplanteerde organen niet meer direct worden afgestoten, resulteert erin dat de criteria voor wat als aanwezig geldt, verruimd kunnen worden en transplantatie dus voor meer mensen een reële optie wordt. De ontwikkelingen op het gebied van de immunosuppressie verlagen de drempel om niet-verwanten als donor te gaan gebruiken. Maar wie wil zich daarvoor lenen? Altruisme kent zijn grenzen en na een donatie zou de donor de uitgenomen nier zelf ook nog wel eens hard nodig kunnen hebben. De winst van het zoeken in die richting is dan ook niet erg groot ${ }^{3}$. Er ontstaat een 'tekort aan donororganen', een aanwezigheidsprobleem ${ }^{4}$.

De mogelijkheid om, door groeiend succesvol gebruik van immunosuppressiva, nieren van niet-verwante personen te transplanteren, biedt nieuwe kansen. Door het toepassen van deze middelen kan geprobeerd worden om het aanwezigheidsprobleem op te lossen door gebruik te maken van de organen van overledenen. Zij hebben zelf (in biologische zin) geen belang meer bij hun nieren. Wanneer men erin slaagt om een nier van een overledene, voordat er ernstige schade aan de nier optreedt, naar een patiënt te verplaatsen, zou iemand die voordien niet geholpen kon worden, nu toch kunnen worden getransplanteerd. Maar deze mogelijkheid genereert weer een eigen problematiek.

Aan het overlijden van een kadaverdonor worden bijzondere eisen gesteld. lemand met een nierziekte is geen geschikte donor, terwijl ook hypertensie een contra-indicatie voor donatie vormt. Ook mag de ontvanger geen grote risico's lopen op, middels het transplantaat overgedragen, infecties en maligniteiten. Verder worden

3. Wel heeft Starzl bijvoorbeeld voor zijn eerste transplantaties een aantal gevangenen bereid gevonden als levende, maar onverwante donor te fungeren (Starzl, 1991). Zie ook $\int 6.7$.

4 In de yoorgaande hoofdstukken is gebleken dat zich een klinische transplantatiepraktijk heeft kunnen ontwikkelen, waarin zowel nieren afkomstig van verwanten, als van overledenen, kadavernieren worden getransplanteerd. In lijn met de voorgaande hoofdstukken, zal ook in dit hoofdstuk de nadruk liggen op de Leidse bijdragen aan en perspectieven op de ontwikkelingen in de transplantatiegeneeskunde. Het creëren van aanwczighteid (en later het creëren van geschiktheid) zal beschreven worden met de nadruk op de ontwikkelingen in Leiden en het aan Leiden gelieerde gebied en hoe ontwikkelingen invloed hebben op hetgeen er in en vanuit Leiden gebeurt. In Leiden worden de eerste twee transplantaties uitgevoerd met een nier afkomstig van de moeder van de patiênt. De ontwikkelingen in Leiden zijn dan nog niet van dien aard, dat er sprake is van schaarste aan donornieren, aangezien iemand pas voor transplantatie in overweging wordt genomen, wanneer er een potentiele donor aanwezig is. In Leiden verkeert het doen van niertransplantaties - ondanks (maar ook dankzii) de vorderingen elders - in een experimentele fase. Vooralsnog $(65,66)$ is het aantal patiënten dat in overweging wordt genomen laag. Elders transplanteert men veel meer en daar vormt - het gebrek aan - aanwezigheid dan ook een probleem waar men dringend oplossingen voor zoekt. 
er eisen gesteld aan de tijd die het kost om een nier te 'verplaatsen' van de donor naar de ontvanger: die tijd mag niet te lang zijn, omdat anders functieverlies optreedt. De ischemische tijd ${ }^{5}$ moet zo kort mogelijk worden gehouden. Het meest ideale is de situatie waarin de operatiekamer, waar de uitname wordt verricht, naast de OK ligt waar de patiënt wordt voorbereid om de nier te ontvangen. Op deze manier blijft de (warme) ischemische tijd het kortst. Speciaal in het geval van een kadavertransplantatie, waarbij de ontvanger in een ander ziekenhuis onder behandeling is dan waar de donor zich bevindt, zal de tijd tussen uitname en implantatie al snel lang zijn. Er zullen dus aanvullende maatregelen moeten worden genomen, zodat het getransplanteerde orgaan bij aankomst niet al te ernstig beschadigd is en nog goed kan functioneren. Door deze eisen komen niet alle mensen die overlijden in aanmerking om als donor te fungeren. Of doordat zij zich niet in de buurt van een ontvanger bevinden, of omdat hun lichamelijke toestand voor overlijden een contra-indicatie vormt.

Het oplossen van deze problemen is niet eenvoudig. Aan het probleem van de contra-indicatie is weinig te doen. Iedere overledene onderzoeken op eventuele contra-indicaties voor donatie, vraagt veel tijd en energie, terwijl de kans op een positief resultaat gering is. Voor het verwerven van gezonde donororganen zou het beter zijn om de groep potentiële donoren in te perken tot een groep met een grotere kans op 'bruikbare organen'. Die categorie zou men kunnen vinden door bijvoorbeeld alleen de 'organen te gebruiken van voorheen jonge, gezonde mensen, waarbij nog geen periode van zuurstoftekort is opgetreden' (Wackers, 1994) ${ }^{6}$. Dit betekent dat de aandacht zich moet richten op mensen die door een acute situatie in een dusdanige toestand verkeren, dat de bloedsomloop (al dan niet kunstmatig) intact is, maar waarvan niet verwacht kan worden dat zij ooit nog uit hun coma zullen 'ontwaken'.

Sommige patiënten die op een intensive care unit ${ }^{7}$ overlijden, lijken geschikt om als donor te fungeren. Door deze potentiële donoren kunstmatig 'in leven te houden', krijgt men controle over het moment van ingaan van het zuurstoftekort voor het donororgaan en heeft men voldoende tijd om de gezondheidstoestand van het donororgaan vast te stellen en andere bepalingen te doen. Hiervoor is het echter noodzakelijk dat de doodverklaring niet meer op de traditionele hart-long criteria is gebaseerd, maar op hersenen-gerelateerde criteria. Deze verandering in het doodscriterium, gecombineerd met de ontwikkelingen op het gebied van de orgaanpreservatie, vergroten de aanwezigheid van donororganen.

5 Tijd waarin het orgaan van zuurstof verstoken is, waardoor weefselbeschadiging optreedt. Onderscheiden wordt warme en koude ischemische tijd. Bij warme ischemie is de zuurstofbehoefte groter dan bij koude ischemie, waarbij door koeling een verlaging van de stofwisseling wordt bewerkstelligd en de schade wordt beperkt.

Bij organen als 'hart' en 'longer' is deze tijd veel korter dan bij nieren (Wackers, 1994) en bij nieren wordt deze tijd verlengd door de ontwikkeling van verschillende presenvatietechnieken.

6 Zie voor een uitgebreide beschrijving en analyse van de ontwikkelingen rond het 'doodscriterium' Constructivist Medicine (Wackers. 1994). In dit boek wordt een heel hoofdstuk (hoofdstuk 5 "Death in the skull') gewijd aan de creatie van het begrip 'hersendood' in relatie tot ontwikkelingen in de geneeskunde. Ik zal mij hier beperken tot het belang dat de verschuiving van het doodscriterium heeft voor de transplantatiepraktijk.

7 Zoals Wackers schrijtt:

With regard to severely brain damaged, artificially ventilated and heart-beating patients under treatment in modern intensive care arrangement doubt arose whether life was still present, or whether death had already arrived. Traditional ways of concluding that death had occurred form the permanent cessation of the heart beat and of spontaneous respiration did not suffice anymore in patients in whom the process of dying had been arrested somewhere between its beginning and its completion. (Wackers, 1994) 


\subsubsection{Aanwezigheidsprobleem Opgelost?}

Aanvankelijk bestaat er in Leiden geen aanwezigheidsprobleem. Immers, voor de eerste transplantaties worden daar alleen organen van verwante donoren gebruikt. Pas later worden ook kadaverorganen getransplanteerd. In 1966 neemt men zich voor om - in samenwerking met TNO - het onderzoek naar de mogelijkheden van het gebruik van kadavernieren te intensiveren (Niertransplantatie-werkgroep, 26 augustus, 1966). Enige maanden later besluit de werkgroep dat actiever naar potentiële donoren zal worden gezocht en dat geprobeerd zal worden andere noodzakelijke voorbereidingen te treffen.

Dr. Lameyer zal per 1-1-1967 enige malen per week de Neurologische Afdeling en de Thoraxchirurgie "verkennen". Prof. Vink zegt toe, dat een parate dienst van getrainde chirurgen op korte termijn kan worden opgezet. Op de chirurgenbijeenkomst in maart zal dit probleem ter tafel gebracht worden. (Prof. Vink, Prof. de Graeff, Dr. Lameyer). (Werkgroep Orgaantransplantatie TNO, 19 december, 1966)

Kort na de jaarwisseling - op 21 januari om precies te zijn - wordt de derde patiënt in Leiden met een kadavernier getransplanteerd en de vierde volgt op 7 maart. Een jaar na de eerste transplantatie wordt de 'living related/cadaver'-ratio op 2-2 gebracht.

Hoewel verschillende centra kadaverdonoren (gaan) gebruiken - die al dan niet worden getypeerd ${ }^{8}-$ blijft het aanwezigheidsprobleem bestaan. Sommigen zien het gebruik van kadaverdonoren niet als mogelijke oplossing. De kans dat er voldoende kadavernieren beschikbaar zullen komen, achten zij klein. Aanvankelijk wordt deze vrees echter niet bewaarheid, omdat naar aanleiding van één in de media alom zichtbare transplantatie zich vele donoren aanmelden. Die transplantatie is de eerste harttransplantatie in Zuid-Afrika. De publiciteit die hieraan gegeven wordt maakt dat transplantatie een bij het publiek algemeen bekende en gewaardeerde nieuwe behandelingsmogelijkheid wordt ${ }^{9}$. Dit heeft niet alleen effect op de acceptatie van niertransplantatie als behandelingsmethode, maar ook op het aantal donoren en (dus potentiële) kadavernieren. Het resultaat is dat Van Rood, in 1969 , in the Lancet kan schrijven dat er een stijgende lijn is waar te nemen in het aantal nieren dat beschikbaar is voor transplantatie.

... during recent months the increased publicity resulting from the involvement of physicians in one way or another in renal transplantation has greatly increased the number of available organs. In the first half of 1968 only 5 kidneys became available in Leiden, but in the next six months this number rose to over 20. (van Rood, 1969 )

Het lijkt er dus op dat het aanwezigheidsprobleem afneemt, door kadaverdonoren te gebruiken voor niertransplantatie.

Het aanwezig zijn van een te transplanteren nier betekent echter nog niet dat het orgaan ook aanwezig is bij de ontvanger. Weliswaar verbetert het aanbod aan transplanteerbare organen, maar aanwezigheid bij een ontvanger kan niet onder alle omstandigheden gegarandeerd worden. Zodra de preservatie een langere (koude) ischemische tijd toestaat, wordt de maximaal te verstrijken tijd - en daarmee ook de mogelijk te overbruggen afstand - groter en zal het voor handen hebben van een

8 (Botha, 27 september, 1967 ; Rolley, 2 november, 1967: Pichlmaier, 10 november, 1967)

9 In hoofdstuk 8 (58.2) zal uitgebreid worden ingegaan op de rol die de harttransplantatie heeft gehad op het kadaverdonor aanbod. 
donor ook gemakkelijker daadwerkelijk resulteren in aanwezigheid van een nier bij de ontvanger. Vooralsnog blijven rond het creëren van aanwezigheid problemen bestaan. De introductie van kadaverdonoren, als oplossing voor het donortekort, is deels verantwoordelijke voor deze problemen en zorgt daarbij voor nieuwe problemen rondom het andere aspect van beschikbaarheid: geschiktheid. Ook voor deze problemen wordt naar oplossingen gezocht.

\subsection{Verspreiding Van 'GeschikTHeid'}

Met de identificatie van een aantal verschillende transplantatie-antigenen en de aanwijzingen voor een matchingseffect krijgt geschiktheid van een orgaan immunologische inhoud. Meer en meer wordt gedacht dat een kwalitatief oordeel gegeven kan worden over een bepaalde donor/ontvanger-combinatie en de kans op afstoting bij deze combinatie ${ }^{10}$. Met monospecifieke antisera en geïdentificeerde antigenen kan immunologische geschiktheid gehanteerd worden als selectiecriterium voor donororganen. Daarmee ontstaat een medisch criterium voor de keuze van een donor. Maar hoe 'verspreidt' dit criterium zich over de wereld? Hoe wordt dit criterium verbonden met de klinische (nier)transplantatiepraktijk?

De Leidse onderzoekers zijn van mening dat matchen op leukocytenantigenen een positief effect zal hebben op het succes van de transplantatiepraktijk. Er worden in Leiden dan ook geen transplantaties uitgevoerd, zonder dat vooraf onderzoek is gedaan naar de leukocytengroepen van ontvanger en donor ${ }^{11}$. Elders wordt niet altijd naar de immunologische geschiktheid gekeken. Veel 'transplantatiecentra' hebben niet de beschikking over een laboratorium dat is ingericht om dit soort typeringen te doen. Weliswaar worden in de, over de wereld verspreide, onderzoekslaboratoria ook typeringen ten bate van transplantatie programma's verricht, maar hun aantal is beperkt. Al met al zijn de klinisch typerende laboratoria dun gezaaid. Aan Leiden gestelde vragen om hulp bij het bepalen van geschiktheid, worden op verschillende punten bekeken. Of hulp wordt geven is afhankelijk van de vraag, van wie de vraag stelt, van welke winst er voor Leiden is en van de afstand van het transplantatiecentrum tot Leiden.

Wanneer vanuit een transplantatiecentrum de vraag komt om patiënten en do. noren te typeren, wordt bekeken of het mogelijk is dat de nierpatiënten en hun potentiële donor(en) naar Leiden komen om zich te laten typeren ${ }^{12}$. Bij 'gebleken geschiktheid' wordt vervolgens een nier van de geselecteerde donor naar de patiënt getransplanteerd door de eigen chirurg, in diens eigen centrum. Op deze manier helpt Leiden bij het selecteren van een geschikte verwante donor voor een bepaalde ontvanger.

Het blijkt echter niet altijd mogelijk donor en ontvanger naar Leiden te laten

10. Langzaam aan lijkt er een eind te komen aan een onzekere startfase, die Starzl als volgt verwoordt: The weakness of the method is, of course, the fact that one is measuring something unknown with a polyvalent antiserum, and as $\mathrm{Dr}$. Calne has pointed out, it is a little bit like shooting buckshot in the air. hoping to strike an unspecified target. (Starzl, et al., 1965)

11 Begin jaren 60 werd nog geen belangrijke praktische betekenis aan leukocytentypering gehecht. ... als de chirurg voor transplantatie voelt, dan gaat hij toch zijn gang, terecht $m$.l., want de immunoloog kan wel wetenschappelijke bijdragen leveren, doch maar zeer beperkte praktische. (Hijmans, 18 juli, 1963 )

12 Totdat de mogelijkheden om bloed te versturen, in technische zin voldoende zijn uitgekristalliseerd en het transport binnen de tijdslimieten kan worden georganiseerd, is het voor een betrouwbare typering noodzakelijk dat het te typeren bloed, in de best mogelijke bewaartoestand naar Leiden komt, namelijk in de persoon zelf. 
komen. Als noodoplossing wordt dan geprobeerd om bloed naar Leiden te sturen, al ziet Van Rood dit niet als een ideale oplossing, zoals blijkt uit zijn antwoord op een verzoek van Kerr uit Newcastle upon Tyne ${ }^{13}$.

The difficulty will be, however, to get the material to Leiden. We have done satisfactory typing on material which was sent to us by direct plane from London Airport to Amsterdam. The short interval between the typing and the bleeding is necessary because we are using an agglutination method which needs fresh

blood....(van Rood, 3 r oktober, 1966)

Van Rood geeft gevolg aan het verzoek, maar de uitwerking heeft veel voeten in aarde. De transporttijd tussen afname en analyse van het bloed mag de - dan gehanteerde - limiet van vier uur niet overschrijden ${ }^{14}$.

Soms is de afstand tot Leiden te groot, waardoor transport van bloed niet mogelijk is. Daarom starten sommige verder weg gelegen centra, om toch voor transplantatie over typeringsgegevens te kunnen beschikken, zelf een typeringslaboratorium en vragen Leiden daarbij regelmatig om hulp. Leiden krijgt dan verzoeken om technieken te demonstreren en mensen te trainen in het hanteren en interpreteren van de tests, om als leverancier te dienen voor typeringssera en voor het uitvoeren van kwaliteitscontroles ${ }^{15}$.

Een van deze verzoeken aan Van Rood om concrete hulp, komt bijvoorbeeld van Woodruff, een vooraanstaand chirurg. Het retrospectieve onderzoek bij zijn patiënten heeft zijn interesse voor het typeren van patiënten en donoren gewekt en hij schrijft te hopen dat ze zelf ook "leukocyte grouping" op kunnen zetten (Woodruff, 25 mei, 1966). De concrete vraag van Woodruff betreft 'typeringssera'. Met die sera meent hij een geschikte nier te kunnen vinden, omdat er volgens hem 'genoeg potentiële kadaverdonoren in de ziekenhuizen liggen en er voldoende tijd is om te typeren, waardoor de kans groter is dat langs deze weg een geschikte donor wordt gevonden, dan wanneer getracht wordt een donor te vinden uit een random populatie' (Woodruff, 13 juni, 1966; Woodruff, 6 juli, 1966). Het feit dat een transplantatiepatiënte van hem de nier van haar vader afstootte, draagt mogelijk bij aan deze wens. Woodruff ziet in dit geval een bevestiging van het belang van matchen, want dat de nier zou worden afgestoten, kon op basis van de retrospectieve typering voorspeld worden (Woodruff, 6 juli, 1966). Bij Woodruff groeit dus het geloof in de voorspellende waarde van matchen.

Niet alleen bij binnen Europa gelegen centra, ook bij centra op andere continen-

13 Ken Porter raadde Kerr aan om Van Rood te verzoeken Kerrs donoren en ontvangers te typeren, zodat er een correlatie gemaakt zou kunnen worden tussen de typeringsgegevens en het beloop van de transplantaties.

Het meest interessante punt in het voorstel van Kerr is niet het op voorhand retrospectief typeren, maar het op een andere wijze kijken naar de relatie tussen donor en ontvanger. Een van zijn doelstellingen is namelijk het typeren van "head injury cases" die mogelijk als donor zouden kunnen fungeren. Hierop anticiperend vraagt Kerr om typering van de "few live donor grafts that we are doing, and possibly at some later date the larger task of grouping our intermittent dialysis panel" (Kerr, 15 oktober, 1966). Maar aangezien nog niet aan de randvoorwaarden voor een geslaagde transplantatie kan worden voldaan, is zijn concrete vraag minder verstrekkend.

14 Aangezien het bloed zo vers mogelijk moet zijn, impliceert dit ook dat er goede afspraken moeten worden gemaakt over het moment van arriveren op Schiphol, Wanneer alles klopt, kan iemand al op Schiphol aanwezig zijn om het bloed op te halen en het vervolgens zo snel mogelijk naar Leiden te brengen. Daarnaast is het belangrijk dat het op een dag gebeurt, dat er in het laboratorium ruimte en tijd is om het te analyseren. Het bloed kan immers niet bewaard worden.

15 Zoals bijvoorbeeld Dr. Abbot uit Leeds (Abbott, 2t november, 1966). 
ten groeit de behoefte aan typeringsgegevens. Met sommige van deze centra onderhoudt Leiden ook contacten, maar voor deze centra geldt dat noch het sturen van bloed, noch het naar Leiden laten komen van ontvangers en donoren, een reële optie is. Voor het verkrijgen van typeringsgegevens van hun patiënten en donoren, zijn die centra genoodzaakt zelf een laboratorium op te zetten. De rol van Leiden hierbij is verschillend. Soms is Van Rood persoonlijk behulpzaam, maar meestal wordt personeel in Leiden getraind om vervolgens 'thuis' het laboratoriumwerk te gaan doen (Botha, 29 oktober, 1966). De onder chirurgen veelal sterke wens om te gaan transplanteren, is er debet aan dat de voorbereidingen voor typeren wel eens wat gehaast gaan, hetgeen tot fouten en verlies van antisera leidt. Een voorbeeld hiervan zijn de ervaringen van Botha. Deze Zuid-Afrikaan heeft in 1966 nog geen functionerend typeringslaboratorium en beschikt nog niet over antisera ${ }^{16}$. Hij vraagt direct bij Van Rood om antisera en wil ook de Leidse technieken gaan gebruiken (Botha, 7 november, 1966). Mede omdat een medewerkster van Botha - Marrie Vooijs - gedurende negen maanden in Leiden getraind wordt in het gebruik van de laatste technieken en antisera, stuurt Van Rood de benodigde antisera naar Kaapstad. Maar het opzetten van zo'n lab blijkt niet alleen afhankelijk van de aanwezigheid van antisera, maar ook van training van het overige personeel. Het goed gebruiken en volgen van de procedures op de 'bij de sera horende' wijze is, voor effectief gebruik, essentieel. Dat blijkt echter geen eenvoudige zaak. Gedurende afwezigheid van Botha, en voordat Vooijs terug is, worden er fouten gemaakt die de bruikbaarheid reduceert, waardoor de typering onbetrouwbaar wordt ${ }^{17}$. Het idee van geschiktheidsbepaling voor transplantatie laat zich makkelijker verspreiden, dan het typeren zelf. Soms is Van Roods directe bemoeienis bij het opzetten van een typeringslaboratorium echter veel groter.

Kort na de eerste niertransplantatie in Leiden, ontvangt Van Rood Kelly's verzoek om hulp bij het opzetten van een typeringslaboratorium ${ }^{18}$. De ervaringen in Minneapolis voor wat betreft de overlevingsduur van kadavernieren, maken matchen in zijn ogen noodzakelijk. Kelly wil daarom een situatie creëren waarin een ontvanger geen ongematchte kadavernier meer gegeven hoeft te worden. Om deze wens te kunnen verwezenlijken wendt ook hij zich tot Van Rood ${ }^{19}$.

16 Botha zal ruim een jaar later de typeringen doen van de eerste harttransplantatiepatiênt en diens donor.

17 De antisera zijn dan nog niet dusdanig gestandaardiseerd dat voor ieder antigeen een antiserum is. Bij Botha blijkt niet iedereen hiervan op de hoogte te zijn. waardoor fouten worden gemaakt bij de opgestuurde antisera.

The antisera which you sent me previously

Most unfortunately my Senior Technologist, who received the sera during my absence, did not realize the importance of keeping examples of the same specificity under a batch number. In her enthusiasm, she dispensed the sera into smaller volumes to prevent repeated thawing. The result was that I found about 15 ampoules, each containing $2 \mathrm{ml}$. of serum, all labelled anti-4a, etc. There was no indication of whether this was no. $22, \mathrm{No} .463$ or No. 940. For this reason we can use only one sample for each specificity at the moment. (Botha, 20 september, 1967)

In een P.S. schrijft hij vervolgens nog dat overenthousiasme de oorzaak is geweest van het beperikt bruikbaar worden van de antisera.

You do understand that your wonderful gift of several individual antisera got "messed-up" through overenthusiasm, and not through negligence? (Botha, 20 september, 1967)

18 Zie paragraaf 6.3

19 Terloops breidt hij daarmee ook de mogelijkheden voor het vergroten van de aanuezigheid uit. Specifically $\mathrm{I}$ am interested in the possibility of matching cadaverdonors with prospective kidney recipients under circumstances in which the donor dies during open heart surgery and circulation to the kidney can be maintained for a number of hours with preservation of the kidney in relatively good condition. In 
Kelly voegt met zijn verzoek een nieuw aspect toe aan het idee van het prospectief typeren van kadaverdonoren. Kelly's oplossing gaat verder dan het idee van Woodruff om voor een bepaalde patiënt een kadaverdonor te zoeken, want hij wil een wachtlijst met getypeerde patiënten instellen. Wanneer zich een donor aandient, zou uit deze wachtende patiënten de beste match geselecteerd kunnen worden (Kelly, 3r maart, 1966; Kelly, 5 juli, 1966). Wanneer leukocytengroepen van een potentiële donor worden gecorreleerd met die van de wachtende nierpatiënten, gaat immunologische geschiktheid het criterium vormen voor de keuze van de patiënt die een niertransplantatie krijgt. De donornier vormt dan het uitgangspunt, waar de meest geschikte ontvanger bij wordt gezocht. Kelly's doel is dus het uitvoeren van prospectief gematchte kadaverniertransplantaties. Terwijl men in Leiden zelf pas net de eerste transplantatie met een levende donor heeft verricht, prikkelt Kelly de Leidse groep om over een volgende stap na te denken en nodigt hen zelfs uit om aan de verwezenlijking daarvan mee te werken 20 . Per kerende post reageert Van Rood dan ook enthousiast op dit interessante verzoek.

I was delighted to receive your letter of March 31. Your reasoning on the usefulness of leukocyte grouping in kidney cadaver transplantation is almost identical to our own. Of course we would be delighted if we could be of any real assistance in the typing of these kidney cadaver donors and recipients. (van

Rood, 7 april, 1966)

In het verlengde van de besprekingen die rond de Transplantation Conference hebben plaatsgevonden over het toepassen van typeren bij kadaverdonoren, adviseert Van Rood Kelly om iemand te belasten met het opzetten van een typeringslaboratorium en een screeningsprogramma. Hierbij geeft Van Rood aan dat velen matchen erg belangrijk vinden voor (nier)transplantatie en het NIH ook een "Leucocyte Program" heeft ingesteld "for further knowledge of homograft matching and the general leucocyte grouping in particular" (van Rood, 7 april, 1966). Ten aanzien van het uitvoeren van matchen voor niertransplantatie denkt men nog primair aan 'lokale' opzetten $^{21}$, want Van Rood schrijft:

The general feeling at the moment is that it is almost a conditio sine qua non that those groups active in kidney transplantation should develop their own leucocyte grouping and matching techniques. (van Rood, 7 april, 1966) Hiermee geeft Van Rood enerzijds zijn hoge verwachtingen over het belang van matchen weer, maar anderzijds is hierin ook te lezen dat hij nog geen rekening houdt met uitwisseling van typeringsgegevens tussen transplantatiecentra. Ieder centrum moet zijn eigen technieken ontwikkelen. Ook de aard van zijn pleidooi voor het opzetten van een screeningsprogramma lijkt deze constatering te rechtvaardigen.

... it would be extremely useful if you set up the techniques for screening

selected cases we also will place patients dying in the intensive care unit on extra corporeal circulation to similarly protect renal viability during the several hours or so that it takes to mobilize the recipient and carry the operation to the point where the kidney can be transplanted from the donor. (Kelly, 31 maart, r966)

20 Later krijgt Van Rood meer van dit soort verzoeken. Het idee van een pool van ontvangers wordt door meerderen gezien als een zinvol idee, waar de eerder genoemde Kerr er een van is.

We have a group of about 30 patients on intermittent dialysis on whom we would eventually like to get lymphocyte grouping to correlate with the groups of potential donors such as head injury cases. (Kerr, is oktober, 1966)

21 Zơn laboratorium vervult een lokale functie. In het laboratorium worden zowel de patiènten, als de daar aanwezige donoren getypeerd, die ook in dat centrum zullen worden getransplanteerd. 
leukocyte antibodies. I presume, that you have a department of obstetrics, and they should be able to provide enough sera to find antibodies recognizing most of the antigens now described. I think it is an extremely essential point, as it will take quite some time before good antibodies will be available commercially. If you set up such a screening laboratory, this would imply, of course, that you make a choice for your technique. Local factors, so as technical help, possibilities to bleed a panel regularly, getting large amounts of sera and so on, play a very important role, and 1 am not able from this distance to advise you on this point. Each of the techniques has its own advantage and disadvantage. (van Rood, 7 april, 1966) Volgend op deze brief voeren Kelly en Van Rood (intercontinentale) telefoongesprekken, waaruit de toezegging voortvloeit dat "if this can be arranged with the authorities here" Van Rood met Kelly en diens groep wel een samenwerkingsprogramma wil starten. Verder zegt hij dat hij in november ' 66 en maart ' 67 respectievelijk in de VS en in Canada zal zijn en dan eventueel ook naar Minneapolis zou kunnen komen en wanneer Kelly iemand zou kunnen vinden die leiding wil geven aan het werk in Minneapolis, zij hem nog voordien kunnen trainen (van Rood, 6 mei, 1966).

Kelly gaat door met zijn plannen en verzoekt het NIH om financiering, zodat Van Rood jaarlijks kan komen ${ }^{22}$. Hij vindt de bloedbankarts Dr. Edmond Yunis bereid om het typeren op zich te nemen en deze wil graag naar Leiden komen om de technieken te leren. Ook Leiden is - om meerdere redenen - gebaat bij het slagen van dit samenwerkingsverband en, blijk gevend van hun belangstelling, informeert Van Rood naar wat Yunis tijdens zijn verblijf in Leiden wil leren. Yunis krijgt de ruimte om zelf de datum van zijn verblijf te bepalen (van Rood, 12 juli, 1966). Dit is opmerkelijk, omdat Van Rood op dergelijke verzoeken meestal antwoordt dat het erg vol is in het laboratorium.

Ook Kelly lijkt enthousiast over het van de grond komen van de samenwerking. Direct na ontvangst van de brief van Van Rood, krijgt Yunis van Kelly de aanwijzing dat hij contact op moet nemen met Van Rood om diens vragen te beantwoorden. Daarnaast schrijft hij Van Rood, dat hij een brief naar de 'Trustees of the University of Leiden' stuurt, "indicating that this would involve one trip per year with transportation and expenses paid" (Kelly, 22 juli, 1966) 23.

De samenwerking krijgt gestalte en korte tijd later is Yunis in Leiden, waar hij "quite a few bits of information" over de Leidse techniek oppikt (van Rood, I9 september, r966). Ook kijken ze gezamenlijk naar de benodigdheden voor een goed toegerust typeringslaboratorium en komen tot de conclusie, dat de meeste materialen en benodigde ruimte aanwezig zijn en dat enkel wat speciale apparatuur, zoals een high-speed centrifuge, aangeschaft zou moeten worden. De kans groeit dat er

22 Kelly schrijtt aan Van Rood:

I will be submitting a renewal application proposal to the NIH on our transplantation work on September I included in which will be a proposal to carry out histocompatibility matching of a cadaver donor against a battery of prospective recipients maintained on chronic dialysis. You will be listed as a consultant in this effort, and I will request funds to support a yearly visit to this area. (Kelly, 5 juli, 1966)

23 En verder probeert Kelly, naar aanleiding van het voorstel om in november met George Eernisse en Aad van Leeuwen te komen (zoals gezegd gaat uiteindeliik niet George Eernisse, maar Hans Bruning mee), de gevraagde financiering via zijn NIH-contract rond te krijgen (Kelly, 6 september, 1966). De eerste 'trip' wordt uiteindelijk gecombineerd met de Contractors Meeting van het $\mathrm{NIH}$, waardoor Aad van Leeuwen mee kan. 
in de nabije toekomst in Minneapolis een goed typeringslaboratorium van de grond komt. Dat betekent ook dat het voor Van Rood steeds interessanter wordt om daar te gaan typeren. De kans wordt steeds groter dat in plaats van ter plekke veel tijd te moeten besteden aan het inrichten van een laboratorium, het mogelijk wordt om de daar aanwezige patiënten en hun donoren daadwerkelijk te typeren. Dit levert het laboratorium in Minneapolis ook een goed panel op. Hierover spreekt Van Rood uitgebreid met Yunis (van Rood, I9 september, 1966$)^{24}$. Op zich is het typeren van de donor/ontvanger-combinaties zowel voor Kelly, als voor Van Rood in directe zin interessant. Dat het voor Yunis, als panel, ook een interessante groep is, maakt het voor Van Rood ook strategisch interessant. Op deze manier 'krijgt hij' een panel in de VS, dat met de Leidse antisera is getypeerd en dus met de Leidse antigenen overeenstemmende agglutinerende antisera op kan leveren. Op deze manier 'verkoopt' hij zowel 'hun' antigenen, als 'hun' techniek ${ }^{25}$.

De voorbereidingen van de reis naar de Verenigde Staten gaan door. Een van Van Roods wensen is, dat in de verschillende laboratoria de situatie zoals die in Leiden is, zo goed mogelijk geimiteerd wordt. Hiertoe geeft Van Rood een 'verlanglijstje' met niet gemakkelijk transporteerbare apparatuur en faciliteiten ${ }^{26}$. Kelly op zijn beurt, schrijft door te gaan "with making arrangements to have surviving kidney transplant recipients and their respective living donor available for testing" (Kelly, Io oktober, 1966). Zo wordt alles in gereedheid gebracht om er een 'profitable stay' van te maken. Nadat de laatste financiële en organisatorische plooien zijn gladgestreken, vormt Minneapolis van 4 tot en met 7 november 1966 de eerste halte van de onderzoeksreis door de VS.

Enkele maanden na de reis stuurt Van Rood een overzicht van de typeringsresultaten van Kelly's patiënten, met de mededeling dat ook incompatibele combinaties het goed doen. Daarnaast schrijft hij dat het typeringsbezoek, voor het laboratorium een zeer goed panel heeft opgeleverd27. "These typings ought to give Yunis really a very good start indeed." (van Rood, 2I februari, I967) Met dit panel zal Min. neapolis de specificiteiten van nieuwe antisera goed kunnen bepalen. Dit is, zo schrijft Van Rood, voor de groep in Minneapolis (maar ook voor Leiden) van groot

24 Van Rood schetst aan Kelly waarom deze patiënten en hun donoren zo'n interessant panel vormen. As for Dr. Yunis I think this will be a very fine group of people to have as a panel. You have so to say a grip on these patients as they have to come back regularly anyhow and have to give blood regularly. The donors who will be in general family members. You can tell that their blood is needed to see how the transplant is doing. (van Rood, 19 september, 1966)

25 Die verschillende plaatsen dragen zelf bij aan de financiering van de 'kolonisering van de Nieuwe Wereld'. Mogelijk dat dit zelfs indirect als argument wordt gebruikt om ook van anderen financiering te krijgen. Van Rood meldt R.T. Huntley in Denver dat ze ook anderen geld gevraagd hebben en doet daarbij de suggestie dat zij met elkaar in contact kunnen treden om te zien wie, hoeveel geld beschikbaar heeft gekregen, zodat de reis kan doorgaan (van Rood, 22 september, 1966). Als anderen van wie hij subsidie-toezeggingen heeft gekregen, noemt Van Rood: Dr. William D. Kelly, Minnesota; Dr. Paul Russell, Mass, Gen. Hosp. Boston; Dr. F.H. Allen, NY Blood Center.

Zie verder Hoofdstuk 6 voor een inhoudelijk verslag van de onderzoeksreis door de VS.

26 Zoals:

'centrifuge, Zeiss binocular microscopes, incubator, waterbath, tabletop centrifuge, use of $-20 \mathrm{C}$ freezer, +4 C refrigerator with dry ice' (van Rood, 22 september, 1966; van Rood, 27 september, 1966).

Het moeten speciaal Zeiss microscopen zijn in verband met montage van specifieke hulpstukken voor de preparaataflezing.

This is especially essential as the readings are done on an order-made sfide which fits into a holder. This holder on its turn has to be fitted to the microscope ... (van Rood, 22 september, 1966)

27 Met alle zeldzame typen: $4 a+b-, 5 a+b-6 a-b+, 7 a+, 7 c+$ en $7 d+$ (van Rood, 2 f februari, 1967). 
belang. Wanneer Yunis zelf goed in staat is om de specificiteiten te bepalen, komen uit Minneapolis minder te specificeren antisera naar Leiden en kunnen anderen hun sera, voor het bepalen van de specificiteit, naar Minneapolis sturen, in plaats van naar Leiden. Minneapolis zou dan kunnen gaan fungeren als dependance van het Referentielaboratorium Leiden. Vanuit Minneapolis zou het laboratorium in Leiden in ieder geval niet extra belast worden met nog meer 'routinewerk', maar het mogelijk zelfs kunnen ontlasten. Daarnaast - en minstens even belangrijk voor Kelly en Yunis - kan men in Minneapolis een begin maken met het toepassen van prospectief typeren en matchen van donoren en ontvangers.

$\mathrm{Na} 1966$ krijgt men in Leiden steeds vaker vragen om hulp en advies bij het opzetten van prospectieve typering voor kadaverniertransplantaties ${ }^{28}$. In verschillende centra wordt niertransplantatie niet meer als experimenteel gezien, maar als een behandelingsmethode met een aanzienlijke kans op succes. Prospectief typeren wordt daarbij beschouwd als iets waar - op z'n zachtst gezegd - aandacht aan moet worden besteed, of zelfs als noodzakelijke voorwaarde om (weer) met niertransplantaties te kunnen beginnen ${ }^{29}$. De verzoeken om hulp, dan wel advies, beantwoordt Van Rood met het sturen van een aantal reprints van artikelen, waaronder het Eurotransplant-voorstel, zoals dat in Histocompatibility Testing 1967 gepubliceerd wordt.

Het ontstaan van de mogelijkheid om een medisch allocatiecriterium te hanteren voor de toewijzing van donororganen in de transplantatiepraktijk, voegt een nieuw soort adviesvragen toe aan de toch al vele verzoeken om informatie die men in Leiden ontvangt. Hoe moeten de verschillende 'matches' gewaardeerd worden? Hoe een identieke combinatie gewaardeerd moet worden is duidelijk, maar dit soort combinaties is zeldzaam. Echter, ook niet-identieke combinaties blijken het goed te kunnen doen, waardoor ook compatibele combinaties getransplanteerd kunnen worden. Maar wat geldt als compatibel en zijn daar nog kwalitatieve verschillen in te maken? Hierover lopen de meningen uiteen. Verschillende centra die inmiddels beschikken over een typeringslaboratorium, komen nu met dat soort adviesaanvragen bij Van Rood. Ervan uitgaand dat de typering correct en volgens hun eigen, 'Leidse' methode uitgevoerd is, kan hij adviseren in de beoordeling van de mate van gematcht zijn van een bepaalde combinatie en meer in algemene zin advies geven over welke mismatches beter niet gebruikt kunnen worden. Maar bij deze adviezen houdt hij een grote slag om de arm. Meer zekerheid over de verschillende waarderingen ontbreekt nog en zal pas na meerdere jaren onderzoek verkregen kunnen worden. Zo althans reageert Van Rood op de eerder geciteerde brief van Botha, over de matching en condities van de drie potentiële 'cadaver donors' voor drie patiënten (Botha, 27 september, 1967).

I think that what we can do at the moment is to prevent very important incompatibilities like an incompatibility both for $4 \mathrm{a}$ and $8 \mathrm{a}$. The best is to look

28 Onder andere (Mowbray, 30 januari, 1967; Brockis, 2 mei, 1967; Peart, 4 augustus, 1967 ).

29 ,Zoals Dr. Hofflet uit Berlijn, waar ze zijn gestopt met het verrichten van niertransplantaties vanwege de slechte resultaten met ongematchte (kadaver)donoren.

... we are waiting for more favourable conditions to restart transplanting. Our clinic, especially our dialysing section, would then take charge of the non-surgical therapy. We believe, however, that we cannot do without an histocompatibility test (including cadaveric kidneys), and therefore we should like to ask your assistance in solving this special problem. Would you be so kind as to let us know what ways and means you see, e.g. whether serum can be sent to Leiden or whether a colleague of our team can be trained by you in this resp. method. (Hoffler, 27 december, 1967) 
for complete identities or almost identities. Anything between that is to hazy for me and I would not be able to chose either. (van Rood, ro november, 1967)

In Zuid-Afrika gaan de 'typeringszaker', na de harttransplantatie op 3 december 1967, erg goed. Er bestaat daar een groot enthousiasme voor transplantatie en transplantatie-immunologie. De belangstelling is zo groot dat Botha schrijft dat hij het hele land door reist om het enthousiasme te coördineren ${ }^{30}$.

Wereldwijd krijgt het typeren van leukocytenantigenen, teneinde de meest geschikte donor/ontvanger-combinatie te selecteren, meer en meer vaste voet aan de grond. Leiden wordt niet overgeslagen als plaats om verzoeken aan te richten ter verkrijging van informatie, ondersteuning en antisera. De vele vragers krijgen allemaal antwoord, worden van pre-en reprints voorzien en worden voor antisera verwezen naar de serumbank van het NIH, of krijgen antisera uit eigen voorraad. Zo gaat het toenemend gebruik van kadaverdonoren hand in hand met een groei in het typeren van donoren en ontvangers, ter aanvulling op het gebruik van immunosuppressiva.

In de loop van de jaren 60 vindt er een verschuiving plaats in het denken over wie als donor kan fungeren. In centra waar voorheen vooral nieren van verwanten werden getransplanteerd, worden kadavernieren meer en meer gezien als alternatief dan wel aanvulling op het donoraanbod. Verbeteringen in de immunosuppressie verlagen de drempel om niet-verwante donornieren te transplanteren. Wanneer kadavernieren het aanwezigheidsprobleem verminderen en men toch naar de geschiktheid van deze nieren kan kijken, wordt het mogelijk om alleen die nieren bij een bepaalde patiënt te transplanteren, die aan vooraf vastgestelde criteria voldoen. In verschillende transplantatiecentra ontstaan plannen om kadaverniertransplantaties op basis van matchen uit te voeren. Daarbij wordt voor het opzetten van een typeringslaboratorium vaak de hulp en ondersteuning van de Leidse groep ingeroepen. In toenemende mate wordt geschiktheid verbonden aan klinische transplantatie. Als idee raakt geschiktheid verspreid. Daarmee is het nog geen succesvolle praktijk, maar kan het dat wel worden. Het karakter van het aanwezigheidsprobleem verandert van zoeken naar een donor, door de mogelijkheid een antwoord te geven op het geschiktheidsprobleem, in een kwestie van wachten op een geschikte donor. Hoe wordt dit vertaald naar een praktijk? Een kadaverdonor 'dient zich onverwacht aan'. Vervolgens is het de vraag wie van de wachtende en getypeerde ontvangers getransplanteerd zullen worden met de dan aanwezige donornieren? Mits niet alleen het geschiktheidsidee is verspreid, maar ook de faciliteiten aanwezig zijn om kadaverdonoren te typeren, kan Eurotransplant uit de potentiële ontvangers, de meest geschikten selecteren.

\subsubsection{Perifere Laboratoria}

Wanneer transplanteren van kadavernieren in toenemende mate wordt verbonden met het uitvoeren van prospectieve typeringen, neemt het aantal typeringsverzoeken aan de dungezaaide onderzoekslaboratoria toe. Door het grote aantal verzoeken om klinische typeringen, komt in deze laboratoria het onderzoek in de knel ${ }^{31}$. Een

30 Maar voor meer specifieke (match)adviezen vindt Botha zichzelf toch nog afhankelijk van Leiden. I will soon send you our phenotypes, so that you can tell me for which patients we may strive to find identical matches, and which patients should be safeguarded against particular transplants. (Botha, 4 maart, x968)

31 Zie de brief van Zmijewski, in Hoofdstuk 3. 
oplossing hiervoor is het opzetten van meerdere klinische typeringslaboratoria. De meeste typeringsverzoeken kunnen dan over die klinische laboratoria worden verdeeld, zodat de onderzoekslaboratoria zich weer grotendeels op onderzoek kunnen richten. Maar hoe krijgt deze decentralisering vanuit Leiden gestalte?

Ten tijde van de Histocompatibility Testing Workshop in Turijn in 1967 is er, mondiaal gezien, nog geen sprake van een redelijke spreiding van klinische typeringslaboratoria. Voor typeringsdiensten wenden collega's uit Nederland en België, maar ook uit andere Europese landen, zich (onder andere ${ }^{32}$ ) tot Leiden. Zo schrijft Dr. Scheitlin uit Zürich dat in Zwitserland geen "Leukozytengruppierung" mogelijk is en hij verzoekt daarom om samenwerking. Hij vraagt of materiaal gezonden kan worden en hoe dat in zijp werk moet gaan (Scheitlin, 29 augustus, 1967$)^{33}$. In reactie hierop stuurt Van Rood een uitvoerige brief, een handleiding voor het versturen van bloed en het bijbehorende verpakkingsmateriaal. Hij doet het aanbod om een laborant(e) te trainen - waar men in Zwitserland zeer blij mee is - en legt het Eurotransplant-programma uit ${ }^{34}$. Verder vraagt Van Rood Scheitlins mening over de opzet van Eurotransplant en informeert of ze geïnteresseerd zijn om eraan deel te nemen. Daarbij maakt hij de aantekening, dat het om verschillende redenen handig zou zijn wanneer ze zelf typeringsfaciliteiten zouden opzetten.

The second possibility is that you start to do leukocyte determinations yourself.

As it will be quite soon necessary to do so anyhow, you might prefer this. For this reason we have set up a training program....

The best person to do this kind of work is a senior technician who has a background in erythrocyte blood group work or blood transfusion. If you have somebody available who would qualify it would be possible that she or he could be trained in our laboratory. (van Rood, 25 september, 1967 )

In deze bereidwillige toezegging om hulp en service te verlenen zit ook de boodschap verpakt dat, wanneer men in Zürich iets in de transplantatiepraktijk wil gaan betekenen, men daar zelf over een typeringslaboratorium moet beschikken: "I think that this approach is very essential to enable you to participate in the Eurotransplant work" (van Rood, 25 september, 1967 ). Hij voegt hier aan toe dat het geheel nog in een voorbereidend stadium is, maar dat vele centra al interesse hebben getoond en dat ook de WHO het initiatief zou willen ondersteunen. Verder zegt Van Rood dat hij nu nog positief kan reageren op een verzoek om servicetyperingen, maar dat dit in de toekomst om verschillende redenen niet meer haalbaar zal zijn.

Deze en andere reacties op de vele verzoeken om servicetyperingen maken dui-

32 Hoogstwaarschijnlijk ontvangen anderen in Europa - zoals bijvoorbeeld Batchelor, Dausset, KissmeyerNielsen en Ceppellini - gelijksoortige verzoeken.

33 In dit geval wordt het gebruik van typering verbonden met het door omstandigheden verwante donoren moeten gebruiken.

Wegen Schwierigkeiten bei der Transplantationsbeschaffung haben wir uns entschieden, fortan auch verwandte Lebendspender zu verwenden. ... (Scheitlin, 29 augustus, 1967)

34 Van Rood schrijtt aan Scheitlin over de opzet van Eurotransplant:

This is an organisation which was proposed last summer in St. Vincent during the Histocompatibility Testing meeting. The Eurotransplant program hopes to realize the following: a number of collaborating hospitals in Europe will determine the leukocyte groups of patients on chronic dialysis who have no relatives, who are willing and able to donate a kidney. These data will be fed into a computer. The computer and the program are already available. When in one of the collaborating hospitals a cadaver is available, the cadaver can be typed and it can be decided whether one of the recipients of the local team is compatible or near compatible. If this is not the case a telephone call can be put through to the computer and it can be learned in this way where the nearest compatible donor is living. (van Rood, 25 september, 1967 ) 
delijk dat Van Roods visie op de wenselijkheid van perifere laboratoria verandert. De terughoudendheid om anderen in te wijden in de experimentele kunst van het ty. peren, verruilt hij voor het idee dat decentralisering van het typeren niet alleen mogelijk, maar zelfs noodzakelijk is. Het aantal aangevraagde klinische typeringen is in Leiden in enkele maanden tijd zo groot geworden dat nieuwe aanvragen niet meer gehonoreerd kunnen worden. Daarom wordt gesuggereerd om zelf het typeren ter hand te nemen.

... Eurotransplant implies that typing has to be decentralized. I think this is a good thing anyhow as typing facilities should be available in every big city such

as Bruxelles ... (van Rood, 29 november, 1967 )

Decentralisatie behelst echter meer dan slechts het elders inrichten van een laboratorium om te typeren. Niet alleen moeten technieken en procedures op één lijn worden gebracht, ook mensen moeten in de maat gaan lopen en dat levert wel eens problemen op.

Yesterday, Dr. A. Govaerts bitterly expressed me the wrong feeling you gained through my awkward comments about "Eurotransplant" that I was expressing unfriendly criticisms about his aptitude to play his role in our transplantation program. My words have indeed exceeded my thoughts and I meant only to criticize our poor organization, and your European plan seemed to offer so much for the future improvement of this organization.

Your own answer to my comments has thoroughly convinced me that tissue typing should be decentralized and that indeed Dr. Govaerts could take an important part in this matter. ... (Toussaint, 22 december, 1967)

Door de vele verzoeken die aan de Leidse groep worden gedaan om mensen te trainen ${ }^{35}$, ontstaat, bijna ongemerkt, de mogelijkheid om het netwerk van typeringslaboratoria te standaardiseren ${ }^{36}$. Aanvankelijk is iedereen welkom. Technieken worden gedemonstreerd en aangeleerd, en wanneer iemand terug gaat naar de eigen standplaats, krijgt hij of zij een set sera mee, waarmee 'verder geoefend' kan worden.

Naast het klinische doel dat Van Rood met 'Eurotransplant' voor ogen heeft voor zoveel mogelijk patiënten een zo goed mogelijk gematchte nier beschikbaar maken - wil hij tegelijkertijd verder werken aan het onderzoek naar het matchingseffect, nu zowel de weefseltypeerders, als de deelnemende chirurgen, onder de paraplu van 'Eurotransplant' verenigd zijn.

I think also that we should try to make Eurotransplant not only an organization

in which the best donor is fitted to the best recipient but that we also try to analyse the results and publish them together. (van Rood, 2 januari, 1968) ${ }^{37}$

35 (van Rood, 31 januari, 1968; Opitz, 28 februari, 1968; Dick, 1 maart, 1968).

36 Zo worden aanvankelijk typeringen zowel in Brussel als in Leiden uitgevoerd. Hiermee wordt als het ware een mini-Workshop gecreëerd, nu echter met een leraar/leerling verhouding. De betrouwbaarheid van niet in Leiden verrichtte typeringen is een punt van aandacht, maar zou dit na verloop van tijd niet meer mogen zijn. waarna het uitvoeren van controletyperingen niet meer nodig is. Toch is de reproduceerbaarheid van de resultaten uit de verschillende perifere typeringslaboratoria, een van de belangrijkste punten van zorg. De betrouwbaarheid van de gegevens is cruciaal. Het is vanaf het begin van het opzetten van de perifere laboratoria ook duidelijk, dat het aanleren van de gestandaardiseerde technieken niet alleen noodzakelijk is om te kumnen typeren, maar vooral ook om de uitwisseling van de gegevens mogelijk te maken.

37 Het analyseren van de transplantatieresultaten, langs verschillende assen doorsneden, maakt dertig jaar later nog steeds een belangrijk (minder publiek zichtbaar) deel uit van het werk dat bij Eurotransplant wordt verricht. 
De aanvragen blijven binnenstromen: zowel verzoeken om servicetyperingen, als aanvragen om te participeren in Eurotransplant. ledereen wil meedoen aan dit veelbelovende project. Vanuit Leiden wordt veel tijd gestoken in, zoals Van Rood aan Kissmeyer-Nielsen schrijft, decentralisatie van typeren.

At the moment we are busily setting up typing centers. There is a girl from

Govaerts (Bruxelles) now with us and the people in Amsterdam of course know all the tricks already and have received our sera. April ist someone from

Nijmegen will come to be instructed in the leukocyte grouping and then I hope

Groningen will follow soon. Contacts with Louvain are very good too and I think they will be in the very near future also in the game.

This will make it possible to do rather decentralised typings at the end of this year. (van Rood, 18 maart, 1968)

Hoeveel het Van Rood er nu aan is gelegen om het typeren te decentraliseren blijkt uit het gegeven dat - naast alle mensen die vrijwel continu de kunst af komen kijken in Leiden - er een speciale cursus wordt georganiseerd, waar verschillende leidende mensen uit het veld hun technieken komen demonstreren. Op deze manier kan een grote groep belangstellenden in korte tijd kennis maken met het typeren, waarna de 'cursisten' in hun eigen laboratorium verder kunnen oefenen en een klinisch typeringslaboratorium kunnen opzetten.

Het geven van een cursus en op andere manieren trainen van mensen lost echter slechts een deel van de problemen rond decentralisatie op. Naast het feit dat iedereen de technieken moet kunnen uitvoeren, dient ook een gestandaardiseerde serumvoorziening te worden opgebouwd, zodat iedereen met dezelfde technieken en dezelfde sera typeert. Op verschillende gebieden moet veel werk worden verricht om dit te verwezenlijken, want "reproducibility is the main headache of leukocyte typing" (van Rood, 30 augustus, 1968). Eerder schreef Van Rood al aan Dr. A. Walsh (President van de European Dialysis and Transplantation Association (EDTA)), dat een van de grote problemen bij het opzetten van Eurotransplant bestaat uit de noodzaak ervoor te zorgen dat, ondanks decentralisatie, de reproduceerbaarheid gewaarborgd blijft (van Rood, 3 april, 1968). De EDTA wil behulpzaam zijn bij het opzetten van Eurotransplant, hetgeen in dank wordt aanvaard ${ }^{38}$. De kanalen van de EDTA kunnen ook worden gebruikt voor het bekend maken van de cursus. Niet dat het doorgaan van de cursus afhankelijk is van deze bekendmaking, want de belangstelling is zo groot dat niet alle aanvragen voor deelname kunnen worden gehonoreerd.

I was very interested to hear the latest news on Euro-transplants. I am

disappointed that it is not possible for my assistant, Mr. J. Wentzel, B.Sc., to join your course because I am sure he would have gained enormously from doing so. I quite understand however that the course has been so popular that all places are over subscribed. (Harris, 18 juni, 1968)

Met het toenemend aantal perifere laboratoria groeit de behoefte aan antisera voor klinische typering. Hierdoor wordt de schaarste aan antisera problematisch. Alle deelnemende en startende typeringslaboratoria wordt dan ook op het hart gedrukt

38 Maar de invloed van de EDTA mag niet te groot worden. En dat is een andere reden, om op het aanbod om de resultaten van Eurotransplant te publiceren, vriendelijk doch beslist te antwoorden, dat dit toch eerst door henzelf dient te gebeuren (van Rood, 18 oktober, 1968). 
om een 'serumscreeningsprogramma' op te zetten ${ }^{39}$. Voordat er sprake was van Eurotransplant, heerste nog het idee dat ieder laboratorium op deze manier self-supporting zou kunnen zijn, maar door de betrouwbaarheidseis voor het uitwisselen van organen met andere centra, kan er alleen met 'gestandaardiseerde sera' worden gewerkt. De bij Eurotransplant aangesloten typeringslaboratoria volgen de procedure dat, wanneer er antilichaam bevattende sera worden gevonden, men in Leiden de specificiteit bepaalt en daar het besluit neemt om het serum al dan niet op te nemen in de 'ET-serumset'. Dit is de verzameling antisera die Eurotransplant naar alle deelnemende typeringslaboratoria zendt. Een vereiste voor deze opzet - om zo als Eurotransplantgemeenschap self-supporting te zijn voor wat betreft de antisera - is echter dat wordt gescreend. Sommige laboratoria doen dat zonder mankeren en hun activiteiten worden dan ook van harte ondersteund door Van Rood, zoals blijkt uit een bericht aan Sokal in Leuven, waarbij hij expliciet toezegt te zullen helpen bij het bepalen van de specificiteit van de gevonden goede sera (van Rood, 6 augustus, 1968; van Rood, I8 september, 1968). Een enkeling begint zelfs met screenen en besluit pas later om ook klinische typeringen te gaan uitvoeren, zoals Vermylen van het 'Bloedtransfusiecentrum' in Leuven. Hij meldt dat na 4000 multipara gescreend te hebben, hetgeen 20 'interessante sera' heeft opgeleverd, hun laboratorium nu ook voor AZ St. Rafaël wil gaan typeren. Vanwege deze klinische typeringen verzoekt Vermylen om toezending van de te gebruiken testsera (Vermylen, 25 november, 1969).

Screeningsprogramma's kunnen antisera opleveren. Van een aantal laboratoria komt het bericht dat men, na het laboratorium te hebben ingericht, is begonnen met screenen en dat monsters zullen worden opgestuurd (Pichlmayr, 13 september, I968; Land, 25 Oktober, I968). Naar aanleiding van deze aanbiedingen legt Van Rood een aantal criteria vast, waaraan de te specificeren 'interessante antisera' moeten voldoen. De sera moeten voldoende sterk, (hoofdzakelijk) door zwangerschap geïnduceerd en in grote hoeveelheden aanwezig zijn (van Rood, 20 december, 1968). Met het oog op het toenemende tijdgebrek in Leiden, moet de beschikbare tijd zo efficiënt mogelijk gebruikt worden. Een serum dat echt interessant is, moet daarom in voldoende grote hoeveelheid beschikbaar gemaakt kunnen worden, zodat die nieuwe sera ook in alle aangesloten laboratoria voor klinische typering gebruikt kunnen worden. Screenen 'kost' echter ook antisera, want sommige collega's in screenende laboratoria vinden dat zij een panel van getypeerde leukocyten donoren nodig hebben, om zelf de (voorlopige) specificiteit van een interessant serum te kunnen bepalen. De meeste laboratoria hebben deze ambitie echter niet.

De typeringscursus maakt het voor velen mogelijk om te starten met typeren, maar het blijft moeilijk om een hecht, betrouwbaar en voldoende fijnmazig netwerk van typeringslaboratoria te krijgen. De bereidheid om mee te werken is niet voldoende. De technieken moeten aan verschillende eisen voldoen en de beschikbaarheid van antisera moet worden verbeterd. De infrastructuur en procedures moeten worden gecreëerd, om ervoor te zorgen dat identieke materialen en antisera in alle perifere laboratoria beschikbaar zijn, zodat uiteindelijk de geschiktheidsbepaling

39 Veelal wordt gesuggereerd om hiervoor de kraamafdeling te vragen bloedmonsters te leveren (zie ook de brief aan Kelly). Deze kunnen dan worden gescreend op de aanwezigheid van antilichamen. Wanneer in een monster antigenen aanwezig blijken te zijn, kan men een relatief gezonde vrouw vragen om meer serum te leveren. Vervolgens kan de specificiteit van het antilichaam bepaald worden. 
van een bepaalde donor op de ene plaats ook daadwerkelijk iets zegt over de geschiktheid van dat orgaan bij transplantatie in de geselecteerde ontvanger.

Een volgende stap in het betrouwbaar maken van het typeren is het controleren van de kwaliteit van het geleverde werk in de verschillende typeringslaboratoria. Voor de bij Eurotransplant aangesloten typeringslaboratoria zal dit in Leiden worden gedaan door het - daarom zo genoemde - Eurotransplant Reference Laboratory (ETRL). De experimentele controlepraktijk waarin de milt van een donor wordt meegezonden, wordt omgezet in een routinematige controlepraktijk aan de hand waarvan de verrichtte typering steevast wordt gecontroleerd. Zo wordt typeren gedelegeerd aan de perifere typeringslaboratoria, terwijl de standaardisatie, een groot deel van de logistiek en de controle in Leidse handen blijft. Door deze opzet is er in Leiden een lagere werkdruk wat betreft het typeren. Er is een kortere afstand van een potentiële donor tot een laboratorium en is er controle op het tot stand komen van de typeringsgegevens van zowel ontvangers als donoren. Hierdoor ontstaat vertrouwen in de vergelijkbaarheid en betrouwbaarheid van de gegevens die in de Eurotransplant Databank worden opgenomen. Op basis van deze gegevens kan men over de geschiktheid van een bepaalde combinatie besluiten.

\subsection{WACHTEN IN PLAATS VAN ZOEKEN}

Vanuit Leiden wordt geprobeerd om het aantal aanwezige donornieren te vergroten. Door niet alleen levende verwanten als potentiële donoren te beschouwen, maar ook (bijna) overledenen, wordt het mogelijk om veel meer nierpatiënten een transplantatie aan te bieden. Maar bij welke patiënt(en) zal een aanwezige kadaverdonornier worden getransplanteerd? Tegelijkertijd werkt men aan het decentraliseren van het typeren, waarmee het geschikt zijn van een bepaalde ontvanger voor een bepaalde donor kan worden vastgesteld. Meer en meer raken deze activiteiten verbonden aan transplantatie. Maar wat moet er worden gedaan om aanwezigheid en geschiktheid zodanig met elkaar te verbinden, dat dit resulteert in een zo hoog mogelijke beschikbaarheid? Welke maatregelen zijn nodig om zo optimaal mogelijk van het toegenomen aantal te transplanteren donornieren gebruik te maken? Wie komt voor een donornier in aanmerking?

Om deze laatste vraag te beantwoorden, verbindt men geschiktheid met het computerprogramma dat patiënten ordent op hun typeringsgegevens, dat in Leiden is ontwikkeld.

We have been setting up a program on the computer by which people who are equal can be selected and also people who are equal but for one antigen, but for two etc. (van Rood, 5 september/oktober, 1966$)^{40}$.

Door typeringsgegevens in de computer in te voeren en vervolgens de computer de identieke en bijna identieke personen bij elkaar te laten zoeken, kunnen mensen die het best bij elkaar passen, worden geselecteerd. Met dit programma kan bijvoorbeeld gezocht worden naar een verwante donor waarbij uit meerdere potentiële kandidaten een keuze gemaakt moet worden. Bij kadaverdonoren ligt dit anders. De donor kan pas worden getypeerd rond het moment van overlijden. Pas daarna kunnen deze typeringsgegevens worden vergeleken met de opgeslagen gegevens van de wachtende patiënten. Vervolgens moet de donornier, naar het ziekenhuis van de ge- 
selecteerde patiënt worden getransporteerd, zodat deze patiënt ermee kan worden getransplanteerd.

De nieuw ontstane mogelijkheden om kadavernieren met succes te transplanteren, omdat nu ook kadaverdonoren getypeerd kunnen worden, zorgen ervoor dat oude vragen opnieuw kunnen worden gesteld: "How can we find an identical unrelated kidney for patients awaiting a kidney transplant when no identical related kidney is available?" (van Rood, 1967). Ofwel, hoe groot moet de groep wachtende patiënten zijn, om voor een bepaalde kadavernier een geschikte ontvanger te kunnen selecteren? Van Rood vraagt aan zijn toehoorders bij de Conference in St. Vincent (en lezers van zijn voorstel in Histocompatibility Testing ${ }^{1967}$ ) hem te volgen in een gedachtenexperiment.

Assume that one hundred transplant teams decide to cooperate and each such team would have Io patients awaiting a kidney transplant. For these Iooo patients, the leukocyte groups could be typed and the resulting information stored in a computer. When one of the cooperating teams is notified that it will receive a cadaver kidney, the potential donor can be typed for blood and leukocyte groups; if this team has no suitable recipient a telephone call to the computer will locate the best-matched recipient(s) in a matter of minutes. The physician in charge of the appropriate patient can then be contacted to determine whether the cadaver kidney is really suitable for his patient. (van Rood, 1967)

Van Rood heeft dus het idee, dat 1000 patiënten op de wachtlijst voldoende moet zijn om voor iedere donornier een redelijk goed gematchte ontvanger te vinden ${ }^{41}$. De op te richten organisatie Eurotransplant, zal de typeringen van de patiënten en andere noodzakelijke gegevens in de computer bewaren. Een eventuele donor zal worden getypeerd en die typering zal vergeleken worden met de gegevens in de computer, waarna het orgaan aan de meest geschikte ontvanger kan worden toegewezen.

Op het moment dat Van Rood zijn voorstel in St. Vincent presenteert, zijn er nog geen 100 centra waar transplantaties worden gedaan, maar hij verwacht dat dat aantal op korte termijn bereikt zal worden. Hij verwacht ook dat alle benodigde typeringen verricht zullen kunnen worden en dat een computer, inclusief geschikt programma, op korte termijn aanwezig zal zijn. De ontwikkelingen in de serologie zijn dusdanig, dat typeringen redelijk betrouwbaar zijn geworden en serumvoorziening geen probleem meer hoeft te vormen. Ook over het transport van te transplanteren nieren, van het uitnemende naar het transplanterende centrum, is hij hoopvol. Hij verwacht dat een nier voor 24 uur bruikbaar gehouden zal kunnen worden. Voor het feitelijke transport zou een men beroep kunnen doen op de militaire luchtvaart. De vraag blijft of genoeg centra zullen deelnemen en de hele opzet betaalbaar zal (b)lijken. Omdat een patiënt na een geslaagde niertransplantatie makkelijker te behan-

41 Nadat Eurotransplant een aantal jaren functioneert, en het aantal 'full-house' combinaties veel groter blijkt dan verwacht, wordt een schatting gemaakt van de kans op het aanwezig zijn van een perfect gematchte nier, afhankelijk van het voorkomen van het fenotype in de populatie en bij een bepaald aantal donoren. De kans op het vinden van een gematchte donor wordt dan ingeschat op basis van een frequentie van HL.A fenotype van $0,5 \%, 1 \%$ en $2 \%$. De resulterende kans op zo'n match wordt dan bij een donor-pool-grootte van rooo respectievelijk: 0, 99; 1,0 en 1,0 , Op basis van de sterftecijfers en de verwachte overlijdensdiagnosen, wordt geconcludeerd dat voor de patiénten met een fenotype frequentie van 0,5 of meer, ieder jaar een perfect gematchte nier aanwezig zal zijn voor $18 \%$ van die patiënten (van Rood, et al., 1971). 
delen zal zijn en daarna ook minder kosten met zich meebrengt dan dialyse, verwacht Van Rood niet dat de kosten het grote struikelblok voor het project zullen vormen (van Rood, 1967$)^{42}$.

De boodschap komt over. De presentatie van het plan in Italië heeft iets los gemaakt bij de deelnemers. Veel teams zijn bezig leukocytentypering te combineren met het zoeken naar geschikte donoren om transplantaties mee uit te kunnen voeren. Sommigen zijn (noodgedwongen ${ }^{43}$ ) meer gericht op levende, verwante donoren, anderen richten zich uitsluitend op kadaverdonoren. Velen raken door het voorstel geînteresseerd in (de voortgang van) Eurotransplant-in-oprichting. Zo vraagt Kissmeyer-Nielsen rechtstreeks naar de vorderingen, wanneer hij verslag doet van zijn eigen activiteiten.

... we will try to type the recipients as well as the donors, and we have decided only to go ahead if we can find a reasonable match between donor and recipient. This reminds me of your idea of making a register in Holland, and I would like to hear if you have made any progress with your plans in this respect.

(Kissmeyer-Nielsen, 25 september, 1967)

De problemen die Kissmeyer-Nielsen ondervindt bij het vinden van geschikte donoren voor bepaalde patiënten, lijken Van Roods optimisme niet geheel te rechtvaardigen. En ook anderen hebben zo hun bedenkingen over de haalbaarheid van het Eurotransplant-idee. Zo laat Vincent Eijsvoogel zich bijvoorbeeld toch enigszins sceptisch uit over de praktische haalbaarheid. In een brief aan W. Drukker van het Lucasziekenhuis in Amsterdam geeft hij uitleg over hoe en hoeveel bloed voor de verschillende typeringen verzameld moet worden ten bate van leukocytenonderzoek bij hun patiënten. Maar in deze brief stelt Eijsvoogel tevens voor

... om aan de hand van het antigenen-patroon van de toekomstige ontvanger de kans te berekenen dat een identieke donor gevonden kan worden. Is deze kans te verwaarlozen klein dan zou deze patiënt in aanmerking kunnen komen voor iedere willekeurige nier. Wanneer de kans dat een identieke donor gevonden wordt niet te verwaarlozen klein is (maximaal r:17), dan zou je zo'n patiënt kunnen laten wachten tot een dergelijke nier beschikbaar komt.

Zoals je begrijpt valt of staat deze hele opzet met een voldoende aanbod

42 Punt voor punt gaat Van Rood de voorwaarden voor het welslagen van het Eurotransplant-project af:

1. Europe does not yet have one hundred kidney transplant teams, but within a year or two it probably will.

2. With our present facilities the typing, retyping, etc. of tooo recipients would offer no problems.

3. At the moment, about ten European centers do some form of leukocyte typing. Now the (micro) tests are reasonably standardized and reliable, the whole procedure of leukocyte typing is perhaps more time consuming but not much more difficult than determining erythrocyte subgroups. With the general application of micro-tests, the supply of sera will no longer be a problem either. Per definitionem, only kidneys from cadavers that can be typed reliably will be accepted in the program.

4. A computer and appropriate program are already available at the University of Leiden.

5. Transport of the kidney from one center to another, which implies storage for at least 24 hours, will probably not offer serious problems in the very near future. If necessary, it might be possible to obtain the cooperation of military aviation authorities.

6. The last question is whether enough teams will be found that are willing to cooperate, and whether the whole scheme would be too costly. Since a patient who does not reject his graft is so much easier to treat and therefore involves less expense, it seems rather unlikely that this project would fail on these points. (van Rood, 1967)

43 Kissmeyer Nielssen bijvoorbeeld klaagt hierover zijn nood bij Van Rood.

We have got a new transplantation law recently here in this country which allows us to take kidneys from cadavers, but we still have very great difficulties in getting donors in suitable numbers. We are practically only doing transplantations from living relatives. ... (Kissmeyer-Nielsen, 25 september, 1967) 
cadaver-nieren. Ik vraag me dus af of dit voorstel inderdaad practisch haalbaar is, aan de andere kant echter denk ik dat dit de enige wezenlijke bijdragen zijn, die wij op dit moment zouden kunnen leveren. (Eijsvoogel, 8 september, 1967) De gedachte: "iedere transplantatiepatiënt een identieke kadavernier" wordt al kort na de conferentie in Italië, als te hoog gegrepen beschouwd en in zijn reactie naar Eijsvoogel, op diens brief aan Drukker, zwakt Van Rood zijn ambities van het Eurotransplant-project al af.

Gezien onze ervaringen in Leiden, lijkt het mij inderdaad bijzonder

onwaarschijnlijk dat er zoveel cadavernieren los zouden komen, dat je iemand

op een identieke nier zou kunnen laten wachten. (van Rood, 15 september, 1967) Hij vraagt zich dan ook af of het niet verstandiger is om de nadruk te leggen op het streven, nooit een willekeurige nier te geven, "vooral niet aan patiënten die b.v. $4 \mathrm{a}$ en 8 a negatief zijn" (van Rood, 15 september, 1967). De verwachting dat niet voldoende kadaverdonoren beschikbaar zullen komen om iedere patiënt van een optimaal geschikte donornier te kunnen voorzien, maakt dat Van Rood toch op zijn minst wil waarschuwen voor uitgesproken slechte combinaties.

Het is misschien verstandig om dit punt meer te benadrukken. Daarmee wordt

de zaak ook beter verkoopbaar dacht ik. (van Rood, i5 september, 1967 )

Met deze afzwakking van de beloften en de schets van een 'realistischer' beeld, anticipeert Van Rood op de mogelijkheid dat niet voldoende centra genegen zijn om medewerking aan Eurotransplant te verlenen. De belofte klinkt mooi, maar feitelijk heeft Eurotransplant pas wat te bieden wanneer een groot aantal patiënten op de wachtlijst staan en er vanuit een groot aantal centra potentiële donoren worden aangeboden. Pas dan is de kans groot genoeg, dat voor een gegeven donornier een goed gematchte ontvanger kan worden geselecteerd.

Enige tijd later richt Drukker, in zijn hoedanigheid van secretaris/penning. meester van de EDTA, zich direct tot Van Rood. Hij biedt hem aan een brief te schrijven naar de leden van de EDTA, vergezeld van het voorstel, zoals dat in het verslag van de $3 \mathrm{e}$ Workshop gepubliceerd zal worden. Van Rood reageert verheugd en geeft kort de stand van zaken weer (van Rood, 30 november, 1967). Daaropvolgend doet Van Rood suggesties over wat wel en wat niet in die brief vermeld zou moeten worden. Wel zou vermeld moeten worden dat gestart wordt in de "Benelux", maar niet dat de contacten met Leuven en Brussel al bijzonder goed zijn, "om irritatie en misverstanden te voorkomen" (van Rood, I2 december, 1967).

In eigen omgeving wordt ook op andere vlakken hard gewerkt om het testen op histocompatibiliteitsantigenen niet alleen mogelijk en zinvol, maar daadwerkelijk tot een praktijk te maken. Om ook de financiële middelen voor het via Eurotransplant klinisch toepassen van weefseltypering te krijgen, verwijst Van Rood in de 'Preliminary contract renewal application' voor het $\mathrm{NIH}$ contract ${ }^{44}$ expliciet naar de noodzaak van weefseltypering voor succesvol transplanteren. Van Rood stelt dat nu

44 Van Rood stuurt in december 1967 deze Contract Renewal Application naar het NIH, naar Donald Kayhoe, in Bethesda. De budgetaanvraag bedraagt $\$ 54,860$ en wordt gehonoreerd.

Gedurende vele jaren is de bijdrage van het NIH substantieel geweest en het NIH heeft dus ook in grote mate bijgedragen aan de ontwikkeling van Eurotransplant als organisatie en als transplantatiepraktijk.

De volgende onderwerpen worden in dit contract voorstel besproken:

I Monospecific reagents recognizing leukocyte antigens were screened and collected and made available in bulk to the serum bank of N.I.H. A total of 7060 of such serum has been made available.

2 The leukocyte antigens were studied together with appropriate population and family studies, 
duidelijk is, dat voor een succesvolle weefseltransplantatie, donor en ontvanger identiek moeten zijn wat betreft de HL-A-antigenen. Vervolgens doet hij een voorstel omtrent het werk dat ze graag onder het contract willen laten vallen voor de komende periode (maart '68 / maart '69).

As pointed out in the enclosed reprint: "International Cooperation -

EUROTRANSPLANT" the logical implication of the findings mentioned above

is that for patients who can not receive a kidney from a HL-A identical related donor a HL-A identical unrelated donor should be looked for. The proposal to form an organization called Eurotransplant, has been widely accepted and is at the moment in the process of being realized. (van Rood, 12 december, 1967 )

Het zoeken naar HL-A identieke, dan wel bijna identieke niet-verwante donoren is echter niet de enige doelstelling die Van Rood voor ogen heeft. In zijn aanvraag bij het NIH maakt hij de Eurotransplant-onderneming, als bron van data en mogelijk zelfs van antisera (die door de perifere laboratoria ter beschikking van de serumbank zullen worden gesteld), ook voor het NIH interessant.

Eurotransplant krijgt gaandeweg gestalte. Naast het werven van deelnemende centra, worden patiënten getypeerd met het doel hen op de Eurotransplant-wachtlijst te plaatsen en vervolgens worden de HL-A-typeringen in de computer in Leiden ingevoerd. De werkwijze in de Eurotransplantpraktijk is aanvankelijk echter niet, dat na het invoeren van het HL-A-type van een donor, de meest geschikte ontvanger direct op een beeldscherm wordt weergegeven. In plaats daarvan werkt het Eurotransplant-personeel met een uitdraai van de computer. De computer maakt eens in de maand een uitdraai van alle patiënten op de wachtlijst, geordend naar de typering van de aanwezige nier. De patiënten worden op hun HL-A-type gesorteerd. Het HL-A-type (van een eventuele donor) vormt het uitgangspunt. Alle patiënten met een bepaald HL-A-type worden bij elkaar geplaatst, daaronder staan alle patiënten die voor slechts één antigeen met het 'donor' HLA-type verschillen, vervolgens de patiënten die voor twee antigenen afwijken en zo verder. Door voor ieder mogelijk HL-A-type zo'n ordening te maken, ontstaat een lijvig boekwerk ${ }^{45}$. Dit wordt, vanwege de omvang, het 'ET-telefoonboek' genoemd (van Rood, ro maart, 1970) ${ }^{46}$. De wens bestaat om de computer de HL-A-typen van donor en ontvanger te laten vergelijken en dus de computer de 'match' te laten maken, maar aanvankelijk is het praktischer (dan wel noodzakelijk) om met een uitdraai te werken, waarbij de patiënten naar identieke en bijna identieke HL-A-typen zijn gerangschikt. Wanneer

3 The relevance of these antigens for organ transplantation was studied.

4 The purification and chemical definition of these antigens was undertaken. (van Rood, 12 december, 1967)

45 Van Rood informeert Kissmeyer-Nielsen over de ontwikkelingen rond Eurotransplant en schrijt: After some consultation with the people at home we decided to start in the Benelux. In Belgium and Holland a total of about 180 patients are on chronic dialysis and more than $2 / 3$ of them have been fully typed for their leukocyte antigens. Their data have been stored in the computer and rearranged to produce some kind of telephone book. ... (van Rood, 18 maart, r968)

Zie voor voorbeeld pagina van het ET-telefoonboek, bijlage 3.

46 Aan deze werkwijze houdt Eurotransplant geruime tijd vast en Van Rood schrijft twee jaar later aan Kissmeyer-Nielsen:

Every month an updated version of the patients on the analysis [dialysis] are produced. These data are divided in two forms, one is according to pattern, which is a heavy book, which I will not be able to ship to you and the other is a print-out of the patients alphabetically according to centre. These are a few pages and if you know a bit how to read the print-out, it is not too difficult to find the typing you are looking for. (van Rood, to maart, 1970) 
een donor wordt aangemeld, hoeft alleen de pagina met het betreffende HL-A-type te worden opgeslagen om een overzicht te krijgen van de patiënten die het meest geschikt zijn om de nieren van die donor te ontvangen.

Het beeld dat wordt voorgespiegeld is soms mooier dan waargemaakt kan worden. Vanwege een mogelijk wervend effect wordt bijvoorbeeld het moeilijke typeren aangevuld met 'high tech' computergebruik ${ }^{47}$. Dat Van Rood gelijk heeft in de mogelijke werking van zo'n boodschap blijkt uit het gegeven dat het bellen naar het computercentrum door Goodman van de WHO, als een belangwekkende ontwikkeling op het gebied van de transplantatiegeneeskunde wordt genoemd (Goodman, 1 augustus, 1968$)^{48}$. Hij stelt Huttrer van het NIH daarom voor om, in samenwerking met het $\mathrm{NIH}$, een internationale conferentie te wijden aan "regional computer-based leukocyte typing services" en aan het opzetten van een internationaal transplantatieregister ${ }^{49}$. Dat het gebruik van een computer deel uitmaakt van de opzet van Eurotransplant, lijkt een belangrijk punt te zijn in het verkrijgen van steun vanuit de WHO (en het NIH).

Dat Eurotransplant in 1968 een klinische realiteit begint te worden, blijkt ook uit een brief van Van Rood aan Walsh. Hij deelt hem mee dat de uitwisseling van nieren van start gaat in de Benelux en dat geprobeerd wordt om nieren die buiten het eigen gebied aangeboden worden, door bemiddeling van Eurotransplant, getransplanteerd te krijgen (van Rood, 3 april, 1968). Verder beschrijft hij de eerste poging om via Eurotransplant daadwerkelijk een elders aangeboden nier bij een wachtende patiënt te transplanteren. Aan Kissmeyer-Nielsen schrijft hij in die tijd:

Eurotransplant is going strong. We had a kind of disappointment yesterday night. Everything was alright for the first kidney to be transported from Bonn to Leiden where a patient from Utrecht would be operated upon. Everything was fine, matching was extremely good, and it was a rare type at that. Unfortunately the patient died half an hour earlier than we thought and we were not in time to catch the kidney. Next time better. This does show however that these things are already a reality. (van Rood, 4 april, 1968)

Enige tijd later vindt er wel een succesvolle uitwisseling plaats.

Mei 1968 wordt door de betrokkenen aangemerkt als moment dat Eurotransplant daadwerkelijk begint te functioneren, in de zin dat dan daadwerkelijke uitwisselingen plaatsvinden (van Rood, et al., 1969). Dit gebeurt niet alleen bij levende, verwante donoren, maar ook bij kadaverdonoren.

47 Van Rood schrijft aan Prof. Zoutendijk, hoofd van het Centraal Reken Instituut, waar de computerondersteuning vandaan komt en waar de computer zich dan ook bevindt:

Ingesloten vind je een copie van ons Eurotransplant-voorstel. Zoals wij bespraken, heb ik het telefoneren naar de computer om politiek-propagandistische redenen erin gelaten, maar waarschijnlijk is de meest reele oplossing voorlopig het maken van een "telefoonboek" met frequente aanvullingen. (van Rood, 27 september, 1967)

48 Goodman ziet hierbij Eurotransplant slechts als de eerste, regionale "leukocyte typing service". The development of regional computer-based leukocyte typing services of the kinds which are suggested in the attached report on "Eurotransplant".

This second development will be essential as more potential recipients are typed and waiting for donors. The leukocyte typing information on any potential donor is telephoned to the computer centre and then contact is made with the physician of the most compatible potential recipient. (Goodman, 1 augustus, 1968 )

49 Harttransplantatie vormt hiervoor de aanleiding.

1) A registry of information about heart and other organ transplantation, so that a more effective assessment can be made of the value of histocompatibility matching using leukocyte antigens for the prolongation of graft survival. (Goodman, 1 augustus, 1968) 
Ten aanzien van het klinische succes van Eurotransplant maakt Van Rood twee punten. Ten eerste geldt dat, hoe beter de match is, des te beter de prognose. Ten tweede geeft niet alleen een identieke combinatie, maar ook één, mogelijk zelfs twee mismatches, een betere prognose, dan een transplantatie waarbij niet is gematcht. Op basis van deze punten wordt een 'matchings-richtlijn' vastgesteld.

... we have taken for the time being as a guideline that for a cadaver organ a recipient should be sought who is identical for the main HL-A antigens; we do not take the subgroups of these antigens into account. If such a combination is not available, we accept a combination mismatched for one or two antigens and very exceptionally for three antigens. In all instances a crossmatch is considered indispensable. (van Rood, et al., 1969 )

Hierop aansluitend stellen de auteurs van dit artikel de vraag of het praktisch mogelijk is om patiënten een goed gematcht kadaverorgaan aan te bieden. In de beantwoording van deze vraag wordt niet de nadruk gelegd op het aanwezig maken van donororganen voor transplantatie, maar op de winst op het gebied van geschiktheid. Men laat zien dat het aantal goed gematchte patiënten onder de eerste twintig getransplanteerden veel hoger ligt dan verwacht had kunnen worden wanneer Eurotransplant er niet was geweest ${ }^{50}$. Hierbij wordt geen aandacht besteed aan groei in het aantal mogelijk gemaakte transplantaties, noch aan de klinische winst in de zin van het uitblijven, of makkelijker behandelbaar zijn van afstotingsreacties. Nee, het feitelijk aantal mismatches wordt afgezet tegen het verwachte aantal mismatches en daaruit wordt een positieve conclusie getrokken.

The average number of antigens mismatched in the Eurotransplant kidneys was 1.6, of the pre-Eurotransplant kidneys 3.2. We are of the opinion that these data clearly show not only the idea of Eurotransplant was realistic and that

Eurotransplant is functioning, but also that with the help of such an

organization it is indeed possible to provide patients with cadaver organs having a much better than average match for the HL-A antigens. (van Rood, et al.,

1969)

Volgens de auteurs functioneert Eurotransplant naar tevredenheid. De organisatie is erin geslaagd om immunologische geschiktheid als selectiecriterium te laten functioneren en te verbinden aan de klinische (nier)transplantatiepraktijk. Het feit dat ook kadaverdonoren prospectief getypeerd worden en daarmee vooraf bepaald wordt wat als een geschikte combinatie geldt, is een verandering in visie op de verhouding tussen ontvangers en hun donoren. Dat geschiktheid wordt verbonden aan aanwezigheid, laat zien dat er een omslag in het denken over de aard van het verband tussen donoren en ontvangers plaatsvindt. Voor het antwoord op de vraag wie zal worden getransplanteerd, is niet langer de patiënt het uitgangspunt, maar vormt het HL-A-type van de donor het criterium ${ }^{51}$. Anders zouden de mogelijkheden die het

50 De auteurs zeggen het als volgt:

Since May, Eurotransplant has actually begun to function, in the sense that kidneys have been exchanged between centres, and up to the present a total of 20 patients have received an "Eurotransplant" kidney in this way. Ten of the donor-recipient pairs were either identical or nearly identical, to were mismatched for 2 or 3 antigens, and none were mismatched for 4 or more antigens. Are these results an improvement? To answer that question, let us compare these matches with the data of the pre-Eurotransplant era. Instead of to identical or nearly identical matches we would have only 4 instead of 10 donor-recipient pairs mismatched for a to 3 antigens we would have had 7 , and, most significant, instead of no donor-recipient pairs mismatched for 4 or more antigens we would have had 9. ... (van Rood, et al., 1969)

51 In het voorstel, zoals Kelly dat beschrijft, lijkt deze omslag voor het eerst herkenbaar. Het is mogelijk dat dit 
gebruik van overledenen biedt om de aanwezigheid van donororganen te vergroten, niet ten volle kunnen worden benut. Terwijl bij patiënten met een verwante donor wordt gekeken of de donor wel bij de patiënt past, kijkt men bij een kadaverdonor of er een patiënt is die bij de donor past ${ }^{52}$. Potentiële ontvangers zijn, dankzij de door Kolff ontwikkelde - mogelijkheid om nierpatiënten te dialyseren ter compensatie van het nierfalen, altijd aanwezig. Daarom kunnen nierpatiënten wachten op een geschikte donor. Door patiënten te laten wachten op een geschikte kadaverdonor, wordt het ook mogelijk om de effectiviteit van een kadaverniertransplantatie te verhogen door de best passende ontvanger te selecteren. Hoe groter de wachtlijst, des te groter wordt de kans op een goede match en daarmee ook op een klinisch suc. cesvolle transplantatie. Echter, niet alle transplanterende centra worden in de 'Eurotransplant-familie' opgenomen. Hoe komen de 'in- en uitsluitingscriteria' voor deelname aan Eurotransplant, als typeringslaboratorium of als transplantatiecentrum, tot stand?

\subsubsection{De Eurotransplantpraktijk}

Naast het matchen van de typeringsgegevens van donor en ontvanger blijken meerdere problemen overwonnen te moeten worden, alvorens over beschikbaarheid voor transplantatie te kunnen spreken. Wie mogen er meedoen? Wat is de ideale omvang van de organisatie? Wat zijn de geografische en infrastructurele vereisten? Aan welke voorwaarden ten aanzien van typeringsfaciliteiten moet worden voldaan om een succesvolle orgaanuitwisselingsorganisatie te krijgen? Welke technische voorwaarden moeten worden vervuld? Veel van deze vragen kunnen zomer 1967 niet eens gesteld worden; op andere kan slechts een voorlopig antwoord worden gegeven. In de eerste jaren van Eurotransplant zijn de vragen en de antwoorden voortdurend aan verandering onderhevig door de ontwikkeling van de Eurotransplantpraktijk.

Na de lancering van Eurotransplant, worden in Leiden alle activiteiten die gericht zijn op het typeren, matchen en transplanteren van donoren en ontvangers, gezien als bijdrage aan de realisatie van dit voorstel. Het idee van een organisatie die hiervoor zorgt, belooft veel en over de realisatie is men optimistisch. Bij een bespreking in oktober 1967 spreekt Van Loghem de verwachting uit dat de ontwikkelingen gunstig zullen zijn.

Prof. Van Loghem, Chairman:

The important possibility of your Euro-transplant is, that by combining a large number of hospitals, our pool of recipients will be tremendous here in Europe. Organisation and transportation problems can be solved, especially if the military authorities are willing to help. As we will hear this afternoon, progress in preservation is so rapid, that in one year perhaps we will have more time for selection. By having a large number of possible recipients the chance of having a

idee eerder ook tussen anderen besproken is, maar in de schriftelijke bronnen is de brief van Kelly de eerste maal. (Kelly, 31 maart, 1966) (zie paragraaf 6.3 en eerder in dit hoofdstuk)

52 Uiteindelijk blijkt de omkering van de verhouding tussen ontvanger en donor een paradox te zijn, want rond de vraag wie zal worden getransplanteerd wordt de tegenstelling weer opgeheven. In

Eurotransplantverband is de typering van de donor het uitgangspunt voor het aanbod, maar uiteindelijk is het toch de typering van de ontvanger die als criterium voor het al dan niet accepteren van een aanbod geldt. De behandelend arts krijgt namelijk de vrijheid om een bepaald orgaanaanbod te accepteren, dan wel af te wijzen en te wachten op een beter gematchte nier. 
real good outfit increases of course.... (Woelders, et al., 4 september, 1968) De verwachting is dat de Eurotransplant-onderneming een succes kan worden, wanneer alle randvoorwaarden zich in bijzonder gunstige zin ontwikkelen. Men start dan ook hoopvol en energiek. Via verschillende kanalen worden de plannen in pro. fessionele kring - en ook in de media - wereldkundig gemaakt ${ }^{53}$. Daaraan gekoppeld probeert men te inventariseren hoe groot de interesse van centra en de daaraan gekoppelde 'pool' van potentiële ontvangers zou kunnen zijn (van Rood, 30 november, 1967). Over de 'lokale kant' van Eurotransplant, namelijk de organisatie en infrastructuur in Leiden, doet Van Rood zijn beklag bij Ceppellini, maar het idee als zodanig blijft stevig overeind.

Eurotransplant is giving me a lot of local trouble, but the idea is outside Leiden very well received. I am hopeful that we have the whole thing running in about six months if the outside centers are willing to collaborate in the way they appear to do.(van Rood, 28 december, 1967 )

Vanuit geheel Europa komen aanvragen om hulp en samenwerking bij de start van het gebruik van leukocytenantigeentyperingen ten bate van (voornamelijk) niertransplantaties. Van Rood zegt aanvankelijk wel toe de typeringen (zo mogelijk) te zullen doen, maar al heel snel adviseert hij de aanvragers om zelf typeringsfaciliteiten op te zetten of in de directe omgeving samenwerking met een al functionerend laboratorium te zoeken.

Uit de contacten met geïnteresseerden in het typeringswerk, komen ook andere aanbiedingen voort. Enige maanden na het rond komen van de samenwerking tussen Van Rood, Govaerts en Toussaint, schrijft deze laatste aan Van Rood over het aanbod van een levende donor voor de Eurotransplant-lijst. De partner van een patiënte van hem stelt voor om onder bepaalde voorwaarden te fungeren als donor.

He would willingly give one of his own kidneys to some unknown compatible recipient if someone in the same situation (incompatible to a member of his family) would give a compatible kidney to his wife, ... Don't you think that this would be a nice way to start Eurotransplant, or do you believe that it is too early to propose this type of organ exchange at the present time? (Toussaint, II maart, I968)

Op dit bijzondere uitwisselingsvoorstel reageert Van Rood terughoudend. Eerst moet een aantal onderzoeken afgerond zijn en wanneer de uitkomsten goed zijn, kan het aanbod in overweging worden genomen, maar, zegt hij: "I would not be in favour to do this beforehand." (van Rood, 18 maart, 1968)

Naast Brussel, wordt ook de samenwerking met het laboratorium in Leuven uitgebreid (van Rood, I8 maart, I968) en samenwerking met Luik en Gent opgezet (Ringoir, 26 maart, 1968; van Rood, 8 april, 1968) ${ }^{54}$. Van Rood zegt hierbij, dat wan-

53 Denk hierbij bijvoorbeeld aan de contacten met de EDTA (Drukker) en via het verslag van de Workshop in Turijn: Histocompatibility Testing 1967 (Curtoni, et al., 1967).

Ook publieke media verspreiden de berichten dat er een organisatie zal worden opgezet, die de uitwisseling van organen gaat regelen. Ook naar aanleiding van berichten in de krant en via de radio, bereiken Van Rood verzoeken om samenwerking in het kader van het starten van niertransplantatieprogramma's (Berger. 9 jamuari. 1968).

(In Hoofdstuk 8 zal dieper worden ingegaan op de rol van de publieke media bij het ontstaan van de typerings/transplantatiepraktijk in het algemeen en voor de Eurotransplantpraktijk in het bijzondex.)

54 Bij deze mededeling noemt Ringoir tevens dat ze 27 transplantaties hebben gedaan op 24 patiënten. waarvan er nog 14 in leven zijn; dat 8 personen wachten op een transplantatie en dat er een actieve samenwerking bestaat met Alexandre voor het uitwisselen van kadavernieren. De transplanterend chirurg is Dr. Frits Derom. 
neer de patiënten naar Leiden komen om zich te laten typeren, ideaal is. Eventueel kan vanuit Gent ook bloed gestuurd worden, maar dan moet het binnen de 3 à 4 uur in Leiden zijn (van Rood, 3 april, 1968). Zo ontwikkelt Eurotransplant zich stap voor stap, centrum voor centrum. Geleidelijk aan breidt het netwerk zich uit.

At the moment we are busily typing patients in Holland and Belgium. We hope to get the program extended to other countries as well. As this is done more or less on a center to center basis, the whole organization tends to be not so much international as a-national as you know what I mean. (van Rood, $3 \mathrm{I}$ januari, 1968)

Met verschillende transplantatiecentra en typeringslaboratoria in Duitsland ${ }^{55}$ worden contacten onderhouden en ontvangt Leiden verzoeken ${ }^{56}$ en ook vanuit GrootBrittannië en Zwitserland wordt Leiden om hulp en/of informatie verzocht ${ }^{57}$.

De typeringscursus (augustus 1968) maakt een groot aantal mensen vertrouwd met verschillende technieken en daarmee wordt een deel van het betrouwbaarheidsprobleem opgelost. De verschillende typeringslaboratoria, die een bijdrage aan Eurotransplant willen geven, kennen dezelfde technieken. Na de typeringscursus komen nog verzoeken binnen om één of enkele dagen in het Leidse laboratorium mee te mogen lopen, om 'de laatste scherpe randjes te verwijderen' (Pichlmayr, I3 september, 1968).

Eind 1968 beantwoordt Van Rood verzoeken om deelname aan Eurotransplant vol zelfvertrouwen. Hij schrijft dan dat er twee manieren zijn om deel te nemen. In de eerste plaats als transplantatiecentrum. Patiënten moeten dan zowel in Leiden, als in een ander laboratorium worden getypeerd. Dit andere laboratorium kan het typeringslaboratorium van het transplantatiecentrum zelf zijn, of een lab dichtbij. De tweede manier om aan Eurotransplant deel te nemen is door organen van overleden patiënten te leveren. Daarvoor moet het ziekenhuis of zelf over een typeringslaboratorium beschikken, of kunnen terugvallen op een ander typeringslaboratorium. Wanneer noch een eigen laboratorium voorhanden is, noch een typeringslaboratorium binnen een straal van $100 \mathrm{~km}$ aanwezig is, dan - zo biedt Van Rood aan - kan een 'senior analyst' in Leiden getraind worden zodat het ziekenhuis zelf een typeringslaboratorium kan opzetten (van Rood, 20 december, 1968).

Participanten aan het Eurotransplant-project worden ook actief geworven. ledereen die met Van Rood in contact treedt, krijgt het Eurotransplant-voorstel toegestuurd. Zo stuurt Van Rood een verzoek tot samenwerking aan het Bürgerspital in Basel, waarop Dr. Beck echter afwijzend moet reageren (Beck, 23 juni, 1967). Een vergelijkbaar verzoek stuurt hij naar Prof. Herberer in Keulen, met de toevoeging: "We would of course be very happy if you would be willing to join." (van Rood, 14 oktober, 1968). De uitbreiding van het Eurotransplant-netwerk gaat echter minder snel dan gewenst, hetgeen bij Van Rood enige teleurstelling oproept (van Rood, 27 december, 1968). Over het tempo mag hij dan enigszins teleurgesteld zijn, over het geheel genomen is Van Rood toch redelijk positief, zoals blijkt uit een brief aan Tineke Lameyer.

55 Inclusief de DDR.

56 (Pichlmaier, 1o november, 1967; van Rood, 30 november, 1967; Höffler, 27 december, 1967; van Rood, 5 januari, 1968; Paquet, 22 maart, 1968; Walb, 8 mei, 1968; Pichlmayr, 13 september, 1968; Dutz, 8 oktober. 1968; Schlicht, 16 oktober, 1968: Heintz, 20 december, 1968)

57 (Longmore, 15 november, 1967 : Longmore, 23 januari, 1968: van Rood, 31 januari, 1968; Harris, 23 januari. 1968) 
De zaken lopen hier heel aardig, zeker wat Eurotransplant betreft, alhoewel daar natuurlijk ook nog de nodige moeilijkheden te overwinnen zijn. Vooral met de centra uit het buitenland, die een beetje de houding hebben van "wij halen er uit wat er in zit" en proberen zelf zo min mogelijk af te staan. (van Rood, 25

oktober, 1968 )

Naast alle interesse voor Eurotransplant zelf, is er ook interesse - tot zelfs uit Australië - voor het 'matchingsprogramma', waarmee de computer de gegevens van de potentiële ontvangers bewerkt (Archer, 19 december, 1968; Smith, 2 februari, 1968) ${ }^{58}$.

De woorden van Van Rood, dat het Eurotransplant-idee buiten Leiden zeer goed ontvangen is, worden in het jaar volgend op deze uitspraak, door de praktijk gestaafd. Van vele kanten is er interesse voor en participatie in het Eurotransplant-pro. ject. Deze positieve tendens zet zich voort, al blijven er uiteraard ook problemen bestaan. Toch kan Van Rood meer en meer vanuit een sterke positie werven. Naarmate Eurotransplant groeit, wordt het makkelijker om mensen tot participatie in Eurotransplant te bewegen en aan te zetten om typeringslaboratoria in te richten. Van Rood kan in 1970 zelfs stellen, dat als men in Keulen geen typeringslaboratorium opzet, men achter loopt bij de rest van de medische wereld. De boodschap, dat men daar de boot dreigt te missen, is niet mis te verstaan.

I can tell you, that Eurotransplant is working satisfactory. Cooperation between the centres in Germany, Belgium and Holland are increasing every month and we have confidence that this organization will be an extremely important point in the realisation of adequate organ transplantation in our continent. ... I think it will be extremely important that an adequate histocompatibility typing laboratory is founded and operated in Köln. (van Rood, 17 maart, 1970)

Voor Eurotransplant zou een typeringslaboratorium in Keulen betekenen, dat voor een aantal patiënten en donoren de afstand tot een typeringslaboratorium weer wordt verkleind.

Voor deelname aan Eurotransplant wordt een solidaire opstelling vereist. Men neemt deel op basis van wederkerigheid, zoals uit een reactie op een verzoek om ty. peringssera blijkt.

I noticed in our books, that as so far we have not received from you any new sera. Are you screening? I thought that this was the case. At the moment the policy is that you get sufficient sera to type panels so that you can screen for your self the antibodies and to keep a few sets for typing prospective donors. (van Rood, 23 december, 1970)

Het verkrijgen van de 'Eurotransplant serumset' is aan voorwaarden verbonden:

a. this laboratory screens with great activity for new sera, and

b. kidney donors are made available to Eurotransplant. (van Rood, 23 december, 1970)

Zonder bijdragen aan de groep, geen bijdragen van de groep.

Om Eurotransplant tot een succesvol onderdeel van de transplantatiepraktijk te laten uitgroeien, moet voorkomen worden dat Eurotransplant gezien wordt als 'een project van een groepje in Leiden'; het is van belang dat het wordt beschouwd als

58 Later vraagt Smith van het National Computing Centre in Londen naar de gebruikte computers en computerprogramma's en de wiskundige en statistische problemen bij het typeren, hertyperen, enzovoort. en biedt later zijn hulp aan bij het vertalen van de programma's naar een hogere programmeertaal (Smith, 22 maart, 1968). 
een gemeenschappelijke onderneming van alle aangesloten centra, waar Leiden een essentieel onderdeel van vormt.

\subsection{REgionalisering}

Eurotransplant wordt opgericht met het idee dat een aantal problemen in de transplantatiepraktijk door deze organisatie zouden kunnen worden opgelost. Eurotransplant wordt echter ook met vele verschillende problemen geconfronteerd. De factor tijd speelt daarbij een grote rol. In de eerste plaats moeten te transplanteren organen in goede conditie zijn wanneer ze in een ontvanger geimplanteerd worden. Een levensvatbare conditie van een donororgaan is mede afhankelijk van de tijd dat het orgaan, zonder voedingsstoffen en zuurstofvoorziening, buiten het lichaam is geweest. Voor Eurotransplant vormt tijd daarmee ook een beperkende factor van belang, gezien het idee van uitwisseling van organen tussen verschillende ziekenhuizen. Dit betekent dat de ontwikkeling van bewaartechnieken, die het orgaan (buiten het lichaam) gedurende langere tijd in goede conditie houden, van groot belang is. Daarnaast speelt de geografische afstand tussen het ziekenhuis waar de uitname plaats vindt en het centrum waar getransplanteerd zal worden, in combinatie met de wijze en snelheid van transport, een belangrijke rol in het succesvol transplanteren van donornieren.

Niet alleen mag de duur van het transport van het orgaan niet te lang zijn, ook het gehele typeringsproces moet in de kortst mogelijke tijd worden voltrokken. In 1967 bedraagt de tijd, nodig voor het uitvoeren van een typering, ongeveer 2 tot 2 I/2 uur (Woelders, et al., 4 september, 1968). Bij deze typeringstijd moet dan de maximaal toegelaten tijd voor het transport van bloed naar het laboratorium worden opgeteld. Voor wat de maximaal toegelaten transporttijd betreft, is de - door Van Rood geprezen - agglutinatietechniek een beperkende factor. Deze techniek werkt immers alleen met vers bloed, hetgeen betekent dat de transporttijd kort moet zijn. Zolang deze techniek in Leiden wordt geprefereerd, betekent dit dat transport van bloed over grote afstanden naar Leiden praktisch onmogelijk is. Grote afstanden zijn zelfs niet per vliegtuig binnen de tijdslimiet te overbruggen (Beck, 17 augustus, r967). Om toch samenwerking te realiseren - zoals bijvoorbeeld met Luik - wordt gevraagd patiënten en hun familie in Leiden te laten logeren. Dan kunnen zij 's ochtends vroeg naar het ziekenhuis komen en kan het te typeren bloed om 9.00 uur in het lab aanwezig zijn. Voor spoedtyperingen kan men in Luik wel een beroep op Leiden doen 59 .

Wanneer opsturen van bloed de enige mogelijkheid is, moet aan bepaalde voorwaarden worden voldaan. Zo mag het bloed niet langer onderweg zijn dan 4 uur, moet het minimaal $30 \mathrm{ml}$. zijn (maar liever 60 en zo mogelijk $80 \mathrm{ml}$.). Het moet zijn opgevangen in steriel, gesiliconeerd glas met $5 \% \mathrm{Na}-2$ EDTA oplossing in fysiologisch zout en vervolgens op 4-C. worden gehouden, maar mag niet worden ingevroren. En tenslotte, het bloed moet vergezeld gaan van ingevulde formulieren voor het archief (van Rood, 26 januari, r968).

Naast het 'tijdprobleem' van het transport van te typeren bloed en de benodigde tijdsduur voor het uitvoeren van een typering, is ook het gebrek aan voortgang in

59 Daarvoor kan bloed, binnen de termijn, per helikopter naar Leiden worden vervoerd. (van Rood, 8 april. 1968) 
ontwikkeling van bewaartechnieken van organen een beperkende factor. Eerder kwam al ter sprake dat Van Rood in de toekomst een 'houdbaarheid' van 24 uur verwacht (van Rood, 25 september, 1967 ). Zover is het echter nog niet. Vooralsnog blijven eenmaal uitgenomen nieren slechts enkele uren geschikt voor transplantatie.

De genoemde beperkende factoren zorgen ervoor dat Europa verdeeld wordt in regio's. Vanwege de beperkingen wordt de Noordzee door velen in Groot-Brittannië als een onoverbrugbare kloof gezien. Daarom komen zij met voorstellen om de relatie met Eurotransplant op een andere wijze te organiseren.

The North Sea is a major obstacle to the exchange of donor kidneys and we thought that perhaps co-operation between centres in this country, as a sort of sub-division of Eurotransplant, might be the best answer and we can make available our information and results to the whole group. (Swinney, 12 juli, 1968)

Dit idee lijkt gehoor te vinden bij een aantal mensen van het eerste uur. Van Rood schrijft Ceppellini, dat hij de toekomst van Eurotransplant heeft besproken met Kissmeyer-Nielsen en Batchelor ${ }^{60}$. Om verschillende redenen is het misschien verstandig om Europa op te delen in verschillende, grotendeels onafhankelijke, regio's.

The regions could be more or less independent. Have their own typing

procedure, nomenclature, dataprocessing, exchange transport, regulations and

so on. (van Rood, 22 augustus, 1968)

Niet lang daarna wordt mensen in Groot-Brittannië geadviseerd om zelf een 'lokale organisatie' op te zetten.

I feel that as transport overseas is as difficult at the moment, it will be most appropriate that the United Kingdom and Ireland organize between themselves a region of Eurotransplant. (van Rood, 22 september, 1968)

Ook in zuidoostelijke richting vormt de tijd een probleem. Zo voelt Dr. Gurland uit München zich niet geroepen om de naam van de dienstdoende arts voor de kerstdagen te melden aan Van Rood, aangezien er toch nog geen donornieren te verwachten zijn via Eurotransplant.

Since we are not yet in a position to organize the transfer of donor kidneys from the Benelux area, the question which doctor will be in charge of the department during Christmas is no longer open. As soon as we have found a solution to the problem of transportation, which I hope will be so at the beginning of next year, I shall contact you again. (Gurland, 6 december, ig68)

Het is mede vanwege de tijdsproblematiek, dat de voorkeur uitgaat naar een geografisch beperkt netwerk van transplantatiecentra en typeringslaboratoria, in plaats van een wereldomspannend, of Europa omvattend netwerk. De transporttijd van donororganen en van bloed voor typering is al bij een relatief geringe geografische afstand snel te lang om klinisch effectieve uitwisseling van materialen mogelijk te maken. Beschikbaarheid is niet alleen afhankelijk van de fysieke aanwezigheid van een donor, maar minstens zo afhankelijk van andere, aan de 'houdbaarheid' van organen en bloedmonsters gerelateerde, factoren.

Naast afstand als tijdsbeperking, zijn er ook andere beperkingen die regionalisa-

60 En Trnka van de WHO, al vermeldt hij deze niet expliciet in de brief aan Ceppellini. Wel zegt hij dat de WHO het contact tussen de verschillende regio's eventueel wil coördineren wanneer daar door de nationale overheden om wordt verzocht. 
tie rechtvaardigen. Zo schrijft Kissmeyer-Nielsen aan Norma Rowley ${ }^{61}$, dat het inperken van het Eurotransplant-gebied niet alleen te maken heeft met de te overbruggen afstanden, maar ook met de hoeveelheid werk die het verzorgen van de service voor een relatief klein gebied met zich meebrengt.

Van Rood for the time being with his Euro-transplant covering Benelux, North

Western Germany and a part of England with about 200 patients on chronic hemodialysis had plenty to do, and he felt that this region was enough in itself, and that the original plan of Euro-transplant covering most of Europe was impossible. You know that Euro-transplant is actively functioning by now showing that an international exchange of organs is definitely possible, if you get things organized. (Kissmeyer-Nielsen, 15 oktober, 1968)

Zo blijken er meerdere factoren te zijn, die naast de grenzen die aan de (transport)tijd gesteld moeten worden, bijdragen aan de behoefte om Europa in regio's te verdelen. Maar waaruit bestaat het werk dat ervoor zorgt dat een regio met slechts 200 transplantatiekandidaten toch zoveel werk voor de Leidse groep inhoudt? Welke problemen liggen hieraan ten grondslag?

\subsection{BETROUWBAARHEID DOOR UNIFORMITEIT}

Het doel van Eurotransplant is het selecteren van de meest geschikte patiënten om organen van een bepaalde donor te ontvangen. Om dit te realiseren is een vereiste dat de uit verschillende laboratoria afkomstige gegevens, vergelijkbaar en betrouwbaar zijn. Met de ontwikkeling van een netwerk van deelnemende transplantatiecentra en laboratoria wordt het steeds belangrijker (maar ook moeilijker) om hieraan te voldoen.

Voor een goede bepaling van geschiktheid moet erop vertrouwd kunnen worden dat de resultaten van typeringen in de verschillende laboratoria hetzelfde zijn. Daartoe moeten de gehanteerde technieken gestandaardiseerd worden en is het noodzakelijk dat typeringen met dezelfde antisera worden uitgevoerd. Verschillende antisera voor hetzelfde antigeen leiden immers tot verschillende resultaten ${ }^{62}$. In Leiden lost men dit probleem op door alle deelnemende laboratoria te voorzien van één en dezelfde 'set' antisera ${ }^{63}$. De voorraad van deze antisera is echter beperkt, waardoor het aantal typeringslaboratoria dat van de 'serumset' kan worden voorzien, ook beperkt is. Door de introductie van microtechnieken - halverwege de tweede helft van de jaren 60 - gaat de hoeveelheid benodigd serum per bepaling wel omlaag, maar daar staat een sterke groei van het aantal te verrichten bepalingen tegenover. De beperkte hoeveelheid aanwezige antisera is een reden om te streven naar een netwerk van beperkte omvang en pleit voor een indeling in regio's.

Dat men in Leiden en elders onderkent dat Europa in verschillende transplantatieregio's verdeeld moet worden, is herkenbaar in de selectie van deelnemers aan de typeringscursus in Leiden. Gezien de noodzaak van standaardisering, worden voor-

61 Norma Rowley is een medewerkster van Thiel uit Basel, die bij Kissmeyer-Nielsen technieken heeft geleerd. Later in dit Hoofdstuk komt deze correspondentie terug.

62 Zie Hoofdstuk 4. De Vorming van een Typeringspraktijk?

63 Dit lijkt een soort omgekeerde Workshop. In 1965 komen alle onderzoekers met hun eigen sera en technieken naar Leiden om daar een en dezelfde 'set' leukocytendonoren te typeren. Nu zijn de technieken en antisera als 'set' hetzelfde, waarmee de onbekende in de vergelijking verschoven is naar de leukocytenantigenen van de donoren (en de ontvangers). 
namelijk verzoeken afkomstig uit de eigen regio gehonoreerd ${ }^{64}$. Via de typeringscursus wordt een basis gelegd voor een gestandaardiseerd en fijnmazig netwerk van typeringslaboratoria in het eigen verzorgingsgebied.

Verzoeken van buiten de eigen regio worden naar anderen doorverwezen (Pegrum, 28 juni, 1968 ; van Rood, 28 juni, 1968). De voortdurende stroom aanvragen om training van laboratoriumpersoneel, brengen Van Rood ertoe om ook een restrictief toelatingsbeleid te hanteren ten aanzien van degenen die voor langere trainingsperioden naar Leiden mogen komen.

We have restricted us to a very well limited area of people we would probably work with in the near future. Eurotransplant is still not in its final stage, but for the time being we will cover a rather small area consisting of the Benelux and Western Germany. ... we really should start to be a bit careful about the energy we put in training other people. It is for this reason that we decided that six months is really a minimum for someone who wants to visit and work with us. ... (van Rood, 6 augustus, 1968$)^{65}$

Voor de doelmatigheid van de training in het lab, stelt men dus een minimum verblijfsduur in. Van iemand die langdurig wordt getraind, worden betrouwbaarder c.q. vergelijkbaarder resultaten verwacht dan van iemand die korter verblijft. $\mathrm{Dr}$. $\mathrm{H}$. Pichlmaier uit München kan dan ook (verheugd) melden dat hij iemand gevonden heeft die gedurende een half jaar in Leiden getraind kan worden (Pichlmaier, to juni, 1968).

$\mathrm{Na}$ de cursus komen van perifere laboratoria verzoeken om sera, voor typeringen (zoals bijvoorbeeld uit Luik, München ${ }^{66}$, (iets later) Leuven en Hannover ${ }^{67}$ ). Zo dankt bijvoorbeeld Dr. R. Pichlmayr middels een brief, Van Rood voor hetgeen zijn analist tijdens de cursus heeft geleerd. Na 'thuiskomst' heeft de analist verder geoefend met twee ervaren laborantes. Nu wil hij graag echt gaan typeren en vraagt daarvoor de benodigde antisera (Pichlmayr, 13 september, 1968 ) ${ }^{68}$.

Betrouwbaarheid van gegevens lijkt te worden gerealiseerd door standaardisering binnen de eigen regio. Mondiale standaardisering is onhaalbaar. De beschikbare (of te verwerven) hoeveelheden van antisera met gewenste specificiteiten, zijn te beperkt om tot 'standaardsera' te komen ${ }^{69}$. Om toch 'gestandaardiseerde' typeringen

64 Door het 'obstakel Noordzee wordt Groot-Brittannië niet meer tot het eigen verzorgingsgebied gerekend, zodat het kan gebeuren dat Dr. Dick uit Glasgow begin 1968 zelf wel welkom is in Leiden, maar dat zij en haar medewerkers niet voor de cursus in augustus kunnen worden uitgenodigd.

65 Als deel van zijn antwoord aan Pegrum, schreef Van Rood al dat 'trainees' alleen geaccepteerd worden voor een periode van minimaal drie maanden, maar dat hij nog liever heeft dat iemand zes of zelfs negen maanden in Leiden verblijft (van Rood, 28 juni, 1968)..

66 Van Rood stuurt antisera voor "250-500 duplicate tests"en is bereid om gescreende sera te typeren, wanneer die voldoende sterk zijn en in voldoende mate aanwezig. Daarnaast vraagt hij om terugrapportage van de met de sera behaalde matchings- en transplantatieresultaten.

Especially if you have done any transplants we would like to receive the typings of both donor and recipient. In this way the experience obtained with our sera can be made available to all workers using them.... There is another point which interests me and that is the question where you picked up our microagglutination and microcytotoxicity test in the way we are doing it. (van Rood, 20 december, 1968)

67 (van Rood, 18 september, 1968; Pichlmayr, 13 september, 1968; van Rood, 20 december. 1968; Vermylen. as november, 1969 )

68 Het vanuit Leiden versturen van 'grote hoeveelheder' antisera vindt Van Rood nog niet op de meest elegante manier gebeuren. Aan Woodnuff schreef hij kort daarvoor, dat hij vindt dat Batchelor bijvoorbeeld, verder is op dit gebied; dat Batchelor mensen heeft getraind, die nu zelfstandig typeringen doen, met antisera die Batchelor in gebruiksklare vorm naar hen toestuurt.

... he send to them prefilled plates. In this he is certainly a lot ahead of us! (van Rood, 8 augustus, 1968) 
te krijgen, waarbij die typeringen allemaal met dezelfde sera zijn uitgevoerd, moet de grote van het te verzorgen gebied mede afhankelijk worden gemaakt van de hoeveelheid beschikbaar antiserum. De per test benodigde hoeveelheid is gerelateerd aan de techniek die wordt gebruikt ${ }^{70}$. Vandaar dat de voor typering geschikte antisera in Leiden worden verzameld, zodat ze van daaruit, als 'set'71, naar de bij Eurotransplant aangesloten laboratoria kunnen worden verstuurd.

Deze vorm van standaardisering brengt echter ook een grote verantwoordelijkheid met zich mee. Steeds opnieuw moet de standaardisering geproduceerd worden, want het is een standaardisering van verbruiksmateriaal, geen standaardisering door een voorschrift, protocol, of een apparaat. Het is niet zo dat eenmaal geinstalleerd, er slechts onderhoud hoeft te worden gepleegd. Het is ook anders dan met technieken, waarbij, als eenmaal de standaardtechniek is geleerd, er slechts regelmatig gecontroleerd moet worden of de uitvoering ook de juiste resultaten op blijft leveren ${ }^{72}$. Om de antisera te standaardiseren moet steeds opnieuw naar alle verschillende laboratoria dezelfde antisera opgestuurd worden. De aangesloten laboratoria verwachten logischerwijs ook dat de benodigde antisera door Eurotransplant worden geleverd. Enerzijds draagt dit bij aan het succes van Eurotransplant, anderzijds verhoogt dit de druk om zorg te dragen voor een adequate serumvoorziening. Een van de gevolgen daarvan is dat Van Rood eind I 970 aan Kayhoe extra serum uit de serumbank vraagt, omdat hij anders de meer dan 25 laboratoria niet van antisera kan voorzien.

The problem is that we have to supply all centers with the same sera to make our results truly comparable. As all the data are computer analysed changing sera from center to center implies also making new forms and a tremendous amount of extra costs and work. ...(van Rood, 18 november, 1970)

Kortom het creëren van betrouwbaarheid door de praktijk te uniformeren blijft problematisch. Voor een 'klein' gebied slaagt men in het standaardiseren van de typeringstechniek en het uniformeren van de serumvoorziening, hetgeen resulteert in uitwisselbaarheid en vergelijkbaarheid van de resultaten binnen dat gebied. Maar geschiktheid wordt hierdoor een lokaal gegeven. Uitwisseling van donornieren tussen regio's vergt extra inspanningen. Dit nadeel weegt echter niet op tegen de voor-

69 Het produceren van gestandaardiseerde antisera wordt door de Division of Biological Standards niet de moeite waard geacht, doordat de serumbank van het NIH een te kleine voorraad ter beschikking heeft voor èn de karakterisering van de sera èn om vervolgens een voldoende grote hoeveelheid gestandaardiseerde antisera te kunnen maken, waarmee de gehele wereld bediend zou kunnen worden (Anderson, 9 oktober. $1967)$.

70 Aangenomen dat de hoeveelheid antiserum niet direct vergroot kan worden, dien, om het verzorgingsgebied te kunnen vergroten (c.q. te verdichten) de benodigde hoeveelheid antiserum voor de technieken omlaag te worden gebracht. De microcytotoxiciteitstechniek heeft nog maar een fractie van de oorspronkelijke hoeveelheid antiserum nodig en ook voor de agglutinatietechniek probeert men een 'micro'-variant te ontwikkelen.

71 Zón set bestaat uit meerdere antisera voor één specificiteit. Aangezien niet alle antisera op exact dezelfde wijze met antigenen reageren, is het van belang om voor én antigeen meerdere antisera te hebben, die dat antigeen 'kunnen oppikkeri, waarmee de kans verkleind wordt dat dat antigeen wordt gemist. Voor de vergelijkbaarheid is het van belang dat dan ook het serumnummer van het positief reagerende antiserum bekend is.

72 Dit wordt later geregeld door regelmatig een set leukocytenmonsters naar de verschillende labs te sturen; die ze als reguliere typering moeten typeren en de resultaten terugsturen naar Leiden, waar vervolgens gekeken wordt of de resultaten overeenkomen met de 'standaardtypering' in het Eurotransplant Reference Laboratory (ETRL). Daarnaast wordt, tot laat in de jaren ' 90 , gevraagd van iedere getypeerde donor een stukje milt naar Leiden te sturen, waarmee de typering gecontroleerd wordt. 
delen die het in regio's verdelen van Europa biedt. De voorkeur gaat dan ook uit naar een klein en fijnmazig netwerk. Bij de werving van transplantatiecentra en typeringslaboratoria voor deelname in Eurotransplant, wordt dat het uitgangspunt.

\subsection{Europa Verdeeldo}

Omdat bijvoorbeeld de inzichten over de minimale omvang van de wachtlijst wijzigen, wordt regionalisatie nastrevenswaardig. Berekeningen op basis van de populatiefrequenties van de verschillende antigenen laten - anno 1968 - zien dat het aantal op transplantatie wachtende patiënten, minder groot hoeft te zijn dan aanvankelijk werd aangenomen, om toch een redelijke kans op een full-house $m a t c h{ }^{73}$ te hebben. Dit ondersteunt de wens om de omvang van het verzorgingsgebied beperkt te houden.

In de aanvangsjaren van Eurotransplant neemt de expansiedrift snel af. De mogelijkheid van inperking van de regio, biedt meerdere voordelen. Omdat kleinere gebieden volstaan voor het verwezenlijken van het doel van Eurotransplant, ontstaat voor onderzoekers van het eerste uur de mogelijkheid ieder hun eigen verzorgingsgebied te claimen en te krijgen ${ }^{74}$. Daarmee krijgen zij de macht om de te hanteren techniek en de regels waaronder de uitgifte van antisera plaatsvindt, in hun territorium, te bepalen. Verscheidene van deze onderzoekers komen - in de loop van de tijd - aan het hoofd te staan van een internationale uitwisselingsorganisatie en Europa wordt in regio's verdeeld.

Kort na het presenteren van zijn voorstel om een (heel Europa omvattende) internationale orgaanuitwisselingsorganisatie op te richten, stuurt Van Rood informatie rond naar alle mogelijke deelnemers. Binnen een jaar verandert dit beleid. Gaandeweg gaat hij gedifferentieerder om met het verspreiden van informatie over Eurotransplant en toezeggingen van hulp en ondersteuning bij het opzetten van typeringslaboratoria. Begin 1968 zien verschillende onderzoekers het niet meer als noodzakelijk, noch gewenst, om te streven naar een heel Europa omvattende orgaanuitwisselingsorganisatie. Gedurende korte tijd spreekt men dan over 'Eurotransplant-regio's', maar in andere landen (binnen en buiten Europa) komen meerdere zelfstandige initiatieven van de grond. Groot-Brittannië zal dan ook geen Eurotransplant-regio worden, maar een eigen, onafhankelijke organisatie krijgen, zoals Van Rood aan Woodruff schrijft (van Rood, 20 juni, r968). Sommigen willen nog een onderafdeling van Eurotransplant organiseren (Swinney, 12 juli, 1968), terwijl ook de Britse overheid zich bij Van Rood meldt voor informatie en een bezoek om zich te oriënteren in die richting (Dennis, 10 juli, 1968 ) $^{75}$. In tegenstelling tot hetgeen rond het initiatief in Leiden gebeurd is, blijkt in Groot-Brittannië de over-

73 Een donor/ontvanger-combinatie waarbij alle (dan bekende) antigenen overeenkomen.

74 Van Rood informeert Woodruff hierover:

I have lately discussed the future of Eurotransplant with Richard Batchelor, Dausset and Ceppellini. For the time being the following seems to be the most sensible approach: We seriously consider the possibility of dividing Europe in a number of regions. One region would be the United Kingdom and Ireland for which Batchelor would be responsible for the organization of the United Kingdom Chapter of Eurotransplant, providing it with sera and so on. Then there would be a region Scandinavia for which either KissmeyerNielsen or the people in Oslo could be the center. We would take care of the Benelux and North West Germany, Dausset of France and Spain. The Swiss people, either Hollander or Hässig could take care of Switzerland, part of Austria and South West Germany and Ceppellini of Italy. Many of the people don't know this yet, so please keep it under your hat. This is just to give you an idea. ... (van Rood, 20 juni, 1968) 
heid, via de National Health Service, dus wel een rol te willen spelen bij de uitwisseling van organen. Tezelfdertijd is Donald Longmore daar dan echter al lang en breed bezig met het opzetten van een 'matchingsorganisatie' 76 . In Groot-Brittannië is communicatie dan blijkbaar nog een probleem.

In Scandinavië is de praktijk al geruime tijd, dat Kissmeyer-Nielsen typeringen voor een aantal centra verricht en - net als in de Eurotransplant-regio - behulpzaam is bij het opzetten van perifere laboratoria en met traint hij mensen in het gebruik van de, binnen dat verzorgingsgebied gehanteerde, technieken. Naast deze praktische hulp, ontwikkelt Kissmeyer-Nielsen ook plannen voor het opzetten van een organisatie naar het model van Eurotransplant, met het idee om lokaal te beginnen en later de wachtlijsten samen te voegen, zoals blijkt uit een brief aan Van Rood.

It may be practical to start on different centers and later on to try to pool the whole material in one center in Leiden, and this makes it of course very essential that our typing-reagents will be able to detect the same specificities, and I guess, that it will be possible to solve this problem through further close collaboration including exchange of reagents. It is my personal feeling that it will be very essential in this respect to standardize the methods used as much as possible. (Kissmeyer-Nielsen, 27 maart, 1968)

In gebieden waar geen lid van de 'Tissue Typing Club' aanwezig is, is de organisatie van orgaanuitwisseling minder ver. Zo schrijft Horisberger dat in Zwitserland de orgaanuitwisseling nationaal georganiseerd zal worden (Horisberger, 9 september, 1968). Dit staat in contrast met de plannen in Leiden, waar men juist de mogelijkheden onderzoekt om een niet-strikt nationale regio-indeling te maken. Zo vraagt Bruning juist Daussets mening ten aanzien van het voorstel om Zwitserland samen te laten gaan met Zuid-Duitsland (Bruning, 5 september, 1968) 77 . En kort daarna schrijft Dausset op zijn beurt, dat hij ook bezig is een meerdere landen omvattende uitwisselingsorganisatie op te zetten; "Franco-Espano-Lutano-Transplant ${ }^{78}$, that I have called Euro-Transplant Ouest" (Dausset, 24 oktober, 1968) 19. $^{79}$

Uit Zwitserland zelf komen heel verschillende berichten. Daar blijkt geen eenheid van mening te bestaan. Sommige plannen zijn in tegenspraak met de plannen uit Leiden, zoals Bruning die schetst, andere zijn in strijd met die van Dausset, om Frankrijk, Spanje en Portugal één regio te laten vormen. Dit blijkt onder andere uit een brief afkomstig van Gilbert Thiel, hoofd van het transplantatiecentrum in Basel, die schrijft dat, vanwege de terugkomst van Dr. Jeannet uit de VS (die zich daar bij verschillende mensen heeft bekwaamd in verscheidene typeringstechnieken), het

Ministry of Health, schrijt:

Your scheme for a tissue matching service (Eurotransplant) and tissue typing itself are of great interest and I would appreciate discussions with you on both topics and to see the facilities reguired. (Dennis, 1o juli, 1968)

76 National Tissue Service (Longmore, 8 april, 1968; Longmore, 18 juli, 1968).

77 c.c. Hăssig (Schweizerisches Rotes Kreuz Blutspendedienst)

78 Bij 'Lutano' plaatst Van Rood een vraagteken, maar mogelijk bedoelt Dausset hier Portugal mee.

79 Anders dan in Leiden start Dausset met het vooraf besluiten welke typeringstechniek in zijn organisatie moet gaan worden gebruikt.

We had a meeting in September and are now trying to obtain a standardization of the serological methods before beginning anything on patients.

The start was good. The spirit was high and I hope that we will succeed in having a real infrastructure in a few months.

Also I am quite sure that the relation with the other Eurotransplant will be good an will prove fruitful.

(Dausset, 24 oktober, 1968) 
geplande verblijf van Norma Rowley in Leiden wordt afgeblazen (Thiel, 9 oktober, 1968). In dezelfde brief schrijft Thiel dat Jeannet een typeringslaboratorium gaat opzetten in Genève en dat in New York besloten zou zijn om Europa in 5 regio's te verdelen, waarbij Zwitserland samen met Frankrijk en Spanje één regio zou vormen (Thiel, 9 oktober, 1968). Van Rood is echter, in tegenstelling tot wat Thiel denkt, niet op de hoogte van dit 'besluit'. Van Rood - in reactie op de brief van Thiel - correspondeert met Kissmeyer-Nielsen over diens briefwisseling met Norma Rowley ${ }^{80}$. Kort daarop ( 25 oktober) schrijft Van Rood een brief aan Thiel, waarover hij echter, alvorens hem op 2 december te versturen, met een aantal mensen - onder andere Largiadèr in Zwitserland - eerst overleg voert. In tegenstelling tot het op rationele gronden verdedigbare besluit om Ierland en Groot-Brittannië, vanwege het 'obstakel' Noordzee, tot een aparte regio te maken, lijkt er rond de regio-indeling op het Europese vasteland en in Zwitserland zelf, een emotionele strijd te worden uitgevochten. Rowley schrijft aan Kissmeyer-Nielsen dat Jeannet aan Thiel de volgende voorstelling van zaken heeft gegeven. De WHO heeft de techniek van Terasaki, inclusief de van antisera voorziene platen, geadopteerd als de voorkeurstechniek voor het typeren van leukocytenantigenen en stelt die gevulde platen beschikbaar voor een international collaborative effort ${ }^{81}$. $\mathrm{Zij}$ meent verder te hebben begrepen, dat Jeannet en Dausset hebben besloten om met de gevulde platen en de techniek van Terasaki, een panel op te zetten, antisera te identificeren en na verloop van tijd ook orgaanuitwisseling te organiseren (Rowley, 9 oktober, I968).

In de briefwisselingen tussen Kissmeyer-Nielsen en Rowley, en Van Rood en Thiel lijkt een belangenstrijd rond het verdelen van Europa aan de oppervlakte te komen. Zowel Kissmeyer-Nielsen, als Van Rood, hebben contacten met verschillende mensen in het duitstalige deel van Zwitserland (Zürich, Bern, Basel, St. Gallen); terwijl de franstalige Dausset en Jeannet samen - buiten Van Rood en Kissmeyer-Nielsen om - plannen lijken te ontwikkelen, die ook betrekking hebben op

80 Rowley heeft namelijk al bij Kissmeyer-Nielsen diens cytotoxiciteitstechniek geleerd, maar kreeg bif thuiskomst in Basel te horen dat de te gebruiken techniek niet die van Kissmeyer zal zijn, maar de variatie van Terasakd, waarover zij verontwaardigd naar Kissmeyer-Nielsen schrijft.

$I$ immediately offered some strong objections, ..., to the effect that I thought your technique was superior, more advanced, less complicated, less troublesome, and at the very least, more suitable for our needs in Basel than Terasaki's type of commercial endeavours were. (Rowley, 9 oktober, 1968)

81 Kissmeyer-Nielsen geeft in zijn antwoord aan Rowley ook zijn mening over de techniek van Terasaki en de collaborative cffort. Ook hij heeft voor de 'WHO-trial van Terasaki - zoals hij het noemt - sera ter beschikking gesteld. Het was namelijk de bedoeling, dat Terasaki's met sera gevulde testplaten, door verschillende onderzoekers met roo niet-verwante donoren zouden worden getest. Zo zou, naar voorbeeld van de eerdere Workshops in Leiden en Turijn, de specificiteit van verschillende sera kunnen worden vergeleken. Over het experiment als geheel schrijft hij dat het wel wat resultaten heeft opgeleverd, maar dat zijzelf hun testwerk hebben gestaakt vanwege grote problemen met het aflezen van de reacties.

The investigations showed that it was indeed possible to get almost identical results in different laboratories with some sera, and there were all sera with previously known specificity. The computer approach, however. makes it impossible to get any information about a single serum defining a new specificity. Valuable information about new specificities will only appear when 2 or 3 sera of the same kind are included. (Kissmeyer-Nielsen, 15 oktober, 1968)

Met de bedenkingen die Kissmeyer heeft ten aanzien van grootschalige experimenten als die van Terasaki. wordt tevens duidelijk dat het creëren van uniformiteit in typeringstechnieken niet alleen een 'overdrachtsprobleem' is. Niet alleen is het moeilijk om zonder direct contact (zoals gedurende een bezoek of een cursus, gelijk in Leiden gebeurt), bijvoorbeeld schriftelijk, iemand een typeringstechniek aan te leren. Sommigen zijn nogal gehecht aan hun eigen, dan wel vertrouwde techniek. Kissmeyer zegt hierover dat het "extremely unpleasant" is om te moeten werken met een methode waar je onbekend mee bent (Kissmeyer-Nielsen, 15 oktober, 1968). 
het duitstalige deel van Zwitserland. Kissmeyer reageert dus prompt en uitvoerig op Rowley's brief. Hij begint zijn antwoord met de vaststelling dat Jeannet een groot aantal problemen niet goed heeft begrepen. Daarnaast zegt hij overleg te hebben gehad met Van Rood en dat noch Van Rood, noch hijzelf hebben deelgenomen aan een vergadering over de "division of Europe". Hij schrijft dan ook dat ze daarom niet weten waar Jeannet zijn informatie vandaan heeft (Kissmeyer-Nielsen, I5 oktober, 1968). Wel zegt Kissmeyer, dat tijdens de typeringscursus in Leiden, een informeel gesprek heeft plaatsgevonden tussen Batchelor, Trnka, Van Rood en hemzelf, waarbij zij tot de conclusie kwamen dat het nuttig zou zijn om andere regio's naar het model van Eurotransplant te organiseren. Als een van de mogelijke regio's werd onder andere gesproken over "Zwitzerland/Austria + a part of Germany". Maar, zegt hij, dit was een "completely unofficial talk" en vervolgens zegt hij dat Van Rood Dausset en Ceppellini over het idee zou informeren. Kissmeyer besluit zijn brief door te schrijven niet gelukkig te zijn met de ontwikkelingen in Zwitserland, maar dat hij zich er niet al te zeer mee wil bemoeien. Wel vindt hij dat Jeannet te snel kiest voor de techniek van Terasaki en eerst een goede vergelijking zou moeten maken (Kissmeyer-Nielsen, 15 oktober, 1968).

Ook Van Rood is onaangenaam verrast door Jeannets plannen. Deze doorkruisen namelijk de al bestaande Leidse samenwerkingsverbanden met andere centra in Zwitserland. Verschillende mensen zijn al in Leiden geweest en een aantal centra krijgt ook al sera uit Leiden ${ }^{82}$ waarmee getypeerd wordt; werk dat - door middel van milttyperingen - in Leiden wordt gecontroleerd (van Rood, 5 mei, 1968; de Weck, 19 augustus, 1968; van Rood, 30 augustus, 1968 ; Largiadèr, 18 december, ${ }_{1968}{ }^{83}$. In deze periode ontvangt Van Rood de brief van Thiel waarin deze feitelijk de samenwerking met Leiden opzegt. Met Largiadèr is vanaf begin 1968 een actieve samenwerking ontstaan en namens Van Rood verzoekt Eernisse hem commentaar te geven op het concept van Van Roods antwoord aan Thiel. Hierop suggereert Largiadèr om expliciet te zeggen dat ze bezig zijn met het vormen van de regio ZuidDuitsland en Zwitserland en dat zij - Senning en Largiadèr - niet van plan zijn om van techniek te veranderen (Largiadèr, 21 november, 1968). Deze suggesties neemt Van Rood onverkort over in de definitieve brief en hij steekt daarin zijn teleurstelling niet onder stoelen of banken.

I must say that I am disappointed and rather upset about the whole affair. The decision to work together with Switzerland was as you know not made in haste... From your letter I gather now that all the effort of forming a region in Southern Germany and Switzerland, working with uniform techniques and in close collaboration with Leiden, might have been wasted.... (van Rood, 25 oktober, maar verstuurd op 2 december, 1968$)^{84}$.

82 Nu stuurt Van Rood nog sera naar Zwitserland voor het opzetten van een eigen panel. Verzoeken om sera worden alleen gehonoreerd, wanneer deze komen van al bekende contacten. Mensen die geen periode in Leiden hebben doorgebracht, noch de cursus hebben gedaan, krijgen de raad om de sera uit de Serumbank aan te vragen bij Kayhoe (NIH).

83 Daarnaast zoeken anderen contact met Leiden om mensen te laten typeren, waartoe ze bloed in zakken met glaskralen sturen, niet wetend dat dat voor de in Leiden gebruikte technieken niet geschikt is (Horisberger, 27 augustus, 1968; Horisberger, 9 september, 1968 ). Met een bericht in die richting laat Van Rood weten hoe en wanneer te typeren bloed in het lab in Leiden moet zijn (van Rood, 22 september, 1968).

84 Zie bijlage 4: De brief aan Thiel 
Van Rood lijkt zich bedrogen en verraden te voelen. Hij lijkt te vinden dat er misbruik is gemaakt van zijn bereidheid om mensen in de door hen gebruikte technieken te trainen. De samenwerking met Zwitserland als geheel heeft een ernstige deuk opgelopen.

Eenheid is in Zwitserland ver te zoeken. Largiadèr licht Van Rood in over de verdere ontwikkelingen daar. Alleen Jeannet blijkt belangstelling te hebben om de centrale organisatie voor Zwitserland op zich te nemen. Maar daarmee ontstaat een probleem op het gebied van de te gebruiken technieken.

Er [Jeannet] wünscht aus bekanntlichten Gründen die Terasakimethode einzuführen; wir, das heisst de Weck, Thiel, Burri und ich, haben aber darauf hingewiesen, dass die sinnvollste Lösung darin bestünde, dass Jeannet Ihre Techniken übernimt. (Largiadèr, Io december, 1968)

Het gebrek aan consensus doet Largiadèr vrezen dat er geen organisatie komt voor heel Zwitserland. Hij wil daarom in ieder geval voorlopig met Eurotransplant blijven samenwerken (Largiadèr, 10 december, 1968). Maar Largiadèr wil ook samenwerking binnen Zwitserland. Daarom schrijft hij een brief aan zijn Zwitserse collega's, waarin hij nog eens benadrukt hoe belangrijk het is om met een lokale, nationale organisatie aansluiting te krijgen bij een internationale organisatie. Zwitserland moet er volgens Largiadèr voor waken een buitenbeentje te worden.

Gleichzeitig gilt es aber zu verhindern, dass ein schweizerisches "Sonderzügli"

geschaffen wird. Unsere Organisation muss so beschaffen sein, dass sie reibungslos in grössere Zusammenhänge hinein passt. Praktisch gesprochen geht es darum, ob wir Methoden verwenden, die auch im unmittelbar benachbarten Ausland angewandt werden, also darum, ob wir unsere Resultate mit denjenigen anderer europäischer Länder vergleichen können oder nicht.

(Largiadèr, 10 december, 1968)

Hij brengt naar voren dat bij acht universiteitsklinieken in Zwitserland de typering al in samenwerking met Van Rood gebeurt ${ }^{85}$ en dat door alle drie de 'deutschschweizerischen' universiteitsklinieken voorbereidingen zijn getroffen, om te gaan typeren volgens de Leidse methoden (inclusief de microcytotoxiciteitstechniek die ze daar nu gebruiken). Ook voert hij aan dat ze in duitstalig Zwitserland veel meer wetenschappelijk georiënteerd zijn op de noordelijk gelegen landen, dan op Frankrijk en Italië. Vanuit deze overwegingen doet hij het voorstel om Zwitserland een Eurotransplant-onderafdeling te laten zijn.

Unser Vorschlag geht deshalb dahin, die schweizerische Arbeitsgruppe für Leukozytentypisierung als Untergruppe von "Eurotransplant" zu organisieren. Dr. Jeannet als Leiter des schweizerischen Referenzlaboratoriums wäre dabei zuständig und verantwortlich dafür, dass die angewandten Methoden und damit die Resultate mit denen von Eurotransplant vergleichbar sind. (Largiadèr, ro december, 1968)

85 Largiadèr wil de 'Leidse weg' die zij ingeslagen zijn (door hun analiste (Miss. Propradi) voor een half jaar naar Leiden te laten gaan) graag voortzetten en het argument dat Zwitserland moet aansluiten bij het buitenland, gebruikt hij als tegenargument om niet over te hoeven gaan op de techniek van Terasaki. Wir sollen uns deshalb nicht auf eine bestimmte Technik festlegen, nur weil man glaubt, dass diese vielleicht in einigen Jahren bevorzugt werden wird. In einigen jahren wird sich ohnehin auf diesem Gebiet vieles gealndert haben. Jetzt geht es darum, ein System aufzustellen, das heute funktioniert und nicht erst später. (Largiadèr, to december, 1968) 
In het hierop volgende jaar wordt het 'Laboratoire National de Référence pour l. Histocompatibilité' opgericht in Genève, maar Zwitserland wordt niet aan de Eurotransplant-regio toegevoegd ${ }^{86}$, hetgeen, vanuit Leiden gezien, ook helemaal niet de bedoeling was. Dit blijkt onder andere uit een brief die Van Rood - naar aanleiding van het gesprek tijdens de typeringscursus tussen Trnka, Batchelor Kissmeyer-Nielsen en hemzelf, enige maanden voor de Zwitserland-affaire - aan Ceppellini stuurt over de huidige en toekomstige ontwikkelingen rond Eurotransplant. Het aantal patiënten op de wachtlijst neemt gestaag toe en, zo schrijft hij, ze hebben de afgelopen drie maanden 15 transplantaties via de 'Eurotransplant-files' gedaan. Daar voegt hij aan toe: "As things are going along I have the feeling that with the Benelux and Northern Germany we have really all we can handle." (van Rood, 22 augustus, 1968). Er is dus geen sprake meer van dat Van Rood Zwitserland in een geheel Europa omvattend Eurotransplant wil opnemen. Van Rood vraagt zelfs aan Ceppellini of het geen goed idee is om Europa op te delen in zelfstandige regio's, waarbij hij de volgende argumentatie geeft:

The regions could be more or less independent. Have their own typing procedure, nomenclature, dataprocessing, exchange transport, regulations and so on. (van Rood, 22 augustus, 1968 )

Dit lijkt eerder voor de plannen van Jeannet te pleiten dan ertegen. Het ontstaan van de controverse lijkt dan ook eerder te wijten aan een Zwitserse taalstrijd; aan gevoelens van loyaliteit ten opzichte van bestaande contacten; aan gewenst vruchtgebruik van gedane investeringen; aan conservatisme op het gebied van te gebruiken technieken en aan territoriumdrift, dan aan rationele argumenten om Zwitserland al dan niet deel te laten nemen aan Eurotransplant.

Om verschillende redenen komt er uiteindelijk dus geen Europa-omvattende orgaanuitwisselingsorganisatie. Er worden meerdere regio's ingesteld, waarover enkele mensen van het eerste uur de scepter zwaaien. Meestal met respect voor ieders bestaande contacten, wordt Europa verdeeld; rekening houdend met de verschillende eisen die aan de omvang worden gesteld ${ }^{87}$. Kleiner dan de Benelux en Noord-Duitsland zal Eurotransplant niet worden. In de loop van 1968 worden verschillende, van buiten de eigen regio komende verzoeken voor deelname aan Eurotransplant ${ }^{88}$, doorverwezen naar mensen die dichter in de buurt van de aanvragers hun coördinerende activiteiten ontplooien. Later gebeurt dit onder de vlag van het 'zich houden aan de gemaakte (informele) afspraken'. Worden mensen aanvankelijk toch nog geholpen of voorzichtig doorverwezen ${ }^{89}$, later wordt direct gezegd, dat vanwege gemaakte afspraken de verzoeken aan anderen moeten worden gericht (Kissmeyer-Nielsen, 5 oktober, 1968; van Rood, 3r december, 1970). Verzoeken om deelname aan Eurotransplant van binnen de eigen regio daarentegen, worden hartelijk verwelkomd 90 . Daarnaast worden mensen aangeschreven die men graag in Eurotransplant ziet participeren ${ }^{91}$. De vraag wie de verzoeken tot ondersteuning

86 Een formele organisatie als Eurotransplant, wordt in Zwitserland overigens pas in 1985 opgericht: Swisstransplant.

87 Voldoende groot om genoeg patiënten op de wachtlifst te hebben en voldoende klein om de hoeveelheid werk hanteerbaar te houden en de te overbruggen afstanden niet te groot te laten zijn.

88 (van Rood, 7 januari, 1968: Lasio, 8 maart, 1968)

89 (Vilar, 6 juni, 1968; Hayry, 4 oktober, 1968)

90 (Martini, et al., 22 november, 1968)

91 (van Rood, 14 oktober, 1968) 
moet behandelen, grijpt Van Rood aan om bij Dausset het thema 'voorkoming van grensconflicter' aan te kaarten.

Herewith I send you the letter I sent to Garcia-Ortiz. I hope it will be

selfexplanatory. In the future I will inform you of all such requests and would be happy if you could do the same. I think it is essential that we recognize the

"territories" of the others. I hope you feel the same about this. (van Rood, 23 december, I968)

Europa wordt opgedeeld. De overtuiging dat het (in logistieke zin) beter is om binnen kleinere, zelfstandige regio's te werken, wordt mede ingegeven door het idee dat de kans op een identieke donor weliswaar klein, maar niet te klein is. Een mismatch hoeft bovendien niet fataal te zijn vanwege de mogelijkheid immunosuppressiva te gebruiken.

We do have unrelated people which have identical HL-A types. The chance of finding such people with our selection is after rough calculations less than I: 1.000 , but we feel that identity is not necessary for a good result after transplantation, as we feel that incompatibility for one HL-A antigen can be managed by immunosuppression. (Kissmeyer-Nielsen, 15 oktober, 1968)

De ontwikkelingen rond het opzetten van orgaanuitwisselingsorganisaties verlopen (in ieder geval voor wat Eurotransplant betreft) voorspoedig (van Rood, 17 maart, I970). Na verloop van tijd is niet alleen het aantal deelnemende centra in de Benelux en Duitsland toegenomen, maar ontstaan - in weerwil van eerdere ideeën over de omvang van Eurotransplant - ook directe contacten met Oostenrijk. Zo schrijft Van Rood aan Speiser en Steffen in Wenen, dat hij Dr. Eva Wolf (van het Institut für Immunologie der Universität Wien) en Dr. Mayr ontmoet heeft. Deze zijn beiden actief als weefseltypeerders en hij vertelt hen dan hij heeft beloofd "to keep them informed on the proceedings of Eurotransplant and to send them the standard sera used in ET." (van Rood, 13 april, 1970) Uit het vervolg van de correspondentie blijkt dat Oostenrijk zich ook op nationaal niveau heeft georganiseerd (Austrotransplant), wat Van Rood er echter niet van weerhoudt om toch aansluiting bij Eurotransplant aan te bieden (van Rood, 29 mei, 1970). Mogelijk dat door de strubbelingen in Zwitserland het er in dat deel van Europa niet van is gekomen om een grensoverschrijdende regio te vormen. Mogelijk dat de banden tussen Eurotransplant en Austrotransplant daarom worden aangehaald en Oostenrijk uiteindelijk wel deel uit gaat maken van de Eurotransplant-regio. Zwitserland blijft echter toch afzijdig.

In de loop van de tijd wordt zo praktisch geheel 'West' Europa ondergebracht in regio's. Er ontstaan regionale orgaanuitwisselingsorganisaties die zorg dragen voor betrouwbare gegevensuitwisseling en allocatie van donororganen en die in praktische zin het uitwisselen van organen faciliteren en coördineren voor de (meeste) patiënten die in de betreffende regio op de wachtlijst staan.

\subsubsection{Over de Grens}

Er vindt verkaveling van Europa plaats. Zoals gezegd wordt geschiktheid daarmee deels een lokaal gegeven, doordat de regio's zelf verantwoordelijk zijn voor de keuze van serologische technieken, en voor antisera. Primair wordt betrouwbaarheid binnen de regio gecreëerd. Dit betekent dat in een bepaalde regio andere antisera gebruikt kunnen worden dan in andere, met als gevolg dat de typeringsgegevens in de ene regio niet overeen hoeven te komen met de gegevens die in een andere regio (zouden) zijn verkregen. De gegevens die in een bepaalde regio over een bepaalde 
donor verkregen worden, kunnen dus niet zonder meer vergeleken worden met de typeringsgegevens van patiënten op de wachtlijst van een andere regio.

Omdat het idee bestaat, dat de kans groot genoeg is om voor iedere individuele patiënt in een regio een geschikte (dus niet per se identieke) nier tegen te zullen komen, ziet men de ontwikkeling dat de typeringsgegevens niet uitwisselbaar zijn, niet als probleem. Voor het grootste gedeelte van de wachtende patiënten zal het ook daadwerkelijk zo zijn dat de kans op een geschikte donor groot genoeg is; echter niet voor alle. Alleen voor het kleine aantal moeilijke patiënten, waarvoor men verwacht niet eenvoudig een geschikte donor te kunnen vinden, zou over de grenzen van de regio heen gekeken kunnen worden ${ }^{92}$. Hiervoor moet dan wel veel werk verricht worden om de typeringsgegevens te vertalen naar de andere regio's.

For those case which are really difficult (i.e. those patients who have already rejected a kidney, have rare leukocyte groups or very strong antibodies) we would of course be extremely happy to put these in the files with the very difficult ones of the Continent. (van Rood, 22 september, 1968)

Door zo'n aparte 'file' te maken met de 'kansarme' patiënten, wordt het mogelijk om hen extra aandacht te schenken. Door bij iedere donor eerst op die 'Super-Eurotransplantlijst' te kijken of daar een geschikte patiënt is, hebben ook deze patiënten een (grotere) kans op een donornier.

In 1970 neemt het vertrouwen in de toereikendheid van de 'kleine' regio's echter af. Het aantal te herkennen antigenen groeit namelijk en daarmee neemt ook de gewenste 'recipient pool'-omvang toe. In dit verband informeert Van Rood bij Largiadèr of hij al iets meer weet over de verdere ontwikkelingen in Zwitserland.

We would be interested to know as from more recent histocompatibility data it appears that it would be a good idea to make the pool as large as possible.

If the Swiss Group decided that they would like to stay on their own, we probably would have to start cooperation with Scandinavian Transplant. (van Rood, 27 januari, 1970)

Kort daarop stuurt Van Rood Kissmeyer-Nielsen een exemplaar van het 'Eurotransplant-telefoonboek' ten bate van het uitwisselen van organen tussen de twee organisaties (van Rood, Io maart, 1970). Spoedig daarna brengt hij Kissmeyer-Nielsen verslag uit van overleg tussen Eurotransplant en mensen uit Zwitserland en Oostenrijk. Een fusie van Eurotransplant met 'Scandinavian Transplant' brengt hij niet ter sprake, maar wel het toevoegen van 'Leidse sera' aan de set van Kissmeyer, waarmee de systemen nog meer naar elkaar toe zouden groeien.

I think the meeting on Eurotransplant was quite useful. Jeannet reacted favourable and would discuss the possibility at home to join Eurotransplant. Also the people from Vienna were present. All together this will bring our

92 Met de eerste ideeĕn over regionalisatie van uitwisselingsorganisaties, wordt direct met deze categorie patiënten rekening gehouden, zoals Van Rood eind juni en begin augustus al aan Woodruff schrift:

For the rare cases, or those with strong antibodies with a broad specificity we could make a kind of super pool for which we all could try to find adequate donors. (van Rood, 20 juni, 1968)

Difficult cases in "super Eurotransplant file" and would have been typed by all the different regional typing centers and if a donor would come along which was adequate, he could be flown especially to that recipient. (van Rood, 8 augustus, 1968 )

En eind augustus aan Ceppellini:

Only for the cases which are really very difficult to handle ... we could form a kind of super Eurotransplant file. ... (van Rood, 22 augustus, 1968) 
patient pool to near 700. We have decided to reorganize our computer printout to be more compatible with yours.... Would you be willing to use the cytotoxic $4 \mathrm{a}$ and $4 \mathrm{~b}$ in the Scandia Transplant? This would make our systems almost completely compatible, although typing for $4^{\mathrm{a}}$ and $4 \mathrm{~b}$ can be better done by agglutination, of course. (van Rood, 20 maart, 1970)

Maar Van Rood voelt ook dat er grenzen zijn aan het terugbrengen van het aantal regio's. Op vragen van Hugh Fudenberg van de universiteit van California, naar de verwachte ontwikkelingen van weefseltypering en orgaanuitwisseling en het maximaal te bestrijken gebied, geeft Van Rood een voorwaardelijk antwoord. Als de situatie zo zou zijn dat er voldoende antiserum aanwezig zou zijn om alle typeringslaboratoria ter wereld van dezelfde antisera te voorzien - waarmee voor een belangrijk deel het optreden van verschillen in typeringsuitkomsten tussen typeringslaboratoria opgeheven zou kunnen worden; en de genetica van het HL-A systeem duidelijk zou zijn; en de preservatietechnieken ten bate van het transport van organen verder zouden zijn ontwikkeld, dan zou het technisch mogelijk zijn om de gehele wereld één regio te laten vormen. Aan dit rijtje voorwaarden voegt hij nog een ding toe: "Doctor contact" (van Rood, 23 september, 1970). Niet zozeer de kennis of de logistiek vormen de 'noodzaak' van een verdeling in regio's, maar de mensen die op afstand met elkaar moeten werken vormen de bottleneck. De artsen moeten door direct contact het gevoel houden dat de afstand overbrugbaar is. Het lijkt erop dat hij hiermee wil zeggen dat ook binnen formele organisaties de samenwerking is gebaseerd op persoonlijke interessen en de overtuiging dat het zinvol is om die extra inspanningen te verrichten. Dat is dezelfde motivatie die aanwezig was bij de artsen die vóór de oprichting van Eurotransplant met Leiden samenwerkten. Bij te grote regio's worden de afstanden tussen de artsen, zowel letterlijk, als figuurlijk, te groot. Alleen bij die speciale patiënten, de patiënten die op de Supra-Regionalewachtlijst staan, zijn de belangen dusdanig specifiek, dat het contact tussen de doktoren ook over de regio-grenzen heen gewaarborgd is.

\subsection{AanweziG, Geschikt èn Georganiseerd is BeschikbaAR}

In de chirurgische transplantatiepraktijk worden nieren getransplanteerd mits er een donororgaan aanwezig is. Onder invloed van verschillende factoren (verbeteringen in de immunosuppressieve behandeling, matchen van leukocytenantigenen, gespecialiseerde verpleegtechnieken) groeit de vraag naar transplantatie. Tegelijkertijd worden de organen van overledenen steeds meer gebruikt voor transplantaties, wat de groei in het donortekort beperkt. Dat kadaverdonoren echter altijd genetisch onverwant zijn aan de ontvanger levert een geschiktheidsprobleem op. Het is veel moeilijker om afstotingsverschijnselen te bestrijden bij transplantaties met willekeurige onverwante kadaverdonoren, dan bij transplantaties met verwanten. Zoeken naar een geschikte kadaverdonor, dat wil zeggen zoeken naar een (bijna) overledene met liefst dezelfde leukocytenantigenen zou de afstotingsverschijnselen kunnen verminderen. Invoering van het hersendoodscriterium maakt dit zoeken makkelijker omdat er meer tijd ontstaat voor de noodzakelijke bepalingen, en omdat het moment van intreden van het zuurstoftekort van het donororgaan gekozen kan worden, waardoor de ischemische tijd en dus de schade aan het donororgaan beperkt kan worden.

Een zeer belangrijke verbetering in het aanwezig maken van geschikte kadavernieren is het afstappen van het zoeken naar een geschikte donor voor een patiënt en 
over te gaan op het zoeken van een geschikte patiënt voor een donor. In plaats van voor één patiënt onder een klein aantal (bijna) overledenen te zoeken naar een geschikte donor en van die groep potentiële donoren er vervolgens één te gebruiken, wordt geprobeerd om alle potentiële donoren te gebruiken door een wachtlijst van potentiële ontvangers te maken. Hiermee verschuift echter het probleem van aanwezigheid naar geschiktheid. Het typeren van alle ontvangers is veel werk, maar te doen. Problemen daaromtrent zijn oplosbaar, zoals bijvoorbeeld de oplossing dat patiënten naar Leiden komen om zich te laten typeren, zoals dit ook met verwante donoren gebeurde. Het typeren van kadaverdonoren ligt moeilijker. De voor het versturen van bloed beschikbare tijd is beperkt en een bijna overleden patiënt kan niet onbeperkt in leven worden gehouden. Daarom moet in de nabijheid van een kadaverdonor diens bloed kunnen worden getypeerd. Om de typeringsresultaten die in de hiertoe ingerichte laboratoria worden verkregen bruikbaar te maken voor de geschiktheidsvergelijking van donor en ontvanger, moet de bepaling plaats vinden met behulp van dezelfde serologische technieken en dezelfde antisera. Het blijkt niet mogelijk een systeem te verwezenlijken waarin de leukocytenantigenen van iedere patiënt in Europa (of in de Wereld) betrouwbaar vergeleken kunnen worden met iedere potentiële donor.

Er zijn verschillende redenen om niet naar één grote, Wereld- of Europa-omvattende orgaanuitwisselingsorganisatie te streven. Geschiktheid en aanwezigheid spelen beide een rol in het tot stand komen van verschillende regio's binnen Europa. Theoretische problemen maken het praktisch onmogelijk, en verschillen in technieken en imperfecte antisera zorgen voor standaardisatieproblemen. Bij de 'verdeling van Europa' lijken opportunisme en competitie echter ook een rol te spelen naast medische en/of wetenschappelijke criteria, zoals onder andere blijkt uit de casus 'Zwitserland'.

Uniformiteit binnen de regio ten aanzien van het bepalen van geschiktheid is een vereiste, hetgeen tot gevolg heeft dat er interregionale verschillen zijn. Geschiktheid wordt door regionalisatie een lokaal gegeven. Voor enkele patiënten zou dit nadelige gevolgen kunnen hebben. Zij lopen het risico om buiten de boot te vallen. Voor de 'gewone' patiënten op de wachtlijst, heeft de indeling in regio's het voordeel dat de betrouwbaarheid van de typeringen omhoog gaat, terwijl door de korte afstanden het bij een bepaalde ontvanger aanwezig laten zijn van een bepaalde nier makkelijker te realiseren is.

Voor aanwezigheid zijn vooral praktische argumenten te geven die het beperkt houden van het geografisch gebied rechtvaardigen. Om zowel op het gebied van de geschiktheid, als ten aanzien van de aanwezigheid, het grootste rendement te behalen, moeten er veel verschillende zaken worden georganiseerd. Afspraken moeten worden gemaakt, procedures vastgelegd en de uitwisseling van antisera, gegevens en organen moet worden georganiseerd. Pas wanneer aan al deze voorwaarden, op dusdanige wijze is voldaan dat alle organisatorische voorbereidingen van een transplantatie resulteren in een geschikte donornier, aanwezig op de operatiekamer bij de voorbereide ontvanger, kan gesproken worden van een beschikbaar orgaan.

In het volgende hoofdstuk zal worden beschreven hoe de zich ontwikkelende Eurotransplant-organisatie probeert, het verwerven, alloceren en transplanteren stabiel georganiseerd te krijgen en hoe de verwevenheid van (medische) wetenschap en maatschappij daarbij een rol speelt. 


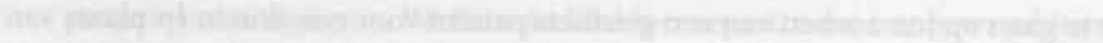

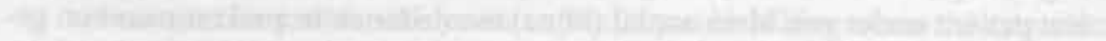
Thin

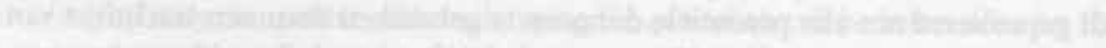

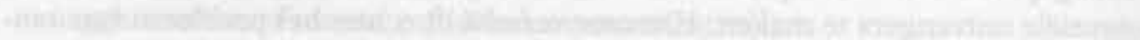
Whath

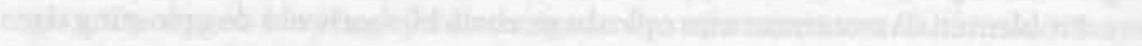
Than

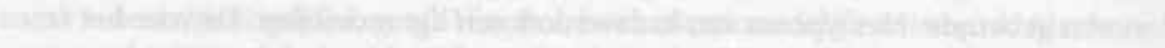

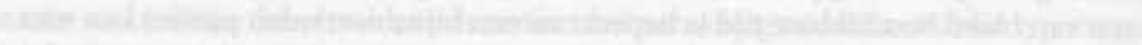

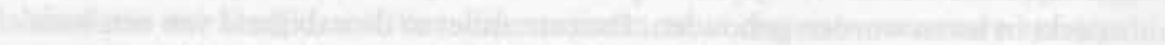

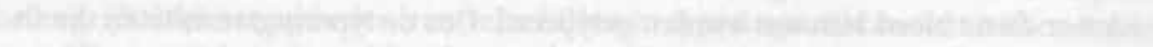

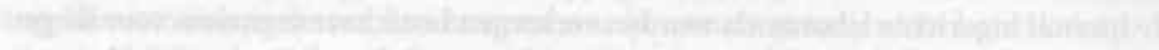

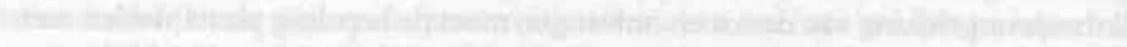

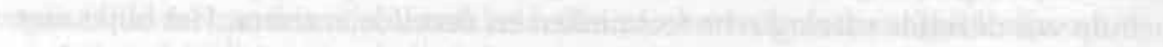

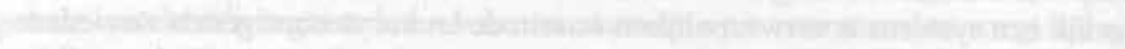

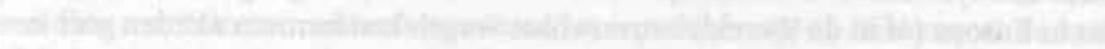

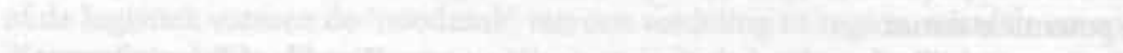

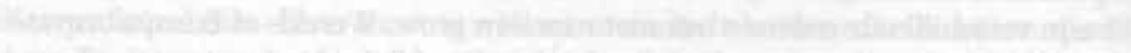
at

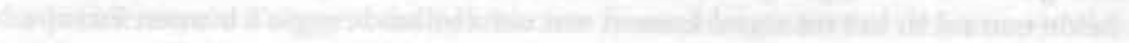

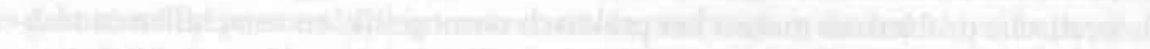

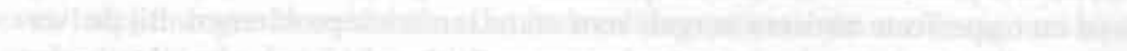

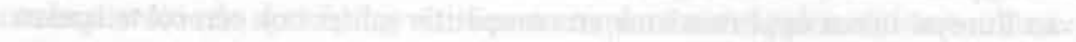

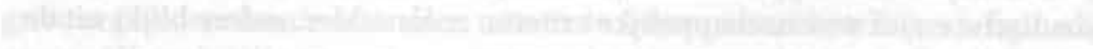

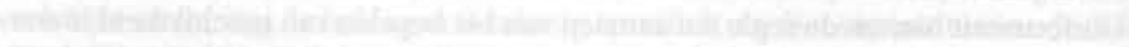

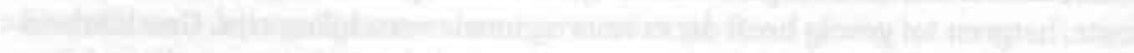

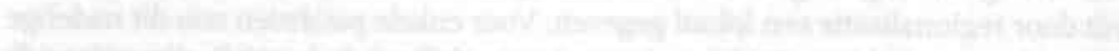

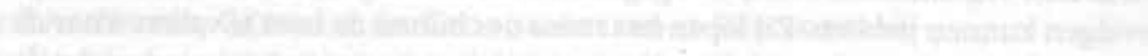

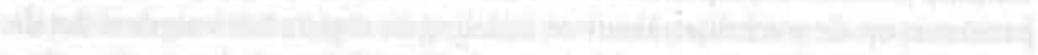

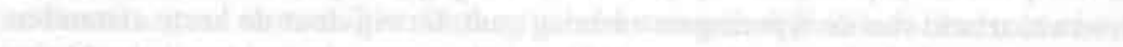

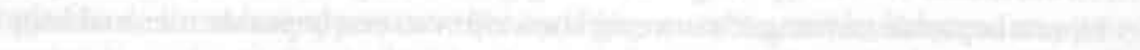

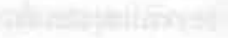

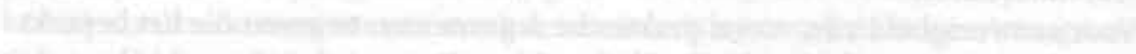

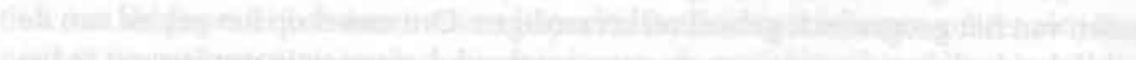

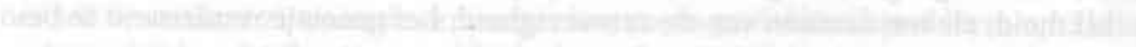

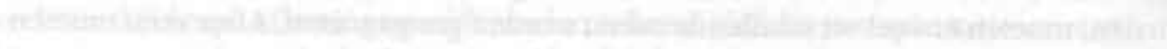

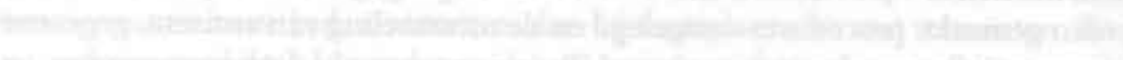

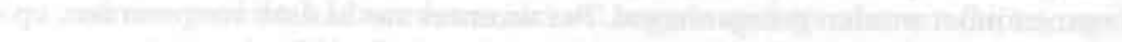

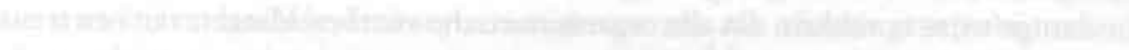

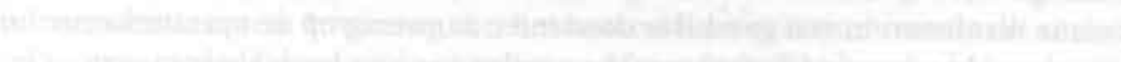

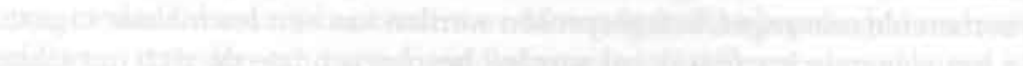




\section{DE WORDING VAN EEN MATCHINGSPRAKTIJK}

\subsection{INLEIDING}

In de voorgaande hoofdstukken is beschreven, hoeveel werk werd verzet om de geschiktheid en de aanwezigheid van donororganen te creëren. De nadruk heeft voornamelijk gelegen op de activiteiten in de ziekenhuizen en laboratoria. Alles wat daarbuiten gebeurde, werd min of meer gezien als 'randvoorwaarde'. In dit hoofdstuk wordt deze verhouding omgedraaid. Alles wat binnen de ziekenhuizen en laboratoria gebeurt, zal nu worden beschouwd als activiteiten die mogelijk worden gemaakt door de wereld buiten het ziekenhuis. Ziekenhuizen bevinden zich immers niet op een eiland waar zij, afgeschermd, een wereld op zichzelf vormen. Zij (met daarbij inbegrepen de laboratoria) zijn verweven met de wereld om hen heen. In dit hoofdstuk zal ik, aan de hand van enkele voorbeelden van belangrijke 'randvoorwaarden', laten zien hoe de verwevenheid van de binnen- en buitenwereld eruit ziet.

Wanneer niertransplantaties eind jaren 60 in verschillende centra op gang komen, ontstaat het donorprobleem. Met het toenemend aantal transplantaties groeit ook de behoefte eraan en daarmee het aanwezigheidsprobleem. Oplossingen voor dit probleem kunnen niet los worden gezien van het geschiktheidsprobleem. Voor een goed functionerende organisatie, met daadwerkelijke beschikbaarheid van donororganen voor nierpatiënten, is het niet alleen noodzakelijk dat de aanwezigheid en de geschiktheid gerealiseerd zijn, maar ook dat de organisatie op orde is. In het vorige hoofdstuk is beschreven hoe Europa verdeeld wordt in regio's en beschikbaarheid voor zoveel mogelijk patiënten wordt gerealiseerd door het inrichten van 'lokale' organisaties. Het functioneren van deze organisaties bestaat echter uit meer dan het uitwisselbaar maken van typeringsgegevens en de toewijzing van een orgaan aan een bepaalde patiënt. Voor een nadere analyse kan onderscheid gemaakt worden tussen intra-organisationele ontwikkelingen (\$8.2) en ontwikkelingen 'om de praktijk heen' ( $\$ 8.3)$. Bij de intra-organisationele ontwikkelingen bespreek ik achtereenvolgens het tot stand komen van voorwaarden en procedures rond de communicatie-infrastructuur en de onderlinge afstemming van transplantatietechnieken (§8.2.I); de organisatie van controle, niet alleen om compliantie te bewerkstelligen maar ook ter controle van de kwaliteit (\$8.2.2); en de ontwikkelingen rond transport van bloed en sera enerzijds en organen anderzijds (\$8.2.3).

Bij de bespreking van de 'ontwikkelingen om de praktijk heen', richt ik mij op 'maatschappelijke inbedding' van de 'medische' praktijk, die de praktijk als het ware 'draagt'. Dit betreft zowel het morele als het juridische gebied. In de afzonderlijke subparagrafen bespreek ik de rol van de 'publiek opinie' bij de maatschappelijke 
acceptatie van transplantatiegeneeskunde ([8.3.I), hoe het maatschappelijk draagvlak wordt gebruikt (\$8.3.2), en hoe de (nationale en internationale) financiering van Eurotransplant tot stand komt (\$8.3.3).

In de afsluitende paragraaf laat ik nog eens zien dat het intra-organisationele domein en het domein van de 'maatschappelijke invloeden' niet los van elkaar staan. Ze kunnen weliswaar ten bate van de analyse los van elkaar gezien worden, maar slechts in samenhang begrepen. Kortom, in dit hoofdstuk zal ik de verwevenheid van verschillende domeinen tonen, alsmede de manier waarop beide domeinen een bijdrage leveren aan het creëren van beschikbaarheid en daarmee aan de matchingspraktijk Eurotransplant.

\subsection{Een Organisatie in Ontwikkeling}

\subsubsection{Voorwaarden en Procedures}

Het organiseren en coördineren van acties, waarbij meerdere lokaties en meerdere mensen betrokken zijn, vraagt meer expliciete afstemming, dan wanneer de acties op één en dezelfde plaats, door één en dezelfde persoon worden verricht. In geval van een niertransplantatie zal de beschikbaarheid niet alleen afhangen van de fysieke aanwezigheid en van de geschiktheid in immunologische zin, maar ook van geschiktheid in anatomische zin. Er moet worden afgesproken hoe, in het geval van een nier, de bloedvaten en urineleider worden afgesneden bij het uitnemen van de donornier. Dit soort problemen doen zich op velerlei gebieden voor, waarover, voor een goed verloop van een transplantatie, afspraken dienen te zijn gemaakt, waarnaar moet worden gehandeld. Een eerste, zeer belangrijk, onderdeel van de coördinatie op afstand is de communicatie.

\subsubsection{Communicatie Infrastructuur}

Nadat Van Rood tijdens de 'Histocompatibility Conference and Workshop' zijn plan om een internationale orgaanuitwisselingsorganisatie op te richten heeft gepresenteerd, probeert hij in Leiden zo'n organisatie van de grond te krijgen. Een plan omzetten in een praktijk is echter niet eenvoudig en hij beklaagt zich dan ook tegenover Ceppellini over het gebrek aan medewerking in Leiden (van Rood, 28 december, 1967 ). Eén probleem is het gebrek aan ruimte. Was aanvankelijk 'Kamer $\gamma^{\prime}$ misschien voldoende voor het verzorgen van de bloedbank; met het toenemen van 'bloed verbruikende operaties' wordt de gang bij Kamer 7 als onderdeel van de bloedbank ingericht. In 1956 komt een einde aan de deplorabele toestand rond kamer 7 en wordt een nieuwe barak betrokken, maar de ruimte is bij ingebruikneming al nauwelijks meer toereikend. Er is zowel een toename in het gebruik van bloed en bloedproducten, als een toename in bepalingen die aan het bloed verricht worden. Daarnaast ontwikkelen zich de onderzoeks- en opleidingstaken van de (inmiddels Immunohaematologie en Bloedbank genoemde) afdeling. Eind ' 67 is het ruimtegebrek dusdanig, dat, om voor Eurotransplant ruimte te scheppen, een stacaravan op het terrein van het AZL wordt gezet ${ }^{1}$.

1 Van Rood had toestemming om cen stacaravan te plaatsen. Aan de toestemming was echter geen maximale grootte verbonden, hetgeen Van Rood goed uitkwam, aangezien hij wel wist dat het "enorme karren" konden zijn (van Rood, $n$ augustus, 2000). Het ziekenhuis was dan ook niet blij met de enorme omvang van deze noodoplossing. Ook Van Rood wilde niet al te zichtbaar hebben dat Eurotransplant vanuit een caravan 
Een deel van de problemen die de Leidse groep bij de oprichting van Eurotransplant ervaart, is terug te voeren op de stacaravan. Maar al snel krijgt Eurotransplant zoveel naam dat de organisatie als argument voor het verkrijgen van extra diensten fungeert. Zo vraagt Van Rood een urgentieverklaring aan voor een telefoonaansluiting bij het hoofd van het secretariaat Immunohaematologie thuis, om de bereikbaarheid van de voor de administratie belangrijke mensen te vergroten (van Rood, 28 februari, 1968 ). Ook in geval van een eventuele transplantatie, gaat de communicatie tussen verschillende centra via de telefoon. Kort na de start van Eurotransplant blijkt dat het telefoonverkeer problemen oplevert. Daarom wordt gezocht naar andere manieren van communicatie, die minder vertragend en gevoelig voor fouten zijn. Telex zou een aantal problemen kunnen voorkomen. Ten bate van de communicatie met andere centra en de "Rijkspolitie en de Marine Luchtvaartdienst" in Eurotransplantverband, wordt plaatsing van een telex aangevraagd bij de heer M.W. Jongsma, de Geneesheer Directeur van het AZL. Van Rood geeft daarbij aan dat de gebruikskosten van telex lager zijn dan van telefoon, en dat telex voor succesvolle uitwisseling van organen belangrijke voordelen heeft.

r. Met deze apparatuur is het ook mogelijk niet alleen in Nederland, maar ook in het buitenland binnen drie minuten een verbinding te verkrijgen. Tijdens de spitsuren zijn telefonische verbindingen met het buitenland vaak onderhevig aan een ernstige vertraging.

2. Met behulp van de telex apparatuur krijgt men steeds een afschrift van de boodschap, zowel voor de ontvanger, als voor verzender, wat het maken van fouten ernstig vermindert. Het spreekt vanzelf dat wanneer met behulp van deze apparatuur leukocytengroepen overgebracht moeten worden, dit een bijzonder belangrijk voordeel is. (van Rood, 16 oktober, 1968 )

Van Rood noemt als belangrijke voordelen van telex, dat zowel de verzender als de ontvanger een kopie heeft van het verstuurde bericht, dat daardoor minder fouten gemaakt worden, en dat het versturen van een telexbericht via een aparte 'lijn' gaat, zodat de telefooncentrale niet onnodig wordt belast ${ }^{2}$. Enige tijd later zet hij dit verzoek extra kracht bij door te verwijzen naar toezeggingen van andere centra om een telexaansluiting te willen aanschaffen, mits andere ziekenhuizen, waaronder het AZL, dat ook doen (Derom, 4 november, 1968$)^{3}$. Van Rood voegt daar aan toe dat, wanneer "bekend is dat een niertransplantatie plaats zal kunnen vinden, een zeer frequent contact met een aantal transplantatiecentra noodzakelijk is." (van Rood, 18 december, 1968 ) Vooral buiten kantooruren zorgt dit drukke telefoonver-

opereerde, daarom zei hij:

" $l \mathrm{k}$ wil die wielen niet zien. Ik wil niet zien dat het een caravan is, want als er mensen uit het buitenland komen, moeten ze toch zien dat het netjes is." (van Leeuwen, 6 september, 1994)

Naast de caravan wordt later nog een bouwket gezet, waar wordt getypeerd, tot in 1970 een nieuw gebouw wordt betrokken (gebouw 23).

2 Daarnaast is het bovendien zo dat een Telexbericht naar meerdere aansluitingen tegelijk verstuurd kan worden, zodat dit nog een extra besparing in tijd en geld oplevert.

Van Rood vraagt niet alleen aan de bij Eurotransplant aangesloten centra om een telex aan te schaffen, ook aan anderen vraagt hij of ze via Telex bereikt kunnen worden, zoals aan Peter Brain in Zuid Afrika, met een vergelijkbare argumentatie: "It is a lot cheaper than a telephone and accurate as a letter and of course quite fast." (van Rood, 30 december, 1968)

3 Gent is bereid een Telex te kopen en te verbinden aan het internationale net, maar Derom wil bevestiging dat het doorgaat.

Het heeft inderdaad geen zin dat alleen ons ziekenhuis een telescriptor zou nemen, wanneer de andere ziekenhuizen zich hierop niet zouden aansluiten. (Derom, 4 november, 1968) 
keer voor veel vertraging en overbelasting van de portier, die dan de telefooncentrale bemant en "het is de laatste weken wel gebleken dat deze de extra belasting van al deze nationale en internationale telefoonaanvragen niet kan verwerken" (van Rood, 18 december, 1968). Kort daarop kan Van Rood aan Derom het bericht sturen, dat de toezegging voor een telex binnen is en ze over niet al te lange tijd aangesloten zullen zijn op het telexnet; dat het 'telexproject' dus doorgaat aangezien, naast Gent, ook Brussel en Leiden over een telex zullen beschikken (van Rood, 23 december, 1968).

Ook Govaerts, van het typeringslaboratorium in Brussel, benadrukt de grote voordelen van telex. Hij beklaagt zich over het moeizame telefonische contact met andere centra wanneer zich een potentiële donor aandient, en over de toenemende kosten die daaraan verbonden zijn. Met een lijst van alle Eurotransplant Centra zou hij al enigszins geholpen zijn, maar de situatie zou pas echt optimaal zijn, wanneer gebruik gemaakt zou kunnen worden van de accuratesse en lagere kosten van telex. Hij noemt tevens de mogelijkheid om de berichten te standaardiseren als een voordeel ten opzichte van de telefoon (Govaerts, 26 december, 1968). In de tweede Eurotransplant Newsletter meldt Van Rood aan de Eurotransplantgemeenschap dat in Brussel en Leiden (en op korte termijn in Gent) een telexaansluiting aanwezig zal zijn 4 .

In Leiden zelf gaat de plaatsing van een telex bij Eurotransplant echter niet snel. Het ziekenhuis als geheel heeft wel een telex aangeschaft, maar een verzoek om een eigen telex in de Eurotranplant-caravan ('de salonwagen') geplaatst te krijgen, wordt afgewezen op grond van het argument dat de kosten te hoog zijn, tegenover een te laag gebruik (A.Z.L., 29 september, 1969). Ondanks dit soort tegenslagen breidt het gebruik van telex zich gestaag uit. Weliswaar heeft niet ieder, bij Eurotransplant aangesloten, transplantatiecentrum of typeringslaboratorium meteen de beschikking over een telex, maar algemeen gesproken, wordt het aantal aansluitingen steeds groter.

Met het dichter worden van het telexnet wordt het gebruik ervan steeds dwingender opgelegd. Doordat in de loop van de tijd een groter aantal centra een telex heeft aangeschaft, dreigen centra zonder telex buiten de boot te vallen. Communicatie via de telefoon met 'telexloze centra' verloopt zoveel moeizamer en vraagt zoveel extra tijd en aandacht vergeleken met het inmiddels routinematige gebruik van de telex, dat deze extra inspanningen er meer en meer bij inschieten. Zo komt er een moment (begin ' 70 ) dat openlijk gezegd wordt dat een bij Eurotransplant aangesloten centrum de beschikking moet hebben over een telex, aangezien het anders niet kan participeren in Eurotransplant. Formeel wordt het nog niet op deze manier gesteld, maar praktisch gesproken kan men niet meer meedoen. Aange-

4 Ondanks dat er dus slechts twee à drie centra met een telex zijn, geeft Van Rood al wel cen van telex afhankelijke attenderingsprocedure.

2. The Belgium Center in Brussels has a telex available nr. 24349 Centrustin and so will have Gent in the near future. Leiden also has a telex installation nr. $327 \mathrm{7}$ e eurotrapla ledn. It has been decided that when one of the typing centers is notified that a cadaver donor will be available, all the collaborating operating centers will be warned by telex that a cadaver kidney is available and they will be asked to indicate to the Typing center whether or not they could transplant a kidney. In this way a lot of time will be saved which is otherwise lost in trying to communicate with a center which can not do the operation anyhow.

For this reason all centers are again urged to obtain permission for a telex connection. If you have not got a telex installation, we would appreciate it if you could let us know whether there is a telex near your center and whether this telex installation could be used for Eurotransplant purposes. (van Rood, jamuari, r969) 
sloten ziekenhuizen wordt per telex gevraagd of ze kunnen transplanteren en uit de patiënten van de positief reagerende centra, wordt vervolgens de best passende geselecteerd (van Rood, 7 april, 1970) ${ }^{5}$. Dit antwoord krijgt Drukker, van het St. Lucas ziekenhuis te Amsterdam, op zijn vraag over de noodzaak van een telexaansluiting voor zijn ziekenhuis (Drukker, 26 maart, 1970). Over het argument van de hoge kosten zegt Van Rood: "Dat menen ze toch niet serieus! Het is niet meer dan een goede 4 dialyses waar ze over zitten te donderjagen." (van Rood, 7 april, 1970), waarna hij vervolgt met het bekende argument van de controleerbare kopie aan beide zijden.

De dekking met telexaansluitingen blijft een punt van zorg, waardoor binnen de Eurotransplantgemeenschap ongelijkheid ontstaat, waarvan uiteindelijk de patiënten de dupe dreigen te worden. Tegen die achtergrond verzoekt Van Rood aan Wijdeveld - in zijn functie van secretaris van de dialysegroep Nederland - om nog eens de aanschaf van telexapparatuur door Nederlandse transplantatiecentra te propageren, want Nederland blijft achter bij het zich internationaal uitbreidende telexnetwerk. In zijn pleidooi tot de werkgroep zegt Van Rood dat de 150 transplantaties die in de eerste twee jaar van Eurotransplant zijn verricht, mede te danken zijn aan de snelle groei van het telexnet en hij geeft een overzicht van de aangesloten centra ${ }^{6}$. Vervolgens schrijft hij: "Helaas schitteren de Nederlandse ziekenhuizen op deze lijst, op één na, door afwezigheid" (van Rood, 6 maart, 1970). Dit heeft als gevolg dat voor deze ziekenhuizen op de telefoon teruggevallen moet worden, wat in het verleden al zo vertragend heeft gewerkt dat donornieren moesten worden weggegooid, naast dat er fouten in het doorgeven van typeringsgegevens zijn gemaakt. Het vóórkomen van fouten vergoelijkt hij enerzijds als horend bij het opstarten van een organisatie, anderzijds echter benoemt hij het ook als reden om snel op het telexnet over te gaan. Daarom vraagt hij hoe het telexnet van de, bij niertransplantatie betrokken, ziekenhuizen uitgebreid kan worden (van Rood, 6 maart, 1970).

In de ET Newsletter, die rond dezelfde tijd verschijnt, formuleert Van Rood communicatie als een algemeen probleem van Eurotransplant (van Rood, maart, 1970). De praktijk van uitsluiting blijkt dwingender dan een voorschrift en sommigen melden hun aansluiting op het telexnet (Wijdeveld, 12 november, 1970).

Intussen zijn er ook nieuwe ontwikkelingen op communicatiegebied, waar de voor-en nadelen van kunnen worden onderzocht. Zo krijgt Van Rood van Largiadèr

5 Van Rood schrijt dat de praktijk afwijkt van de oorspronkelijke doelstelling:

Alhoewel theoretisch in Eurotransplant de best passende ontvanger wordt uitgezocht, gebeurt het in de praktijk echter anders.

Wanneer een nier gemeld wordt, worden alle ziekenhuizen die over telex beschikken, van een bericht voorzien dat er een donor aankomt en of ze kunnen opereren. We proberen dan vervolgens een voorlopige typering die je in o.g. één à anderhalf uur klaar kunt hebben, binnen te krijgen en selecteren dan uit de ziekenhuizen die geantwoord hebben de ontvangers die het best met de donor overeenkomen. Vervolgens gaat er bericht via de telex naar de ontvanger ziekenhuizen en kan de zaak dan in een korte rijd rond zijn. Dit alles is slechts mogelijk met telex; telefoongesprekken nemen zoals we helaas door schade en schande zijn te weten gekomen te veel tijd. Ziekenhuizen zonder telex zitten er dus in vele gevallen naast en komen eigenlijk pas aan bot, wanneer de telex-ziekenhuizen, om welke reden dan ook verstek laten gaan.

Gezien het aantal telex-ziekenhuizen steeds verder toeneemt is die kans bijzonder groot (dat je er naast zit). Conclusie is dus dat wanneer je werkelijk opereren wilt een telex slechts daarvoor de garantie biedt dat je meedoet. (van Rood, 7 april, 1970)

6 Brussel (Dr. Govaerts); Gent (Dr. Berome); Leuven (Dr. Alexandre); Leuven (Dr. Michielsen); Luik (Dr. Lejeune); Giessen (Nachricht für dr. Müller) (politietoestel); TNO (Balner); A.Z.L. Leiden. 
een tip over het bestaan van een fax, waar hij enthousiast op reageert.

I must confess that I have never heard of a Faksimileschreiber, but I will find out, it certainly sounds interesting. (van Rood, 23 februari, 1970)

Naast het gebruik van en onderzoek naar deze 'externe' communicatiemiddelen, vraagt Van Rood bij het AZL. ook 'piepers'7 aan voor de interne communicatie. De praktijk lijkt erom te vragen.

Door de grote groei van de Eurotransplant is het van belang dat de dienstdoende artsen steeds bereikbaar zijn voor het uitzoeken van geschikte patiënten voor de aangeboden nieren. Daar deze artsen vaak hun werk elders in het ziekenhuis hebben is het moeilijk hen "à la minute" te bereiken. Hiertoe zouden piepers uitkomst bieden, en zou de afdeling Eurotransplant 4 piepers willen ontvangen voor de heren: J. Freudenberg; A. Bosma; J. v.d. Does; C. Koch. (van Rood, 27 april, 1970)

Communicatie wordt voor Eurotransplant steeds belangrijker.

\subsubsection{Onderlinge Afstemming Rond Niertransplantatie}

Kwalitatief goede communicatie tussen centra is uiteraard van groot belang voor het soepel verlopen van de uitwisseling van organen. Dit wordt echter niet alleen bepaald door de keuze van het communicatiemedium, maar ook door de inhoud van de communicatie. De boodschap moet eenduidig en zinvol zijn. Door hierover afspraken te maken kan de communicatie ook efficiënt zijn. Govaerts doet een voorstel om het versturen van gegevens via telex te standaardiseren ${ }^{8}$. Standaardisatie van telexberichten maakt deze communicatie eenduidig, maar om aan de doelstellingen van Eurotransplant te kunnen voldoen, is niet alleen concrete pre-operatieve informatie nodig. Evaluatie van transplantatieresultaten is ook een voortdurend punt van aandacht; het is belangrijk dat ook na een transplantatie alle benodigde gegevens naar Leiden worden gestuurd. Begin 1968 wil Van Rood met Alexandre onder andere over dit onderwerp spreken.

If possible I would like to discuss with you then the results we have obtained so far, especially in regard to the problems we have encountered, in particular the administrative ones.

When we were trying this last month to analyse the data we have got, it became clear to me that many essential data were still lacking in our files. I am very sorry about it but for that reason I have to bother you again with a number of "forms". We have filled out the data as far as they are available. You would oblige me very much if your secretary could fill out the missing ones and check the data we put on the forms. Although I hate to bother colleagues with administrative chores, I

7 Een soort Semafoon

8 Govaerts zegt welke gegevens er volgens hem in zo'n standaardbericht moeten staan en geeft een voorbeeld van hoe dit eruit zou gaan zien.

- Patient (donor or recipient) age - Name and first name- Delay before removal of the organs. Type of organ (kidney, heart...) and number ( 1 or 2 )

Localisation of the patient: Hospital, town, Dr. in charge, phone $\mathrm{n}^{*}, \mathrm{Blood}$ group (ABO and Rh), Leucocyte phenotype.

It would give something like this:

- Don. 42 : michaux armand. 4 to $6 \mathrm{~h}$. one kidney. hopital brugmann. bruxelles. dr toussaint 78.48 o

$A+4 a+4 b-6 a+6 B+7 a-7 a p r-7 b+7 c+7 d+8 a-$

centrustin

(Govaerts, 26 december, 1968 ) 
feel that we are for the sake of our patients obliged to do so. (van Rood, 28

februari, 1968)

Die verplichting heeft meerdere kanten. Het is een vorm van respect voor de getransplanteerde patiënten en voor de donoren, om ook het vervolg van een transplantatie te registreren, want met deze gegevens kan een schatting worden gemaakt van de kans op succes bij toekomstige transplantaties. Op een andere manier is het ook een 'verplichting naar hun patiënten': men gebruikt die gegevens namelijk ook om het Matchingseffect te onderbouwen. Aan het effect van matchen ontleent Eurotransplant immers voor een groot deel haar bestaansrecht. De gehele Eurotransplantgemeenschap zou zich daarom ook voor de 'follow-up' van eenmaal verrichtte transplantaties moeten inzetten 9 . Het verzamelen en evalueren van follow-up gegevens wordt op 18 mei 1969 voorlopig tot taak van Eurotransplant c.q. het 'central reference laboratory' gemaakt, tijdens de Eurotransplant Meeting.

Finally it is agreed that it would be useful to collect and publish all the data obtained with the Eurotransplant Organisation. In this context Morelle (Liege) points out that he is of the opinion that it will be necessary for the time being that Leiden remains the central reference laboratory and continues with its coordinating activities. (van Rood, juli, 1969)

Deze taaktoedeling komt niet onverwacht. Om in de toekomst beter in staat te zijn de gegevens actueel te houden, heeft Van Rood eerder al een formulier gemaakt dat gebruikt moet worden om typeringen mee aan te vragen. Hij denkt dat een informatieachterstand voorkomen kan worden wanneer iedereen dat gebruikt (van Rood, 28 februari, 1968 ).

Naast het actueel houden van de follow-up gegevens, is het uiteraard ook bijzonder belangrijk om gegevens op de wachtlijst zo accuraat mogelijk te houden. Alleen met een bijgewerkt en volledig databestand kan de selectie van een geschikte donor/ontvanger-combinatie goed gebeuren. Verouderde gegevens vergroten het risico dat donororganen verloren gaan. Gezien de groei van het aantal patiënten op de wachtlijst en het aantal aangesloten centra, zal ook dit deel van de terugrapportage geformaliseerd moeten worden. Op de bereidwilligheid van de transplanterende chirurgen alleen kan niet meer vertrouwd worden, zoals dat aanvankelijk blijkbaar wel gebeurde. Naar aanleiding van de eerste Eurotransplant Meeting op 6 juni 1968 , schrijft Alexandre bijvoorbeeld aan Van Rood dat een aantal patiënten 'van de computer kan worden verwijderd', of omdat ze zijn overleden, of omdat ze zijn getransplanteerd (Alexandre, 8 juli, 1968). Deze veranderingen beslaan echter een periode van meerdere maanden. Op zich is dit dan nog geen groot probleem, aangezien in deze fase nog niet zoveel patiënten zijn getypeerd en er nog maar een beperkt aantal 'aangesloten centra' is. Maar de groei gaat snel en Van Rood benadrukt in de eerste Eurotransplant Newsletter dan ook nog eens het belang van het prompt doorgeven van wijzigingen in de wachtlijststatus van patiënten.

In the last 6 weeks the number of mutations as far as patients transplanted, taken off dialysis, died etc., was 120 !! If everyone waits two weeks before a change is

9 Naast schriftelijk informatie, wordt ook voorgesteld om donormateriaal zelf te bewaren; om later nog aanvullend onderzoek op te kunnen verrichten wanneer dat nodig mocht zijn.

VIII Alexandre points out that it would be useful to store from each donor either [blood, spleen? MD) and/or lymphnodes for further references. This seems to be an extremely useful and important suggestion.

(van Rood, juli, 1969) 
reported to the computer centre, it is logical that, including the amount of time it takes to get these changes into the computer files, we will have a chronic error in our files of about $25 \%$. It is clear that this is undesirable and that for that reason all people working with Eurotransplant are urged to let us know as quickly as possible of any change which has occurred. (van Rood, I september, 1968) Gezien de afspraken die zijn gemaakt over de wijze waarop Eurotransplant zal gaan functioneren, is dit belangrijk, omdat 'fouten' in het databestand langere tijd zullen blijven bestaan en mogelijk onnodige vertraging en storingen, die de beschikbaarheid niet ten goede zullen komen, zullen opleveren. Tijdens de eerste Eurotransplant Meeting wordt namelijk besloten dat wel de gegevens van alle patiënten in één centrale computer worden opgeslagen, maar dat voor het zoeken naar een geschikte ontvanger via de "person who has access to the last computer printout", direct contact wordt opgenomen met de centra waar de, voor die donor, meest geschikte patiënten onder behandeling zijn (Terpstra, et al., juni, 1968). Het actueel houden van het databestand blijft dus een punt waar voortdurend op gehamerd wordt. Herhaaldelijk wordt een beroep gedaan op behandelende artsen om, liefst per telex, onmiddellijk door te geven wanneer iemand niet meer getransplanteerd kan, dan wel behoeft te worden ${ }^{10}$. De consequenties van het niet op tijd doorgeven van dit soort informatie kunnen dramatisch zijn, zoals Van Rood volgens de notulen van de vierde Eurotransplant Meeting stelt.

Communication not only on the clinical course of the kidney graft but also on the more prosaic administrative aspects remains essential. Too many kidneys are lost because we tried to have them transplanted in patients who had either died or had already been transplanted. ... It is also extremely important to warn the Eurotransplant administration immediately if a patient through an intermittent illness (hepatitis infection etc.) cannot be operated for a period of time. (van Rood, maart, 1970)

Zeker met de decentralisatie van de donornierallocatie, middels distributie van de 'uitdraai van de computerfile, is het risico dat nieren 'verloren gaan' door het gebruik van achterhaalde gegevens niet onaanzienlijk. Toch is dit de weg die wordt ingeslagen.

It will probably be possible in 1969 to distribute at least once a month, perhaps even more often, to all of the typing centers a computer print-out, in which all the recipients are tabulated according to their leukocyte groups. A list will go with this print-out to indicate in what center the recipients are being treated.

(van Rood, januari, 1969)

Uit het gebruik van deze 'uitdraai', het 'ET-telefoonboek', blijkt de waarde die aan matchen wordt gehecht. Voor het gebruik van het ET-telefoonboek geldt het uitgangspunt dat de daarin vermeldde typering van de patiënten eenduidig en juist moet zijn. Op basis van die overtuiging is het vervolgens mogelijk om, met de meest recente gegevens van alle patiënten op de wachtlijst in de hand, te bepalen waar de

10 Zeker wanneer de communicatie nog vooral via de telefoon moet gaan, is de snelheid van informatieoverdracht een belangrijk argument om de file zo up-to-date mogelijk te houden.

It has been stressed again that it will be of the utmost importance to notify the typing centers immediately, as soon as a patient has either been transplanted or has become unavailable for transplantation for other reasons. For Belgium this is the Blood Bank of the Hopital St. Pierre tel.nr. 380000 and for Holland the Blood Bank or the University Hospital in Leiden, tel.nr. 47222. In this way again time can be saved when a donor is available. (van Rood, januari, 1969) 
meest geschikte ontvanger zich bevindt. Niet alleen is het mogelijk geworden om een donor met alle patiënten te vergelijken, maar door het ET-telefoonboek kan dit ook buiten Leiden, zodat het donorcentrum zelf direct contact kan opgenomen met het transplanterende centrum, om de logistiek rond de orgaanuitwisseling verder te organiseren. Het enige dat voor het bepalen van de 'meest geschikte ontvanger' noodzakelijk is, is duidelijkheid over de regels die gehanteerd moeten worden om geschiktheid te bepalen. Deze regels geeft Van Rood nog eens in de eerste Eurotransplant Newsletter, zodat alle aangesloten centra en geïnteresseerden hier kennis van kunnen nemen en er geen misverstanden over kunnen bestaan.

It might be useful to repeat our rules for accepting donor-recipient

combinations. ABO compatibility is a conditio sine qua non, a kidney donor with blood group $\mathrm{O}$ can be considered as a universal donor. The Rhesus factors are not taken into account i.e. a Rhesus positive donor can be transplanted into a Rhesus negative recipient. As far as the leukocyte antigens are concerned:

Identity for the HL-A system is best. If such a recipient can not be found, a donor-recipient combination which is identical for all antigens but one is looked for. In general we try to stay clear from the mismatches for the $4 \mathrm{a}$ and $8 \mathrm{a}$ or LA2 antigens. If even such a combination can not be found, the kidney is either not used or a donor-recipient combination is taken which is mismatched for two antigens. If possible the mismatch should be compatible, i.e. the donor should lack antigens the recipient carries. (van Rood, I september, 1968)

Met deze regels lijkt het geen probleem meer om snel in het ET-telefoonboek te kijken welke patiënt het beste past bij de bloed- en leukocytengroepen van de donor $^{11}$, en contact op te nemen met diens behandelend arts.

Dit idee, dat decentralisatie van de allocatie inhoudt, gaat velen echter te ver. Het verdelen van de 'macht' is prima, maar wanneer dat te veel moeite kost, is men ook gaarne bereid om wat macht in te leveren. Uit de notulen van de Eurotransplant Meeting van 18 mei 1969 , blijkt dat, tegen de zin van Van Rood, de Eurotransplantgemeenschap anders besluit.

In the following discussion it becomes clear that there are factors which complicate the picture. Representatives of some of the centres point out that they don't have the time to make the necessary telephone calls to "sell" a kidney. They would appreciate if Leiden would continue to take the burden of this. De Graeff (Leiden) makes a suggestion which is accepted that there would be for each region one centre which takes the responsibility for this. For the Netherlands this would be Leiden if the local centre cannot make the telephone calls themselves. For Belgium it would be Bruxelles, for Germany this would have to be discussed in the German group first. As long as this has not been

11 Overigens blijft de vraag 'wat is een goede, dan wel acceptabele match' tot op de dag van vandaag actueel. Als voorbeeld wijs ik hier op een passage uit de notulen van de vierde Eurotransplant Meeting, waarin de dan geldende 'regels worden gegeven.

10. In the discussion on the problem of what can be considered as an acceptable match the following agreement was reached:

a. It should always be tried to look for identity for the 4 and $4 \mathrm{~b}$, and $6 \mathrm{a}$ and $6 \mathrm{~b}$ antigens. Identity is also best for the antigens of the Seven and LA series, but compatibility is here regarded as equally good while incompatibility for one antigen is considered to be acceptable. A definite position on this extremely important point can be taken when the new computer programs are ready and the data are available to assess the feasibility of this rule. (van Rood, maart, 1970)

Maar, zoals ook uit dit citaat blijkt, de matchingsregels zullen geëvalueerd worden en (dus) veranderen. 
arranged, Leiden will try to coordinate the communication between the German centres. (van Rood, juli, 1969)

Het is mogelijk dat deze oppositie achterwege zou zijn gebleven, wanneer er een telexnetwerk beschikbaar zou zijn geweest, dat alle centra omvatte. Daarvan is echter geen sprake en het communicatiemiddel telefoon blijkt niet toereikend geacht te worden om de distributie van organen te decentraliseren ${ }^{12}$. Het maandelijks rondsturen van een geactualiseerd ET-telefoonboek is een hele opgave, maar wanneer daarmee voorkomen wordt dat men in Leiden alle telefoontjes moet plegen om een donornier 'te verkopen' zal dat de moeite waard zijn.

Kort na de start van donororgaanuitwisseling via Eurotransplant, vragen problemen in de praktijk om extra (coördinatie-)inspanning. In het 'First Progress report', dat Van Rood bijna een jaar na het Eurotransplant-voorstel uitbrengt, doet hij verslag van het eerste jaar ${ }^{13}$ en geeft hij een overzicht van de te verwachten ontwikkelingen en te nemen maatregelen en besluiten. Zo kondigt hij de typeringscursus aan, waarmee alle zestien centra tegen het eind van het jaar, voorlopige typeringen zouden moeten kunnen uitvoeren, en vestigt hij de aandacht op het groeiende probleem van de toelevering van typeringssera aan de centra.

An important point is the procurement of typing sera to the different centers.

Although theoretically it is not necessary that the same sera are used by all centers, this is in view of the computer program used, to be preferred. This problem has been solved by the introduction of a micro agglutination test. The test was adopted for EDTA blood by Dr. P. Mattiuz from an agglutination test for defibrinated blood used by Dr. Kissmeyer Nielsen. (van Rood, juni, r968)

$\mathrm{Na}$ een beschrijving van de techniek en de daarmee behaalde resultaten, schrijft hij dat in de tweede helft van 1968 "sets of sera and reagents will be made available to the collaborating centers" (van Rood, juni, 1968). Daarnaast roert hij de punten transport van donornieren, procedure voor nieruitname en accurate informatievoorziening aan.

Een van de problemen betreft het op de 'juiste' wijze uitnemen van de donornier. Van Rood gaat er daarbij vanuit dat op dit gebied tot uniformiteit gekomen moet worden.

To obtain uniformity of the procedure of removing the kidney from the cadaver it will be necessary that the surgeons involved, discuss the procedure and perhaps organize a "workshop". A discussion on this topic will take place on Thursday

12 Overigens is het mij niet geheel duidelijk of, en zo ja, hoe lang de 'nationale centra' de allocatie hebben verzorgd. Wel is gedurende enige jaren het ET-telefoonboek regelmatig verstuurd naar een aantal regionale typeringscentra, die ook konden assisteren bij het selecteren van een ontvanger.

Each month we send a complete print-out of the Eurotransplant file sorted according to groups to 17 typing centres. [Amsterdam C.L.B.; Nijmegen; Groningen; Antwerpen: Brussel: Leuven (LA); Leuven (LM); Luik; Gent; Bonn: Giessen; Hannover, Heidelberg; München: Genève; Wenen en Aarhus.]

If you have typed a potential donor you may request these centres for assistance in the selection of a recipient. (van Rood, 14 augustus, r970)

13 Gedurende het eerste jaar hebben 16 centra aansluiting gezocht bij Eurotransplant en zijn 246 ontvangers getypeerd. - Hierover zegt hij: "It is clear that the majority of the potential recipients have been typed." (van Rood, juni, 1968) - Verder doet hij verslag van de wijze waarop getypeerd is en hoe de typeringsgegevens met behulp van de computer worden verwerkt tot een 'print-out', waarop niet alleen de typering wordt vermeld, maar ook de reacties op individuele sera. Ook zegt hij dat niet alleen identieke typeringen bij elkaar worden gezet, maar eveneens diegenen die identick zijn op een antigeen na. Alleen in Amsterdam (CLB, Engelfriet), Brussel (Université Libre de Bruxelles, Govaerts) en Leiden (AZL. Van Rood) kunnen dan typeringen worden verricht. 
June 6 th during the conference on organ transplantation. (van Rood, juni, 1968) Tijdens deze vergadering wordt dan ook een proces in gang gezet om uiteindelijk te komen tot een uniforme uitnameprocedure, maar het zal enige tijd in beslag nemen alvorens de chirurgen op een lijn zitten.

The following point which was discussed was the exact surgical procedure for removing the donor kidney. The suggestion was made and accepted that each team would send to all other teams a description of the procedure used for procuring the kidney from the cadaver donor and for implanting it in the recipient. After the receipt of these descriptions a discussion could be started by mail. If necessary it is possible to have another meeting on this point. It is also possible to organize a "workshop" (for instance in Rotterdam) to demonstrate in what way the kidney is removed. This is obviously an extremely important point: an excellent matched kidney with not sufficient long vessels or ureter is still of no use to the transplanting team. (Terpstra, et al., juni, 1968)

Dr. Gurland uit München stuurt - weliswaar veel later - een korte handleiding voor het uitnemen van een nier, zoals dat in München gedaan wordt, tezamen met de 'criteria voor de ideale donor' en een aanduiding omtrent welke perfusievloeistof gebruikt moet worden (Gurland, 6 december, I968) ${ }^{14}$. Mogelijk moet dit slechts beschouwd worden als het geven van informatie, maar bij uitwisseling van een donornier zullen zij toch ook verwachten dat de donornier aan deze criteria voldoet om in hun ziekenhuis getransplanteerd te kunnen worden. Wanneer de criteria per ziekenhuis verschillen en het usance wordt om deze ook als zodanig bekend te maken bij andere ziekenhuizen, kan de situatie ontstaan, dat bij een donornieruitname eerst naar de criteria van het beoogde transplantatiecentrum gekeken moet worden om te zien hoe de nier precies dient te worden uitgenomen. Dit komt de uitwisselbaarheid niet ten goede. Mede daarom is het effectiever om een goede, voor alle centra acceptabele richtlijn uit te vaardigen over de uitname van een donornier.

14 Op een $\mathrm{A}_{4}$-tje geeft Gurland puntsgewijs de in München gehanteerde uitnameprocedure: REMOVAL OF DONOR KIDNEY

1. Transverse upper abdominal incision

2. Exposure of the retroperitoneal kidneys

3. Dissection of kidney vessels and section as near to the vena cava and aorta as possible

4. Dissection of the ureter with special care to preserve the blood supply. At least $6 \mathrm{~cm}$ is needed for the oblique end-to-end anastomosis.

CRITERIA FOR IDEAL DONOR

I. Donor must be recently dead, with no previous limitation of renal function before his final illness.

2. Kidneys must be macroscopically normal

3. No clinical symptoms or sighs of renal disease.

4. Serum creatinine should be less then $\mathrm{r} \mathrm{mg} / \mathrm{rooml}$ and in no case greater then $\mathrm{r}, 5 \mathrm{mg} / 100 \mathrm{ml}$

5. No infectious illness or wounds.

6. Blood group compatibility

7. The transplanted organ must be anatomically suitable

8. Age less then 70

9. Kidneys must be easily perfused.

PERFUSION SOLUTION

Ringer's solution $500 \mathrm{ml}$

Mannitol 10\% $50 \mathrm{G}$.

Human albumin 20\%

Heparin 2500 Units $0.5 \mathrm{ml}$

Bicarbonate $4 \%$ added to make the $\mathrm{pH}_{7,4}$

The fluid is perfused with a pressure of $120 \mathrm{~cm}$ water at $4^{\circ} \mathrm{C}$.

(Gurland, 6 december, 1968 ) 
Daarmee wordt enerzijds de procedure versneld en anderzijds zouden de transplantatiecentra weten wat ze kunnen verwachten. Van hen wordt dan verwacht dat ze hun lokale technieken laten aansluiten op hetgeen door de richtlijn geregeld is.

Zover is het in 1968 echter nog niet. Wel krijgt Van Rood dan vragen over wat te doen bij een eventuele donoraanmelding.

Van onze chirurgen vernam ik, dat zij belangstelling hebben om kennis te nemen van de maatregelen, die zij kunnen nemen indien zij eventueel de mogelijkheid zouden hebben van een donor een nier ter transplantatie aan te bieden aan een centrum dat hieraan behoefte zou hebben. Zou u mij de informatie bovenbedoeld kunnen verstrekken? (Trommel, ig augustus, 1969) Naast dit soort vragen, wordt er geinformeerd naar wat gedaan moet worden om nierpatiënten zo goed mogelijk voor te bereiden. Ook uit men bezorgdheid omtrent de vraag of patiënten met zeldzame antigenen niet benadeeld zullen worden door deelname aan de Eurotransplantgemeenschap (Twiss, 4 maart, 1969). Na overleg met Dr. Struyvenberg, krijgt Dr. Twiss op deze vragen van Van Rood als antwoord, dat deze patiënten, wat de kans op een nier betreft, niet benadeeld worden vanwege het beleid om ook mismatches toe te staan, maar dat die nier 'dus gemiddeld minder goed zal passen' en 'dat wanneer besloten is om een patiënt een niertransplantatie te laten ondergaan, je, afgezien van de leucocytengroepen, een nefrectomie moet laten verrichten' (van Rood, ro maart, 1969). Daarnaast krijgt Twiss ook antwoord van Struyvenberg. Hierin ligt de nadruk op de nefrectomie en vormt de toestand van de patiënt de beperkende factor, wanneer het op het uitnemen van de eigen nieren aankomt.

Het verdient aanbeveling om bij een te transplanteren dialysepatiënt nefrectomie te laten verrichten, wanneer hij in een zodanige toestand is, dat de operatie waarschijnlijk goed wordt verdragen. ... Het essentiële punt is, dat de patiënt klaar is, wanneer de nier wordt aangeboden. (Struyvenberg, In maart, 1969) Na verloop van tijd wordt dit soort informatie ongevraagd, directiever van aard en meer in het algemeen gegeven. Zo geeft Eurotransplant een 'manual' uit, waarmee getracht wordt de aangesloten centra zo goed mogelijk te informeren (Eurotransplant, 1970). Het heeft als neveneffect dat de informatie in de manual ook als norm gehanteerd wordt. Vanuit Eurotransplant verwacht men dat de verschillende centra 'in de pas gaan lopen'.

Eurotransplant is now functioning well for some years. It became clear that some standardization for organisation and transport of blood for leucocytetyping and organs is necessary. To different donor and/or transplantation centres bottles for blood for blood-typing and containers for organtransport are sent with a prescription for use etc. An organisation plot and a manual for cadaveric kidney preservation are added to this letter too. (Terpstra, 1970) ${ }^{15}$ In 1970 heeft Eurotransplant zich ontwikkeld tot een gevestigde praktiik, waar rekening mee moet worden gehouden wanneer men in de transplantatiewereld actief wil zijn. Eurotransplant heeft kant en klare antwoorden op verzoeken om informatie voor aansluiting bij de organisatie ${ }^{16}$.

De follow-up gegevens van de verrichtte transplantaties zijn van groot belang voor

15 Zie Bijlage 5: Manual for Cadaver-Kidney-Transplantation.

16 Zoals vragen om informatie ormtrent de voorwaarden en eisen waaraan voldaan moet worden voor deelname in Eurotransplant (de Jong, 14 september, 1970).. 
het verlenen van legitimiteit aan de hele opzet van Eurotransplant. Maar Eurotransplant is niet de enige die evalueert. Wereldwijd wordt getransplanteerd en geëvalueerd. De resultaten worden onder andere besproken tijdens een, door de WHO bijeengeroepen, samenkomst van experts. Van deze bijeenkomst doet Van Rood verslag tijdens de Eurotransplant Meeting van 18 mei 1969. De belangrijkste conclusies zijn dat er een matchingseffect aantoonbaar is, maar dat een goede match geen garantie is voor succes, noch dat een slechte match gegarandeerd gevolgd wordt door oncontroleerbare afstoting. Hiermee ontstaat keuzevrijheid voor de behandelend arts, hetgeen betekent dat niet op de perfecte match hoeft te worden gewacht.

These data indicate that matching will be able to improve the prognosis of a kidney graft, but it is the final responsibility of the doctor in charge of a patient who has to receive a transplant whether or not to wait for a very good match or to accept a poorer one.

Difficulties for instance in dialysis could make such a postponement of the transplantation too high a risk for the recipient. A positive crossmatch, however, is an absolute contra-indication for transplantation. (van Rood, juli, 1969 ) Op basis van de beschikbare gegevens is men geneigd te concluderen dat er sprake is van een matchingseffect, waarbij men aantekent dat matchen niet zaligmakend is. Zowel 'goede matches', als 'slechte' hebben al onverwachte resultaten opgeleverd. Deze 'niet te verklaren' resultaten verhinderen dat matchen tot absolute norm wordt verheven en temperen het optimisme.

Although the good matches show a better prognosis than the poor ones, even

good matches can fail. In other words: don't expect wonders from every good

matched donor-recipient pair. (van Rood, juli, r969)

Evaluatie van de follow-up gegevens zal, vanwege het beperkte matchingseffect, een dubbele betekenis krijgen. Ten eerste krijgt evaluatie de betekenis van controle of de transplantaties goed zijn uitgevoerd. Dat gebeurt aan de hand van de overleving van de transplantaten. Ten tweede wordt de evaluatie van follow-up gegevens ook gebruikt om positieve en negatieve factoren op het gebied van matching te achterhalen, zodat meer duidelijkheid wordt verkregen omtrent de regels voor matching in relatie tot afstoting ${ }^{17}$.

Inmiddels is duidelijk dat niet alle, voor het verlengen van transplantaatoverleving relevante, antigenen herkend kunnen worden. Door het bewaren van bloed of monsters van andere weefsels, wordt de mogelijkheid open gehouden om op een later tijdstip, de dan te bepalen typering met de follow-up gegevens te correleren. Bij de analyse van de beschikbare gegevens van de eerste jaren van Eurotransplant, is al gebleken dat dit voor een goede evaluatie van de follow-up gegevens van wezenlijk belang is.

We have started, in collaboration with the operating centres, to evaluate the results of the kidney transplants. For final evaluation, time is too short, but it

17 Voorspellen in positieve zin mag dan achter blijven bij wat men wenst, voorspellen in negatieve zin heeft meer consensus opgeleverd. Men is het eens over de status van een positieve crossmatch als absolute contra-indicatie - ongeacht de kwaliteit van de 'match' - voor transplantatie van de betreffende donornier naar de positief reagerende ontvanger. Hiermee kan voorkomen worden dat een getransplanteerde nier meteen wordt afgestoten. Zo kan zowel de dubbele belasting van de patient - met een transplantatie en een afstoting - worden voorkomen, als het verloren gaan van de donornier. Vandaar dat het gerechtvaardigd lijkt om de uitgebreide uitwisseling van patiëntensera op te zetten. 
can be stated that the results so far indicate that over $65 \%$ of the transplants are functioning satisfactory of the total number of transplants performed.

Evaluation of the typing was difficult, because the numbers of antigens for which we are able to type, has increased from 9 HL/A antigens in 1968 to over 20 in 1970 . For some of these antigens anti-sera have not yet been found in the Eurotransplant region and we are dependent on help from other centres to obtain the reagents needed to recognize these antigens. (van Rood, ro maart, 1970)

Tijdens de vierde Eurotransplant Meeting wordt besloten om van iedere donor antigeen materiaal te bewaren ${ }^{18}$ en om de drie maanden een verslag van het func. tioneren van het transplantaat naar Leiden te sturen.

Only in this way we can check whether the rules we adhere to in selecting a donor/recipient pair is really in your patient's best advantage. (van Rood, maart, 1970)(sic)

Van Rood verbindt het verkrijgen van een regelmatige stroom follow-up gegevens, met het belang van de patiënten. Alleen met deze gegevens kunnen de allocatieregels op hun gepastheid worden beoordeeld.

Het organiseren van de internationale orgaanuitwisselingsorganisatie Euro. transplant behelst veel meer dan het uit een lijst kiezen van een patiënt met een bepaalde weefseltypering die overeenkomt met de weefseltypering van een donor. Het verkrijgen van die respectievelijke weefseltyperingen is het resultaat van erg veel werk en inspanningen op verschillende gebieden (hetgeen in eerdere hoofdstukken is getoond). De keuze van een donor/ontvanger-combinatie ook te laten resulteren in een succesvolle transplantatie, vergt een hoge mate van coördinatie. Enerzijds zijn hiervoor goed functionerende communicatiemiddelen nodig, anderzijds regels en voorschriften die bijdragen aan het omzetten van geschiktheid in een feitelijke transplantatie. Geschiktheid blijkt hierbij niet meer alleen afhankelijk te zijn van de weefseltypering als zodanig, maar ook van de afspraken over wat als geschikt geldt, de fysieke conditie en anatomie van een donornier. Naast het regelen van deze facetten zijn er echter nog vele andere zaken die moeten worden georganiseerd. De Eurotransplantgemeenschap moet ook betrouwbaar zijn, zodat zij een stabiele factor vormt, en de basis is van een succesvolle uitwisselingspraktijk. Op verschillende manieren moeten daarvoor, liefst door de gemeenschap zelf, vormen van controle worden georganiseerd.

\subsubsection{Organiseren van Controle}

Met de ontwikkeling van een transplantatiepraktijk ontstaat ook meer en meer behoefte aan controle. De door de Eurotransplantgemeenschap zelf uitgevaardigde regels en richtlijnen verplichten de leden moreel om hieraan te voldoen, maar daarmee is nog niet gezegd dat iedereen dat ook in praktijk brengt. Door het onafhankelijke, egalitaire, zelfsturende en democratische karakter van de organisatie, kan het opvolgen van de regels niet echt worden afgedwongen en dus ook niet worden gegarandeerd. Om de compliantie te vergroten kan de gemeenschap besluiten, controle achteraf te laten plaatsvinden en sancties te verbinden aan het 
niet opvolgen van de voorschriften. Als oprichter van Eurotransplant, is Van Rood de leider van het geheel en is het ook in zijn belang dat het Eurotransplant-project een succes wordt. De Leidse groep is er dus bij gebaat dat de deelnemers in het gareel gaan en blijven lopen. Vanuit deze optiek is het niet vreemd dat een groot deel van de controle op de zich ontwikkelende praktijk, in Leidse handen wordt genomen c.q. gegeven. Door controle uit te oefenen op de vele taken die gedecentraliseerd worden, zoals onder andere de typeringen, wordt de Leidse groep, in de hoedanigheid van Eurotransplant, toch de coördinerende spil van de Eurotransplantgemeenschap. Echter, het verkrijgen van controle is een proces dat, lang voordat Eurotransplant van start gaat, al in gang is gezet.

\subsubsection{1 ledereen In De Pas Houden}

Controleren is niet altijd als zodanig te herkennen. Controle krijgen over een situatie gaat vaak ongemerkt en gebeurt meestal niet doordat een instantie actief toeziet op de uitvoering van taken. Wat in een zekere situatie dient te gebeuren, wordt vaak op indirecte wijze bepaald. Ontwikkeling tot 'autoriteit' op een bepaald gebied, is zo'n vorm van controle. Dit gebeurt deels door eigen activiteiten, maar vooral door hetgeen anderen doen. Een autoriteit op een bepaald gebied zijn is een etiket dat door anderen aan iemand wordt toegekend, en komt onder andere tot uiting in het volgen van adviezen en aanwijzingen van de betreffende persoon. De autoriteit krijgt controle op afstand. Ook Van Rood, en met hem de gehele Leidse groep, krijgt dat etiket en dus enige controle: ze kunnen in zekere mate bepalen wat er elders gebeurt.

Sinds het begin van de jaren 60 krijgt Van Rood steeds vaker verzoeken om informatie, advies en hulp. Dit is een praktische vorm van erkenning. Door positief op die verzoeken in te gaan, controleert Van Rood op afstand. Het hele Leidse pakket aan kennis, kunde en vaardigheden wordt door het geven van informatie, advies en hulp geëxporteerd. Door mensen op te leiden, zorgen zij ervoor dat hun denk- en werkwijzen elders worden toegepast, waarmee zij tevens een vorm van afhankelijkheid creëren. Leiden is het referentiepunt; Van Rood wordt zo de autoriteit die hulp kan bieden bij problemen.

De Leidse groep beperkt zich niet tot het geven van informatie en aanleren van technieken. De al verkregen vooraanstaande positie wordt nog verder versterkt door met de Leidse antisera ook elders panels te typeren. Met deze panels kan vervolgens lokaal verder gewerkt worden (naar model van de situatie in Leiden). Zo wordt een deel van de controle gedelegeerd aan het panel, en verkrijgt Leiden controle op afstand zonder dat daar nog direct inspanningen voor moeten worden geleverd.

Doordat men in Leiden deze status krijgt, ontstaan er meer mogelijkheden voor controle op afstand. Controle wordt ook verkregen door taakdifferentiatie binnen een samenwerkingsverband. In de samenwerking met nefrologen is het Van Roods verantwoordelijkheid om donor en ontvanger te typeren. Vanuit de andere betrokken disciplines krijgt Van Rood de autoriteit toebedeeld om over geschiktheid op immunologisch gebied te beslissen. Daarmee krijgt hij dus ook (voor een deel) controle over wat er in de operatiekamer gebeurt. Of deze OK nu in Leiden of in Leuven staat, doet niet ter zake.

Al dit soort activiteiten maken het mogelijk dat Van Rood, als autoriteit op zijn gebied, een voorstel kan doen om tot internationale orgaanuitwisseling te komen. De verzoeken om hulp etc. stoppen niet nadat hij dit voorstel heeft gedaan; inte- 
gendeel. Wanneer de verzoeken al niet op Eurotransplant zijn gericht, dan vestigt Van Rood in zijn beantwoording wel de aandacht op het project. Met Eurotransplant doet hij een dubbele belofte: a. een grotere kans op beschikbare donornieren en b. door matchen een kleinere kans op afstoting van het transplantaat. Deze beloften brengen vele ziekenhuizen ertoe om aansluiting bij Eurotransplant te zoeken. Tezamen met ziekenhuizen die niet willen transplanteren, maar wel donoren willen leveren, vormen zij de Eurotransplantgemeenschap. De groei van de gemeenschap gaat gepaard met een afname in het gevoel van gedeelde verantwoordelijkheid, terwijl de behoefte aan materialen groter wordt. Er moet steeds meer worden gedaan om de leden in het gareel te houden en om aan de materiële behoeften te voldoen.

Naast bovenstaande (sociale) controlemechanismen dient zich echter ook een groot (logistiek) controleprobleem aan. Onafhankelijk van de geschiktheid van een donororgaan voor een bepaalde patiënt, blijkt er een grote bedreiging van het transplantaat op de loer te liggen, namelijk: circulerende antilichamen. Hierdoor zou zelfs een 'identieke nier' 19 te gronde kunnen gaan.

More and more data have become available indicating that pre-existing cytotoxic antibodies in the serum of the recipient can cause a hyper acute rejection of the transplanted kidney. For that reason it is imperative that a crossmatch of the serum of the recipient with the lymphocytes of the donor is performed.

We will try to do this as much as possible. However, this implies that we need serum of all your recipients. As most of the patients on dialysis obtain blood transfusions regularly, it is necessary to send us a fresh sample of serum (at least $\mathbf{2} \mathrm{ml}$ ) of these patients every four to six weeks. (van Rood, I september, 1968)

Op een enkele communicatiestoornis na ${ }^{20}$, komt deze boodschap over ${ }^{21}$, maar het vergt nogal wat organisatie en medewerking.

The question is raised how serum for crossmatching can be distributed to the typing centres. In contrast to earlier decisions on this, Van Rood says he hopes it will be possible to send every six weeks fresh serum if at least in the meantime transfusions have been given, to the regional centre. This will then divide the samples and distribute them to the local typing centres. At the moment it appears possible to accomplish this with about $5 \mathrm{ml}$ of serum. (van Rood, juli, 1969)

Lange tijd na de eerste gesprekken hierover, tijdens de eerste, informele Eurotransplant Meeting, blijkt de praktijk anderhalf jaar later nog niet zo dat iedere zes weken serum van iedere patiënt wordt verstuurd. De vierde ET Newsletter (met bijlagen) is geheel aan dit onderwerp gewijd. Van Rood legt uit dat van de 500 patiënten op de wachtlijst bij alle tien de typeringslaboratoria, recent serum aanwezig moet zijn, voor het uitvoeren van een kruisproef. Deze distributietaak is echter te omvangrijk voor het Leidse laboratorium en daarom vraagt Van Rood de behandelend artsen om zelf de typeringscentra van de sera te voorzien. Hij stelt voor om aan het niet-

19 'Identiek' is nog altijd slechts identiek voor de te herkennen antigenen en andere factoren. Zelfs bij identieke tweelingen blijkt afstoting mogelijk. (Boonstra, 15 september, 1994)

20 Een enkeling meent dat de patiènten op de wachtlijst eens in de zes weken naar Leiden moeten gaan om daar hun bloed te laten controleren, maar dit wordt direct door Van Rood ontzenuwd (Twiss, 18 maart. 1969: van Rood, 25 maart, 1969).

21 Vanuit Leuven (Acad. ZH. St. Rafaël) worden al snel sera van patiënten die in aanmerking komen voor transplantatie gestuurd (Bosteels, 7 jamuari, 1969). 
versturen van sera ook consequenties te verbinden.

As an extra incentive we propose that if a kidney becomes available and the typing centre has two potential recipients, but there is serum for crossmatching from only one recipient, the one from which crossmatching serum was available (assuming the crossmatch is negative) will get the kidney.

THEREFORE IF YOU WANT TO HAVE YOUR PATIENTS ON HEMODIALYSIS TRANSPLANTED, BE CERTAIN THAT CROSSMATCHING SERUM IS SENT BY YOU OR YOUR STAFF TO THE TYPING CENTRES. (van Rood, 15 januari, 1970 (1969)) (sic)

De Newsletter gaat vergezeld van een adreslijst van alle typeringscentra, serum-verzendmateriaal en een richtlijn voor het verzamelen en versturen van de sera.

Kort na de publicatie van deze Newsletter, benadrukt Van Rood nog eens het belang van crossmatching voor iedere transplantatie en schrijft hij te hopen dat iedereen het daarmee eens is.

As has been outlined in the newsletter nr.4, we are greatly concerned with the necessity to do a crossmatch before every kidney transplant. I hope that the suggestion made in the newsletter nr.4 can meet with your approval. (van Rood, Io maart, 1970)

Het organiseren van de crossmatchprocedure lijkt een heet hangijzer te worden. Waar Van Rood schrijft dat het voor het laboratorium in Leiden een te grote belasting is om alle sera te verzamelen en vervolgens weer te distribueren, lijkt een geheel gedecentraliseerde distributie op te veel problemen te stuiten. Afgezien van de toename aan werk, wat dit voor alle Eurotransplant-centra zou opleveren, wordt ook de kans op fouten bij het versturen van de sera, vele malen groter. Vandaar dat uiteindelijk de Eurotransplant Meeting besluit de sera door de regionale laboratoria naar alle typeringslaboratoria te laten distribueren (van Rood, maart, I970). Het is de vraag of deze taakverlichting het gewenste effect zal hebben, want ofschoon men het erover eens is dat alles gedaan moet worden om hyperacute afstoting te voorkomen, zou de motivatie om sera op te sturen achter kunnen blijven, aangezien "the cross matching procedures as they are being used at the moment are not sensitive enough to detect all dangerous antibodies in the recipient" (van Rood, maart, 1970). Dit leidt ertoe dat niet iedereen overtuigd is van de noodzaak van de aanwezigheid van serum van potentiële ontvangers in ieder typeringslaboratorium en zes weken later hebben slechts 6 van de 46 transplantatiecentra sera rondgestuurd. Vandaar dat H. Schippers - de tijdens de vierde Eurotransplant Meeting bij de Eurotransplantgemeenschap geïntroduceerde Administratief Directeur van Eurotransplant een brief schrijft naar alle transplantatiecentra. Hij benadrukt daarin nog eens dat de artsen door deze nalatigheid hun patiënten benadelen, of zelfs onnodig belasten dan wel in gevaar brengen, wanneer - ondanks afwezigheid van crossmatch-serum - toch getransplanteerd wordt (Schippers, in mei, 1970).

Het zal duidelijk zijn dat een omvangrijk distributie- en opslagnetwerk van sera moet worden opgezet en in stand gehouden, om ervoor te zorgen dat voor iedere potentiële ontvanger, in ieder aangesloten typeringslaboratorium, een adequate test kan worden uitgevoerd. Onderlinge afspraken maken is één ding, in de geest daarvan handelen is een tweede. Op basis van afspraken een praktijk organiseren is niet in een handomdraai gerealiseerd.

Niet alleen wat betreft het typeren en de crossmatch probeert de Leidse groep de controle te verkrijgen, ook voor de procedure van het aanmelden van een donor en 
de daarop volgende stappen geeft Van Rood een richtlijn uit. Hiermee probeert hij, onder andere door het geven van telefoonnummers, problemen te voorkomen. Via deze hulp probeert hij tevens een standaardprocedure te introduceren. Door alle benodigde gegevens bij elkaar te zetten, bereikt hij dat al die gegevens bij de verantwoordelijke arts aanwezig zijn. Doordat hij de volgorde van handelingen bepaalt en de verschillende keuzemogelijkheden geeft, stuurt hij ook de handelingen zelf en krijgt hij controle over wat er gebeurt (van Rood, oktober, 1968$)^{22}$.

Eurotransplant wint aan 'autoriteit'. Richtlijnen worden vanuit Eurotransplant uitgevaardigd en taken worden door de 'gemeenschap' aan Eurotransplant toebedeeld. Ondanks de centrale positie van Eurotransplant blijft de gemeenschap uiteindelijk toch 'de baas'. De Eurotransplant Meetings zijn besluitvormende vergaderingen van de Eurotransplantgemeenschap. Om dit goed te laten functioneren probeert Van Rood steeds opnieuw de aangesloten centra en de aan die centra verbonden mensen zoveel mogelijk betrokken te laten zijn. Zo opent hij ook (de notulen van) de Meeting in maart 1970.

After the welcome (almost all centres attended with one or more members) it was stressed again that Eurotransplant could only improve its function if there would be a free and open discussion on its short comings The old adagio: 'If you are satisfied tell others, if you are dissatisfied tell us (in this case the

Eurotransplant administration in Leyden)' is still an extremely good one. (van Rood, maart, 1970) (sic)

De aanstelling van de Administratief Directeur laat echter zien dat de leiding van de 'gemeenschap' meer en meer in handen van Eurotransplant komt. Zeker gezien de taken die hij moet gaan vervullen.

It will be Mr. Schippers' task, not only to supervise the administration of

Eurotransplant but also to improve its function and the essential

communication lines between the different centres. (van Rood, maart, 1970)

Het aanstellen van de Administratief Directeur is een formalisering van de al veel langer bestaande centrale leiding in de Eurotransplantgemeenschap. Met het groeien van de gemeenschap wordt de coördinatie steeds moeilijker en dreigt het zelfbestuur op basis van wederkerigheid, tekort te schieten. Steeds meer draagt de gemeenschap de dagelijkse leiding over aan de Eurotransplant-administratie in Leiden.

\subsubsection{Kwaliteitsbewaking}

Als start van Eurotransplant worden mogelijke ontvangers getypeerd, de typeringsgegevens verzameld en toegankelijk gemaakt voor raadpleging wanneer een nierdonor zich aandient. Hiervoor is het van groot belang, zowel voor de patiënt, als voor Eurotransplant, dat de opgeslagen typering ook de 'juiste' is. Wat geldt als de 'juiste' is enerzijds afhankelijk van de biologische individualiteit van de patiënt (zijn of haar (leukocyten)antigenen), maar anderzijds van de specifieke antigenen die met de beschikbare antisera herkend kunnen worden alsmede van de betrouwbaarheid van de techniek. Door de toename van het aantal typeringen, kan aan één en dezelfde typering niet meer even veel aandacht worden besteed als voorheen. De verantwoordelijkheid jegens de patiënten neemt echter niet af en deze mogen niet de dupe 
worden van verkeerde gegevens in de 'Eurotransplant-file'. Tijdens de eerste Eurotransplant Meeting wordt dan ook afgesproken, de techniek te controleren door de typering twee maal uit te voeren. Zo wordt én de techniek gecontroleerd én kunnen fouten door (de uitvoering van) de techniek herkend en gecorrigeerd worden (van Rood, I september, 1968). Aangezien dan de typeringen voor het overgrote deel nog in Leiden worden verricht, controleert men daar met de herhaling van de typeringen zowel de techniek, als hun eigen handelen. Wanneer twee maal dezelfde typering uit de bus komt, lijkt het resultaat betrouwbaar, zowel voor de patiënt, als voor de techniek. Komen de resultaten niet overeen, dan is nader onderzoek noodzakelijk voordat een besluit wordt genomen over de in het ET-telefoonboek op te nemen typering.

Met de groei van de Eurotransplantgemeenschap wordt naast het beheersen op afstand ook een andere vorm van controle belangrijker, namelijk toezicht. De decentralisatie van het typeren wordt gecontroleerd, doordat mensen die de typeringen moeten gaan uitvoeren, in Leiden worden opgeleid. Vervolgens wil men controleren of de typeringslaboratoria hun werk zo uitvoeren, dat de resultaten bruikbaar zijn. Men wil kijken of uitgevoerde typeringen reproduceerbaar, betrouwbaar en vergelijkbaar zijn, en daarmee uitwisselbaar tussen de verschillende laboratoria. In het kader van Eurotransplant gaat het laboratorium in Leiden - al (door henzelf) het WHO Reference Laboratory voor typeringssera genoemd - ook optreden als Eurotransplant-referentielaboratorium (ETRL). Typeringen worden zowel in perifere typeringslaboratoria, als in Leiden verricht en vervolgens vergeleken. Er wordt weliswaar gesteld dat het simultaan typeren gericht is op het bepalen van de betrouwbaarheid van het typeren, maar daarmee wordt tevens de kwaliteit van het werk in het perifere laboratorium bekeken.

It was decided that one of the most important things we can do at the moment is to determine the reliability of leukocyte grouping. For this reason all groupings are done not only in the local center, but also in the reference center which for the time being is in Leiden. The data so collected will be analysed and published in order to assess the reliability of the test. (van Rood, januari, 1969) In de loop van de tijd en met een toenemend aantal perifere typeringslaboratoria, verschuift de reden van typeringsduplicatie. Werd eerst de techniek als zodanig onderzocht en geëvalueerd, nu wordt de uitwisselbaarheid c.q. vergelijkbaarheid van resultaten gezien als hetgeen gecontroleerd en verbeterd moet worden.

Next the important point is discussed that it is still necessary to make sure that the typing results of one centre are completely comparable with those of another. To achieve this it will of course be necessary to use the same antisera and to check as frequently as possible the results of the typing obtained in one patient. In this context Alexandre (Louvain) points out that he has frequently noticed differences in the typing results done in Leiden and in Bruxelles. (van Rood, juli, 1969)

Op het bericht dat er ook tussen Leiden en Brussel verschillen in typeringen voorkomen, reageert Van Rood door nog eens te zeggen dat het typeren nog niet volledig betrouwbaar is. Vandaar dat het volgens hem raadzaam is zo goed mogelijke sera te zoeken en patiënten meerdere malen te typeren. Daar voegt hij aan toe, dat discrepanties in typeringen met het referentielaboratorium niet altijd aan 'fouten' in het 'perifere' laboratorium hoeven te worden toegeschreven.

It should also be realized that the Leiden laboratory is not fool proof and that 
they can make as well mistakes as the others and because the load of work is so much greater, the number of mistakes in Leiden might actually be greater than elsewhere. For all these reasons it will be necessary to continue double typing i.e. not only in the local centre but also in the reference centre which is for the moment Leiden. (van Rood, juli, 1969)

Het steeds opnieuw versturen van bloedmonsters stuit op bezwaren. Daarom wordt besloten dat bij de tweede bloedafname, wanneer de eerste twee typeringen overeenkomen, de typering maar door één laboratorium hoeft te worden herhaald ${ }^{23}$. In het daarop volgende jaar wordt de tweede typering afgeschaft, maar blijft de duplicering door het referentielaboratorium gehandhaafd; waarbij het laboratorium van Govaerts in Brussel dit voor België gaat doen. Bij problemen zullen de 'regionale referentiecentra' bloedmonsters uitwisselen (van Rood, maart, 1970) ${ }^{24}$. Hiermee lijkt men de kwaliteit van de individuele typeringen te kunnen garanderen. Als toets van de vergelijkbaarheid voert Eurotransplant een uitwisselingsschema in van bloedmonsters die door alle laboratoria getypeerd moeten worden. Hiermee kan de vergelijkbaarheid van de verschillende laboratoria ook daadwerkelijk zichtbaar worden gemaakt.

To insure further consistency, once every two weeks a blood sample will be shipped by one typing centre to all other centres. This will be done in turn so that in a year's time about twenty samples will be tested. The results will be compared and analysed by computer and redistributed. (van Rood, maart, 1970) ${ }^{25}$

De garantie van de kwaliteit van de verrichtte typeringen is dus een voortdurende zorg voor de Eurotransplantgemeenschap. Hier wordt veel tijd (en geld) in geïnvesteerd. De beste typeringsresultaten worden bereikt met antisera die eenduidige afleesresultaten geven. Wanneer ieder laboratorium dan diezelfde, goede sera gebruikt, zou de kwaliteit van de typeringen gegarandeerd moeten zijn. Daarom geeft Eurotransplant de ET-serumset uit, waarmee de typeringslaboratoria moeten werken. Ook dit is echter geen eenvoudige opgave. Goede antisera zijn op zich al schaars en verder zijn sommige antigenen alleen met de cytotoxiciteitstechniek te herkennen (daar heeft Leiden aanvankelijk zelf geen antiserum-'leveranciers' voor).

23 Zoals in de Eurotransplant Newsletter No.3 staat:

In the discussion which follows it is pointed out that this is often difficult to realize because of transport difficulties etc. Finally the suggestion is adopted that the typing is done in duplicate by the local centre and the reference centre in Leiden and that on the second bleeding if the first two results agreed the typing is done only in the local centre or in Leiden. Most of the members were of the opinion that the two typing laboratories should agree between themselves before sending the results to the doctor in charge of the patient. Van Rood (Leiden) promised to discuss this with Govaerts (Bruxelles) who was not present during the meeting. (van Rood, juli, 1969)

24 De toon in de notulen van de Fourth Eurotransplant Meeting, wordt formeler.

6. Concerning duplicate determinations to assure high standards of reproducibility and consistency of the results the following was decided: $\mathbf{a}$. All local typing centres will do duplicate typings on their patients with the regional reference centre. For the time being Brussels is the reference centre for Belgium, and Leyden will be the reference centre for Holland and Germany. It is hoped that in the near future regional centres in Germany will take over this task for Germany. b. When the typing gives difficulties on several occasions or an unusual type occurs, the blood will be exchanged between the different regional centres. (van Rood, maart, 1970)

25 Deze manier van vergelijken vertoont overeenkomsten met de Histocompatibility Testing Workshops, al is hier het vergelijken van de 'typeurs' de doelstelling. terwill de Workshops gericht zijn op het vergelijken van de verschillende antisera. In de latere Histocompatibility Testing Workshops worden overigens ook 'cell panels' rondgestuurd, die in het eigen laboratorium kunnen worden getypeerd, zodat de vervolgens geretourneerde resultaten met elkaar kunnen worden vergeleken. 
On the availability of the sera it is pointed out that for most of the antigens which can be recognized with the micro agglutination test sufficient sera are available. The situation is as yet more difficult for the antigens which can be recognized only by the cytotoxicity test, especially the antigens HL-AI, HL-A3 en HL-A9. The first two however, are at the moment commercially available from Hyland (Los Angeles) and it appears to be likely that serum for the last antigen will become also available from that source in the near future. (van Rood, juli, 1969 )

De hier genoemde problemen in de serumvoorziening van cytotoxische antisera ten spijt, wordt tijdens de vierde Eurotransplant Meeting besloten om de cytotoxiciteitstechniek algemeen in te voeren. De typeringslaboratoria worden daarbij vrijgelaten in hun keuze voor de techniek van Kissmeyer-Nielsen, of voor de NIH methode (Terasaki's techniek) "as long as its typing results checks with those of the other centres" (van Rood, maart, 1970). De EDTA-agglutinatietechniek, waar men in Leiden de meeste ervaring mee heeft, krijgt meer bescheiden, aanvullende toepassingsgebieden toebedeeld.

It is felt by most of the typing centres that for the time being the EDTA agglutination technique has advantages as: 1 . independent check on the cytotoxicity test. 2 . better information on the $4 \mathrm{a}$ and $4 \mathrm{~b}$, and $6 \mathrm{a}$ and $6 \mathrm{~b}$ antigens. It should not be forgotten either that this is the only possible way to determine the antigens of the second now well established tissue system, the group Five. Attempts are being made to produce a good strong anti 5 a. (van Rood, maart, 1970) Dat met de agglutinatietechniek in het verleden de basis is gelegd voor het huidige werk, doet niet ter zake 26 . Andere technieken worden nog niet rijp bevonden om voor klinische typering te worden gebruikt, maar ook daar wordt aan gewerkt 27 .

Naast alle activiteiten direct gericht op de uitvoering van de typering, wordt ook op een andere manier controle op de typering uitgeoefend. Eerder begon men kadaverdonoren retrospectief te typeren aan de hand van (stukjes) ingevroren milt ${ }^{28}$. Zo wordt van een donor, die om een of andere reden ${ }^{29}$ niet vooraf te typeren is, achteraf bepaald wat diens leukocytengroepen zijn en in welke mate deze overeenkomen met de typering van de ontvanger ${ }^{30}$. Binnen Eurotransplant gebruikt men dezelfde

26 Er wordt wel gewerkt aan het ondervangen van enkele nadelen van de agglutinatietechniek, om het in onbruik raken ervan af te remmen, of zelfs de balans weer naar deze techniek te laten doorslaan.

Work is well in progress to convert the EDTA agglutination technique into a low ionic strength lymphocyte agglutination technique which can be done on one to two days old heparin blood. This should take the rush out of agglutination typing and make it possible to do all typings on one blood sample. (van Rood, maart, 1970)

27 Hierbij vormen enerzijds de techniek zelf, maar anderzijds weer de beschikbaarheid van antisera de beperkende factoren.

For the time being the micro complement fixation test is regarded as being experimental. It is certainly not the intention to burden the typing centres with this technique before all the pitfalls have been worked out and good monospecific, strong reacting anti sera are available, It is expected that this will be possible in the end of 1970 or early 1971. (van Rood, maart, 1970)

28 (Alexandre, 8 juli, rg68; van Rood, 8 maart, r968; Kierfeld, r april, 1968)

29 Te grote afstand tot typeringslaboratorium; geen tijd om te typeren door snel overlijden donor, niet met prospectief typeren bezig zijn; etc.

30 Uit de eerste Eurotransplant Newsletter (1 september r968) blijkt dat de keuze van een ontvanger nog lang niet altiijd door matchen bepaald wordt.

To get as much information as is possible we would like to ask you again to collect the spleens of the donors who could not be typed before transplantation. Pack them in ice and send them frozen to Leiden. If we have not typed the recipient yet, we would of course like to have a possibility to do this too. This can be done in the normal way by telephone appointment Leiden (47222-ext. 438r) (van Rood, $\mathrm{r}$ september, 1968 ) 
procedure om de (spoed) typering van de donoren te controleren. Men vraagt om met de te transplanteren nier(en), ook de milt mee uit te nemen, die in te vriezen en naar Leiden te sturen. Aan de hand van een miltextract worden de weefselkenmerken van de donor bepaald en vervolgens vergeleken met de voor de transplantatie verkregen typering ${ }^{31}$. Het retrospectieve typeren wordt op deze manier niet meer gebruikt om het matchingseffect aan te tonen, maar krijgt een controlerende functie. Aan de hand van de milttypering wil men iets zeggen over de kwaliteit van $\mathrm{de}$, door het perifere typeringslaboratorium verrichtte, prospectieve typering. In de loop van de tijd worden zo van een toenemend aantal transplantatiecentra retrospectief de milten getypeerd, hetzij ter verkrijging van een typering van een donor, hetzij ter controle van een prospectieve typering (van Leeuwen, 1969$)^{32}$. Er wordt dus erg veel gedaan om de resultaten van de verschillende laboratoria met elkaar in overeenstemming te brengen en te houden.

Als neveneffect van deze activiteiten wordt het 'Leidse' Eurotransplant gezien als de spil waar het geheel om draait en waar men niet buiten kan. Eurotransplant controleert en dat wordt ook verwacht. Soms gebeurt de controle zo subtiel, dat men denkt Eurotransplant te controleren, terwijl men eigenlijk zichzelf controleert. Zo stuurt Eurotransplant uittreksels uit het ET-telefoonboek met de gegevens van patiënten van een bepaald ziekenhuis, naar de respectievelijke centra. Eurotransplant doet dit om de juistheid van de geregistreerde gegevens te laten controleren. Niet altijd realiseert men zich, dat door het aanleveren van correcties, men eigenlijk - via Eurotransplant - ook controle uitoefent op het eigen werk.

De laatste print-out van de Eurotransplant computer heeft ons in verband met de vermelding van onze patiënten daarin nog enig verdriet bezorgd. Teneinde jullie zoveel mogelijk werk te besparen geef ik hier een overzicht van de naar onze mening nog bestaande hiaten. (Wijdeveld, 12 november, 1970)

Onafhankelijk van de vraag waardoor de hiaten zijn ontstaan, wordt zo bewerkstelligd, dat de centra mede verantwoordelijk zijn voor wat uiteindelijk in de Eurotransplant-file wordt opgeslagen. De controle brengt zowel lokale problemen, als problemen in Leiden aan het licht, waardoor de totale kwaliteit verbeterd.

Hoewel dit een lange brief lijkt, zijn wij toch voor mijn gevoel niet ver van de ideale situatie meer af. Wij zijn Eurotransplant erkentelijk voor het vele werk dat ten bate van onze patiënten verricht wordt en herhalen graag onze bereidheid daaraan ook dezerzijds zo veel mogelijk bij te dragen. (Wijdeveld, I2 november, 1970)

31 In 1996 wordt, vanwege kostenbesparingen, het hertyperen van iedere donor gestaakt en een meer steekproefsgewijze controle gestart. Het typeren middels absorptie/inhibitie-experimenten is dan overigens al lang vervangen door serologische-en zelfs DNA-technieken.

32 Ook hierbil getuigt men in Leiden van 'bescheidenheid' wanneer gezegd wordt dat men kan proberen de antigenen te bepalen aan de hand van de (absorptie $=$ ) inhibition test. Directe bepaling geniet echter de voorkeur.

In this connection it is the best to ship $50 \mathrm{ml}$. of heparin blood to Leyden were the cells can be frozen. Also suspension made from lymphnodes can be used in this way. If this is for one reason or another not feasible the spleen should be removed from the donor, cut in small blocks (approximately $5 \mathrm{ml}$. times, $5 \mathrm{ml}$. times $5 \mathrm{ml}$.) and stored at $-20 \mathrm{C}$. Care should be taken that the spleen sample is well labelled. The name of the donor and the date the spleen was taken out, and if possible the name of the recipient should be included. Such spleens can be sent frozen in dry ice, to Leyden, were we can try to determine the antigens with the help of an inhibition test. It should, however, be repeated that venous blood or lymphocytes from lymphnodes freshly shipped to Leyden, so that it can be frozen in the control freezing apparatus, is much to be preferred. In the near future it will be possible to use platelets, (van Rood, ro maart, 1970) 
Het stijgen van de kwaliteit, maakt het steeds interessanter om deel uit te maken van de gemeenschap, waardoor de bereidheid om een bijdrage te leveren aan een succesvolle uitbouw van het Eurotransplant-project groeit.

\subsubsection{Organiseren van Transport}

Herhaaldelijk is transport al beschreven als een punt van aandacht. Of dit nu de overdracht van kennis, het beschikbaar maken van gegevens of het verplaatsen van apparatuur, materialen of bloed en organen betreft; alles wat vervoerd moet worden stelt daaraan zijn eigen bijzondere eisen. Voor ieder te transporteren goed geldt, dat het stabiel, mobiel en combineerbaar gemaakt moet worden, maar wat dat inhoudt, is steeds anders. Eurotransplant is voor een groot deel het product van alle, in de loop der jaren daaromtrent verrichtte, inspanningen en probeert het verplaatsen van donornieren naar ontvangers mogelijk te maken. In het creëren van beschikbaarheid van donornieren, zijn alle aspecten van stabiel, mobiel en combineerbaar maken vertegenwoordigd. Zonder volledig te zijn kan direct al gezegd worden dat nieren op een voor transplantatie geschikte wijze dienen te worden uitgenomen, gepreserveerd en getransporteerd. Maar ook bloed en serum moeten om verschillende redenen van de ene naar de andere plaats worden vervoerd, waarbij er geen veranderingen in de samenstelling, activiteit of hoeveelheid mogen optreden. Deels zijn afspraken en maatregelen die stabiliteit, mobiliteit en combineerbaarheid moeten bewerkstelligen al besproken in de voorgaande paragrafen. In de hier volgende paragrafen zal dit uitgebreid worden met de maatregelen aangaande het transport van enerzijds bloed en sera, en anderzijds dat van organen. Net als ten aanzien van het verwerven van controle-instrumenten, besteedt men al lang voor het starten van Eurotransplant aandacht aan een goede organisatie van het trans. port. Het gegeven dat op een bepaald moment sera wel transporteerbaar zijn, maar leukocyten nog niet, is sterk van invloed op de specifieke vorm van de Leidse Workshop in 1965 .

\subsubsection{Transport van Bloed en Sera}

Lang voordat zelfs maar wordt gedacht aan een uitwisselingsorganisatie, wordt al bloed getransporteerd voor typeringsdoeleinden. Halverwege de jaren 60 worden al typeringen, aan de hand van bloed, uitgevoerd om te onderzoeken of een nier van de aanwezige, verwante donor ook geschikt is voor de patiënt. Verschillende malen komt Guy Alexandre uit Leuven per eigen, snelle, auto het te typeren bloed naar Leiden brengen (van Leeuwen, 6 september, 1994). Maar wanneer het mogelijk is om de beoogde ontvanger en zijn of haar donor(en) voor deze klinische typeringen naar Leiden te laten komen, zodat er met vers bloed gewerkt kan worden, krijgt dit de voorkeur ${ }^{33}$.

Als aanvulling op de mogelijkheden om ter plaatse een panel te gaan (her)typeren, typeert Van Rood ook mensen voor collega-onderzoekers, zoals bijvoorbeeld Amos, zodat zij 'thuis' in een panel kunnen worden opgenomen (van Rood, I6

33 Twee, of zelfs meer mensen naar Leiden laten komen, brengt echter problemen met zich mee. De fysieke aanwezigheid van de patiénten en hun donoren moet worden betalid en geregeld. Patienten van Alexandre bijvoorbeeld, moeten al om 6.45 uur uit Leuven vertrekken, orn tussen to.00 uur en ro.30 uur in het laboratorium te kunnen zijn. Later aankomen betekent immers dat het laboratoriumpersoneel tot laat in de avond moet werken (van Rood, 1 april, r966). Zie hiervoor ook Hoofdstuk 6. 
augustus, 1966). Het elders (her)typeren wordt wegens tijdgebrek een probleem. Als alternatief voor het over laten komen van de mensen, stelt Van Rood aan Richard Batchelor toch voor om de mogelijkheden om bloed af te nemen en dit zeer snel naar Leiden te versturen, te onderzoeken. Dit heeft als bijkomend voordeel dat in Leiden, naast de bepalingen, middels absorptie ook de controle op de typering kan worden uitgevoerd - vanwege de imperfecties in de antisera ${ }^{34}$ (van Rood, 20 oktober, 1966). Eerder dat jaar was hij nog geen voorstander van het versturen van bloed, vanwege de kosten en het vele extra werk (van Rood, 22 maart, 1966). Maar de toenemende belangstelling voor het 'leukocyten werk' dwingt hen echter tot deze stappen.

Bij retrospectief typeren speelt eenzelfde problematiek. Met de technieken die Van Rood in 1966 gebruikt, is het, gezien de te overbruggen afstanden en de daarvoor benodigde tijd, niet mogelijk om bloedmonsters te sturen. De ontwikkelingen zijn echter wel dusdanig, dat, wanneer de afstand niet te groot is, het versturen van bloedmonsters naar Leiden tot de 'standaardmogelijkheden' begint te behoren. Centra die redelijk in de buurt van Leiden liggen en met een klinische vraag komen, worden bediend, mits de transporttijd binnen de gestelde limiet kan blijven (van Rood, 19 oktober, 1966; van Rood, 25 november, I966). Met EDTA als conserveermiddel blijft het bloed 'zo goed als' vers en kan de agglutinatietechniek worden gebruikt ${ }^{35}$. Transport van bloed is mogelijk, wanneer de tijd die verstrijkt tussen afname en aankomst in het laboratorium niet meer dan maximaal vier uur bedraagt. Haalbaarheid van transport binnen de toegestane tijd is de beperkende factor ${ }^{36}$. Het alternatief is om zelf te gaan typeren, ter voorkoming van allerhande (bloed)transportproblemen, maar gedurende een overgangsperiode worden nog vele verzoeken om servicetyperingen gehonoreerd. Naar vele aanvragers worden vooralsnog 'receptacula'37, voorzien van EDTA en instructies, verstuurd ${ }^{38}$. Maar in toenemende mate geeft Van Rood het advies om ook zelf een 'typing unit' op te zetten, vooral wanneer de afstand tot Leiden groot is. Bij deze adviezen voegt hij de toezegging serum te zullen screenen en medewerkers te trainen. Als te hanteren test adviseert hij de cytotoxiciteitstest, die hij dan, om verschillende - vooral pragmatische - redenen, prefereert boven de agglutinatietechniek (van Rood, 5 januari, 1968).

Het animo om zelf direct een typeringslaboratorium op te zetten, is echter niet bij iedereen even groot. Bij het ontbreken van plannen in die richting blijft men zoeken naar oplossingen voor slechte bereikbaarheid. Zo oppert Kierfeld om per sportvliegtuig bloed naar het militaire vliegveld Valkenburg, bij Leiden, te vervoeren, waar het dan kan worden opgehaald (Kierfeld, 2 april, 1968). Anderen onderzoeken of het leger ingeschakeld kan worden bij het transport.

Wir sind derzeit im Gespräch mit der Bundeswehr wegen eines Hubschrauber-

Dienstes. Vielleicht sollten die Patienten jedoch selbst zu Ihnen kommen.

(Pichlmayr, 13 september, 1968)

34 ANAP (Agglutination Negative Absorption Positive) reacties.

35 Dan de enige in Leiden voor 'klinische' typeringen gehanteerde techniek.

36 (van Rood, 31 oktober, 1966; van Rood, 1 juni, 1967; Beck, 23 juni, 1967; Beck, 17 augustus, 1967: Scheitlin. 29 augustus, 1967 ; van Rood, 25 september, 1967 ; van Rood, 29 augustus, 1967)

37 Receptakel: vat om een vloeistof op te vangen. (Geerts, et al., 1999)

38 (van Rood, 28 september, 1967; Höftler, 7 februari, 1968; van Rood, 26 januari, 1968; Ringoir, 26 maart. rg68; van Rood, 3 april, 1968) 
Het vervoer van (anti)sera is ook niet altijd probleemloos verlopen. Hoe kan dit materiaal vervoerd worden zonder dat de reactiviteit verloren gaat? Kan dit op omgevingstemperatuur, of moeten de sera worden ingevroren, en zo ja, op welke temperatuur en in welke hoeveelheden? Al doende leert men en er ontstaat een levendige uitwisseling van antisera per (lucht)post ${ }^{39}$. Zo biedt ook de mogelijkheid om leukocyten in te vriezen en daarmee geschikt te maken voor opslag, perspectief op het transporteerbaar worden van leukocyten. Daartoe informeert Van Rood naar 'door de lucht transporteerbare vloeibare stikstof-vaten' (van Rood, 29 augustus, 1968; van Rood, ro oktober, 1968). Er wordt veel gedaan om verschillende materialen transporteerbaar te maken, zodat ze, onafhankelijk van de plaats van herkomst, kunnen worden bewerkt en geanalyseerd.

Succesvol vervoeren is mede afhankelijk van het transport zelf (vooropgesteld dat transporteerbaar maken gelukt is). Het mag theoretisch mogelijk zijn om binnen een bepaalde tijd van A naar B te komen, in de praktijk moet dit nog worden gerealiseerd. Tijdens een van de eerste Eurotransplant Meetings blijkt dat onder andere het transport van bloedmonsters niet altijd even soepel verloopt, hetgeen een belem. mering vormt om alle typeringen dubbel uit te voeren. Er worden eisen gesteld aan het transport, maar men moet ook rekening houden met de regels daarvan.

It is also pointed out that if the bleeding is done early enough, most samples can be send "special parcel post" by train, which is fast and cheap. (van Rood, juli,

1969)

Aangezien de dienstregeling 'vast ligt', zullen andere zaken zo veranderd moeten worden dat van de trein gebruik kan worden gemaakt. Dit vergt weer 'organisatie'. Om 'de trein te halen' moet (mogelijk) de tot dan toe gehanteerde praktijk gewijzigd worden. Uit de 'Instructie voor bloed/serumtransport per trein' blijkt, dat dit erin kan resulteren dat bloed in de zeer vroege ochtend moet worden afgenomen, aangezien 'de verzending' om 7.45 uur moet worden aangeboden bij het "Districts Post Office in The Hague, "Foreign Department, fifth floor" (van Rood, II maart, r970) ${ }^{40}$. Wanneer, voor het verkrijgen van het monster, de komst van de patiënt noodzakelijk is, zal deze dus al zeer vroeg in de ochtend naar het ziekenhuis moeten komen, evenals degenen die het bloed afnemen. In r970 wordt het transport per trein verder gefaciliteerd door de algemene acceptatie van de cytotoxiciteitstechniek, die met 'heparine bloed' kan worden uitgevoerd.

In this connection it was pointed out that especially heparin blood samples can be stored quite well for 12 hours or longer. Train express shipments are fast. reliable, and cheap. All centres are urged to find out the train connections with the other typing centres and to try to make arrangements with the local train companies in order to make fast shipments possible. (van Rood, maart, 1970) Naast de praktische problemen rond transport, ontwikkelen zich in de loop van de tijd ook formeel juridische problemen, waarop geanticipeerd, dan wel gereageerd moet worden. Het goederenverkeer over grenzen heen is gereguleerd. Om dit zo snel mogelijk geregeld te krijgen besluit men tijdens de Eurotransplant Meeting van I8 mei 1969, dat daarover overleg met de 'Raad van Europa' moet worden gepleegd.

Next Engelfriet (Amsterdam) reported a meeting of the Council of Europe in

39 (van Rood, 17 augustus, 1966; Klein, 28 oktober, 1967: Berah, 31 augustus, 1967; Botha, 19 januari, 1967: Botha, 20 september, 1967 ; Govaerts, 19 juni, 1967 )

40 Zie Bijlage 7 : Instructies voor bloed- en serumtransport per trein. 
Helsinki. The Council of Europe has constituted a number of agreements to facilitate transport across borders of blood grouping reagents and therapeutic substances of human origin. In principle it would be possible to use these agreements also for Eurotransplant and during the meeting of the Council of Europe it was agreed in principle that this would also been done for the typing reagents used for leukocyte grouping. The question was whether or not the present meeting agreed that this would be a laudable initiative. There was general agreement that this should be done and it was decided that Engelfriet and Van Rood would contact the Council of Europe to work out the details further. (van Rood, juli, 1969) (sic)

Zo wordt er op verschillende manieren aan gewerkt om transport van bloed en (anti)sera op de best mogelijke manier te organiseren en te realiseren. Het transport van organen profiteert van deze inspanningen, maar daar moeten wel extra voorzieningen voor worden getroffen.

\subsubsection{Transport van Donornieren}

Naast bloed en antisera voor typeringsdoeleinden, worden namens Eurotransplant ook organen vervoerd. Ook dit transport moet worden georganiseerd en is duide. lijker zichtbaar voor 'de buitenwereld' dan het transport van bloed en sera.

Eind ' 67 leeft bij Van Rood de optimistische gedachte, dat de ontwikkelingen op het gebied van orgaanpreservatie dusdanig zijn, dat de tijdsduur die mag verstrijken tussen uitname en transplantatie, 24 uur zal gaan bedragen. Transport tussen het uitnemende en implanterende ziekenhuis zou binnen die tijd mogelijk moeten zijn, ook wanneer die plaatsen verder uit elkaar zouden liggen (van Rood, 25 september, I967). Zo gesteld lijkt, gezien de toegelaten transporttijd, het transport van een nier eenvoudiger te realiseren, dan het transport van bloed voor de agglutinatietest. Het bloedtransportprobleem tracht men op te lossen door het typeren te decentraliseren. En 'wanneer het decentraal typeren eind I 968 gerealiseerd is', zo schrijft Van Rood op I 8 maart aan Kissmeyer-Nielsen, blijven nog slechts 'enkele probleempjes' over.

Then, if that point is solved, the only other problem is to get people to

collaborate and to organize the transport. I don't think this will cause too many

troubles. (van Rood, 18 maart, x968)

De aanmelding van patiënten levert niet zo veel problemen op. De aanvragen voor typering van nierpatiënten voor opname in het bestand van Eurotransplant, zodat zij getransplanteerd kunnen worden met een voor hen geschikte nier, 'stromen binnen'. Wat het transport betreft is men optimistisch. Daarbij hoopt men vooral op hulp van het leger, zoals Van Loghem het in een vraag aan Van Rood over 'Eurotransplant' op 20 oktober 1967 stelt.

The important possibility of your Euro-transplant is, that by combining a large number of hospitals, our pool of recipients will be tremendous here in Europe.

Organisation and transportation problems can be solved, especially if the military authorities are willing to help. As we will hear this afternoon, progress in preservation is so rapid, that in one year perhaps we will have more time for selection. By having a large number of possible recipients the chance of having a real good fit increases of course. (Woelders, et al., 4 september, r968)

Inderdaad blijken verscheidene legeronderdelen bereid hun medewerking aan het transport van organen voor transplantatie te verlenen, evenals andere overheidsdiensten zoals politie en douane. Dit aspect van het transport blijkt weinig 
problemen op te leveren. Van Rood meldt in zijn verslagen over de voortgang in het opzetten van Eurotransplant:

We are busily working on this, and it looks as if the military forces of the different countries are willing to cooperate and the whole thing is a matter of protocol, which can be worked out rather easily. (van Rood, 3 april, i968) Ruim twee jaar later staat in een artikel in het NRC Handelsblad hoe de Marine Luchtvaartdienst al geruime tijd haar medewerking verleent aan Eurotransplant.

Dag en nacht staan op de marinevliegbasis Valkenburg een Neptune-vliegtuig en een helikopter beschikbaar voor opsporings- en reddingswerk in een deel van de Noordzee. Sinds ruim anderhalf jaar worden deze toestellen echter ook gebruikt voor Eurotransplant, een op I mei 1968 opgerichte organisatie, gevestigd in Leiden, die een belangrijke schakel vormt bij de niertransplantaties en die steeds belangrijker wordt. (Bulterman, 7 juli, I970)

Achteraf gezien lijken er in de aanvangsjaren van Eurotransplant weinig problemen te zijn met het feitelijke transport. De organisatie ervan heeft soms echter meer voeten in aarde.

Aan Govaerts (Brussel) schrijft Van Rood dat tussen hen de uitwisseling van nieren ook per trein kan gebeuren, hetgeen 2 I/2 uur duurt, maar dat er in Leiden aan gewerkt wordt om dit met vliegtuigen van de luchtmacht te organiseren (van Rood, 3 april, 1968). De medewerking van verschillende luchtmachten (Duitsland en Nederland) is toegezegd, maar moet worden 'geformaliseerd' (van Rood, 5 april, 1968). Hiervoor heeft niet alleen 'Leiden' contacten met eventuele 'transporteurs'; Alexandre onderhoudt contacten met de Belgische luchtmacht. Wanneer men in België een donornier ongebruikt moet laten, komen daar de Nederlandse ziekenhuizen in beeld als mogelijk 'afzetgebied' van donornieren. Naar aanleiding van een helikoptervlucht van Leuven naar Leiden, neemt het leger direct contact op met Alexandre, omdat zij 'dit in de toekomst beter willen organiseren' (Alexandre, 6 mei, 1968).

Yesterday I have had a meeting in Brussel at the Army Headquarters to organize the transport of blood and/or kidneys by helikopter and I have explained to them your plans for Eurotransplant and the meaning of it. (Alexandre, 9 mei, 1968) Alexandre schrijft dat ook de Belgische Luchtmacht bereid is om nieren naar ieder ziekenhuis in Nederland te vervoeren, maar daarvoor een lijst van die ziekenhuizen wil hebben, zodat vooraf de landingsplaatsen kunnen worden bepaald. De omgeving van ieder ziekenhuis zal daartoe worden gefotografeerd, zoals dat ook al voor Leuven en Gent is gedaan. Met deze hulp zullen minder donornieren verloren hoeven gaan.

I think that this represents a good step toward the practical realisation of

Eurotransplant. Indeed, three weeks ago, we were obliged to throw away a

kidney that could not be used by Gent neither by Brussel and in the future I see

no reason why we could not send a kidney through Eurotransplant to one of the

Holland centers. As you know the flight from Louvain to Leiden by helikopter

takes only 50 minutes. (Alexandre, 9 mei, 1968)

Hier voegt Alexandre aan toe dat wanneer men in Nederland geinteresseerd is, er snel een afspraak met "Dr. Vink" 41 gemaakt moet worden "to settle the conditions of preservation of the graft during transportation and so on" (Alexandre, 9 mei, I968). Het transport komt letterlijk van de grond. In deze fase van de zich ontwik-

41 Hoogleraar chirurgie te Leiden. 
kelende Eurotransplantpraktijk spelen Luchtmacht, Marine en Politie een belang. rijke rol bij het vervoer van organen. In het 'First Progress Report', dat Van Rood voor de eerste Eurotransplant Meeting schrijft, spreekt hij de hoop uit dat de samenwerking met verschillende 'autoriteiten' in de toekomst kan worden voortgezet.

Transport of blood and organs has been made possible in the past through the generous help of the civil and military authorities. It is hoped that this can be continued. (van Rood, juni, 1968)

Deze samenwerking vormt de aanleiding om als Eurotransplantgemeenschap te proberen de rol van overheidsinstanties bij transport verder uit te breiden. Het gegeven dat deze instituten ten bate van het algemeen belang zijn (en mogelijk ook het gegeven dat zij 24 uur per dag bemand c.q. beschikbaar zijn), speelt hierbij misschien een rol.

The matter of transport was discussed and it was decided to try to work this out with the help of the military and civilian authorities. The chairman Prof. Vink promised to look into this matter for Holland, while Dr. G. Alexandre from Louvain reported that the military airforce in Belgium was willing to put the helikopters to the disposal of Eurotransplant. In the meantime it has been brought to our notice by $\mathrm{Dr}$. Alexandre that there exists an organization called Euro-aid, which apparently has a number of light planes for medical transport between different countries. It is also possible that the council of Europe might be helpful in this respect. (Terpstra, et al., juni, 1968)

In de eerste Eurotransplant Newsletter, worden deze twee laatste mogelijke bronnen van hulp bij transport niet genoemd, maar de hulp van politie en defensie des te nadrukkelijker. Van Rood stelt dat "We and all our patients are greatly indebted to them." (van Rood, I september, 1968). Door de goede ervaringen ten aanzien van het regelen van het transport, krijgen ook anderen het advies hiervoor contact te zoeken met militaire luchtvaart en politie autoriteiten (Woelders, 30 augustus, 1968$)^{42}$. Zo meldt Van Rood aan Ceppellini, dat ze tweehonderd patiënten hebben getypeerd en dat de laatste drie maanden vijftien transplantaties 'via de Eurotransplant-files' zijn gedaan. Voor de Italianen zou dit ook een mogelijkheid zijn, waarbij het transportprobleem eenvoudig opgelost kan worden "if you really get some people of the police and military together" (van Rood, 22 augustus, I968).

Het 'bij elkaar krijgen' van de verschillende instanties is één ding, ze bij elkaar houden een ander. Er wordt veel aandacht geschonken aan het onderhouden van contacten, waarbij men zeer voorkomend is, zodat ook in de toekomst op hun medewerking kan worden gerekend. Zijn belofte aan de Commandant van de Vliegbasis Valkenburg, van de Brandeler, gestand doend, stuurt Van Rood een kopie van een lezing over Eurotransplant. Daarbij bedankt hij nog eens uitgebreid voor bewezen diensten.

Vanzelfsprekend wil ik ook van deze gelegenheid gebruik maken om u en uw organisatie nogmaals hartelijk te danken voor alle steun en medewerking, die wij in het verleden hebben mogen ondervinden. Ook in de toekomst hopen wij op uw assistentie te mogen blijven rekenen. (van Rood, ro oktober, 1968) Wanneer problemen optreden bij het vervoer per marinehelikopter van Leiden naar

42 Door Mevr. Bertie Woelders, dan de secretaresse van Eurotransplant/Van Rood.

Walls schrijtt terug dat ze de mogelijkheden van bloedtransport naar Leiden door de RAF onderzoeken en hen op de hoogte zullen houden (Walls, 17 september, 1968).. 
Leuven, haast men zich de benodigde informatie uit Leuven zo snel mogelijk ter beschikking van de commandant van de Vliegbasis te stellen (Woelders, I november, $1968)^{43}$.

Bij nieuwe aanvragen voor participatie in Eurotransplant en de uitvoering van ty. peringen wordt ook de afstand tot Leiden een factor. Zo schrijft Van Rood op de brief van Dr. Mueller-Eckhardt uit Giessen, als opdracht aan zijn secretaresse: "Bellen, Waar ligt het" (Mueller-Eckhardt, 28 november, 1968). Wanneer de plaats binnen de 'actieradius' ligt is eventueel samenwerking mogelijk. Een maand later krijgt hij schriftelijk een positief antwoord (van Rood, 24 december, 1968). Dat de actieradius een rol speelt in de praktische deelname aan Eurotransplant, blijkt uit een brief van Gurland uit München, die schrijft dat wegens het nog niet kunnen overbrengen van nieren uit het Benelux-gebied', deelname aan Eurotransplant nog niet mogelijk is (Gurland, 6 december, 1968) ${ }^{44}$. De afstand, gerelateerd aan de duur van het transport, vormt dus nog een probleem voor München, althans, vanuit de 'Benelux'. Vermoedelijk zijn de respectievelijke luchtmachten niet bereid om naar München te vliegen; per helikopter is dat geen onaanzienlijke afstand.

Voor grotere afstanden zijn andere transportmogelijkheden aanwezig. Voor het versturen van materiaal en sera, tot naar Australië en Zuid-Amerika toe, wordt al enige tijd gebruik gemaakt van de diensten van het expeditiebedrijf COPEX ${ }^{45}$. Transport via commerciële kanalen, brengt echter weer eigen problemen met zich mee. Zo heeft een vliegtuig van de KLM 15 minuten vertraging opgelopen, omdat het stond te wachten op een nier voor Zürich, die om medische redenen niet kwam. Copex vraagt Van Rood om opheldering over dit incident. Waarom is de annulering niet bijtijds doorgegeven (Copex Expeditiebedrijf, 22 oktober, 1968)? Ook deze mensen moeten te vriend gehouden worden, want men heeft hun hulp nog nodig.

Het succes van het transport is natuurlijk sterk afhankelijk van de aanwezigheid van transporteurs. Naast het feitelijke transport, is echter ook de conditie van het getransporteerde bij aankomst een belangrijke beoordelingsgrond voor bepaling van 'succes'. Zoals bloed en sera hun reactiviteit moeten behouden gedurende het transport en de daarmee verstreken tijd, zo moet een te transplanteren nier weer kunnen gaan functioneren en urine produceren. Een belangrijke handeling die dit mogelijk moet maken is het 'spoelen' van de nier. Spoelen zorgt ervoor dat het bloed uit de nier wordt verwijderd, zodat dit de nier niet kan verstoppen wanneer het stolt, en verder wordt de nier met de spoelvloeistof gekoeld. Hierdoor gaat het metabolisme omlaag en treedt minder schade als gevolg van zuurstoftekort op. Aan het ontwikkelen van deze preservatietechnieken wordt hard gewerkt, maar de belofte gaat nog steeds niet verder dan een tijdsvenster van 24 uur. Tijdens het transport moet de nier gekoeld blijven en om dit zo goed mogelijk te kunnen waarborgen, wordt ook hiernaar onderzoek verricht ${ }^{46}$.

43 Vergelijkbare informatie uit andere buitenlandse plaatsen wordt ook direct naar de vliegbasis gestuurd (Woelders, 13 november, 1968 ).

44 In hoofdstuk 7 wordt het aspect tijd geillustreerd met dit voorbeeld.

45 Van Rood adviseert Rubinstein om ook gebruik te maken van COPEX: They handle all our material and are quite experienced" (van Rood, 30 oktober, 1967).

46 Van Rood maakt melding van de lopende initiatieven vanuit Eurotransplant, maar vraagt tevens aan de Eurotransplantgemeenschap om hun kennis met elkaar te delen.

Recent information presented at the New York meeting indicates that it is extremely likely that preservation of kidneys will be possible in 1969 for at least 24 hours. Studies are at the moment in preparation to evaluate the various containers which are available. Anyone who has new information on this point is urged 
Niet alleen de kwaliteit van de 'containers' ten aanzien van het constant houden van de temperatuur is van belang, er worden ook andere eisen aan de verpakking gesteld en deze zijn niet alleen 'medisch' van aard. Om het transport via Copex en door de KLM zo soepel en foutloos mogelijk te laten verlopen, geeft de KLM onder andere aanwijzingen over de te gebruiken dozen. Zo vragen zij om de 'kleine zendingen' toch in 'dozen van behoorlijke afmetingen' te verpakken, 'opdat ze gemakkelijker te lokaliseren zijn' en om op deze dozen "speciale labels met hierop vermeld "EUROTRANSPLANT" aan te brengen, om de belangrijkheid van de zending aan te geven" (Koopmans, 30 september, 1969 ) 4748 .

Het aandeel van de commerciële organisaties in het transport voor Eurotransplant neemt toe. De bijdrage van de genoemde maatschappelijke instituties wordt rond 1970 minder, mede door het groeiende beslag dat op hen gelegd werd. Wel kan de hulp van politie worden ingeroepen om transporten veiliger en sneller te laten verlopen, zoals Van Rood aan de "leden van de Nederlandse centra" meedeelt.

Ondergetekende en collega J.L. Terpstra hebben onlangs een gesprek gevoerd met de Rijkspolitie, betreffende het vervoer van bloed en cadaver organen met auto's van de Rijkspolitie. Het is hierbij gebleken dat slechts bij hoge uitzondering dergelijk vervoer nog door de politieauto's kan geschieden. Hoewel de politie in deze zeer hulpbiedend is, is het onmogelijk gebleken personeel en wagens langere tijd (soms $4-6$ uur) te onttrekken aan de normale politie taken. Wel kunnen en willen zij ook gaarne begeleidend werk, wat aanzienlijk minder tijd kost, blijven verrichten. Indien het vervoer niet met een personen auto of taxi kan geschieden, kan het beste een ambulance wagen hiervoor worden ingeschakeld. Het verdient aanbeveling hiervoor een locale firma te selecteren waarmee eventueel een contract tegen gereduceerd tarief kan worden afgesloten. Opgemerkt moet worden, dat uit veiligheidsoverwegingen het verstandiger is met een ambulance dan met een particuliere auto te rijden! De Rijkspolitie is bereid bijstand te verlenen met het omzeilen van verkeersknopen c.q. het snel loodsen door verkeersophopingen. Indien dergelijke bijstand gewenst wordt, is het noodzakelijk hiervoor een aanvraag te richten naar Driebergen tel.: 03438 . 4242. Deze centrale post zal dan de begeleiding coördineren van de Rijkspolitie en gemeentepolitie in die steden, welke gepasseerd worden. De Rijkspolitie zou het op prijs stellen om ook wanneer geen interventie noodzakelijk is toch op de

to communicate this to the other participants of Eurotransplant. (van Rood, januari, 1969)

Ruim een jaar later is de preservatie van nieren nog steeds in onderzoek (en zal dat tot op de dag van vandaag ook blijven).

As to the future of Eurotransplant: it is clear that storage of organs will become more and more important. On Friday morning the r 3 th a group of about twenty-five came together to discuss further actions to be taken. It was decided at that meeting that for the time being it will be tried to use the fluid as described by Gelin. The exact procedure is attached. The Heidelberg group promised to investigate whether the Collins fluid as recently described is better than the Gelin procedure. (van Rood, maart, 1970)

47 Hierbij makt de KL.M nog de aantekening, dat de zendingen als 'gewoon pakket' behandeld zullen worden. Gezien het feit dat niet alle zendingen per KLM zullen worden vervoerd, lijkt het ons, afgezien van de mogelijkheden, niet wenselijk het cabinepersoneel bij dit vervoer in te schakelen. (Koopmans, 30 september, 1969)

48 Enige tijd later worden nieren vervoerd in polystyreen dozen, die zowel groot en licht, als isolerend zijn. When your thermos flask arrived, still a little ice-slush was present. In Eurotransplant we use an other method: Foam plastic boxes with a very high isolationpower at very low costs ( $\mathrm{H} . \mathrm{Fl} .4,50$ per box). The kidney is wrapped otherwise, though sterility is better kept than in your procedure ( see Eurotransplant prescriptions). The transplant was in fairly good condition, produced some urine from the start, but there was severe tubular necrosis. .2. (Terpstra, 1970) 
hoogte gesteld te worden. Dat is ook in ons eigen belang daar zij beter op de hoogte zijn van eventuele obstakels die men op de weg kan tegenkomen. (van Rood, februari, 1970)

Het is dus niet zo dat de politie zich geheel terugtrekt, maar het feitelijke transport over de weg moet op andere wijze worden georganiseerd.

Om de medewerking van de marineluchtvaartdienst niet in gevaar te brengen, is men omzichtig in het gebruik van hun bereidwilligheid. Wel wordt, gezien de al bestaande goede contacten, om informatie gevraagd ${ }^{49}$, maar assistentie bij vervoer wordt alleen ingeroepen als het echt noodzakelijk is. Voor die assistentie heeft men overigens, tot dan toe, nooit hoeven betalen, zoals Terpstra aan Abbot schrijft (Terpstra, 1970). Het is begrijpelijk dat 'Eurotransplant' er veel aan gelegen is om de relatie met zowel de politie, als de militaire overheden zo goed mogelijk te houden 50 .

Naarmate de tijd vordert en Eurotransplant groeit, veranderen ook de regels van het spel. Niet alleen binnen de Eurotransplantgemeenschap worden procedures en regels afgesproken, ook verschillende overheden mengen zich met regelgeving in de ontwikkeling van de praktijk. Bij de eerste niertransporten kijkt men niet naar het overschrijden van landsgrenzen. Later passeren sommige zendingen wel de douane, maar wanneer deze doordrongen zijn van het belang van de inhoud levert dit geen vertraging op (Terpstra, 1970 $)^{51}$. Om niet voor onverwachte verrassingen te komen, wint men informatie in bij Mme M. Revillard van het 'Centre De Recherches D'Information et de Documentation Notariales' te Lyon. Zij stuurt informatie over de internationale regels met betrekking tot het transport van organen (van Rood, 24 maart, I970). Bij het verplaatsen van donororganen wordt nu ook voldaan aan (internationale) regels aangaande het vervoer. Het volgen van internationale regels hangt samen met veranderingen die Eurotransplant in de loop van de tijd meemaakt. Steeds meer verschillende zaken moeten over steeds grotere afstanden worden getransporteerd. $\mathrm{Bij}$ ieder nieuw te transporteren materiaal wordt gezocht naar de 'best mogelijke manier' van vervoer, of dat nu de verpakking, de temperatuur, het conserveermiddel, of het transportmiddel betreft. Telkens moet worden geanticipeerd op veranderende omstandigheden. Daar komt bij dat, ten aanzien van de transporteurs, geanticipeerd moet worden op veranderingen in de bereidheid van instituties als leger en politie om een bijdrage te leveren aan dat transport. Ten aanzien van dit punt is men in zekere zin niet in staat gebleken om deze bereidheid stabiel te houden. Op korte termijn was het kosteloos verlenen van deze assistentie een

49 Zo vraagt Van Rood aan Van De Brandeler of er een centrale instantie is voor het verkrijgen van kaarten, aangezien zij regelmatig verzoeken om plattegronden van de verschillende landingsplaatsen bij ziekenhuizen in Nederland krijgen (van Rood, 12 maart, 1970)..

Soms geeft men vanuit de ziekenhuizen zelf verschillende landingsmogelijkheden aan.

Met betrekking tot de aan- en afvoerwegen van Nijmegen neem ik aan dat deze genoegzaam bekend zijn. Landing van helikopters kan plaats vinden op het zweefvliegveld te Malden, dat op luchtkaarten staat. Voor eventuele landingen van vliegtuigen kan het militaire vliegveld bij Amhem gebruikt worden. (Wijdeveld, 13 januari, 1970)

50. Afgezien van de aanwezige transportfaciliteiten, is ook het gegeven dat dit kosteloos gebeurt, niet oninteressant, aangezien veel van de kosten die gemaakt worden voor een transplantatie nog niet aan de (verzekeraar van) de patiënt (kunnen) worden doorberekend.

51 Soms wordt daar wat 'druk' aan toegevoegd.

We never met problems with customs. They know about, or are told about the severe implications of delay and when necessary pressure from our side on the right places works out very well. We even broke through a strike once at Frankfort airport. Of course of importance is that the highest in rank available in the hospital talks directly to the custom-officer ... (Terpstra, 1970) 
bijzonder prettig gegeven, maar op langere termijn zouden het juist weleens de kosten kunnen zijn die voor de afname in bereidheid verantwoordelijk gesteld moeten worden. Uit oogpunt van stabiliteit was het misschien beter geweest wanneer ook de genoemde instituties een compensatie voor de door hen verleende diensten was gegeven. Nu was hun medewerking afhankelijk van de eer die zij stelden in het verlenen van bijstand in situaties van 'levensgevaar'. Dit is een frase die Terpstra geschrapt zag uit zijn concept van een brief aan $\mathrm{Abbot}^{52}$. Ook wanneer een compensatie zou zijn gegeven, had het beschikbaar stellen van helikopters, vliegtuigen en (politie)auto's niets afgedaan aan de bereidwilligheid om het publiek te dienen, maar zou mogelijk op langere termijn het kostenaspect een minder doorslaggevende rol hebben gespeeld en zou het transport van donororganen tot een overheidsdienst hebben kunnen uitgroeien. In de loop van de tijd worden echter keuzes gemaakt en kansen gegrepen in het licht van de dan ingeschatte consequenties.

Van Rood schreef in reactie op het stranden van de eerste transplantatie in Eurotransplant: 'volgende keer beter' 53 . Een transplantatie was mogelijk geweest, maar geluk ontbrak. Concluderend kan worden gesteld dat 'het geluk' nog gedeeltelijk georganiseerd moest worden. De 'bijna eerste Eurotransplant transplantatie' maakte daarbij zichtbaar waar het aan schortte. Voor het werkelijk beschikbaar krijgen van donororganen voor patiënten, ofwel, voor het goed functioneren van Eurotransplant, moeten veel zaken worden geregeld. Dit is echter nauwelijks op voorhand mogelijk. De vele afspraken die gemaakt worden, de procedures die worden vastgesteld en alles wat geregeld wordt rond transport, is vaak geregeld of vastgesteld, nadat er een probleem aan het licht is gekomen. In de loop van de tijd wordt men steeds succesvoller in het organiseren van 'geluk', hetgeen voor een groot aantal patiënten resulteert in het voor hen beschikbaar komen van een donornier.

\subsection{Grenzenloze Geneeskunde}

Grenzenloze geneeskunde, geen grenzeloze geneeskunde. Er is geen grens tussen 'binnen en buiter'. Wanneer die grens wordt 'getrokken', heeft men daar een bedoeling mee. In deze paragraaf zal duidelijk worden dat de Eurotransplantpraktijk niet zonder een 'buitenwereld' bestaat en niet had kunnen ontstaan. De zogenaamde 'maatschappelijke invloeden' op de medische praktijk, maken deel uit van die praktijk. De morele, juridische en praktische 'invloeder' behoren tot de praktijk, net als de medisch-wetenschappelijke/technische bijdragen. Om het heel direct te zeggen: zonder mensen die als patiënt willen figureren, is er geen medische praktijk. Door 'ziekte' tot een oplosbaar en - voor een groot deel - van 'schuld' ontdaan probleem te maken, is een cultuur ontstaan, waarin 'patiënt zijn' een gelegitimeerd gedragspatroon is geworden. Deze vergaand gemedicaliseerde cultuur maakt het ook mogelijk dat er een 'markt' ontstaat voor transplantatiegeneeskunde. In deze cultuur kan zoiets als een 'transplantatiepraktijk' ontstaan en Eurotransplant maakt daar deel van uit.

De verwevenheid van maatschappij en medische praktijk levert maatschappelijke erkenning op voor Eurotransplant als een legitieme, op grond van medische crite-

\$2 Terpstra schreef en Van Rood haalde door:

Besides the Dutch Forces have a rule and are also proud of stand by in cases of civil life and death situations, (Terpstra, 1970)

53 (van Rood, 4 april, 1968) in 57.4 . 
ria, orgaanverdelende organisatie. De ET-wachtlijst wordt daarbij als een rechtvaardige wijze van handelen gezien. Hiermee wordt een medisch criterium voor het sociale recht op gezondheidszorg gehanteerd (waarbij het overigens de vraag is of bij de ontwikkeling van de wachtlijst aan dit sociale grondrecht is gedacht). In de volgende paragrafen zullen achtereenvolgens de vorming van de 'publieke opinie' over transplantatiegeneeskunde, mechanismen waarmee actieve medewerking van leken en professionals wordt verkregen en financiële aspecten rond Eurotransplant worden beschreven.

\subsubsection{Publieke Opinie}

Een belangrijke factor in de wording van de transplantatie-en de matchingspraktijk is de publieke opinie: de openbare mening, zoals die van de meerderheid van het publiek is ${ }^{54}$. Gezondheid en gezondheidszorg staan hoog op de publieke agenda. Men lijkt de dood te vrezen en omarmt daarom alles wat de dood (tijdelijk) buitenspel zet. Bijna per definitie heeft de gezondheidszorg de publieke opinie mee. Geldt dat ook voor de manier waarop de media deze 'boodschap' in relatie tot de 'oprichting' van Eurotransplant bekend maken en hoe gaat 'het publiek' daarmee om? De transplantatiegeneeskunde, met haar retoriek van 'the Gift of Life', is bij uitstek een deel van de geneeskunde dat gezien wordt als strijdend tegen de dood; een deel dat daar bovendien in lijkt te slagen.

\subsubsection{Transplantatie in de Media}

De internationale aandacht van de media voor de eerste harttransplantatie in de wereld en de impact die dit heeft op het publiek, overtreffen beide vele malen de nationale aandacht voor en impact van de eerste niertransplantatie in Nederland. Toch is deze harttransplantatie - eind ' 67 - ook voor de niertransplantatiepraktijk van groot belang. Eerder in datzelfde jaar lanceert Van Rood het idee van Eurotransplant. Dit wordt onder andere via Het Parool bekend gemaakt aan het publiek. In het betreffende artikel krijgt Van Rood de gelegenheid om uit te wijden over de oprichting en de rationale van Eurotransplant. 'Eurotransplant' is de naam waaronder dr. J.J. van Rood ... het denkbeeld lanceert om te geraken tot een soort internationale 'Nierbank' (van Rood, oktober, 1967$)^{55}$.

Wanneer op 3 december 1967 de eerste harttransplantatie wordt uitgevoerd, duiken de media daar bovenop. In het kielzog van de harttransplantatie varen andere vormen van transplantatie mee op deze publiciteitsstroom. Dr. Martin Botha, verantwoordelijk voor de typering van de patiënt en zijn donor, geeft publiekelijk erkenning voor de hulp die hij uit Leiden heeft ontvangen. Vanwege de druk die na de transplantatie ontstaat om zo snel mogelijk ook de typeringsgegevens te publiceren, stuurt Botha een telegram aan Van Rood.

$=I$ HOPE MY PUBLIC ACKNOWLEDGEMENT TO WORLD PRESS RADIO AND TELEVISION FOR YOUR ASSISTANCE HAVE BEEN CARRIED AS DESIRED STOP I HAVE BEEN PRESS-GANGED RELUCTANTLY INTO IMMEDIATE PUBLICATION OF TISSUE-TYPING FOR REASONS HEART TRANSPLANT IN SOUTH AFRICAN MEDICAL JOURNAL STOP PLEASE

54 Omschrijving uit Van Dale (Geerts, et al., 1999).

55 Van dit artikel corrigeert Van Rood de drukproef. Zie bijlage 8: Correcties op drukproeven van artikel in 'Het Parool.' 


\section{SEND IMMEDIATELY AIRMAIL YOUR FULL BIBLIOGRAPHY OF PUBLICATION AND COMMUNICATIONS ON SUBJECT FOR POSSIBLE \\ PUBLICATION $=$ BOTHA + $(\text { Botha, } \text { 10 december, } 1967)^{56}$}

In het jaar voorafgaand aan de harttransplantatie zijn er inderdaad veelvuldig contacten geweest tussen Botha en Van Rood. De getoonde waardering is dan ook zeer welkom. Van Rood begint zijn antwoord op het telegram van Botha dan ook met "Congratulations! What a wonderful success! Thank you also really very much for the credit you have given us" (van Rood, 18 december, 1967 ). Hij voegt daar aan toe dat de publiciteit wel eens van (doorslaggevend) belang kan zijn bij het verkrijgen van een nieuw laboratorium en geeft vervolgens een opsomming van 'hun' belangrijkste bijdragen ${ }^{57}$. In zijn afsluiting herhaalt Van Rood nog eens zijn felicitaties, vraagt of ze nog iets nodig hebben en spreekt de verwachting uit dat na dit 'eerste schaap, er meer zullen volgen' (van Rood, 18 december, 1967 ) ${ }^{58}$. Van Rood schrijft verder dat het eerbetoon dat zij hebben mogen ontvangen hen 'quite a lot of good' heeft gedaan, maar dat niet iedereen even blij is met de berichtgeving.

... the older people in the faculty are a bit upset about what they call unwanted publicity. (van Rood, 28 december, 1967 )

In een reactie op de brieven van Van Rood verontschuldigt Botha zich daarvoor en laat daar direct een aanklacht tegen de pers op volgen.

If some of your senior colleagues are upset about publicity in the lay press, I am indeed sorry. There cannot be any other medical people in the world, at the moment, who know better than Chris Barnard and myself how impossible it is to avoid unwanted and unpleasant publicity, once the news media decide that they want to make news.

We can decide that we will keep our mouths closed, but these vultures always find somebody who is willing to talk, and from a few casual bits of information, they make a very long story. (Botha, I5 januari, 1968)

$\mathrm{Na}$ het geven van zijn reisschema voor de komende tijd, met een optreden voor de BBC en hopelijk een verblijf in Leiden, en met informatie over de typering en het beloop van de tweede harttransplantatie, sluit hij zijn brief af met:

With my kindest regards, and warmest direct, personal thanks for my undeserved and unwanted "fame", in the lay people's mind, as a transplantation

S6 Op 30 december verschijnt in het South African Medical Journal een artikel getiteld: "Human heart transplantation-the tissue typing tests" $($ Botha, 1967$)$. Later wordt dit gevolgd door een artikel in de Lancet (Botha, 1969).

57 Als belangrijkste bijdragen noemt Van Rood:

1 recognition of pregnancy as a stimulus per se for the formation of leukocyte antibodies....

2 The realisation that the strong antigens ought to give rise to antibodies with a similar but not identical pattern of reactivity and the realization that a simple statistical method as carried out by computers, would enable us to select such sera. Our best publication is the $\mathrm{ICl} \mathrm{tg}_{9}$. I think that this is really our main contribution.

3 The method of the preimmunized recipient.

4 I am not able to see quite how important our last publication regarding the question whether donor and recipient who must be really identical instead of only compatible, is. I think it might turn out to be quite important indeed. ...

5 The Eurotransplant idea is of course not original. It certainly will involve a hell of a lot of hard work. (van Rood, 18 december, 1967 )

58 Daar voegt hij aan toe dat de gevolgen nog wel eens groter uit kunnen vallen dan ze op zichzelf al zijn. Because the whole thing is so emotionally loaded, 1 foresee important changes in the attitude of the public as a result of this operation, which might even in the long run far out way the consequences which in themselves are already really staggering. (van Rood, 18 december, 1967 ). 
immunologist, (Botha, 15 januari, 1968)

Ook collega's schrijven Van Rood met vragen naar aanleiding van de publiciteit. Pavol Iványi uit Praag vraagt naar de betrokkenheid van Van Rood en zijn mensen bij het typeren voor de harttransplantatie. Tot dan toe hebben zij hun informatie vooral uit de krant moeten halen en daarin werd een maal Van Rood genoemd, als zijnde degene die de typeringen had uitgevoerd. Hij wil graag weten hoe de vork nu precies in de steel zit (Iványi, 25 januari, 1968). Volgens Van Rood had Leiden "little to do with the African business". Maar in het vervolg van de brief maakt hij duidelijk dat er wel banden zijn.

I know Botha for many years and his technician in charge of tissue typing is a

girl who worked with me for something like ten years. After this period she immigrated to South Africa, came back for a holiday and worked again 9

months with us to learn tissue typing. Of course we gave our sera along when she went back to South Africa and these were used in both cases.

I have seen the results of the Washkansky case and as far as I can make out

from this, the match was indeed quite good. (van Rood, 31 januari, I968)(sic) ${ }^{59}$ Naast reacties uit professionele kring, krijgt Van Rood ook van het publiek allerhande verzoeken en vragen 60 .

De 'media hype' - zoals we het nu noemen - rond de eerste harttransplantatie dringt tot Leiden door. Zo krijgt Van Rood ook een verzoek van de BBC om mee te werken aan een documentaire over de 'Immunologen'. De recente publiciteit rond orgaantransplantatie speelt hierbij een belangrijke rol. De 'Senior Science Producer', Philip Daly schrijft:

Immunology, I realise, is an extremely difficult subject for a television audience but I believe the recent organ transplant have focused popular attention on the immune response and made the lay public eager to know more. I am also aware that there are several exceptionally good expositors in this field who might be prepared to accept the challenge of explaining their work to an interested audience. (Daly, 7 juni, 1968)

Verschillende mensen van naam zullen worden gevraagd om mee te werken. Van Roods bijdrage zal gaan over 'tissue typing', dieper ingaan op 'the uniqueness of the individual" en over "Euro-transplants"61. Op dit verzoek

59 Zie Bijlage 9: 'Match' van de eerste harttransplantaties in Kaapstad.

60 Veel reacties van het publiek zijn vragen over hoe men als donor kan fungeren. Dit soort vragen zullen in de volgende paragraaf behandeld worden.

Daarnaast zijn er ook vreemdsoortige vragen. Zo vraagt iemand om een 'testikeltransplantatie', een verzoek dat Van Rood doorverwijst naar Amos. Om redenen van privacy kan ik hier slechts een geannonimiseerde referentie van geven. (Patiënt T., I september, 1968)). Half serieus, half schertsend schrijtt Amos de man terug (c.c. Van Rood).

Dr. Van Rood was indeed too modest in referring you to me, It is true that the transplantation of testicles is of interest to all immunogeneticists, but most attempts have unfortunately failed. It is, however, rumoured that Dr. van Rood has been successful and has himself received an implantation of a third testicle from a bull. Perhaps he could confirm this and explain the procedure and effects in more detail. (Amos, 20 september, 1968)

Dit is meer een grap onder collega's, dan een serieus ingaan op de vraag van een patiènt, maar over het algemeen gaat men op verzoeken om informatie en hulp wel serieus in.

61 In de outline van het programma worden de verschillende bijdragen genoemd. DRAFT OUTLINE OF PROPOSED 50 MINUTE BBC-1 DOCUMENTARY ON "THE IMMUNOLOGISTS" In the main each contributor would be filmed in an interview situation with DR. STEPHEN BLACK who would also link and narrate the programme.

I. DR. STEPHEN BLACK Opens programme with references made to recent surgical attempts to 
reageert Van Rood positief ${ }^{62}$. De documentaire wordt gemaakt en krijgt bij uitzending, begin oktober, de titel mee: 'The Trouble With Being One Self'. De documentaire wordt goed ontvangen, zowel bij de BBC zelf, als bij de overige pers (Baker, et al., 15 oktober, 1968).

Uit eigen land komen ook verzoeken om mee te werken aan documentaires. Zo maakt de Medische Faculteit Rotterdam een film over Transplantatie, waarbij voor het deel over 'weefseltypering' volledig op de inbreng uit Leiden wordt afgegaan (Hooghoudt, 1969). Ook dit verzoek wordt gehonoreerd en er worden verschillende scènes opgenomen in Leiden. Het oorspronkelijke script, dat door de heer Hooghoudt van de audiovisuele dienst van het Academisch Ziekenhuis Dijkzicht wordt toegezonden, rept met geen woord van Eurotransplant, maar veel van het werk dat door Eurotransplant wordt verricht, is al wel verbeeld, zoals blijkt in het begin van het script ${ }^{63}$.

Helikopter komt overvliegen over stad; mensen op terrasje kijken op.

Beelden uit helikopter, piloot met helm; spanning.

Mensen op weiland (witte jas) kijken naar lucht. Man kijkt op horloge en daarna weer gespannen naar de lucht.

Helikopter komt met donderend geraas recht op camera aanvliegen.

Haren verwaaien, stof waait op, uit de helikopter komt een mannetje geklommen (wieken staan nog niet stil).

Man rent over weiland in richting van ziekenhuis; camera volgt hem op de voet

a.h.w. meerennend (camera schokt en trekt langs voeten man).

Man rent door gangen ziekenhuis en omstanders worden weggedrukt of

vluchten schichtig weg.

Man komt operatiekamer binnen waar alles en iedereen klaar staat.

Emmertje met orgaan wordt overhandigd. ... (Hooghoudt, 1969)

Voor de patiënt in deze documentaire is een orgaan beschikbaar, de chirurgen kunnen de transplantatie uitvoeren. Door een film over transplantatie zo te beginnen, wordt een specifiek beeld gegeven van de bijdrage van het transport. Het transport, als het meest spannende en heroīsche deel van het creëren van beschikbaarheid, wordt gebruikt als uithangbord. De beelden van 'spanning', 'snelheid' en 'voor dit transport moet alles wijken', onderstrepen het belang dat aan transplantatie gehecht

transplant organs from one person to another, and the immune reaction involved.

2. SIR PETER MEDAWAR Why is there an immune reaction? Its relation to the Uniqueness of the Individual.

3. PROFESSOR J.L GOWANS What is the mechanism of rejection? What cells are responsible?

4. DR. TERASAKI's film showing lymphocytes attacking and killing tumour cells in the same way as they attack and destroy a graft.

5. PROFESSOR NILS JERNE How cells recognise "foreignness" and how cells become immunologically competent.

6. SIR PETER MEDAWAR How to prevent cells artificially from going into the attack. Anti-Lymphocytic serum. Immuno-suppressive drugs. The possibility of an acquired tolerance?

7. DR. JAN VAN ROOD Tissue typing. Elaborates on the uniqueness of the individual. "Euro-transplants"

8. DR. K. BRUNNER The immune reaction in relation to malignant tissues.

9. FUTURE PROSPECTS Personal statements from each contributor. Possibility of heterografts. The ethical dilemma.

(Daly, 7 juni, 1968)

62 Zelfs ondanks ontstane wrevel ten aanzien van de $\mathrm{BBC}_{\mathrm{r}}$ nadat hij al enkele malen vergeefs om een copy van in hun laboratorium gemaakte opnamen heeft gevraagd (van Rood, 14 juni, I968).

63 Het script is voorzien van 'frames' (beeldschetsen) tussen de regels en van geluidsinformatie. 
(moet) word(t)(en). Het lijkt erop dat met het overdragen van het 'emmertje', het 'werk' kan beginnen. Zo gaat het script ook verder:

De problemen waarmee wij bij transplantatie te maken krijgen zijn van tweeërlei aard.

Allereerst hebben wij de chirurgische problemen. De moeilijkheden liggen

hierbij vooral op het gebied van de vaatchirurgie.

Meer en meer blijkt echter dat de grote problemen van transplantatie niet op

chirurgisch gebied liggen. ... (Hooghoudt, 1969)

In de rest van de film wordt alleen het matchen belicht. Dit wordt ingeleid door het beeld van een 'krantenkop', die de werkelijk 'grote problemen van transplantatie' laat zien.

Dit wordt op dramatische wijze geillustreerd door een patiënt die enige dagen na een chirurgisch geslaagde transplantatie plotseling ernstig ziek wordt en overlijdt. De kranten schrijven dan: getransplanteerd orgaan werd afgestoten (of vergelijkbare tekst afh. van te verkrijgen kop.) (Hooghoudt, 1969)

Aangezien het een film is van - en waarschijnlijk ook voor - de medische faculteit, is het niet vreemd dat het grote probleem in de film 'afstoting' is. De film zal achtereenvolgens behandelen: (het mechanisme van) afstoting, de bestrijding en preventie daarvan met (minder) immunosuppressiva. Hierbij wordt weefseltypering als een van de methoden genoemd en wordt het principe van "matchen" uitgelegd64. Uit met de hand bijgeschreven tekst blijkt dat het werk van Eurotransplant toch iets meer aan de orde zal komen dan in de oorspronkelijke opzet, maar het blijft beperkt tot de keuze van een ontvanger uit het 'ET-telefoonboek'. Weefseltypering, waarbij het gehele verhaal over matching door Eurotransplant wordt inbegrepen, wordt in de film gelijkgesteld met een 'technisch probleem', dat, eenmaal opgelost, geen moeilijkheden meer zal opleveren. Alleen op ethisch gebied verwacht men blijvende problemen.

In de publieke pers wordt meer aandacht besteed aan maatschappelijke aspecten. Zo verschijnt in het 'Friesch Dagblad' van zaterdag 18 januari 1969 een artikel met de kop: "Nederlands pionierswerk voor orgaantransplantaties". In dit artikel wordt gesteld dat er weliswaar nog geen harttransplantaties in Nederland worden verricht, maar dat de eerste harttransplantatie door Nederlands onderzoek mogelijk is geworden.

Hartoperaties zijn in Nederland aan de orde van de dag, een harttransplantatie geschiedde er nog nimmer. Toch werd reeds de éérste Zuidafrikaanse hartoverbrenging mogelijk mede door Nederlands werk, verricht in 't weefseltyperingscentrum voor niertransplantatie van het Leidse Academisch Ziekenhuis en wel door de internist dr. J. J. van Rood en diens uit Alphen afkomstige medewerkster, mej. A. van Leeuwen. Als eersten in de wereld slaagden zij erin mensen op grond van hun witte bloedcellen - waaraan tevoren nooit veel aandacht was geschonken - in negen groepen in te delen. ... Dankzij dit team kunnen nu de weefselgroepen worden getypeerd, hetgeen vooral bij transplantaties van belang is. (Anonymus, 18 januari, 1969)

In dit artikel wordt, naast een historisch overzicht en uitleg, ook aandacht geschon-

64 De film zal verder gaan met een stukje over 'het donor-orgaan' en worden afgesloten met 'ethische aspecteri. (Hooghoudt, 1969) 
ken aan wie als donor (kunnen) fungeren; dat 'in Leiden een computer annex een administratie staat te wachten op de opgave van zo'n ter beschikking gestelde nier' en wat er vervolgens wordt gedaan.

Van Leiden uit regelt de internationale organisatie "Eurotransplant" de nierverdeling voor de Benelux, West-Duitsland en enkele Engelse ziekenhuizen, terwijl 'n Deens centrum dat voor de noordelijke landen doet. (Anonymus, 18 januari, 1969)

Er moet volgens de auteur 'vanuit de maatschappii' worden bijgesprongen om 'technische problemen' op te lossen.

Tegenwoordig kan de - gekoelde - nier enige tijd in leven worden gehouden, zij het dat veelal de marineluchtvaartdienst-met-helikopters of de rijkspolitie-metsnelle-wagens bij de (ook internationale) overbrenging moeten worden ingeschakeld. Mede in verband met deze operaties komt - zoals in Leiden - bij een enkel ziekenhuis een helihaven. (Anonymus, 18 januari, 1969)

Wanneer vervolgens ook wordt verteld voor wie al dit werk van belang kan zijn en dat 'wanneer het orgaan vlug op gang komt, de patiënt het ziekenhuis veelal na veertien dagen kan verlaten', ontstaat een beeld dat mensen op verschillende manieren aanspreekt. Door te appelleren aan het chauvinisme, plaatst men de Nederlandse medische wetenschap op een voetstuk. Verder wordt de mogelijkheid geschetst dat men hiervan deel kan uitmaken, als (onverhoopt) slachtoffer van een (auto)ongeluk. Daarnaast wordt transplantatie tot een zaak van algemeen en nationaal belang gemaakt door de inzet van de marineluchtvaartdienst en de politie te noemen. Wanneer al deze inspanningen dan resulteren in de mogelijkheid om iemand, die voordien aan het dialyseapparaat was gekluisterd, na veertien dagen met een 'nieuwe nier' uit het ziekenhuis te ontslaan, kan de lezer haast niet anders dan grote sympathie voor de transplantatiegeneeskunde voelen.

De 'positieve berichtgeving in de pers' is op meerdere wijzen van belang voor de transplantatiepraktijk. Enerzijds wordt een positief beeld geschetst, anderzijds zorgt het ervoor dat het publiek geneigd is 'actief' medewerking te verlenen. Dit is een reden waarom medici die publiciteit ook zoeken. Zo zegt Van Rood tegen de heer Roos van de Telegraaf (redactie wetenschappen), verbaasd te zijn dat nog geen journalist hem heeft benaderd over "twee jaar Eurotransplant". Dit blijkt echter veroorzaakt door een communicatiestoornis, want $\mathrm{er}$ is al herhaaldelijk verzocht om een interview met Van Rood 'over dit belangwekkende onderwerp' en hij ziet dit dan ook 'graag tegemoet' (Roos, 5 januari, 1970).

Met de toename van het aantal niertransplantaties, ontstaan ook kritische geluiden over aspecten van de transplantatiepraktijk. Zo stelt Bulterman in zijn artikel ook de kosten van vervoer aan de orde en noemt dat al in de ondertitel: "NIERTRANSPLANTATIES NEMEN SNEL TOE Naar schatting tweehonderd vijftig in I970; Defensie draagt kosten van vervoer." Hij begint het artikel vervolgens met recente ontwikkelingen op het gebied van de transportkosten.

Tussen de ministeries van Volksgezondheid en Defensie zijn sinds kort besprekingen gaande over de vraag hoe in de nabije toekomst het kostenvraagstuk met betrekking tot het vervoer van voor transplantatie bestemde organen moet worden opgelost. Dit is met name actueel in verband met het toenemend aantal niertransplantaties. (Bulterman, 7 juli, 1970)

Het aantal transplantaties is echter nog dusdanig dat de kosten (nog) geen groot probleem vormen. 'De toestellen moeten toch gedurende een bepaalde periode een 
voorgeschreven aantal uren in de lucht zijn'65. In de rest van het artikel wordt uitgebreid en positief bericht over wat Eurotransplant is en hoe gewerkt wordt. Verder worden in het artikel toekomstige ontwikkelingen besproken, waaronder de discrepantie tussen het aantal patiënten op de wachtlijst, het aantal verkeersdoden en het aantal beschikbare nieren.

Het grote tekort aan transplantatie-nieren valt overigens moeilijk te rijmen met het grote aantal mensen dat jaarlijks in het verkeer omkomt. Volgens sommige medici moet het mogelijk zijn dat deze categorie elk jaar tenminste 150 nieren "oplevert". (Bulterman, 7 juli, 1970)

Het tekort aan donornieren wordt overigens niet toegeschreven aan een gebrek aan bereidheid bij het publiek om organen voor transplantatie te doneren, maar aan onvoldoende actieve medewerking (bewust of onbewust) in de ziekenhuizen waar verkeersslachtoffers worden behandeld alsmede aan technische problemen ${ }^{66}$. Als gevolg van het 'orgaantekort' zal een deel van de patiënten chronisch gedialyseerd moeten worden, waarvan een deel overlijdt voordat een nier beschikbaar is.

Het beeld dat in de media wordt geschetst van de transplantatiepraktijk in het algemeen en de Eurotransplantpraktijk in het bijzonder is over het algemeen zeer positief. Transplantatie van organen is altijd nieuws geweest, maar de publiciteitsgolf na de eerste harttransplantatie maakt de orgaantransplantatie tot een, bij een breed publiek bekende en gewaardeerde, 'hoogtechnische' medische behandelingsvorm. Deze publiciteit en bekendheid mist zijn uitwerking niet: het Publiek reageert!

\subsubsection{2 'Publiek in Actie'}

De bekendheid die de transplantatiegeneeskunde in korte tijd verwerft, gaat gepaard met een gevoel van solidariteit met nierpatiënten in afwachting van een donornier. Een aantal mensen zet dit gevoel van solidariteit om in daden. Naar aanleiding van de harttransplantatie in Kaapstad, ontvangt Van Rood vele brieven van mensen die zich 'aanmelden' als donor ${ }^{67}$. Deze brieven worden prompt beantwoord met het verzoek om de huisarts over dit aanbod in te lichten en een briefje bij zich te dragen waarop deze wilsbeschikking kenbaar wordt gemaakt.

Zeer geachte Mevrouw van Broekhoven,

Hartelijk dank voor Uw brief d.d. 7 dec. 1967

Wij vinden uw aanbod zeer sympathiek en zouden $u$ willen adviseren dat $u$ en

uw man altijd een briefje bij u draagt met dezelfde inhoud als de brief die u naar

65 De opmerkingen over het dragen van de kosten van het vervoer door Defensie, blifken in het artikel minder kritisch bedoeld te zijn, dan de subtitel doet vermoeden. Veeleer wordt dit aangegeven als een mogelijke bedreiging voor het succesvol blijven functioneren van Eurotransplant, dan als een morele veroordeling van oneigenlijk gebruik van publieke middelen.

66 De auteur haalt in dit verband prof. dr H.W. ten Cate, hoogleraar in Amsterdam, aan die 'als vermoedelijke oorzaak van het feit dat dit niet gebeurt onlangs noemde':

- dat in ziekenhuizen waar verkeersslachtoffers worden behandeld onvoldoende of niet wordt gedacht aan het mogelijke gebruik voor transplantatie van de organen

- dat men er in deze ziekenhuizen misschien tegenop ziet de nabestaanden om toestemming te vragen. ofschoon volgens de hoogleraar een weigering vrijwel nooit voorkomt

- dat na het vaststellen van de dood, de nieren van de overledene tot op het moment van verwijdering nog als het ware in leven moeten worden gehouden, terwijl ook de bloeddruk op peil moet biliven.

(Bulterman, 7 juli, 1970)

67 (van Broekhoven-Vermeulen, 7 december, 1967: Hollweg, 9 december, 1967 ; Krudwig, 1o december, 1967: Stoffels, 18 december, 1967 ) Dit is slechts een klein aantal van de vele verzoeken om informatie en

aanmeldingen uit binnen- en buitenland. 
mij stuurde. U zoudt eventueel aan uw huisarts kunnen vragen zijn

handtekening erbij te zetten en te verklaren dat $\mathrm{u}$ helemaal gezond bent. (van

Rood, 14 december, 1967 )

Naast verzoeken c.q. aanmeldingen van particulieren krijgt Van Rood ook van het Groene Kruis een verzoek. Bij het Groene Kruis aangesloten leden vragen om een officiële kaart waarop vermeld staat dat zij bereid zijn na hun dood een orgaan af te staan. De heer Pleijsier van het Groene Kruis Den Haag schrijft op 22 december I967 een brief, waarin hij melding maakt van het verzoek van een aantal leden van hun vereniging "om ingelicht te worden over de formaliteiten inzake het na hun overlijden beschikbaar stellen van weefsels en organen voor transplantatiedoeleinden". Deze verzoeken wil hij niet geheel toeschrijven aan de recente publiciteit rond transplantaties.

Deze verzoeken blijken deels te zijn ingegeven door dagbladpublikaties als gevolg van de recente harttransplantatie, deels ook naar aanleiding van ons initiatief de Medische Informatiekaart een wijdere verspreiding te geven, door deze aan onze

leden kosteloos ter beschikking te stellen. (Pleijsier, 22 december, 1967)

Van Rood vindt dit een interessant idee en wil daar op de een of andere manier iets mee doen, maar vreest, door het uitblijven van verdere contacten, dat het "in de modder is blijven steken" (van Rood, 4 januari, 1968). Dit is echter niet het geval. Het idee van een donorcodicil - of dit nu een eigen brief, of een 'officiële kaart' betreft - gebruiken mensen om hun wens ten aanzien van het doneren van organen, kenbaar te maken. En in het artikel in het Friesch Dagblad, wordt dit ook genoemd als één van de bronnen voor donornieren.

Verscheidene overgeplante nieren zijn afkomstig van verongelukte mensen, van wie nabestaanden toestemming verleenden of die zelf een briefje-met-

toestemming bij zich droegen. Vooral omdat een verongelukt mens veelal verder gezond is, heeft het gebruik van zijn nier zin! (Anonymus, 18 januari, 1969)

\subsubsection{Actie uit 'Eigen' Kring}

De publiciteit rond transplantatie en vooral rond de eerste harttransplantatie heeft een positieve bijdrage geleverd aan de bekendheid van de transplantatiegeneeskunde en aan de bereidheid van het publiek daaraan een bijdrage te leveren. De toenemende behoefte aan donororganen vormt voor de direct betrokken medici ook aanleiding om initiatieven van allerlei aard te ontplooien. Men kan niet volstaan met de hoop dat mensen het initiatief nemen om een codicil bij zich te dragen. Er wordt geprobeerd om in ieder geval de eigen zaken in orde te hebben, dan wel te brengen. Zo wordt gekeken naar, voor de transplantatiegeneeskunde relevante, wetgevingen, die effect kunnen hebben op het aantal donororganen. Op een 'lang geleden gestelde vraag' aan de juridische werkgroep van het Nederlandsche Roode Kruis, "in verband met de vraag wat de bezwaren tegen het geen-bezwaar-systeem waren", krijgt Van Rood antwoord middels een fragment van de notulen van bijeenkomst van de Juridische Werkgroep d.d. 4 maart ' 70 . Van Rood stelde de vraag: "Wanneer mag de Staat inbreuk maken op de rechten van het individu? (m.b.t. orgaantransplantatie en de rechten op een lijk)" (Bes van Till, 17 april, 1970). Het antwoord wordt afgesloten met een samenvatting van de discussie hierover:

De Staat kan inbreuk maken op de rechten van het individu, zij het ook dat dit op wettelijke voorschriften moet berusten en dat bij de vaststelling daarvan rekening zal moeten worden gehouden met de rechten, die voortvloeien uit 
respectievelijk de grondwet en internationale verdragen. (Bes van Till, 17 april, I970)

Voor de toekomst is dit een gunstig perspectief. Eurotransplant ontplooit verschillende (praktische) initiatieven om het aantal donoren 'op peil' te houden. Deze initiatieven zijn niet zozeer van voorwaarden scheppende aard, maar meer gericht op het vergroten van het aantal donoren. Zo worden de in transplantatie geinteres. seerde ziekenhuizen, wanneer zij daar om verzoeken, geinformeerd over de mogelijkheden op dat gebied. In de tweede 'ET-Newsletter' van januari ' 69 , doet Van Rood verslag van hierop gerichte acties.

... there have been two more or less unofficial gatherings of people involved in Eurotransplant. One took place in Leiden in the middle of October and was especially organized to interest colleagues in the work of kidney transplantation in general and the idea of Eurotransplant more specifically. The main purpose of that meeting was to increase the number of offers of potential cadaver donors. The meeting has been a success and partly as a result of this, the number of donors made available has increased sharply. (van Rood, januari, 1969)

In de maanden die volgen blijkt echter, dat de aldus verkregen medewerking niet stabiel is. Het aantal donoren dat wordt aangemeld, blijkt nogal te variëren, hetgeen wordt toegeschreven aan het aanmeldingsgedrag van de collega's, niet aan variaties in het aantal 'geschikte' overlijdensgevallen. Vandaar dat tijdens de Eurotransplant Meeting op 18 mei wordt voorgesteld, na de zomer actie te ondernemen om het aantal donoren weer op te vijzelen (van Rood, juli, 1969). Het beperkte aantal aangemelde donornieren blijft echter een punt van zorg en ook voor dit probleem - net als voor het probleem van de werkdruk door het typeren - worden oplossingen deels in decentralisering gezocht, zoals blijkt uit een brief van Van Rood aan Terpstra.

Het lijkt me misschien het beste indien de verschillende donorziekenhuizen zouden "verdeeld" worden over de 5 à 7 transplantatiecentra waarbij dus ieder transplantatiecentrum de geestelijke begeleiding van een aantal donorziekenhuizen had.

Het transplantatiecentrum kan dan deze donorziekenhuizen regelmatig met patiënten besprekingen, operatiedemonstraties of eenvoudige drankgelagen proberen warm te houden. (van Rood, 21 april, 1970)(cursief MD)

Door de aanmelding van een donor uit de anonimiteit te halen, hoopt Van Rood dat de betrokkenheid van de donorziekenhuizen zal toenemen. Door collega's die de transplantatie uit willen voeren 'een gezicht' te geven voor de aanmeldende artsen en hen bekend te maken met de transplantatiepraktijk, hoopt hij hun persoonlijke betrokkenheid bij de transplantatiepraktijk te bevorderen, zodat zij in hun dagelijkse praktijk vaker aan de mogelijkheid van donatie zullen denken. Het feit dat deze betrokkenheid 'warm gehouden' moet worden, illustreert dat, ook onder artsen, niet alleen rationele argumenten een rol spelen bij de participatie in de transplantatie. praktijk.

De publieke opinie vormt een belangrijke factor in het ontstaan van de transplantatie-en matchingspraktijk, omdat gezondheid en gezondheidszorg hoog op de publieke agenda staan. Vooral de sectoren van de gezondheidszorg, die pogen een onafwendbare dood te bestrijden, staan in hoog aanzien bij het publiek. Toch is het niet zo dat de gezondheidszorg de publieke opinie per definitie mee heeft, laat staan dat meteen alle medewerking van het publiek verwacht mag worden. De manier waarop medische mogelijkheden in de publiciteit worden gebracht, zijn van grote 
invloed op de publieke opinie. Daarom betracht Van Rood nogal eens voorzichtigheid in (vermeend) contact met journalisten, maar tegelijkertijd gebruikt Eurotransplant de pers veelvuldig om een bericht de wereld in te sturen, waarmee positieve reacties uit het publiek worden verkregen. Men is zich wel degelijk bewust van de rol die de publieke opinie speelt in de ontwikkeling van transplantatiepraktijken. Daarom probeert men op verschillende manieren te anticiperen op mogelijk negatieve berichtgeving. Men wil de gekweekte goodwill niet in gevaar brengen, zodat uiteindelijk het aantal beschikbare donornieren zo groot mogelijk wordt.

\subsubsection{Maatschappelijk Draagvlak voor de Transplantatiegeneeskunde}

Eind jaren zestig is er een groot maatschappelijk draagvlak voor transplantatiegeneeskunde. Dit draagvlak is echter niet alleen 'veroorzaakt' door de (publiciteit rond de) harttransplantatie in Kaapstad, en ook niet door de ontwikkeling van Eurotransplant. Dit zijn slechts enkele factoren die hieraan bijdragen. Het feit dat in de loop van decennia de geneeskunde als geheel herhaaldelijk in staat blijkt om gezondheids- en levensbedreigende situaties het hoofd te bieden, zoals met penicilline, insuline, chirurgie of chemotherapie, heeft na de tweede wereldoorlog voor een groot vertrouwen in de geneeskunst gezorgd. Aan deze lijst wordt de transplantatiegeneeskunde toegevoegd. De verworvenheden van de geneeskunde vormen echter op zich geen afdoende verklaring voor het maatschappelijk draagvlak van de transplantatiegeneeskunde. Naast de bovengenoemde, meer algemene verklaringen, zijn er redenen aan te wijzen die specifieke groepen betreffen. Ten gevolge van uiteenlopende drijfveren kunnen mensen hun medewerking verlenen aan bijvoorbeeld onderzoek, wanneer hen dat gevraagd wordt. Zo kan medewerking worden verkregen door te appelleren aan een gevoel van (morele) plicht of aan loyaliteit. Morele plicht en loyaliteit verschillen slechts gradueel van elkaar, maar toch kan er een onderscheid in gemaakt worden. Als loyaliteit als een verplichting wordt gevoeld, of zelfs wordt afgedwongen, dan is er geen sprake meer van loyaliteit, maar van een 'morele plicht'. Met andere woorden, loyaliteit vindt zijn oorsprong in een positieve motivatie, terwijl morele plicht uit negatieve motivatie, namelijk angst voor morele veroordeling, voortkomt. Beide motivaties spelen van meet af aan een belangrijke rol in de ontwikkeling van de transplantatiepraktijk. In de volgende paragrafen maak ik het bovengenoemde onderscheid door bepaalde categorieën mensen te verbinden met een van beide motivaties. Dit wil echter niet zeggen dat iedereen dit ook daadwerkelijk als zodanig heeft ervaren ${ }^{68}$.

\subsubsection{Medewerking uit Plicht}

Het appel op morele plicht wordt bij verschillende groepen ook op verschillende wijze gedaan. In verband met de zorgverlening aan stralingsslachtoffers - waartoe het IRS (Instituut voor Radiopathologie en Stralingsbescherming ${ }^{69}$ ) is opgericht zijn er eind jaren ' 50 , begin jaren ' 60 , onderzoeken gaande naar behandeling van stralingsslachtoffers. Een van de mogelijke behandelingen is een beenmergtrans-

68 Het is goed mogelijk, dat iemand die ik bij loyaal indeel, het zelf wel degelijk als plicht zag en orngekeerd: dat iemand uit de categorie die ik met 'morele plicht' associeer, zijn of haar medewerking zelf puur als loyaliteit opvatte. Toch maak ik dit onderscheid, omdat ook mensen die een beroep op mensen uit deze categorielen doen, een vergelijkbare redeneertrant laten zien.

69 Zie Hoofdstuk 5. 
plantatie. Voor dit project zoekt men in 1960 donoren die, in geval van nood, beenmerg kunnen en willen afstaan. Hiervoor wordt geen advertentie in de krant gezet, noch wordt er een informerend artikel over gepubliceerd. Door rechtstreeks bepaalde instanties te benaderen, probeert men mensen te vinden die aan specifieke criteria voldoen. Van Rood schrijft in zijn 'Verslag van de vanuit het IHB ten bate van het IRS verrichtte werkzaamheden', dat, om mensen bereid te vinden 'in geval van nood" als beenmergdonor op te treden, geprobeerd werd om "een besloten groep te benaderen, waarvan bovendien enigermate op discretie kon worden gerekend" (van Rood, 1960). Deze bijzondere kenmerken denkt hij onder andere te kunnen vinden in de gelederen van de Rooms Katholieke Kerk. Vandaar dat contact wordt opgenomen met "de Praeses van het Seminarie te Warmond".

Deze beschikte aanvankelijk afwijzend. Na een persoonlijk onderhoud met de arts van het seminarie collega Walenkamp kan deze afwijzing ongedaan gemaakt worden en kon door collega Van Putten en collega Van Rood een persoonlijk onderhoud met de leerlingen van het Seminarie georganiseerd worden. Naar aanleiding hiervan hebben ruim 60 Seminaristen zich gemeld als adspirant beenmergdonores. (van Rood, 1960)

Kort na aanmelding en keuring van deze vrijwilligers, schrijft Van Rood aan Walenkamp, dat nog geen directe gesprekken met individuele personen nodig zijn, aangezien "het tijdstip van een eventuele donatie voorlopig nog ver verwijderd lijkt" (van Rood, 28 maart, 1960). Hieruit blijkt dat er op dat moment nog geen sprake is van uitvoering van een 'beenmergtransfusie' in de nabije toekomst ${ }^{70}$. Een belangrijk kenmerk van de groep is dus, naast een veronderstelde verhoogde geneigdheid om zich aan te melden als potentiële donor, ook dat de groep stabiel blijft ${ }^{71}$. Stabiel in de zin dat de mensen te vinden zijn wanneer het nodig is en ze, ook na langere tijd, nog bereid zijn om beenmerg te doneren. Bij deze aankomende priesters mag in ieder geval verwacht worden dat zij eenvoudig traceerbaar zullen zijn. Daarnaast wordt een beroep gedaan op hun hulpvaardige en opofferingsgezinde instelling ten aanzien van hun medemens. Toch moet ook deze groep 'onderhouden' worden. Door de nog aanwezige studenten die zich bereid hebben verklaard te het herkeuren, kan meteen bekeken worden hoeveel van de oorspronkelijk aangemelde potentiële donoren er nog beschikbaar zijn (van Rood, 12 december, 1961 ). In de jaren die volgen, blijven deze contacten, tot aan sluiting van het Seminarie in Warmond, bestaan. Er wordt regelmatig een beroep gedaan op de seminaristen om zich niet alleen beschikbaar te stellen als eventuele donor, maar ook om actief medewerking te verlenen aan uiteenlopende onderzoeken naar leukocytenantigenen, zoals immunisatieonderzoek en huidtransplantatie-experimenten. Daarnaast wordt een aantal van hen benaderd voor regelmatige plasmaforese. Opvallend hierbij is, dat gaandeweg, de doelstelling wordt verbreed van 'het fungeren als beenmergdonor', tot 'het fungeren als proefpersoon in verschillende experimenter'. Aan deze experimenten

70 Al bleek dit echter korte tijd later (eind 1960 ) toch wel de aangewezen behandeling te zijn, overigens zonder succes voor de betreffende patiënt. (Zie verder $\int 5.4$ Beenmergtransplantaties)

In de joer jaren is naar het idee van aangemelde potentiele donoren, de stichting Europdonor opgericht, die een databank beheert van potentiële donoren, die op basis van hun HLA-typering geselecteerd kunnen worden om voor een bepaalde patiënt het benodigde beenmerg te leveren.

71 Defensie wordt ook als betrouwbare instantie aangemerkt voor het verwerven van vrouwelijke donoren. 'Querido stelt de Marva voor als instituut waar mogelijk een stabiele populatie is te verwerven'. (Werkgroep Beenmergtransplantatie, 16 juni, 1960: Steenbergen, 5 augustus, 1960) 
zijn weliswaar enige risico's verbonden, maar daarvoor worden verzekeringen afgesloten. Daarnaast wordt deze mensen gevraagd om als leverancier van antiserum te dienen, wanneer zij, na immunisatie, een geschikt antilichaam blijken te hebben ontwikkeld. In 1964 kan men zich opgeven voor "plasmaforese en beenmergpunctie" (van Leeuwen, et al., 15 december, 1964 ) 72 .

De sluiting van het Theologicum en Philosophicum (in 1967) maakt - naast de toename van het aantal niertransplantaties - nieuwe wervingsacties noodzakelijk. Daarvoor wordt opnieuw toegang gezocht tot andere katholieke instituten via de Hoogeerwaarde Heer Haring, waarbij Van Rood verwijst naar de levensinstelling ten aanzien van de medemens'.

Zoals $\mathrm{U}$ misschien ook vernomen heeft, is het in de afgelopen jaren mogelijk geweest nieren van vrijwilligers te transplanteren bij patiënten die anders aan een nierinsufficiëntie zouden overlijden.

Onze afdeling is bij dit onderzoek betrokken omdat wij door het bepalen van de zogenaamde groepen van witte bloedcellen (de leucocytengroepen) aan

kunnen geven welke donor het beste bij een patiënt past. Om dit onderzoek naar behoren te kunnen verrichten moeten wij de beschikking hebben over vrijwilligers die bereid zijn eens in de 4 à 6 weken wat bloed af te staan. ...

In de afgelopen jaren hebben de studenten van het Philosophicum en het Theologicum te Warmond ons op bovengenoemde wijze geholpen. ... Nu echter het Theologicum en het Philosophicum uit Warmond gaan verdwijnen, zoeken wij naar een andere stabiele groep die qua levensinstelling bereid zijn om op deze wijze tijd (en wat bloed) aan zijn medemens te geven. ... Mijn vraag is of U zou kunnen bemiddelen dat wij, hetzij bij een klooster of bij een andere Katholieke instelling geintroduceerd zouden kunnen worden zodat wij medewerking voor ons onderzoek zouden kunnen werven. (van Rood, 9 mei, 1967)

De ervaringen met het Seminarie in Warmond hebben het vertrouwen in de naastenliefde van katholieken, waarop werd geanticipeerd, niet beschaamd en dat er door de opofferingsgezindheid van de seminaristen een stabiel panel gevormd kon worden $^{73}$. Voortbouwend op deze 'samenwerking' en wederom rekenend op de gevoelens van naastenliefde, wil Van Rood wederom specifiek bij katholieke instellingen donoren werven voor onderzoeksdoeleinden ${ }^{74}$, om daarmee het 'Leidse Panel' te kunnen versterken. Ook het eigen, 'Leidse Panel' moet onderhouden worden. Liefst dus ook weer uit katholieke kring, maar als dit niet mogelijk blijkt moeten andere groepen worden aangesproken. Ook deze groepen zouden liefst een vorm van morele plicht, dan wel loyaliteit moeten voelen, om hun medewerking aan het onderzoek te verlenen, door regelmatig bloed te geven.

Naast de donoren uit Warmond, waren veel van de donoren in het panel afkom-

72 (Bloedtransfusiedienst, 15 december, 1964; van Leeuwen, et al., 3 februari, 1965; van Leeuwen, et al., 26 mei, 1965: van Leeuwen, et al., 1966)

73 Een groot aantal seminaristen heeft ook bloed gegeven als onderzoeksmateriaal voor de tweede Histocompatibility Workshop. (Anonymus, et al., 1965)

74 Het eventueel fungeren als beenmergdonor is uit beeld verdwenen. Het is echter ook mogelijk dat dit achterwege wordt gelaten om de kans op medewerking te vergroten, aangezien het 'alleen geven van tijd en een beetje bloed' veel minder op bezwaren zou kunnen stuiten en de mogelijkheid om toch iemand als beenmergdonor te werven ook onderzocht kan worden op het moment dat dit bij een bepaalde paneldonor opportuun is.

Helaas heb ik niet kunnen achterhalen wat op het verzoek van Van Rood aan de heer Haring geantwoord is. 
stig uit het ziekenhuis ${ }^{75}$. Om daar opnieuw donoren te werven, vraagt Van Rood toestemming aan 'Hoofd afd. Personeelszaken der Rijksuniversiteit te Leiden', de heer Neuteboom. Hij wil een wervende brief verspreiden onder het - in het ziekenhuis werkzame - personeel van de universiteit.

In de afgelopen jaren hebben de personeelsleden van het Academisch

Ziekenhuis, zowel de leden van de medische faculteit, als zij die in dienst zijn

bij het ziekenhuis, hun medewerking voor deze onderzoekingen verleend. Met de toename van het aantal niertransplantaties is het echter nodig dat we deze groep vergroten. (van Rood, 3 mei, 1967)

In de wervende brief voor het AZL-personeel probeert Van Rood iedereen persoonlijk aan te spreken, door te verwijzen naar de in hun ziekenhuis behaalde successen. Het personeel heeft, door medewerking te verlenen, hier een belangrijke rol in gespeeld. Voor het toenemende aantal klinische bepalingen dat gedaan moet worden in verband met het toenemende aantal niertransplantaties, is een grote hoeveelheid antiserum nodig. Het panel speelt een belangrijke rol bij het verkrijgen van die sera. Van Rood legt uit dat de specificiteit van de positief reagerende sera, alleen met behulp van het panel kan worden bepaald.

De reagentia voor de bepalingen van deze witte bloedcelgroepen zijn helaas nog niet te koop. Deze moeten wij zelf vinden en gedeeltelijk maken. Dit is minder moeilijk dan het zo lijkt, omdat ongeveer een kwart van de vrouwen die één of meer kinderen hebben gehad antistoffen vormen waarmee deze groepen herkend kunnen worden. Voor het vinden van deze antistoffen en de karakterisering van deze antistoffen is het echter noodzakelijk de beschikking te hebben over een groep mensen die bereid is om $1 \mathrm{x}$ per 4 à 6 weken wat bloed af te staan. (van Rood, 9 mei, 1967 )

Later lijkt men van familieleden van getransplanteerden te verwachten dat zij als het ware wat terug doen voor alles wat voor hun familielid gedaan is. Tijdens de vierde Eurotransplant Meeting wordt onder andere gesproken over het zoeken naar nieuwe antiserumdonoren, waarbij op medewerking van verwanten wordt gerekend, op grond van de verwachting dat zij een soort 'morele plicht' zullen voelen om mee te werken.

Finally, all present were again asked to assert their influence to procure good anti sera. Family members of patients who have been pregnant should all be screened for the presence of leucocyte antibodies. Only a few of them will carry good typing antibodies but these will almost certainly be willing to be plasmapheresed regularly and will so produce a large amount of top anti sera. (van Rood, maart, 1970)

Zo wordt een appel gedaan op 'morele plicht' bij verschillende groepen en op verschillende manieren. Bij de groep 'Katholieken' gaat dit via het geloof, bij medewerkers wordt geprobeerd hen medeplichtig te maken aan het succes, maar ook aan eventueel falen, terwijl bij familieleden gezegd lijkt te worden: wij hebben dit voor uw naaste gedaan, $u$ bent in de gelegenheid iets terug te doen voor ons, maar vooral voor al die patiënten die nog niet geholpen zijn.

75 Dit gebruikt Van Rood zelfs als argument om nieuwe paneldonoren onder het personeel te werven. als voortzetting van het verleden.

In de afgelopen jaren hebben ongeveer 500 mensen, die werkzaam zijn op het Academisch Ziekenhuis of bij de medische faculteit ons al met dit onderzoek geholpen. (van Rood, 9 mei, 1967) 


\subsubsection{Medewerking uit Loyaliteit}

In welke vormen speelt loyaliteit een rol in de ontwikkeling van de transplantatiepraktiik? Veel van de eerste niertransplantaties worden gedaan met donornieren die afkomstig zijn van een verwante van de patiënt. In een tijd dat een overledene nog niet of slechts zeer sporadisch als donor werd gezien, was men voor het verrichten van een transplantatie aangewezen op een levende donor. Steeds weer wordt er daarbij de nadruk op gelegd, dat het afstaan van een nier vrijwillig moet gebeuren en dat de gezondheid van de donor daarmee niet in gevaar mag worden gebracht. Loyaliteit aan de ontvanger moet de motivatie vormen om een nier af te staan. Iemand moet intrinsiek en positief gemotiveerd zijn om loyaal te zijn en te blijven. Wanneer hier verandering in komt, trekt men zich terug, of verandert loyaliteit in plicht, hetgeen niet altijd gewenst is. Uit loyaliteit willen vele verwanten graag een nier afstaan, die hun familielid, 'hun eigen vlees en bloed', weer gezond zal maken. Het afstaan van een nier is echter niet geheel risicoloos. Dat maakt deze vorm van doneren dan ook niet zaligmakend. Bovendien heeft niet iedere nierpatiënt een potentiële verwante donor. Vanwege deze problemen komt de nadruk steeds meer te liggen op het gebruik van kadaverdonoren. Maar ook dit blijkt, ondanks het oplossen van juridische belemmeringen, niet zo gemakkelijk te verwezenlijken.

We have got a new transplantation-law recently here in this country which allows us to take kidneys from cadavers, but we have still very great difficulties in getting donors in suitable numbers. We are practically only doing transplantations from living relatives. We are trying to extend our search for suitable cadaver-donors to various hospitals in the surroundings, ... (KissmeyerNielsen, 25 september, 1967)

Niet alleen is niet iedereen die overlijdt geschikt om als donor te dienen, ook kan het verkrijgen van toestemming om organen uit te nemen, een moeilijk te nemen drempel vormen. Loyaal zijn aan een familielid ligt meer voor de hand, dan loyaliteit aan een onbekende. Bij een onbekende rijst de vraag aan wie men nou eigenlijk loyaal is. Aangezien de ontvanger onbekend is, lijkt het loyaliteit aan een abstractie. Het lijkt op loyaliteit ten aanzien van de (transplantatie)geneeskunde. Donatie van een orgaan stelt de geneeskunde in staat om haar heilzame werk te verrichten voor een onbekende patiënt. Loyaliteit kweken voor een onbekende gaat via de abstractie van de geneeskunde en is veel moeilijker, dan iemand vragen om loyaal te zijn aan een familielid; een gegeven dat bijna van nature aanwezig is. Loyaliteit van familieleden is dan ook van groot belang geweest bij vele niertransplantaties. Niet alleen voor de betreffende nierpatiënten, maar ook voor het ontwikkelen van de transplantatiepraktijk.

In Leiden speelt loyaliteit ook een belangrijke rol op de achtergrond van de zich ontwikkelende transplantatiepraktijk. Mede dankzij de inzet van vele medewerkers van de bloedbank, die regelmatig hun eigen bloed gebruiken in experimenten en tests $^{76}$, kan de typerings- en transplantatiepraktijk zich in Leiden ontwikkelen. De loyaliteit met het eigen werk is dan ook zeker relevant, zelfs zonder dat een klinische toepassing in beeld is.

Buiten de persoonlijke loyaliteit van de onderzoekers en hun directe medewer-

76 Mevr. Van Leeuwen zegt, daar op terugkijkend, in een interview: "Ja, we werden wel getapt" (van Leeuwen, 6 september, 1994). 
kers, zijn ook verschillende instanties loyaal. Voorbeelden hiervan zijn: Het Academisch Ziekenhuis, als faciliteiten verlenende instantie; de Rijksuniversiteit Leiden, als onderzoeksomgeving; het ministerie van Sociale zaken en Volksgezondheid, als officiële internationale bemiddelaar en coördinator; en het Nederlandsche Roode Kruis als klankbord ${ }^{77}$. De loyaliteit van deze instanties bestaat daarin dat zij medewerking verlenen aan de ontwikkeling van de transplantatiepraktijk.

Het grote maatschappelijke draagvlak dat eind zestiger jaren bestaat, wordt ten dele gevoed door de op de eerste harttransplantatie volgende publiciteit. Transplantatiegeneeskunde lijkt te beloven, dat weer een aantal levensbedreigende gezondheidsproblemen kunnen worden verholpen. Dit maatschappelijke draagvlak komt tot uiting in de medewerking die wordt verkregen. Hierbij doet het er niet toe of deze medewerking voortkomt uit gevoelens van morele plicht, dan wel door loyaliteit. 78

\subsubsection{Financiering ET en ET voor Financiering}

Het opzetten van een organisatie gaat gepaard met kosten waarvoor financiering gevonden moet worden. Het opzetten van Eurotransplant lijkt op meerdere manieren van deze algemene regel af te wijken. Eurotransplant is geen organisatie die 'van de grond af' opgebouwd moet worden. Eurotransplant wordt eerder gebruikt om financiering te genereren voor werk dat voordien uit andere bronnen werd betaald 79 , dan dat het geld nodig is om Eurotransplant zelf vorm te geven.

Het opzetten van de Eurotransplant-organisatie kan gezien worden als een volgende stap in het leukocytenantigeen-, HLA-onderzoek. Dit onderzoek is stevig ingebed in de vakgroep Immunohaematologie \& Bloedbank van de Leidse Medische faculteit, c.q. het AZL. Op verschillende manieren krijgt deze groep financiering en andere vormen van ondersteuning. Daar profiteert het Eurotransplantwerk van mee. Zo schrijft Van Rood bijvoorbeeld aan Prof. Dr. L. Kukenheim Ezn., Secretaris der Senaat der Rijksuniversiteit Leiden, dat "per I april I968, door de Stichting Roode Kruis Bloedbank Leiden, aan de Bloedbank en afdeling Immunohaematologie een z.g. salonwagen ter beschikking werd gesteld", waar - zo gaat hij verder - op het ogenblik een belangrijk gedeelte van het histocompatibiliteitsonderzoek plaatsvindt (van Rood, 17 juni, 1968) en in dezelfde brief meldt hij dat Eurotransplant is opgericht.

77 (van Rood, 17 juni, 1968; Ministerie van Sociale zaken en Volksgezondheid, 4 februari, 1969; van Rood, 24 maart, 1970; Bes van Till, 17 april, 1970)

78 Uit verzakelijking van deze gevoelens, in combinatie met een aanhoudend donortekort, komen problemen naar voren als bijvoorbeeld 'doneren voor donoren' (alleen transplanteren wanneer de ontvanger, of diens verwanten tot donatie bereid zijn). Op basis van de loyaliteitsgedachte is dit standpunt verdedigbaar.

79 Deze bronnen zijn echter al eens dermate talrijk geweest, dat het beheer daarvan grote problemen veroorzakte, waarbij het bestuur van de Faculteit Geneeskunde het nodig vond in te grijpen en dit mede te delen aan het College der Curatoren van de Rijksuniversiteit Leiden.

Ter Uwer informatie delen wif U mede dat wil op 13 dezer een onderhoud gehad hebben met de heren Loeliger en Van Rood, betreffende een aantal zakelijke problemen, verbonden aan het uit verschillende bronnen gefinancierde en in verschillend verband uitgevoerde wetenschappelijke werk van laatstgenoemde. Geld uit de WHO en Dept. of Health USA, wordt beheerd door de administrateur van Interne Geneeskunde. ...

Bovendien heeft Prof. Querido zich bereid verklaard welwillend toezicht uit te oefenen op het geheel der wetenschappelijke werkzaamheden van Dr. van Rood en eventucel als bemiddelaar op te treden.

Wij menen dat aldus de gecompliceerde positie van dr. Van Rood zo goed mogelijk zal zijn geregeld. (Bestuur van de Faculteit der Geneeskunde, 22 juli, 1965) 
De verwevenheid van het leukocytenantigeenonderzoek met de transplantatiepraktijk in Leiden 80 - waar Eurotransplant dus uit voortvloeit - blijkt onder andere uit het gegeven dat Van Rood een copy kriigt van een brief van Struyvenberg ${ }^{81}$ (afdeling Nierziekten), aan Jongsma (Directeur Geneesheer AZL), waarbij hij een mogelijke kostenreductie van niertransplantaties schetst. De kosten van transplantatie op zich zijn dus wel van belang, maar Eurotransplant wordt in dit verband niet genoemd.

Het project Eurotransplant, is aanvankelijk één van de vele. De financiering van dit project vormt dan ook geen probleem. Maar wanneer Eurotransplant daadwerkelijk van de grond komt, vraagt het steeds meer aandacht, tijd, en ruimte, en wordt ook het kostenaspect een punt van zorg. Aanvankelijk wordt het voor Eurotransplant verrichtte werk betaald uit onderzoeksgelden. Maar met de groei van Eurotransplant ${ }^{82}$, wordt onder andere om de financiële aspecten beter te kunnen regelen, gezocht naar een vorm van institutionalisering. In dit verband is er sprake van dat Eurotransplant direct onder het ministerie van Volksgezondheid zal vallen, maar tevens wordt dan al als alternatief gesproken over een Stichtingsvorm (van Rood, 18 oktober, 1968$)^{83}$. Dezelfde financiële aspecten die institutionalisering vereisen, staan de oprichting van een Stichting echter in de weg. Zoals uit de notulen van de Eurotransplant Meeting van 18 mei ' 69 blijkt, vormt het gebrek aan geld het struikelblok rond de "Foundation act of the Eurotransplant Foundation".

The first question of course is what to do with the act. We have a choice between three possibilities:

a. To start the organization under the Foundation act right away. This is at the moment rather difficult because there are no funds available.

b. To wait until funds are available and then to start to use really the Foundation.

c. To dissolve the Foundation right away.

After some discussion it appears best to stick to possibility 2 . In other words.

First will be attempted to solve the financial problems and then the organization

80 Zie ook Hoofdstuk s.

81 Struyvenberg is in Leiden iemand die veel steun verleent aan het idee om leukocytenantigenen te matchen bij niertransplantaties, zoals Alexandre dat als chirurg vanaf het eerste uur vanuit Leuven is (van Rood, 11 augustus, 2000).

Struyvenberg luidt de noodklok over een tekort aan bedden in het Isolatiepaviljoen ( 4 bedden), waardoor aangeboden donornieren afgewezen moeten worden (Struyvenberg, 6 mei, 1969). (Evenals het IRS, is Eurotransplant één van de, aan het AZL gelieerde, organisaties, die tezamen met verschillende (ondersteuning verlenende) onderdelen van het ziekenhuis, in Leiden gezamenlijk de transplantatiepraktijk vormen.) Struyvenberg stelt dan voor een ander paviljoen van het AZL (het 'Balanspaviljoen') aan te passen voor semi-geisoleerde verpleging. Struyvenberg voert hierbij een mogelijke verlaging van de kosten als bijkomend argument aan. Semi-geisoleerd verplegen is blijkbaar goedkoper dan volledige omgekeerde isolatie, want Struyvenberg schrijf:

Naast het belang van cen ongehinderde voortgang van de transplantatiebehandeling, is een bijkomend voordeel van de hier aangegeven oplossing de mogelijkheid om door middel van een vergelijkend klinischbacterologisch onderzoek uit te maken of het in de toekomst nodig blijft om pas getransplanteerde patienten volledig geisoleerd te verplegen, dan wel of het mogelijk is om met een betrekkelijk eenvoudige semi-steriele verpleging dezelfde resultaten te behalen. (Struyvenberg, 6 mei, 1969)

82 Groei in het aantal patiênten op de wachtlijst, in het aantal aangesloten transplantatiecentra en typeringslaboratoria.

83 Van Rood schrijft dit aan de Beheerder van Interne Geneeskunde, Mr. B.W. Janssen: Er bestaan op het ogenblik plannen dat Eurotransplant inderdaad zou kunnen vallen onder de Volksgezondheid, met name is Siderius bereid de staatssecretaris te vragen een brief te schrijven naar W.H.O. opdat er een internationale integratie ontstaat. Dit neemt niet weg dat daarnaast een eventuele Stichtingsvorm, hetzij in verband, hetzij los van de Nierstichting, te overwegen blijft. Heb je hier nog verdere informatie over? (van Rood, 18 oktober, 1968) 
will start to function under the auspices of the Eurotransplant Foundation. (van Rood, juli, 1969)

Van Rood voegt hier aan toe dat "the department of Immunohaematology" voor het lopende jaar nog genoeg geld heeft om Eurotransplant te financieren, maar dat tegen het einde van 1969 geld beschikbaar moet komen voor voortzetting van de activiteiten 84 .

Op verschillende manieren wordt duidelijk dat het project Eurotransplant op zijn einde loopt en overgaat in een zelfstandige organisatie: de Stichting Eurotransplant. Deze overgang wordt gemarkeerd door de wijzigingen in de financieringsstructuur $^{85}$ en door veranderingen in de aansprakelijkheid. Op het moment dat Eurotransplant wordt ondergebracht in een stichting, ontstaat ook op dit gebied een nieuwe situatie. De beheerder van Interne Geneeskunde schept enige duidelijkheid in de hoofdelijke aansprakelijkheid van bijvoorbeeld laboratoriumpersoneel.

Voorbeeld: Fout in jouw "telefoonboek". De analiste die de foutieve bepaling maakte is in dienst van het Ziekenhuis en niet in dienst van Eurotransplant. Zo gauw we mensen in dienst van Eurotransplant krijgen wordt de zaak anders en moeten we een verzekering sluiten. (Janssen, 2 oktober, 1969)

Zolang personeel in dienst is van het ziekenhuis, is de betreffende persoon verzekerd. Voor Eurotransplant zelf ligt dit anders. Als stichting is Eurotransplant een zelfstandige rechtspersoon en kan in die hoedanigheid worden aangesproken, maar daarvan zijn de gevolgen niet zo ernstig.

... Op dit moment kan dus een onrechtmatige daad, begaan in het buitenland, Eurotransplant een claim kosten. ... Op het ogenblik kan er niets anders gebeuren dan dat Eurotransplant failliet zou worden verklaard. (Janssen, 2 oktober, 1969) Eurotransplant wordt een zelfstandige, onafhankelijke organisatie.

Aanvankelijk genereert Eurotransplant, als concreet en veelbelovend project, financiering, maar na verloop van tijd moet voor de steeds zelfstandiger functionerende organisatie gericht naar financiering worden gezocht. Door de groei en het klinische belang, is het feit dat Eurotransplant uit onderzoeksbudget wordt gefinancierd niet meer te legitimeren. Naast al bestaande en ter vervanging van bronnen moeten nieuwe financiering(svorm)en gevonden worden.

\subsubsection{Nationale Financieringsbronnen}

In de loop van de jaren is de financiering afkomstig geweest van verschillende bronnen ${ }^{86}$. Naast het ziekenhuis en de universiteit, die van oudsher voor een groot deel

84 De verwachting is dan immers dat de financiering door het NIH zal worden stopgezet.

85 Na enige tijd (en onderhandelingen met onder andere Delta Loyd, waar Van Rood familiaire banden mee heeft) wordt de gewenste lumpsum' financiering geregeld. Voor elke patiënt die wordt ingeschreven, ontvangt Eurotransplant een vast bedrag.

86 Zo schrijft Van Bekkum bijvoorbeeld aan De Graeff en Van Rood, lang voor het Eurotransplant-voorstel, rond het instellen van de 'transplantatiewerkgroep TNO' eind 1965 :

Het is nu de tijd om overtollige gelden van NIH. Radio Veronica, en het Anjerfonds te kanaliseren in deze nieuwe onderneming. (van Bekkum, 4 december, 1965)

Rond de oprichting van Eurotransplant worden ook nieuwe fondsen gecrelierd uit bestaand geld. Zo zijn daar het Privé Wetenschappelijk Krediet (PWK) van Van Rood en de stichting van het Ontwikkelingsfonds Immunohaematologie. Het PWK werd gevormd door geld dat Van Rood binnen de muren van het ziekenhuis met zijn privépraktijk verdiende, doch naar eigen zeggen, in tegenstelling tot collega's, dit geld niet besteedde aan salarisverhogingen van jonge artsen, maar gebruikte om (met geld van het IRS bijvoorbeeld) extra personeel aan te nemen.

... Het Prive Wetenschappelijk Krediet, waar ik dus, in tegenstelling tot mijn collega's, de gelden van de particuliere 
van de financiering verantwoordelijk zijn, worden vanuit verschillende nationale in. stanties bepaalde onderwerpen, die op enige manier te maken hebben met het leukocytenantigeen onderzoek of met (nier)transplantatie, gefinancierd. De aanloopperiode van Eurotransplant is goed verlopen, maar nu moet onderzocht worden of en hoe de organisatie kan worden geconsolideerd. Eurotransplant valt uiteindelijk niet rechtstreeks onder het ministerie. Er moeten dus andere voorzieningen worden getroffen voor het dekken van de kosten. Men probeert het ministerie echter op verschillende manieren te betrekken in de verdere ontwikkeling van Eurotransplant, bijvoorbeeld door het ministerie behulpzaam te laten zijn bij het regelen van de financiële ins en outs van Eurotransplant. Een belangrijk gegeven daarvoor zijn de werkelijke kosten die door Eurotransplant worden gemaakt ${ }^{87}$. Hiermee wendt Van Rood zich tot Dr. P. Siderius, directeur-generaal van het ministerie van Volksgezondheid.

... Na berekening is gebleken dat de kosten per patiënt ongeveer fl. tooo zullen bedragen. Dit wil zeggen de kosten van ongeveer drie dialyses of anders gesteld ro dagen dialyse behandeling.

Op het ogenblik bestaat er de mogelijkheid om de werkzaamheden van Eurotransplant onder te brengen in een Stichting. Dit zou echter alleen wenselijk zijn wanneer deze stichting ook de financiële consequenties van de Eurotransplant organisatie op zich zou kunnen nemen. (van Rood, 9 juni, 1969) Door bemiddeling van het ministerie wil hij in contact komen met de Ziekenfondsraad, om te kunnen bespreken welk vergoedingensysteem het meest geschikt is.

Wij stellen voor dat de organisatie het beste gediend zou zijn indien iedere patiënt een 'lidmaatschaps'prijs per jaar zou betalen aan de Eurotransplant Stichting, die de hoofdelijke onkosten voor dat jaar zouden dekken. (van Rood, 9 juni, 1969$)^{88}$

praktijk instopte. In die tijd zag ik nog steeds patiēnten. ... Die inkomsten die gingen integraal in het Prive Wetenschappelijk Krediet en dat waren niet minne bedragen. Dat liep in de tonnen. Het PWK en privépraktijk was en is het nog steeds een gebeuren dat in het ziekenhuis plaatsvindt. En de chirurgen gebruiken het bijvoorbeeld om de salarissen aan velbelovende jongere chirurgen aan te passen, zodat ze niet daar de periferie toe gaan. En het inkomen van een ambtenaar chirurg is in de orde van grootte van een derde of een kuart van een matig gesitueerie chinurg in de periferie. Dat gebeurt in mindere mate ook bij de interne vakken, Kindergeneeskunde. En wij waren dus in zoverre cen uitzondering dat we dat niet gedaan hebben en het geld gewoon in een PWK gestopt hebben en daandoor een enorme mate van zelfstandigheid hadden. We waren onafhankelijk van de universiteit... (van Rood, ct al., 17 juni, 1998)

Het Ontwikkelingsfonds Immunohaematologie is een overeenkomst tussen Van Rood en het AZL, ter compensatie van de gederfde inkomsten uit privéconsulten, door zijn grote bemoeienis bij Eurotransplant.

87 De slotalinea van de nota van Van Rood, waarin hij laat zien hoe de kosten van het histocompatibiliteitsonderzoek zijn opgebouwd $(f 850000,-$ voor ongeveer 800 patiěnten). luidt: Uiteraard zijn bovengenoemde berekeningen slechts een grove approximatie. Op het ogenblik wordt op verzoek van de commissie Haemodialyse en Niertransplantatie (Voorzitter Prof. Dr. Jhr. J. de Graeff), door de administratie van het Academisch Ziekenhuis te Leiden een nacalculatie verricht om te zien of deze getallen inderdaad juist zijn. (van Rood, ro juni, 1969)

De Interne Accountantsdienst AZL doet eind oktober 1969 verslag van haar nacalculatie, waarbij sommige kosten hoger uitvallen, en andere lager (Interne Acountantsdienst AZL, 31 oktober, 1969). In de begeleidende aanbiedingsbrief van dit rapport aan de Gezondheidsraad, geeft Van Rood aan dat moeilijk te voorspellen is hoe de kosten zich verder zullen ontwikkelen. Het aantal antigenen dat herkend kan worden neemt toe, terwi]l de technieken continu veranderen. Zo hebben meerdere factoren invloed op de kosten.

88. Dit voorstel werd tijdens de Eurotransplant Meeting op 18 mei 1969 al door de

Eurotransplantgemeenschap besproken in het verlengde van de discussie over het al dan niet oprichten van de stichting. Hoe de financiering te realiseren van de door Eurotransplant te leveren diensten? Men verwacht hierbij op problemen te stuiten bij de ziektekostenverzekeraars.

The easiest solution is of course to charge each patient in Eurotransplant a fixed sum per year. From this 
De ontwikkeling van Eurotransplant gaat voort, met meer patiënten op de wachtlijst, meer aangesloten transplantatiecentra en meer typeringslaboratoria. Maar enige maanden later schrijft Van Rood aan Siderius dat het aantal getransplanteerde patiënten in het afgelopen jaar de roo nog niet haalde, terwijl 500 het streefgetal was. Van Rood wil dat het potentieel aan kadaverdonoren in Nederland beter wordt gebruikt.

Nu alle voorbereidende werkzaamheden uit de weg geruimd zijn lijkt het essentieel dat ook op dit laatste punt de zaak echt ter hand genomen wordt. Hoe vreemd en luguber het ook mag klinken, dit is voornamelijk een organisatie probleem. Alleen in Nederland vinden er meer dan 2000 verkeersongevallen met dodelijke afloop plaats. Alleen al uit deze groep zou een veelvoud van de voor Nederland noodzakelijke nieren verkregen kunnen worden. Het is essentieel dat Nederland een bijdrage aan de "donorpool" levert, daar men niet kan verwachten dat, zoals het de afgelopen jaren het geval is geweest, andere landen en in dit geval met name België ons wel donororganen toestuurt, maar ze zelf nooit van ons ontvangt.

Zoals wij reeds in voorafgaande gesprekken mochten bespreken ligt het in de bedoeling een doorberekeningssysteem te creëren, waarmee ook de financiële problemen van Eurotransplant uit de weg geruimd kunnen worden. Voor het echter zover is, zal een belangrijke hoeveelheid administratief en

organisatorisch werk gedaan moeten worden. (van Rood, 1o oktober, 1969) Het is voor dit werk, dat Van Rood aan Siderius vraagt een 'administrateursplaats' ter beschikking te stellen. Op termijn zal die door Eurotransplant zelf worden betaald. Siderius antwoord positief:

Ter ondersteuning zal vanwege het Ministerie van Sociale Zaken en

Volksgezondheid een bijdrage worden verleend in de kosten van voorbereiding verbonden aan de opzet en organisatie van een Nederlandse "donorpool" in het kader van de Eurotransplant Organisatie.

De bijdrage bestaat daaruit dat voor een periode van een half jaar, 100\% rijkssubsidie zal worden verleend in de personeelskosten verbonden aan de instelling van een functionaris in de rang van administrateur. (Siderius, 21 november, 1969 )

Niet lang daarna maakt Van Rood gebruik van dit aanbod en dient bij het Ziekenhuis een aanvraag in om de heer H.M.A. Schippers aan te stellen als 'Administratief Directeur' voor Eurotransplant, waarbij hij ten aanzien van de financiering vermeldt, dat Eurotransplant van het ministerie van Sociale Zaken en Volksgezondheid een garantiesom ontvangt en toezeggingen heeft van Belgische en Duitse ziekenhuizen dat zij de benodigde gelden ter beschikking zullen stellen, terwijl met de $\mathrm{Ne}$ derlandse ziekenfondsen overleg in voorbereiding is (van Rood, 6 maart, 1970).

Van bestaande geldstromen kan lang gebruik worden gemaakt, maar structurele financiering van de Eurotransplant-organisatie is minder makkelijk te realiseren.

sum all expenses such as typing, computer cost, administration, transport etc, could be paid. During the discussion it became clear that most of those present thought it rather unlikely that the insurance companies would be willing to pay such a fixed price. Because non of these assurance companies were present at the meeting it was decided on the suggestion of De Graeff (Leiden), to install a number of national committees which would negotiate this problem directly with the local insurance companies. Michielsen (Louvain) agreed to arrange such a committee for Belgium, Siedek (Bonn) for Germany and Wijideveld (Nijmegen) for Holland. (van Rood, juli, 1969) 
Hierdoor wordt de financiering fragmentarisch ${ }^{89}$. De dreiging van droogvallen van de NIH-bron ${ }^{90}$ zorgde er eerder al voor dat ook TNO, in de persoon van Prof.Dr. J.W. Tesch, om aanvullende financiering werd gevraagd ${ }^{91}$.

Er wordt echter niet alleen nationaal naar financiering gezocht. Aangezien in het verleden ook uit internationale bronnen grote sommen beschikbaar zijn gekomen, biedt dit ook voor Eurotransplant mogelijkheden.

\subsubsection{Internationale Financiering}

Sinds 1965 heeft de Leidse groep, evenals drie andere groepen in Europa, een contract met het $\mathrm{NIH}^{92}$, waardoor jaarlijks een aanzienlijke som geld beschikbaar komt. In het eerste jaar zijn er nogal wat problemen over de uitvoering van het contractoverigens niet alleen met de Leidse groep ${ }^{93}$ - maar deze lijken voor een groot deel tijdens de jaarlijkse 'Contractors Meeting' te worden opgelost. De subsidie moet echter ieder jaar opnieuw aangevraagd worden en vormt dus geen absoluut zekere bron van financiering. In de 'Contract Renewal Application', die Van Rood in 1967 verstuurt, verzoekt hij een deel van het budget te mogen gebruiken voor het opzetten van Eurotransplant (van Rood, I2 december, 1967) ${ }^{94}$. Amos schrijft Van Rood, dat het waarschijnlijk wel goed komt met het NIH-contract.

Money is very scarce but our own program has not yet been cut back and in view of the publicity over the heart transplant, I don't think it will be. (Amos, 22 december, 1967$)$

Amos heeft gelijk, de NIH geldkraan wordt niet dichtgedraaid en de belangrijkste bron van relatieve rijkdom blijft bestaan.

Naast het NIH zijn er meerdere internationale instanties waar een beroep op kan

89 Zo wordt bijvoorbeeld de stichting Fondsenwervingsacties Volksgezondheid verzocht om 'financiering van het transport van donornieren' en krijgt Eurotransplant daarvoor een bijdrage van $f$ to.000,- (Emden, et al., 24 april, 1970).

90 Beêindiging van het contract is onafhankelijk van de relatie met Leiden.

Zeer onlangs is ons bericht dat de Amerikaanse regering, mede onder druk van de politieke situatie in de Verenigde Staten, en Vietnam, zich genoodzaakt zal zien het contract per 1 juli 1969 te beëindigen. (van Rood, 14 oktober, 1968)

De gevreesde opzegging van het contract vindt echter niet plaats en tot ver in de jaren ' 70 ontvangt het IHB geld van het NIH.

91 Ook hier betreft het een verzoek om een 'administratieve kracht' aan te mogen trekken, maar van meer uitvoerende aard dan de administratief directeur. Deze functie wordt nodig geacht gezien de snel toenemende werkzaamheden van Eurotransplant, waarbij de verwachting is dat dit niet meer uit NIH. gelden betaald zal kunnen worden. De taakomschrijving ornvat: administreren leukocytengroepen van ontvangers, donoren, computerrijp maken van gegevens, contact met CRI, het contact onderhouden met de centra (25) die medewerken aan het Eurotransplant project, die verband houden met het verzamelen van reagentia, die wij nodig hebben voor de leukocytengroepen bepalingen (van Rood, 8 oktober, 1968).

92 Datering contract: 24 juni $1_{965}$. Jaarijiks bedrag $\$_{40} 000-545000$

93 Ook Ceppellini heeft herhaaldelijk moeilijkheden met het NIH over de uitvoering van het contract. Het contract vraagt het vullen van de 'serumbank, terwijl de 'contractors' het contract daardoor wel eens als 'knellend' ervaren, zich teveel beperkt voelen in hun wetenschappelijke vrijheid. (van Rood, 2 december: 1965: van Rood, 17 november, 1965; Ceppellini, 1 april, 1966; van Rood, 22 april, 1966; Overman, 28 april, 1966; van Rood, 2 maart, 1966). Na de 'contractors meeting' schrijft Van Rood een bedankbrief voor de 'profitable visit to Washingtori.

I have the feeling that apart from a good deal of quite interesting scientific information exchange, the Meeting helped also in clearing away some misunderstandings and frictions. (van Rood, 28 november. 1966)

94 Daarnaast zullen andere projecten worden voortgezet, zoals de genetische studies met Ceppellini. antigeenisolatie en chemische karakterisering: screening en specificering van antisera. Het gevraagde budget bedraagt dan $\$ 54.860$, wat ongeveer overeenkomt met $f$ 200.000,- (uitgaande van een koers van is If 3,60 ) (van Rood, 12 december, 1967) 
worden gedaan. Via het IRS heeft de Leidse groep ook een ingang bij Euratom, waar fondsen kunnen worden gezocht. Op een verzoek in die richting reageert R.K. Appleyard aanvankelijk voorzichtig door te zeggen dat ze niet direct geld kunnen toezeggen voor Eurotransplant, maar wel een zeer positieve houding aan willen nemen (Appleyard, 25 oktober, 1967$)^{95}$. Hierop stuurt Van Rood een ruwe schatting ter hoogte van \$ 66000 naar Appleyard. Het betreft de kosten voor het eerste jaar van Eurotransplant, uitgesplitst naar ruimte, personeel en instrumentarium (van Rood, 5 januari, 1968).

Een andere instantie die een deel van de financiering voor haar rekening zou kunnen nemen, is de Whitehall Foundation. De Whitehall Foundation toont zich geinteresseerd, maar wil een en ander in een persoonlijke ontmoeting verder rechtstreeks met Van Rood bespreken (Wright Rumbough, 30 juni, 1967). Aan dit verzoek gehoor gevend heeft Van Rood een gesprek met Dr. G.P. Berry, (Technical Director van de Whitehall Foundation) zoals hij schrijft aan de leiding van Interne Geneeskunde en de Bloedbank Commissie.

Volgens de mij ter beschikking staande gegevens gaat het hier om een bedrag van ongeveer 100.000 gulden per jaar.

Indien dit geld inderdaad ter beschikking wordt gesteld, zal ik proberen zo min mogelijk voorwaarden hieraan te verbinden van de kant van de Foundation. Met name zal ik trachten toestemming te verkrijgen deze gelden ook voor nieuwbouw te gebruiken en voor het leggen van "internationale contacten en verspreiding van informatie op internationaal niveau".

Dit is min of meer een eufemisme voor reiskosten, die anders vrij moeilijk te verkrijgen zijn. Eventuele punten die hierbij waarschijnlijk voor de Foundation van belang zijn:

I. Het Eurotransplant project

2. De betekenis van de weefselantigenen voor het ontstaan en de behandeling van maligniteiten.

Beide onderwerpen zijn zo ruim dat zij, gezamenlijk met de toestemming om te bouwen, de mogelijkheid bieden om te doen met het geld wat wij willen. (van

Rood, 17 oktober, 1967)

Van Rood krijgt een uitnodiging voor een gesprek met Berry, die graag bijgepraat wil worden "on the important work that you are doing, ..." (Berry, 3 november, 1967). Kort na het gesprek stuurt Van Rood hem het "request for a grant from the Whitehall Foundation" 96 . De opzet om zo min mogelijk voorwaarden aan deze subsidie te verbinden lijkt niet helemaal te slagen, maar er wordt wel een behoorlijke subsi-

95 Op zich is Appleyard niet afwijzend, maar of er geld van Euratom komt blijft de vraag.

Although we are presently in a situation which prevents us to take any commitment for the future, I wish to let you know that we will certainly adopt a very positive attitude towards Eurotransplant. In order to prepare any future intervention of Euratom in this project, it would however be necessary to have an evaluation of the expenses. (Appleyard, 25 oktober, 1967 )

96 Dit verzoek voor het (gedeeltelijk) financieren van Eurotransplant omvat:

Een eenmalige bouwsubsidie van $\$ 80$ ooo voor een nieuw laboratorium (waarvoor de Nederlandse overheid een som van " $\$ 280,000$ " heeft toegekend ): een jaarlijkse subsidie voor een periode van vijf jaat van S ro ooo, voor "short term salaries, transportation and services"; voor eenzelfde periode jaarlijks \$ 10 ooo voor instrumenten; en een subsidie voor onderzoek naar automatisering van serologische tests, waarbij hij zegt dat het op voorhand niet te plannen is welke apparatuur over twee jaar noodzakelijk zal zijn: "For this reason a grant is requested for the purchase of as yet unspecified instruments of $\$$ ro,000.a year, for a period of five years' (van Rood, 8 december, 1967 ). 
die toegekend. Met ingang van Augustus 1968 krijgt het IHB van de Whitehall Foundation, \$20 ooo per jaar, voor een periode van drie jaar (van Rood, 3 juli, 1968). Met deze toezegging in de hand, probeert Van Rood om bij Siderius hierop weer een aanvulling te kriigen.

Zoals uit bijgaande stukken blijkt hebben wij van de Whitehall Foundation een grant voor drie jaar gekregen van $\$ 20,000$ U.S. per jaar. Wij worden slechts geacht van deze gelden werkzaamheden te verrichten op het gebied van de orgaantransplantatie in het algemeen. Ik heb vernomen dat het in principe mogelijk is onder de z.g. "stimuleringsregeling" te komen tot een overeenkomst met de Nederlandse regering, waarbij dit bedrag, uiteraard onder bepaalde voorwaarden, en tenminste nadat een werkgroep gevormd is, aangevuld kan worden met gelden van de Nederlandse regering. (van Rood, 2 september, 1968) Vooral uit de correspondentie vooraf, over de aanvraag bij de Whitehall Foundation, blijkt - zeker kort na het Eurotransplant-voorstel - hoe Eurotransplant vooral wordt gebruikt als uithangbord, als een hoog te waarderen resultaat van het leukocytenantigeenonderzoek. Het concrete karakter van de diensten die door Eurotransplant zullen worden geleverd, de verbondenheid met andere delen van de geneeskunde en daarmee de bijdrage aan het 'redden van levens' - wat vooral door de Zuid-Afrikaanse harttransplantatie(s) direct in beeld is gekomen - zorgen ervoor dat de geneigdheid om financiële bijdragen te (blijven) leveren, alleen maar wordt vergroot. Met Eurotransplant lijken beloften van bijna tien jaar leukocytenonderzoek te worden ingelost.

\subsection{De MatchingspraktijK EURotransplant}

Ruim een jaar na de 'Conference on Histocompatibility Testing' in St. Vincent, met de lancering van het idee van een Internationale Orgaanuitwisselingsorganisatie, doet Van Rood in Eurotransplant Newsletter No.I verslag van de eerste, informele Eurotransplant Meeting en van de vorderingen in de organisatie en coöperatie in het eerste jaar.

Until the end of August 296 patients of different dialyses centres have been typed. More than a roo of them are either transplanted, have died or were taken off dialyses. (van Rood, 1 september, 1968)

Vervolgens geeft hij een overzicht van het aantal 'aangesloten' centra in de verschillende landen, waaruit de "potential recipients" afkomstig zijn ${ }^{97}$, gevolgd door het aantal spoedtyperingen - "often during the nights and week-ends" - sinds september 1967 (32) en het aantal transplantaties dat daaruit is voortgevloeid.

They all concerned potential kidney donors. In total 20 kidneys of 13 donors were transplanted after typing. Of these 20 kidneys 14 were transported from one centre to another. (van Rood, I september, 1968)

Ruim een half jaar later (op I8 mei 1969 ) is er weer een Eurotransplant Meeting. Tijdens deze bijeenkomst, waar vertegenwoordigers van bijna alle met Eurotransplant samenwerkende centra aanwezig zijn, wordt gesproken over de groei die Eurotransplant doormaakt, maar ook melding gemaakt van opdoemende problemen ${ }^{98}$. De grote schommelingen in het aantal aangemelde potentiële donoren per maand

97 Nederland 6, Belgiè 5, Duitsland 4, Engeland $x$ en Zwitserland $x$ centrum

98 Ook hier geeft Van Rood weer een overzicht van wat er tot dusver is gedaan.

In the last year 128 potential donors had been typed. Of these, 128 donors 48 had been used: in 24 both kidneys could be used and of the other 24 donors only 1 kidney could be used. In other words 80 potential 
en de daarin afnemende tendens, zijn belangrijke punten van zorg. Dit staat lijnrecht tegenover de groei van het aantal patiënten op de wachtlijst. Het aantal aangeboden donoren moet omhoog gebracht worden, maar tevens mag het aantal patiënten op de wachtlijst verder groeien. Men spreekt zelfs expliciet over de optimale omvang van de wachtlijst (500), dat boven het huidige aantal ingeschrevenen ligt (350), waarmee Eurotransplant overigens wel de grootste functionerende organisatie is (van Rood, juli, 1969). Wat het aantal wachtende patiënten betreft, vindt men dat het optimum nog niet is bereikt. Toch verschijnt nog geen maand later een artikel in de Lancet, waarin Van Rood schrijft dat de wachtlijst groot genoeg is om voor vrijwel ieder aangemeld donororgaan een geschikte ontvanger voorhanden te hebben ${ }^{9}$. Wanneer hij het aantal potentieel beschikbare donoren relateert aan het aantal mensen op de wachtlijst, rekening houdend met de criteria voor de gewenste 'match', concludeert hij dat het niet nodig is het verzorgingsgebied te vergroten om de wachtlijst verder te laten groeien. Het stijgend aantal dialyseplaatsen zal voldoende 'op een niertransplantatie wachtende patiënten' opleveren.

Met het voorstel om meerdere regio's op te zetten, wordt een aantal problemen opgelost. De maximaal te overbruggen afstand blijft binnen de perken, de hoeveelheid werk voor Eurotransplant wordt hiermee gecontroleerd, de hoeveelheid te distribueren en te bewaren sera voor 'kruisproeven' blijft beperkt, het aan alle typeringslaboratoria leveren van een uniforme set antisera blijft realiseerbaar, en last but not least: verschillende groepen van het eerste uur, uit de 'Tissue Typing Club' krijgen de mogelijkheid om hun eigen evenknie van Eurotransplant op te zetten.

In een artikel in de Transplantation Proceedings gebruiken de schrijvers, onder aanvoering van Van Rood, een aantal van deze argumenten als verantwoording van het creëren van regio's. Daarbij worden overigens alleen die argumenten gebruikt, die in directe relatie tot patiënten staan; de meer organisatorische argumenten noemt men hier niet.

The area of the Benelux countries and north-western Germany comprises 50 million people among whom there will be, early next year, over 300 patients on chronic dialysis awaiting a transplant. On the basis of our more recent experience we feel that this number of patients is quite large enough to make it possible for over $80 \%$ of the donor organs to find a suitable recipient as they become available, even if a "suitable" donor-recipient combination is being defined as one in which donor and recipient are identical or mismatched for only one of the main HLA antigens as defined above. For this reason we have suggested that it might be opportune to divide Europe into regions, (van Rood, et al., 1969)

In het verlengde van de organisatorische voordelen van opdeling in regio's, sugge-

donors were typed but the kidneys were not transplanted. In half of the cases this was due to the fact that the condition of the kidneys was such that transplantation seemed not justifiable (e.g. hypertension, infection etc.). In $35 \%$ the patient recovered, in 10\% the family of the potential donor refused and in $5 \%$ there were difficulties with the anatomy of the donor kidney, there was a positive crossmatch etc. (van Rood. juli. 1969)

99 Overigens kunnen er, gezien de tijd die het duurt voor artikelen daadwerkelijk verschijnen, vragen gesteld worden aan het democratisch gehalte van de Eurotransplant Meeting. Voorstellen worden niet alleen voorbereid, maar dus ook al vertaald naar een groter publiek, zodat alleen met zeer goede en dringende argumenten daarop terug gekomen zal kunnen worden. Tijens de ET-meetings zal het meer neerkomen op het kweken van steun voor een bepaald beleid, dan dat het beleid daar gevormd wordt. De democratie moet dus gevonden worden in de structuur van de organisatie. 
reerde Van Rood eerder al dat de WHO als een soort coördinatiecentrum zou kunnen optreden (van Rood, 22 augustus, 1968). Voor het instellen van een "'super" Eurotransplant-file', lijkt hij het toch wenselijk te vinden om de onafhankelijkheid van de regio's enigszins in te perken. Tijdens een gesprek over de toekomst van Eurotransplant ${ }^{100}$ heeft Trnka gezegd, dat coördinatie door de WHO wel mogelijk is, wanneer de verschillende nationale overheden daarvoor een verzoek indienen. Hierop informeert Van Rood bij Siderius of de Nederlandse regering eventueel zo'n verzoek zou willen doen (van Rood, 31 augustus, 1968). Hij zegt erbij dat Ceppellini en Dausset al mondeling hebben toegezegd in principe bereid te zijn de organisatie van deze onderafdelingen van Eurotransplant op zich te nemen. Korte tijd later stuurt Van Rood een concept voor een brief aan de 'Director-General van de WHO' naar het ministerie van Volksgezondheid. Hierin zet hij nog eens de huidige situatie uiteen, waarbij hij opmerkt dat 'voorlopig in ieder geval de klinische samenwerking met de Belgische transplantatiecentra behouden is'101, maar dat het gunstig zou zijn wanneer dat ook op regeringsniveau geformaliseerd zou worden. Daarnaast zou het verzoek aan de WHO gedaan moeten worden om de regio-overstijgende coördinatie op zich te nemen (van Rood, 21 oktober, 1968).

Het succes van Eurotransplant wordt onder andere afgemeten aan het behalen van de doelstelling om beter gematchte donornieren voor transplantatie te leveren. Uit de gehanteerde criteria blijkt, dat hierbij het ideaal van een perfecte match wel wordt nagestreefd, maar geen absolute norm is. Beter dan 'random' wordt al gezien als een voordeel, ongeacht de vraag of dat ook klinische voordelen voor de ontvanger heeft. Het succes van Eurotransplant beschrijft Van Rood in de ze Newsletter als een verbetering in de gemiddelde mismatch.

On an average donor and recipient were only mismatched for 1.27 antigens

which compares favourably with the 3.00 mismatched antigens if

Eurotransplant had not been working. (van Rood, juli, 1969)

Daarnaast wordt het succes afgemeten aan het aantal daadwerkelijk verrichtte transplantaties, in combinatie met de kwaliteit van de 'match' en vergeleken met hoe die verdeling zou zijn geweest wanneer niet was gezocht naar de beste ontvanger voor een bepaalde nier.

4I patients have received a kidney graft via the files of Eurotransplant.

The HL-A matches, taking only the following antigens into account: $4 \mathrm{a}, 4 \mathrm{~b}, 6 \mathrm{a}$, $6 \mathrm{~b}, 7 \mathrm{a}, 7 \mathrm{~b}, 7 \mathrm{c}, 7 \mathrm{~d}, \mathrm{LA} 2$ have been as follows:

$\begin{array}{lrr}\text { identical } & 3 & (0,6) \\ \text { identical but one } & 16 & (6,0) \\ \text { identical but two } & 16 & (8,2) \\ \text { identical but three } & 6 & (9,0) \\ \text { identical but four } & \circ & (17,2)\end{array}$

If Eurotransplant had not been functioning the distribution would have been as given in parenthesis. (van Rood, januari, 1969)

Naarmate de tijd vordert en Eurotransplant de startfase ontgroeit ${ }^{102}$, spreekt men

100 Het gesprek tijdens de typeringscursus (augustus 1968) tussen Van Rood, Kissmeyer Nielsen, Batchelor en Trnka.

101 Dit ten koste van samenwerking van de 'franstalige' Belgische ziekenhuizen, met Frankrijk.

102 Dat Eurotransplant de startfase is ontgroeid, blijkt eens te meer uit de manier waarop met de leden van de Eurotransplantgemeenschap wordt gecommuniceerd. Vanuit het centrum: Eurotransplant, stuurt de 
ook in andere termen over 'succes': niet meer alleen in termen van verbetering van de match, maar ook in termen van groeiende aantallen. Enerzijds de groei in de zin van aantallen getypeerde patiënten en de 'dichtheid van het Eurotransplant netwerk van transplantatiecentra en typeringslaboratoria' ${ }^{103}$, anderzijds het aantal mensen dat daadwerkelijk getransplanteerd wordt nadat zij op de wachtlijst hebben gestaan. Daarbij is het overlijden van patiënten gedurende de periode dat zij op de wachtlijst staan $^{104}$, een punt dat zorgen baart, zoals Van Rood aan de Eurotransplantgemeenschap meedeelt in Newsletter no. 7 .

We are coming near to the moment that Eurotransplant will be functioning for two years. The situation is as follows: Over 1000 patients have been typed; 576 are awaiting a kidney transplant, $16_{2}$ were transplanted, of the others most died, a few were transplanted with kidneys from near relatives. The high mortality in the untransplanted patients poses us for a tremendous problem. These 576 patients awaiting a transplant are treated by $4 \mathrm{I}$ centres in The Netherlands, Belgium and Germany. Typing can be performed in 12 centres. Since May Ist, 1968,278 donors have been typed of which 106 were used: of 50 only one kidney was used and of 56 two kidneys were used. Resulting in a total of 162 kidney transplants. (van Rood, ro maart, 1970)

Ondanks het feit dat in toenemende mate vragen worden gesteld bij het nut van het selecteren van een ontvanger ${ }^{105}$, hetgeen Van Rood in de notulen van de vierde Eurotransplant Meeting erkent, houdt hij het belang van matchen overeind. Hij erkent dat matchen niet zaligmakend is, maar houdt vol dat dit het uiteindelijke resultaat gunstig beïnvloedt. De transplantatiepraktijk kan niet meer zonder Eurotransplant. De spilfunctie van Eurotransplant rond het verwerven, transporteren en toewijzen van organen, is hecht verweven geraakt met het geloof in matchen. Dat alles tezamen heeft ervoor gezorgd dat, in haar verzorgingsgebied, de matchingspraktijk Eurotransplant, een gevestigd en geaccepteerd onderdeel van de transplantatiepraktijk is geworden.

chinurg Terpstra, begin 1970, aan de collega's binnen de Eurotransplantgemeenschap de brief over de noodzaak van standaardisering van organisatie en transport en aangezien deze brief vergezeld gaat van een aantal manuals en voorschriften, lijkt daarmee een eind te komen aan het accepteren van lokale variaties (Terpstra, 1970; Eurotransplant, 1970).

103 Naar buiten toe wordt vooral dit criterium als succes geêtaleerd, zeker wanneer daarmee mogelijk weer een 'maas in het net' kan worden gedicht (van Rood, 17 maart, 1970).

104 Ongeveer een kwart van de aangemelde patiënten overlijdt voor transplantatie.

105 Zie ook hoofdstuk 6. 


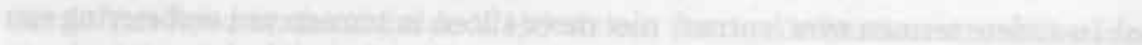

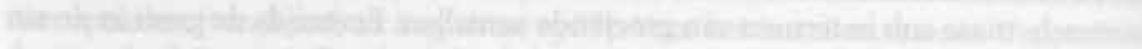

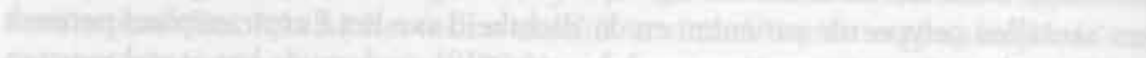

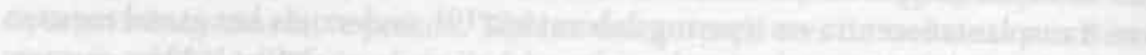

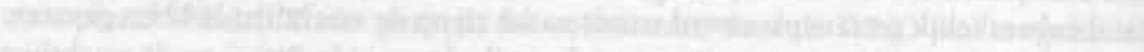

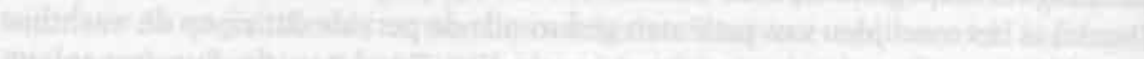

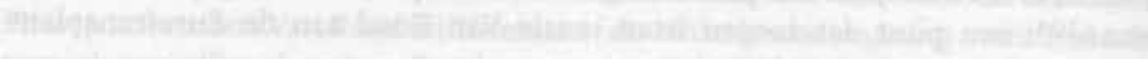

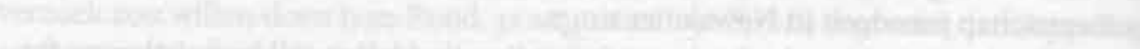

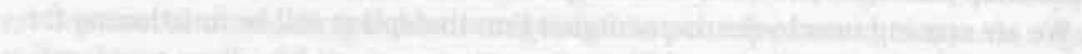

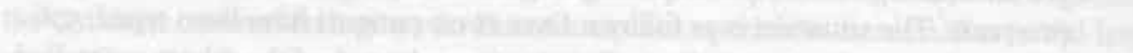

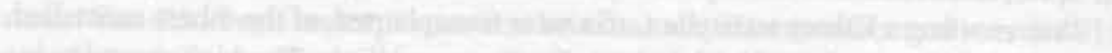

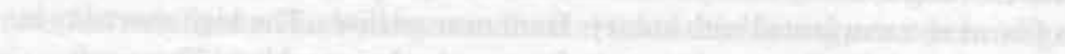

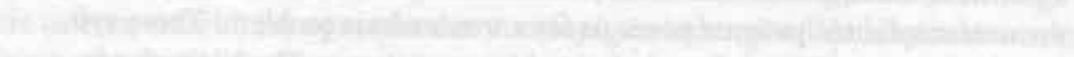

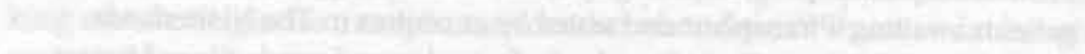

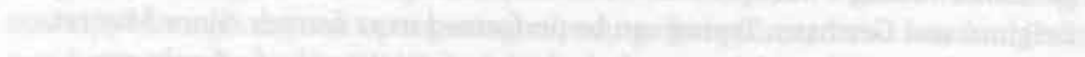

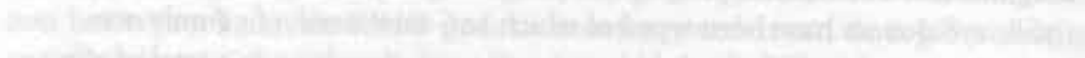

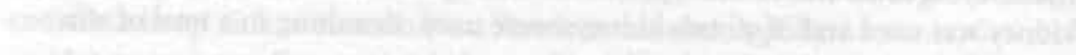

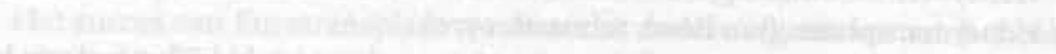

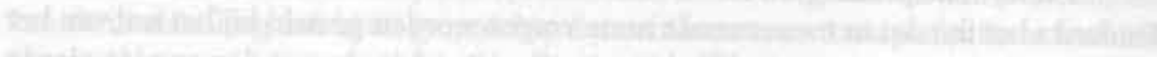

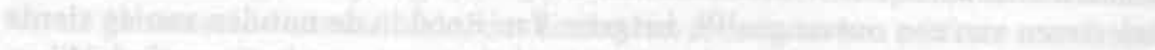

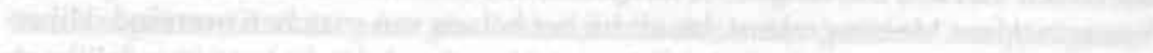

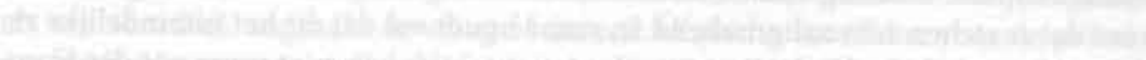

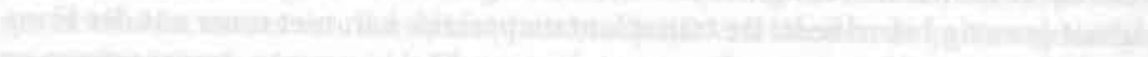

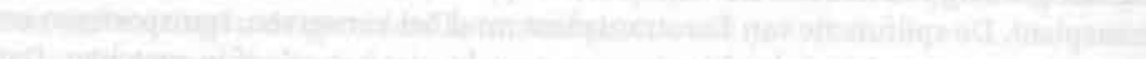

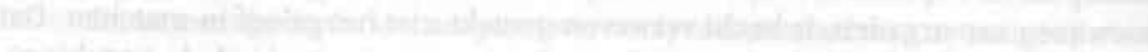

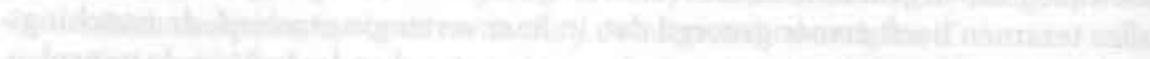

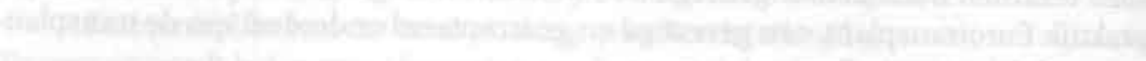

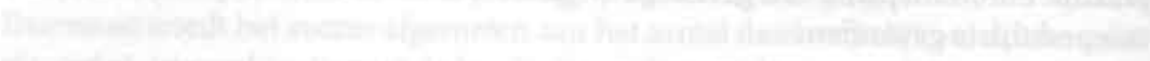




\section{EPILOOG}

\subsection{INLEIDING}

De transplantatiepraktijk is een succesvolle praktijk. Het is een praktijk die voor een belangrijk deel door Eurotransplant mogelijk wordt gemaakt. In dit boek is het ontstaan van Eurotransplant beschreven aan de hand van verschillende thema's. Door die thema's in afzonderlijke hoofdstukken te bespreken, is inzicht gegeven in de ontwikkelingen in de complexe transplantatiepraktijk. Door het gehele boek spelen twee centrale vragen: wat is Eurotransplant en waar is de Eurotransplantpraktijk op gebaseerd? In de eerste hoofdstukken ligt de nadruk op de ontwikkeling van kennis over het HLA-systeem en de praktijken die zich in samenhang daarmee vormen. Naarmate het boek vordert, verschuift de nadruk van de vorming van kennis naar de vorming van praktijken die de kennis als het ware waar moeten maken. Een onderliggende vraag in het boek is of de kennis over het HLA-systeem het bestaan van Eurotransplant legitimeert, of dat het bestaansrecht van Eurotransplant misschien (mede) op andere gronden is gebaseerd.

Ten tijde van de oprichting van Eurotransplant is transplanteren zonder risico op afstoting nog een belofte en hoopt men deze belofte door verder onderzoek naar het HLA-systeem in te lossen. Als dit lukt, dan zal de kwaliteit van de match een geldig medisch criterium zijn. Matchen blijkt echter niet de Heilige Graal van de transplantatiegeneeskunde te zijn en succesvol transplanteren zonder immunosuppressiva te gebruiken blijkt in de praktijk niet haalbaar. Toch geniet Eurotransplant een groot aanzien op basis van de toepassing van het medisch criterium. Met de kwaliteit van de match als criterium voor wie in aanmerking komt voor een donornier, heeft de transplantatiepraktijk een neutraal, op medisch-wetenschappelijke kennis gebaseerd verdelingscriterium. Dit criterium lijkt gericht op vergroting van de kans op een - ook op langere termijn - succesvolle transplantatie voor de patiënt. Maar wordt het gegeven dat patiënten moeten wachten op een geschikte nier wel gelegitimeerd door het belang van matchen? Op deze vraag kan geen simpel antwoord worden gegeven.

In dit boek is beschreven hoe een typeringspraktijk ontstaat binnen de transplantatiepraktijk en hoe verschillende problemen leiden tot de Eurotransplantpraktijk. Als samenvatting en beschouwing zal in dit hoofdstuk kort terug gekomen worden op de ontwikkeling van het fundament, het HLA-systeem, vervolgens op de fusie van de immunohaematologische laboratoriumpraktijk met de chirurgische transplantatiepraktijk, en tenslotte op het uitgroeien van deze nieuwe matchingspraktijk tot de medisch-maatschappelijke organisatie Eurotransplant. Na deze uiteenzettingen volgt een slotbeschouwing over het legitimiteitsvraagstuk. 


\subsection{BOUW VAN EEN FUNDAMENT}

Door middel van immunisatie-experimenten heeft Medawar in de jaren 40 laten zien dat afstoting door leukocyten wordt veroorzaakt en dat het immuunsysteem beinvloed kan worden zodat een transplantaat wordt getolereerd. Begin jaren 50 identificeert Dausset de antigenen op leukocyten als de veroorzakers van de immuunreactie. Maar pas nadat Van Rood en Payne - onafhankelijk van elkaar - in 1958 in het serum van 'zwangere' vrouwen een stabiele bron van antilichamen vinden, komt het onderzoek naar leukocytenantigenen echt tot ontwikkeling. Nu kan gezocht worden naar een verklaring voor het gegeven dat monozygote tweelingen elkaars organen na transplantatie tolereren en waarom in andere gevallen organen als 'vreemd' worden herkend. Na verloop van tijd wordt duidelijk dat er een antigeensysteem (het latere HLA-systeem) is, aan de hand waarvan het immuunsysteem eigen en niet-eigen onderscheidt. Daarmee wordt ook duidelijk waardoor de transplantatiechirurgie in het verleden soms succes had, maar meestal faalde. Dit inzicht maakt echter niet duidelijk of, en zo ja hoe, deze kennis over de transplantatie-antigenen gebruikt kan worden. Bij de mogelijke toepassingen van deze kennis wordt aanvankelijk nog niet gedacht aan transplantaties, maar kort daarop begint men zich af te vragen of die kennis over de mechanismen van het immuunsysteem te gebruiken zou kunnen zijn om de kans op afstoting van organen te verkleinen. Uit de transplantatiechirurgie was inmiddels bekend dat de kans op afstoting bij transplantaties tussen familieleden kleiner is dan bij transplantaties met een random gekozen donor. Zou kennis over het HLA-systeem meer inzicht kunnen geven in de achterliggende mechanismen van dit verschil? Zou dan ook te voorspellen zijn bij welke HLA. combinaties de kans op afstoting gering is? Dat zijn de vragen die eind jaren vijftig en begin jaren zestig van de vorige eeuw rijzen. Duidelijke antwoorden zijn er in eerste instantie niet. Theoretisch is het voorstelbaar dat kennis over het immuunsysteem zo kan worden vertaald, dat de kans op afstoting van organen wordt verkleind, maar of dat ook daadwerkelijk mogelijk zal zijn, is onzeker.

Ondanks bovenstaande onzekerheden komt de Eurotransplantpraktijk van de grond. Dat maakt deze praktijk tot een bijzondere: door bij de inrichting gebruik te maken van onzekere kennis over het HLA-systeem, wordt in zekere zin een hypotheek op de toekomst genomen. Men verwacht dat het succes van transplantaties aanzienlijk zal kunnen worden verbeterd, als rekening wordt gehouden met het HLA-systeem. Met deze belofte in gedachten, wordt Eurotransplant opgericht. De belofte moet echter nog wel worden waargemaakt. Omdat er in de beginjaren te weinig kennis is over de kenmerken van het HLA-systeem, is het echter onduidelijk of die belofte wel waar te maken is. Vandaar dat Eurotransplant, naast het matchen, ook de evaluatie van de verrichtte transplantaties ter hand neemt. Ook Eurotransplant heeft dan nog wel iets weg van "shooting buckshot in the air, hoping to strike an unspecified target" (Starzl, et al., I965). Desalniettemin heeft men van meet af aan geprobeerd de Eurotransplantpraktijk zo rationeel mogelijk aan de hand van de beschikbare HLA-kennis te organiseren.

Voor het functioneren van het medisch criterium in de transplantatiepraktijk heeft dit als consequentie, dat van meet af aan wordt gewerkt met een criterium waar haken en ogen aan zitten. Anders dan bij de introductie van insuline of penicilline in de medische praktijk, waarbij men - zo lijkt het althans - kan genezen aan de naald en succes min of meer verzekerd is, is het belang van matchen onzeker. Weliswaar is er theoretische zekerheid, want het geval van de identieke tweeling laat 
immers zien dat matchen op basis van het HLA-systeem belangrijk zou kunnen zijn, maar het is de vraag in hoeverre dit ideale geval benaderd kan worden. Zou het resultaat van een transplantatie verbeteren wanneer het HLA-systeem van donor en ontvanger - voor de antigenen die men dan kan herkennen - overeenkomen? Met retrospectief en prospectief onderzoek probeert men op deze vraag een antwoord te geven en te bepalen wat als goede overeenkomst geldt. Men weet niet hoe het HLA. systeem eruit ziet, hoeveel verschillende antigenen er zijn, of bepaalde antigenen cruciaal zijn in het kader van acceptatie/afstoting, et cetera.

Paradigmatische voorbeelden zijn er in het onderzoek niet. Het voorbeeld van de identieke tweeling functioneert niet als richtinggevend voorbeeld, want aangezien identieke tweelingen qua HLA-systeem hetzelfde zijn, kan dit voorbeeld geen inzicht bieden in de vraag in hoeverre de kans op een succesvolle transplantatie wordt bepaald door de mate van overeenkomst tussen HLA-systemen. Verder is onduidelijk of de dan bekende bloedgroepsystemen, zoals het ABO- en Rhesus-systeem, goede referentiekaders zijn voor nader begrip van het HLA-systeem. Het HLAsysteem lijkt complexer dan het ABO-systeem, maar hoeveel verschillende antigenen zijn mogelijk? En welke invloed heeft deze complexiteit op afstoting dan wel acceptatie? Stelt dit bijzondere eisen aan de wijze waarop de praktijk moeten worden georganiseerd? Ondanks de onduidelijkheden op verschillende gebieden is Eurotransplant van start gegaan. In dit boek is onderzocht hoe de Eurotransplantpraktijk is ontstaan en wat de rol van kennis over het HLA-systeem daarbij is geweest.

In hoofdstuk $\mathrm{I}$ is beargumenteerd waarom de theorie van Latour een goed kader bood om dit te onderzoeken. Volgens Latour bestaat het toepassen van kennis in de maatschappij uit het transleren van kennis. Dat wil zeggen dat kennis in een praktijk toepasbaar wordt gemaakt, door een nieuwe maatschappelijke praktijk te creëren. Praktijken veranderden zodat bepaalde kennis in die praktijk werkzaam wordt. Latour heeft erop gewezen dat er geen maatschappelijke automatismen zijn waardoor kennis gaat functioneren in praktijken. Kennis werkt bijvoorbeeld alleen als die kennis is ingebed in een praktijk waarin mensen zich gedisciplineerd gedragen. Wanneer - de eerder genoemde voorbeelden aanhalend - een arts bijvoorbeeld een antibioticum voorschrijft dat twee maal daags oraal moet worden ingenomen, dan werkt dat medicijn alleen onder voorwaarde dat patiënten zich aan deze voorschriften houden. Of als iemand de eerste keer wordt gevaccineerd en na een half jaar inderdaad terugkomt voor een tweede vaccinatie, dan biedt zo'n vaccin in bepaalde gevallen de eerste 15 jaar bescherming. Wanneer de patiënten zich gedisciplineerd gedragen en de voorschriften volgen, is succes min of meer gegarandeerd en is het toepassen van de kennis geslaagd.

In het geval van orgaantransplantatie, zo is in dit boek betoogd, is de toepassing van kennis echter nog complexer. Uiteraard zijn er ook in de transplantatiepraktijk allerlei sociale regels waar mensen zich aan moeten houden. Maar ook al houdt men zich aan die regels, dan nog is dat geen garantie voor succes. De vertaling van de kennis over het HLA-systeem naar de transplantatiepraktijk gaat gepaard met onzekerheid. De kennis heeft niet de status van kant-en-klare kennis die bij toepassing tot een voorspelbare verbetering zal leiden. Er kan nog niet met zekerheid worden gezegd dat het matchen van donor en ontvanger succes zal hebben. Sommigen zijn optimistisch over het belang van de HLA-match voor het slagen van transplantaties. Anderen zijn minder optimistisch en vinden een HLA-match niet van wezenlijk belang voor het slagen van een transplantatie en zien meer heil in het verder ontwik- 
kelen van immunosuppressiva. Omdat succes niet gegarandeerd is, is het gebruik van het HLA-systeem in de transplantatiepraktijk iets dat voortkomt uit méér dan een besluit op louter wetenschappelijke gronden. Dat wordt duidelijk als we ons voorstellen hoe een transplantatiepraktijk eruit zou zien zonder HLA-typeringen (maar met immunosuppressiva). Een kwalitatieve wachtlijst zou van een dergelijke praktijk geen deel uitmaken.

Het matchen van donor en ontvanger is een geinstitutionaliseerde praktiijk geworden, waarin Eurotransplant een sleutelpositie inneemt. In hoofdstuk 2 en 3 heb ik de achtergronden van deze praktijk beschreven. Eind jaren vijftig worden door verschillende onderzoekers, op verschillende plaatsen in de wereld, de eerste antisera gevonden die de aanzet vormen voor het vinden van de eerste antigenen na MAC - waarvan later duidelijk wordt dat de meesten daarvan onderdeel zijn van het HLA-systeem. Het vinden van de antisera gebeurt toevallig, in die zin dat men niet op zoek was naar antisera, noch naar transplantatie-antigenen. Later heeft Van Rood het identificeren van 'zwangere vrouwer' als zeer geschikte bron van antisera, een voorbeeld van serendipiteit genoemd. Als hoofd van de bloedbank komt hij min of meer toevallig in aanraking met een anomaal verschijnsel in de haematologie: een transfusiereactie zonder voorafgaande transfusie. Het gaat om een pas bevallen vrouw, met meerdere zwangerschappen achter de rug. Door de verschillende zwangerschappen blijkt zij tegen de leukocyten in het donorbloed geïmmuniseerd te zijn, wat uiteindelijk als verklaring wordt gegeven voor het optreden van de transfusiereactie. Vanwege de klinische setting waarin Van Rood zich bevindt, kan hij - zoals in hoofdstuk 2 is betoogd - meer met het anomale geval doen, dan de medewerkers van het CLB. Ook daar waren anomale gevallen onderzocht, maar onder andere door het gebrek aan nauwe contacten met patiënten, is nader onderzoek moeilijker te organiseren. De conclusies rond Mevrouw H. brengen Van Rood en zijn medewerkers op het idee om gericht naar antisera te zoeken en deze te testen tegen een panel van roo leukocytendonoren. Uit de gegevens die dit oplevert, wordt met behulp van een computer, een reactiepatroon zichtbaar gemaakt, waaruit Van Rood de conclusie trekt dat het leukocytenantigeensysteem een dialleel systeem is. Hij noemt de door hem gevonden antigenen $4^{\mathrm{a}}$ en $4 \mathrm{~b}$.

Het zoeken naar antigenen krijgt door de Leidse bevindingen een nieuwe impuls en ook elders op de wereld worden antigenen beschreven. Maar omdat onderzoekers verschillende technieken en donorpanels gebruiken, zijn de resultaten die worden geboekt nauwelijks vergelijkbaar. In hoofdstuk 3 is beschreven hoe men dit probleem probeert op te lossen. De in de wetenschap gebruikelijk wijze van vergelijkbaar maken van gegevens, namelijk door die gegevens zo precies mogelijk af te beelden en te beschrijven, blijkt niet toereikend om de in verschillende centra gevonden antigenen vergelijkbaar te maken. De te herkennen antigenen kunnen niet worden afgebeeld en zijn alleen als reactie tussen antisera en leukocyten 'zichtbaar' te maken. Pas wanneer een bepaald antiserum reageert met de leukocyten van een bepaalde donor, kan gezegd worden dat het bij de antilichamen in het serum horende antigeen, zich op de leukocyten van die donor bevindt. Tijdens de tweede workshop wordt daarom een nieuwe benadering gehanteerd: er wordt een center of laborator y testing ${ }^{1}$ gecreëerd. Delen van laboratoria van over de gehele wereld worden 
opnieuw ingericht op één plek. De onderzoekers wordt gevraagd om hun eigen antisera te gebruiken in hun eigen technieken (waarvoor hun eigen laboratorium als het ware wordt ingevlogen) en daarmee allemaal dezelfde leukocytendonoren te typeren, het Leidse donorpanel. Het donorpanel fungeert als meetlat waarlangs alle verschillende antisera in de wereld worden gelegd. Alleen door ieder afzonderlijk serum te laten reageren met dezelfde leukocyten, kunnen de sera met elkaar vergeleken worden. Op deze manier worden de verschillende resultaten uit het laboratorium. onderzoek vergelijkbaar gemaakt en ontstaat een gemeenschappelijke taal, met het Leidse donorpanel als standaard-vertaalsleutel. Zo verkrijgt men in het center of laboratory testing een eerste indruk van het leukocytenantigeensysteem, de latere HLAclassificatie.

Het wereldwijde onderzoek naar het HLA-systeem is dus bijzonder, omdat het classificatiesysteem via een center of laboratory testing tot stand komt. Classificatiesystemen voor planten of dieren zijn bijvoorbeeld ontwikkeld, doordat onderzoekers exemplaren van planten of dieren verzamelden, uitstalden in kabinetten en musea, beschreven of tekenden, et cetera. Daardoor konden de verzamelde monsters met elkaar vergeleken en geordend worden, waardoor regelmatigheden zichtbaar werden en algemene uitspraken over de onderlinge samenhang konden worden gedaan. Het HLA-systeem komt echter tot stand via een tussenliggende stap. De door verschillende onderzoekers beschreven antigenen, kunnen niet ter vergelijking naast elkaar worden gelegd, maar worden pas vergelijkbaar nadat onderzoekers hun sera aan de hand van hetzelfde panel hebben getypeerd. Pas dan kunnen de verschillende reactiepatronen van sera worden vergeleken, waardoor er duidelijkheid wordt gecreëerd over de vraag welke, door verschillende onderzoekers onderscheiden, antigenen dezelfde blijken te zijn en welke verschillend.

De opzet van een center of laboratory testing blijkt vruchtbaar, want twee jaar later wordt deze op vergelijkbare wijze toegepast in Turijn. Nadien verdwijnt de noodzaak om naar één plaats te komen - als gevolg van de keuze voor de cytotoxiciteitstechniek - doordat ingevroren leukocytenmonsters naar de verschillende laboratoria kunnen worden gestuurd. Na het typeren, worden de resultaten geretourneerd, verzameld en geanalyseerd, in overeenstemming met het oorspronkelijke concept. De eerste, door Amos georganiseerde, Workshop in 1964 heeft de verschillende leukocytenonderzoekers bij elkaar gebracht, terwijl het center of laboratory testing de verschillende lokale praktijken samenvoegt tot één leukocytenonderzoekspraktijk, waar uitwisseling van antisera, technieken en kennis plaatsvindt. Naast de onderzoekspraktijk, die vrij snel tot bloei komt, begint zich ook een meer klinisch georiën-

Calculation is het zo dat er gegeneraliseerde uitspraken worden gedaan op basis van elders verzamelde gegevens die daar stabiel, mobiel en combincerbaar zijn gemaakt. Stabiel, onveranderilik over tijd; mobiel: onveranderlijk over plaats en transporteerbaar, en combinecrbaar. op gestandaardiseerde wijze stabiel en mobiel gemaakt, waardoor grote hoeveelheden gegevens met elkaar kunnen worden vergeleken, opgeteld en bewerkt. Een enquête wordt bijvoorbeeld bif een groot aantal mensen afgenomen, hun antwoorden op de vragen worden vastgelegd op enquéteformulieren, de enquêteformulieren worden verzameld en de daarop vastgelegde meningen worden vergeleken en opgeteld. Zo kunnen gegeneraliseerde uitspraken worden gedaan over de mening van alle geënquêteerden tezamen.

Het probleem van de leukocytenonderzoekers is dat zij als het ware werken aan een vergelijking met twee onbekenden. Noch van de antilichamen, noch van de antigenen weten zij iets. Ook al zouden zij hun experimenten op gestandaardiseerde wijze uitvoeren en de uitkomsten op gestandaardiseerde wijze vastleggen, dan nog zijn hun resultaten onderling niet te vergelijken. In het Center of Laboratory Testing wordt een van de variabelen gestandaardiseerd, zoals de vragenlijst van de enquête. Nu kunnen de resultaten van de verschillende onderzoekers wel met elkaar worden vergeleken. 
teerde praktijk te ontwikkelen: de typeringspraktijk.

$\mathrm{Na}$ de vaststelling dat de leukocytenantigenen inderdaad een rol spelen bij de afstoting van getransplanteerde organen en weefsels - waarna ze ook transplantatieantigenen genoemd gaan worden - ontstaat er een typeringspraktijk. Typeringen worden in eerste instantie alleen verricht in de onderzoekslaboratoria waarin de onderzoekers van het eerste uur werkzaam zijn. Deze typeringen zijn vooral ten behoeve van onderzoek: men wil de transplantatie-antigenen in kaart brengen. Dat doet men door sera van zwangere vrouwen te testen en te specificeren aan de hand van donorpanels. Dit onderzoek heeft dus tot doel om nieuwe antigenen te identifi. ceren en gevonden antigenen verder te specificeren. Naast deze wetenschappelijke doelstelling wordt een klinische doelstelling geplaatst: de typeringen kunnen ook uitgevoerd worden met het oog op hun klinische relevantie voor de transplantatiepraktijk. Omdat transplantatie-antigenen een rol spelen bij afstoting, zou -indachtig het ideaal - afstoting voorkomen of verminderd kunnen worden, door de leukocytenantigenen van ontvanger en donor met elkaar overeen te laten komen: te matchen. Een van de problemen die zich hierbij voordoen is dat de laboratoria die kunnen typeren dun gezaaid zijn. Wanneer het aantal verrichtte transplantaties toeneemt omdat het aantal chirurgen dat - onder bescherming van immunosuppressiva - wil gaan transplanteren toeneemt, groeit ook de vraag naar typeringen. Naast het gebruik van immunosuppressiva om de transplantaten voor de patiënten te behouden, vestigen ook de chirurgen hun hoop op het matchen van donor en ontvanger.

De groeiende belangstelling voor klinische typeringen heeft echter tot gevolg dat de onderzoekslaboratoria steeds minder aan onderzoekswerk toekomen. Op verschillende manieren wordt gezocht naar oplossingen voor dit probleem. Een van de oplossingen is het starten van perifere typeringslaboratoria, die gericht zijn op het doen van klinische typeringen. Het NIH is hierbij behulpzaam door een serumbank te starten. Aan beginnende onderzoekers verstrekt de serumbank sera en handleidingen voor technieken, waardoor het aantal plaatsen toeneemt waar kan worden getypeerd. Van Rood en andere onderzoekers trainen mensen in hun onderzoekslaboratoria, waarna zij op hun thuisbasis een perifeer laboratorium kunnen opzetten en daar voornamelijk typeringen met het oog op klinische toepassingen verrichten. Gaandeweg ontstaat zo een netwerk van aan ziekenhuizen verbonden laboratoria, waarin op vergelijkbare wijze typeringen worden verricht. Dit netwerk maakt het mogelijk om op basis van matching organen te transplanteren van een donor naar een ontvanger, die niet in hetzelfde laboratorium getypeerd zijn. In hoofdstuk 4 is beschreven dat de ontwikkeling van de typeringspraktijk minder vanzelfsprekend en moeiteloos is verlopen, dan het bovenstaande doet vermoeden. Met name heeft het NIH nogal eens een andere visie op zaken, dan vertegenwoordigers van de onderzoekspraktijk.

De groeiende kennis over het HLA-systeem probeert men te gebruiken om de kans op afstoting bij transplantaties te verkleinen, hoewel er weinig kennis is over de details van dit systeem. Hoeveel antigenen moeten minimaal overeenkomen voor een aanvaardbaar resultaat? De eerste decennia van het HLA-onderzoek leveren echter geen duidelijke antwoorden op. Geen eenduidige antwoorden op de vraag wat een goede match is en ook geen onbetwiste uitspraken over het belang van zo'n match. Gaandeweg blijkt dat de antwoorden veel moeilijker zijn dan men aanvankelijk vermoedde, onder andere omdat het HLA-systeem een zeer complex systeem 
blijkt te zijn. Veel complexer dan bijvoorbeeld het ABO-systeem, dat in de beginjaren als denkmodel voor het matchen werd gehanteerd. Steeds opnieuw worden nieuwe antigenen geïdentificeerd, waardoor het systeem complexer wordt en het aantal mogelijke verschillende antigeencombinaties toeneemt. De kennis over het HLA-systeem groeit, maar juist dat maakt dat matchen moeilijker wordt.

\subsection{Fusie van Praktijken}

Hoewel er dus geen sprake is van toepasbare kennis, waaruit duidelijke richtlijnen af te leiden zijn, verkrijgt matchen een plaats in de transplantatiepraktijk. De ontwikkeling en het gebruik van immunosuppressiva is hierbij van groot belang. Immunosuppressiva maken transplantaties mogelijk en matchen is hierop een aanvulling. Mocht blijken dat matchen niet de verwachte resultaten oplevert, dan leidt dat niet tot extra problemen, aangezien het gebruik van immunosuppressiva de basis vormt waarop transplantaties worden uitgevoerd. In hoofdstuk 5 is beschreven hoe de eerste transplantatie in Leiden tot stand komt.

Met de vaststelling dat de leukocytenantigenen een rol spelen bij het optreden van transfusiereacties en dat zwangerschap slechts tegen enkele antigenen immuniseert, ontstaat de mogelijkheid om gericht oplossingen te zoeken voor een aantal specifieke bloed-en bloedstollingsproblemen. Vanuit het juist opgerichte Instituut voor Radiopathologie en Stralingsbescherming (IRS) bestaat hiervoor, na de gebeurtenissen rond mevrouw H., grote belangstelling. De samenwerking met de bloedbank krijgt inhoud in de vorm van financiering van onderzoek en detachering van personeel, om oplossingen voor stollings- en immuniteitsproblemen te zoeken, die het gevolg zijn van een mogelijk stralingsongeval. In het begin van de jaren zestig boekt men weliswaar succesjes met gematchte trombocytentransfusies, maar louter teleurstellingen met beenmergtransplantaties. In dezelfde tijd probeert men met huidtransplantatie-experimenten aan te tonen dat matchen een overlevingsduurverlengend effect heeft, maar worden geen significante verschillen gezien.

Inmiddels neemt (wereldwijd) het aantal te herkennen antigenen toe, terwiil op het gebied van niertransplantatie Starzl met een combinatie van immunosuppressiva en ontstekingsremmende middelen veel vooruitgang boekt. Daardoor wordt het voor steeds meer chirurgen interessant om te onderzoeken of zij zelf met niertransplantaties van start kunnen gaan. Zo ook in Leiden, waar de Niertransplantatiewerkgroep, mede op instigatie van Van Rood, deze mogelijkheden onderzoekt en voorbereidt. Verschillende Leidse actoren komen in deze werkgroep samen. Ten eerste het IRS, dat ter voorbereiding van de zorg voor stralingsslachtoffers, de faciliteiten moet creëren om patiënten met een verlaagde afweer, zo goed mogelijk te kunnen verplegen en behandelen; maar gebrek aan kennis heeft over de precieze eisen die aan deze faciliteiten worden gesteld. Ten tweede chirurgen, die hun werkgebied graag willen uitbreiden naar transplantaties, maar daarbij te maken kriigen met patiënten die, door het gebruik van immunosuppressiva, een verlaagde afweer hebben. En ten derde de afdeling Immunohaematologie en Bloedbank, die zowel met de chirurgen, als met het IRS, al langdurig relaties onderhoudt, en op verschillende manieren behulpzaam kan zijn bij de voorbereiding en uitvoering van niertransplantaties. Uit deze samenwerking ontstaan de plannen voor een eerste experimentele transplantatie, waarbij het bepalen van de leukocytengroepen van ontvanger en donor deel uitmaakt van de voorbereidingen en dus onderzocht wordt of de donor een geschikte kandidaat is voor de ontvanger. Bij deze en volgende trans- 
plantaties probeert men, wanneer er meerdere potentiële donoren zijn, de HLAsystemen van ontvanger en donor zoveel mogelijk overeen te laten komen. Er zijn echter nog geen duidelijke richtlijnen waaraan een goede match minimaal dient te voldoen. Ontvanger en donor worden weliswaar gematcht, maar de eerste transplantaties behouden, mede om die reden, een experimentele status. Niettemin wordt weefseltypering in Leiden een van de voorbereidende onderzoeken voor niertransplantatie.

Nochtans blijft de vraag onbeantwoord of matchen relevant is. In hoofdstuk 6 is beschreven hoe geprobeerd wordt om het belang van matching aan te tonen. In het verlengde van de activiteiten in het Center of Laboratory Testing maakt Van Rood een rondreis - met medeneming van antisera en laboratoriummateriaal - om elders getransplanteerde patiënten en hun donoren te typeren. Deze gegevens zet hij af tegen het beloop van de transplantatie in termen van overleving van het transplantaat en de ontvanger, en het al dan niet optreden van (acute) afstotingsreacties. Door ook prospectief te typeren, waarbij men de keuze voor een bepaalde donor (levendverwante donoren) en later een bepaalde ontvanger (bij kadaverdonoren) afhankelijk maakt van het aantal overeenkomstige antigenen, start men een Center of Clinical Experimentation. Door het klinische beloop van deze patiënten te relateren aan de typeringsgegevens van donor en ontvanger, wil men ook klinisch aantonen dat er sprake is van een positief effect van matchen op het transplantatiesucces. Dit zou ervoor pleiten niet willekeurig om te gaan met donororganen, maar de meest geschikte donor/ontvanger-combinatie te selecteren.

De resultaten van de transplantaties worden gebruikt ter evaluatie van de relevantie van het matchen. Het typeren en matchen heeft dus een dubbele functie: enerzijds om de kans op afstoting te verkleinen; anderzijds kunnen de resultaten van de verrichtte transplantaties worden gebruikt om de kennis over het belang van matchen te verfijnen. Zonder overdrijving kan worden gesteld dat typeren deze dubbele functie, sinds de eerste transplantaties, tot op heden heeft behouden. Eurotransplant is als organisatie in die zin niet alleen een rekencentrum (center of calculation) geworden, dat met behulp van een computer bepaalt wat de best mogelijke match is; het heeft ook altijd de status behouden van epidemiologisch experimenteercentrum. De gegevens over het succes, dan wel falen van transplantaties worden gebruikt om te onderzoeken of, en zo ja welke, antigenen relevant zijn om te matchen.

\subsection{Medisch MaAtschappelijKe Institutionalisering}

Tot nu heb ik in deze discussie de nadruk gelegd op de complexiteit van het HLAsysteem en de onzekerheden die daaruit voortvloeien voor de transplantatiepraktijk. Wanneer deze complexiteit uitsluitend een medisch-technisch probleem zou zijn, was de oplossing relatief eenvoudig: meer onderzoek naar leukocytenantigenen leidt tot het ontrafelen van het HLA-systeem, hetgeen zal kunnen resulteren in een perfecte match, waarmee het ideaal van de identieke tweelingtransplantatie is gerealiseerd. In dit boek is betoogd dat het niet zo simpel ligt. Zelfs al zou het zo zijn dat, op basis van de kennis over het HLA-systeem, een perfecte match zou kunnen worden gemaakt, dan kan dit gegeven alleen worden benut, als er voldoende organen zijn. Matchen op basis van HLA-typeringen van kadaverdonoren, zo is in hoofdstuk $\mathrm{r}$ uitgelegd, is niet alleen een cognitieve aangelegenheid, maar wordt pas mogelijk als er een grote pool is van ontvangers. Een matchingspraktijk is méér dan 
alleen het (cognitief) vergelijken van twee typeringen, omdat het een (sociale) organisatie veronderstelt, waarin organen aanwezig zijn, getypeerd, gepreserveerd en getransporteerd kunnen worden, et cetera. In dit boek is beschreven dat de sociale kant van de matchingspraktijk misschien nog wel complexer is dan de cognitieve kant. De ontwikkeling van deze complexe sociale praktijk is in de hoofdstukken 4. 5 en 6 beschreven, terwijl hoofdstuk 7 geheel is gewijd aan de sociale ontwikkeling van Eurotransplant.

Voor transplantatie van organen is meer nodig dan een matchingspraktijk alleen. Naast vergelijkbare gegevens moeten er donororganen aanwezig zijn. Aanvankelijk maakt men bij transplantaties gebruik van levende donoren, dat wil zeggen familieleden. HLA-typeringen zijn in deze gevallen opportuun om de relatief kleine kans op afstoting bij verwanten nog verder te verkleinen. Door de familieverwantschap kunnen namelijk ook niet te herkennen antigenen identiek zijn. De introductie van kadaverdonoren maakt het gebruik van HLA-typeringen echter van groter belang, omdat de kans klein is dat het HLA-type van een willekeurige donor overeenkomt met dat van de ontvanger. Omdat toentertijd de immunosuppressiva een beperkte effectiviteit hadden, werden organen in de meeste gevallen afgestoten. Daarom ontstond het idee dat dit probleem kon worden verkleind door bij een kadaverdonor vooraf immunologisch onderzoek te doen. Alleen als de HLA-typen van donor en ontvanger voldoende op elkaar lijken, zou een orgaan moeten worden getransplanteerd.

In theorie is vooraf typeren van kadaverdonoren mogelijk, maar praktisch gezien blijkt het niet eenvoudig te realiseren. In hoofdstuk 7 is besproken dat tijd een belangrijke beperkende factor is en dat het gebrek daaraan ook morele en praktische vragen oproept. Is het geoorloofd een stervende bloed af te nemen om zo snel mogelijk de leukocytengroepen te bepalen, of moet gewacht worden tot de persoon daadwerkelijk voldoet aan de overlijdenscriteria? En waar moet dat bloed worden onderzocht? De morele vraag wordt opgelost door speciaal voor de transplantatiegeneeskunde een nieuw overlijdenscriterium te gaan hanteren: het hersendoodcriterium. De praktische problemen probeert men op te lossen door of de transporttijd te bekorten, of de tijdslimiet te verruimen. Of men nu bloed per sportwagen vanuit Leuven naar Leiden brengt; of dat men patiënten op het vliegveld bloed afneemt ${ }^{2}$, of dat er technieken worden ontwikkeld om de houdbaarheid van het bloed te vergroten: op verschillende manieren wordt geprobeerd om met het relatief kleine aantal laboratoria, uiteindelijk zoveel mogelijk transplantatiecentra te voorzien van klinisch bruikbare typeringsgegevens.

De beperkte tijd en de steeds verder toenemende werkdruk zorgen ervoor, dat de typeringspraktijk na verloop van tijd steeds verder decentraliseert. Hoewel men in Leiden in eerste instantie servicetyperingen voor andere centra doet, blijken ook daar grenzen aan te moeten worden gesteld. Om echter het typeren te kunnen decentraliseren, zonder de betrouwbaarheid in gevaar te brengen, is het noodzakelijk een vergaande standaardisatie in te voeren. Iedereen moet met dezelfde antisera en technieken werken en die ook op precies dezelfde manier hanteren. Men moet erop kunnen vertrouwen dat een typering, uitgevoerd op plaats A., dezelfde resultaten 
oplevert als wanneer hetzelfde monster op plaats B. zou zijn getypeerd. Leiden coördineert dit voor een deel van West Europa. Vele mensen komen voor kortere of langere trainingsperioden meewerken in het laboratorium en er wordt zelfs een speciale cursus georganiseerd. Daarnaast worden alle samenwerkende laboratoria, door de Leidse groep, van dezelfde antisera voorzien (de latere ET-serumset).

Een deel van de voornoemde praktische problemen wordt hiermee opgelost. De afstand van de eventuele donoren tot het dichtstbijzijnde laboratorium wordt door decentralisatie verkleind en daarmee wordt het mogelijk om veel meer donoren van een betrouwbare typering te voorzien. Daarnaast wordt ook het typeren van patiënten gemakkelijker. Deze inspanningen hebben echter nauwelijks zin, wanneer de verschillende typeringen alleen voor lokaal gebruik bedoeld zijn, dat wil zeggen dat ze worden gebruikt om uit een beperkt aantal levende donoren de meest geschikte voor een bepaalde patiënt te selecteren. Het aanwezigheidsprobleem voor patiënten zonder potentiële donoren wordt er niet mee verholpen. Om de verworven mogelijkheden en gegevens op de meest effectieve manier te gebruiken, is het nodig om anders naar de relatie donor/ontvanger te kijken. Effectiviteit, in de zin van maximale overlevingsduur van een donornier, wordt niet bereikt door te kijken of een bepaalde donor bij een bepaalde ontvanger past, maar door te bezien bij welke patiënt een bepaalde donor het beste past. Welke ontvanger is het meest geschikt om een nier van een bepaalde donor te ontvangen? Terwijl bij een transplantatie tussen verwanten, de ontvanger de bepalende factor is, wordt bij een kadaverdonortransplantatie de geschiktheid van een bepaalde combinatie volledig afhankelijk gemaakt van het HLA-type van de donor. Het idee voor een kwalitatieve wachtlijst is geboren. Dit betekent echter, dat patiënten meestal lang moet wachten tot er een, voor hem of haar, geschikte donor is.

Typeren decentraliseren heeft echter ook een keerzijde. Geschiktheid is nu, ook van kadaverdonoren, gemakkelijker te bepalen, maar op het gebied van de aanwezigheid ontstaat er een nieuw probleem. Overwoog men vroeger alleen een transplantatie wanneer zowel een ontvanger als een donor aanwezig waren, nu kunnen donor en ontvanger weliswaar beiden worden getypeerd, maar hoeven dan niet noodzakelijkerwijs op dezelfde plaats te zijn. Nu zijn de typeringen gemakkelijk te verrichten (en kunnen, omdat ze snel transporteerbaar zijn, worden vergeleken). maar moet het fysiek bij elkaar brengen van de geschikte combinatie georganiseerd worden. Rond dit probleem blijkt dat Eurotransplant zich niet alleen richt op de geschiktheidskant, maar ook bij het creëren van de 'aanwezigheid' een belangrijke rol speelt.

De geschiktheid van een bepaald donororgaan is geen eigenschap van het orgaan, noch van de ontvanger. De geschiktheid van een donornier wordt gecreëerd in de computer van Eurotransplant. Uit de verzamelde gegevens wordt door de computer een schifting gemaakt, tot slechts één of enkele individuen overblijven. De computer creëert als het ware de meest geschikte donor/ontvanger-combinatie. Blijft het probleem van de gescheiden aanwezigheid van donor en ontvanger. Aangezien de computer 'bepaalt' waar het orgaan en de ontvanger zich ten opzichte van elkaar bevinden, ligt het voor de hand dat ook het transport van een orgaan vanuit Leiden wordt georganiseerd. Dit betekent dat in Leiden beschikbaarheid in de zin van aanwezigheid wordt geregeld. Zo wordt door Eurotransplant zowel de geschiktheid als de aanwezigheid georganiseerd en kan een patiënt worden getransplanteerd.

In het eerste deel van Hoofdstuk 8 is beschreven hoe de Eurotransplantpraktijk 
ontstaat en door het uitvaardigen van regels en richtlijnen (op verschillende gebieden, zoals communicatie, orgaanuitname, controle en transport) de handelingspraktijken in de verschillende centra en laboratoria stabiliseert. In het tweede deel is beschreven hoe de 'Eurotransplant-organisatie' verweven raakt met de 'eromheen liggende' maatschappij. Hierbij is aandacht besteed aan de relatie tussen de positie die de transplantatiepraktijk krijgt in de publieke opinie en de wijze waarop de media over de geneeskunde, en in het bijzonder over transplantaties, bericht. De media-aandacht heeft ook effect op het publiek in die zin dat individuele burgers en maatschappelijke organisaties een actieve rol gaan spelen in de Eurotransplantpraktijk. De opbrengst aan gedoneerde organen blijft echter onevenredig achter bij de verwachting, wat onder andere geweten wordt aan een te lage betrokkenheid van artsen in perifere ziekenhuizen. Gebrek aan gevoelens van morele plicht of loyaliteit zouden hierbij een rol kunnen spelen, vandaar dat ook in die richting naar oplossingen wordt gezocht. Deze gevoelens zijn voor de ontwikkeling van de transplantatiepraktiik altijd van belang geweest. De verwevenheid van medische wetenschap en maatschappij komt zeker tot uitdrukking in de strijd die wordt gevoerd over de vraag hoe eerst het wetenschappelijk onderzoek en later de Eurotransplantpraktijk te bekostigen. Uit vele (nationale en internationale) bronnen wordt geld verkregen om uiteindelijk te kunnen bouwen aan de matchingspraktijk Eurotransplant.

\subsection{Slotbeschouwing}

Eurotransplant wordt opgericht in de overtuiging c.q. verwachting, dat matchen op HLA-antigenen een gunstig effect zal hebben op de overlevingsduur van getransplanteerde nieren. Deze verwachting wordt slechts in zeer beperkte mate vervuld. Aanvankelijk meent men dat het matchingseffect nog niet zo duidelijk kan worden aangetoond, doordat alleen voor de herkenbare antigenen gematcht kan worden en de verwachting bestaat dat het aantal te herkennen antigenen nog zal groeien. Op zich klopt deze veronderstelling, maar tot op heden is de verwachting niet waargemaakt. Met andere woorden: het gebruik van het medisch criterium wordt niet gelegitimeerd door aanwezigheid van een matchingseffect. Toch wordt matchen op HLA-antigenen gehanteerd als medisch verdelingscriterium voor schaarse donororganen en dit wordt ook maatschappelijk breed ondersteund. Aangezien het medisch criterium niet gelegitimeerd wordt door het succesvol toepassen van kennis, rijst de vraag wat het gebruik van dit criterium dan wel legitimeert. Deze vraag zal ik tot besluit bespreken.

Een verklaring voor het ondersteunen van dit criterium zou gevonden kunnen worden in verschillende, niet medische argumenten. Het medisch criterium lijkt te worden gebruikt onder verwijzing naar het ideaal van de tweelingtransplantatie. Daar komt bij dat met dit criterium een persoonsonafhankelijk verdelingscriterium wordt gehanteerd, waardoor een neutrale, rechtvaardige verdeling van de schaarse organen ontstaat. Wanneer matchen niet meer als medisch criterium zou worden gebruikt, zou er een 'neutraal' en breed geaccepteerd verdelingscriterium wegvallen. Het medisch criterium zoals dat tot op de dag van vandaag door Eurotransplant wordt gehanteerd, vervult dan ook andere functies dan alleen het optimaliseren van het transplantatieresultaat. Het medisch criterium fungeert als kapstok voor de gehele Eurotransplantpraktijk, waarbij de kapstok zelf meer of minder zwak blijkt te zijn. Naast een rechtvaardige, onafhankelijke verdeling van schaarse organen, coördineert Eurotransplant ook een groot deel van de logistiek rond transplantaties, 
zowel wat betreft de orgaanverwerving als het transport.

De conclusie die uit dit onderzoek kan worden getrokken, is dat het succes van de Eurotransplantpraktijk dan ook niet zozeer gelegen is in het succesvol toepassen van de kennis over het HLA-systeem, als wel in een succesvolle transformatie van een ideaal in een uitwisselingspraktijk. De groei in kennis over het HLA-systeem heeft niet geleid tot een matchingsysteem dat de situatie van het tweeling-ideaal imiteert, of zelfs maar benadert. Daarbij is het niet zo dat matchen vergeefse moeite is. Nee, matchen heeft wel degelijk effect, maar in de praktijk is de meerwaarde beperkt. Aan het overlevingspercentage bij het gebruik van immunosuppressiva alleen, worden slechts enkele procenten toegevoegd. Meer belang kan worden gehecht aan het voorkómen van iatrogene effecten van het gebruik van immunosuppressiva. Matchen vermindert de kans op afstoting en de ernst van optredende afstotingsverschijnselen. Hierdoor volstaan lagere doseringen immunosuppressiva om het transplantaat te behouden. Dit heeft als gunstig neveneffect dat de natuurlijke afweer van de patiënt minder ernstig in zijn functioneren wordt beperkt, waardoor opportunistische infecties en kankercellen minder gelegenheid krijgen. Er zijn dus meerdere redenen om een transplantatie afhankelijk te maken van de resultaten van een HLA-match, die niet primair de verlenging van de transplantaatoverleving dienen.

Naast de argumenten voor het handhaven van de HLA-match als belangrijk criterium, zijn er ook argumenten tegen. In de Verenigde Staten hecht men, om uiteenlopende redenen, een minder groot belang aan de HLA-match. Een van die redenen is dat de kans op een geschikt orgaan niet voor iedereen gelijk is. De heterogene samenstelling van de populatie, met verschillende etnische bevolkingsgroepen, leidt tot deze ongelijkheid, waardoor sommige bevolkingsgroepen systematisch benadeeld lijken te worden. In de Eurotransplant-regio zou dit eveneens een probleem kunnen worden, aangezien ook hier een toename aan heterogeniteit in de populatie - ook voor wat betreft verschillende HLA-typen - te zien is, hetgeen consequenties heeft voor de medisch wetenschappelijke neutraliteit van het matchingscriterium.

Gezien de beperkte winst die door matchen behaald wordt, lijkt het vreemd dat niet eerder een allocatieprotocol als het Eurotransplant Kidney Allocation System in gebruik is genomen. Hiervoor kunnen een aantal mogelijke verklaringen worden geven. Een eerste verklaring is dat, aangezien matchen het uitgangspunt van Eurotransplant was, verlating van dit uitgangspunt een bedreiging voor het bestaan van de organisatie zou kunnen vormen. Eurotransplant zou daarmee ongeloofwaardig kunnen worden. En matchen heeft, naast optimaliseren van het transplantatiesucces, ook andere functies vervuld. Wachttijden en zelfs het gegeven dat patiënten gedurende die tijd overlijden, kon gerechtvaardigd worden door het perspectief op een goed gematcht orgaan. Verder vormde matchen de drijfveer om een organisatie op te bouwen, die het mogelijk maakte zoveel mogelijk donororganen bij zoveel mogelijk geschikte ontvangers te (laten) transplanteren. Eurotransplant is hiervan het resultaat: een samenwerkingsverband van aanvankelijk slechts enkele ziekenhuizen, met een centrale registratie van patiënten en met een faciliterende en coördinerende functie voor het opzetten en controleren van perifere typeringslaboratoria. Met de groei van het aantal aangesloten transplanterende en niet-transplanterende ziekenhuizen en typeringslaboratoria, nam de coördinerende en regulerende rol van Eurotransplant steeds verder toe en werd ook het transport centraal geregeld. Daarnaast werd de controlerende rol van Eurotransplant verder geformaliseerd en uitge- 
breid naar kwaliteits- en effectiviteitscontrole van de, in Eurotransplant-verband verrichte, transplantaties. Al met al genoeg redenen om Eurotransplant met haar mogelijk discutabele matchingscriterium in stand te houden.

Naast deze eerste verklaring voor het niet veranderen van het allocatieprotocol van Eurotransplant, kan nog een tweede verklaring worden gegeven waarom het allocatieprotocol niet eerder wezenlijk veranderd is: het ontbreken van de noodzaak om het in formele zin te veranderen, aangezien de praktijk van meet af aan toch al op verschillende punten op ETKAS leek. Ten eerste kon, om verschillende redenen, slechts bij een klein percentage van de aangeboden donororganen, het orgaan worden toegewezen aan een HLA-identieke ontvanger. Dit betekende dat de meeste ontvangers een donororgaan met I, 2, 3, of meer mismatches kregen. Ten tweede had de vrijwillige basis, waarop de samenwerking met en in Eurotransplant is gestoeld, als gevolg dat lokale, of regionale regelingen wel eens de voorkeur kregen, boven de mogelijkheid donoraanbiedingen via Eurotransplant te laten lopen. Dit ondergroef uiteraard de uitgangspunten van Eurotransplant en was in strijd met de solidariteitsgedachte, maar was moeilijk te bestrijden.

Waarom is ETKAS dan wel ingevoerd? Een reden was dat er problemen ontstonden rond het uitwisselen van donororganen. De uitwisselingsbalans tussen landen was na verloop van tijd behoorlijk scheef geworden. Sommige landen kregen meer organen uit het buitenland, dan dat er vanuit dat land naar andere landen werd 'geëxporteerd'. Zo ontstond een situatie dat aan de wederkerigheid tussen verschillende landen en centra meer en meer getwijfeld werd. Deze, en andere kleine en grotere, problemen gaven aanleiding om uiteindelijk toch een nieuw allocatieprotocol te ontwikkelen. Met dit protocol wordt de bestaande praktijk voor een groot deel geformaliseerd en deels gecorrigeerd. $\mathrm{Al}$ met al is het begrijpelijk dat het zo lang heeft geduurd voor een protocol als ETKAS werd ingevoerd.

Een allocatiecriterium dat uitsluitend is gebaseerd op matchen, is minder legitiem dan een allocatieprotocol als ETKAS. Enerzijds omdat matchen niet heeft waargemaakt wat er bij de start van Eurotransplant van werd verwacht, anderzijds omdat ETKAS meer in overeenstemming is met de al lang heersende praktijk, waarbij de controle op de allocatie met dit protocol is verhoogd en de flexibiliteit ten aanzien van allocatieregels wordt verruimd. Bij de start van Eurotransplant ontleende deze organisatie haar legitimiteit aan het verwachte matchingseffect. Dit betekent echter niet dat met een afnemende legitimiteit van matchen als allocatiecriterium, ook de legitimiteit van Eurotransplant afneemt. De coördinerende en faciliterende rollen die Eurotransplant rond het toepassen van matchen heeft ontwikkeld, zijn voor de transplantatiepraktijk van dermate groot belang, dat dit de legitimiteitsafname ruimschoots compenseert, hetgeen door de invoering van ETKAS nog eens wordt versterkt.

Het mag zo zijn dat Eurotransplant misschien niet volledig heeft kunnen voldoen aan het ideaal van een Full-House-Match voor iedere ontvanger, feit is wel dat Eurotransplant een spilfunctie vervulde bij de ontwikkeling van de transplantatiepraktijk en dit nog steeds doet, want op de vleugels van de matchingspraktijk heeft Eurotransplant gezorgd voor een sociaal systeem van orgaanverdeling dat als rechtvaardig wordt ervaren. Matchen is hierbij de icoon van Eurotransplant geworden: een voor zichzelf sprekend beeld dat de Eurotransplantpraktijk representeert. 


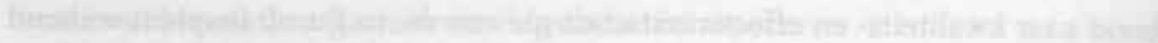

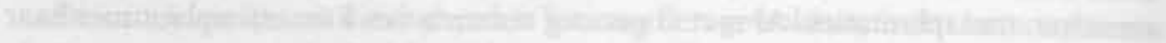
4.

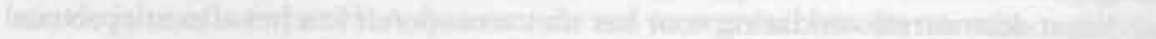

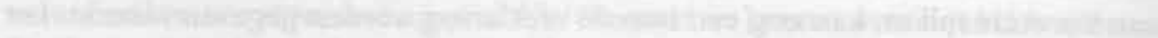

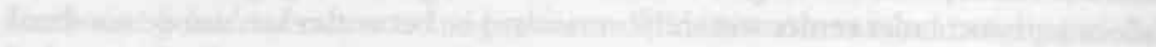

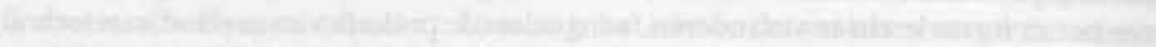

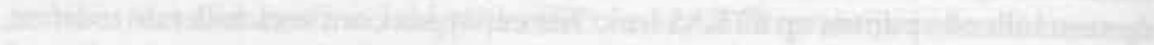

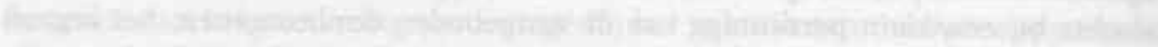

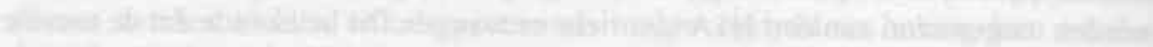

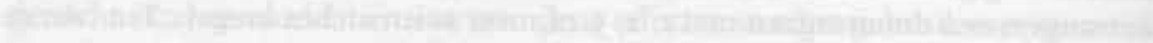

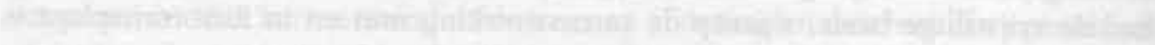

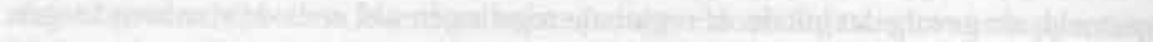

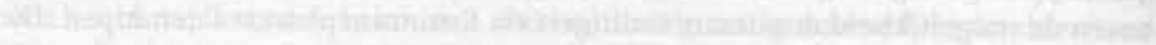

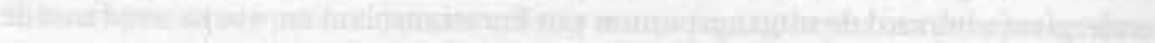
ant

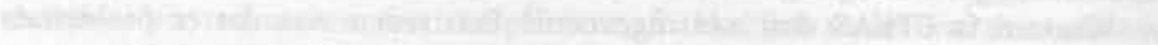

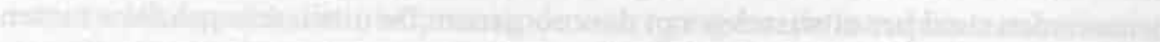

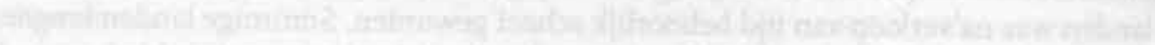

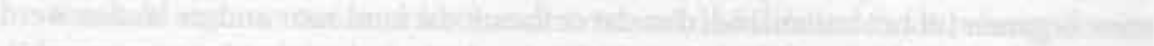

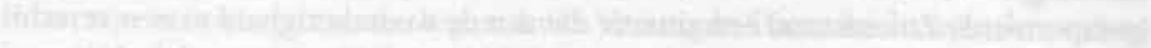
Chand

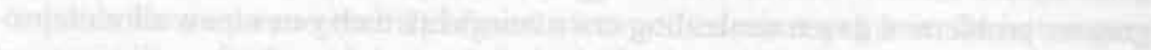
Jark

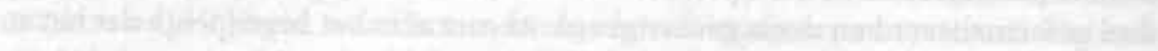
Ir

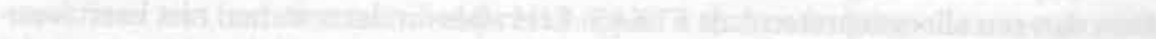

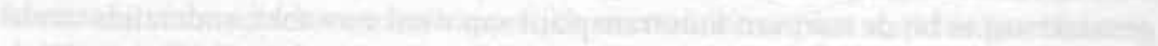

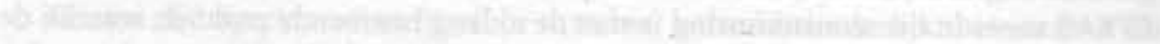
a

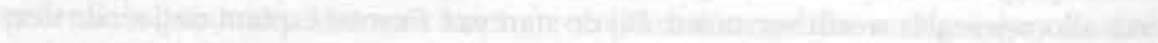

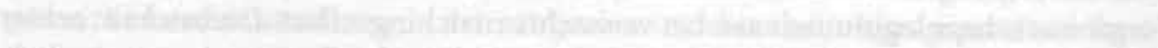

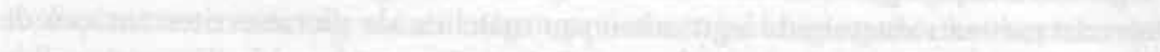

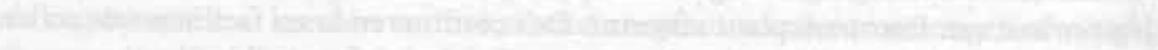

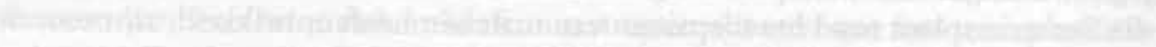

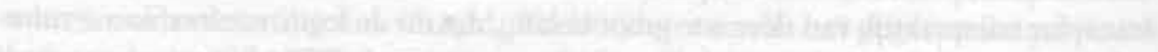

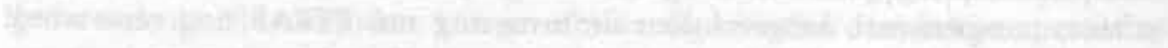

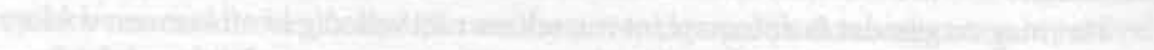

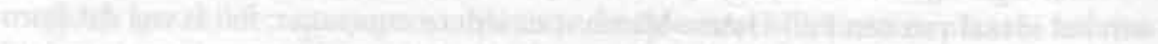

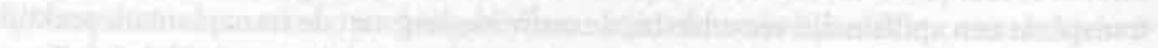

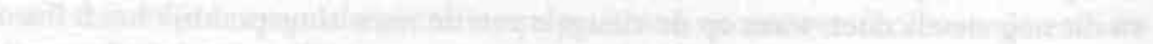

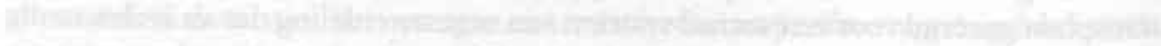

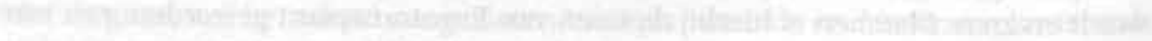

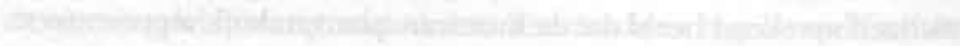




\title{
BIJLAGEN
}

\author{
Bijlage 1: Het Eurotransplant-voorstel \\ (van Rood, 1967)
}

\section{A Proposal for International Cooperation in Organ Transplantation: EUROTRANSPLANT}

\section{J. J. VAN ROOD}

Department of Immunohematology. University Hospirat, Leiden

There is little doube that matching for the leukocyte HL-A system* can improve the survival of a kidney graft if the donor is a near relative (Dausset el al 1967. Payne et of 1967. van Rood et al 1967b, and Terasaki et at 1967). Improvement is most marked when donor and recipient are sibs and their leukocyte groups identical with respect to the HL-A system. If, to the contrary, there is no identity. it makes little difference whether there is compatibility or incompatibility for the HL-A system. It was concluded that only identity (or near identity) ean improve kidney grafi survival significantly (van Rood ef $a / 1967 \mathrm{~b}$ ).

As discussed extensively elsewhere in this book, only sibs can be truly identical, because they may have received the same alleles from each parent. $A$ parent and child ean only be identical if both parents carry at least one identical allele (see van Rood et al, this issuc, Table VIII). It is not only a fact that identical parent-child combinations occur but it also seems probable that in such combinations kidney grafts function better than average. This argues in favor of the occurrence in unrelated individuals - i. c. parents - of alleles that are identical at least for kidney transplant purposes (van Rood et al $1967 \mathrm{a}+\mathrm{b}$ ).

The occurrence of such alleles is a priori likely but the question is, how frequently do they occur? Preliminary data indicate that they may be more frequent than previously assumed (Ceppellini et al, this issue; van Rood et at, this issue). If this is so, it is logical to expect that unrelated individuals with alleles which are both identical also exist. Such individuals have indeed been encountered. It has still to be proved that their leukocyte groups are identicat not only serologically but also for transplan. tation purposes. For the moment we will assume this to be so.

These two findings, i.e. I. grafts exchanged between donor-recipient pairs identical for the HL-A system do better than those exchanged between non-identical pairs and 2 . unrelated individuals can be identical for the HL-A sys. $t e m$, immediately raise the question: How can wo find an identical unrelated kidncy for patients awaiting a kidney transplant when no identical related kidney is available? This question has been asked before (Amos 1965). but we are now in a much better position to answer it.

Assume that one hundred transplant teams decide to cooperate and each such team would have 10 patients awaiting a kidney transplant. For these 1000 patients, the leukocyte groups could be typed and the resulting information stored in a cemputer. When one of the cooperating teams is notified that it will receive a cadaver kidney, the potential donor can be typed for blood and leukocyte groups; if this team has no suitable recipient a telephone call to the computer will locate the best-matched recipient(s) in a matter of minutes. The physician in charge of the appropriate patient can then be contacted to determine whether the cadaver kidncy is really suitable for his patient.

Let us take a closer look at the necessary provisions:

1. Europe does not yet have one hundred kidney transplant teams, but within a year or two it probably will.

2. With our present facilities the typing, retyping. etc. of 1000 recipients would offer no problems.

3. At the moment, about ten European centers do some form of leukocyte typing. Now the (miero) tests are reasonably standardized and reliable, the whole procedure of leukocyte typing is perhaps more time consuming but not much more difficult than determining erythrocyte subgroups. With the general application of micro-tests, the supply of sera will no longer be a problem either. Per definitionem, only kidneys from cadavers that can be typed reliably will be accepted in the program.

4. A computer and appropriate program are

\footnotetext{
- The term HL-A systen wilt be used here to designate a malor comples theus antigen sntem in man fefr. Nomen. clature). Other terms uied are group Four (van Rovd). Hu-1 (Dauset). LA (Payne and Bodmer). Du-1 iAmns).
} 
already available at the University of Leiden.

5. Transport of the kidney from one center to another, which implies storage for at least 24 hours, will probably not offer serious prob. lems in the very near future. If neccessary, it might be possible to obtain the cooperation of military aviation authorities.

6. The last question is whether enough teams will be found that are willing to cooperate, and whether the whole scheme would be too costly. Since a patient who does not reject his gratt is so much easier to treat and therefore involves less expense, it seems rather unlikely that this project would fail on these points.

International cooperation in organ trans. plantation is thus certainly a possibility. Work has already been begun to get the necessary organization which we called for the time being EUROTRANSPLANT started. This will be a slow process, and it should not be expected that it will be possible to attain anything significant before 1969.

By then, a similar organization may atready have been started in the United States of America. If storage methods have been further improved by that time, it might even be possible to bave transatlantic cooperation. This is very much to be desired, because it is just through transatlantic cooperation that leuko. cyte typing has become the reality it is today.

September 1967

\section{References}

Amos, D. B. (1969). During the Second Conference and Workshop on Histocomparibility Tesring. Leiden.

Ceppellini, R., Curtoni, E. S., Mattiuz, P. L., Miggiano, V., Seudeller, G. and Sern, A. (1967). Genetics of leukocyte antigens. A family study of segregation and linkage. Histocompatibitiry Testing 1967.

Dausset, J., Rapaport, F. T. \& Legrand, L. (1967) Selection des donneurs par les groupes tissulaires. Advance in Transplantation. First International Congress of the Transplantation Society, Paris.Munksgaard, Copenhagen.

van Rood, J. J., van Leeuwen, A., van Blankenstein, M., Schippers, A., Pearse, R. and Volkers, W. S. (1967a). The immunogeneties of the group Four, Five and Nine systems, Histocompatibilliy Testing 1967.

van Rood, J. J., van Leeuwen, A., Bruaing, J. W. and Porter, K. A. (1967b). The importance of leukocyte antigens in renal transplantation. Advance in Transplantasion. First International Congress of the Transplantation Society. Paris. Munksgaard.

Terasaki, P. J., Mickey, M. R. and McClelland, J. D. (1967). Serotyping for homotransplantation XII. Evaluation of 200 antisera for their ability to detect transplantation antigens. Advance in Transplantation. First International Congress of the Transplantation Society. Paris. Munksgaard, Copenhagen.

Payne, R., Perkins, H. A. and Najarias, J. S. (1967). Compatibility for specifie leukocyte antigens in kidney transplants using the agelutination test. Advance in Transplantotion. First International Congress of the Transplantation Society. Paris. Munksgaard, Copenhagen. 
Bijlage 2: Antigenen in 1967

(van Rood, 1970)

Table 6-1 Leukagie Antigans Rosngnizad io Date

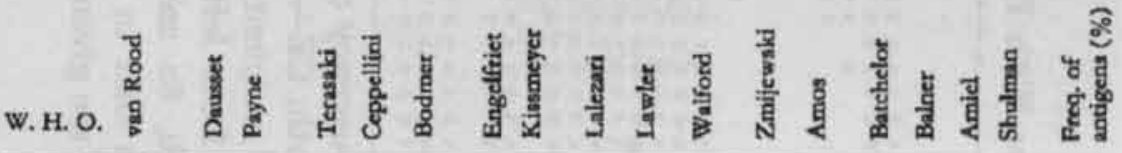

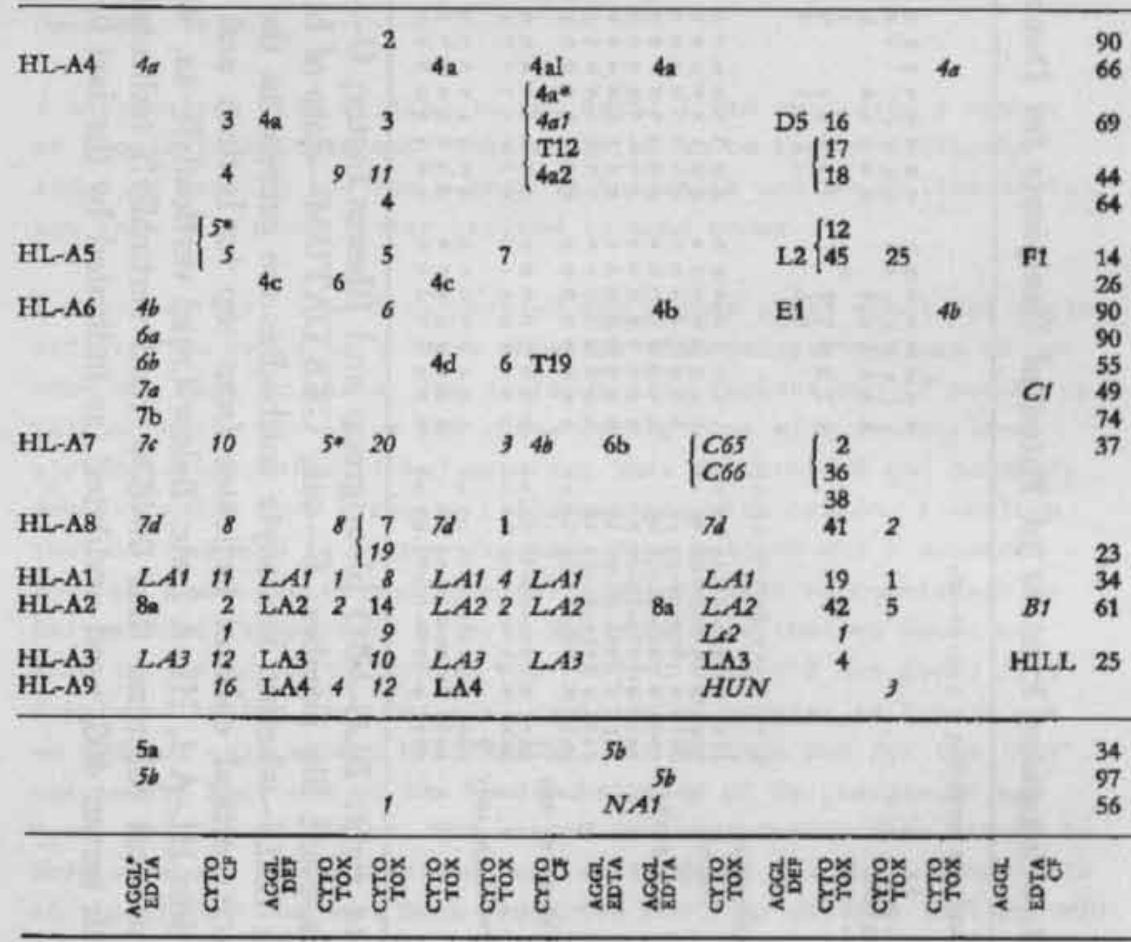

Most of these data were collected during the Turin Workshop, 1967. The name of the principal investigator is given at the top. W. H. O. means that this is the nomenclature accepted by a Wotld Health Organiration expert commitee. Two entigens connected by a brace showed an identical disttibution in the Turin panei. Antigens in the same horizontal row, indicated in italics, reacted identically with all 96 leu kocyte samples of the panel. At the bottom the technigue ( $\theta)$ used by the investigator is indicated. 
Table 3.-Computer Printouk of Potentill Recipients for Donor With Phenotype HL-A 1,2,8,12

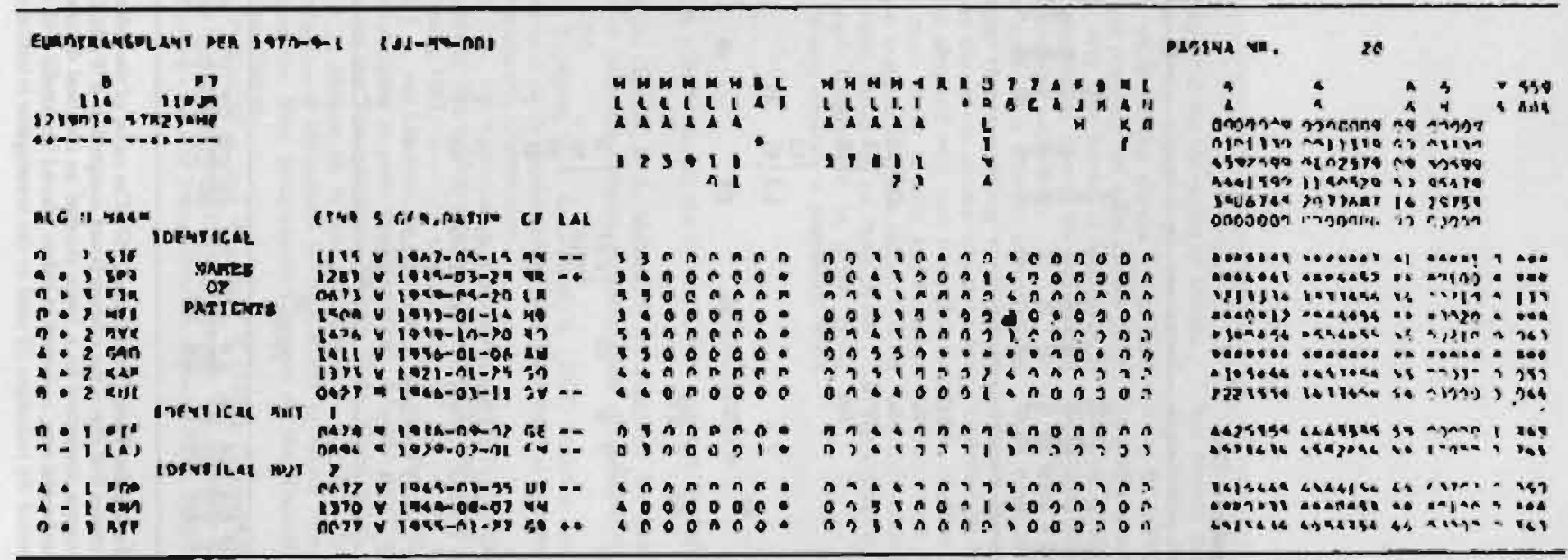

- Left to right: BLG-ABO bloodgroup and Rhesus factor; U-urgency class; NAAM - Name; ETNR -Eurotransplant file number; S-sex; GEB.DATUM-date of birth; CE-dialysis center where patient is treated; LAL-whether leukocyte antibodies are present in the recipient. Next are the typing results given. Each vertical column indicates from top to bottom and from left to right first the antigens studied: thus HL-A 1, HL-A 2 etc. Below (read verticallyl) $4 a, 4 b, 6 a$ and $6 b$ the sera numbers are given in vertical columns: thus 004630 (read verticallyl) indicates that in this column the results obtained with serum 463 , used undiluted (as indicated by the last 0 ) gre given. 
Bijlage 4: De brief aan Thiel

(van Rood, 25 oktober, maar verstuurd op 2 december, 1968)

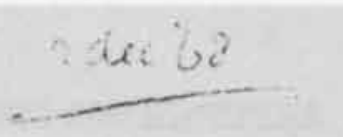

October 25, 1908.

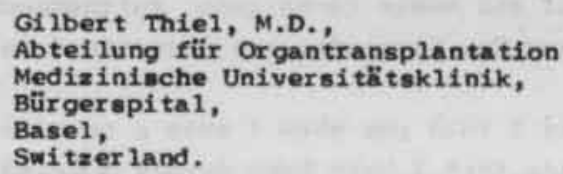

Dear Dr. Thiel,

I have waited with writing to you until I had contacted a number of people in Switzerland. This appeared to be rather difficult and I am leaving now for a trip to Australia and would like to let you know that your letter arrived in good order.

I must say that I am disappointed and rather upset about the whole affaix. The decision to work together with Switzerland was as you know not made in haste. The devision into regions had of course my full support, but as we had close connections with Switzerland already (vide infra) I had expected that Switrerland and Southern Germany would form a region collaborating with Leiden. I realize that Switzelland is rather far amay from Holland and I wondered whether I was overextending myself. When $I$ made my commitinent to Switzerland it was only after I had made sure that we would be able to put up whatever help was needed. This did not imply full supply of typing, sera but also training of people: as I told you we did not only expect Mrs. Rowley, but we have had for the last six months here one of the headtechnicians of Dr. Laxgiader and Prof. Senning of Ztirich. She stayed so long because they wanted to have somebody in Switrerland who really knows all the ins and outa of the trade. She went back yesterday and I am certain that ohe win be able to do a good job.

From your letter I gather now that all the effort of forming a region in Southern Germany and Switzerland, working with uniform 
October 25, 1968.

$-2-$

techniques and in close collaboration with Leiden, might have becn wasted. This is the more disappointing , lecause as you know we have only a limited number of places in the laboratory and the fact that this technician from Zïrich was here prevented for instance that some of my onw technicians were introduced to a few of the newer techniques. Furthermore, I know that Prof. Senning and Dr. Largiader are determined not to switch to any other method.

As I told you when I make a commitment I stick to it and I must say that I have been deeply worried about the whole thing. The more because Dr. de Weck from Bern knew that the Girl was here that Hässig has known abboteur activities from the beginning on ( $I$ always before $I$ did anything in this field in Switzerland contacted him).

As far as I know the only place in Durope where Burotransplant is already functioning is the Benelux and a part of Germany. A couple of days ago we had a case in which the possibility was considered to fly a kidney from Rotterdam to Zirich where a recipient with an Ideal fit was available. We worked the whole thing out and I can tell you now that this is soeething which can be done.

I will be back in December and will then certainly contact you or one of the other people in Swizerland. In the meantime I will aend a copy of this letter to Drs. Hässig, Jeannet, de Weck, Senning and lagiader. Needless to say that I hope that we w111 etil1 be able to work somethigg out which will be agreeable to all.

Sincerely yours,

Jen J, van Rood, M.D. 
Bijlage 5: Manual for Cadaver-Kidney-Transplantation

(Eurotransplant, 1970)

\section{$\therefore$ \\ IIANUEL FOR CADAVER-K IDNEY-TRANSPLAWTAT ION}

All communications to:

1. Dr. Hintzen 01710-47222 extension 2600 or calling system 32 at home $01710-50503$ or

Dr. Kalff $01710-47222$ extension 2600 or calling system 810 at home $01710-51978$

2. Dr. Terpstra 01710-47222 estension 2307 or calling system A5 at home $01710-53500$

Aftor the first announcement all additional information and roports to oxtension no. 2307 .

Pre-conditions for an eventual doner for cadaver k1dney trans-

\section{plantation:}

1. daath should not be expected within 2 hours

2. the results of recent determinations of the donorAs

- blood urea nitrogen

- blood creatinine

- blood group + rhesus factor

- presence of proteinuria

3lucosuria

urine sediment abnormalities

should be known.

3. Assurance of family consent in writing

4. age between 15 and 50 years; between 45 and 50 years a

donor is not suitable if there are signs of arteriosclerosis.

5. the potential donor is not suitable when there is:

a. a malignancy, with the exception of tumors of the nervous system (namely glioma, astrocytoma)

b. long periods of shock (hypotension for longer than 1 hour 1.e. Systol1e) blood pressure below 90 . Thls depends also on the age of the donor, whether or not the donor had a previously normal blood pressure.

c. hypertension 1.e. when the diastolic pressure ls higher than 105 .

d. presence of infection as for example sepais, furuculus ete.

e. diseases of the kidneys, oystopyelitis.

f. (malignant) systemic diseases.

6. In case of death of the donor $100 \mathrm{mg}$ heparin should be given intravenously. 


\section{INSTRUCTIONS FOR REMOVING A CADAVER KIDNEY}

In principle the maximum admissable time between the death of the donor and the beginning of refrigeration of the kidney is 15 minutes.

\section{Necessary instruments:}

1. sterile instrument-set for nephrectomy with sufficient sterile cloths, gloves, and sterile plastic bags (at least 6) and 3 sterile infusion systems with extra long tubing $(80 \mathrm{~cm})$ 2. sterile ice (see below)

3. refrigeration fluid (Saline at $4^{\circ} \mathrm{C}$, with $50 \mathrm{cc}$ procaine 28 per $500 \mathrm{cc}$ Saline, with $10 \mathrm{mg}$ Heparin per $500 \mathrm{cc}$ Saline; total amount needed $\pm 8 \times 500 \mathrm{cc}$.)

4. sufficient help with the laparotomy (minimum 2)

\section{Technique:}

1. Median laparotomy from proc. xyphoideus to symphysis after disinfection with iodine only of the total ventral part of the body.

2. A big retractor is placed in the incision.

3. The total small bowel is pushed to the right.

4. Open the peritoneum over the right iliac artery and the distal aorta (cave ureter).

5. Isolate the right common iliac artery (attention to avoid damage of the iliac and caval veins)

6. Ligate distally and proximally around common iliac artery, arteriotomy, and introduce the rigid end of the perfusion tube, ligate the artery around the tube proximally from arteriotomy. 6. Start the refrigeration fluid through this perfusion tube under pressure (quick infusion)

7. Clamp the left common iliac artery

8. Clamp the aorta in the hiatus aorticus with a big clamp

9 Make a wider opening of the laparotomy proximally by cutting the costal arches and by and intercostal incision and incise the diaphragm as well on the left and right sides.

10. Mobilize the left colic flexure and the spleen.

11. Splenectomy.

12. Prepare free the left renal vein and ligate the adrenal and spermatic ovarian veins.

13. Prepare free the origin of the left renal artery, just next to the aorta. 
14. Satinsky clamp on the aorte around the orizin of the reasal artery.

15. Littie erteriostomy after 11zeture around the origin of the left renal artery as close to the sorta as possibie. Introduce a no. 4 polythene canula with a luer-lock connection into the second infusion-tube, tying the 11 gature vary olose to the arteriotany. Start the verrigerated solution $\left(4^{\circ} \mathrm{C}\right)$ under slight pressure so that the solution runs amoothly through the system.

16. Prepare the kidney free from fat-tlsaue lateraliy and on the frontal and dorsal part of the kidney.

In the medial part, especially in the region between the renal vessels and the pyelumureter, let the fat remain to avold damage to the ureteric artery.

17. Bxpose and free the ureter with ample fat and vessels to a point distal from the cross-point with the common 11 lac satery.

16. Then the k1dney is thus 1 lberated, transsoct the renal artery together with a patch of aorta.

7j. Clamp the left renal vein as far as posaible to the caval vein; transsect the renal vein as far as possible from the kidney; transsect the ureter as distaliy as possiblo. 20. The kidney with the perfusion zolng on is placed on a sterile side table. The perfusion is continued until the fluld from the vein is clear of blood; In general 500-1000 co has to be perfused through the kidney to be sure ita tempersture is low enough. Seldam is a period longer than 5 minutes necessary. The kidney takes on a whit aspect. Beware of too hlgh a pressure of the infusionl 20. Stop the refrizeration and the rinsing perfuaion. Place the kidney in a sterile plastic bas with $\pm 100 \mathrm{cc}$ cooling fluid. Place this plastic bag in a second sterile bag with 100-200 grams of sterile lce. These two sre placed in $a$ third storile plastic baz. All jazs are tied shut individually. Around these plastic bags one or two very thick towols are wrapped to preserve the 1ce. Wo further lcing of the kidney is necessary otherwise the kidney mey be damezed by freezing. 21. Transport to Leydun, surzical department, operating theater.

1va. If possible 19 and 20 to be done by somebody else (STIRII.B). 
19a. Surgeon removes the right kidney.

20a. Incialion retroperitoneally by the right colonic flexurs to far distally.

b. Preparing freo the right renal vein with additional caval vein.

c. Proparing freo the right renal artery behind caval vein to aorta.

a. Statinsky clamp on the aorta around the origin of the renal artery.

o. Arterlotamy in the renal artery olose to the aorta.

f. Introduction of the rinsing canula (polythene tube no.4) + 1igature tied close to arteriotomy. Start rinsing with the cold solution $\left(4^{\circ} \mathrm{C}\right)$

3. Preparing free of the kidney from a latercl direction out of the surrounding fat. Let ample fat remein in the corner betweon renal artery and ureter (ureteric artery) and kidney-pelvis.

h. Prepare and free the ureter in distal direction and in sny ense to beyond the orossing of the common illac artery.

1. Then the kidney is prepared free, transsect the artery close to the sorta, medially of the arterlotomy.

j. Transsect the renal vein from the caval vein, or take a patch of caval vein too.

k. Soe under 1 ; otc.

\section{General remerks:}

1. All possible haste is necessary between the time of death of the donor and the beginning of the refrigerating of this kidney. The refrizerating is already beginning when the parfusion-tube Is in the right 11 lac artery and when the infusion runs fast. Hith some prectioe this may be achleved within 5 minutes. If the Infusion runs good (and this infusion is at $4^{\circ}-5^{\circ} \mathrm{C}$ ), the left and right kidney can be removed as quickly as possible but not at the cost of the accuracy.

2. Avold the opening of elamps and cutting in or on arteries or veins. Annoying loss of blood may develop which will obscure the viow of the operating fleld.

3. A very large entrance which is kept open, and good light are essentlal for quifk and accurste work.

4. In case of double renal arteries or veins a large patch of aorte or vein wall in which both vessels end has to be removed 5. Stronz asepsis is necessary. 
6. Composition of the perfusing-fluid:

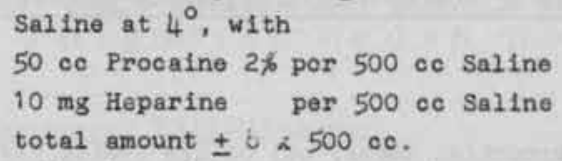

To be kept in the rafrizerator side by side in separate bottles (saline, procamic $100 \mathrm{cc} 2 \%$ heparin $5 \mathrm{cc}$ ) and only to bo mixed when the death of the patient is to be expected. imen the mixed fluid has been kopt for a period longer than 12 hours the Procaine and heparin will deteriorate, then new compositions of the perfusion fluid is necessary. It is advisable to control the actual temperature of the fluids in the refrigerator several times!

An expediont way to do this is to place an accurate thermometer in a 500 oc bottle of physiologic saline. This bottle should be placed in the refrizerator at the same time as the other bottles of saline, procaine and heparine.

7. It is recommendable to practise the removal of a kidney on a cadaver.

b. For good communication between the medical attondant who certifies death and the operating group which will remove the kidney, one fized telephone number with one person who has to be present permanently (someono who does not have to help with nephrectomy) is necessary. This central telephonist has to be kept informed where everybody can be reached whether by telephone or by a calling syatem.

9. It should be discussed beforehand where the operation will take place and what will be the quiekest way to transport the donor after doath to the operating room. In an emergeney, if transport will take too much time, the operation has to take place in bed.

10. Sterile lce is obtalnable by freezing long narrow plastio bags with sterile water in the freezing chambor of a refrizerator. A socond bag has to bo put around the first for extrs securlty. These bags should remain in the refri gerator. The ice in the plastic bags has to be hammerod into piecos before use, by preference on a sterile under-layer and with a sterlle hammer. 


\section{Schome for the course of events with a cadaver-kidney-trans-} plantation.

Phase A

There is a potential donor; he, or hls fanlly has Givon a written pormission for the transplantation.

Phase B

The medical attendant reports that the exitus is imminent. Phase C

The medical attendant reporta that the donor has died.

Prase D

The aurgeon takes out the kidney, cools and Judges the transplant, and reports this to the surgical group

which will transplant the kidney and to the internist etc.

Phase $\mathrm{B}$

Transplantation of the kidney. 
Bijlage 6: Wat te doen bij een mogelijke orgaandonor

(van Rood, oktober, 1968)

\section{WHAT TO DO}

if you are treating a patient who might be a POTENTIAL ORGAN DONOR

\section{Contact the nearest TYPING center:}

For the Netherlands and Germany this is day and night (including week-ends)

University Hospital Leiden, area code 01710.

Hospital number 47222 , ask for Eurotransplant from 8.30 till 18.00, extension 4381 .

During evening, night and week-ond extension 2200.

\section{for Belgium:}

Call Bruxelles, Hospital St. Pierre, Service de Transfusion Sanguine, number 380110 and ask for Miss de Vetter. From 8.00 till 18.00 .

During evening, night and week-end call University Hospital Leiden, 01710,47222 , ask for Eurotransplant, extension 2200 and ask whether blood can be sent for typing. As a rule this will be possible.

\section{Arrange TRANSPORT.}

for centers in the Netherlands.

for distances over $200 \mathrm{~km}$ during daylight call Marine Vliegkamp Valkenburg area code 01718 , airfield 3841 . extension 80 or 70 (operatie officier van de wacht) and ask if transport of blood by helicopter is possible.

for distances under $200 \mathrm{~km}$ and at night call Rijkspolitie Driebergen, area code 03438 , Rijkspolitie 4321 and ask if transport of blood by fast police car is possible.

for centers in Belgium.

for distances over $50 \mathrm{~km}$ during daylight call Brasschaat, area code 02 number 630005 or 630851

for distances under $50 \mathrm{~km}$ and at night call the nearest

Gommandant Mobiele Rijkswacht Groep and ask if transport of blood by fast police car is possible. 


\section{Take the following BLOOD SAMPLES from the potential donor}

1. $60 \mathrm{ml}$ blood mixed with $6 \mathrm{ml} 5 \% \mathrm{Na}^{2}$-EDTA dissolved in buffered saline. Mix thoroughly.

2. $10 \mathrm{ml}$ heparine blood. Mix thoroughly.

3. $10 \mathrm{ml}$ blood, defibrinated durieng 10 minutes with 10 glass beads ( $3 \mathrm{~mm}$ diameter). Mix thoroughly.

4. $10 \mathrm{ml}$ clotted blood.

Mix samples 1, 2 and 3 well (turn them at least 3 times).

Siliconized glassware can be used for 1, 2 and 3, but is not necessary, Label all containers: name patient, birth date, date and hour of bleeding. Complete request form for leukocyle groups. The glass containers and request forms can be ordered from Eurotransplant, Department of Immunohaematology, University Hospital, Leiden, The Netherlands.

4. as soon as the blood is under way to the typing center CALL the typing center AGAIN and inform it of the aproximate time of arrival of the blood.

5. Make certain that you can be reached by telephone from two to four hours after the blood has reached the typing center. You will then be called and the results of the typing will be given to you together with a list of names of the best fitting potential recipients, their doctors. thelephone numbers etc.

As has been discussed during the First Eurotransplant meeting. the doctor in charge of the potential donor will contact direcily the doctor in charge of the potential recipient. Transport of the kidney can be arranged as outlined under 2 .

J.J. van Rood,

Leiden, October 1968 
Bijlage 7: Instructies voor bloed-en serumtransport per trein (van Rood, 11 maart, 1970)

\section{EUROTRANSPLANT Newsletter $\mathrm{Nr} .8$}

\section{Instruotions for bioxd/serum trangport by train}

Between Leyden and Bruxelles transport of blood etc. is arranged as follows:

1) The shipment has to be delivered at the Districts Pogt office in The Hague, "Foreign Department, fifth floor", at 7.45 o'clock A.M. Departure The Hasue 8.42 A.K. Arrival Bruxelles-Midi 10.55 A.M.

2) On the parcel you write:

The name of the Hospital, Telecraphe Restante, Bruxelles-Midi.

3) Your shipment has to be stamped and sent by "Express Mail" but not as registered matter.

4) Attach special customers label (sample included)

5) Addressee is informed by telephone or telex about time of arrival parcel.

6) Hовpital collects parcel at the Post Office (Bruxelles, Avenue Fosny

It will certainly be possible to send in the similar way material from Bruxelles to Leyden and from Germany to Leyden. 
Bijlage 8: Correcties op drukproeven van artikel in 'Het Parool'

(van Rood, oktober, 1967)

\section{HET PARCLL}

carf

(nkben met een regel hasenrutmte)

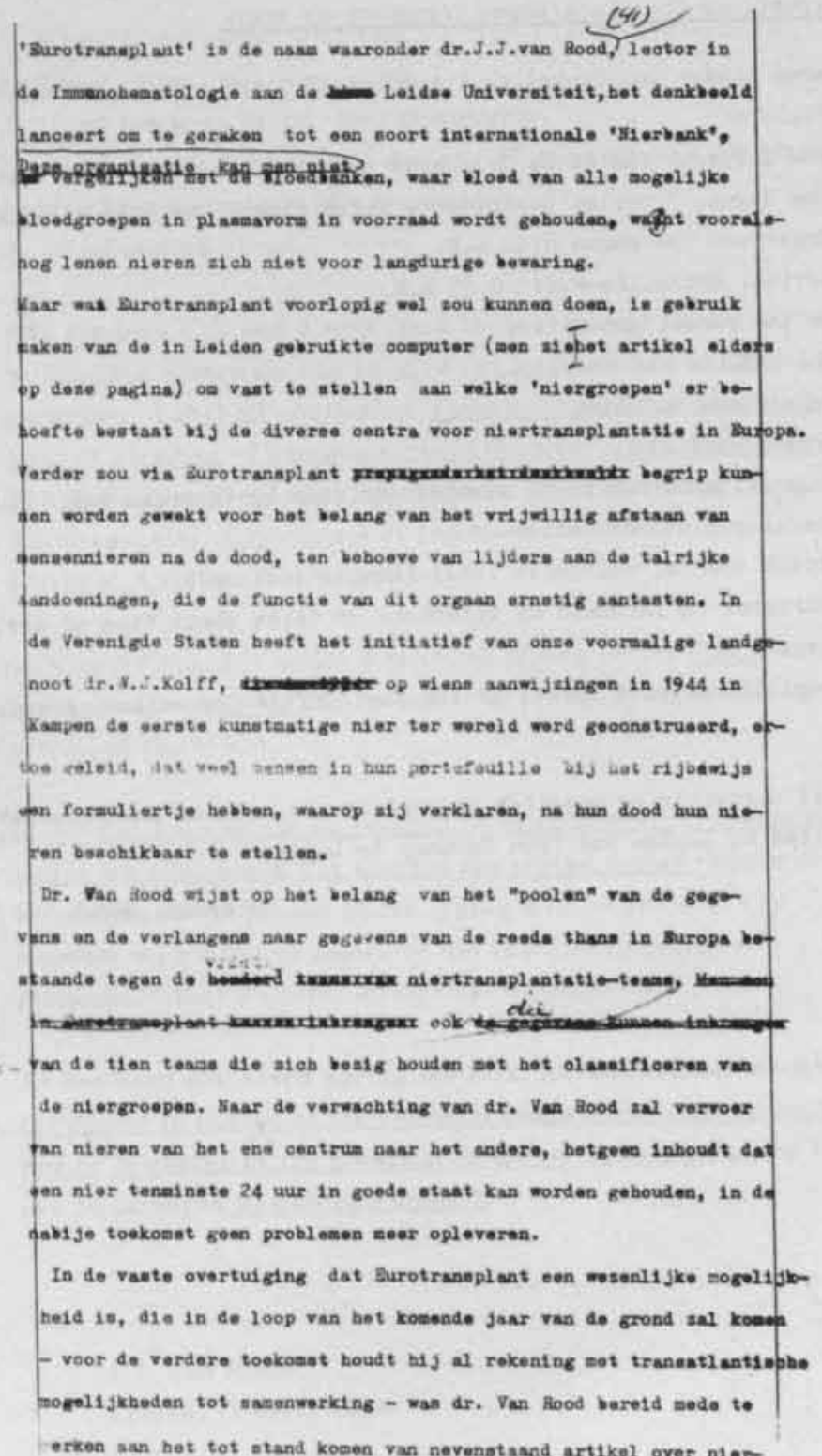




\section{HET PARCL}

2.

(tikken met cen regel maseenrutmee)

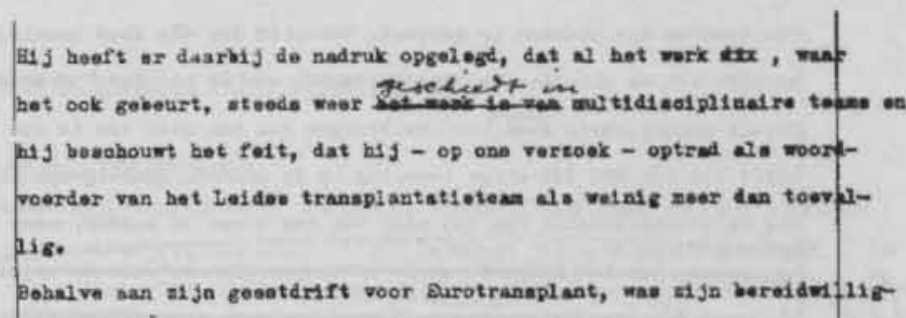

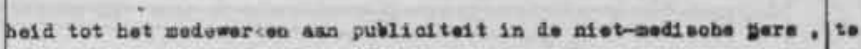

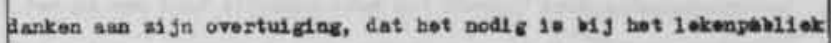
pegrip te rakken voor bot belang van bot afetesn ven nlerea en pan 21 jn behoefte on geboekatanf te sien, dat or ook in Sederland

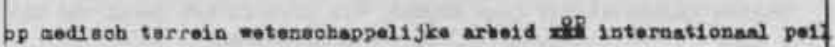
tedrack wordt verrichto 


\section{HET PAROL}

2.

frikken met ein tenel rursenruimte)

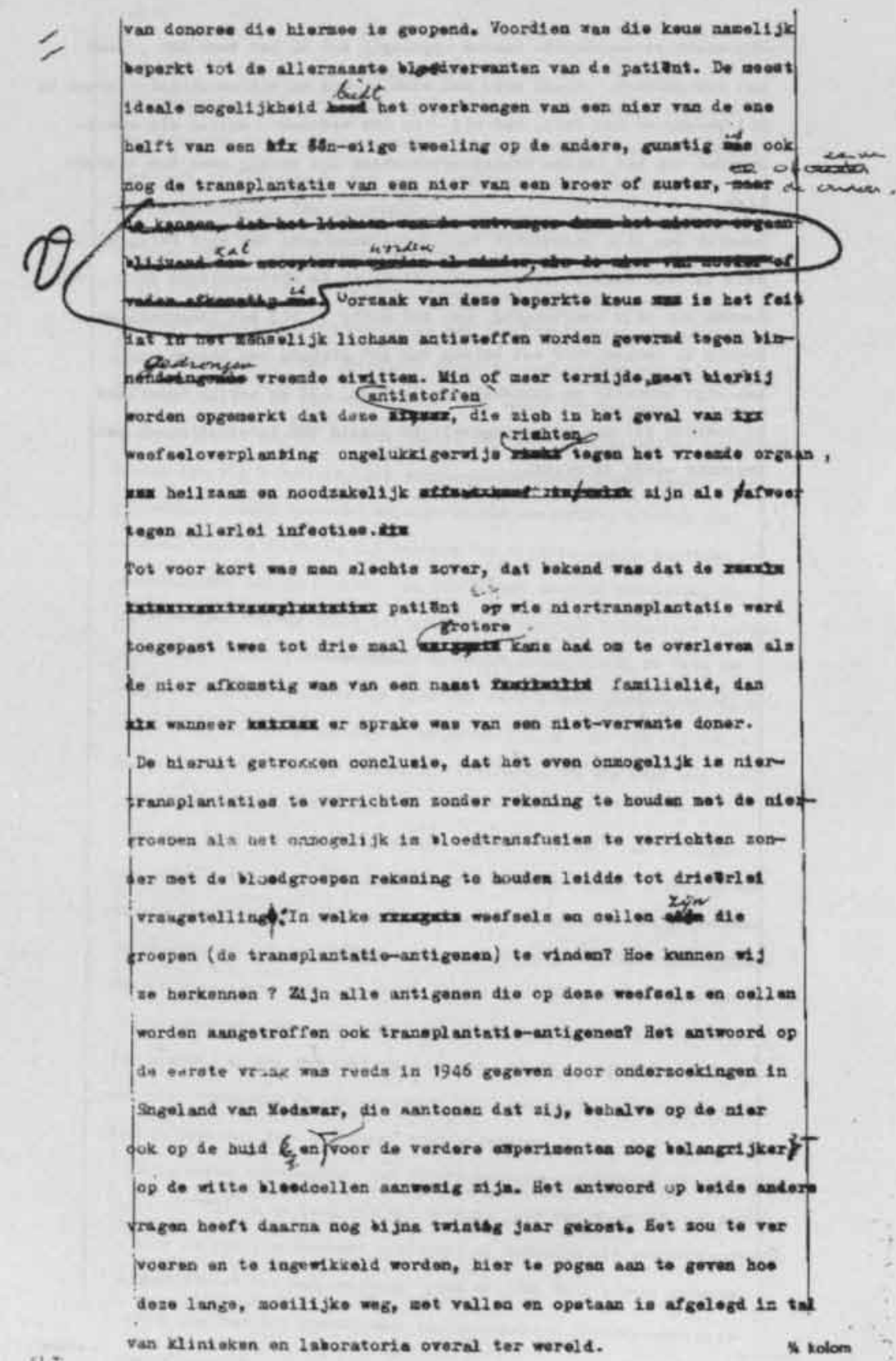




\section{Correcties artikel "Het Parool".}

1. blz. 3 onderaan.

Voor wat Nederland betreft weten wij dat ex in Leiden zeven niertransplantaties hebben plaatsgevonden. Dit is te clanken aan de aanwezigheid van mogelijikheden voor lanydurige behandeling met een kunstmatige nier, van een geschoold chirurgisch team en van mogelijkheden om patienten geisoleerd te verplgen.

2. blz. 4 bovenaan. cen-eilge tweeling op de andere. De transplantatie van een nier van andere bloedverwanten, b.v. een broer of zuster, vader of moeder is evenzeer soms mogelijk, coch heeft ie's minder kans van slagen.

3. blz. 3 onderaan.

Het betekent tevens, dat de hier aangeduide mogelijkheden van de toekomst nog voor nauwelijks afzienbare t. jt het yiute befang van haemodialyse onver let laten. Deze zal in elk geval van grote betekenis blijuen om patienten ........ 
Bijlage 8: 'Match' van de eerste harttransplantaties in Kaapstad (Botha, 1970)

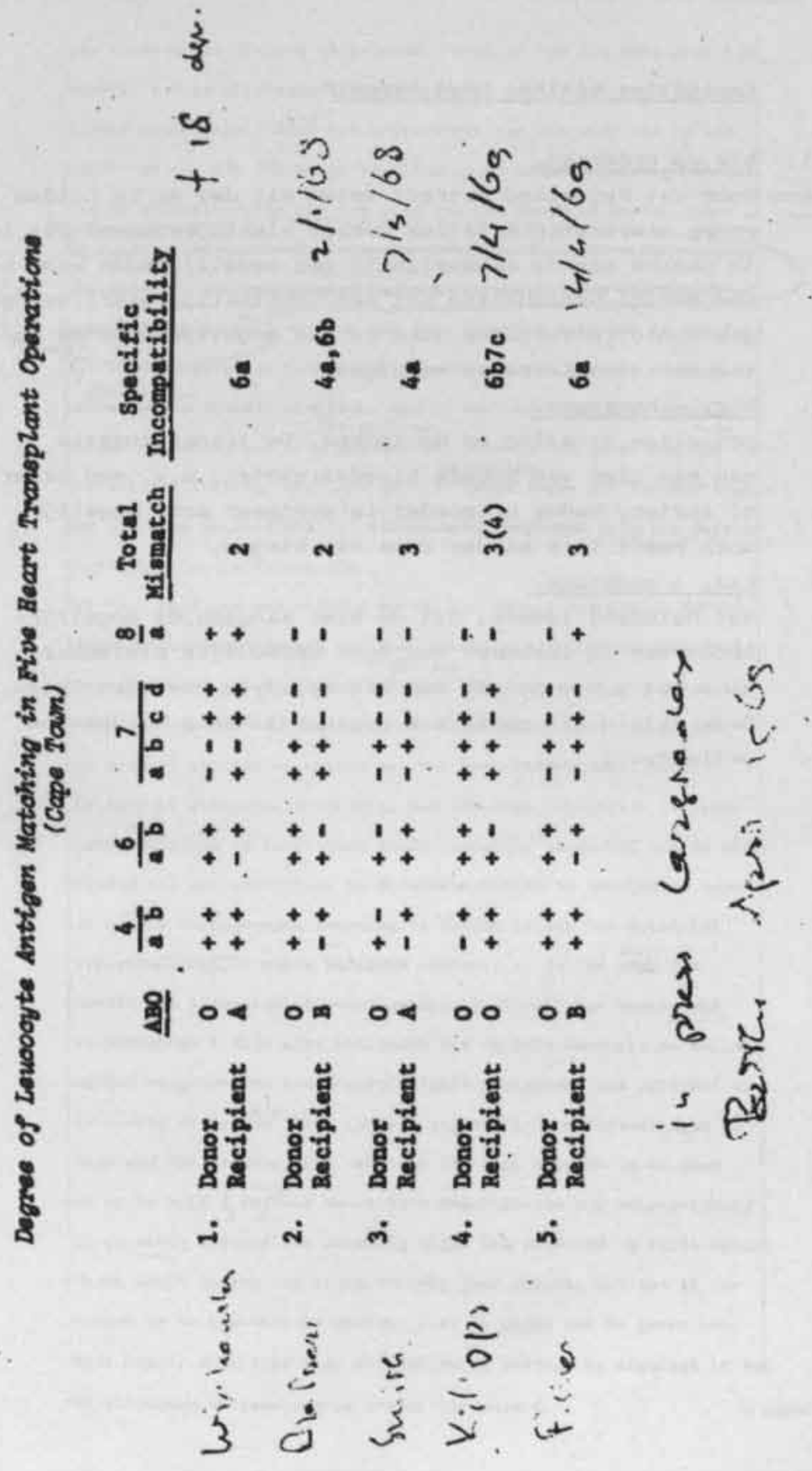




\section{SUMMARY}

Since the second half of the previous century, organ transplantation has expanded enormously. For the first time in history a transplantation practice emerged. The Eurotransplant Foundation is the center of this transplantation practice for the Netherlands and a number of other European countries. This foundation coordinates the exchange of transplantation organs between affiliated transplantation centers in the Netherlands, Belgium, Luxembourg, Germany, Austria and Slovene. This book is the account of research into the development of Eurotransplant. The description is aimed at the role of the matching criterion. How did the theory on (and the empirical research into) matching develop? How important was this criterion for the rise of the transplantation practice? Which problems were thought to be solved by founding an organ exchange organization? The research into the development of Eurotransplant was conducted through study of primary information sources. The reason for this is that in this way, more insight can be obtained in local developments in research and clinical practice. This study has been based mainly on the archives at the Blood Bank of the Academic Hospital in Leiden, as well as on the Eurotransplant archives, covering a period until 1970. Through analysis of the primary sources, an attempt is made to give a differentiated opinion on the legitimacy of the matching criterion and the Eurotransplant Kidney Allocation System protocol (ETKAS), and of the legitimacy of the Eurotransplant organization as a whole. The framework used for this analysis is derived from the modern Science and Technology Studies (STS). This study agrees with this research tradition. In thematically ordered chapters, a picture is sketched of several largely simultaneously occurring developments. By doing so, an insight is offered into the development processes of scientific knowledge, as well as into the development of complex practices.

Following the introductory chapter in which the research question on the rise of Eurotransplant is laid out, chapter 2 gives a description of a development that starts with a clinical observation in 1958 , and leads to the beginning of the development of a leukocyte antigen system. In his 1962 thesis, Van Rood described a general applicable method with which further research can be done on this system. This method however, cannot accomplish mutual comparability of the several local research products. To solve this problem the several parallel developments in leukocyte research in the world are synchronized - as described in chapter 3-by standardizing one of the variables. In 1965 a Center of Laboratory Testing is created, by inviting several researchers to meet, and to have them type the same leukocyte 
antigen samples, with their own techniques and antisera. By using this method, the test results become comparable, the various antisera can now be compared as well. Chapter 4 shows how effort is made to distribute the newly obtained comparability worldwide, or to retranslate it to local research practices. In these processes two mutually dependent groups and approaches can be discerned. The research groups try to standardize the antigen variable, among others by typing panels - determining the antigens of the individual donors - on several places, in analogy with the International Reference Panel in Leiden. The NIH, as a large organization, prefers to standardize the antisera, and to make these available for everybody. The researchers however, have to feed the NIH-Serumbank with the necessary sera. The different objectives of these groups are at odds with each other, which has its repercussions on the collaboration.

Chapter 5 returns to the local, Leiden background of the above mentioned developments; how does the fitting in of knowledge development, and interweaving this with local clinical practices, produce the interconnectedness of typing with the renal transplantation practice in Leiden. A description is given of what happens prior to the first renal transplantation in Leiden, and how the typing of leukocyte antigens is combined with this procedure. Chapter 6 describes several efforts to show the positive influence on the final transplantation outcome of matching. Experimental, retrospective and prospective research methods are used to justify the use of typing as donor selection criterion. The presence of the matching effect is attempted to be proven in different manners. However, on the effect of matching, no consensus is obtained. Chapter 7 reveals why, in spite of the lack of confirmed knowledge, in 1967 a proposal is made to institutionalize the uncertain knowledge. By matching unrelated, deceased donors with renal patients on a waiting list, for many more patients a donor kidney can be made available than without exchange. In part this organization already developed - in a process of co-evolution of medical-technical science and Society - in the preceding decennium, but extending Eurotransplant to a matching practice requires adjustments of original ambitions. This is how Europe is divided in separate regions, and typing is decentralized. In chapter 8 the necessary arrangements and agreements between all the collaborating transplantation centers and typing laboratories are described, in order to have the matching practice function as an apparent internal medical-scientific endeavor. In the second part of chapter 8 , some specific examples of public involvement in the matching practice are explicitly shown. The rise of Eurotransplant is no internal scientific affair. In the ninth and final chapter a retrospect is given on the development of Eurotransplant. First the development of the cognitive foundation of the matching practice is described once more. Next, the merger of several medical disciplines is discussed, after which some reflections are given on the medic social development of Eurotransplant. Finally the legitimacy of the matching criterion and of Eurotransplant are considered, and a view of the allocation protocol ETKAS, that Eurotransplant launched in 1996.

Eurotransplant was founded with the expectation that matching for HLA antigens would have a beneficial effect on the survival time of transplanted kidneys. This expectation was fulfilled only to a limited extent. However, Eurotransplant adhered for a long time to matching as the main criterion for kidney allocation. This criterion has played a formal role for a long time, but since the introduction of ETKAS, formal criteria are also more in agreement with the allocation practice that was developed in the late sixties. 


\section{BRONNEN}

\section{LITERATUUR}

Amos, B., Ward, F.E., Zmijewski, C.M., Hattler, B.G., \& Seigler, H.F. (1968). Graft donor selection based upon single locus (haplotype) analysis within families. Transplantation, 6(4). 524-34.

Amos, D.B. (1964). Summary. Paper presented at the Histocompatibility Testing, Conference and Workshop, 7-12 June, Washington D.C. \& Durham.

Amos, D. B, (r968). Human Histocompatibility Locus HL.A. Science, 159(16 February), 659-60.

Amos, D.B., Hattler, B.G., Hutchin, P., McCloskey, R., \& Zmijewski, C.M. (r966). Skin donor selection by leucocyte typing. Lancet, 1 (7432), 300 . 2.

Anonymus (1969, 18 januari). Nederlands pionierswerk voor orgaantransplantaties. Friesch Dagblad,

Balner, H., Cleton, F.J., \& Eernisse, J.G. (I965). Histocompatibility Testing 1965. Report of a Conference and Workshop., Series Haematologica, (Vol. II, ). Copenhagen: Munksgaard.

Balner, H., van Leeuwen, A., Dersjant, H., \& van Rood, J.). ( 1967$)$. Chimpanzee Iso-antisera in Relation to Human Leukocyte Antigens. In E.S. Curtoni, P.L. Mattiuz, \& R.M. Tosi (Eds.), Histocompatibility Testing 2967 . Report of a conference and workshop. Torino and Saint-Vincent, Italy, 14-24 June 1967. (pp. 257-65). Copenhagen: Munksgaard.

Bosch, LJ., Jansz, A., Lammers, H.A., van Leeuwen, A., \& van Rood, J.J. (196r). A study of the antigenic structure of the thrombocyte by means of thrombocyte sunvival time estimation. Paper presented at the the Eighth Congress of the European Society of Haematology, Wien.

Botha, M.C. $(1967)$. Human heart transplantationthe tissue typing tests. South African Medical Joumal, 41(48), $1265-8$.

Botha, M.C. (1969). Leucocyte-antigen matching in donor selection for heart transplantation. Human heart transplantation-the tissue typing tests. Lancet, 2(7619). 508-12.

Botha, M.C. (r970), Application of Leukocyte Typing to Human Organ Transplantation. In F. Largiadèr (Ed.), Organ Transplantation, (pp. 112-29). Stuttgart: Georg Thieme Verlag.

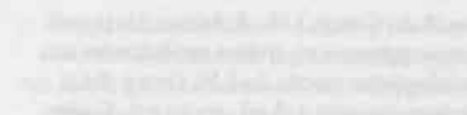

Brent, L (1997). A History of Transplantation immunology, San Diego: Academic Press.

Bruning, J.W., van Leeuwen, A., \& van Rood, J.J. (1965). Leukocyte Antigens. In H. Balner, F.J. Cleton, \& J.G. Eernisse (Eds.), Histocompatibility Testing 1965. Report of a Conference and Workshop., (Vol. II, pp. 275-84). Copenhagen: Munksgaard.

Bulterman, P. (1970, 7 juli). NIERTRANSPLANTATIES NEMEN SNEL TOE. NRC Handelsblad ?

Ceppellini, R., Curtoni, E.S., Leigheb, G., Mattiuz, P.L, Miggiano, V.C., \& Visetti, M. (1965). An Experimental Approach to Genetic Analysis of Histocompatibility in Man. In H. Balner, F.J. Cleton, \& J.G. Eernisse (Eds.), Histocompatibility Testing 1965. Report of a Conference and Workshop.. (Vol. 11, pp. 13-23). Copenhagen: Munksgaard.

Curtoni, E.S., Mattiuz, P.L. \& Tosi, R.M. (1967). Histocompatibility Testing 1967 . Report of a Conference and Workshop Torino and SaintVincent, Italy, $14-24$ June 1967 . Series Haematologica, . Copenhagen: Munksgaard.

Curtoni, E.S., Mattiuz, P.L. \& Tosi, R.M. (1967). Nomenclature: HL.A. In E.S. Curtoni, P.L. Mattiuz, \& R.M. Tosi (Eds.), Histocompatibility Testing 1967 . Report of a Conference and Workshop Torino and Saint-Vincent, Italy, 14-24 June 1967. (pp. 449). Copenhagen: Munksgaard.

D'Amaro, J. Hensen, E., \& van Rood, J.J. (197x). The Micro-Complement-Fixation Test. III. Autamatic Quantitative Scoring with a Microscope Densitometer. Tissue Antigens, 1, 171-7.

Dausset, J. (r954). Leuco-agglutinins IV. Leucoagglutinins and bloodtransfusion. Vox Sang. 4(rgo).

Dausset. J. (1958). Iso-leucoanticorps. Acta Haematologica, 20, 156-66.

Dausset, J., Rapaport, F.T. (1995). The HLA Story. In R.B. Gallagher, Gilder, J., Nossal, G.J.V., Gaetano Salvatore (Ed.), Immunologr The Making of a Modem Science, (pp. m-20). London: Academic Press.

Dausset, J., Nenna, A., \& Brecy, H. (1954). V. Leukoagglutinins in chronic idiopathic or symptomatic pancytopenia and in paroxysmal nocturnal hemoglobinuria. Blood, the Journal of Hematology, 9, 696-720. 
De Planque, B.A., Greep, I.M., \& Balner, H. (r970). Immunosuppressie en andere modificaties van immunologsiche reactie. In J.M. Greep (Ed.). Ongaantransplantatic, (58 ed., pp. $51-75)$. Leiden: Stafleu.

Eernisse, J.G., van Rood, H. (1958). Enthrocyte survival time studies using DFP32. Paper presented at the VIIth International Congress of the International Society of Hematology, Rome.

Eurotransplant (1999). The Eurotransplant Foundation's Aims. Bron: Internet, bezoekdatum: 8 february, 2000 , Internetadres:

http://www.transplant.org/Eurotransplant/rechts z.html

Fox, R.C., Swazey, J.P. (1992), Spare Parts: Organ Replacement in American Society. Oxford: Oxford University Press.

Gabl, F., Riethmuller, G., K., S., \& Zeiss, I. (1967). Probleme der Transplantationsimmunologie. Bericht über eine internationale Klausurtagung am 14./15. April 1967 in Titisee/Schwarzwald. Zeitschrift für Immunitätsforschung, 133. 413.55.

Geerts, G., den Boon, T. (1999). Van Dale, Groot Woordenboek der Nederlandse Taal, (13 ed., ). Utrecht - Antwerpen: Van Dale Lexicografie.

Hintzen, A.H.J. (1971). Niertransplantatic; Een retrospectief onderzock bij eenendertig patiënten. , Rijksuniversiteit Leiden.

Latour, B. (1987). Science in Action: How to Follow Scientists and Engineers Through Socicty. Cambridge: Harvard University Press.

Lawrence, H.S. (1964). Summation. Paper presented at the Conference and Workshop on Histocompatibility Testing, Washington D.C. \& Durham.

Medawar, P.B. (1944). The behaviour and fate of skin autografts and skin homografts in rabbits. Journal of Anatomy, 78(5), 176-99.

Medawar, P.B, (r945). A second study of the behaviour and fate of skin autografts and skin homografts in rabbits. Joumal of Anatomy, 79(4). $157 \cdot 76$.

Mickey, M.R., Kreisler, M., Albert, E.D., Tanaka, N., \& Terasaki, P.I. (1971). Analysis of HL-A incompatibility in human renal transplants. Tissue Antigens, 1(2), 57-67.

Ogden, D.A., Porter, K.A., Terasaki, P.I., Marchioro, T.L. Holmes, J.H., \& Starzl, T.E. (1967). Chronic renal homograft function: correlation with histology and lymphocyte antigen matching. American Joumal of Medicine, $43(6), 837 \cdot 45$.

Payne, R. (1957). Leucocyte agglutinins in human sera. A.M.A. Archives intemal Medicin, 99. 587. 606.

Payne, R., Rolfs, M.R. (1958), Fetomaternal Leucocyte Incompatibility. Joumal of Clinical Investigation, $37.1756-63$.

Starzl, T.E. (199r). My thirty-five year view of organ transplantation. In P.I. Terasaki (Ed.). History of transplantation: Thirty five recollections, (pp. 14582). Los Angeles: UCLA Tissue Typing Laboratory.

Starzl. T.E. (1992). The puzzle people: memoirs of a transplant surgeon. Pittsburgh: University of Pittsburgh Press.
Starzl, T.E. (1993). The French Heritage in Clinical Kidney Transplantation. Transplantation Reviews. $7(2$ (April)), 6571.

Starzl, T.E., Marchioro, T.L, \& Faris, T.D. (1966). Renal homotransplantation: 20 to 36 months later. Military Medicine, 131(6), 489-92.

Starzl, T.E., Marchioro, T.L. Faris, T.D., \& Zuhlke, V. (1966). Renal homotransplantation: 21 to 37 months later. Urol Int, 21(2), 159-62.

Starzl, T.E., Marchioro, T.L. Terasaki, P.1., Porter, K.A., Faris, T.D., Herrmann, T.]., Vredevoe, D.L., Hutt, M.P., Ogden, D.A., \& Waddell, W.R. (1965). Chronic survival after human renal homotransplantation. Lymphocyte-antigen matching. pathology and influence of thymectomy. Annals of Surgery, 162(4), 749-87.

Terasaki, P.I., Vredevoe, D.L., Porter, K.A., Mickey, M.R. Marchioro, T.L., Faris, T.D., Herrmann, T.J., \& Starzl, T.E. (1966). Serotyping for homotransplantation. V. Evaluation of a matching scheme. Transplantation, 4(6), 688.99.

van Loghem, J.J., Sauer, A.J., van der Hart, M., Bok, J., \& Brinkerink, P.C. (1956). Zeldzame immunologische afwijkingen als oorzaak van bloedtransfusiereacties bij een lijder aan verworven haemolytische anaemie. Nederlands Tijdschrift voor de Geneeskunde, 100, 314-23.

van Rood, J.). (1962). Leucocyte Grouping. A method and its application. Unpublished Thesis, Rijksuniversiteit Leiden.

van Rood, J.J. (1962). Leukocytengroepen. Nederlands Tijdschrift voor Geneeskunst, 106(13), 692*4.

van Rood, J.). (1966). The Serological Recognition of Transplantation Antigens in Man (a review). Proceedings or the Ninth International Congress of Internal Medicine. Amsterdam, 7-10 September $1966,70-7$.

van Rood, J.J. (1967). Immunogenetics of the group four, five and nine system. In Curtoni, Mattiuz, \& Tosi (Eds.), Histocompatibility testing 1967; Report of a conference and workshop, Torino and SaintVincent, Italy, $14 \cdot 24$ June 1967. (pp. 203-19). Kopenhagen: Munksgaard.

van Rood, J.J. (1967). Preface. In E.S. Curtoni, P.L. Mattiuz, \& R.M. Tosi (Eds.), Histocompatibility Testing 1967. (pp. 3-6). Copenhagen: Munksgaard.

van Rood, J.J. ( $\left(1_{9} 67\right)$. A Proposal for International Cooperation in Organ Transplantation:

Eurotransplant. In Curtoni, Mattiuz, \& Tosi (Eds.). Histocompatibility testing 1967 : Report of a conference and workshop, Torino and Saint-Vincent, Italy, 14-24 June 1967. (pp. 451-2). Kopenhagen: Munksgaard.

van Rood, J.). (r969). Tissue Typing and Organ Transplantation. The Lancet(June 7), 1142-6.

van Rood. I.J., van Rood, A. (1969). Problemen bij Orgaantransplantaties, 1) de immunologische aspecten. Natuar en Techniek, 37(6), $210-6$.

van Rood, J.). (1970). Leukocyte Groups in Man and Their Relation to Transplantation Antigens. In F. Largiadèr (Ed.), Organ Transplantation, (pp. 103II). Stuttgart: Georg Thieme Verlag.

van Rood, 1.). (1993). HLA and 1. Annual Review in Immunolgy, 11, 1*28.

van Rood, J.J., Eernisse, J.G. (1959). Durée de Vie et 
Comportement Physiologique des Plaquettes. Sang, $X X X(7), 677 \cdot 87$.

van Rood, J.J., Eernisse, 1.G., \& van Leeuwen, A. (1957). Some Studies on the Effect of Circulating Thrombocyte-Antibodies on the Lifespan of Thrombocytes. Paper presented at the 6 th Congress of the European Society of Hematology, Copenhagen.

van Rood, J.J., Eernisse, J.G., \& van Leeuwen, A. (1958). Leucocyte Antibodies in Sera of Pregnant Women. Nature, 282 (June 21), 1735-6.

van Rood, J.J., Leeuwen, A.v., Pearce, R., \& Does, J.A.v.d. (1969). Leukocyte Typing and Kideny Transplantation in Unrelated Donor-Recipient Pairs. A Study in Patients of Drs. S. Peart, J.F. Mowbray, and G.R.J. Alexandre. Transplantation Proceedings, 1(x), 372-5.

van Rood, J.J., Loeliger, E.A. (1959). Les Critères des Transfusions de Plaquettes. Sang, XXX(7), 694. 700 .

van Rood, J.)., van Leeuwen, A., \& Bosch, LJ. (r961). Leucocyte antigens and transplantation immunity. Paper presented at the The Eighth Congress of the European Society of Haematology, Wien.

van Rood, J.J., van Leeuwen, A., \& Bruning, J.W. $(1967)$. The relevance of leucocyte antigens for allogeneic renal transplantation. Journal of clinical pathology. 20(Symp. Tissue Org.

Transplant.,1967), 504-12.

van Rood, J.J., van Leeuwen, A., Bruning. J.W., \& Porter, K.A. (1967). The importance of leukocyte antigens in renal transplantation. A study of patients of: G.R.J. Alexandre, J. van Geertruyden, W.D. Kelly, J.P. Merrill, J. Morelle, J.F. Mowbray, J. Murray, P.S. Russel, T.E. Starzl, Ch. Toussaint \& M.F.A. Woodruff. Paper presented at the The First International Congress of the Transplantation Society, Paris.

van Rood, J.J., van Leeuwen, A., \& Eernisse, J.G. (r958). Antibodies Against Leucocytes in Sera of Pregnant Women. Paper presented at the the Seventh Congress of the International Society of Blood Transfusion, Rome.

van Rood, J.J., van Leeuwen, A., \& Eernisse, I.G. (I959). Antistoffen tegen leukocyten in serum van zwangere vrouwen. Nederlands Tijdschrift voor Geneeskunde, 103(38), 1928-31.

van Rood, J.J., van Leeuwen, A., \& Eernisse, J.G. (1959). Leucocyte Antibodies in Sera of Pregnant Women. Vox Sanguinis, 4, 427*44.

van Rood, J.J., van Leeuwen, A., \& Eernisse, J.G. $(1967)$. Leukocyte Groups and Their Clinical Importance.

van Rood, J.J., van Leeuwen, A., Eernisse, J.G., Frederiks, E., \& Bosch, L.J. (1964). Relationship of Leukocyte Groups to Tissue Transplantation Compatibility. Annals of the New York Academy of Sciences, 120 (November 30), $285-98$.

van Rood, J.J., van Leeuwen, A., Freudenberg, J., \& Rubinstein, P. (1971). Prospects in Host-Donor Matching. Transplantation Proceedings, $\mathrm{HI}_{\mathrm{2}}$ (June)), 1042-50.

van Rood, J.J., van Leeuwen, A., Schippers, A. Ceppellini, R., Mattiuz, P.L., \& Curtoni, S. (1966). Leukocyte groups and their relation to homotransplantation. Annals of the New York Academy of Sciences, 129 (December 30), 4677.72.

van Rood, J.J., van Leeuwen, A., Schippers, H.M.A., Zwerus, R, \& Terpstra, J.L. (r971). Perspectives in Transplantation: Eurotransplant. Transplantation Proceedings, III, I (March), 933-41.

van Rood, J.J., van Rood, A. (r970). Problemen bij Orgaantransplantaties. 3) toepassingsmogelijkheden in de kliniek. Natuur en Techniek, $38(8)$.

Wackers, G.L (1994). Constructivist medicine. Rijksuniversiteit Limburg.

Zmijewski, C.M., McGloskey, R.V., \& St. Pierre, R.L. ( 1967$)$. The effect of environmental Extremes on the Detectibility of Leukocyte Isoantigens in Normal Humans with inference to Tissue Typing of Prespective Donors. In E.S. Curtoni, P.L. Mattiuz, \& R.M. Tosi (Eds.), Histocompatibility Testing 1967, (pp. 397-405). Copenhagen: Munksgaard.

\section{PRIMAIRE BRONNEN}

A.Z.L. (29 september, 1969). Brief aan Van Rood, een verzoek d.d. 22 augustus om een Telex-machine in de Eurotranplantcaravan afwijzend, vanwege hoge kosten en beperkt gebruik. Leiden.

Abbott, C.R. (21 november, 1966). Brief aan Van Rood, over heropening 'renal transplantation unit', vragend om training van een analist en om servicetyperingen in de tussentijd. Leeds.

Abrahms, C. (6 september, 1966). Brief aan Van Rood, zich excuserend voor het wegens ziekte niet antwoorden. Starzl dringt ex bij hem op aan om zelf typeringslaboratorium op te zetten, en hij verzoekt om een nog een mogelijkheid om Leiden te bezoeken. Johannesburg.

Alexandre, G.P.J. (22 maart, 1966). Brief aan Van Rood, stemt in met voorstel en stuurt transplantatiepatiënten en hun donoren om hen in Leiden te laten typeren. Leuven.

Alexandre, G.P.J. (12 januari, 1967). Brief aan Van Rood, lijst met alle transplantaties sturend. waarvan de laatsten kadaverdonoren zijn. Echter geen milten beschikbaar. Leuven.

Alexandre, G.P.J. (6 mei, 1968). Brief aan Van Rood. dankend voor typering van 'afgelopen vrijdag' van mogelijke harttransplantatiepatient, bloed werd vervoerd door helicopter, waar hij met leger nog verder contact over zal hebben. Leuven.

Alexandre, G.P.J. (8 juli, 1968). Brief aan Van Rood, over de van de wachtlijst te verwijderen namen en vragend naar typeringsinformatie over donoren en milten. Leuven.

Alexandre, G.P.J. (9 mei, 1968). Brief aan Van Rood, over vergadering op Hoofdkwartier Leger, om het sturen van bloed en/of nieren per helikopter te organiseren, en over verder te nemen maatregelen. Leuven.

Allen, F.H.). (10 maart, 1967). Brief aan Van Rood, over het aan Lalezari geven van sera voor de Workshop, over initiatieven rond het organiseren van informatie-uitwisseling ten aanzien van potentiele donoren en ontvangers van nieren, en over onderzoek naar het invriezen en ontdooien van lymphocyten. New York. 
Amos, D. B. (ro november, 1964). Brief aan Van Rood, over Voorzitterschap van Histocompatibility Testing 1965 , en over Overman (NIH). Durham.

Amos, D.B. (13 juli, 1964). Brief aan Van Rood, over verslaglegging eerste Workshop. Durham.

Amos, D.B. (16 november, 1964). Brief aan Van Rood, over Voorzitterschap van Histocompatibility Testing en toekomstige meetings, nomenclatuur. NIH-standaards. Durham.

Amos, D.B. (18 december, 1964). Brief aan Van Rood, over financiering ' 65 Workshop, geen 'gesplitste dagen' willen, en problemen met groep Four. Durham.

Amos, D.B. (21 augustus, 1964). Brief aan Van Rood, over organisatie 1965 'Histocompatibility Testing Conference and Workshop'. Durham.

Amos, D.B. (23 maart, 1964). Brief aan Van Rood, over NIH en eerste Workshop. Take glassware with you'. Durham.

Amos, D.B. (7 mei, 1965). Brief aan Fred Allen (als voorbeeld van de brieven aan alle geinviteerden). hem uitnodigend om aan de Conference deel te nemen. Durham.

Amos, D.B. (20 april, 1965). Brief aan Van Rood, over doel van de 65 Workshop, en voorstel om sessie te houden met leden van de 'Tissue Typing Club' over toekomst van de 'Club'. Durham.

Amos, D.B. (23 februari, 1965). Brief aan collegae van het 'organizing committee', over de genodigden voot de 1965 Conference en Workshop. Durham.

Amos, D.B. (23 februari, 1965). Brief aan Van Rood. vraag over NIT test beantwoordend. Durham.

Amos, D.B. (25 februari, 1965). Brief aan Terasaki, over Starzl en verzoek om serum.

Amos, D.B. (4 mei, 1966). Brief aan Van Rood, over organisatie 'Torino', 'identieke resultater' in verschillende tests, en 'NIH contractors meeting'. Durham.

Amos, D.B. (r6 maart, 1966). Brief aan Van Rood, over NIH, Zmijewski en huidtransplantatieexperiment. Durham.

Amos, D.B. (31 maart, 1966). Brief aan Van Rood, over 'panels', de problemen met repliceren met andere sera, en standaardisatie. Durham.

Amos, D.B. (5 oktober, 1967 ). Brief aan Collegae, over Brief aan Science over Nomenclature. Durham.

Amos, D.B. (13 maart, $\mathrm{r}_{9} 67$ ). Brief aan Ceppellini en Van Rood, over Anja Tilikainen en Pavol Ivanyi, welke zelfstandig startend zijn, maar ervaren onderzoekers. Durham.

Amos, D.B. (22 december, 1967). Brief aan Van Rood, over Brief aan Science over Nomenclature. Durham.

Amos, D.B. (20 september, I968). Brief aan Patient T (c.c. Van Rood), over interessant probleem, maar er wordt beweerd dat Van Rood een betere bron van informatie voor testikel implantatie is. Durham.

Amos, D.B., van Rood, J.J. (12 juli, r965). Brief van Amos/Van Rood aan Wilson, hem toestaand ook aan de Workshop deel te nemen. Leiden.

Amos, D.B., Zmijewski, C.M. (5 oktober, 1967). Brief van Amos en Zmijewski aan Van Rood, in reactie op telefoongesprek over Brief aan Science over Nomenclature. Durham.
Anderson, S.G. (9 oktober, 1967). Notulen van discussie in de 'Division of Biological Standards' tussen Dr. J.J. van Rood, K.LG. Goldsmith en S.G. Anderson 9-10-1967, over mogelijkheid om serumstandaarden te creěren voor een aantal van de menselijke transplantatie antilichamen. Londen.

Anonymus (23 september, 1946), Van start gaan AZ1. bloedbank.

Anonymus, van Leeuwen, A. (1965). Lijst van donoren van het Theologicum/Philosophicum Warmond, beschikbaar op $18,19,20$ of 21 augustus 1965 . Leiden.

Appleyard, R.K. (25 oktober, 1967). Brief aan Van Rood, van Euratom, over tijdelijk niet in staat zijn Eurotransplant financieel te ondersteunen. Brussel.

Archer, G.T. (19 december, 1968). Brief aan Van Rood, vragend om het Eurotransplant Computer programma, om te gebruiken voor het Australian National Transplant Register'. Sidney.

Baker, E., Daly, P., (BBC) (15 oktober, 1968). Brief aan Van Rood uit naam van Philip Daly, verslag doend van de uitzending van "The Trouble With Being Oneself" en de gunstige ontvangst door de $B B C$ en de Pers. Londen.

Beck, E.A. (17 augustus, 1967 ). Brief aan Van Rood, nog geen samenwerking tussen Basel en Leiden. niet haalbaar om bloed te sturen om te laten typeren, geen analist beschikbaar om te trainen. maar neemt contact op in de toekomst. Basel.

Beck, E.A. (23 juni, 1967 ). Brief aan Van Rood, een samenwerkingsaanbod afslaand vanwege slechte transportfaciliteiten en tekort aan kadaverorganen, maar met de aanbieding om milten te sturen. Basel.

Berah, M. (3r augustus, 1967). Brief aan Van Rood, met verzoek om hulp, en gebruik van microtechnieken in relatie tot klinisch typeren. Melbourne.

Berah, M. (3r juli, 1967). Brief aan Van Rood, over donorpanel, NIH sera "starter package", en verzoek om hulp bij interpretaties. Melbourne.

Berger, 1. (9 januari, 1968). Brief aan Van Rood, over het via kranten en radio hebben gehoord over het Eurotransplant initiatief en dat zij willen starten met het transplanteren van nieren. Basel.

Berry, G.P. (3 november, 1967). Brief aan Van Rood, de ontmoetingsdatum vaststellend op 17 november 1967 , om te spreken over een subsidie van de Whitehall Foundation. Princeton, New Jersey.

Bes van Till, H.A.H. (r7 april, 1970), Brief aan Van Rood, over vergadering van Commissie Orgaantransplantatie met antwoord op vraag over welke bezwaren er zijn aan het 'geen bezwaar systeemi. Den Haag.

Bestuur Isolatiepaviljoen (3 december, 1964). Verslag Bestuur Isolatiepaviljoen, 3 december 1964 . Leiden.

Bestuur Isolatiepavilioen (13 oktober, 1964). Verslag Bestuur Isolatiepaviljoen, 13 oktober $1_{96} 6$. Leiden.

Bestuur Isolatiepaviljoen (20 juni, 1965). Verslag Bestuur Isolatiepaviljoen, 28 mei 1965. Leiden. 
Bestuur Isolatiepaviljoen (23 maart, 1965). Verslag Bestuur Isolatiepaviljoen, 23 maart 1965 . Leiden.

Bestuur Isolatiepaviljoen (27 oktober, 1965). Verslag Bestuur Isolatiepaviljoen, 27 oktober 1965 en verslag ziektegeschiedenis in IP behandelde patiënten maart 1965-oktober 1965. Leiden.

Bestuur Isolatiepaviljoen (28 april, 1965). Verslag Bestuur Isolatiepaviljoen, 28 april 1965. Leiden.

Bestuur Isolatiepaviljoen (1966). Concept-plan voor de behandeling van stralingsongevallen. Leiden.

Bestuur Isolatiepavilioen (6 mei, 1966). Agenda Bestuur Isolatiepaviljoen, 6 mei r966. Leiden.

Bestuur Isolatiepaviljoen (6 mei, 1966). Verslag Bestuur Isolatiepaviljoen, 6 mei 1966. Leiden.

Bestuur Isolatiepavilioen (30 maart, 1966). Verslag Bestuur Isolatiepaviljoen, 30 maart 1966. Leiden.

Bestuur Isolatiepaviljoen ( 8 mei, 1967). Verslag van niertransplantatie patiënten, d.d. 8 mei 1967 .

Bestuur Isolatiepavilioen (oktober, 1967 ). Overzicht Niertransplantaties oktober 1967 .

Bestuur van de Faculteit der Geneeskunde ( 22 juli, 1965). Brief aan 'College der Curatoren RijksUniversiteit Leideri, over het hebben geregeld van de problemen die voortkwamen uit de financiering uit verschillende bronnen. Leiden.

Bloedbank anonymus (r959). aantal afgenomen donores.

Bloedbank/AZL (1949). Transfusieverslag, Leiden.

Bloedbank/AZL (1952). Aanvraagformulier Bloedtransfusie. Leiden.

Bloedtransfusiedienst ( 15 december, $\mathrm{rg}_{64}$ ). Anamnestische vragenlijst voor keuring van donoren Theologicum Warmond, d.d. I5 december 1964 .

Bosteels, V. (7 januari, 1969). Brief aan Van Rood, vergezeld van cross-match sera. Leuven.

Botha, M. (7 november, 1966). Brief aan Van Rood. vragend om typringsera, om te kunnen gaan typeren voor Abrahams in Johannesburg. Kaapstad.

Botha, M. (29 oktober, 1966). Brief aan Van Rood, dankend voor inspanningen om jemand te trainen in Leiden, en het starten van screening aankondigend. Kaapstad.

Botha, M. (1o december, 1967). Telegram aan Van Rood, na eerste Harttransplantatie, vragend om bibliografische informatie om erkenning te geven voor 'bijstand' van Leiden. Kaapstad.

Botha, M. (19 januari, 1967). Brief aan Van Rood, dankend voor 'antileukocytensera' en gescreende sera sturend, en etnische problemen noemend. Kaapstad.

Botha, M. (20 september, 1967 ). Brief aan Van Rood, een grote hoeveelheid serum sturend om te worden gescreend en gespecificeerd, over het starten met typeren voor transplantatiedoeleinden en over het verloren gaan van antisera. Kaapstad.

Botha, M. (27 september, 1967). Brief aan Van Rood, vragend om matchingsadvies, aangaande drie patiënten en drie problamatische, prospectieve kadaverdonoren. Kaapstad.

Botha, M. (4 maart, 1968). Brief aan Van Rood, over dat hij het enthousiasme voor immunologie in relatie tot de (hart)transplantatie in Zuid Afrika coördineert, een verzoek om matchingsadvies aankondigend, en over gebruik van ALS met typeren; over Bantu-materiaal; en vragend om antisera. Kaapstad.

Botha, M. (15 januari, 1968). Brief aan Van Rood, over hun contact met de pers en wat hij en Marrie Vooijs hen hebben verteld over de Leidse bemoeienis met de harttransplantatie, en over verloop van nieuwe harttransplantatiepatiènten. Kaapstad.

Brockis, J.G. (2 mei, 1967). Brief aan Van Rood, over komst naar Transplantation Conference en verzoek om samenwerking in het opzetten van typeringsfaciliteiten voor hun kadavertransplantatieprogramma.

Bruning, J.W. (5 september, 1968). Kopie van brief aan Dausset, gezonden aan Hāssig (Schweizerisches Rotes Kreuz Blutspendedienst). over voortgang van Eurotransplant en vragend om mening over voorgestelde schema met Zwitserland en Zuid-Duitsland samen. Leiden.

Bruning, J.W. (17 april, 1968), Brief aan Stevens (KNMG), over lezing: Immunologische compatibiliteit bij orgaantransplantaties. Leiden.

Buchanan, D.I. (7 december, 1965). Brief aan Van Rood, met verzoek om sera te typeren door het 'WHO reference laboratory'. Edmonton, Alberta, Canada.

Centraal proefdieren bedrijf TNO afd. Vermeerdering (24 mei, 1968). Brief aan Van Rood, met bereidverklaring om honden te fokken. Rijswijk.

Ceppellini, R, (1 april, 1966). Brief aan Van Rood, over NIH, politieke stappen richting niertransplantatie en experimentele huidtransplantaties op gematchte ontvangers. Turijn.

Ceppellini, R. (2 augustus, 1966). Brief aan Van Rood, over de Workshop, voorgestelde onderwerpen, cytotoxiciteitstests en schrijven van huidtransplantatie-experiment. Turijn.

Ceppellini, R. (8 augustus, 1966). Brief aan Amos en Zmijewski, copy aan Van Rood, over de Workshop, Genetica als onderwerp, voorbereidingen met Van Rood, en omvang van de Workshop. Turijn.

Ceppellini, R. (8 augustus, 1966). Brief aan Van Rood, welke kopie van brief aan Amos en CMZ vergezelt, over de benodigde hulp voor het typeren van de families voor de Workshop, en voortzetting van huidtransplantatieproject. Turijn.

Ceppellini, R. (II juli, 1966). Brief aan Van Rood, over Brief over Nomenclature, internationale panels en erkenning. Turijn.

Ceppellini, R, (3 juni, 1967). Brief aan Van Rood, over organisatie van de Workshop en Conference, in het bijzonder het programma van de Conference. Turijn.

Ceppellini, R. (25 november, 1967 ). Brief aan Van Rood, over schrijven van Histocompatibility Testing 1967, dat Trnka cen subsectie over Nomenclature niet wil ondertekenen, en Van Rood ondersteunend in zijn 'Credits discord'. Turijn. 
Cleton. F.J. (Ir Februari, 1965). Concept plan voor het bacteriologisch onderzoek in het "IsolatiePaviljoenr. IRS. Leiden.

Commissie van Advies IRS ( 9 augustus, 1977). Nota bestemd voor het Bestuur L.R.S. Leiden.

Copex Expeditiebedrijf (22 oktober, 1968). Brief aan Van Rood, verantwoording vragend voor het niet bijtijds mededelen van afgelasting van transport van een nier op ar oktober naar Zürich. Amsterdam.

Daly, P., (BBC) (7 juni, 1968). Brief aan Van Rood, met verzoek om medewerking te verlenen aan documentaire over "the Immunologists". Londen.

Dausset. I. (15 december, 1964). Brief aan Amos over organisatie van de 1965 Workshop. Parijs.

Dausset, J. (3 februari, 1965). Brief aan Van Rood, over identiek zijn van anti-Yc en anti-6c. Parijs.

Dausset. J. (3 maart, 1965). Brief aan Van Rood, over serum typering en over de Workshop. Parijs.

Dausset, J. (19 september, ${ }_{9} 67$ ). Brief aan Van Rood. met voortzetting van verschil van mening discussie, Parijs.

Dausset. J. (24 juli, 1967). Brief aan Van Rood, om hun verschillen van mening te regelen. Parijs.

Dausset. J. (24 oktober, 1968). Brief aan Van Rood, over het opzetten van 'Euro-Transplant Ouest', maar eerst standaardiseren van serologische methoden. Parijs.

de Graeff. J. ( 6 oktober, 1965). Agenda vergadering Niertransplantatiewerkgroep dd. 6 oktober 1965 . Leiden.

de Jong. J. (14 september, 1970). Brief aan Van Rood, heeft dialyseafdeling gestart en vraagt om de voorwaarden en eisen die Eurotransplant stelt voor toekomstige transplantatiepatiënten. Rotterdam.

de Weck, A.L (19 augustus, 1968), Brief aan Van Rood, dankend voor typeringscursus, en stuurt containers voor 'reference serum samples'. Bern.

Dennis, C. (ro juli, 1968). Brief van Principal Medical Officer, Ministry of Health, aan Van Rood, met verzoek om Leiden te bezoeken om Eurotransplant en de benodigde typeringsfaciliteiten te zien en te bespreken. Londen.

Derom, F. (4 november, 1968). Brief aan Van Rood, over bereidheid om Telex-aansluiting te verkrijgen, maar alleen waaneer andere ziekenhuizen ook meedoen. Gent.

Dick, H.M. (1 maart, 1968). Brief aan Van Rood, met verzoek om Leiden te mogen bezoeken in relatie tot plannen om immunohaematologisch laboratorium op te zetten. Glasgow.

Drukker, W. (26 maart, 1970). Brief aan Van Rood, over noodzaak van Telex-aansluitinng en een helihaven met Schiphol op to minuten. Amsterdam.

Dutz, H. (8 oktober, 1968). Brief aan Van Rood, met vraag om informatie en mogelijkheid om deel te nemen aan Eurotransplant, en met verzoek om iemand te trainen in Leiden. Berlijn (DDR).

Eernisse, J.G., van Rood, J.J. (28 april, 1958). Brief aan Professor Dr. A.J.M. Holmer

(Vrouwenkliniek AZL), informatie geven over zwangerschapsgeinduceerde leukocytenantilichamen, en verzoekend om samenwerking met hun onderzoek. Leiden.

Eijsvoogel, V.P. (9 november, 1965). Brief aan Van Rood, met resultaten van de bloedtests van de moeder (donor) Eerste Nederlandse niertransplantatie. Amsterdam.

Eijsvoogel, V.P. (8 september, 1967). Kopie van brief aan Drukker, gezonden aan Van Rood, over het typeren van bloed van prospectieve transplantatiepatiènten door het CLB en Leiden. Amsterdam.

Emden, A.v., Stichting Fondsenwervingsacties Volksgezondheid (24 april, 1970). Brief aan Van Rood, financiële ondersteuning verlenend voor transport van donornieren tot een totaal van $f$ 10.000,- 's-Gravenhage.

Eurotransplant (1970). MANUAL FOR CADAVERKIDNEY-TRANSPLANTATION. Leiden.

Goodman, H.C. (r augustus, 1968). Brief aan Huttrer (NIH), kopie gezonden aan Van Rood, voorstel voor Informatieregister over hart-en andere transplantaties en over ontwikkeling van regionale, computer-based leukocytentyperingsdiensten als Eurotransplant. Genève.

Govaerts, A. (19 juni, 1967). Brief aan Van Rood. stuur vandaag nieuw serum BOESCH vanwege niet arriveren vorige zending. Brussel.

Govaerts, A. (26 december, 1968). Brief aan Van Rood, over vooruitgang in typeren met microtechnieken, maar geinteresseerd in 'superspeed microcytotox', en over problemen met het maken van contact met andere centra in geval van een donor, daarom vragend wanneer telex beschikbaar is. Brussel.

Gurland, H.). (6 december, 1968). Brief aan Van Rood, over resultaten van door Leiden getypeerde donoren en patiënten, en hun deelname in Eurotransplant uitstellend tot transportfaciliteiten geregeld zijn, en ook de daar gebruikte chirurgische procedure aangaande de donornier sturend. München.

Harris, R. (18 juni, 1968), Brief aan Van Rood, zijn teleurstelling uitend over overinschrijving van typeringscursus, over gestart zijn met prospectieve weefseltyperingsafdeling, en klagend dat de serumbank van het NIH talmt met uitgifte van sera. Manchester.

Harris, R. (23 januari, 1968). Brief aan Van Rood, vragend naar de voortgang van Eurotransplant. Manchester.

Hayry, P. (4 oktober, 1968). Brief aan Van Rood, over dat het Finse Rode Kruis een typringslaboratorium start en daarom informatie over Eurtransplant vragend. Helsinky.

Heintz, R. (20 december, 1968). Brief aan Van Rood, meldend dat zi starten met niertransplantatie en vragen om typering van hun patiënten en later van prospectieve donoren. Aken.

Hijmans, W. ( 18 juli, 1963 ). Brief aan Van Rood, over Lectoraat, bouw/uitbreiding Bloedbank, eerste contacten NIH indirect via Amos mooier wanneer $\mathrm{NIH}$ initiatief overneemt en over beperkte rol immunologie bij transplantatie. Leiden. 
Höffler, D. (27 december, 1967). Brief aan Van Rood, vragend om hulp bij testen op 'histocompatibiliteit, maar Niertransplantaties zijn gestopt totdat elkders verbeterende resultaten worden gezien. Berlijn.

Höffler, D. (7 februari, 1968). Brief aan Van Rood, vragend om bloed 'containers' omdat transport minder dan 4 uur in beslag zal nemen. Berlijn.

Hollweg, E. (9 december, 1967 ). Brief aan Van Rood. gelezen hebbend over "bank für gewebeverpflanzung' en hernzelf als donor aanbiedend, met verzoek om de noodzakelijk formulieren naar hem op te sturen. Ludenscheid.

Hooghoudt, T.E.H. (1969). Brief aan Van Rood, vergezeld aan script voor film over Transplantatie, met voorgestelde data voor film shoots. Rotterdam.

Hooghoudt, T.E.H. (1969). Script: TRANSPLANTATIE VAN WEEFSELS EN ORGANEN. Rotterdam.

Horisberger, B. (9 september, 1968). Brief aan Van Rood, over gebrek aan voortgang in Zwitserland aangaande weefseltypering, vragend om typering van patiënten en mededeling dat orgaanuitwisseling nationaal wordt georganiseerd. St. Gallen.

Horisberger, B. (27 augustus, 1968). Brief aan Van Rood, over overtuigd zijn dat weefseltypering noodzakelijk is en vragend om typering van patiënten, zolang geen laboratorium beschikbaar is. St. Gallen.

Huntley, R.I. (12 september, 1966). Brief aan Van Rood, over financiele zaken aangaande de reis naar Denver en logistiek rond donoren en ontvangers. Denver.

Immunohaematologie \& Bloedbank (17 januari \& 21 januari, I966). Lijst van huiddonoren voor twee ontvangers. Leiden.

Interne Acountantsdienst AZL (3r oktober, 1969). Brief aan Van Rood, aanbiedend rapport 69.200 .4 . d.d.30 oktober 1969 over de kosten van histocompatibiliteitstests. Leiden.

Iványi, P. (25 januari, 1968). Brief aan Van Rood, vragend om aanvullende informatie aan krantenberichten over harttransplantatie in Zuid Afrika en Van Rood's rol daarbij. Praag.

Janssen, B.W. (2 oktober, 1969). Brief aan Van Rood, over de wettelijke aansprakelijkheid van Eurotransplant en de consequenties voor personeel in dienst bij het ziekenhuis, dan wel bij Eurotransplant. Leiden.

Joysey, V.C. (ND). Draft: Rappid preparation of a leukocyte suspension and a microcytotoxicity test. Cambridge.

Kelly, W.D. (5 juli, 1966). Brief aan Van Rood, over Dr. E. Yunis, die in combinatie met het niertransplantatieprogramma de histocompatibiliteitstyperingen zal starten, en over hun inspanningen om bij het $\mathrm{NIH}$ financiering te krijgen. Minneapolis:

Kelly. W.D. (6 september, 1966). Brief aan Van Rood, enthousiast over voorstel om in november te komen typeren en dat hij het NIH om financiering zal vragen. Minneapolis.

Kelly, W.D. (to oktober, 1966). Brief aan Van Rood, financiering door $\mathrm{NIH}$ van typerinen in november nog niet rond, maar treft wel voorbereidingen om ontvangers en hun donoren dan beschikbaar te hebben. Minneapolis.

Kelly, W.D. (22 juli, 1966). Brief aan Van Rood, over De. E. Yunis, die een brief asan Van Rood zal sturen, en dat Kelly zelf een brief aan de Universiteit Lieden stuurt over het feit dat Van Rood eens per jaar naar Minneapolis komt. Minneapolis.

Kelly, W.D. (3r maart, 1966). Brief aan Van Rood, over initiatief om kadaverdonoren te matchen met mogelijke niertransplantatie-ontvangers. Minneapolis.

Kerr, D.N.S. (15 oktober, 1966). Brief aan Van Rood, verzoekend om samenwerking bij het matchen van donoren met mogelijke niertransplantatie ontvangers. Newcastle.

Kierfeld, G. (r april, r968). Brief aan Van Rood. vragend of blooe van ontvanger en donor tegelijkertijd nodig zijn en een ingevroren milt, daarnaast vragend om formulieren en verpakkings-en transportmaterialen voor bloed. Essen.

Kierfeld, G. (2 april, 1968). Brief aan Van Rood, mededelend dat bloed kan worden verzonden per sportvliegtuig naar militair vliegveld nabij Leiden. Essen.

Kissmeyer-Nielsen, F. (25 september, 1967). Brief aan Van Rood, dankend voor sera om te testen, over retrospectieve milttypering van niertransplantaties, en nieuwe Transplantatie-wet in Denemarken, welke het gebruik van kadaverdonoren toestaat. Aarhuis.

Kissmeyer-Nielsen, F, (5 oktober, 1968). Brief aan Moureau, kopie gezonden aan Van Rood, over het typeringsserumprobleem, hetgeen enig verband houdt met losse plannen om Europa op te delen in kleine regio's. Aarhuis.

Kissmeyer-Nielsen, F. (15 oktober, 1968). Brief aan Norma Rowley, kopie gezonden aan Van Rood. over gesprekken tussen Van Rood, Batchelor, Trnka and Kissmeyer, tijdens welke Van Rood aangaf genoeg patiènten wachtend op een geschikte nier te hebben en daarom voorstelt Europa in regio's te verdelen. Aarhuis.

Kissmeyer-Nielsen, F. (27 maart, 1968). Brief aan Van Rood, over het typeren voor andere centra, het opzetten van een uitwisselingsorganisatie, en dat ze tesamen met Mattiuz ze twee cytotoxiciteitstechnieken hebben vergeleken, welke niet exact dezelfde resultaten opleveren. Aarhuis.

Klein, G. (28 oktober, 1967). Brief aan Van Rood, over het sturen van sera via Stokholm naar Bombay en Trivandum waar Bremberg is, vragend om instructies en suggesties over hoe de tests uit te voeren en verheugt zich op samenwerking in het chimpansee project. Stokholm.

Knight, P.R. (7 februari, 1968). Brief aan Van Rood, over trage vooruitgang en ontmoedigd zijn door negatieve berichten van Terasaki. Adelaide.

Kolff. W.). (16 maart, 1967 ). Brief aan Van Rood, over initiatieven om typeringslaboratorium op te zetten, mogelijk met gesimplificeerde technieken. Cleveland. 
Koopmans, P.W., (KL.M) (30 september, 1969). Brief aan Van Rood, met instructies betreffende het vervoer van nieren door de lucht. Schiphol.

Krudwig, U, (ro december, 1967). Brief aan Van Rood, heeft in "Kölner Stadt-Anzeiger" d.d. 9-12. '67. gelezen over "europaischer bank für gewebeverpflanzung' en kondigt zichzelf aan als donor, vraagt om verdere instructies en vraagt over een financiële vergoeding aan verbonden is. Keulen.

Lameijer, L.D.F. (5 augustus, 1965). Brief aan Taap en de anderen, over haar eerste transplantatie in Londen, d.d. 5-8-1965. Londen.

Lameijer, L.D.F. (6 augustus, 1965). Brief aan 'Jaap', over haar transplantatie in Londen, d.d. 6.8.1965. Londen.

Lameijer, L.D.F. ( 13 juli, r965). Brief aan 'Jaap, Ab en anderen', over eerste ervaringen in Londen bij Mowbray en Peart. Londen.

Land, W. (25 Oiktober, 1968), Brief aan Van Rood. verzockend om antisera, biedt sera van

'Zwangere vrouweri' aan en zegt de sera te willen gebruiken voor hart en niertransplantaties, waarbij zif gebruik maken van de in Leiden gebruikte techniek. München.

Largiadèr, F. (ro december, 1968), Brief aan Burri (Basel), Frei (Lausanne), Hassig (Bern), Horisberger (St. Gallen), Jeannet (Genève), Thiel (Basel) en De Weck (Bern), vertrouwelijke kopy gestuurd aan Van Rood, over

'Gesamtschweizerische Zusammenarbeit auf dem Gebiet der Leukozytentypisierung'. Zürich.

Largiadèr, F. (to december, 1968). Brief aan Van Rood, geeft een hernieuwd overzicht van de leukocytentyperings-situatie in Zwitserland: leannet staat tamelijk alleen in zijn pogingen. Zürich.

Largiadèr, F. (18 december, 1968). Brief aan Van Rood, drie milten van nierdonoren vergezellend voor leukocytentypering. Zurich.

Largiadèr, F. (ar november, 1968). Brief aan Eernisse. aanvullingen op de brief aan Thiel gevend, over toekomst van typeren in Zwitserland. Zürich.

Lasio, E. (8 mart, 1968). Brief aan Van Rood, wil na het hebben gelezen van artikel over Eurotransplant, graag deelnemen. Milaan.

Longmore, D. (15 november, 1967). Brief aan Van Rood, vraagt om hulp en samenwerking bij typeren van Neurochirurgischepatiënten, voor zijn eerste hart/longtransplantatie. Londen.

Longmore, D. (8 april, 1968). Brief aan Van Rood, over het hebben opgezet van transplantatieorganisatie en dat hij Calne helpt bij experimentele levertransplantatie. Londen.

Longmore, D. (18 jull, 1968). Brief aan Van Rood. over typeren met Batchelor's en Van Rood's technieken, over het hebben opgezet van 'National Tissue Service' voor prospectief onderzoek van harten, en vraagt film te leen over typeringstechnieken. Londen.

Longmore, D. (23 januari, 1968). Brief aan Van Rood. ingevulde 'Eurotransplant' formulieren aankondigend en dankend voor al de hulp. Londen.

Martini, G.A., Rodeck, Havemann, Lange, \& Malchow
(22 november, 1968). Brief aan Van Rood, start van niertransplantaties aandondigend, en verzoekend om lid te mogen worden van de 'Eurotransplant group'. Marburg/Lahn.

Mayer, F.D. (Ir december, 1967). Brief aan Van Rood. van Gateway International, over 'Falcon Plastic MICROTEST plates', Los Angeles.

Ministerie van Landbouw en Visserij, Wagenvoort, W. (30 juni, 1965). Verklaring welke stelt dat er geen bezwaar is tegen import van sera, cellulaire suspensies en ander biologische materiaal, bestemd voor wetenschappelijk onderzoek. 'sGravenhage.

Ministerie van Sociale zaken en Volksgezondheid (4 februari, 1969). Brief aan Van Rood, vervolg van Eurotransplant, en bijeenkomst op 23 januari 1969, met de namen voor de WHO-commissie: "On Basic Requirements for International Cooperation in Organ Transplantation": Terasaki, Ceppellini, Dausset, Kissmeyer-Nielsen. Den Haag.

Morris, P.J. (4 september, 1967). Brief aan Van Rood, dankend voor hulp bij het opzetten van weefseltypering in Australie. Melbourne.

Morris, P.J. (21 juni, 1968). Brief aan Van Rood, over komst naar Leiden en informerend naar Jor's switch naar cytotoxicity. Melbourne.

Mowbray. I. (30 januari, 1967). Brief aan Van Rood. informerend naar voortgang in milttyperingen en vragend om discussie over 'prospective typing system for cadaveric transplants'. Londen.

Mueller-Eckhardt (28 november, 1968). Brief aan Van Rood, verzoekend om service-typeringen voor startend niertransplantatieprogramma. Giessen.

Nauta, J. (6 september, 1963). Brief aan Van Rood, geeft medewerking van chirurgen in reactie op brief van Amos d.d. 13 augustus (via Hijmans) over $\mathrm{NIH}$-contract en vraagt of in Leiden gestart moet worden met transplantaties. Leiden.

Niertransplantatie-werkgroep (26 augustus, 1966). Agenda transplantatievergadering, d.d. 29 augustus 1966. Leiden.

Niertransplantatie-werkgroep (1967). Overzicht Niertransplantaties Oktober 1967 . Leiden.

Opitz, A. (28 februari, 1968). Brief aan Van Rood. vragend om training van medewerkers in typeringstechnieken, en dankend voor hulp bij transplantatie. Berlijn.

Overman, J.R. (28 april, 1966). Brief aan Van Rood. over het deponeren van sera in de Serumbank en geeft toestemming om geld te gebruiken voor aanstelling personeel, maar lichte reductie van budget door het niet zenden van sera aan senumbank. Bethesda.

Paquet, K.). (22 maart, 1968). Brief aan Van Rood. dankend voor tijd in Leiden, start van typeringslaboratorium aankondigend en bereid om in Eurotransplant samen te werken. Bonn.

Patiēnt I. (r september, 1968). Brief aan Amos, verwezen door Van Rood, informerend naar mogelijkheid om subject te zijn voor experimentele testikeltransplantatie.

Payne, R. (24 februari, 1965). Brief aan Amos met kritiek op Workshop plannen. Palo Alto, Califoria.

Peart, W.S. (4 augustus, 1967). Uitnodiging aan Van 
Rood, am te komen en te vertellen over de recente vooruitgang in weefseltypering en hen te adviseren over opzetten typeringsdienst. Londen. Pegrum, G.D. (28 juni, 1968). Brief aan Van Rood, vragend om training van analisten en samenwerking met Eurotransplant in de toekomst. Hammersmith.

Pichlmaier, H. (ro november, 1967). Brief aan Van Rood, dat zij een kadaverniertransplantatieprogramma hebben en overwegen een 'levende donor' programma te starten en daarvoor hulp vragen met het typeren van die nierdonoren. München.

Pichlmaier, H. (ro juni, 1968). Brief aan Van Rood, over dat zij een analist hebben gevonden die gedurende zes maanden getraind kan worden en dankend voor hulp met het typeren. München.

Pichlmayr, R. (13 september, 1968). Brief aan Van Rood, dankend dat Tidow bij de 'Histocompatibility Course' kon zijn en geeft voortgangsrapport over typeringslaboratorium en inspanningen om militair transport geregeld te krijgen, en vragend om servicetyperingen. Hannover.

Pleijsier, E., (Groene Kruis) (22 december, 1967). Brief aan De Graeff, met verzoek om informatie over formaliteiten om weefsels en organen na overlijden te kumnen doneren. Den Haag.

Potworowski, E.F. (22 mei, 1968). Brief aan Van Rood, dat 'Medical Research Council' weefseltypering pusht en hartchirurgen met harttransplantaties willen beginnen. Montreal.

Querido, A. (4 juni, 1964). Brief aan Van Rood, Goslings, Sobels, Jongsma, Kuenen, van Putten en Cleton, over voorbereidingen om Isolatiepaviljoen in gebruik te kunnen nemen. Leiden.

Rapaport, F.T. (14 augustus, 1967). Brief aan Van Rood, over Workshop Turijn, 'permanent memento' voor Ceppellini, en organisatie van volgende Congress Transplantation Society. New York.

Ringoir, S. (26 maart, 1968). Brief aan Van Rood, bereidverklaring om deel te nemen aan Eurotransplantproject. Gent.

Rolley, R.T. (2 november, 1967 ). Brief aan Van Rood, vragend om antisera en mededelend dat ze gestart zijn met het typeren van kadaverdonoren en het screenen op antilichamen. Richmond.

Roodzant, s.v.R. (12 november, 1968). Begroting dienstjaar ro7o. Leiden.

Roos, K., (Dagblad de Telegraaf) (5 januari, 1970). Brief aan Van Rood, betwistend dat ze niet hebben gevraagd om een interview over "Twee jaar Eurotransplant". Amsterdam.

Rowley, N. (9 oktober, 1968). Brief aan KissmeyerNielsen, door hem gekopiēerd en gestuurd aan Van Rood, dat volgens Jeannet Zwitserland Terasakis techniek moet gaan gebruiken vanwege verdeling van Europa. Basel.

Rubinstein, P. (12 oktober, 1967). Brief aan Van Rood, over chirurgen die willen dat hif ontvangers en donoren voor niertransplantaties gaat typeren, en vraagt toestemming om hiervoor Leidse sera te gebruiken. Santiago.
Rubinstein. P. ( 12 september, 1967). Brief aan Van Rood, over regelen van verschillen van mening met Dausset, en zijn situatie en werk in Chili. Santiago.

Russell, P.S. (23 februari, 1965). Brief aan Van Rood, een vraag over gebruik van NIT test beantwoordend. Boston.

Russell, P.S. (30 augustus, 1966). Brief aan Van Rood, instemming met komst Van Rood naar Boston om patiënten te typeren. Boston.

Sanderson, A. (4 lanuari, 1967). Brief aan Van Rood, herhaling van resultaten in Leiden met invriezen en ontdooien van lymphocyten. East Grinstead.

Scheitlin, W. (29 augustus, 1967). Brief aan Van Rood, vragend om samenwerking bij typeren met betrekking tot uitbreiding naar levende-verwante donoren. Zürich.

Schippers, H.M.A. (u mei, 1970). Brief aan Eurotransplantgemeenschap, herhaald verzoek om serum voor kruisproeven te sturen en om zich aan de administratieve regels te houden. Leiden.

Schlicht, L (16 oktober, 1968). Brief aan Van Rood, dankend voor informatie over Eurotransplant, is onder de indruk en hoopt in de toekomst mee te kunnen doen. Mannheim.

Siderius, P. (21 november, 1969). Brief aan Van Rood, aankondigend dat het Ministerie van Sociale Zaken en Volksgezondheid, die aanstelling van een administrateur willen financieren voor de periode van een half jaar, als ondersteuning van het starten van de "donor pool" in de Eurotransplantorganisatie. Leidschendam.

Smith, LM. (2 februari, r968). Brief aan Van Rood. vagend om literatuur over de toepassing van computers voor opslag weefseltypes en voor de evaluatie van compatibiliteit, in voorbereiding op ontmoeting met Sylvia Lawler en Roy Batchelor. Londen.

Smith, L.M. (22 maart, rg68). Brief aan Van Rood, vragend om informatie over de voor Eurotransplant en de Workshops gebruikte Computer Programma's, speciaal geinteresseerd in wiskundige en statistische problemen, en hulp aanbiedend bij vertaling naar hogere programmeertaal. Londen.

Starzl, T.E. (7 september, 1966). Brief aan Van Rood, over 'geldinzameling' voor reis naar Denver, over Iwasaki's artikel en over het starten van transplantatieprogramma in Witwatersrand (SA). Denver.

Starzl, T.E. (17 oktobet, 1966). Brief aan Van Rood, over het bij elkaar hebben van geld voor ries naar Denver, en informerend naar noodzaak van fysieke aanwezigheid van donor voor typering. Denver.

Starzl, T.E. (31 januari, 1967). Brief aan Van Rood, over klinische data van Denver-patiënten, een verklaring gevend voor het niet naar Denver hebben opgeroepen van alle patiënten, en de ietwat teleurstellende resultaten met prospectieve typeringen noemend. Denver.

Steenbergen, C.L. (5 augustus, 1960). Versiag van de vergadering betreffende het beenmergproject, gehouden op 29 juli 1960 . Leiden. 
Steenbergen, C.L (20 december, 1963). Ontwerpbegroting IRS 1965. Leiden.

Steenbergen, C.L. (1964). Jaarverslag IRS juli 1962januari 1964 . Leiden.

Steenbergen, C.L. (9 december, 1965). Brief aan Van Rood, over het sinds de start van het IRS gedetacheerd zijn van personeel op de bloedbank. en nieuwe apen weigerend. Leiden.

Steenbergen, C.L. (1966). Jaarverslag IRS 1964t965. Leiden.

Stewart, J.W. (3 april, 1968). Brief aan Van Rood, milten van harttransplantaties zonder prospectief matchen aanbiedend. Londen.

Stoffels, D. ( 18 december, 1967 ). Brief aan Van Rood, heeft gelezen over "Organspendedienst" en biedt haarzelf aan als donor. Keulen.

Struyvenberg, A. (6 mei, 1969). Brief aan M.W. Jongsma (Dir. Geneesheer AZL), over beddentekort in Isolatiepaviljoen IRS voor niertransplantatiepatiënten, toename in aantal en evaluatie van noodzaak van volledige isolatie. Leiden.

Struyvenberg. A. (tr maart, 1969). Brief aan Twiss, over nephrectomy afhankelijk van fysieke situatie van de patiënt, niet van kans om een dononnier te kriigen. Leiden.

Swinney, I. (12 juli, 1968). Brief aan Van Rood, zou graag aan Eurotransplant mee willen doen, maar Noordzee is groot obstakel, stelt onderafdeling van Eurotransplant in Groot Brittanniè voor. Newcastle upon Tyne.

Terasaki, P.L. (9 februari, 1965). Brief aan Amos, over correleren van resultaten met aggiutinatie/cytotoxiciteitsvergelijking in samenwerking met Payne, Van Rood en Dausset. Los Angeles.

Terpstra, J.L (1970). Brief aan Collegae betrokken bij orgaantransplantatie, over gebleken noodzaak van standaardisatie van organisatie en transport van bloed en organen, en verschillende manuals bijsluitend. Leiden.

Terpstra, J.L. (t970). Concept brief, brief (d.d. 24 mei 1970) van Dr. C.R. Abbott (Leeds) beantwoordend, over samenwerking met Marinevliegdienst en procedures van transporteren van nieren in 'Foam plastic' dozen, en over het nooit hebben van problemen met douane. Leiden.

Terpstra, J.L, van Rood, J.J. (juni, 1968). Notulen van de eerste Eurotransplant Meeting, gehouden in het St. Lucas Ziekenhuis in Amsterdam op donderdag, 6 juni, 1968. Leiden.

Thiel. G. (9 oktober, 1968). Brief aan Van Rood, annuleren van komst van Norma Rowley naar Leiden, en het hebben van plannen voor verdeling van Europa. Basel.

Tinbergen, W.). (november, 1966). Ervaringen met de Ratteniertransplantatie. Rijswijk.

Toussaint, C. (16 juni, 1966). Brief aan Van Rood, vragend om service-typeringen bij retrospectieve levend.verwante transplantaties. Brussel.

Toussaint, C. (22 oktober, 1966). Brief aan Van Rood, dankend voor informatie in brief van 6 oktober, en klinische informatie over de drie patiènten gevend. Brussel.
Toussaint, C. (22 december, 1967). Brief aan Van Rood, zich verontschuldigend voor het veroorzaken van problemen met Govaerts en instemming gevend aan dat Govaerts typeren in Brussel gaat verzorgen. Brussel.

Toussaint, C. ( 10 maart, rg 68). Brief aan Van Rood, met nieraanbieding van partner van patiente, in ruil voor aanbod aan zijn vrouw. Brussel.

Trommel, 1.H. (19 augustus, 1969). Brief aan Van Rood, vragend om maatregelen welke moeten worden genomen wanneer een potentiele donor beschikbaar zou komen voor transplantatie in ander centrum. Woerden.

Twiss, E.E. (4 maart, 1969). Brief aan Van Rood, met immunologische en nephrologische vragen, betreffende de frequentie verdeling van antigenen en noodzaak van nephrectomy. Rotterdam.

Twiss, E.E. (18 maart, 1969). Brief aan Van Rood, informerend over mogelijkheid om patiënten lokaal te screenen op leukoagglutininen, in plaats van hen naar Leiden te laten kornen. Rotterdam.

van Bekkum, D.W. (ro december, 1964). Brief aan Van Rood, over gebruik van chimps in leukocyten groepen onderzoek. Rijswijk.

van Bekkum, D.W. (4 december, 1965). Brief aan De Graeff en Van Rood, over instelling van Transplantatie Werkgroep TNO, en hoe dat te financieren. Rijswijk.

van Bekkum, D.W. (2r september, 1967). Brief aan Rapaport, over ongelukkig gevoel over de speciale plaats die Beenmerg en Orgaantransplantatie krijgen in volgende Congres van de Transplantation Society. Rijswijk.

van Broekhoven.Vermeulen, G.W.R. (7 december. 1967). Brief aan Van Rood, heeft gelezen over "Eurotransplant" en meldt zichzelf en haar echtgenoot aan als donor. Sneek.

van der Weerdt, C.M. (27 juli, 1965). Brief aan Dt. G. Eernisse, verslag doend van bloedonderzoek patiènt V. Amsterdam.

van Hooff, H. (14 december, 1981 ). Brief aan Van Rood, over hermatchen eerste patiëntenserie voor retrospectieve onderzoeksdoeleinden. Leiden.

van Leeuwen, A. (9 maart, 1966). Brief aan Prof. Ceppellini, sera voor typeringsdoeleinden vergezellend. Leiden.

van Leeuwen, A. (1969). Laboratoriumoverzicht van milttyperingen en transplantatieuitkomst van patiënten van Alexandre, Michielsen, Ringoir, v.d. Slikke (Groningen), Largiadèr, Bonn. Brussel. Nijmegen, Leiden.. Leiden.

van Leeuwen. A. Anonymus (15 december, 1964). Lijst donoren Theologicum Warmond, d.d. 15 december 1964 .

van Leeuwen, A., Anonymus (3 februari, 1965). Lijst donoren Philosophicum Warmond, d.d. 3 februari 1965. Leiden.

van Leeuwen, A., Anonymus (26 mei, 1965). Lijst donoren Philosophicum Warmond, d.d. 21,24 en 25 mei 1965, met ABO bloedgroep. Leiden.

van Leeuwen, A., Anonymus (r966). Lijst donoren. gedeeltelijk van Philosophicum/Theologicum Warmond met hun respectievelijke ontvanger van huidtransplantaat op 17 januari Dr. D. Schmeenk. 
en op 21 januari Dr. A. Struyvenberg. Leiden. van Rood, J.J. (1954). Verslag van de werkzaamheden van de bloedbank over de periode van $x$ oktober $1952-1$ januari 1954 .

van Rood, J.J. ( 1960$)$. verslag werkzaamheden IHB voor Werkgroep Beenmergtransplantatie, IRS.

van Rood, J.J. (15 juni, 1960). Brief aan Directorium IRS, over aanschaf van automatische meetapparatuur voor gammastraling. Leiden.

van Rood, J.J. (28 maart, r960). Brief aan Dr.H.A.G.M. Walenkamp (huisarts Seminarium Warmond), de persoonlijke gesprekken met potential beemnergdonoren uitstellend, bij gebrek aan behoefte, maar hebben bij jemand wel abnormaliteiten gevonden. Leiden.

van Rood, J.). ( $1 \mathrm{r}$ december, 196r). Bloedbank jaarverslag. Leiden.

van Rood, J.J. (II juli, 196r). verslag bespreking Werkgroep Beenmergtransplantatie, in juli $196 \mathrm{t}$.

van Rood, J.J. (12 december, 1961). Brief aan Van Putten, IRS, met voorstel om de overgebleven seminaristen te Warmond te herkeuren. Leiden.

van Rood, J.). (15 november, 196r). Brief aan Van Putten. IRS, over aanschaf van een celloscoop voor leukocyten tellen. Leiden.

van Rood, J.J. (r9 september, 1963). Brief aan Jan Nauta, over het starten met transplantaties in Leiden vanwege successen in Denver en ontwikkelingen op leukocytenantigeengebied, met advies om in Denver te kijken hoe het moet en in Boston bij Merril hoe het niet moet. San Francisco.

van Rood, J.J. (23 september, 1963). Brief aan Wil. Aad, Frans, Hans, George en wie er verder terecht of ten onrechte van mening is dat ik wel eens iets van me kon laten horen, Wil Hijmans dankend voor inspanningen rond verkriigen van $\mathrm{NIH}$. contract, over ongewenst risico om 'sera leverancier' te worden door NIH-contract, over plannen bouw bloedbank en werk bij Rose Payne. Palo Alto.

van Rood, J.). (2 november, 1964). Brief aan Geneesheer-Directeur AZL, vragend om medewerking bif organisatie van tweede internationale 'histocompatibility testing Workshop', Leiden.

van Rood, J.). (It december, 1964). Brief aan Amos, over NIH contract, wie uit te nodigen voor de 'Conference and Workshop', en financiêle zaken aangaande de Boerhaave-cursussen. Leiden.

van Rood, J.). (14 december, 1964). Brief aan Prof. Sobels, verzoekend om financiering van ro chimpansees. Leiden.

van Rood, J.J. (17 december, r964). Brief aan Dr. D.W. van Bekkum, over toestemming voor to chimpansees, die echter niet mogen worden bestraald. Leiden.

van Rood, J.J. (22 september, 1964). Brief aan Amos, over waar de volgende 'tissue histocompatibility meeting' gehouden moet worden, wie uit te nodigen, en financiele zaken. Leiden.

van Rood, J.J. (1965). Inleiding in programmaboekje "Conference and Workshop on Histocompatibility Testing, Leiden, augustus 1521. $1965^{\circ}$. Leiden. van Rood, J.J. (2 december, 1965). Brief aan Dr. John R. Overman (NIAID, NIH), over niet in staat zijn sera aan de NIH serumbank te leveren. Leiden.

van Rood, J.J. (2 juni, 1965). Brief aan Dr. Jean Dormont, dat uitnodiging voor Conference niet ook de Workshop omvat. Leiden.

van Rood, I. J. (ro november, 1965 ). Brief aan Dr. H. Stadler, over erkenning geven aan WHO Reference Laboratory voor het bepalen van specificiteit van serum. Leiden.

van Rood, J.J. (t4 april, t965). Application For Financial Help For The Workshop On Histocompatibility Testing Leiden. I5 - 2ith augustus ig65. EURATOM. Leiden.

van Rood, J.). (17 december, 1965). Brief aan Dr. Cl. Hŏgman, over bepaalde specificiteit van een serum. Leiden.

van Rood, J.J. (17 juni, 1965). Brief aan Bestuur van de Medische Faculteit, uitleg gevend over gang van zaken ronde verzekeringen. Leiden.

van Rood, 1.). (17 mei, 1965). Brief aan Rose Payne, over haar vragen betreffende de Workshop. Leiden.

van Rood, 1.1. (17 november, 1965). Brief aan Amos, over N.I.H. contractdiscussie, Van Rood's ontmoeting met Medawar over stichting van de 'Transplantation Society', problemen als consequentie van de Workshop en zijn hoop en verwachtingen noemend op het typeren van Ceppellini's huidtransplantaties. Leiden.

van Rood, J.I. (18 maart, t965). Brief aan Dr. N. Raphael Shulman, over niet in staat zijn om complementfixerende antisera te testen voor de Workshop. Leiden.

van Rood, J.J. (18 november, 1965). Brief aan Prof. Ag. Jean Dausset, over tekst van

'Histocompatibility Testing 1965 ' en dat hij naar Parijs komt voor retrospectieve typering van niertransplantaties. Leiden.

van Rood, J.). (19 januari, 1965). Brief aan Prof. Ag. Jean Dausset, over identiek zijn van de herkende antigenen $6 \mathrm{c}$ and $\mathrm{Yc}_{\mathrm{c}}$. Leiden.

van Rood, J.). (21 oktober, r965). Brief aan Munksgaard, met de tekst voor de folder over het boek "Histocompatibility Testing", Leiden.

van Rood, J.). (22 december, 1965). Brief aan De: Goodman, WHO, sturende de Proceedings, en de WHO erkenning geven voor het Reference Laboratory. Leiden.

van Rood, J.J. (22 januari, 1965). Brief aan Amos. over geld voor de Conference and Workshop, wie uit te nodigen voor de Workshop, en over de atmosfeer in de groep. Leiden.

van Rood, I.). (23 december, 1965 ). Brief aan Dr. Rapaport, met samenvatting van "Current Status of human Leukocyte Groups" voor het 'Symposium on Transplantation Antigens and Tissue Typing (Feb, 14)', Leiden.

van Rood, J.). (24 maart, 1965). Fondsenwervende brief aan de CIBA foundation voor de 1965 Conference en Workshop. Leiden.

van Rood, J.1. (25 januari, 1965). Brief aan Prof. R. Ceppellini, over immuniseren van vrouwen om sterke specifieke antisera te krijgen. Leiden.

van Rood. J.). (25 november, 1965). Aankondiging 
lezing IRS: Leucocytengroepen en

Transplantatieantigenen. Leiden.

van Rood, J.J. (26 januari, 1965). Brief aan Prof, G.M.

Edington, Nigeria, over onderzoeksreis naar

Nigeria. Leiden.

van Rood, J.). (26 november, 1965). Brief aan De. Cl.

Hogman, over erkenning geven aan WHO

Reference Laboratory voor het bepalen van specificiteit van serum. Leiden.

van Rood, J.). (27 oktober, 1965). Brief aan Prof. Sobels, verzoekend om financiering van extra chimpansees. Leiden.

van Rood, J.J. (1966), samenvatting van: Leukocyte Groups and their Clinical Importance.

van Rood, J.1. (1 april, 1966). Brief aan Alexandre, over het typeren van patiënten en hun donoren in Leiden. Leiden.

van Rood, J.). (r april, 1966). Brief aan Dr. Starzl, over sturen van 'girl naar Terasaki en naar hem, en prettig hem beter te leren kennen. Leiden.

van Rood, J.J. (2 maart, 1966), Brief aan Dt. John R. Overman (NIAID, NIH), over NIH serumbank en verspreiding van kennis over leukocytengroepen. of door antisera (NIH) of door het typeren van panels van contractanten (Van Rood). Leiden.

van Rood, H.J. (3 januari, 1966). Brief aan Dr. Ceppellini, over "Big Deal" van Dr. Balner, het maken van antisera in apen. Leiden.

van Rood, J. (3 mei, 1966). Brief aan Woodruff, over komen naar Edinburgh om

transplantatiecombinaties te typeren en over welke uitrusting nodig is. Leiden.

van Rood, J.J. (5 april, 1966). Brief aan Mr. William Chandler, Falcon Plastics Co., als ondersteuning van Terasaki's inspanningen om hen de 'disposable oil-chamber' voor microcytotoxiciteiten agglutinatietests te laten produceren. Leiden.

van Rood, J.J. (5 juni, r966). Brief aan Woodruff, over resultaten van typeringen van getransplanteerde patiënten en hun donoren in Edinburgh, hetgeen vergelijkebaar is met patronen in Leuven. Leiden.

van Rood, J.J. (5 september/oktober, 1966). Brief aan Prof. Ceppellini, over voortgezetten samenwerking aangaande huidtransplantaties, en vraag om van de serumbank sera te vragen voor de voorbereidenden typeringen van Workshopdonoren. Leiden.

van Rood, J.J. (6 mei, r966). Brief aan Prof. W.D. Kelly, bereidverklaring tot starten samenwerking . en mogelijkheid om naar Minneapolis te gaan. Leiden.

van Rood, J.). (6 oktober, 1966). Brief aan Toussaint, met eerste resultaten van typering van transplantatieparen van Woodruff, Alexandre en Toussaint. Leiden.

van Rood, J.J. (7 april, 1966). Brief aan Prof. William D. Kelly, over bruikbaarheid van leukocytengroepering bij kadavernier transplantatie en aanmoedigend om eigen typeringsfaciliteit en screeningsprogramma op te zetten. Leiden.

van Rood, J.J. (It augustus, r966). Brief aan Prof. Ceppellini, over toevoegen 'looking for sera with identical reactions' aan de projecten voor Workshop Turijn. Leiden. van Rood, J.J. (ra juli, rg66). Brief aan William D. Kelly, ermee instemmend dat $\mathrm{Dr}$. Yunis naar Leiden om weefseltyperingstechnieken te leren. en vragend om brief voor Universiteit. Leiden.

van Rood, J.). (12 september, 1966). Brief aan Cyril Abrahms, hem verwijzend naar Botha in Kaapstad om weefseltyperingstechnieken te leren, omdat Leiden 'overbevolkt' is, Leiden.

van Rood, I. (14 december, 1966). Brief aan Prof. Ceppellini, over typeringsdata van 'States' en Turijn' die erg slecht lijken. Leiden.

van Rood, J.). (15 augustus, 1966). Brief aan André Govaerts, antwoordend op zijn verzoek om naar Leiden te mogen komen, en informeren naar zijn hondenwerk. Leiden.

van Rood, J.F. (16 augustus, 1966). Brief aan Dr. Amos, over aankomst en typeren van mensen uit Durham en resultaten sturend, datum van Paris meeting, doel van Contractors meeting NIH. Leiden.

van Rood, 1.). (16 mei, 1966). Brief aan Dr. Amos, over Workshop, identieke sera, het toelaten van startende mensen tot de Workshop, datum Paris meeting, en Contractors meeting NIH. Leiden.

van Rood, J.). (17 augustus, 1966). Brief aan Dr. Lawler, antisera $4 \mathrm{a}$ and $6 \mathrm{a}$ via de lucht sturend, en informerend naar samenwerking met Batchelor, Goldsmith en Chalmers. Leiden.

van Rood, J.). (18 april, 1966), Brief aan Dr. John R. Overman (NIAID, NIH), over zijn antwoord op tegenvoorstel van Van Rood over typeren panels van contractanten, en over onzekerheid en frustratie over de recente ontwikkelingen. Leiden. van Rood, J.J. (18 maart, 1966). Brief aan Dr. Terasaki, over het sturen van een 'girl' naar hem. om hun panels (ook Walford's en Payne's) te typeren als informatieuitwisseling, en over retrospectief typeren van niertransplantaties. Leiden.

van Rood, J.J. (19 oktober, 1966). Brief aan Reinhard Nagel, sending five 3 oml containers with EDTA aan collect blood for leukocyte groups, and asking whether they are able aan find direct transportation from Berlin aan Amsterdam or Rotterdam. Leiden.

van Rood, J.J. (rg september, 1966). Brief aan Prof. W.D. Kelly, over dat Dr. Yunis in Leiden is geweest, noodzakelijkheid van het opzetten van een leukcocytengroeperingslaboratorium en referentie panel in Minneapolis. Leiden.

van Rood, I.J. (20 oktober, 1966). Brief aan Batchelor, over het voor Batchelor typeren van een panel. maar niet de tijd hebben om te komen en ter plekke te doen, in plaats daarvan voorstellen de mogelijkheden van het naar Leiden sturen van bloed te onderzoeken. Leiden.

van Rood, J.). (2t juni, 1966). Brief aan Toussaint. over typeren van drie transplantatieparen. Leiden.

van Rood, J.). (22 april, 1966). Brief aan Prof. Ceppellini, over problemen met NIH-contract, experiment met huidtransplantaties op 'randomly matched people', en Workshop Turijn. Leiden.

van Rood, J.J. (22 augustus, 1966). Brief aan Prof. W.D. Kelly, met de aanbieding zijn patiënten te bestuderen en een referentie panel te typeren, en 
vragend om reiskostenvergoeding voor overtocht Mevr. van Leeuwen. Leiden.

van Rood, J.J. (2a maart, 1966). Brief aan Batchelor. over het met Sylvia Lawler hebben gesproken over het starten van leukocytengroepering in England maar er niet voor om bloed naar Leiden te sturen vanwege werk en kosten. Leiden.

van Rood, I.J. (22 maart, 1966). Brief aan Prof. Ceppellini, met rekening voor computergebruik, en dat Mattiuz in Leiden is. Leiden.

van Rood, J.J. (22 september, 1966). Brief aan Dt. Huntley, dankend voor het financieren van een deel benodigd voor het komen van hemzelf met Eernisse of Bruning en Van Leeuwen, over aantal mensen dat getypeerd kan worden gedurende het verblijf, verdere financiele regelingen en laboratoriumbenodigdheden. Leiden.

van Rood, J.J. (23 augustus, 1966). Brief aan Dr. Paul Russell, informerend in belangstelling voor samenwerking door het typeren van patiënten en mensen met huidtransplantatie. Leiden.

van Rood, 1.J. (23 augustus, 1966). Brief aan Dr. Starzl, over niet doorgaan van 'girl' naar Terasaki en hem, maar hij kan zelf komen met Eernisse en Van Leeuwen. Leiden.

van Rood, J.J. (24 mei, 1966). Brief aan Dr. Zmijewski, bezig ZMiewski's sera te testen, problemen met subsidie NIH, het Ceppellini aansporen om aan de Workshop te gaan werken, en over problemen met de computerafdeling. Leiden.

van Rood, J.J. (24 mei, 1966). Brief aan Woodruff. dankend voor mogelijkheid om te typeren en over het nu naar Leuven gaan. Leiden.

van Rood, J.J. (25 juli, 1966). Brief aan Toussaint, over typeringsresultaten van drie transplantatieparen. Leiden.

van Rood, J.J. (25 november, 1966). Brief aan Reinhard Nagel, antwoorden op vragen over het sturen van bloed voor typeren ( 4 uren toelaatbaar) en aanbiedend om receptacula te sturen. Leiden.

van Rood, J.J. (26 april, 1966). Brief aan Erik Thorsby, diens komst naar Leiden bevestigend. Leiden.

van Rood, J.). (27 juni, I966). Brief aan Dr. Zmijewski, moeilijkheden met antiserum 5 a en leukocytendonoren, glaswerk en nog steeds proberend contact met Ceppellini te krijgen. Leiden.

van Rood, I.J. (27 mei, 1966). Brief aan Woodruff, zich verontschuldigend voor het uitstel van zijn vertrek naar Edinburgh en vragend om klinische gegevens over de transplantatiepatiënten en hun donoren. Leiden.

van Rood, J.). (27 september, 1966). Brief aan Edmund Yunis, met lijst noodzakelijke laboratorium uitrusting. Leiden.

van Rood, J.J. (28 december, 1966). Brief aan Prof. Ceppellini, over typeringsdata van 'States' en Turijn' die toch niet zo slecht bliiken te zijn. Leiden.

van Rood, J.J. (28 januari, r966). Bijlage bij brief aan Prof. R. Ceppellini over gedachten over Nomenclature. Leiden.

van Rood, J.). (28 jamuari, 1966). Brief aan Prof.
Ceppellini, over gedachten over Nomenclature. Leiden.

van Rood, I.T. (28 november, 1966). Brief aan $\mathrm{Dr}$. Huntley, dankend voor de mogelijkheid om het materiaal te bestuderen, en verzoekend om verdere informatie over de klinische uitkomst van de transplantaties. Leiden.

van Rood, J.J. (28 november, 1966). Brief aan Dr. John R. Overman (NIAID, NIH), dankend voor bezoek aan Washington en het opruimen van misverstanden en fricties. Leiden.

van Rood, J.). (28 november, 1966). Brief aan Dr. Paul Russell, dankend voor de mogelijkheid om zijn patiëntenmateriaal te bestuderen. Leiden.

van Rood, J.J. (28 november, 1966). Brief aan Prof. W.D. Kelly, dankend voor de mogelijkheid om zijn patiēnten te bestuderen, en verzoekend om verdere informatie over de klinische uitkomst van de transplantaties. Leiden.

van Rood, J.J. ( 28 september, 1966). Brief aan Dr. Allen, over reisschema, paneltypering en financiële kant van de reis naar de VS. Leiden.

van Rood, J.J. (28 september, 1966). Brief aan Dr. Paul Russell, over reisschema, typeren van patiênten en huidtransplantaties en financiele kant van de reis naar de VS. Leiden.

van Rood, J.J. (30 juni, 1966), Brief aan Dr. Terasaki, over het sturen van een 'girl' naar Terasaki om panels te typeren als informatieuitwisseling. micro-agglutinatie, en over retrospectief typeren van niertransplantaties, ook van Starzl. Leiden.

van Rood, J.J. (30 juni, 1966). Brief aan Toussaint, over typeren van een paar op 1 juli, met voorstel om de twee andere paren op 8 juli te typeren. Leiden.

van Rood, J.J. (30 maart, 1966). Brief aan Louis Revol, erin toestemmend dat een medewerker van Revol naar Leiden komt om weefseltyperingstechnieken te leren. Leiden.

van Rood, J.J. (3o november, 1966). Brief aan Dr. Rubinstein, over indruk dat leukocytengroepen weinig belang hebben voor klinische transplantatie, dat Rosenfield's en Lalezari's technieken worden gebruikt met de autoanalyzer. en stuur interessante sera meet aanzienlijke voorraad. Leiden.

van Rood, J.J. (3r oktober, 1966). Brief aan David Kerr, ermee instermmend om so typeringen te doen in eerste half jaar. Leiden.

van Rood, J.J. (31 oktober, 1966). Brief aan Dr. Starzl. over dat hijzelf komt met Bruning en Van Leeuwen, en beperkingen van de gebruikte techniek. Leiden.

van Rood, J.J. ( 1 juli, 1967 ). Brief aan Prof. Jean Dausset, over gerezen misverstanden. Dordogne.

van Rood, J.). ( $\mathrm{x}$ juni, 1967). Brief aan Beck, op verzoek van $\mathrm{Dr}$. Thiel sturen van beschrijving van techniek en vereisten om leukocytengroepering in Leiden te laten uitvoeren. Leiden.

van Rood, J.). (3 februari, 1967). Brief aan Dr. Anja Tilikainen, over het niet in de positie zijn om haar te inviteren voor de Workshop, misschien via Amos. Leiden.

van Rood, J.J. (3 mei, 1967). Brief aan W.F. Neuteboom (PZ), permissie vragend om een 
wervende brief te laten circuleten om meer paneldonoren te verkrijgen, vanwege groeiende behoefte, Leiden.

van Rood, I.) (7 augustus, 1967). Brief aan Dr. Starzl. over hoe de resultaten van het gezamelijke Denver-onderzoek te publiceren, en over compatibiliteit in verhouding tot incompatibiliteit en identiciteit. Leiden.

van Rood, J.J. (7 augustus, 1967). Brief aan Mr. B.W. Janssen, over heraanstellen van voormalige medewerker voor typeren in Turijn. Leiden.

van Rood, .). ( 8 december, 1967). Brief aan G.P. Berry (Whitehall Foundation), een "request for a grant from the Whitehall Foundation" aanbiedend, tot een totaal van \$ 230000 over periode van vijf jaar. Leiden.

van Rood, J.I. (9 mei, 1967). Brief aan universiteitspersoneel in ziekenhuis, met verzoek om zich op te geven als paneldonor. Leiden.

van Rood, J.). (9 mei, 1967). Brief aan W.P.M. Haring, over vervanging van paneldonoren vanwege sluiting van Theologicum en Philosophicum. Leiden.

van Rood, J.). (to november, 1967 ). Brief aan Dr. Botha, met matchingsadvies in antwoord op vraag Leiden.

van Rood, J.). (r2 april, 1967). Brief aan Dr. Anja Trilikainen, haar uitnodigend voor de Conference, niet voor de Workshop. Leiden.

van Rood, J.1. (r2 december, 1967). Brief aan Dr. W. Drukker (EDTA), over sturen begeleidende brief bii Eurotransplant-voorstel. Leiden.

van Rood, J.J. (rz december, 1967 ). Preliminary Contract Renewal Application N1H-contract March 15, 1968 till March 15, 1969. Leiden.

van Rood, J.). (13 oktober, 1967 ). Brief aan Ceppellini. over brief Amos die in 'Science' gepubliceerd moet worden, hetgeen leidt tot Erkenningsdiscussie. Leiden.

van Rood, J.J. (13 oktober, 1967). Brief aan Drs. Essenstam (Gezondheidsorganisatie TNO), over aanschaf invriesapparatuur vor lymphocyten. Leiden.

van Rood, J.1. (14 december, 1967). Brief aan Dr. Trnka, over de inhoud van de typeringscursus, en

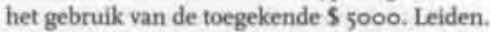

van Rood. J.). (14 december, 1967). Brief aan Mw. G.W.R. van Broekhoven.Vermeulen, dankend voor aanbod om donor te zijn, met advies orn altijd een brief bij zich te dragen die deze wens uitdrukt. Leiden.

van Rood, 1.1. (14 juni, 1967). Brief aan Dr. Trnka, een voortgangsrapport gevend voor to 66 en verzoeken om voortzetting van financiering voor 1967. Leiden.

van Rood, J.J. (15 augustus, 1967). Brief aan Prof. C.L.H. Majoor, met verzoek om lezing te mogen geven over belang van leukocytenantigenen voor overleving van niertransplantatie. Leiden.

van Rood. I.J. (15 september, 1967). Brief aan Dr. Eijsvoogel (CL.B), over haalbaarheid van perfecte match met kadaverdonoren in Eurotransplant project. Leiden.

van Rood. I.J. (17 oktober, 1967). Brief aan Driemanschap Interne Geneeskunde t.a.v. Prof.
Dr. J. de Graeff en leden Bloedbank Comité, over financiering van Eurotransplant door Whitehall Foundation, maar breder gebruik. Leiden.

van Rood, J.). (18 december, 1967). Brief aan Dr. Botha, hem feliciterend met zijn pogingen bij de eerste harttransplantatie, dankend voor de erkenning en hun belangrijkste bijdragen aan 'het veld' gevend. Leiden.

van Rood, J.). (18 oktober, 1967 ). Brief aan Prof. J.J. van Loghem (CLB), over commentaar op Amos brief, die in Science gepubliceerd gaat worden. Leiden.

van Rood, J.J. (21 februari, 1967). Brief aan Prof. W.D. Kelly, de typeringsresultaten van de patiènten sturend, met bespreking van de 'groeperingen' en over de kwaliteit van het panel voor Yunis. Leiden.

van Rood, J.J. (23 januari, 1967). Brief aan Dr. Starzl, informerend naar waarom niet alle patiĕnten en hun donoren zijn getypeerd, en vanaf wanneer Terasaki prospectieve typeringen heeft uitgevoerd. Leiden.

van Rood, I.J. (24 april, verstuurd 27 juni, 1967 ). Notitie aan Drs. Lameyer, Vink, de Graeff en Struyvenberg, over resultaten van retrospectief onderzoek naar donorontvanger match. Leiden.

van Rood. J.J. (24 augustus, 1967). Brief aan Dr. J. Dausset, over verschillen van mening over 'wie zag wat het eerst', Leiden.

van Rood, I.J. (24 oktober, 1967). Brief aan Amos en Zmijewski, reactie op brief van Amos te publiceren in 'Science'. Leiden.

van Rood, J.J. ( 25 september, r967). Brief aan Dr. W. Scheitlin, informatie gevend over het versturen van bloed ter typering en over Eurotransplant. Leiden.

van Rood, J.J. (27 september, 1967). Brief aan Prof. Dr. G. Zoutendijk, over inspanningen om financiering te krijgen voor programmeur bij CRI, en over 'ET-Telefoonboek'. Leiden.

van Rood, 1.J. (28 december, 1967 ). Brief aan Ceppellini, vragend om commentaar op 'Seminars in Hematology' artikel, samenwerking bii familieonderzoek, eerste maanden van Eurotransplant, en over brief Amos in 'Science'. Leiden.

van Rood, J.). ( 28 december, 1967). Brief aan Dr. Botha, dankend voor al de publiciteit en erkenning aan Leiden gegeven, en verzoekend om details over de groepering en hoe alles was gedaan. Leiden.

van Rood, J.J. (28 september, 1967 ). Brief aan Dr. Franz, 2 labflessen met EDTA en 1 reserve sturend, om terug te ontvangen met $60 \mathrm{ml}$ bloed totaal en geklonterd bloed. Leiden.

van Rood, J.). (29 augustus, 1967). Brief aan Dr. Zuhlke, met positieve reactic op typeringsverzoek, 'maar stuur ontvanger en donoren bij voorkeur naar Leiden voor typering vanwege betere resultater'. Leiden.

van Rood, J.J. (29 november, 1967 ). Brief aan Toussaint, over starten van Eurotransplant en decentraliseren van typeringsfaciliteiten. Leiden.

van Rood, J.J. (30 november, 1967 ). Brief aan Dr. H. Pichlmayer, met positieve reactie op 
typeringsverzoek, 'maar stuur ontvangers, donoren en familieleden bij voorkeur naar Leiden voor typering'. Leiden.

van Rood, J.]. (30 november, 1967 ). Brief aan Dr. W. Drukker (EDTA), over ontvangst van Eurotransplant en sturen van begeleidende brief bij Eurotransplant-voorstel. Leiden.

van Rood. 1.1. (30 oktober, 1967). Brief aan Rubinstein, over typeren van niertransplantatiedonoren en ontvangers, en vertellend dat zij overstappen op de cytotoxiciteitstechniek. Leiden.

van Rood, J.J. (oktober, 1967). Correcties op drukproeven van artikel in 'Het Parool. Leiden.

van Rood, J.). (r september, r968). Eurotransplant Newsletter no. I. I september r968. Leiden.

van Rood, J.). (2 januari, 1968). Brief aan Toussaint, zijn blijdschap over de actieve paticipatie van $\mathrm{Dr}$. Govaerts uitdrukkend, en over het in duplo typeren in Brussel en Leiden. Leiden.

van Rood, J.). (2 september, 1968). Brief aan Siderius. informerend naar mogelijkheden om een aanvullende subsidie te geven bij de subsidie van de Whitehall Foundation. Leiden.

van Rood, J.). (3 april, I968). Brief aan André Govaerts, over Miss de Vetter die spoedig zal vertrekken, na aggiutinatic en cytotoxiciteitstechniek in Leiden te hebben geleerd, en over uitwisseling van nieren per trein (2.5 uur) en in onderhandeling met militaire autoriteiten over gebruik van vliegtuigen. Leiden.

van Rood, J.J. (3 april, 1968). Brief aan Ringoir, over bereidheid om patienten te typeren, die liefst naar Leide moeten komen, maar sturen van bloed ook mogelijk, wanneer aan vereisten wordt voldaan. Leiden.

van Rood, J.J. (3 april, 1968). Brief aan Walsh, over samenwerking tussen European Dialysis and Transplantation Association en Eurotransplant, over eerste mislukte poging om nier uit te wisselen, maar vol vertrouwen, en over decentraliseren van typeren en het organiseren van transport. Leiden.

van Rood, J.J. (3 juli, 1968). Brief aan J.A. Moffet, President Whitehall Foundation, dankend vooer subsidie van $\$ 20000$ per jaar voor drie jaar. Leiden.

van Rood, J.J. (4 april, 1968). Brief aan Kissmeyer, over overstap naar cytotoxiciteit en pech bij eerste Eurotransplant orgaan bemiddeling. Leiden.

van Rood, J.J. (4 januari, I968). Brief aan De Graeff, over verzoek voor officiele donorkaart voor leden van Groene Kruis, maar verder niets gehoord hebbend. Leiden.

van Rood, J.J. (5 april, r968). Brief aan De Graeff en Vink, over het net gemist hebben van een donor in Bonn, maar overtuigd zijn van mogelijkheid van uitwisseling, en over noodzaak om transport formeel te regelen met Duitse en Nederlandse Luchtmachten. Leiden.

van Rood, J.J. (5 januari, 1968). Brief aan Dr. Höffler, over starten van typeringslaboratorium, training van medewerker, het opzetten van een screeningsprogramma, en adviserend om cytotoxiciteitstechnick te gebruiken, te prefereren boven agglutinatietechniek. Leiden.

van Rood, I.J. (5 januari, 1968). Brief aan R.K. Appleyard (Euratom), een schatting gevend van de opstartkosten van Eurotransplant van meer dan \$ 66 ooo. Leiden.

van Rood, J.J. (5 mei, 1968). Brief aan Largiadèr, over niet begrilpen van Thiel's houding, de tesultaten sturend van milttyperingen, en zeggend uit te kijken naar komst van miss Propradi met wie zij het familieonderzoek zullen bespreken. Leiden.

van Rood. J.). (6 augustus, 1968). Brief aan K. Berg (Oslo), uitleggend dat om in Leiden getrained te kunnen worden je uit de Eurotransplant regio moet komen, en de creëring van andere regiơ's aankondigend. Leiden.

van Rood, J.). (6 augustus, r968). Brief aan Sokal. over veelbelovende resultaten en bereid te helpen met bepalen van specificiteit van gevonden goede antisera. Leiden.

van Rood, J.J. (7 januari, 1968). Brief aan Curtoni (Turijn), over via Greep ontvangen verzoek om infomatie over Eurotransplant, zullen tweede Newsletter sturen wanneer deze af is, Leiden.

van Rood, J.). (8 april, 1968). Brief aan Lejeune, met positieve reactie op typeringsverzoek, 'maar stuur ontvangers, donoren en familieleden bij voorkeur naar Leiden voor typering'. Leiden.

van Rood, I.J. (8 augustus, 1968). Brief aan Woodruff, over typeringssituatie in Groot Brittanniê en het niet opnemen van Groot Brittannie in Eurotransplant. Leiden.

van Rood, J.). (8 maart, 1968). Brief aan Kierfeld, over typeren van EDTA-bloed, receptacula sturend en verzoekend om ingevroren milten van kadaverdonoren. Leiden.

van Rood, J.). (8 oktober, 1968), Brief aan Tesch (TNO), verzoekend om aanstelling van administratief personeel, om de toegenomen werkdruk door Eurotransplant te veriichten. Leiden.

van Rood, J.J. (ro oktober, 1968). Brief aan Cdt. VIb. Valkenburg v.d. Brandeler, en kopie van de lezeing over Eurotransplant aanbiedend, zoals gegeven in New York, en nogmaals bedankend voor de ontvangen assistentie en hopend dat dat wordt voortgezet in de toekomst. Leiden.

van Rood. J.). (to oktober, I968). Brief aan Dt. Botha. komende van Perth via Kaapstad, verzoekend om compensatie voor 'consultantship and advice', met P.S. nog niet gehoord van Kayhoe over vloekbaar-stikstof container, zich nu direct wendend tot 'Linde company'. Leiden.

van Rood, J.J. (14 juni, 1968). Brief aan Philip Daly $(B B C)$, uitnodiging aanvaardend om deel te nemen aan documentaire over the Immunologists", en zijn ongenoegen uitend over Peter Goodschild, die geen kopie stuurt van in Leiden gemaakte film. Leiden.

van Rood. J.). (14 oktober, 1968). Brief aan Prof. Herberer, informatie over Eurotransplant sturend, en hopend dat ze willen meedoen. Leiden.

van Rood, I.). ( 14 oktober, 1968). Brief aan Prof. Sobels (IRS), verzoekend om overname van financiering van twee analisten, vanwege de 
verwachte beeindiging van het $\mathrm{NIH}$-contract per I fuli 1969 . Leiden.

van Rood. 1.). (16 oktober, 1968). Brief aan Jongsma, verzoekend om een telex-aansluiting voor Eurotransplant. Leiden.

van Rood. J.J. (17 juni, 1968). Brief aan Prof. Dr. L Kukenheim Ezn. (Secretaris der Senaat der Rijksuniversiteit Leiden), brief gedateerd 2 juli beantwoordend, onder andere over de 'salonwagen' waarin

histocompatibiliteitsonderzoek plaats vindt en over het zijn gestart met oprichten orgaanuitwisselingsorganisatie. Leiden.

van Rood, 1.J. (18 december. 1968). Brief aan Jongsma, nogmaals vragend om een telexaansluiting voor Eurotransplant vanwege problemen gedurende de nacht. Leiden.

van Rood, J.J. (18 maart, 1968). Brief aan Kissmeyer, over starten met Eurotransplant in Benelux, hebben $2 / 3$ van 180 patiënten getypeerd en 'ETtelefoonbook' geproduceerd, over decentralisering van typeren, en het transport moeten organiseren. Leiden.

van Rood, J.J. (18 maart, rg68). Brief aan Sokal, over verschillende mogelijkheden voor samenwerking. en de cytotoxische typeringsresultaten van Alexandre's patiënten sturend. Leiden.

van Rood, J.J. (18 maart, 1968). Brief aan Toussaint, voorzichtig reagerend op nieruitwisselingsaanbod. Leiden.

van Rood, J.). (18 oktober, r968). Brief aan Mr. B.W. Jansen (manager Interne Geneeskunde AZL). over plannen voor Eurotransplant laten vallen onder Ministerie van Volksgezondheid, maar ook een stichting is een mogelijk institutionaliseringsvorm. Leiden.

van Rood, J.J. (18 oktober, r968). Brief aan Parsons, over publiceren (Eurotransplant) transplantatiegegevens in jaarverslag EDTA. Leiden.

van Rood, J.J. (18 september, 1968). Brief aan Brocteur, agglutinatie-sera sturend voor typering: spoedtyperingen zullen in de toekomst door Govaerts gedaan worden, maar vooralsnog in Leiden, en blij dat ze zijn gestart met screenen op antisera. Leiden.

van Rood, J.J. (20 december, 1968). Brief aan Dr. Land, over sturen van typeringssera, het opzetten van een screeningsprogramma, over resultaten van transplantaties, en over waar ze hun techniek hebben geleerd. Leiden.

van Rood, J.J. (20 december, 1968). Brief aan Prof. De. G.A. Martini, Medizinische Universitătsklinik der Universităt Marburg, over deelnemen aan Eurotransplant op twee mogelijke manieren: a. als transplantatie centrum, of b. orgaanverwerving. Leiden.

van Rood, 1.). (20 juni, 1968 ). Brief aan Woodruff. over beschikbaarheid van microagglutinatietechniek en bereid om agglutinerende sera te sturen, maar moeilijkheden hebbend met het controleren van alle resultaten en voorstellend om eerder getypeerde mensen als controle te gebruiken. over vooruitgang met Eurotransplant en (vertrouwelijk) over 'verdelen van Europa in aantal regio's'. Leiden.

van Rood, J.). (21 oktober, 1968). Brief aan Siderius, conceptbrief voor WHO sturend, waarin Nederlandse Regering de WHO vraagt op te treden als 'coordinating office' voor Eurotransplant Regio's. Leiden.

van Rood, J.). (22 augustus, 1968). Brief aan Ceppellini, na te hebben geproken met Kissmeyer-Nielsen en Batchelor over toekomst van Eurotransplant, het verdelen van Europa in regio's voorstellend. Leiden.

van Rood, J.J. (22 september, 1968). Brief aan Dr. Horisberger, bereid om te typeren, maar bloed moet vers zijn, niet als in de Terasaki-test, en bloed mag niet later dan 9.00 of 10,00 uur in de morgen in laboratorium zijn. Leiden.

van Rood, J.J. (22 september, 1968). Brief aan J.R. Anderson, over organiseren van Groot-Britannié en Ierland regio van Eurotransplant vanwege transportproblemen. Leiden.

van Rood, I.J. (23 december, 1968). Brief aan Dausset, kopie van brief aan Garcia-Ortiz sturend, en hopend dat ze elkaars territorium zullen respecteren. Leiden.

van Rood, J.). (23 december, 1968). Brief aan Derom, over toestemming voor telex-aansluiting, welke in januari operationeel zal worden. Leiden.

van Rood, J.J. (24 december, 1968). Brief aan MuellerEckhardt, de mogelijkheden van deelname aan Eurotransplant gevend, 1 . als opererend team, 2. als orgaanleveranciers: Leiden.

van Rood, J.J. (25 oktober, 1968). Brief aan Dr. T. Lameyer, over ontwikkelingen in Leiden en problemen met nieuwe centra in Eurotransplant. Leiden.

van Rood, J.). (25 oktober, maar verstuurd op 2 december, 1968). Brief aan Thiel, over teleurgesteld en 'rather upset' zijn over de ontwikkelingen in Zwitserland, ontwikkelingen aangezet door Jeannet, weg van samenwerking met Leiden, al gelegde contacten ten spijt. Leiden.

van Rood, J.). (26 februari, 1968). Brief aan Knight, geruststellend over mogelijkheden van prospectief matchen. Leiden.

van Rood, J.J. (26 januari, I968). Brief aan Dr. Höffler, de vereisten voor het versturen van bloed voor typering geven, betreffende receptacula en de manier en tijd van transport. Leiden.

van Rood, J.J. (27 december, t968). Brief aan Dr. Winterhoff Münster, zijn teleurstelling over het tempo van ontwikkelingen bevestigend. Leiden.

van Rood. J.J. (28 februari, I968). Brief aan Alexandre, over komst naar Leuven om resultaten en problemen te bepreken, en verzoekend om aanvullende informatie over patiënten. Leiden.

van Rood, J.). (28 februari, 1968). Brief aan Jongsma, verzoekend om een telefoonaansluiting bij het hoofd administratie IHB. Leiden.

van Rood, J.). ( 28 juni, 1968). Brief aan Morris, overstap naar cytotoxiciteit bevestigend. Leiden.

van Rood, J.J. (28 juni, 1968). Brief aan Pegrum, met afwijzende reactie op verzoek om weefseltyperingstraining. Leiden.

van Rood, 1.). (29 augustus, 1968 ). Brief aan D.E. 
Kayhoe, vragend om informatie over vloeibare stikstof container. Leiden.

van Rood. J.). (30 augustus, 1968), Brief aan DE. A.L. de Weck, acht serummonsters sturend, agglutinerende en cytotoxische, met advies om zich te wenden tot Miss Popradi in Zürich wanneer problemen met agglutinaterende sera. Leiden.

van Rood, J. J. (30 augustus, 1968). Brief aan Ellison Davis van het 'Monographs Department', van de Excerpta Medica Foundation, met gecorrigeerde kopie van bijdrage aan discussie op het symposium over orgaantransplantatie in juni. Correcties over beschikbaarheid van microcytotoxiciteitstechniek, heterotransplantatie en evaluatie van transplantatieresultaten. Leiden.

van Rood, J.). (30 december, 1968). Brief aan Peter Brain, dankend voor sera, computerprogramma's sturend, en dat zij alleen 'family study material' sturen wanneer ingevroren, en vragend of zij cen telex hebben. Leiden.

van Rood, J.J. (31 augustus, 1968). Brief aan Siderius, informatie gevend over voortgang van Eurotransplant, en informerend naar mogelijkheid dat Nederlandse Regering aan WHO vraagt om als 'coordinating office' voor Eurotransplant Regio's op te treden. Leiden.

van Rood, J.). (3r december, 1968). Brief aan Prof. J. Hamburger, met correcties op de drukproef van de Rondetafelconferentie in Dublin. Leiden.

van Rood, 1.J. (3r januari, r968). Brief aan Dr. Vogt, hem toestemming gevend om naar Leiden te komen, maar hem vragend om te komen nadat zij nieuwe laboratoriumruimte hebben in maart. of om naar de cursus in augustus te komen. Leiden.

van Rood, J.J. (3x januari, 1968). Brief aan Harris, over voortgang van Eurotransplant en het anationale karakter van de organisatie. Leiden.

van Rood, I.J. (31 januari, I968). Brief aan Iványi. over de banden tussen Leiden en Kaapstad. Leiden.

van Rood, J.). (3r januari, r968). Brief aan Largiadèr. met positieve reactie op verzoek om training in weefseltypering. Leiden.

van Rood, J.J. (juni, 1968). Eurotransplant First progress report. Leiden.

van Rood, J.J. (oktober, 1968). WHAT TO DO if you are treating a patient who might be a POTENTIAL ORGAN DONOR. Leiden.

van Rood, J.J. (9 juni, 1969). Brief aan Siderius, verzoekend om bemiddeling tussen Eurotransplant en Ziekenfondsraad, om financiele compensatie van Eurotransplantdiensten te regelen. Leiden.

van Rood, J.J. (ro juni, 1969). Rapport: Kosten Histocompatibiliteits Onderzoek. Leiden.

van Rood, J.). (1o maart, 1969). Brief aan Dr. Twiss, over dat zeldzame leukocytentypen zelfde kans op donornier hebben, en om nephrectomie te verrichten op patiënten op de wachtlijst. Leiden.

van Rood, J.). (ro oktober, 1969). Brief aan Siderius, over stagnatie in ontwikkeling van Eurotransplant door gebrek aan donoren, dat zou kunnen worden verholpen door beter organisatie, daarom vragend om een administrateur te financieren. Leiden.

van Rood, J.J. (25 mart, 1969). Brief aan Dr. Twiss, over misverstand over kruisproeven, niet patiënten maar hun serum moet worden gestuurd. Leiden.

van Rood, J.). (januari, 1969). Eurotransplant Newsletter no. 2. Leiden.

van Rood, J.). (juli, 1969). Eurotransplant Newsletter no. 3. juli 1969 . Leiden.

van Rood, J.J. (6 maart, 1970). Brief aan E. Renner. dankend for brief van 8 maart, en geruststellend over ongeval door startende organisatie, maar het verkriigen van een Telexinstalatie stimulerend. Leiden.

van Rood, J.J. (6 maart, 1970). Brief aan Jongsma, met verzoek om H.M.A. Schippers als Administratief Directeur voor Eurotransplant aan te stellen, die zal worden betaald door Ministerie van Volksgezondheid, en Duitsen en Beigische ziekenhuizen, terwijl met Nederlandse ziektekostenverzekeraars gesprekken worden voorbereid. Leiden.

van Rood, J.J. (6 maart, 1970). Brief aan Wijdeveld, verzoekend om propageren van beschikbaarheid van Telex-aansluitingen bij alle transplantatiecentra in Nederland. Leiden.

van Rood, I.J. (7 april, 1970). Brief aan Drukker, over noodzaak van Telex-aansluiting voor Eurotransplantpraktijk, maar helihaven niet noodzakelijk. Leiden.

van Rood, J.J. (10 maart, 1970). Brief aan KissmeyerNielsen, over uitwisseling van organen tussen Scandiatransplant en Eurotransplant, en daarom ET-telefoonboek sturend. Leiden.

van Rood, J.). (10 maart, 1970). Eurotransplant Newsletter no. 7: Leiden.

van Rood, J.). (II maart, 1970). Eurotransplant Newsletter no, 8: Instructions for blood/serum transport by train. Leiden.

van Rood, J.J. (12 maart, 1970). Brief aan Cdt. VIb. Valkenburg y.d. Brandeler, met verzoek om informatie over cartografieautoriteit, voor kaarten van landingsplaatsen bij ziekenhuizen. Leiden.

van Rood, J.J. (13 april, 1970). Brief aan Speiser en Steffen, over het hebben gesproken met $\mathrm{Dr}$. Wolf en Dr. Mayr, het hen hebben beloofd om hen op de hoogte te houden over Eurotransplant en om hen hun standaardsera te sturen. Leiden.

van Rood, J.J. (14 augustus, 1970). Eurotransplant Newsletter no. 10. Leiden.

van Rood, J.). (17 maart, 1970). Brief aan Dr. W. Moller, Bad Godesberg, over dat Eurotransplant naar tevredenheid werkt, en noodraak voor Keulen om een histocompatibiliteits typeringslaboratorium te hebben. Leiden.

van Rood, J.J. (18 november, 1970). Brief aan D.E. Kayhoe, dankend voor serumcatalogus, over communicatieproblemen aangaande bet sturen van methode beschrijvingen, en verzoekend om grotere boeveelheden van sera voor ET-serumset. Leiden.

van Rood, J.J. (20 maart, r970). Brief aan KissmeyerNielsen, over bijeenkomst over Eurotransplant met Zwitserse en Oostenrijkse mensen, die 
postitief reageendend, en over synchronisatie met Scandia Transplant. Leiden.

van Rood, I.J. (21 april, 1970). Brief aan Terpstra, over het aan transplantatiecentra geven van de verantwoordelijkheid om contacten met 'donor ziekenhuizen' te onderhouden. Leiden.

van Rood, 1.]. (23 december, 1970). Brief aan Dr. A. Btirger, Med. Klinik der Univ. München, over het hebben gekregen van verzock om sera, maar geen sera gevonden met screening te hebben ontvangen en de voorwaarden voor participatie in Eurotransplant gevend. Leiden.

van Rood, 1.). (23 februari, r970). Brief aan Largiadèr. dankend voor mening over Zuid-Duitsland en voor informatie over 'faximileschreiber'. Leiden.

van Rood, J.). (23 septermber, 1970). Brief aan H.H. Fudenberg (San Fransisco), zijn vraag over toekomstige ontwikkelingen van weefseltypering en orgaanuitwisseling beantwoordend, automatisering zal optreden, bij voorkeur niet te grote regio's en kosten zullen verminderen. Leiden.

van Rood, J.J. (24 maart, 1970). Brief aan Mme M. Revillard, Centre De Recherches D'Informatie et De Documentation Notariales, Lyon, dankend zeer bruikbare informatie over internationale regels aangaande het transport van organen. Leiden.

van Rood, 1.J. (27 april, 1970). Brief aan hr. Biber (AZL), verzoekend om 'Piepers' om dienstdoende artsen beter te kunnen bereiken. Leiden.

van Rood, J.J. (27 januari, 1970). Brief aan Largiadèr, dankend voor informatie van enige contact dat zij in Zwitserland hebben, en zou hen graag in Eurotransplant hebben, vanwege recente histocompatibiliteitsgegevens. Leiden.

van Rood, J.). (29 mei, 1970). Brief aan Dr. Speiser (Austrotransplant), informerend of zij met hun nationaal georganiseerde uitwisselingsorganisatie aan de cisen voldoen om in Eurotransplant te kunnen participeren. Leiden.

van Rood, J.J. (3r december, 1970). Brief aan Dr. J.M. Kreisler (Madrid), hem naar Dausset sturen, om te worden opgenomen in orgaanuitwisselingsprogramma van Frankriik. Spanje en Portugal waar Dausset voor zou zorgen. Leiden.

van Rood, H. . (februari, 1970). Rondschrijven Eurotransplant nt, 9: Gericht aan de leden van de Nederlandse centra. Leiden.

van Rood, J.I. (maart, t970). Minutes FOURTH EUROTRANSPLANT MEETING, held at Leyden. rath March 1970. Leiden.

van Rood, J.J. (15 januari, 1970 (1969)). Eurotransplant Newsletter no. 4 . Leiden.

van Rood, I.J., Bruning, J.W., \& Cleton. F.J. (12 januari, 1964). Werkgroep Niertransplantatie, sectie immunologie: Immunologie bij niertransplantatie. Leiden.

Vermylen, C. (25 november, 1969). Brief aan Van Rood, over screenen op antisera en na 20 interessante sera te hebben gevonden uit 4000 monsters, willen ze beginnen met klinisch typeren voor AZ St Rafaell. Leuven.

Vilar, M. (6 juni, r968). Brief aan Van Rood, wil graag komen met bloed van donor en ontvangers [Van Rood voegt toe: "Parijs"]. Madrid.

Vink, M. (23 november, 196r). Brief aan f. de Graeff, J.J. van Rood, A. Zwaveling, L.M. van Putten, M.J. de Vries, H.J. Stol (dierenarts) over start van 'werkgroep orgaantransplantatie'. Leiden.

Walb, D. $(8$ mei, 1968), Brief aan Van Rood, vragend om informatie over, en om deel te nemen aan Eurotransplant. Ulm am Donau.

Walls, J. (17 september, 1968). Brief aan Van Rood, ingevulde formulieren sturend, en dat ze onderzoeken of R.A.F. gebruikt kan worden voor transport van bloed. Newcastle upon Tyne.

Werkgroep Beenmergtransplantatie (16 juni, 1960). Verslag bijeenkomst werkgroep Beenmergtransplantatie 16 juni 1960. Leiden.

Werkgroep Beenmergtransplantatie (december 8 . 1960). concept Brief of L.M. van Putten TNO/IRS aan $\mathrm{Dr}$. Windemuller, RCN Petten. Leiden.

Werkgroep Beenmergtransplantatie (6 april, 196r). Verslag Werkgroep Beenmergtransplantatie IRS dd. 6 april $196 \mathrm{r}$. Leiden.

Werkgroep Beenmergtransplantatie fro januari. 1961). Verslag Werkgroep

Beenmergtransplantatie IRS dd, 10 januari 1961. Leiden.

Werkgroep Beenmergtransplantatie (14 maart, 196r). Bespreking actieve leden van de Werkgroep beenmergtransplantatie op woensdag $\mathrm{I}_{4}$ maart r96r. Leiden.

Werkgroep Beenmergtransplantatie (25 juni, 1964). Verslag bijeenkomst werkgroep Beenmergtransplantatie, IRS en Bestuur Isolatiepaviljoen, 25 juni 1964 . Leiden.

Werkgroep Beenmergtransplantatie (ND). Omgekeerde isolatie; Een nieuwe ontwikkeling in ziekenverpleging. Leiden.

Werkgroep Niertransplantatie ( 1964$)$. Verslag van de Sixth International Homograft Transplantation Conference, gehouden te New York, van 6-8 februari 1964 .

Werkgroep Niertransplantatie (3 februari, 1964). Verslag werkbespreking niertransplantaties dd. 3 februari 1964 . Leiden.

Werkgroep Niertransplantatie (II maart, 1964). Verslag werkbespreking niertransplantaties dd. II maart 1964. Leiden.

Werkgroep Niertransplantatie (20 jamuari, 1964). Verslag werkbespreking niertransplantaties dd. 20 januari 1964 . Leiden.

Werkgroep Niertransplantatie (3 maart, 1965). Agenda en Verslag vergadering Niertransplantatiewerkgroep dd. 3 maart 1965 . Leiden.

Werkgroep Niertransplantatie ( 13 oktober, 1965 ). Verslag Werkgroep Niertransplantatie 13 oktober 1965. Leiden.

Werkgroep Orgaantransplantatie TNO (19 december. 1966). Agenda Werkgroep Orgaantransplantatie TNO, d.d. t9 december 1966 . Leiden.

Werkgroep Orgaantransplantatie TNO (19 december. 1966). Verslag Werkgroep Orgaantransplantatie TNO, d.d. t9 december 1966 . Leiden.

Werkgroep Orgaantransplantatie TNO (23 maart, 1967). Verslag Werkgroep Orgaantransplantatie 
TNO, d.d. 23 maart 1967 . Leiden.

Werkgroep Orgaantransplantatie TNO 18 maart, 1968). Verslag Werkgroep Orgaantransplantatie TNO, d.d. 8 maart 1968 . Leiden.

Werkgroep Orgaantransplantatie TNO $(24$ maart, 1969). Verslag Werkgroep Orgaantransplantatie TNO. d.d 24 maart 1969 . Leiden.

Wiijdeveld, P. (12 november, 1970). Brief aan Van Rood, met correcties voor de ET-wachtliist en de aanwezigheid van een Telex-aansluiting meldend. Nijmegen.

Wijdeveld, P. (13 januari, 1970). Brief aan Van Rood, aankondigend dat hun laboratorium niet kan functioneren als een Eurotransplant Typerings laboratorium voor de komende jaren, maar dat ze wel nieren zullen aanbieden wanneer aanwezig. Nijmegen.

Wilson, H.E. (22 november, 1965). Brief aan Van Rood, over publicatie van Workshop resultaten. $\mathrm{Hij}$ heeft bedenkingen over resultaten vanwege andere dan "home conditions". Columbus, Ohio.

Woelders, B.G. (1 november, 1968). Brief an Cdt. VIb. Valkenburg v.d. Brandeler, brief en foto's aanbiedend, afkomstig van Alexandre from Leuven, om toekomstige landingsproblemen te voorkomen. Leiden.

Woelders, B.G. (13 november, 1968). Brief aan Cdt. Vlb. Valkenburg v.d. Brandeler, kaarten van Academisch Ziekenhuis en stad Gent (Belgie)) sturend om te gebruiken voor landing, Leiden.

Woelders, B.G. (30 augustus, 1968 ). Brief uit naam van Van Rood aan Dr. J. Walls (Newcastie upon Tyne), over regelingen voor het versturen van bloed, donorcentrum zorgt voor transport, R.A.F. geprobeerd? Leiden.

Woelders, B.G., van Rood, J.J. (4 september, 1968). Brief uit naam van Van Rood aan Dr. Greep, met gecorrigeerde kopie van bijdrage aan de discussie op 20 oktober 1967 . Leiden.

Woodruff, M.F.A. (6 juli, 1966). Brief aan Van Rood, over organiseren van leukocytentypering in Groot-Britanniê, en dat hij zoekt naar kadaverdonor voor patiënt die eerdere levend/verwante transplantatie afstootte. Edinburgh.

Woodruff, M.F.A. (I3 juni, 1966). Brief aan Van Rood, dankend for definitieve resultaten of retrospectief onderzoek en gretig om eigen weefseltyperingslaboratorium op te zetten met Van Rood's hulp, en over zoeken van kadaverdonor voor patiënte terug aan de dialyse na afstoten levend/verwant transplantaat. Edinburgh.

Woodruff, M.F.A. (25 mei, 1966). Brief aan Van Rood, dankend voor stimulerend bezoek en hopend eigen weefseltyperingslaboratorium op te kunnen zetten. Edinburgh.
Workshop-groep ( 1965 ). Workshop on

Histocompatibility Testing 1965, Notes to the Participants. Leiden.

Workshop-groep (12 juli, 1965). Nutulen van de bijeenkomst "Workshop" op maandag 12 juli 1965. Leiden.

Workshop-groep (21 juni, 1965). Nutulen bijeenkomst "Workshop" op maandag 21 juni 1965 , Leiden.

Workshop-groep (25 juni, 1965). Nutulen bijeenkomst "Workshop" op vrijdag as juni 1965. Leiden.

Wright Rumbough, I.J. (30 juni, 1967). Brief aan Van Rood, over dat Whitehall Foundation geinteresseerd is in het geven van subsidie, maar dat persoonlijk contact met njeuwe technische Directeur, Dr. George Packer Berry noodzakelijk is, om te laten plaatsvinden gedurende VS reis van Van Rood.

Zmijewski, C.M. (4 januari, 1965). Brief aan Van Rood, over organisatie van afgelopen en toekomstige workshop. Durham.

Zmijewski, C.M. (20 juni, 1966). Brief aan Van Rood, over geen anti-sb in zijn sera, en Workshop organisatie. Durham.

Zmijewski, C.M. (28 april, 1966). Brief aan Van Rood, over problemen met NIH aanvraag. workshop organisatie, Europese gegevens en analyse verschillen met Amos. Durham.

Zmijewski, C.M. (30 september. 1966). Brief aan Van Rood, over NIH's Serumbank, typeren van panel bij Duke, en het typeren van panels bij anderen die het niet waard zijn. Durham.

\section{GESPREKKEN EN INTERVIEWS}

Interview met van Rood, J.). (21 december, 1993). Kennismakings interview.

Interview met Bruning, H. (6 september, 1994). Interview, gehouden op 6 september 1994 .

Interview met van Leeuwen, A. (6 september, 1994). Interview, gehouden op 6 september 1994 .

Persoonliik gesprek met Boonstra, I. (Is september, 1994). Nier uitgewisseld tussen identieke tweelingen kan worden afgestoten.

Interview met Calne, R.Y. (30 september, 1994). Interview aansluitend op Wellcome Witness Seminat on the Early History of Renal Transplantation.

Interview met Starzl, T.E. (30 september, 1994). Interview aansluitend op Wellcome Witness Seminar on the Early History of Renal Transplantation.

Persoonlijk gesprek met van Leeuwen, A. (17 oktober. 1994). Gesprek tijdens archiefverkenning.

Persoonlijk gesprek met van Rood. J.J., van Leeuwen, A. (17 juni, 1998$)$. Bespreking concepten $\mathrm{H}_{2}-5$.

Persoonlijk gesprek met van Rood, J.J. (II augustus, 2000). Bespreking concepten $\mathrm{H}_{2}-8$. 


\section{CURRICULUM VITAE}

Michiel van Dorp werd op 2 augustus 1962 te Groningen geboren. Zijn vroege jeugd heeft hij in Winsum (Gr.) doorgebracht. Vervolgens enige tijd in Groningen gewoond en daar het eerste jaar van de lagere school doorlopen. In Coevorden heeft hij de lagere school voltooid en doorliep daar aan de RijksScholenGemeenschap vervolgens, van 1975 tot en met 1982 , het VWO. Na het behalen van zijn diploma, gaf hij gevolg aan de Eerste Oproep van Defensie ter vervulling van zijn Dienstplicht. $\mathrm{Na} 16$ maanden kreeg hij groot verlof en trad - ter overbrugging - in dienst bij Intergas BV, alwaar hij CV-ketels assembleerde. In 1984 startte hij met de opleiding HBO-V. Na drie jaar studie aan de Academie voor Gezondheidszorg in Zwolle maakte hij in 1987 de overstap naar de Rijksuniversiteit Limburg (nu Universiteit Maastricht) om daar Gezondheidswetenschappen te studeren. Ter aanvulling van de studie Theorie van de Gezondheidswetenschappen, volgde hij ook het volledige curriculum van Geestelijke Gezondheidskunde. In 1993 ontving hij voor beide studierichtingen zijn bul. Op I september 1993 trad hij in dienst bij de vakgroep Gezondheidsethiek en Wijsbegeerte van de Faculteit Gezondheidswetenschappen, om als Assistent in Opleiding promotieonderzoek te doen naar de Ontwikkeling van Transplantatiepraktijken. Eind 1999 liep deze aanstelling af. Halverwege 2000 trad hij in dienst bij VercomNet BV, een internetbedrijf dat onder andere gericht is op het bedienen van medische professionals met informatie via het internet. Zijn doelstelling is om zijn kennis en ervaring in te zetten ter ondersteuning, dan wel verbetering van kwaliteit van zorg. 

In 1996 stelt Eurotransplant - de orgaanuitwisselingsorganisatie voor te transplanteren organen in de Benelux, Duitsland en Oostenrijk (en sinds 2000 Slovenië) - een nieuw allocatieprotocol in werking, het Eurotransplant Kidney Allocation System protocol (ETKAS). Dit lijkt een breuk met het verleden. Voorheen was de mate van overeenstemming van HLA-antigenen van donor en ontvanger - de match - het allocatiecriterium. Naast de match wordt in het ETKAS-protocol ook rekening gehouden met de wachttijd van de patiēnt, met de afstand van de ontvanger tot de donor en met bestaande samenwerkingsverbanden. Een medische praktijk die niet meer op uitsluitend medische gronden verdelingsbesluiten neemt, lijkt op het eerste gezicht morele problemen binnen te halen. Met ETKAS wordt echter geprobeerd om de gemiddelde wachttijd te verkorten, correcties voor zeldzame HLA-typen en homozygositeit toe te passen, een redelijk evenwicht in de uitwisseling van donornieren tussen landen te bereiken en een optimale HLA-match-verdeling en algemene transplantatie-uitkomst te garanderen. ETKAS zou daarmee juist een aantal morele problemen oplossen.

In dit boek wordt de ontwikkeling van Eurotransplant onderzocht. De beschrijving richt zich op het ontstaan en de rol van het matchingscriterium. Hoe heeft zich de theorievorming over (en het empirisch onderzoek naar) matchen ontwikkeld? En hoe belangrijk was dit criterium bij het ontstaan van de transplantatiepraktijk? Nadat de auteur deze vragen heeft beantwoord, sluit hij af met een beschouwing over de legitimiteit van Eurotransplant.

Michiel van Dorp studeerde Gezondheidswetenschappen met als afstudeerrichtingen Theorie van de Gezondheidswetenschappen en Geestelijke Gezondheidskunde aan de Universiteit Maastricht. Vanuit de vakgroep Gezondheidsethiek en Wijsbegeerte van de UM heeft hij zijn promotieonderzoek verricht in het archief van Eurotransplant.

\section{(1) Thela Thesis}

ISBN 9051705611

NUGI 732 